\title{
Evolucionismo: \\ Darwin y enfoques actuales
}





\section{Evolucionismo: \\ Darwin y enfoques actuales}

Wenceslao J. González 
Coordinador de la Serie de Filosofía y Metodología de la Ciencia Wenceslao J. González

\section{EVOLUCIONISMO: DARWIN Y ENFOQUES ACTUALES}

Cualquier forma de reproducción, distribución, comunicación pública o transformación de esta obra solo puede ser realizada con la autorización de sus titulares, salvo excepción prevista por la ley. Diríjase a CEDRO (centro Español de Derechos Reprográficos, www.cedro.org) si necesita fotocopiar o escanear algún fragmento de esta obra.

No está permitida la reproducción total o parcial de este libro, ni su tratamiento informático, ni la transmisión de ninguna forma o por cualquier medio, ya sea electrónico, mecánico, por fotocopia, por registro u otros métodos, sin el permiso previo y por escrito de los titulares del Copyright.

$Q R$ code es una marca registrada por Denso Wave, inc.

DERECHOS RESERVADOS 2009, respecto a la primera edición en español, por

(C) Wenceslao J. González

(C) Netbiblo, S. L.

\section{netbiglo}

www.netbiblo.com

NETBIBLO, S. L.

C/. Rafael Alberti, 6 bajo izq.

Sta. Cristina 15172 Oleiros (La Coruña) - Spain

Tlf: +34 981915500 • Fax: +34 981915511

www.netbiblo.com

editorial@netbiblo.com

Miembro del Foro Europeo de Editores

ISBN: 978-84-9745-409-4

Depósito Legal: C-4312-2009

Directora Editorial: Cristina Seco López

Editora: Paola Paz Otero

Producción Editorial: Gesbiblo, S. L.

Impreso en España - Printed in Spain

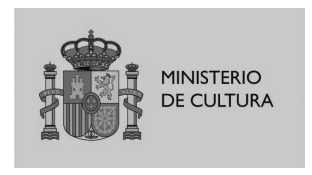

Esta obra ha sido publicada con una subvención de la Dirección General del Libro, Archivos y Bibliotecas del Ministerio de Cultura, para su préstamo público en Bibliotecas Públicas, de acuerdo con lo previsto en el artículo 37.2 de la Ley de Propiedad Intelectual. 


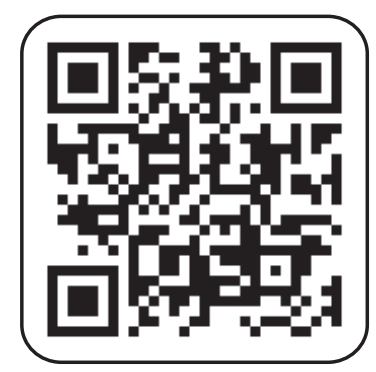

¿Cómo se utiliza?

Si tu móvil no dispone de lector de códigos, descarga e instala de manera gratuita el más adecuado según tu teléfono.

Estas son algunas recomendaciones:

D Si se trata de un iPhone, NeoReader es una buena opción: http://get.neoreader.com

D Para modelos de Blackberry, puedes instalar Beetagg: http://get.beetagg.com

D Si el teléfono es un Nokia o similar prueba, por ejemplo,

Kaywa Reader:

http://reader.kaywa.com

Abre la aplicación y enfoca el código QR. el código QR.

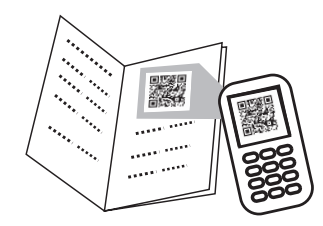

Al aceptar, se abrirá una ventana con el contenido del código. 



\section{ÍNDICE GENERAL}

\section{Prólogo}

Wenceslao J. González

1. Contexto histórico y análisis filosófico

El evolucionismo desde una perspectiva contemporánea: El enfoque filosófico-metodológico

Wenceslao J. González.

PARTE I

DARWIN Y LA TEORÍA DE LA EVOLUCIÓN

2. La evolución de los experimentos mentales darwinianos

James G. Lennox.

3. 'EEstá surgiendo una nueva Teoría general de la Evolución?' Una valoración filosófica de la evaluación de Stephen Jay Gould acerca de la Teoría de la Evolución contemporánea Jean Gayon.

PARTE II

EVOLUCIONISMO Y BIOLOGÍA ACTUAL

4. Los experimentos mentales en la Biología evolucionista actual

James G. Lennox.

5. El concepto de "especie" en la Biología evolucionista: Polémicas actuales Alfredo Marcos.

\section{PARTE III EVOLUCIONISMO Y ECONOMÍA}

6. Tres ideas evolutivas en Economía: Las poblaciones, la pura curiosidad y el cambio tecnológico

Santiago López García

7. La idea de evolución en Hayek: Instituciones, orden social y proceso económico 


\section{PARTE IV \\ EPISTEMOLOGÍA Y EVOLUCIONISMO}

8. Evolucionismo bio-cosmológico y Epistemología evolucionista en Popper

Juan Arana

9. Racionalidad como adaptación evolutiva en Herbert A. Simon: Una comparación con Karl Popper y Reinhard Selten

Francisco J. Castro.

Índice de nombres

229

Índice temático

237

Serie de Filosofía y Metodología de la Ciencia 


\section{Prólogo}

\section{Wenceslao J. González}

Con motivo del bicentenario del nacimiento de Charles Darwin y el 150 aniversario de la publicación de su libro emblemático — The Origin of Species by Means of Natural Selection-, se ha renovado el interés por el evolucionismo y se ha centrado la atención en el darwinismo. Como anticipo a este doble aniversario, en 2008 se publicó el libro Evolutionism: Present Approaches, que hacía una lectura del evolucionismo desde distintos ángulos. Se insistía en que, a través de la Historia, ha habido diversos planteamientos acerca de la evolución y se ponía un especial empeño en contemplar esos tipos de evolucionismos desde la Filosofía y Metodología de la Ciencia.

La editorial Netbiblo ha visto conveniente que, ya dentro del 2009, se haga una versión castellana del libro, de modo que llegue a más personas e instituciones. Evolucionismo: Darwin y enfoques actuales se publica así para sumarse al reconocimiento a la labor investigadora de Charles Darwin al tiempo que ofrece nuevas perspectivas de análisis. La estructura del volumen permite apreciar que el enfoque es novedoso. En efecto, tras proporcionar el contexto de análisis del evolucionismo - histórico y filosófico-metodológico-, el libro dedica cuatro bloques temáticos a una serie de cuestiones clave, como son la Teoría de la Evolución de Darwin, la Biología actual, la Economía y la Epistemología. Cada uno de estos apartados consta de dos capítulos, para abordar distintas vertientes del problema.

Como editor de la versión inglesa y responsable asimismo de la edición castellana, deseo agradecer a la editorial Netbiblo su interés por hacer llegar a un público amplio los enfoques actuales del evolucionismo. Esto incluye a filósofos y biólogos, pero también a economistas y otros científicos sociales. Al igual que el original inglés, un cometido central ha sido que el contenido esté escrito de manera clara. Por eso, los cambios respecto del texto de hace un año han sido mínimos: ampliaciones en la información bibliográfica facilitada y algunas aclaraciones. Cada uno de los colaboradores del volumen ha visto con claridad el objetivo de lograr nuevas cotas de difusión en este libro de la Serie de Filosofía y Metodología de la Ciencia.

Ámsterdam, 28.10.2009 



\section{Contexto histórico y análisis fillosófico}





\title{
El EVOLUCIONISMO DESDE UNA PERSPECTIVA CONTEMPORÁNEA: EL ENFOQUE FILOSÓFICO-METODOLÓGICO ${ }^{1}$
}

\author{
Wenceslao J. González
}

Desde un punto de vista actual, el evolucionismo aparece como un ámbito que conlleva múltiples facetas. Por un lado, el análisis histórico revela que hay una clara diversidad en cuanto a los evolucionismos que han de ser evaluados, donde el darwinismo es una concepción clave que ha estado precedida y seguida por otras posturas evolucionistas. Por otro lado, un estudio filosófico-metodológico de estos evolucionismos —entre ellos, la influyente concepción desarrollada por Charles Darwin - tiene una riqueza que excede los contenidos de cualquier libro al uso. En efecto, el evolucionismo tiene una gran influencia sobre la Ciencia - sobre todo en Biología - con consecuencias filosóficas que son relevantes tanto para la Filosofía y Metodología general de la Ciencia como para los dominios especiales (Filosofía de la Biología, Filosofía de la Economía, etc.). Además, el evolucionismo posee una innegable repercusión en partes centrales de la Filosofía, tales como la Teoría del Conocimiento, la Metafísica y la Ética.

Ante esta multiplicidad de facetas del evolucionismo, este capítulo busca ofrecer el contexto del enfoque filosófico-metodológico acerca de las posiciones evolucionistas. Tiene en cuenta las principales líneas de la trayectoria histórica y, de este modo, sigue dos ejes para realizar esta contextualización: 1) La diversidad de evolucionismos: Hacia una estructura filosófico-metodológica, que se enfoca hacia el análisis histórico del evolucionismo, donde se resalta la existencia de una diversidad de posiciones evolucionistas; y 2) Desde una perspectiva filosófica acerca de la Naturaleza al naturalismo en Filosofía, donde la Filosofía aparece asimismo de diferentes formas: a) las influencias filosófico-metodológicas en el enfoque de Darwin; b) las fases iniciales del influjo filosófico darwiniano; y c) la relevancia filosófica contemporánea del darwinismo. Más tarde, hay una explicación de la articulación y origen del libro así como una bibliografía de los temas abordados.

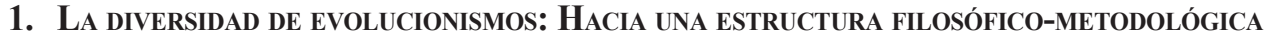

"Evolucionismo" es un término polisémico: su sentido y referencia varía según los periodos históricos y la Escuela de Pensamiento (y, a veces, en el mismo autor desde una etapa de su vida a otra) ${ }^{2}$. Además de la diversidad lingüística, el evolucionismo también incluye diferentes campos, puesto que abarca una amplia variedad de enfoques tanto en la Ciencia como en la Filosofía. Así, el evolucionismo se encuentra en las Ciencias de la Naturaleza — principalmente, en la Biología - al igual que en las Ciencias Sociales, no sólo en el plano de la Ciencia Básica

\footnotetext{
Agradezco a Jean Gayon sus comentarios a la versión original de este texto.

2 Esta variedad puede encontrarse en la lista de publicaciones que se ofrece en la bibliografía de este capítulo, donde hay una distinción entre el darwinismo y los otros tipos de evolucionismo.
} 
(p. ej., en Paleontología) sino también en el nivel de la Ciencia Aplicada (p. ej., en la Economía evolucionista). En Filosofía aparece al tratar cuestiones teoréticas (p. ej., en Metafísica) y en los debates sobre asuntos prácticos (p. ej., en Ética).

Inicialmente, "evolucionismo" es una doctrina biológica que empezó antes de Charles Robert Darwin (1809-1882), un autor cuyos aniversarios - dos siglos desde su nacimiento y 150 años desde su libro clave - han de tenerse en mente. Según Jean Gayon, "ramificados en torno a la 'evolución' estaban, entre otros, la antigua teoría de la embriogénesis como expansión de un organismo preformado (éste es el sentido primario de 'evolución' en los siglos XVII y XVIII); la teoría asociada de la preexistencia de gérmenes (germs), en conexión con la cual Charles Bonnet, naturalista suizo, fue el primero en aplicar 'evolución' no sólo a la generación individual, sino también a la Historia de la aparición sucesiva de especies; la morfología transcendental del siglo XIX, con su énfasis en los paralelismos entre embriogénesis y la complejidad gradual de las especies (...)”3.

Generalmente, se ha visto el evolucionismo dentro del amplio contexto del interés por algún tipo de progreso. Recibió un impulso con las posiciones de Darwin, principalmente las enunciadas en The Origin of Species ${ }^{4}$ y The Descent of Man ${ }^{5}$. Pero el evolucionismo posee numerosas perspectivas posteriores, algunas de ellas son claramente diferentes de sus planteamientos, aun cuando se mantenga como una figura clave en el desarrollo de esta concepción. Además, el evolucionismo llega a ser una Filosofía, en el sentido relevante de reflexión racional sobre la realidad como un todo ${ }^{6}$ (natural, social y artificial). A este respecto, tiene influencia en las áreas principales de la indagación filosófica: Teoría del Conocimiento, Metafísica, Ética, etc. Entre ellas, el evolucionismo tiene un papel crucial en la Filosofía general de la Ciencia así como en dominios especiales de esta esfera (Filosofía de la Biología, Filosofía de la Economía, etc.).

Además de la Biología, el evolucionismo ha impregnado muchos otros campos científicos, que incluyen un amplio rango de temas dentro de las Ciencias Sociales: Psicología, Sociología, Antropología, Economía, Ciencia Política, ... Más aún, cabe afirmar que el evolucionismo - en general, y el darwinismo, en particular — puede ser visto también como una cosmovisión intelectual, que va más lejos de su estatuto de teoría científica para atraer la atención de mucha gente ${ }^{7}$. Desde este punto de vista, es bastante obvio que el evolucionismo está inserto en enfoques culturales (en literatura, periodismo, etc.) y tiene una relevancia prominente en

\footnotetext{
3 Gayon, J., "From Darwin to Today in Evolutionary Biology", en Hodge, J. y Radick, G. (eds), The Cambridge Companion to Darwin, Cambridge University Press, Cambridge, 2003, p. 242. "In his Palingénésie philosophique (1769), Bonnet argued that God had prearranged the ocurrence of new species in the germs of the first organisms he had created. For this reason, Bonnet extended the use of the word 'evolution' (literally 'unfolding') to the genesis of species", GAYON, J., "From Darwin to Today in Evolutionary Biology", pp. 261-262.

4 Darwin, CH., The Origin of Species by Means of Natural Selection: or the Preservation of Favoured Races in the Struggle for Life, John Murray, Londres, 1859; reimpreso en edición facsímil por Harvard University Press, Cambridge, MA, 1964.

5 Darwin, Ch., The Descent of Man and Selection in Relation to Sex, John Murray, Londres, 1871, 2 vols.

6 Por una parte, hay una visión metafísica dentro del enfoque evolucionista; y, por otra parte, el evolucionismo - al menos en su rama darwinista - ha elaborado una concepción metafísica. Cfr. Hull, D. L., The Metaphysics of Evolution, SUNY Press, Albany, NY, 1990.

7 Cfr. Ruse, M., The Evolution-Creation Struggle, Harvard University Press, Cambridge, MA, 2005; y Bowler, P. J., Monkey Trials and Gorilla Sermons: Evolution and Christianity from Darwin to Intelligent Design, Harvard University Press, Cambridge, MA, 2007.
} 
debates sociales en algunos países (especialmente, en Estados Unidos) con repercusiones en la vida ordinaria (educación, legislación, etc. $)^{8}$.

Hay que tomar en consideración los aspectos históricos del evolucionismo, debido a la diversidad de concepciones evolucionistas en liza. A este respecto, el análisis sigue aquí los siguientes cuatro pasos, que prestan una particular atención a la Biología: 1) etapas iniciales del evolucionismo; 2) el enfoque biológico de Darwin acerca de la evolución, que también se ve en términos filosóficos (esto es, la posibilidad de ser un "naturalista"); 3) la consideración de una revolución intelectual introducida por el darwinismo; y 4) otros evolucionismos relacionados con la Biología, que son tratados desde diferentes ángulos (tales como el "árbol de la vida" [tree of life], el proceso de evolución, la microevolución y la macroevolución).

\subsection{Etapas iniciales}

En cuanto a los primeros evolucionistas, Michael Ruse sugiere "ir hacia atrás cerca de trescientos años" 9 . Conecta entonces la idea de "evolución" con una noción amplia de "progreso", un avance hacia una vida mejor. También asocia a Jean-Antoine-Nicolas Caritat, marqués de Condorcet (1743-1794), con el movimiento desde el reconocimiento del progreso en el mundo social (debido principalmente a nuevos descubrimientos en la Ciencia) hacia el progreso - una escalada - en el mundo biológico.

Tiene entonces evolución un carácter positivo dentro de este contexto, en la medida en que se asume que el concepto de "progreso" incluye una mejoría relacionada con los resultados o lo obtenido ${ }^{10}$. Además, se puede asumir que este evolucionismo inicial trae consigo la idea de transición en cuanto al nivel de complejidad, porque en la vida social —al igual que en la Naturaleza - los organismos se pueden organizar desde lo más simple hasta lo más complejo.

George Louis Leclerc, conde de Buffon (1707-1788), desarrolló una exposición pre-darwiniana del cambio orgánico, si bien su abarcante investigación acerca de la Historia Natural tiene fundamentos diferentes ${ }^{11}$ : su perspectiva comporta que la índole de cada familia biológica está fijada por su molde interno. "Al argumentar que una forma ancestral individual (single) puede diverger en un número de 'especies', Buffon se acerca al concepto moderno de evolución. Su reconocimiento de que la migración a distintas partes del mundo puede causar la divergencia también marca un esfuerzo pionero en el estudio de la distribución geográfica como indicio (clue) en la Historia de la vida. Pero su idea según la cual el entorno (environment) actúa directamente sobre el organismo, a través de las partículas orgánicas, está a gran distancia de la teoría de la selección natural" ${ }^{12}$.

\footnotetext{
8 Estas disputas yacen lejos del alcance de este capítulo filosófico-metodológico. Además, estas “guerras culturales" sólo en parte son filosóficas en su origen y han conducido a un enorme número de publicaciones, muchas de las cuales se encuentran frecuentemente cargadas de propuestas ideológicas.

9 Ruse, M., Darwinism and Its Discontents, Cambridge University Press, N. York, 2006, p. 9.

10 Sobre "progreso científico", véase Gonzalez, W. J., "Progreso científico, Autonomía de la Ciencia y Realismo", Arbor, v. 135, n. 532, (1990), pp. 91-109; y Niniluoto, I., Is Science Progressive?, Reidel, Dordrecht, 1984. Acerca de "progreso biológico", cfr. Ayala, F. J., "The Concept of Biological Progress", en Ayala, F. J. y Dobzhansky, Tн. (eds), Studies in the Philosophy of Biology, Reduction and Related Problems, Macmillan, Londres, 1974, pp. 339-355.

11 Cfr. Buffon, [George Louis Leclerc,] conde de, Histoire Naturelle, générale et particulière, 36 vols., Imprimerie Royale puis Plassan, París, 1749-1788.

12 Bowler, P. J., Evolution: The History of an Idea, University of California Press, Berkeley, 1983; edición revisada, University of California Press, Berkeley, 1989, pp. 74-75.
} 
La progresividad en la evolución es un supuesto aceptado por Erasmus Darwin (1731-1802), sobre todo en su obra Zoonomia (1794-1796) ${ }^{13}$, donde se interesa por las "leyes de la vida orgánica”. En el caso del cambio natural, lo considera una adaptación de las plantas y animales a su medio ambiente (environment). Más aún, el abuelo de Charles Darwin ha sido asociado a otra figura clave: Jean-Baptiste-Pierre-Antoine de Monet, caballero de Lamarck (1744-1829), porque Erasmus "también había apoyado una producción natural, prolongada, de las formas de vida más altas a partir de las más bajas y el mono como ancestro del hombre" ${ }^{14}$.

Lamarck fue uno de los autores cuyas obras zoológicas estaban en la biblioteca del Beagle durante la travesía de Darwin (1831-1836) ${ }^{15}$. Jean Baptiste de Monet acepta una "generación espontánea" en el caso de las formas de vida más elementales y una progresión ascendente de los organismos hasta llegar a la forma humana. Aun cuando pensaba que hay a veces divisiones y caprichos (debidos generalmente a los efectos heredables del uso y de la ausencia de uso, como el cuello de la jirafa), la imagen de conjunto de la Naturaleza es de progreso, como sucede también en las mejores sociedades humanas ${ }^{16}$.

De nuevo, junto a la aceptación de la variabilidad en el mundo natural (en este caso se incluye el rasgo específico de la herencia de los caracteres adquiridos), en esta versión del enfoque evolucionista se asume el supuesto de la complejidad en Biología: "según Lamarck, las plantas y los animales que existen actualmente han surgido mediante un proceso natural de transformación, debido a las propiedades que hacen más complejos (complexifying properties) a los fluidos que corren por sus tejidos, y los cambios adaptativos que se llevaron a cabo cuando se modificaron los hábitos en respuesta a las alteraciones ambientales" ${ }^{17}$.

Indudablemente, esta idea de complejidad puede llevar a la existencia de algún tipo de jerarquía en el mundo natural. De hecho, Stephen Gould, que ha estudiado a Lamarck en este contexto, ha señalado que "su teoría (...) descansa sobre el concepto de jerarquía, con causas diferentes en dos niveles básicos (primary levels)" ${ }^{18}$. Al principio - hasta 1797-, Jean Baptiste de Monet aceptaba la idea de las especies como entidades estables. Pero luego se convirtió en partidario del evolucionismo: esta nueva perspectiva se encuentra en su lección inaugural de curso en el Muséum d'Historie Naturelle (1800); y aparece más tarde en sus tres obras principales: Recherches sur l'organisation des corps vivans (1802) ${ }^{19}$, Philosophie zoologique (1809) ${ }^{20}$, e Histoire naturelle des animaux sans vertèbres (1815-1822) ${ }^{21}$.

13 Darwin, E., Zoonomia; or, The Laws of Organic Life, J. Johnson, Londres, 1794-1796. Esta publicación de su abuelo fue leída con todo detalle por Charles Darwin, cfr. Hodge, J., "London Notebook Programmes and Projects of Darwin's London Years", en Hodge, J. y Radick, G. (eds), The Cambridge Companion to Darwin, p. 45.

14 Hodge, J., "London Notebook Programmes and Projects of Darwin's London Years", p. 45.

15 Sloan, Ph. R., "The Making of a Philosophical Naturalist", en Hodge, J. y Radick, G. (eds), The Cambridge Companion to Darwin, p. 30.

16 Cfr. Ruse, M., Darwinism and Its Discontents, pp. 9-10.

17 Sloan, Ph. R., "The Making of a Philosophical Naturalist", p. 21.

18 Cfr. Gould, S. J., The Structure of Evolutionary Theory, Belknap Press, Cambridge, MA, 2002, capítulo 3: "Seeds of Hierarchy", p. 175.

19 Lamarck, J. B. [De Monet, Caballero] De, Recherches sur l'organisation des corps vivans, Maillard, París, 1802.

20 Lamarck, J. B. [De Monet, CABallero] de, Philosophie zoologique, ou, Exposition des considérations relative à l'Histoire naturalle des animaux, Chez Dentu [et] L'Auteur, París, 1809.

21 Lamarck, J. B. [DE Monet, CABallero] DE, Histoire naturelle des animaux sans vertèbres, 7 vols. París, $1815-1822$. Reimpreso por Culture et Civilisation, Bruselas, 1969. 
Pero Darwin dijo muy poco sobre Lamarck ${ }^{22}$, aun cuando su famoso planteamiento "funcionalista" - el enunciado contraintuitivo según el cual la forma se sigue de la función como pauta de la Historia de la vida - fue también aceptado por Darwin ${ }^{23}$. A tenor del enfoque biológico de Lamarck, la variedad en el mundo natural — o biodiversidad - es una consecuencia de la escala evolutiva. Así, su postura resalta la "dimensión vertical" de la evolución, mientras que la concepción de Darwin destaca el "aspecto horizontal" de la evolución o, al menos, la posibilidad de una pluralidad de ramas simultáneas del "árbol de la vida". A su juicio, dentro del proceso evolutivo en el mundo natural, hay un incremento de la complejidad que se debe a la ampliación de la diversidad biológica ${ }^{24}$.

Figura 1

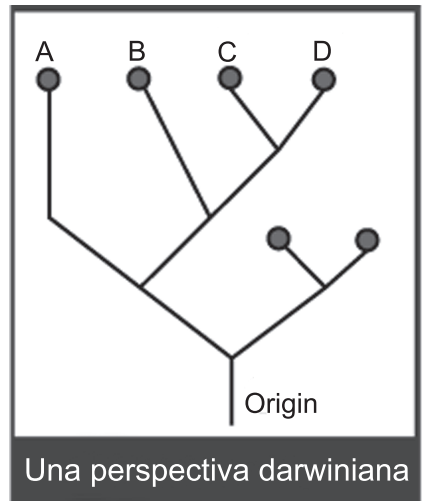

\section{Figura 2}

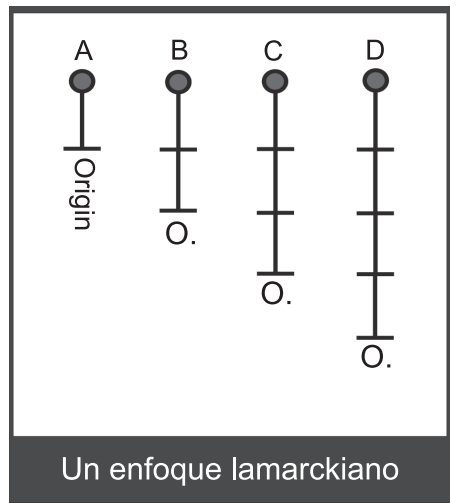

No obstante, Lamarck llegó a ser cada vez más consciente de la importancia de la diferenciación. Esto quiere decir que, de manera progresiva, introdujo complejidad en sus series, que les hizo parecerse más y más a un árbol. Utiliza la expresión "série rameuse" en su Philosophie zoologique para reflejar esta preocupación ${ }^{25}$. En su enfoque, como pone de relieve Peter Bowler en la figura 3, "cada punto de la escala del ser que observamos hoy se ha obtenido mediante una progresión a partir de un acto separado de generación espontánea. Conforme más abajo en la escala esté hoy el organismo, más reciente será el primer antecesor que lo produjo. Así, la evolución no es un sistema de un descendiente común, sino que consta de líneas separadas que avanzan en paralelo a lo largo de la misma jerarquía" ${ }^{26}$.

22 Cfr. Gould, S. J., The Structure of Evolutionary Theory, pp. 170 y 192-197. Hay comentarios críticos explícitos respecto de "Lamarck nonsense of a "tendency to progression", DARwin, CH., Letter to Hooker, 11 de enero de 1844 (citado en The Structure of Evolutionary Theory, p. 175).

23 Cfr. Gould, S. J., The Structure of Evolutionary Theory, p. 177. "We may view Lamarck and Darwin as occupying the common ground of functionalism, with their differing mechanisms of natural selection and soft inheritance as versions of the same deeper commitment. (...) But Lamarckism also includes a second set of concepts, which, when combined with the first set into Lamarcks's full system, builds an evolutionary theory truly opposed to Darwin's chief theoretical concept and operational principle as well", The Structure of Evolutionary Theory, p. 179.

24 La diferencia entre ambas perspectivas se refleja en las figuras 1 y 2, que están basadas en RuSE, M., The Darwinian Revolution, The University of Chicago Press, Chicago, 1979, cap. 1.

25 Cfr. Lamarck, J. B. [De Monet, Caballero] De, Philosophie zoologique, tomo segundo, p. 463, "Tableau servant à montrer l'origine des différens animaux".

26 Bowler, P. J., Evolution: The History of an Idea, edición revisada, p. 85. La figura 3 aparece en esa misma página. 


\section{Figura 3}

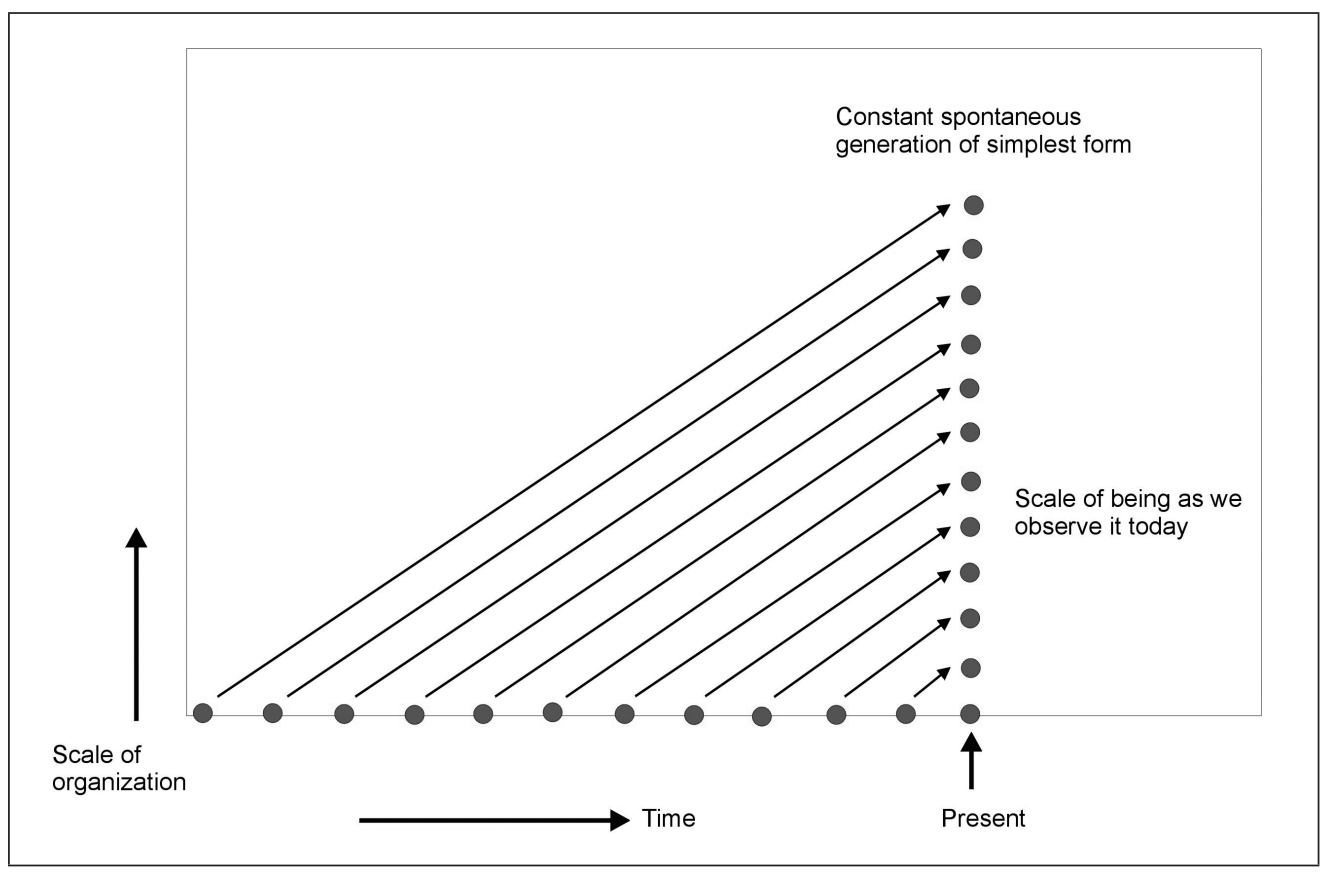

Robert Chambers (1802-1871), que reconoció a Lamarck como su principal fuente de inspiración ${ }^{27}$, fue otro autor que fue leído por Charles Darwin (y por Alfred Russel Wallace). Chambers fue un publicista escocés que, en 1844, publicó anónimamente el libro Vestiges of the Natural History of Creation ${ }^{28}$. Este texto ha sido considerado como "el libro sobre la evolución paradigmático de la etapa victoriana inicial" ${ }^{29}$. El asunto importante aquí es que Darwin, antes de publicar sus principales obras, no estaba solo en cuanto al hecho de apoyar algún tipo de evolucionismo. En efecto, "no hubo carencia de evolucionistas o de compañeros de viaje hacia finales de la década de 1830: Baden Powell, William Carpenter, Robert Chambers y Francis Newman serían ejemplos" ${ }^{30}$.

Mientras tanto Augustin Pyrame De Candolle (1778-1841) había defendido que "todas las plantas de un país dado están en guerra unas con otras", lo que fue usado por Charles Lyell en su libro más representativo — Principles of Geology, 1830-1833 - , en sus comentarios

\footnotetext{
27 Cfr. The Structure of Evolutionary Theory, p. 174.

28 Chambers, R., Vestiges of the Natural History of Creation, Churchill, Londres, 1844. Reimpreso en facsímil con una introducción de James A. Secord: The University of Chicago Press, Chicago, 1994.

29 Waters, C. K., "The Arguments in the Origin of Species", en Hodge, J. y Radick, G. (eds), The Cambridge Companion to Darwin, p. 116.

30 Brooke, J. H., "Darwin and Victorian Christianity”, en Hodge, J. y Radick, G. (eds), The Cambridge Companion to Darwin, p. 203. Aun cuando la perspectiva de Chambers fue un precedente de la concepción darwiniana, el libro Vestiges fue una de las razones para retrasar la publicación de la postura evolucionista de Darwin, puesto que no quería ser asociado con algunas de las propuestas del libro "anónimo".
} 
acerca de la lucha competitiva (competitive struggle) como la auténtica causa de la extinción de las especies ${ }^{31}$. Esta idea suena similar a las propuestas de Thomas Malthus que tuvieron influencia sobre Darwin. Pero se trata aquí de Candolle, que fue un botánico ginebrino que resaltó la Botánica tanto fisiológica como clasificatoria. Su trabajo fue el contenido del curso sobre Botánica que Henslow impartió en la Universidad de Cambridge en torno a 1828, que fue seguido por Darwin ${ }^{32}$.

Etienne Geoffroy Saint-Hilaire (1772-1844) fue otro científico en favor de la evolución cuyo trabajo fue conocido por Darwin antes del viaje del HMS Beagle. Lo conoció en la Universidad de Edimburgo, en la Facultad de Medicina, en torno a 1826. Fue a través de Robert Grant, experto en Anatomía comparada ${ }^{33}$. Geoffroy fue uno de los arquitectos principales de la Morfología "idealista" (o transcendental), que "había propuesto el encontrar afinidades estructurales - $\mathrm{O}$ 'unidad de tipo'- entre clases de animales previamente clasificadas como pertenecientes a grupos taxonómicos totalmente separados" 34 .

Alfred Russel Wallace (1823-1913) fue un biogeógrafo y colector de especies que aparece estrechamente asociado con la publicación del volumen El origen de las especies. La razón es que Darwin recibió en 1858 un artículo suyo no publicado donde — según C. Kenneth Waters - "anticipaba muchas de las propias ideas de Darwin sobre la evolución, incluyendo la idea de selección natural" ${ }_{35}$. Pero esto requiere más análisis, puesto que la mayor parte de las ideas darwinianas ya estaban formuladas en su libro inédito de $1844^{36}$. La década siguiente, Wallace publicó un artículo que apoyaba una suerte de evolución orgánica, como sucesión de eventos ramificados (donde proponía que la clasificación habría de ser presentada de una manera genealógica y usando un "árbol” para representar la "divergencia” entre las especies) ${ }^{37}$.

Wallace estaba interesado en la distribución y transmutación de las especies. Más aún, en 1855 pensó que cada especie que llega a existir en coincidencia de espacio y tiempo con otra tiene una especie preexistente estrechamente asociada ${ }^{38}$. Tres años más tarde envió a Darwin un artículo no publicado con ideas similares acerca de la evolución. Esto hizo que Charles Darwin dejase de lado un largo libro en preparación y que escribiese "una síntesis" (abstract), que completó en nueve meses. Así, en noviembre de 1859 publicó ese resumen con el título $O n$ the Origin of Species by Means of Natural Selection.

\footnotetext{
31 Cfr. Lyell, Ch., Principles of Geology, John Murray, Londres, 1830-1833, 3 vols. Reimpreso en facsímil con una introducción de M. J. S. Rudwick, The University of Chicago Press, Chicago, 1990, II, p. 131; y RADICK, G., "Is the Theory of Natural Selection Independent of its History?", en Hodge, J. y Radick, G. (eds), The Cambridge Companion to Darwin, p. 160.

32 Cfr. Sloan, Ph. R., "The Making of a Philosophical Naturalist”, p. 23.

33 Cfr. "The Making of a Philosophical Naturalist", p. 20.

34 Sloan, Ph. R., "The Making of a Philosophical Naturalist”, pp. 20-21.

35 Waters, C. K., "The Arguments in the Origin of Species", en Hodge, J. y Radick, G. (eds), The Cambridge Companion to Darwin, p. 117. Sobre su visión evolucionista, cfr. Wallace, A. R., Contributions to the Theory of Natural Selection, Macmillan, Londres, 1870 (reimpreso por AMS Press, N. York, 1973).

36 En 1844 Charles Darwin escribió sobre Geological Observations on the Volcanic Islands visited during the Voyage of H. M. S. Beagle, que se publicó más tarde en el volumen de Darwin, Ch. y Wallace, A. R., The Evolution by Natural Selection, con un prólogo de Sir Gavin de Beer, Cambridge University Press, Cambridge, 1958. Véase también, a este respecto, la carta de Darwin a su amigo Joseph Hooker, fechada el 11 enero de 1844.

37 Cfr. Wallace, A. R., "On the Law Which Has Regulated the Introduction of New Species", Annals and Magazine of Natural History, v. 16, $2^{\mathrm{a}}$ ser., (1855), pp. 184-196.

38 Cfr. Bowler, P. J., Evolution: The History of an Idea, edición revisada, p. 185.
} 
Aunque el elenco de evolucionistas antes de la publicación del Origin se puede ampliar, el aspecto importante es constatar que había diversos científicos que, o bien trabajando sobre animales o bien estudiando plantas, estaban a favor de algún tipo de evolución. El interés por la transmutación de las especies en esa época no era la tendencia dominante del momento, pero en modo alguno era desconocida antes del viaje de Darwin en el buque de guerra HMS Beagle. Esto es relevante tanto para comprender su enfoque sobre la evolución como para evaluar su revolución intelectual. A este respecto, ya se utilizaba una Metodología comparativa en casos que le eran de interés (p. ej., en Embriología, en Anatomía o en Paleontología) y la utilizaban aquellos que eran afines al evolucionismo.

\subsection{El enfoque de Darwin sobre la evolución: ¿Un “naturalista filosófico”?}

"Naturalista filosófico (philosophical naturalist)" es la denominación que Darwin utiliza para describir su propio enfoque en 1837, pocos meses después de su navegación en el Beagle 39 . Esta posición es diferente de la "Historia Natural" y de la "Filosofía de la Naturaleza" (natural philosophy). En este contexto, Historia Natural tiene un espectro más amplio que un enfoque meramente biológico: incluye Geología, Geografía, costumbres humanas, etc. (como se puede ver en obras como la Histoire Naturelle de Buffon). Aun cuando abarca distintos campos, tales como el estudio geológico de la "Teoría de la Tierra" o la "Historia de la Tierra", algunos trataron de resaltar la Historia Natural en la línea de la tradición de Linneo (las posturas del botánico Carl von Linné). Entonces el sentido de la expresión "Historia Natural” se relaciona con la ordenación sistemática de las plantas (así como de los animales) y el descubrimiento de nuevas especies.

Mientras tanto, la "Filosofía de la Naturaleza" (natural philosophy), al menos en la tradición británica de Isaac Newton —el autor de Philosophiae Naturalis Principia Mathematica-, estaba encaminada hacia la búsqueda de leyes generales en la Naturaleza (principalmente, leyes físicas) y las expresaba mediante fórmulas matemáticas. Darwin quería seguir una ruta distinta, trabajando de modo habitual fuera de estas tradiciones. Inicialmente su búsqueda de nuevas pautas estaba relacionada con los anatomistas comparativos y los geólogos teóricos, y paulatinamente se movió hacia la explicación causal del cambio biológico ${ }^{40}$.

Llama la atención que, para caracterizar su propia posición, Charles Darwin apenas utiliza la palabra "evolución" " En efecto, "aunque en El origen de las especies la última frase dice (en todas las ediciones) que 'evolucionan (evolved) formas inagotables (endless) de las más hermosas y maravillosas que se han dado - y que se dan ahora_-', a Darwin no le gustaba que a su teoría acerca de la transmutación de las especies se le llamase 'Teoría de la Evolución'. (...) Para Darwin — y para muchos otros naturalistas ingleses de su época—, 'evolución' era

\footnotetext{
39 "The law of the succession of types, although subject to some remarkable exceptions, must possess the highest interest to every philosophical naturalist", DARwIN, CH., Journal of Researches into the Geology an Natural History of the Various Countries Visited by H. M. S. Beagle, Colburn, Londres, 1839. Reimpreso en BARretT, P. H. y Freeman, R. B. (eds), The Works of Charles Darwin, Pickering, Londres, 1986, vol. 2, p. 164. Cfr. Sloan, Ph. R., "The Making of a Philosophical Naturalist", p. 17.

40 Cfr. Sloan, Рн. R., "The Making of a Philosophical Naturalist”, pp. 17-18.

41 El análisis del enfoque de Charles Darwin y de su revolución intelectual sigue aquí las líneas trazadas en Gonzalez, W. J., "Towards a New Framework for Revolutions in Science”, Studies in History and Philosophy of Science, v. 27, n. 4, (1996), pp. 607-625; en especial, pp. 618-624. Esto incluye observaciones acerca de la controversia entre el creacionismo de William Paley y el evolucionismo darwiniano.
} 
una palabra ambigua. Evocaba diversas teorías que estaban estrechamente asociadas con la historia de las especies, tanto con un desarrollo individual como con una interpretación progresiva de conjunto acerca de la Historia de la Naturaleza" ${ }^{42}$. En lugar de la expresión "evolución”, prefería “descendencia con modificación" (descent with modification) ${ }^{43}$.

Históricamente, el punto clave es cómo se formó el enfoque de la selección natural. Esta cuestión requiere un análisis cuidadoso del itinerario intelectual que siguió Darwin antes de publicar The Origin of Species ${ }^{44}$. Durante este periodo, que comienza con el famoso viaje del Beagle (1831-1836) y que termina con la impresión del libro Origin (1859), cambió varias veces su concepción sobre este tema. De hecho, aunque introduce una importante novedad conceptual, como resultado de su investigación individual, lo hace en conexión con los científicos de su tiempo y bajo la influencia de los planteamientos de algunos de sus predecesores y contemporáneos.

Al principio, incluso durante la travesía del Beagle ${ }^{45}$, Darwin fue fijista y creacionista en un sentido muy cercano a Charles Lyell. Esta es la posición de Darwin en enero de 1836, cuando el barco está cerca de Nueva Gales del Sur (Australia) ${ }^{46}$. El transformismo aparece en el Red Notebook, que escribió en el transcurso de la última parte del viaje y que continuó en marzo de 1837, cuando ya estaba de vuelta en Gran Bretaña. En sus notas desde la primavera de 1837 hasta el otoño de 1838 adopta dos caracterizaciones sucesivas de hipótesis transformistas: la versión aislacionista y la transformación cuasi-lamarckiana (Notebook C). Más tarde, en los últimos meses de 1838, llega al principio de "selección natural", tras un año y medio pensando sobre la transmutación de las especies. Por tanto, después de haber sido fijista, Darwin se mueve hacia la selección natural en su tercera concepción transformista.

42 Gayon, J., "From Darwin to Today in Evolutionary Biology", en Hodge, J. y Radick, G. (eds), The Cambridge Companion to Darwin, p. 242.

43 Ruse, M., Darwinism and Its Discontents, p. 15.

44 Este caso ha sido estudiado por un dilatado número de especialistas, entre ellos están Himmelfarb, G., Darwin and the Darwinian Revolution, Morton, N. York, 1968; MooreheAD, A., Darwin and the Beagle, Crescent Books, N. York, 1969; Gilson, E., D’Aristote à Darwin et retour, Vrin, París, 1971; Hull, D. L., Darwin and His Critics: The Reception of Darwin's Theory of Evolution by the Scientific Community, Harvard University Press, Cambridge, 1973; Grinnell, G., “The Rise and Fall of Darwin's First Theory of Transmutation”, Journal of the History of Biology, v. 7, (1974), pp. 259-273; Gillespie, N. C., Charles Darwin and the Problem of Creation, The University of Chicago Press, Chicago, 1979; Ruse, M., The Darwinian Revolution, The University of Chicago Press, Chicago, 1979; Ospovat, D., The Development of Darwin's Theory (Natural History, Natural Theology and Natural Selection, 1838-1859), Cambridge University Press, Cambridge, 1981; Sulloway, F. J., "Darwin's Conversion: The Beagle Voyage and its Aftermath", Journal of the History of Biology, v. 15, (1982), pp. 325-396; Templado, J., Historia de las teorias evolucionistas, Alhambra, Madrid, 1982; Bowler, P. J., Evolution: The History of an Idea, University of California Press, Berkeley, 1983; Grinnell, G., "The Rise and Fall of Darwin's Second Theory of Transmutation", Journal of the History of Biology, v. 18, (1985), pp. 51-70; KoHn, D. (ed), The Darwinian Heritage, Princeton University Press, Princeton, 1985; y Hodge, J., “London Notebook Programmes and Projects of Darwin's London Years", pp. 40-68.

Sobre este tema, un libro equilibrado y muy informativo es Castrodeza, C., Teoría histórica de la selección natural, Alhambra, Madrid, 1988. Una amplia bibliografía sobre este tema está compilada en BowLER, P. J., Evolution: The History of an Idea, edición revisada, pp. 365-422. Información bibliográfica adicional se puede encontrar en Hodge, J. y Radick, G. (eds), The Cambridge Companion to Darwin, pp. 424-460.

45 Además de lo que vio durante su larga navegación, Darwin recibió también la influencia de los viajes científicos realizados por otros naturalistas, cfr. Drouin, J.-M., "De Linné à Darwin: Les voyageurs naturalists", en SERRES, M. (ed), Eléments d'histoire des sciences, Bordas, París, 1989, pp. 321-335.

46 Cfr. Gruber, H. E., Darwin on Man: A Psychological Study of Scientific Creativity, Wildwood House, Londres, 1974, p. 438. En la carta a su amigo Joseph Hooker, fechada el 11 de enero de 1844, Darwin reconoce que ha cambiado de parecer y que ha abandonado su opinión original acerca de las especies como inmutables: "At last gleams of light have come, and I am almost convinced (quite contrary to the opinion I started with) that species have not (it is like confessing a murder) immutable". 
Por consiguiente, no llega a su Teoría de la Evolución — dedicada a la selección natural— en un instante, tras leer a Thomas Malthus (1766-1834) en septiembre de $1838^{47}$. No obstante, el libro de este último, titulado Essay on the Principle of Population (1798) ${ }^{48}$, tuvo una influencia apreciable en la noción de "lucha por la existencia" (the struggle for existence) ${ }^{49}$. Pero el cambio conceptual de Darwin no fue sencillo: su enfoque acerca de la idea de selección natural no estuvo completamente maduro hasta 1844, cuando finaliza un ensayo de unas 200 páginas sobre el tema, que amplía en los años 1856-1857. Y el principio de "evolución" no figura en la primera edición de The Origin of Species $^{50}$ : aparece en la sexta edición del libro, que se publicó diez años después (1869) ${ }^{51}$.

Más aún, Darwin no incluye la palabra “evolución” en ninguno de los títulos de los quince capítulos que componen El origen de las especies; y, más tarde, en su famoso libro The Descent of Man (1871), el término evolution no aparece en el título de un solo capítulo. Además, en la breve sinopsis que preparó para cada uno de estos capítulos (treinta y seis, contando con los dos libros), como un sumario tras los títulos de los capítulos, no hay mención a la "evolución". La razón es clara: su novedad intelectual, el cambio conceptual, descansa en la teoría de la modificación de las especies mediante selección natural, y sólo después de muchos años la llama "evolución" 52 . Estos hechos ayudan a entender que el cambio conceptual de Darwin tuvo lugar despacio: desde su fijismo de 1836 a su evolucionismo de 1869 hay un periodo de 33 años.

Después de su cambio conceptual, la evolución orgánica o biológica tiene en el enfoque de Darwin varios componentes centrales. a) Todas las especies que han vivido sobre la faz de la Tierra, incluyendo las actuales, pueden configurar un único árbol de la vida. De este modo, hay especies ancestrales comunes. b) La selección natural es el mecanismo clave - la causa principal o agente - responsable de toda la diversidad sobre la Tierra, lo que incluye una modificación adaptativa y progresiva desde especies ancestrales hasta sus descendientes ${ }^{53}$.

47 Cfr. Hodge, J. y Radick, G., "Introduction", en Hodge, J. y Radick, G. (eds), The Cambridge Companion to Darwin, p. 8; y Waters, C. K., "The Arguments in the Origin of Species", pp. 118-119. Darwin leyó la sexta edición del libro de Malthus, publicada en 1826.

48 Malthus, Th. R., An Essay on the Principle of Population as it affects the Future Improvement of Society, with Remarks on the Speculations of Mr. Godwin, M. Condorcet, and Other Writers, J. Johnson, Londres, 1798. Reimpresa por la University of Michigan Press, Ann Arbor, 1959.

49 Cfr. Bowler, P. J., "Malthus, Darwin, and the Concept of Struggle", Journal of the History of Ideas, v. 37, (1976), pp. 631-650. Desde el punto de vista de la configuración interna de la Teoría de la Evolución, se ve normalmente a Darwin apoyando tres elementos principales: a) la variabilidad en términos de diferencias entre individuos de la misma población; b) una escasez de recursos para el nivel de desarrollo de la población (una influencia malthusiana); y c) la heredabilidad de los rasgos diferenciadores. Siguiendo estos elementos, lo que incluye adaptación es la selección de los más aptos (selection of the fittest) y la descendencia con modificación.

50 "Nowhere in the first edition of the Origin can the phrases 'theory of evolution' or 'principle of evolution' be found, nor even the word "evolution"”, GAYON, J., "From Darwin to Today in Evolutionary Biology", en HodGE, J. y Radick, G. (eds), The Cambridge Companion to Darwin, p. 242.

51 "Now things are wholly changed, and almost every naturalist admits the great principle of evolution", DARWIN, CH., The Origin of Species, The University of Chicago Press, Chicago, 1952, cap. xv, p. 241.

52 De hecho, la palabra "evolución" cambia su sentido y referencia. Antes del evolucionismo, se entendía como lo opuesto a "involución”, relacionadas ambas a un organismo y sus características (que pueden e-volucionar o involucionar); mientras que con Darwin y otros el término "evolución” pasa a significar la modificación de la realidad misma para formar una cosa distinta (una nueva especie), que incluye algún tipo de selección.

Fue un cambio de significado desde "despliegue" (unfolding) a "epigénesis". A comienzos del siglo XIX, varios embriólogos empezaron a usar la palabra "evolución" en el sentido de "epigénesis". Esta acepción epigenética se extendió luego a la Historia de las especies. Spencer fue el filósofo que dio al sentido epigenético su pleno significado en todas las áreas de conocimiento (en torno a la década de 1850).

53 Cfr. Hodge, J. y Radick, G., "Introduction", en Hodge, J. y Radick, G. (eds), The Cambridge Companion to Darwin, p. 3. 
c) La selección sexual es el mecanismo secundario. "Esta era una idea que Darwin había tenido desde el principio: los organismos compiten dentro de las especies por sus congéneres (mates), y de este modo se producen las adaptaciones como la cola del pavo real" ${ }^{54}$.

Dentro del evolucionismo de Darwin, algunas ideas previas acerca de la "evolución" parece que son asumidas de alguna manera: i) el rasgo de complejidad en la Naturaleza, puesto que reconoce "la infinita complejidad de las relaciones entre todos los seres orgánicos"; ii) el supuesto de la variabilidad en la Naturaleza debido a los mecanismos internos (en su caso, biológicos y orientados hacia la selección natural); iii) la característica de una modalidad de progresividad, en la medida en que la lucha por la vida puede producir la supervivencia de los más adaptados (dentro del árbol de la vida, que no es linear en ningún sentido relevante); y iv) el rasgo de un tipo de jerarquía en el mundo natural, que puede surgir de la supervivencia de las formas sofisticadas (esto incluye que formas menos desarrolladas se encaminarán hacia la extinción) ${ }^{55}$.

Donde parece haber tenido éxito Darwin es en presentar la evolución como un hecho más que en argumentar que la selección natural es el mecanismo clave de este proceso ${ }^{56}$. "El argumento acerca del hecho de la evolución no lo separa de su argumento en favor de su mecanismo de evolución; pero, al enfocar hacia el hecho, podemos ver que hay tres estrategias. Primera, Darwin mira hacia el mundo del cuidador de animales y plantas para convencernos de que un cambio significativo puede ocurrir de hecho, y que debemos aceptar la analogía según la cual puede darse un cambio significativo en la Naturaleza y que se da [de hecho]. Segunda, Darwin presenta su mecanismo de selección natural donde se implica que, si está siempre operando un mecanismo tan fuerte y poderoso como éste, ha de haber algún efecto, y este efecto será una inequívoca evolución (full-blown evolution). Tercera, Darwin recorre toda la gama de áreas biológicas de investigación (inquiry), mostrando que se explican mediante evolución y, a la inversa, que ellas apoyan la evolución" ${ }^{57}$.

Sin embargo, comparado con otros biólogos de su época, hay poco cambio en el enfoque de Darwin en cuanto a cuestiones metodológicas relacionadas con la experimentación. A este respecto, se le ve a veces como un aficionado. Más aún, Ruse considera que Darwin tenía “procedimientos de experimentación toscos (crude); después de todo, la Biología entonces era bastante primitiva en estos aspectos, con poco más que un escalpelo y una regla" ${ }^{58}$. Además, en este caso, "especialmente en el Origen, que escribe para un público amplio en lugar de hacerlo para los especialistas" ${ }^{59}$. Pero fue capaz de ver el gran problema de la evolución: la causa final; y ofreció novedades conceptuales para caracterizar la causa final de la evolución de modo naturalista ${ }^{60}$. A este respecto, fue un "naturalista filosófico" (philosophical naturalist).

54 Ruse, M., Darwinism and Its Discontents, p. 17.

55 Algunas de estas ideas se desarrollan en Cunninghan, S., Philosophy and the Darwinian Legacy, University of Rochester Press, Rochester, NY, 1996, pp. 8-12. Cfr. Darwin, CH., The Origin of Species, edición facsímil, Harvard University Press, Cambridge, MA, 1964, pp. 61, 80-81 y 470-471.

56 "Natural selection has been the main but not exclusive means of modification", Darwin, CH., The Origin of Species, facsimile edition, p. 6.

57 Ruse, M., Darwinism and Its Discontents, p. 27.

58 Darwinism and Its Discontents, p. 22.

59 Ruse, M., Darwinism and Its Discontents, p. 22.

60 Algunos autores piensan que la concepción de Darwin puede verse como una perspectiva teleológica, cfr. RICHARDS, R. J., The Meaning of Evolution: The Morphological Construction and Ideological Reconstruction of Darwin's Theory, The University of Chicago Press, Chicago, 1992. Pero habitualmente esto se ve de otra manera: al modo de un mecanismo. 


\subsection{Una revolución intelectual}

¿Ha introducido Darwin una "revolución científica" con su enfoque evolucionista? Esta cuestión depende de manera directa del asunto de cómo se caracterice una "revolución científica". Prima facie la revolución en la Ciencia, entendida ésta como una actividad humana, puede ser conceptual, empírica o heurística. En este profundo cambio científico, puede haber en liza tanto elementos internos (lenguaje, estructura, conocimiento, método, ...) como factores externos (sociales, culturales, ecónomicos, ...).

Ciertamente este problema se ha tratado en extenso en el caso de Thomas Kuhn, que propuso una caracterización inicial de las revoluciones científicas (centrada en el cambio de paradigma) y, más tarde, ofreció una versión revisada (con matrices disciplinares y ejemplares, menos radical en cuestiones de "inconmensurabilidad"), para llegar a una tercera postura de índole lingǘstica (donde la inconmensurabilidad es "local") ${ }^{61}$. Pero sus conocidos planteamientos sobre revoluciones científicas han sido criticados de distintas maneras, tanto por razones filosóficas y metodológicas - conectadas con su aceptación original de posiciones relativistas - como a tenor de consideraciones de Historia de la Ciencia ${ }^{62}$. Dentro de este marco, resulta especialmente relevante la alternativa a las revoluciones científicas propuesta por Paul Thagard.

\subsubsection{La revolución conceptual en un contexto histórico}

Thagard ofrece una perspectiva de las revoluciones en la Ciencia diferente de la postura kuhniana. Presenta una teoría de las revoluciones conceptuales para iluminar algunos casos históricos: el desarrollo por Copérnico de la teoría del sistema solar, la Mecánica newtoniana, la teoría del oxígeno de Lavoisier, la Teoría de la Evolución de Darwin, la Teoría de la Relatividad de Einstein, la Mecánica Cuántica y la teoría geológica de la tectónica de placas ${ }^{63}$. Me parece que es un análisis más sofisticado que la propuesta kuhniana, en la medida en que el foco está ahora en las "revoluciones conceptuales" y que hay una exposición más detallada de los cambios conceptuales en la Ciencia. No obstante, esta perspectiva muestra también diversas deficiencias. Por eso, habría que añadir algunos nuevos elementos para la comparación de la Ciencia real, tal como fue, con esta nueva estructura para las revoluciones científicas ${ }^{64}$.

Aquí el foco de atención está en el análisis de la revolución darwiniana ${ }^{65}$, que aparece en muchas ocasiones en su libro ${ }^{66}$. A mi juicio, requiere una reformulación para estar completamente

61 Cfr. Kunn, Tн. S., The Structure of Scientific Revolutions, The University of Chicago Press, Chicago, 1962 ( $2^{\mathrm{a}}$ ed., 1970); Kunn, Tн. S., "Second Thoughts on Paradigms", en Suppe, F. (ed), The Structure of Scientific Theories, University of Illinois Press, Urbana, 1974 (2a ed., 1977), pp. 459-482; y Kunn, Tн. S., The Road Since Structure. Philosophical Essays, 1970-1993, with an Autobiographical Interview, editado por James Conant y John Haugeland, The University of Chicago Press, Chicago, 2000.

62 En rigor, Kuhn tiene tres etapas filosófico-metodológicas y cada una de ellas ha tenido sus observaciones críticas, que son más intensas respecto de su visión inicial. Cfr. GonZalez, W. J., "Las revoluciones científicas y la evolución de Thomas S. Kuhn”, en Gonzalez, W. J. (ed), Análisis de Thomas Kuhn: Las revoluciones científicas, Trotta, Madrid, 2004, pp. 15-103; y Machamer, P. K., "Las revoluciones de Kuhn y la Historia 'real' de la Ciencia: El caso de la revolución galileana”, en Gonzalez, W. J. (ed), Análisis de Thomas Kuhn: Las revoluciones cientificas, pp. $253-273$.

63 Cfr. Thagard, P., Conceptual Revolutions, Princeton University Press, Princeton, 1992.

64 Cfr. Gonzalez, W. J., "Towards a New Framework for Revolutions in Science”, pp. 607-625.

65 Hay asimismo críticas acerca de la existencia de una "revolución darwiniana". Para Peter J. Bowler, tenemos una "revolución evolucionista" (evolutionary revolution) en lugar de una revolución darwiniana, en la medida en que la idea of "evolución" fue aceptada pronto mientras que la "selección natural" fue reconocida más tarde (durante el siglo XX). Cfr. Bowler, P. J., The Non-Darwinian Revolution. Reinterpreting a Historical Myth, Johns Hopkins University Press, Baltimore, MD, 1988. No obstante, éste no es el análisis más frecuente.

66 Después de A. Lavoisier, Ch. Darwin es el autor más citado en el libro de Thagard: aparece en cuarenta y cinco páginas. Sobre el contexto histórico de Lavoisier, cfr. BenSAUde-Vincent, B., Lavoisier. Mémoires d'une révolution, Flammarion, París, 1993. 
a tono con los hechos históricos que la convirtieron en una revolución conceptual. En otras palabras, la información adicional se usa para mostrar la necesidad de un apoyo histórico más amplio para sostener su posición, puesto que el estudio de la Historia de la Ciencia revela que las revoluciones conceptuales son más complicadas que lo descrito en su libro. (De facto, el propio Thagard reconoce esta complejidad y la necesidad de un modelo mejor ${ }^{67}$ ). Por eso, se añaden algunos comentarios filosóficos para aclarar las revoluciones conceptuales y para conectarlas con el progreso científico. Así, el primer paso aquí es ofrecer algunos puntos clave para la reconstrucción histórica de la aparición de la Teoría de la Evolución, que será seguida por una evaluación filosófica de los cambios conceptuales introducidos por Darwin.

Sin duda, este caso tiene semejanzas con la revolución conceptual de Antoine Lavoisier, porque — según el análisis de Thagard — ${ }^{68}$ la teoría madura de la década de 1780 fue precedida por tres intentos previos (1772, 1774 y 1777), y está claro que ningún científico es una isla: el desarrollo de las ideas científicas se lleva a cabo en un contexto social ${ }^{69}$. En la revolución química, al igual que en la revolución biológica, el cambio conceptual fue el resultado del trabajo teórico y empírico de años, y la revolución no fue algo repentino (un tipo de conversión psicológica kuhniana).

Lavoisier y Darwin no ofrecieron una explicación satisfactoria de sus descubrimientos en un primer momento: ellos reinterpretaron sus observaciones empíricas cuando lograron tener nuevos conceptos. Los dos autores tienen una directa dependencia de sus respectivas épocas, puesto que ambos pertenecen a un ambiente intelectual donde algunos científicos cuentan - hasta cierto punto - con ideas similares (o, al menos, coinciden en rechazar algunas perspectivas científicas importantes); y, al mismo tiempo, ambos trabajan tomando en consideración las contribuciones teóricas y empíricas de sus contemporáneos. Proporcionan una innovación conceptual, añadiendo algo relevante de lo que sus contemporáneos no han sido conscientes y, por tanto, sus contribuciones llegan a ser revolucionarias.

Según Thagard, "la Teoría de la Evolución de Darwin debe ser vista como un reto (challenge) directo para las concepciones creacionistas de sus contemporáneos" ${ }^{70}$. Este trasfondo debería ser analizado en el contexto del clima intelectual del siglo XIX que recibe el autor de The Origin. Aunque el libro destaca la influencia sobre Darwin de varios autores partidarios de la transmutación de las especies (como Erasmus Darwin; Jean Baptiste de Monet, caballero de Lamarck; o Robert Chambers) y Thagard destaca la llamativa influencia de Thomas Malthus sobre Charles Darwin, para completar la imagen de este periodo hace falta resaltar otras influencias que hacen más comprensible el lento cambio conceptual darwiniano.

En efecto, es un hecho histórico que, cuando Darwin está pensando acerca de la "selección natural", hay una tradición intelectual que es diferente del fijismo y que está a favor de una transmutación de las especies (aunque no es la tendencia dominante en este periodo y Darwin contribuyó a hacerla más respetable). Esta tradición tiene una repercusión: cambia

\footnotetext{
67 "I expect someday we will have computational models of reasoning and learning that are rich enough to provide a much more detailed account of the conceptual generation displayed in Darwin's notebooks", THAGARD, P., Conceptual Revolutions, p. 135.

68 Cfr. Thagard, P., Conceptual Revolutions, pp. 39-46.

69 Thagard mismo señala este aspecto en un artículo posterior, que lo aplica a la revolución química: "Lavoisier had numerous teachers, friends, and associates who contributed to the development of his ideas", THAGARD, P., "Mind, Society and the Growth of Knowledge”, Philosophy of Science, v. 61, (1994), p. 636.

70 Thagard, P., Conceptual Revolutions, p. 132.
} 
el modo de pensar sobre el problema que se debate, no sólo en la línea de la selección natural darwiniana - en The Origin —, que incluye la "lucha por la existencia" como un componente, sino también en la perspectiva de la lucha por la vida de Alfred Russel Wallace. Así, las ideas de Darwin no eran impensables para otros científicos de su época y el panorama conceptual respecto de las especies biológicas tiene ciertamente más elementos que el puro contraste entre un creacionista fijista de inspiración teológica (William Paley) y un evolucionista crítico con el creacionismo (Charles Darwin).

De facto, Darwin tiene más semejanzas con sus contemporáneos que lo sugerido por Thagard, y científicos importantes que tuvieron relaciones directas con Darwin no son mencionados en Conceptual Revolutions. Este es el caso de Charles Lyell (1797-1875), cuyo libro The Principles of Geology (1830) tuvo una fuerte influencia sobre Darwin durante la travesía del Beagle ${ }^{71}$. A ambos les disgustaba la interferencia en cuestiones científicas de la ortodoxia de la Iglesia Anglicana, y los dos compartían un interés común por la Geología, que tuvo una repercusión en Darwin, quien consideraba que el problema del origen de las especies era de carácter geológico. La Geología de Lyell conformó el marco esencial de la concepción de Darwin: tomó de Lyell la idea de un cambio continuo en la Naturaleza, si bien Lyell vinculaba esto con una punto de vista de estado uniforme (steady-state), que es claramente diferente de la evolución progresiva ${ }^{72}$.

Existen asimismo ciertas afinidades entre Darwin - al menos en una fase de su herencia intelectual - y algunos autores del siglo XIX, la mayor parte de los cuales no aparecen en el libro de Thagard: son los naturalistas en favor de algún tipo de transformismo, tales como Giovanni B. Brocchi (1772-1826) ${ }^{73}$, Etienne Geoffroy Saint-Hilaire (1772-1844), Christian L. von Buch (1774-1853), Augustin P. De Candolle (1778-1841), Lorentz Oken (1779-1851) o William Yarrell (1784-1856) ${ }^{74}$.

Sucede que Darwin recibe la influencia de varios científicos, inicialmente fijistas y más tarde transformistas, tales como Edward Blyth (1810-1873) ${ }^{75}$ y William B. Carpenter $(1813-1885)^{76}$. Hay otros en favor del evolucionismo que, de alguna manera, están cercanos

71 En el otoño de 1831, Darwin encontró el primer volumen de Principles of Geology de Lyell, cuando el Beagle se estaba preparando para el viaje. En él Lyell daba razones para explicar la falta de acierto de las Escuelas de Geología cuando tratan de la Historia geológica de la Tierra. El segundo volumen de Los principios de Geología, de 1832, que está relacionado con el lamarckismo y la desaparición de las especies, llegó a Montevideo (Uruguay) hacia finales de 1832. El tercer volumen de este libro, donde hay reflexiones sobre las causas del cambio geológico, lo recibió en las Malvinas (Falklands Islands) en la primavera de 1834. Cfr. SLoAn, Pн. R., "The Making of a Philosophical Naturalist", en Hodge, J. y Radick, G. (eds), The Cambridge Companion to Darwin, pp. 25-27. El libro de Lyell, en la medida en que está relacionado con los seres vivos como agentes de la configuración geológica, fue importante para hacer pensar a Darwin sobre cómo surgen las nuevas especies.

72 Cfr. Bowler, P. J., Evolution: The History of an Idea, edición revisada, p. 21.

73 El geólogo histórico italiano Giovanni B. Brocchi "explained the extinction of species as [being] due to the exhaustion of a finite quantity of life force. On the Brocchian view, species extinction was thus dependent on internal causes, on analogy with the eventual extinction of a vegetative lineage propagated from an apple tree", SloAn, PH. R., "The Making of a Philosophical Naturalist", p. 31.

74 Cfr. Hodge, J., "London Notebook Programmes and Projects of Darwin's London Years”, pp. 51,54 y 61.

75 "Several naturalists have been credited with anticipating the discovery of natural selection, principally, William Charles Wells, Patrick Matthew, and Edward Blyth (...). The notebooks confirm the fact that there was no crucial input from these sources, and it is doubtful if any of these so-called precursors of selectionism anticipated the true spirit of Darwin's theory", Bowler, P. J., Evolution: The History of an Idea, edición revisada, p. 165.

76 "St. George Jackson Mivart claimed (...) that resemblances among various branches of evolution defy natural explanation $(1871 ; \ldots)$. Mivart insisted that such parallel developments must result from predispositions to evolve in certain directions imposed on life by its Creator. The physiologist William Benjamin Carpenter tried to substantiate this belief on a smaller scale by demonstrating what appeared to be regular patterns of evolution in shells of minute sea creatures, the Foraminifera (1888)", Bowler, P. J., Evolution: The History of an Idea, edición revisada, p. 225. 
a Darwin, tales como Thomas H. Huxley (1825-1895) o Herbert Spencer (1820-1903). Estos factores históricos son relevantes para esta revolución científica: el conjunto completo de la revolución darwiniana es más multifacético e intrincado que la mera controversia con una modalidad específica de creacionismo (el fijismo del tipo desarrollado por Paley) ${ }^{77}$.

Al mirar el contexto histórico de Darwin, lo que se ve es una abigarrada atmósfera intelectual en lugar de un panorama uniforme: por una parte, la presencia de una tendencia fijista que se encuentra en científicos relevantes (G. Cuvier, R. Owen ${ }^{78}$, W. Whewell, J. L. R. Agassiz, ...), con importantes diferencias entre sus posiciones; $\mathrm{y}$, por otra parte, hay también un grupo de autores con actitud favorable hacia alguna versión de transformismo (bien sea creacionista o no), tales como J. B. de Lamarck, G. B. Brocchi, E. Geoffroy, R. Chambers, A. de Candolle, Ch. L. von Buch $^{79}$, St. George Jackson Mivart ${ }^{80}$, H. Spencer, o A. R. Wallace.

Claramente, la revolución darwiniana pertenece al segundo grupo: es una revolución conceptual desde el punto de vista del rechazo del fijismo; y su innovación principal se encuentra en el descubrimiento de un mecanismo particular: la selección natural, que será más tarde la piedra de toque de su caracterización de la "evolución". Thagard, sin embargo, enfoca la cuestión desde la perspectiva de la controversia con la "hipótesis creacionista", en lugar de resaltar la revolución conceptual realizada por Darwin al rechazar el fijismo en Biología —y, por tanto, al introducir la transmutación de las especies de acuerdo con la selección natural-. Así, su esquema histórico habría de ser completado de manera más precisa ${ }^{81}$.

Obviamente, no hay duda que El origen de las especies y, en general, la postura darwiniana acerca de la evolución es de facto incompatible con dos formas de creacionismo: el fijista estricto, donde las especies creadas de manera separada no pueden dar lugar a una nueva - hay sólo un cambio hacia nuevas variedades-, puesto que el diseño biológico estaría completamente prefigurado; y el fijista moderado, donde el Creador pudo tener una intervención más o menos frecuente para generar nuevas especies. Ninguno de estos dos casos encaja con la evolución biológica por selección natural ${ }^{82}$.

Sin embargo, el evolucionismo es compatible con teorías biológicas que, inspiradas en la idea de "creación", aceptan la presencia de leyes biológicas y de tendencias puestas inicialmente en la Naturaleza por el Creador, de modo que las nuevas especies pueden aparecer siguiendo los mecanismos de selección natural (como también otros mecanismos de cambio biológico que puedan ser descubiertos). Esta posibilidad, que Thagard admite que no contradice la posición de

\footnotetext{
77 Este contexto histórico no afecta a la originalidad de su innovación conceptual, puesto que Darwin no tomó de un autor anterior la idea de selección natural como mecanismo evolutivo.

78 "Owen did not accept natural selection and wrote such a bitterly critical review of the Origin of Species that many historians have dismissed him as an outright opponent of evolution. There is still some debate over the true state of Owen's opinions on this score", Bowler, P. J., Evolution: The History of an Idea, edición revisada, p. 133.

79 L. von Buch escribió sobre la flora de las Islas Canarias (Physikalische Beschreibung der Canarische Inseln, 1825), y es citado en la correspondencia entre A. R. Wallace y Ch. Darwin de 1860.

80 St. George Jackson Mivart fue "a Catholic zoologist who admitted the evolution of organic forms and the existence of natural selection, but opposed Darwin in two points: first, Mivart believed that evolution occurred by sudden changes; second, he thought that the major evolutionary factor was an internal tendency to vary in a given direction, rather than natural selection alone", GAYON, J., "From Darwin to Today in Evolutionary Biology", p. 243.

81 Cfr. Thagard, P., Conceptual Revolutions, pp. 131-135.

82 Además de esta incompatibilidad, hay otra diferencia en cuanto al enfoque: las posturas de Darwin están relacionadas con especies existentes en lugar de guardar relación con la cuestión de cuál fue el origen mismo; es éste un asunto que esas posiciones consideran básico.
} 
Darwin $^{83}$, debería llevarnos a tratar el problema en términos más cautos que lo hecho en el libro Conceptual Revolutions ${ }^{84}$.

Thagard evita duplicar las excelentes narrativas que han ofrecido los historiadores de la Ciencia. El énfasis está en articular una nueva perspectiva cognitiva de las revoluciones científicas. Pero, respecto de la caracterización de la teoría que es abandonada tras la revolución, hay una notable diferencia entre las presentaciones de las revoluciones de Lavoisier y de Darwin. En el caso de la Química, la teoría aparece como completamente desarrollada y la teoría del flogisto de Georg Stahl puede ser vista como una competidora seria para la teoría del oxígeno de Lavoisier; mientras que, en el caso de la Biología, la situación resulta por completo diferente: junto a Darwin el libro incluye otra teoría, pero no parece que sea en modo alguno un competidor real. La tabla 6.1. muestra este fenómeno de una manera muy expresiva: en Darwin hay 15 elementos de prueba (pieces of evidence), 3 hipótesis principales, 3 hipótesis auxiliares y 7 hechos ${ }^{85}$; mientras que la otra posición —que Thagard llama "hipótesis creacionista" - sólo cuenta con una única proposición. Si volvemos sobre las proposiciones de entrada en el ejemplo de Lavoisier (la tabla 4.1.) ${ }^{86}$, hay 6 hipótesis en favor del oxígeno y también 6 hipótesis para el flogisto.

Para comprender la llamativa diferencia entre la presentación que hace Thagard de la revolución química y la revolución biológica, hay varias posibilidades, de las cuales parecen ser las principales: 1) que el creacionismo considerado (de William Paley) fuese en efecto una teoría científica pobre; 2) que el debate debiera ser reformulado de una manera diferente. Así, en lugar de comparar la posición evolucionista con una concepción teológica (como la Teología Natural de Paley), el evolucionismo de Darwin debería ser comparado con otra postura científica, como el fijismo de Georges Cuvier (que defiende que los organismos basados en la semejanza incluyen especies fijas) ${ }^{87}$.

Es de sobra conocido que Darwin criticó el "creacionismo" de su época. Además, el evolucionismo y el creacionismo (actualizado hace algún tiempo en la posición del "diseño inteligente" [intelligent design]) ${ }^{88}$ suelen ser presentados como posturas antitéticas. Thagard descansa en esta contraposición para elaborar su alternativa. Pero también reconoce como hecho histórico que Darwin no estaba en contra de la idea de creación, en la medida en que "la sexta edición de Origin — en su elocuente párrafo final— contiene una referencia al Creador que no estaba en la primera edición" ${ }^{89}$. Y la sexta edición es especialmente importante puesto que ahí utiliza el término "evolución”, que no aparece en la primera edición.

83 Cfr. Thagard, P., Conceptual Revolutions, p. 136.

84 A este respecto, cfr. Bowler, P. J., Evolution: The History of an Idea, edición revisada, pp. 169-170.

85 Cfr. Thagard, P., Conceptual Revolutions, p. 143.

86 Cfr. Conceptual Revolutions, p. 83.

87 Entre los libros de Cuvier figura Le Règne animal distribué d'après son organization, publicado en 1817, que tuvo una repercusión muy importante en su época.

88 Cfr. Bene, M., Darwin's Black Box: The Biochemichal Challenge to Evolution, Free Press, N. York, 1996. Esta postura tiene numerosos críticos, entre ellos figura F. J. Ayala, que sigue una ruta de objeciones distinta a la habitual. Sostiene que la concepción del diseño inteligente es la que no resulta compatible con el creacionismo, puesto que achacaría directamente al Creador aquellos defectos de diseño biológico que existen actualmente. Considera, en cambio, que el darwinismo sí resulta compatible con la idea de un Dios creador. Cfr. AyalA, F. J., Darwin and Intelligent Design, Fortress Press, Minneápolis, MN, 2006.

89 Thagard, P., Conceptual Revolutions, p. 136. 
Acerca de la segunda posibilidad - el reformular las posiciones del debate de una manera diferente-, cabe ofrecer varios argumentos teoréticos. Hasta cierto punto se basan en ideas del propio Thagard. Implícitamente, acepta que el creacionismo y el evolucionismo son compatibles cuando asevera que hoy "los creacionistas que nieguen la evolución biológica se encuentran en los lindes (on the fringes) de la Ciencia" ${ }^{90}$. El creacionismo es entonces una concepción filosófica o teológica — según sea el marco de reflexión utilizado — en lugar de una postura científica; por esta razón, es posible ser creacionista y evolucionista al mismo tiempo, puesto que pertenecen a dos niveles de análisis diferentes ${ }^{91}$.

Desde este punto de vista, la dicotomía entre "selección natural" y "creación divina" no es correcta, debido a que la selección natural puede ser el resultado de la creación divina. De nuevo, esto es señalado por Thagard: "uno siempre puede mantener que fue Dios quien creó el universo con leyes que, finalmente, dieron lugar a la selección natural y la evolución biológica" ${ }^{92}$. Así, lo que realmente excluye es una concepción histórica de creacionismo empapada de fijismo (la teoría de Paley de 1802) en lugar de excluir la compatibilidad entre creacionismo y evolucionismo, en la medida en que la primera es una opción filosófica (o, en su caso, teológica) y la última es una posición científica.

\subsubsection{Consideraciones filosóficas}

Filosóficamente, tanto la alternativa construida por Darwin contra el fijismo biológico como el tiempo que empleó en elaborar su propia posición pueden ser presentados como un caso muy ilustrativo de revolución conceptual. A mi juicio, la reconstrucción de su itinerario intelectual - principalmente para llegar a la "selección natural" como mecanismo biológico-y la interrelación con otras contribuciones de su época, pueden enseñarnos varias cosas para una perspectiva general acerca de las "revoluciones conceptuales" en la Ciencia.

1) En principio, los nuevos conceptos científicos, aun cuando introducen novedad no son, en cuanto tales, completa y radicalmente nuevos. Esto es así en la medida en que hay ideas anteriores o contemporáneas que son compatibles con los nuevos conceptos y que nos ayudan a aceptarlos (o, al menos, que los hacen más aceptables, cuando todavía está en vigor otra tradición científica —o "programa de investigación”-). 2) El cambio conceptual requiere un tiempo de maduración — no es algo "instantáneo"-, puesto que necesita un soporte sólido — teórico y empírico - antes de poderse llevar a cabo la sustitución de la antigua teoría por la nueva.

3) La justificación de los nuevos conceptos no se debería hacer sólo mediante la comparación con los conceptos antagónicos (en este caso, el fijismo basado en Natural Theology, de W. Paley), sino considerando también posiciones cercanas al autor revolucionario, aunque esas posturas pudieran no ser las dominantes en ese periodo. Así, algunas revoluciones científicas podrían ser menos "revolucionarias" de lo que aparecen prima facie ${ }^{93}$. La revolución científica

\footnotetext{
90 Conceptual Revolutions, p. 132.
}

91 Muchos biólogos asumen esta compatibilidad entre estos dos niveles de análisis en sus vidas ordinarias.

92 Thagard, P., Conceptual Revolutions, p. 136. Periódicamente hay científicos que aceptan perspectivas en sintonía con estas líneas, tal como hace Francis S. Collins: "there is nothing inherently in conflict between the idea of a creator God and what science has revealed", Collins, F., The Language of God, Free Press, N. York, 2006 , p. 81.

93 Esta es una de las razones por las que se ha discutido la cuestión misma de un "revolución" introducida por Darwin, cfr. Ruse, M., Darwinism and Its Discontents, pp. 5-6 y 23-24. 
requiere novedad conceptual, pero esto puede surgir de una modificación de otros conceptos que ya están en uso por otros autores. (Y es también posible que diversos científicos, trabajando cada uno por su cuenta, puedan descubrir conceptos muy cercanos, tal como sucedió - hasta cierto punto - con Wallace y Darwin, o incluso que logren alcanzar conceptos completamente compatibles y convergentes, como aconteció con Newton y Leibniz).

4) Un punto clave del nuevo sistema conceptual es su nexo con la realidad y su intento de captar esa adecuación con la realidad (y esto requiere que sea más cercano que sus competidores a la información disponible del mundo), porque los sistemas conceptuales tienen la realidad como su último asidero. Así, los conceptos no son puras "construcciones" o meras "representaciones mentales", sino que son elementos intelectuales orientados a dominar la realidad con un nivel de fiabilidad mayor que cualquiera de sus posibles alternativas.

Resulta particularmente interesante que Thagard insista en Darwin como realista ${ }^{94}$. Sus sucesivos intentos de innovar un sistema conceptual para captar el transformismo biológico pueden ser entendidos en clave realista: los conceptos tienen un carácter cognitivo y buscan conocer la realidad tal como es. Así, los conceptos captan aspectos reales del mundo biológico, y el cambio en favor de conceptos nuevos se hace pensando en cómo corregir nuestro conocimiento de esa realidad (para conocer más elementos o para conocerlos mejor). Por tanto, los conceptos están bajo revisión, pero tienen una dimensión objetiva basada en la realidad misma que se posee de manera intelectual. El cambio conceptual tiene un componente progresivo: incrementa nuestro conocimiento del mundo, no sólo desde un punto de vista cuantitativo sino también desde una perspectiva cualitativa.

A través del cambio conceptual hay una innovación que contribuye al progreso en la Ciencia. Esta mejora no es un avance puramente conceptual, puesto que las revoluciones se hacen en la Ciencia mirando hacia el dominio intelectual de lo real, lo que abre la puerta a nuevas prácticas: la realidad —el mundo tal como es — tiene la última palabra para aceptar o rechazar nuevos conceptos. Dentro de esta estructura, el progreso en la Ciencia no es ni pura continuidad, como pensaban los neopositivistas, ni una sucesión de paradigmas inconmensurables, como Kuhn sugirió en la primera versión de su propuesta metodológica ${ }^{95}$.

Aun cuando Thagard evita los excesos de los neopositivistas y de Kuhn, puesto que está más cercano a la Historia de la Ciencia y describe los cambios conceptuales de manera más cuidadosa, su nueva perspectiva cognitiva es todavía defectuosa debido a la noción de "concepto". Tal como he resaltado ${ }^{96}$, hay un elemento objetivo en los conceptos, que hace inteligible el progreso científico y deja de lado el esquema reductivo de los neopositivistas lógicos (que confunde el plano del sentido, central para el significado, con lo que debería ser el terreno de la verdad, haciendo muy difícil la revisión histórica de los conceptos en el proceso

94 Cfr. Thagard, P., Conceptual Revolutions, p. 149.

95 Sobre la noción de "progreso" en la Ciencia, cfr. Gonzalez, W. J., "Progreso científico, Autonomía de la Ciencia y Realismo", pp. 91-109. El progreso científico requiere al menos la interrelación de los niveles de la Ciencia semántico, epistemológico y metodológico. Véase también Gonzalez, W. J., "The Philosophical Approach to Science, Technology and Society", en Gonzalez, W. J. (ed), Science, Technology and Society: A Philosophical Perspective, Netbiblo, A Coruña, 2005, pp. 3-49.

96 Sobre las características de los "conceptos", cfr. GonZalez, W. J., "El empirismo moderado en Filosofía Analítica: Una réplica a P. F. Strawson”, en Falguera, J. L., Zilhão, A. J. T., Martínez, C. y SagüIllo, J. M. (eds), Palabras y pensamientos: Una mirada analítica, Publicaciones Universidad de Santiago, Santiago de Compostela, 2003, pp. 207-237; en especial, pp. 230-233. 
cognitivo para incrementar nuestro conocimiento) al igual que la estructura relativista de las revoluciones científicas kuhnianas (que transforma el avance de los conceptos científicos en una tarea psicosociológica, donde la racionalidad de la Ciencia cede el paso a una posición historista que no garantiza la conmensurabilidad de las teorías).

Acierta Thagard con su nueva perspectiva cognitiva cuando destaca el papel de los conceptos en la revoluciones científicas. Pero su visión de las revoluciones conceptuales tropieza a la hora de caracterizar qué es un "concepto", pues lo reduce a "representación mental" en lugar de aceptar una dimensión objetiva de índole cognitiva ${ }^{97}$. Esta limitación afecta a su descripción de los cambios conceptuales y debilita su alternativa a las revoluciones científicas kuhnianas. (Sucede, además, que la postura de Kuhn sobre los conceptos ha atraído la atención de los autores situados dentro del enfoque cognitivo) ${ }^{98}$.

Indudablemente, los conceptos son más que representaciones mentales de la realidad: buscan captar objetivamente la realidad en cuanto tal, aun cuando sea desde una perspectiva que no permite un conocimiento exhaustivo ${ }^{99}$. Así, el progreso científico se debe también a la inteligibilidad de la realidad y los conceptos atienden a la variabilidad de los procesos reales. La realidad tiene entonces un papel destacado, lo que en el caso de la Teoría de la Evolución ha sido sugerido por John Maynard Smith: "fueron de hecho las similaridades entre los diferentes géneros — $\mathrm{O}$ de especies - de animales y plantas, semejanzas que hacen posible una clasificación natural, aquello que condujo a Darwin, Lamarck y otros a buscar una explicación evolutiva del origen de las especies, al igual que fue el hecho de la adaptación lo que les sugirió a ellos teorías en cuanto a cómo tuvo lugar la evolución" ${ }^{100}$.

A tenor de este análisis de las revoluciones conceptuales, que combina argumentos históricos y filosóficos, parece claro que las posturas de Thagard requieren algunas revisiones. Una cuestión clave es que el cambio conceptual en la Ciencia es más complicado que lo expuesto en Conceptual Revolutions; y, por tanto, hay una dificultad intrínseca para obtener un algoritmo que sea capaz de dominar la diversidad de detalles del cambio conceptual. De hecho, el libro ofrece un esquema de un cambio conceptual revolucionario en lugar de una completa descripción de una revolución conceptual real. Así, el modelo computacional para la evaluación de teorías - el programa conexionista de ordenador llamado ECHO — sólo puede manejar algunos aspectos del cambio conceptual revolucionario: es una presentación esquemática de una compleja interrelación de factores que intervienen en una revolución conceptual. La reconstrucción histórica de los casos como la revolución darwiniana suscita un conjunto de problemas para una teoría de la coherencia explicativa desarrollada mediante un modelo computacional de evaluación de teorías.

\footnotetext{
97 Después de publicar Conceptual Revolutions, Thagard ha continuado insistiendo en los conceptos como representaciones mentales cuando explica la adquisición de nuevos esquemas científicos. A su juicio, las nuevas representaciones mentales nos permiten comprender la revolución científica y apreciar la mayor coherencia explicativa de la nueva teoría (tal como en el caso de la teoría del oxígeno de Lavoisier). Cfr. Thagard, P., "Mind, Society and the Growth of Knowledge", pp. 637-638.

98 Cfr. Barker, P., Chen, X. y Andersen, H., "Kuhn on Concepts and Categorization”, en Nickles, Th. (ed), Thomas Kuhn, Cambridge University Press, Cambridge, 2003, pp. 212-245; y Nersessian, N. J., "Kuhn, Conceptual Change, and Cognitive Science", en Nickles, Th. (ed), Thomas Kuhn, pp. 178-211.

99 Cfr. Gonzalez, W. J., "El empirismo moderado en Filosofía Analítica: Una réplica a P. F. Strawson", en Falguera, J. L., Zilhão, A. J. T., Martínez, C. y Sagüillo, J. M. (eds), Palabras y pensamientos: Una mirada analítica, pp. 230-233.

100 Maynard Smith, J., The Theory of Evolution, Cambridge University Press, Cambridge, 1993, p. 38.
} 


\subsection{Otros evolucionismos}

Junto al enfoque de Darwin hay otras versiones de evolucionismo. Algunas de ellas están orientadas hacia "el árbol de la vida", mientras que otras insisten en el tipo de proceso de la evolución. Desde la publicación de The Origin of Species, un amplio número de biólogos han estado convencidos de la evolución como hecho. Pero un asunto distinto ha sido cómo entender la estructura de la vida y la aceptación de la selección natural como mecanismo de evolución. "Mayr enumera cinco tipos de teorías de la evolución que estuvieron funcionando entre 1860-1940: Geoffroyism, ortogénesis —incluido el lamarckismo original—, saltacionismo - incluida la teoría de la mutación-, el darwinismo, y el neo-darwinismo. Señala que 'la mayor parte de los autores entre 1860 y 1940 adoptaron una mezcla de estas teorías'. Peter Bowler añade otra más: la evolución teísta, donde el proceso es dirigido por Dios" ${ }^{101}$.

\subsubsection{Del "árbol de la vida" al proceso de la evolución}

Había dos ideas centrales en The Origin of Species: el árbol de la vida y la selección natural (entendida como proceso evolutivo). En relación con la primera idea, "las especies cambian con el tiempo, con algunas especies que se van a extinguir mientras que otras van a continuar o se dividirán entre múltiples especies de descendencia. Darwin ilustró la pauta resultante como ramas de un árbol que divergen. La segunda idea, la selección natural, ofrecía el dar cuenta de cómo pueden cambiar las especies. A tenor de esta idea, las especies cambian mediante un proceso de selección afín al método de la selección artificial que los cuidadores utilizaban para modificar variedades domesticadas de plantas y de animales" ${ }^{102}$.

Ambas ideas —el árbol de la vida y la selección natural — fueron cuestionadas, de uno u otro modo, por numerosos científicos. Históricamente, "muchos de los evolucionistas del siglo XIX — y de comienzos del siglo XX—, cuando no la mayor parte de ellos, permanecieron netamente escépticos ante la selección natural" ${ }^{103}$. Esto quiere decir que la crítica al darwinismo no vino sólo de fuera de la tendencia evolucionista, puesto que se dio el caso entre los partidarios de las distintas versiones del evolucionismo de debatir temas como la variación y el papel de la selección natural ${ }^{104}$.

Un punto inicial de crítica a esta concepción evolucionista fue reconocido por el propio Darwin: su Teoría de la Evolución no proporciona una exposición del origen de las variaciones. En esta primera esfera de controversia, su postura estaba en favor de cambios aleatorios, pequeños y continuos. Para la posición de la "ortogénesis", hay dos opciones sobre cómo ocurrieron los cambios, pero en ambas las variaciones están dirigidas en lugar de ser parte de un proceso aleatorio: a) las variaciones como producto de una suerte de élan vital —un impulso interno del organismo mismo- que dirigiría la formación de especies; y b) las variaciones como resultado de influencias ambientales, tales como el clima o el suministro de comida. Estas opciones, que incluyen el trabajo posterior de Theilhard de Chardin, fueron

\footnotetext{
101 Cunninghan, S., Philosophy and the Darwinian Legacy, p. 26. Cfr. Mayr, E., "Prologue: Some Thoughts on the History of the Evolutionary Synthesis", en Mayr, E. y Provine, W. B. (eds), The Evolutionary Synthesis: Perspectives on the Unification of Biology, Harvard University Press, Cambridge, 1980, pp. 5-6; y BowLER, P. J., The Eclipse of Darwinism: Anti-Darwinian Evolution Theories in the Decades around 1900, Johns Hopkins University Press, Baltimore, 1983, p. 7.

102 Waters, C. K., "The Arguments in the Origin of Species", pp. 117-118.

103 "The Arguments in the Origin of Species", p. 123.

104 El análisis sigue aquí a Cunninghan, S., Philosophy and the Darwinian Legacy, pp. 27-30.
} 
decayendo de modo gradual como teorías competidoras relevantes, debido a la ausencia de pruebas científicas convincentes.

Como segunda esfera de controversia sobre el darwinismo aparece el nexo preciso entre las variaciones y el proceso de formación de las especies ${ }^{105}$. Según Darwin, la selección natural opera para mantener las variaciones favorables y eliminar las desfavorables. Esta concepción puede ser criticada a tenor de la necesidad de tener algo más para explicar la complejidad biológica. Thomas Henry Huxley y Francis Galton — sobrino de Darwin — criticaron la opción darwiniana, y apoyaron grandes variaciones de tipo discontinuo para explicar la formación de nuevas especies. "Huxley siempre pensó que las nuevas especies surgían por 'saltos' [saltations] (grandes cambios repentinos)" ${ }^{106}$. Además de él y Galton, los biólogos que defendieron una imagen del origen de las especies no gradual, con saltos, incluye a la mayoría de los primeros mendelianos: William Bateson, Hugo De Vries, Lucien Cuénot, Wilhelm Johannsen y — de alguna manera, más tarde — Richard Goldschmidt ${ }^{107}$.

Lejos de haber sido olvidada, en décadas recientes esta perspectiva ha ganado nuevos partidarios. Esta "importante postura alternativa de descendencia con modificación está representada por la 'teoría del equilibrio puntuado' (theory of punctuated equilibrium) de Niles Eldredge y Stephen Jay Gould, donde se postula que el aumento preponderante de cambio evolutivo está concentrado durante el evento de la especiación o 'cladogénesis' (cladogenesis) ${ }^{108}$. Eldredge y Gould no proponen que el cambio que lleva a las nuevas especies sea tan rápido que ocurra en una sóla generación (como algunos genetistas creían a comienzos del siglo XX)" ${ }^{109}$. Teniendo en cuenta los datos paleontológicos, piensan que las especies evolucionan más rápidamente cuando emergen a partir de dividirse (splitting) que lo hacen más tarde. Esta postura altera la pauta darwiniana general del árbol genealógico.

Las hipótesis adaptativas aseveran que la selección natural desempeñó un específico papel causal en la evolución biológica. Esto lleva hacia el debate en torno al "adaptacionismo", puesto que Stephen Jay Gould y Richard Lewontin "criticaron a los biólogos por adherirse de manera acrítica a las narraciones imaginarias ('just-so' stories) acerca de la selección natural $^{110}$. Ellos fueron tan lejos como proponer que el adaptacionismo es infalsable (unfalsifiable); puesto que la derrota de una hipótesis adaptativa le permite inventar otra, no hay un modo de refutar el adaptacionismo como una propuesta acerca de la Naturaleza. Gould y Lewontin también defendieron una postura 'pluralista' sobre el proceso evolutivo, según la cual la selección natural es una importante influencia sobre el rasgo (trait) evolución, pero no es la única" ${ }^{111}$.

\footnotetext{
105 Respecto del proceso de formación de especies, es particularmente influyente el planteamiento de E. Mayr donde, como pauta habitual, pide un periodo de aislamiento geográfico entre las poblaciones involucradas.

106 Brooke, J. H., "Darwin and Victorian Christianity”, p. 205.

107 Cfr. Gayon, J., "From Darwin to Today in Evolutionary Biology”, p. 247.

108 Cfr. Eldredge, N. y Gould, S. J., "Punctuated Equilibria: An Alternative to Phyletic Gradualism", en Schopf, T. J. M. (ed), Models in Paleobiology, Freeman, San Francisco, CA, 1972, pp. 82-115.

109 Gayon, J., "From Darwin to Today in Evolutionary Biology", p. 247.

110 Cfr. Gould, S. J. y Lewontin, R. C., "The Spandrels of San Marco and the Panglossian Paradigm: A Critique of the Adaptationist Programme", Proceedings of the Royal Society of London, B 205, (1979), pp. 581-598. Reimpreso en Sober, E. (ed), Conceptual Issues in Evolutionary Biology, $3^{\mathrm{a}}$ ed., The MIT Press, Cambridge, 2006, pp. 79-97.

111 Sober, E., "Metaphysical and Epistemological Issues in Modern Darwinian Theory”, en Hodge, J. y RAdick, G. (eds), The Cambridge Companion to Darwin, pp. 282-283.
} 
Otra fuente de críticas es el nivel de cambio biológico ${ }^{112}$. Esta tercera esfera de controversia es "que la evolución es algo que no sólo ocurre al nivel de las especies, sino que también se da en otros niveles" "113. Se basa en una observación común en Paleontología (p. ej., los diversos órdenes de mamíferos). Además de la distinción entre especies o géneros (genera) y nivel superior, podemos considerar los organismos a diversos niveles de existencia, principalmente como individuo y grupo. Puede darse una diferencia en la pauta de la vida que incluye "una confrontación potencial entre dos niveles, el individuo y el grupo. (...) Nadie quiere negar que la ‘selección de grupo' (por usar el nombre común para llevar a cabo la selección para la adaptación de grupo) puede existir y probablemente exista. (...) Generalmente, los evolucionistas practicantes (practicing evolutionists) no quieren conceder a la selección de grupo un papel muy significativo" ${ }^{114}$.

Más recientemente se ha llamado la atención sobre otro problema relevante para el evolucionismo darwinista. Es el cuarto en la lista de controversias y está relacionado con la configuración del "árbol de la vida". La cuestión versa sobre el resultado del cambio biológico, en la medida en que la evolución comporta varios procesos que hacen sea problemática la "noción de linajes de especies independientes" (notion of independent species lineages) ${ }^{115}$. El debate es sobre la filogenia del entero mundo viviente. Este reto, planteado por Carl Woese ${ }^{116}$, afecta a la visión darwiniana clásica acerca de la genealogía de las especies, de los seres vivientes.

\subsubsection{Evolucionismo en torno a la "selección natural"}

Ciertamente muchos simpatizantes del evolucionismo darwiniano "aceptaron las ideas de Darwin sobre la transmutación y la común descendencia sin comprometerse con la selección natural. Esto permaneció como actitud habitual hasta bien entrado el siglo XX" ${ }^{117}$. Así, históricamente la mayoría de los ataques al darwinismo entre el libro principal (1859) y la década de 1930 estuvieron enfocados sobre la existencia misma de la selección natural en cuanto hecho. Este episodio es conocido como el "eclipse del darwinismo": la crítica a la idea según la cual la selección natural es una causa —en sentido ontológico — del cambio evolutivo adaptativo ${ }^{118}$.

Parece innegable que se suscitaron un buen número de dificultades relevantes para la aceptación de la selección natural como principal proceso de la evolución ${ }^{119}$. 1) La ausencia en

\footnotetext{
112 Hay algunos autores que apoyan la evolución sin selección o consideran que la selección natural es sólo una causa secundaria: ven la evolución como un resultado de un tipo de regulariedades relacionadas con el incremento de entropía. Cfr. Brooks, D. y Wiley, E. Evolution as Entropy, The University of Chicago Press, Chicago, 1986; Wicken, J., Evolution, Thermodynamics and Information, Oxford University Press, N. York, 1987; y WiLEY, E. O., “Entropy and Evolution”, en Weber, B. H., Depew, D. J. y Sмith, J. D. (eds), Entropy, Information and Evolution, The MIT Press, Cambridge, MA, 1988, pp. 173-188.

A este respecto, cfr. MARCos, A., "Información y Entropía", Arbor, v. 140, n. 549, (1991), pp. 111-135; MARCos, A., "Información y evolución”, Contextos, v. 9, n. 17-18,(1991), pp. 197-221; y MARcos, A., "Neodarwinismo, Termodinámica y Teoría de la Información: Estado de la cuestión”, Estudios Filosóficos, v. 41, n. 117, (1992), pp. 215-252.

113 Gayon, J., "From Darwin to Today in Evolutionary Biology", p. 246.

114 Ruse, M., Darwinism and Its Discontents, pp. 145-146.

115 Gayon, J., "From Darwin to Today in Evolutionary Biology", p. 248.

116 Cfr. Woese, C. R., Kandler, O., y Wheelis, M. L., "Towards a Natural System of Organisms: Proposal for the Domains Archaea, Bacteria, and Eucarya", Proceedings of the National Academy of Science, v. 87, (1990), pp. 4576-4579; y Woese, C. R., "Default Taxonomy: Ernst Mayr's View of the Microbial World", Proceedings of the National Academy of Science, v. 95, (1998), pp. 11043-11046.

117 Waters, C. K., "The Arguments in the Origin of Species", p. 137.

118 Cfr. Bowler, P. J., The Eclipse of Darwinism: Anti-Darwinian Evolution Theories in the Decades around 1900, Johns Hopkins University Press, Baltimore, 1983.

119 El análisis se desarrolla en GAYON, J., "From Darwin to Today in Evolutionary Biology”, pp. 250-254.
} 
El origen de las especies de una teoría de la transmisión hereditaria de los caracteres. 2) Un enfoque cuantitativo (variación, índice de supervivencia, tasa de reproducción, papel del cambio, ...) para mostrar una serie de complejidades distantes de las expectativas de Darwin, que llevaron a los especialistas biométricos (Karl Pearson, W. F. R. Weldon, ...) a reformular la selección natural en términos estadísticos. 3) El redescubrimiento del trabajo de Gregor Mendel, la investigación sobre la hibridación de plantas ${ }^{120}$, una perspectiva genética que parecía dar apoyo al mutacionismo saltacionista en vez del seleccionismo gradualista. Pero la indagación sobre la mosca Drosophila en torno a la década de 1920, realizada por Thomas H. Morgan y William Castle, contribuyó a dar una solución a este problema. Así, fue una plataforma para la selección natural como causa necesaria y suficiente de una evolución adaptativa.

En torno a finales de los años 20 y comienzos de la década de 1930 hubo un impulso crucial para el evolucionismo: la Genética de poblaciones matemática de Ronald A. Fisher ${ }^{121}$, J. B. S. Haldane ${ }^{122}$ y Sewall G. Wright ${ }^{123}$. Ellos mantuvieron varias ideas: i) la selección natural no cambia de manera automática hacia una población en Genética de poblaciones teórica; ii) la Genética de poblaciones lleva a pruebas (evidence) acerca de la selección natural como causa del cambio evolutivo: el estudio de H. B. D. Kettlewell sobre el melanismo (melanism) industrial en la mariposa colorada (peppered moth/ Biston betularia) ${ }^{124}$; y iii) se introdujo entonces una modificación conceptual relevante: la existencia de la selección natural no depende de un principio malthusiano. "Para que la selección natural tenga lugar, sólo se requieren tres condiciones: variaciones heredables, aptitud diferencial (differential fitness) y la correlación entre estos dos fenómenos" ${ }^{125}$.

Respecto del apoyo de la Genética de teoría de poblaciones, cabe resaltar que "síntesis moderna" (modern synthesis) fue la denominación utilizada para las diversas disciplinas que, siguiendo una ruta evolucionista, trabajaron en las décadas de 1930 y 1940 . Ahí confluyen tres modalidades de Genética desarrolladas por Theodosious Dobzhansky ${ }^{126}$ : a) la nueva Genética de poblaciones matemática (conectada con S. G. Wright); b) la Genética citológica (basada en la Escuela de Th. H. Morgan); y c) la Genética experimental de poblaciones silvestres [wild] (basada en la investigación rusa sobre la mosca Drosophila). En 1937 Dobzhansky fue claro en su apoyo al legado de Darwin.

Pocos años más tarde —en 1947- hay otro paso en esta dirección: el libro de Julian Huxley Evolution: The Modern Synthesis ${ }^{127}$. Su planteamiento fue una recuperación de líneas darwinianas en la medida en que conectó métodos y pruebas (evidence) disponibles de varias disciplinas: Anatomía comparada, Ecología, Embriología, Genética, Geografía, Paleontología, etc. La idea era resaltar la selección natural en cuanto a la capacidad explicativa (más que

120 Mendel, G., "Versuche über Plflanzenhybriden", Verhandlungen des naturforschenden Vereines in Brünn, Bd. IV für das Jahr 1865, Abbandlungen, pp. 3-47.

121 Cfr. Fisher, R. A., The Genetical Theory of Natural Selection, Clarendon Press, Oxford, 1930.

122 Cfr. Haldane, J. B. S., Possible World, and Other Papers, Chatto and Windus, Londres, 1927.

123 Varios de sus escritos principales se reimprimieron en Wright, S., Evolution: Selected Papers, editado por W. Provine, The University of Chicago Press, Chicago, IL, 1986.

124 Cfr. Kettlewell, H. B. D., "Selection Experiments on Industrial Melanism in the Lepidoptera”, Heredity, v. 9, (1955), pp. 323-342.

125 GAYON, J., "From Darwin to Today in Evolutionary Biology", p. 252.

126 Cfr. Dobzhansky, Th., Genetics and the Origin of Species, Columbia University Press, N. York, 1937.

127 Huxley, J., Evolution: The Modern Synthesis, Allen and Unwin, Londres, 1942. Reimpreso con una nueva introducción: J. Wiley, N. York, 1964. 
como capacidad predictiva) respecto de diferentes clases de hechos. Así, junto a la especiación basada en adaptaciones morfológicas, el darwinismo debería ser capaz de lidiar con la variación geográfica, las tendencias filogenéticas, etc.

Inicialmente, la "síntesis moderna" estuvo encabezada por Th. Dobzhansky ${ }^{128}$ (Genética); J. Huxley y Ernst Mayr ${ }^{129}$ (Zoología); George G. Simpson ${ }^{130}$ (Paleontología) y G. Ledyard Stebbins ${ }^{131}$ (Biología de plantas). Más tarde, después de 1950, hubo una expansión: Konrad Lorenz $^{132}$ y Nikolas Tinbergen ${ }^{133}$ (Etología); David Lack, Robert MacArthur y Edward O. Wilson ${ }^{134}$ (Ecología); Conrad H. Waddington ${ }^{135}$ (Biología evolutiva), etc. Estos autores contribuyeron a un alto grado de reconocimiento de la selección natural hacia mediados del siglo $\mathrm{XX}^{136}$, especialmente en torno a 1959, cien años después del libro principal de Darwin.

Interpretaciones globales de la síntesis moderna hay al menos dos: la perspectiva dinámica (o "tradicional") de la Teoría de la Evolución y la orientación estadística de esta teoría científica. Ambas comparten la idea siguiente: el enfoque de la síntesis moderna explica el cambio evolutivo en la medida en que contribuye a diferenciar algunos fenómenos de población (tales como selección, deriva [drift], mutación y migración). Pero la interpretación dinámica está enfocada hacia las causas de la evolución. Así, la síntesis moderna ve a la selección y la deriva [drift $]$ como causas del cambio de población. Mientras tanto la interpretación estadística de la Teoría de la Evolución mantiene que las explicaciones de la síntesis moderna sólo se ocupan de la estructura estadística de la población ${ }^{137}$.

\subsubsection{Después de 1959: Micro y macro}

Alrededor de 1959, fecha del centenario de la publicación de The Origin, los biólogos evolucionistas tuvieron su apogeo. Desde esta aceptación generalizada hasta el momento actual han pasado varias cosas que invitan a ser un poco más prudentes. Los eventos de las últimas cinco décadas tienen que ver con la microevolución (aquellos cambios evolutivos que se dan el plano de las especies biológicas) y la macroevolución (aquellas modificaciones que tiene lugar

128 Más tarde publicó Dobzhansky, Th., "Chance and Creativity in Evolution”, en Ayala, F. J. y Dobzhansky, Th. (eds), Studies in the Philosophy of Biology, Reduction and Related Problems, pp. 307-338.

129 Cfr. MAYr, E., Animal Species and Evolution, Harvard University Press, Cambridge, MA, 1963; y MAYr, E. y Provine, W. B. (eds), The Evolutionary Synthesis: Perspectives on the Unification of Biology, Harvard University Press, Cambridge, MA,1980.

130 Cfr. Simpson, G. G., Tempo and Mode in Evolution, Columbia University Press, N. York, 1944; y Simpson, G. G., The Meaning of Evolution: A Study of the History of Its Significance for Man, Yale University Press, New Haven, CT, 1949.

131 Cfr. Stebins, G. L., The Basis of Progressive Evolution, University of North Carolina Press, Chapel Hill, 1969; y Stebins, G. L., "Botany and the Synthetic Theory of Evolution", en Mayr, E. y Provine, W. B. (eds), The Evolutionary Synthesis: Perspectives on the Unification of Biology, pp. 139-152.

132 Cfr. Lonenz, K., Evolution and Modification of Behavior, Harvard University Press, Cambridge, 1961 (publicado por Methuen, Londres, 1965).

133 Cfr. Tinbergen, N., The Study of Instinct, Oxford University Press, N. York, 1951 (reimpreso en 1961).

134 Cfr. Wilson, E. O., Sociobiology: The New Synthesis, Harvard University Press, Cambridge, MA, 1975.

135 Cfr. Waddington, C. H., The Strategy of the Genes, Allen and Unwin, Londres, 1957.

136 Cfr. Gayon, J., "From Darwin to Today in Evolutionary Biology", pp. 253-254; y Depew, D. J. y WeBER, B. H., Darwinism Evolving: Systems Dynamics and the Genealogy of Natural Selection, The MIT Press, Bradford, 1995, caps. 10-12.

137 Cfr. Walsh, D. M., "The Pomp of Superfluous Causes: The Interpretation of Evolutionary Theory”, Philosophy of Science, v. 74, (2007), pp. 281-303. 
por encima del nivel de las especies y, por tanto, son de mayor escala). Ambos han suscitado cuestiones sobre el evolucionismo, en especial en la rama darwiniana ${ }^{138}$.

Acerca de la microevolución se han señalado problemas localizados en tres sectores ${ }^{139}$ : a) la diversidad de una gran cantidad de polimorfismo (polymorphism) a nivel de las proteínas y el $\mathrm{ADN}$; b) la teoría de la selección de grupo y el debate sobre el altruismo evolucionista; y c) el problema de la altura competitiva (competitive highness) y la cuestión de la complejidad. Relacionadas con la macroevolución hay dos terrenos principales de preocupación: 1) las dificultades en la Paleobiología, y 2) la alternativa propuesta por el "equilibrio puntuado" ( punctuated equilibrium), esto es, el planteamiento sobre la Teoría de la Evolución de Stephen Jay Gould.

La selección natural se pensó orientada hacia el incremento de la aptitud (fitness) de las especies en su relación con el entorno o medio ambiente. Este avance fue entendido como una adaptación. Pero la existencia de una gran cantidad de polimorfismo a nivel de las proteínas y el ADN fue considerado como un reto a la adaptación debida a la selección natural. En 1968 Mooto Kimura informó que la tasa en la que los aminoácidos son reemplazados en proteínas - en cuanto que evolucionan - es más o menos constante y, por tanto, no está bajo el control de la selección natural ${ }^{140}$ (entendida en términos darwinianos).

Aquello que M. Kimura llamó "la teoría neutral de evolución de proteína" (the neutral theory of protein evolution) fue redenominada de manera provocativa como "evolución no darwiniana" un año después por dos biólogos moleculares: Thomas Jukes y Jack King ${ }^{141}$. "El constante marcaje (ticking of) no adaptativo de la sustitución de aminoácido fue entonces redenominado (dubbed) por Zuckerland como 'cierre molecular' (molecular lock), que daría a la Biología el prestigio de la Física y la Química con lo atómico y otros relojes naturales (natural clocks) ${ }^{142}$. De entrada, los darwinistas estaban desanimados por este hallazgo; muchos suponían que debe ser posible, al menos en principio, asignar un valor único de ajuste (unique fitness value) a cada aminoácido. Sin embargo, no les llevó mucho tiempo a los darwinistas reconocer que el neutralismo es nodarwiniano sólo si uno asume que la evolución debe ocurrir sólo en un nivel, presumiblemente el más bajo, y que la selección natural es la única fuerza directriz" ${ }^{143}$.

Selección de grupo fue otro debate acerca de la microevolución, que está también conectado con las reflexiones sobre el altruismo evolutivo. El asunto está directamente relacionado con la discusión sobre las "unidades de selección" ${ }^{144}$. El problema vino de la aparente imposibilidad

\footnotetext{
138 El análisis se apoya en lo expuesto en GAYON, J., "From Darwin to Today in Evolutionary Biology", pp. 254-260.

139 Sobre la microevolución, cfr. Ayala, F. J., Molecular Evolution, Sinauer, Sunderland, MA, 1976.

140 Cfr. Kimura, M., "Evolutionary Rate at the Molecular Level”, Nature, v. 217, (1968), pp. 624-626.

141 Cfr. King, J. L. y Jukes, T. H., "Non-Darwinian Evolution: Random Fixation of Selectively Neutral Mutations", Science, v. 164, (1969), pp. 788-798.

142 Cfr. Zuckerland, E., "On the Molecular Evolutionary Lock”, Journal of Molecular Evolution, v. 26, (1987), pp. 34-46. El código genético tiene redundancia, que impide que algunas partes del genoma puedan quedar expuestas a la selección natural, en la medida en que — en algunos casos - un ácido nucleico puede ser cambiado por otro sin modificación alguna en su funcionalidad. Esto se debe también a algunas partes de las proteínas que no tienen casi relevancia funcional. A este respecto, a nivel molecular hay algunos rasgos que no son una consecuencia de selección natural.

143 Grene, M. y Depew, D., The Philosophy of Biology. An Episodic History, Cambridge University Press, Cambridge, 2004, pp. 271-272, nota.

144 Cfr. Ereshefsky, M. (ed), The Units of Evolution: Essays on the Nature of Species, The MIT Press, Cambridge, MA, 1992; y Sober, E. y Wilson, D. S., "A Critical Review of Philosophical Work on the Units of Selection Problem", Philosophy of Science, v. 61, (1994), pp. 534-555. Reimpreso en Hull, D. y Ruse, M. (eds), The Philosophy of Biology, Oxford University Press, Oxford, 1998, pp. 198-220.
} 
de selección natural, entendida en el sentido tradicional, para dar razón de algunos cambios naturales adaptativos. Darwin "rechazó casi por completo la noción de selección de grupo. Tuvo una famosa controversia privada con Wallace sobre este tema ${ }^{145}$. Hay sólo un caso donde Darwin admite abiertamente la existencia de 'selección tribal', cuando trató de explicar el origen del sentido moral en la especie humana" ${ }^{146}$.

V. C. Wynne Edwards fue un ecologista que escribió en favor de la selección de grupo. Mantuvo que es posible encontrar algunos animales que amplían o restringen el número de sus crías (por ejemplo, en el caso de los pájaros) "por el bien de la especie" como respuesta a la disponibilidad o escasez de comida ${ }^{147}$. Pero, por un lado, la idea de "selección de grupo" no es nueva dentro del evolucionismo, puesto que ya aparece en las discusiones entre A. R. Wallace y Ch. Darwin; y, por otro lado, la posibilidad de una selección de grupo parece ser una extensión del concepto de "selección natural" en vez de algo incompatible con él.

Si las dos objeciones al darwinismo previas están enfocadas principalmente hacia los procesos, la tercera controversia en el sector microevolutivo - el problema de la altura competitiva (competitive highness) y la cuestión de la complejidad - se centra directamente en los resultados biológicos. Según la selección natural darwiniana, funciona como un proceso causal para incrementar la aptitud (fitness). Para el biólogo teórico Stuart Kaufmman, debería considerarse la "auto-organización" que incluye limitaciones para la capacidad adaptativa de la selección natural. En otras palabras, "el tapiz de la vida es más rico que lo imaginado por nosotros (...). Pero el tapiz tiene un diseño de conjunto (overall design), una arquitectura, una cadencia de entretejido y un ritmo que reflejan la ley subyacente — los principios de auto-organización_—" ${ }^{148}$.

De un lado, el problema planteado por Stuart Kaufmman es una limitación de la capacidad adaptativa de la selección natural, que mira a este proceso desde el interior: "superado un cierto nivel de complejidad, hay serios límites a la habilidad de los sistemas orgánicos para evolucionar hacia un nivel más alto de aptitud (fitness) o incluso para mantenerse ellos a un nivel dado de aptitud" ${ }^{149}$. Pero, de otro lado, la complejidad es un asunto que ha de ser considerado en la transición desde la microevolución a la macroevolución, lo que incluye una cuestión predictiva: ¿hay bases razonables - teóricas y empíricas - para esperar que, en el futuro, las líneas evolutivas incrementarán el nivel de complejidad? ${ }^{150}$.

Explícitamente, la macroevolución ha generado más preocupación al darwinismo que la microevolución, en la medida en que las pruebas disponibles acerca de los cambios en el nivel de las especies biológicas es mucho mayor que los datos sobre los cambios evolutivos a mayor escala. La Paleobiología es un campo donde se ha de considerar la interacción entre micro y

\footnotetext{
145 Sobre las concepciones de Wallace, cfr. Wallace, A. R., Studies: Scientific and Social, Macmillan, Londres, 1900.

146 Gayon, J., "From Darwin to Today in Evolutionary Biology", p. 255. Cfr. Gayon, J., Darwin et l'après-Darwin, Kimé, París, 1992; traducido al inglés por Matthew Cobb: Darwinism's Struggle for Survival: Heredity and the Hypothesis of Natural Selection, Cambridge University Press, Cambridge, 1998, pp. 70-73.

147 Cfr. Wynne-Edwards, V. C., Animal Dispersion in Relation to Social Behaviour, Oliver and Boyd, Edimburgo, 1962; y Grene, M. y Depew, D., The Philosophy of Biology. An Episodic History, p. 267.

148 Kauffman, S. A., At Home in the Universe: The Search of Laws of Self-Organization and Complexity, Oxford University Press, N. York, 1995, p. 185. Acerca de esta postura, cfr. Ruse, M., Darwinism and Its Discontents, p. 161.

149 Gayon, J., "From Darwin to Today in Evolutionary Biology", p. 257.

150 Este tema le ocupa a Szathmary, E. y Maynard Smith, J., “The Major Evolutionary Transitions”, Nature, v. 374 , (1995), pp. 227-232.
} 
macro. El punto de crítica es tanto epistemológico como metodológico: la selección natural puede usarse para explicar las adaptaciones a nivel "local" (microevolución), mientras que es un proceso insuficiente para producir fenómenos como extinciones masivas o sus consecuencias (tales como diversificaciones explosivas). En otras palabras, la macroevolución requiere algunos procedimientos adicionales junto a la selección natural ${ }^{151}$.

"Equilibrios puntuados" (punctuated equilibria) es una opción en la crítica al darwinismo en cuanto al asunto de la divergencia biológica. Para este planteamiento, la macroevolución - al menos, la divergencia morfológica - es más una consecuencia de la especiación que el resultado de una selección continua. Más aún, la selección natural tiene un papel, pero es el ritmo de la especiación y de la extinción de eventos lo que determina las pautas macroevolutivas (al menos, genealógicas y macroecológicas) que se observan en una amplia escala geológica ${ }^{152}$.

Stephen Jay Gould y Richard Lewontin argumentaron que los darwinistas asumieron de manera demasiado rápida que la naturaleza viva es adaptativa y funcional. Ellos no niegan la existencia de adaptaciones biológicas, pero rechazan una suerte de "pan-adaptacionismo": cada rasgo orgánico debería ser funcional en la medida en que es un producto de la selección natural. Entonces, haciendo "referencia al filósofo leibniziano en el Cándido de Voltaire, acusaron a los evolucionistas de panglosianismo, de pensar que estos deben ser los mejores de todos los rasgos posibles en el mejor de todos los mundos posibles. Y, para completar el caso, que supuestamente los evolucionistas inventaron las narraciones imaginarias ('just-so' stories) — denominadas de esta manera a partir de las historias fantásticas de Rudyard Kipling - con escenarios de selección natural que llevan a la adaptación" ${ }^{153}$.

Actualmente, desde un punto de vista científico, hay una imagen global dual en cuanto al evolucionismo, en general, y el darwinismo, en particular. Por una parte, hay una fuerte influencia de las ideas darwinianas sobre la Biología (como también sobre otras disciplinas científicas, principalmente en las Ciencias Sociales). Y, por otra parte, no es serio proponer que la selección natural es una causa trivial del cambio evolutivo. Aparece como un mecanismo poderoso, aunque no es "todopoderoso. La selección natural tiene sus límites; límites que han sido reconocidos desde la época de Darwin (él mismo anota muchos de ellos)" ${ }^{154}$. No obstante, considerada como un todo, es una de las claves para comprender los cambios en el mundo orgánico. A este respecto, no hay aún una llamada en favor de otra "revolución conceptual", aunque periódicamente se señalan algunas limitaciones y restricciones.

Microevolución y macroevolución han planteado algunos problemas al darwinismo a lo largo de las últimas cinco décadas. Se han ocupado principalmente de la selección natural como proceso (características y límites) y su capacidad causal. En el caso de la microevolución, las críticas todavía conectan la selección natural y la adaptación ${ }^{155}$. Mientras tanto, en la esfera de la macroevolución, la búsqueda de una única teoría causal aparece como problemática. Hay ahora más interés en pautas (filogenéticas) que en algunos procesos, pero "la Biología

151 Cfr. Raup, D., Extinction. Bad Genes or Bad Luck?, Norton, N. York, 1991.

152 Cfr. Eldredge, N., Macro-Evolutionary Dynamics. Species, Niches and Adaptive Peaks, McGraw-Hill, N. York, 1989.

153 Ruse, M., Darwinism and Its Discontents, p. 135.

154 Darwinism and Its Discontents, p. 165.

155 Lo que Kimura llama "neutral mutations are not adaptations; altruistic traits can be explained by an enlarged concept of selection; and self-organization, while it can generate order or oppose natural selection, does not produce adaptation", GAYON, J., "From Darwin to Today in Evolutionary Biology”, p. 258. 
evolutiva permanece hoy, en gran medida, descriptiva y como Ciencia Histórica" ${ }^{156}$. Más aún, la principal cuestión filosófica sobre el cambio evolutivo sigue en su lugar: ¿cómo explicar la transición de lo irracional a lo racional?

\section{Desde una perspectiva filosófica de la Naturaleza al naturalismo en Filosofía}

Durante la segunda mitad del siglo XIX tiene lugar la progresiva configuración del "evolucionismo" como Filosofía. Parece claro que esto sucede tras las contribuciones científicas de Charles Darwin y de otros autores de ese periodo. Esta transición desde posiciones científicas a perspectivas filosóficas es el resultado de varios factores. Entre ellos están que evolucionismo podía ser entendido como una cosmovisión — una visión de la realidad como un todo-, que puede tener el carácter general que acompaña a la Filosofía, y el rasgo de "enfoque radical" del evolucionismo — en el sentido literal: que va a las raíces_, puesto que puede ofrecer una perspectiva con "causas profundas" de los fenómenos naturales y sociales.

Pero hay aquí varios niveles de análisis. 1) El propio Darwin recibió la influencia de concepciones filosóficas que tienen consecuencias apreciables para su orientación metodológica. A este respecto, sus fuentes principales de influencia fueron John Herschel y William Whewell (principalmente en la "convergencia de las inducciones [consilience of inductions]") como instrumento metodológico. 2) Las ideas darwinianas pronto tuvieron repercusión sobre dos tipos de enfoques filosóficos: los relacionados con fenómenos naturales —el mundo biológico-y los conectados con la concepción del hombre y la sociedad. 3) Sus posturas fueron más tarde ampliadas para llegar a configurar una Filosofía naturalista propiamente dicha (p. ej., en Metafísica, Ética, Filosofía de la Mente, ...). 4) El evolucionismo, sea darwiniano o de una versión alternativa, ha sido utilizado para entender la Filosofía de la Ciencia en su faceta general y diversas ramas en la vertiente especial (Filosofía de la Biología, Filosofía de la Economía, etc.), debido a la aceptación de posiciones evolucionistas en las teorías científicas y en las prácticas científicas.

\subsection{Influencias filosófico-metodológicas en el enfoque de Darwin}

Cabe reconocer de manera incuestionable la existencia de una "deuda de Darwin" con los filósofos, especialmente con John Herschel y William Whewell ${ }^{157}$. Esto quiere decir que, además de las influencias de ideas científicas, tanto previas como contemporáneas - principalmente, de la Biología y la Geología-, late una influencia filosófica en su Teoría de la Evolución. En efecto, "puede que Darwin no hubiera leído mucha Filosofía; pero el modelo de teorización científica que puede hallarse en Herschel hacia comienzos de la década de 1830 fue, sin duda, de la mayor importancia para su propia creatividad en el campo de la Historia Natural [de base] filosófica (philosophical natural history)" ${ }^{158}$.

John Herschel era hijo de William y autor del libro Preliminary Discourse on the Study of Natural Philosophy (1830) ${ }^{159}$. Este volumen ofrece una reflexión sobre los objetivos, estructura,

\footnotetext{
156 GAYON, J., "From Darwin to Today in Evolutionary Biology”, p. 260.

157 Cfr. Ruse, M., "Darwin's Debt to Philosophy: An Examination of the Influence of the Philosophical Ideas of John F. W. Herschel and William Whewell on the Development of Charles Darwin's Theory of Evolution", Studies in History and Philosophy of Science, v. 6, (1975), pp. 159-181. Sobre sus posiciones acerca de la Metodología de la Ciencia, cfr. Lennox, J., "Darwin's Methodological Evolution", Journal of the History of Biology, v. 38, (2005), pp. 85-99.

158 GAYON, J., "From Darwin to Today in Evolutionary Biology", p. 261.

159 Sloan, Ph. R., "The Making of a Philosophical Naturalist", en Hodge, J. y Radick, G. (eds), The Cambridge Companion to Darwin, p. 23.
} 
logros y procedimientos de la Ciencia. Le dio a Darwin "por primera vez (...) una exposición sistemática de la Metodología científica" "160. Así, a) el objetivo de la Ciencia es adscribir ciertos fenómenos a las "causas verdaderas" (verae causae), esto es, las causas con una existencia real en la Naturaleza, en lugar de ser una mera hipótesis en la mente. Esta búsqueda de "causas verdaderas" fue una meta de Darwin. b) La estructura de la Ciencia implica que los hechos son clasificados dentro de leyes empíricas, y las teorías superiores resultan de una consideración de estas leyes. Son utilizadas para organizar una nueva serie de fenómenos. c) El proceso para asegurar el conocimiento de la Naturaleza pasa a través de la inducción. Es una inducción "activa" en vez de una inducción "pasiva" (de acuerdo con la distinción de Francis Bacon) ${ }^{161}$.

Teniendo en cuenta este tipo de consideraciones filosófico-metodológicas, "las ideas marco de Darwin están casi siempre en la zona intermedia entre los 'hechos generales' de la Naturaleza y las 'hipótesis' teóricas justificables mediante sus consecuencias. Su talento especial estuvo en comprender que esta aproximación metodológica era crucial para el éxito de las teorías causales en Historia Natural. La descendencia con modificación, aunque sea más un 'hecho general' que una 'hipótesis', es sin embargo ambos" ${ }^{162}$.

William Whewell es otra fuente de influencia filosófico-metodológica sobre Darwin, debido a su aceptación del procedimiento de la "convergencia de las inducciones [consilience of inductions]" ${ }^{163}$. Tiene lugar cuando una inducción que se ha obtenido a partir de una clase de hechos coincide con una inducción lograda a partir de otra clase. Así, esta convergencia se entiende como una prueba (test) de la teoría en la que aparece ${ }^{164}$. "En la segunda parte de Origin, siguiendo las prescripciones de Whewell, a quien conoció personalmente, Darwin trató de explicar [científicamente la evolución] en una variedad de áreas: instinto, Paleontología, distribución geográfica, sistemática, Anatomía, Embriología, y [otras] más. Debido a su éxito al usar las hipótesis evolutivas para explicar tal cantidad de factores distintos, sintió que había tenido éxito para mostrar que la evolución era verdadera (true): que era un hecho y no una teoría" ${ }^{165}$.

Hoy en día la "convergencia de las inducciones" se presenta como una versión de la "inferencia hacia la mejor explicación" (inference to the best explanation), cuando el énfasis se pone en la unificación. Se asume que, si una hipótesis es verdadera — un contenido del mundo real—, entonces varios factores se siguen a partir de ella. Darwin "planteó (set out) de manera deliberada el construir una convergencia, y sintió con cierta razón que había tenido éxito" "166. Comparó los organismos de las islas (Galápagos y el archipiélago de Cabo Verde) y del continente (América y África). Pensaba que había explicado la mayor parte de la diversidad biológica mediante la evolución entendida como un hecho. Consideraba que esta convergencia podía ser utilizada en favor de la existencia de la evolución misma en cuanto hecho. Así, en

160 SloAn, PH. R., "The Making of a Philosophical Naturalist", p. 24.

161 Cfr. "The Making of a Philosophical Naturalist", p. 24.

162 Gayon, J., "From Darwin to Today in Evolutionary Biology", p. 261.

163 En asuntos de evolución, la postura de Whewell fue contraria. Una de las objeciones fue que "Darwin could not adduce a single example of one species evolving in nature into another. Nor had plant and animal breeders, through all their efforts, succeeded in producing a single new species", Hull, D. L., "Darwin's Science and Victorian Philosophy of Science", en Hodge, J. y Radick, G. (eds), The Cambridge Companion to Darwin, p. 184.

164 Cfr. Whewell, W., The Philosophy of the Inductive Sciences, Parker, Londres, 1840.

165 Ruse, M., Darwinism and Its Discontents, p. 38.

166 Darwinism and Its Discontents, p. 38. 
el caso del registro fósil, si incluye algún tipo de progresividad — rasgo que se requiere en la evolución en el sentido darwiniano-- entonces cabe pensar en la evolución como un hecho y que, además, se pueden mostrar las secuencias esperadas de la evolución ${ }^{167}$.

Ambos filósofos - Herschel y Whewell - reflexionaron sobre la Ciencia mirando hacia la Física newtoniana como un ideal científico. Los dos resaltaban la importancia de buscar la causa de los fenómenos. Así, "Herschel proponía que los mejores ejemplos de la Ciencia establecen una causa verdadera o vera causa. Establecer una vera causa (...) comporta probar tres cosas: (1) la existencia de la causa; (2) la adecuación o competencia de la causa para producir los efectos que han de ser explicados; y (3) la responsabilidad de la causa acerca de los efectos" ${ }^{168}$. A este respecto, Darwin ofreció una analogía entre la selección artificial y la selección natural según el ideal de Herschel de proporcionar una causa verdadera (vera causa).

Whewell tenía una concepción metodológica donde una causa "sólo se podía establecer sobre la base de la convergencia (consilience), la proeza de mostrar que una amplia variedad de fenómenos, aparentemente separados, podían ser explicados como resultado de la misma causa. La propuesta de Darwin, según la cual los fenómenos que abarcan desde la Embriología hasta la distribución biogeográfica pueden ser explicados en términos de la transmutación por medio de la selección natural, se adhiere al ideal de Whewell de la convergencia" ${ }^{169}$. Esta Metodología parece compatible con una noción de "causa" (como la vera causa de Herschel), y ambas parecen recibir el apoyo de Darwin.

\subsection{Etapas iniciales en la influencia filosófica de Darwin}

Pronto, tras las principales publicaciones de Darwin, fue apreciable la presencia de algunas respuestas filosóficas. Básicamente, este eco seguía tres líneas destacadas, de diferente índole: i) aquellos pensadores que suscribían su concepción, pero que trataban de "ajustarla" para encajar la posición dentro de una tradición o perspectiva; ii) aquellos filósofos que compartían las propuestas centrales del enfoque darwiniano, pero querían "modificar" algunas ideas para tratar nuevos problemas o cuestiones distintas; y iii) quienes se oponían a las tesis filosóficas incluidas en los enunciados científicos de Darwin, bien fuesen sobre la Naturaleza o bien acerca del ser humano ${ }^{170}$. Hasta cierto punto, estos estadios iniciales de influencia ocupan un lugar hasta que finaliza el primer cuarto del siglo XX.

Obviamente, hay también otros pensadores cuya posición es más compleja que estas tres opciones. Este es el caso de un filósofo de la época de Darwin: John Stuart Mill (1806-1873), quien no encaja de modo claro en los grupos de partidarios u oponentes. Inicialmente alaba The Origin of Species, en la medida en que ofrece una especulación destacada que tiene hipótesis legítimas y de acuerdo con las reglas de inducción. Sin embargo, considera después que "Darwin y sus seguidores no han proporcionado prueba alguna en absoluto de la Teoría de la Evolución" "171. Así, junto a una nueva línea de investigación abierta por el evolucionismo,

\footnotetext{
167 Cfr. Bowler, P. J., Fossils and Progress, Science History Publications, N. York, 1976.

168 Waters, C. K., "The Arguments in the Origin of Species", p. 120. Véase también Ruse, M., "Darwin's Debt to Philosophy: An Examination of the Influence of the Philosophical Ideas of John F. W. Herschel and William Whewell on the Development of Charles Darwin's Theory of Evolution", pp. 159-181.

169 "The Arguments in the Origin of Species", p. 122.

170 Cfr. Cunninghan, S., Philosophy and the Darwinian Legacy, pp. 18-25. Además, pueden verse asimismo los capítulos 2 y 3 .

171 Hull, D. L., "Darwin's Science and Victorian Philosophy of Science”, p. 187.
} 
que está llena de promesas y cuyo resultado nadie era capaz de prever, J. Stuart Mill vio algo diferente de Darwin: que las "adaptaciones en la Naturaleza proporcionan un amplio balance de probabilidad en favor de la creación mediante inteligencia (creation by intelligence)" ${ }^{172}$.

Justo en esos años - el periodo tras El origen de las especies - Herbert Spencer (18201903) tuvo influencia filosófica, con una repercusión particular en el campo evolucionista. Por un lado, es visto - hasta cierto punto - como un "ajustador" del darwinismo, en la medida en que trató de encajar las ideas de Darwin en la tradición intelectual, de modo que usó la evolución como una nueva solución para problemas antiguos (tales como el sentido y la finalidad de la existencia). Así, "algunos han proclamado que utilizó la evolución como un sustituto (replacement) de la religión" " ${ }^{173}$. Pero, por otro lado, la perspectiva de Spencer, de modo claro, parece más lamarckiana que darwiniana, tanto sobre la evolución biótica como acerca de la evolución social. Apoyó la "evolución orgánica como parte integrante de un progreso general ascendente que caracteriza literalmente a todas las cosas: en cuanto que se mueven de lo indiferenciado hacia lo diferenciado, o en cuanto a lo que llamó un movimiento de lo homogéneo hacia lo heterogéneo" ${ }^{174}$.

Relevantes pragmatistas americanos, tales como Charles S. Peirce (1839-1914), William James (1842-1910) y John Dewey (1859-1952), son vistos como "modificadores", puesto que pensaban acerca del enfoque de Darwin en cuanto una manera de reformular muchas de las cuestiones fundamentales de la Filosofía ${ }^{175}$. En tal caso, el darwinismo contribuye a un giro filosófico que parte desde "categorías fijas" para llegar a un énfasis en los procesos y en una "indagación sin límites" (open-ended inquiry) ${ }^{176}$. Además, Peirce "estaba impresionado inicialmente por la teoría de Darwin, la encontraba como una aplicación legítima de los métodos estadísticos a la Biología, en una época en la que la Estadística estaba llegando rápidamente a lo suyo propio" 177 .

Hubo también oposición al darwinismo, una actitud que tomó distintas formas en Filosofía. Las objeciones tuvieron repercusión en diferentes áreas filosóficas, tales como la Metafísica, la Teoría del Conocimiento y la Ética. Así, junto a otros pensadores, hay un grupo relevante de idealistas británicos de la primera hora, tales como Thomas Hill Green (1836-1882) y James Hutchison Stirling (1820-1909), que "estaban entre los oponentes más frontales al naturalismo de la concepción darwiniana. [George Edward] Moore y [Bertrand Arthur] Russell, formados en la tradición idealista, bien pudieron heredar algo de la antipatía hacia el naturalismo que era una característica del Pensamiento idealista" ${ }^{178}$.

Henri Bergson (1859-1941) representa una oposición al darwinismo dentro de un entorno evolucionista. Le desagradaban las categorías inmutables en Filosofía, pero no deseaba

\footnotetext{
172 J. Stuart Mill escribió esto en su libro Three Essays on Religion, publicado en 1874. El texto es citado en Hull, D. L., "Darwin's Science and Victorian Philosophy of Science", p. 187.

173 Philosophy and the Darwinian Legacy, p. 19. Sus principales contribuciones están en SPENCER, H., The Principles of Biology, William and Norgate, Londres, 1864-1867, 2 vols.

174 Ruse, M., Darwinism and Its Discontents, p. 19. Cfr. SPEncer, H., "Progress: Its Law and Cause", Westminster Review, v. 67, (1857), pp. 244-267.

175 Además de los filósofos ya citados, también Friedrich Nietzsche estuvo influido por Darwin, aunque no fue de manera directa sino a través de la lectura de darwinistas alemanes. Cfr. SмIтн, C. U. M., “'Clever Beasts who Invented Knowing,' Nietzsche's Evolutionary Biology of Knowledge”, Biology and Philosophy, v. 2, (1987), pp. 1-27.

176 Cfr. Cunninghan, S., Philosophy and the Darwinian Legacy, p. 19.

177 Hull, D. L., "Darwin's Science and Victorian Philosophy of Science", p. 188.

178 Cunninghan, S., Philosophy and the Darwinian Legacy, p. 19.
} 
suscribir un naturalismo incompatible con la idea de creación. "Tomó mucho de su evolucionismo de Herbert Spencer" ${ }^{179}$, aun cuando Bergson escribió su libro principal contra las propuestas centrales del enfoque de Spencer ${ }^{180}$. Su planteamiento estaba surcado por una evolución creadora: L'Evolution créatrice ${ }^{181}$. Con esta postura Bergson trataba de evitar la perspectiva mecánica de la evolución en favor de un impulso vital (élan vital) que confería el impulso creativo. "Insistió en el carácter de flujo de la realidad y creía que nuestro acceso más fiable a ella era a través de lo que llamaba 'intuición'. Su preferencia por la intuición sobre la naturaleza fija de las clasificaciones intelectuales irritaba a Russell”" ${ }^{182}$.

\subsection{Relevancia filosófica contemporánea del darwinismo: Preferencia por los naturalismos en Filosofía}

Sobre la relevancia filosófica del darwinismo, dentro de un contexto más cercano, Kitcher apunta que hay dos posturas contrapuestas que han polarizado la atención desde hace tiempo. En un extremo están aquellos que resaltan la autonomía de la Filosofía y concluyen — con el Tratactus de Wittgenstein - que "la teoría de Darwin no tiene más que ver con la Filosofía que cualquier otra hipótesis de las Ciencias de la Naturaleza" 183 . Y en el otro extremo "están los naturalistas que mantienen que 'ahora que conocemos' éste o aquel otro hecho del cosmos, del cerebro humano o (lo que es más pertinente para la finalidad presente) el papel de la selección natural en la evolución de los homínidos, los problemas tradicionales se resuelven fácilmente" ${ }^{184}$.

Si bien el propio Wittgenstein —en especial, en su primera etapa — no es el mejor ejemplo del primer extremo, parece que hay sin duda filósofos que, de modo habitual, asumen la propuesta de una "plena pureza": que la mayoría de los conceptos y de los métodos en Filosofía no se ven afectados por las contribuciones de Ciencia alguna. Mientras tanto hay autores en favor del "hiper-naturalismo", que niega haya genuinos elementos filosóficos al margen del lenguaje de la Ciencia. Comúnmente, los darwinistas están más cerca del segundo extremo que del primero.

Básicamente, además de la Filosofía de la Ciencia — tanto general como especial-, hay tres áreas de la Filosofía que han recibido una influencia directa del evolucionismo, en particular de la rama darwiniana: la Metafísica, la Teoría del Conocimiento y la Ética. Junto a ellas, hay también otras áreas de la Filosofía, tales como la Filosofía de la Mente y la Antropología Filosófica, que también tienen la repercusión directa del evolucionismo darwiniano. Habitualmente, las ideas recibidas son aquellas relacionadas con algunas propuestas centrales: a) el supuesto de anti-esencialismo en Metafísica; b) la aceptación de la variabilidad y la revocabilidad del conocimiento humano (en general y, en consecuencia,

\footnotetext{
179 Ruse, M., "Belief in God in a Darwinian Age", en Hodge, J. y Radick, G. (eds), The Cambridge Companion to Darwin, p. 339.

180 Debo esta idea a Jean Gayon. Comunicación personal, junio de 2008.

181 Cfr. Bergson, H., L’Evolution créatrice, Alcan, París, 1907 (repr. PUP, París, 1959). Vers. inglesa de Arthur Mitchell: Creative Evolution, Henry Holt and Company, N. York, 1911 (reimp. Dover, N. York, 1998). Cfr. GiLson, E., D'Aristote à Darwin et retour, Vrin, París, 1971.

182 Cunninghan, S., Philosophy and the Darwinian Legacy, p. 21

183 Wittgenstein, L., Tractatus Logico-Philosophicus, edición bilingüe alemán-inglés, con traducción inglesa de C. K. Ogden y F. P. Ramsey, Routledge and Kegan Paul, Londres, 1922 (reimpreso en 1971). Nueva traducción inglesa de D. F. Pears y B. F. McGuinness, en Routledge and Kegan Paul, Londres, 1961 (reimpreso en 1981), n. 4.1122.

184 Kitcher, Ph., "Giving Darwin his Due”, en Hodge, J. y Radick, G. (eds), The Cambridge Companion to Darwin, p. 399.
} 
también el conocimiento científico); y c) la consideración de los valores éticos como dotados de una raíz natural y cambiables "evolutivamente".

\subsubsection{Posiciones de inspiración darwiniana en Filosofía de la Ciencia: Tesis de Metafísica, Teoría del Conocimiento y Ética}

Tanto la Filosofía, considerada en conjunto, como la Filosofía de la Ciencia, de modo particular, han recibido la influencia darwiniana durante muchos años. La repercusión es más apreciable en algunos ámbitos — Metafísica, Teoría del Conocimiento y Ética — que tienen conexiones con áreas específicas de la Filosofía de la Ciencia, como son aquellas que piensan la configuración de la realidad en términos científicos, la caracterización del conocimiento fiable acerca del mundo (natural, social o artificial) y el tipo de valores éticos que han de ser utilizados por los científicos (tanto endógenos a su actividad como exógenos a ella). En todos ellos — Ontología de la Ciencia, Epistemología y Ética de la Ciencia — hay filósofos que tienen una fuente de inspiración darwiniana.

Metafísica es uno de los campos filosóficos donde aparecen algunas cuestiones darwinistas — principalmente las relacionadas con "el árbol de la vida"- que han tenido consecuencias para la Filosofía de la Ciencia. Estas tesis centrales pueden ser integradas en varios niveles de análisis: i) la perspectiva general sobre la realidad, donde el evolucionismo de Darwin ha sido utilizado en favor del naturalismo ontológico, aun cuando el autor de The Origin of Species no fue partidario de esa posición ${ }^{185}$; ii) la caracterización de los objetos naturales desde un enfoque anti-esencialista, en la medida en que las especies son consideradas como realidades que evolucionan sin una estructura interna definida (esto es, propiedades que sirven de base para la referencia identificante) ${ }^{186}$; y iii) la visión del cambio en el mundo natural abierto a la novedad, que otorga un papel especial a lo azaroso (chance) ${ }^{187}$. Estas tesis metafísicas tienen una clara repercusión sobre algunas Ontologías de la Ciencia (concepciones del entramado de la realidad a partir de un punto de vista científico).

Teoría del Conocimiento es otro campo filosófico donde pueden encontrarse una serie de posiciones enraizadas en una influencia darwiniana. Están conectadas con el "árbol de la vida" y, en especial, al proceso de "selección natural". Las consecuencias de estas tesis para la Epistemología — el estudio del conocimiento científico — son directas. Esos filósofos que han estado inspirados por el evolucionismo en su análisis del conocimiento humano, en general, o del conocimiento científico, en particular, han seguido básicamente una de estas dos rutas: ${ }^{188}$

1) Evolución de los contenidos cognitivos, entendido esto en un sentido amplio, que da lugar a una modalidad de evento histórico: el conocimiento humano evoluciona a través de diferentes procesos y lleva a diversos productos que pueden cambiar de un periodo a otro. Esos cambios pueden ser considerados como una perspectiva compatible con propuestas del "giro

\footnotetext{
185 Pueden verse a este respecto los trabajos de Peter McLaughlin y Michael Ruse en HösLe, V. y Illies, CH. (eds), Darwinism and Philosophy, Notre Dame University Press, Notre Dame, IN, 2005.

186 Esta es la opinión que sostiene Elliott Sober: "There are strong reasons to think that Darwinian theory undermines this essentialist picture [i.e., intrinsic properties] of biological species", SoBER, E., "Metaphysical and Epistemological Issues in Modern Darwinian Theory", p. 275. No obstante, la controversia sobre la noción de "especies" todavía sigue recibiendo atención en el momento actual.

187 Cfr. "Metaphysical and Epistemological Issues in Modern Darwinian Theory", p. 267.

188 Cfr. Rescher, N. (ed), Evolution, Cognition, and Realism: Studies in Evolutionary Epistemology, University Press of America, Lanham, 1990.
} 
histórico" (Thomas Kuhn, Imre Lakatos, etc.) ${ }^{189}$, aun cuando "evolución" e "historicidad" tienen diferencias desde un punto de vista conceptual ${ }^{190}$.

2) Evolución en cuanto un proceso o rasgo característico del conocimiento humano en sí mismo considerado, bien sea individual o social, donde se dan algunos factores señalados por Darwin. En este segundo caso, hay muchos autores que, de un modo u otro, se autocalifican como "evolucionistas" acerca del conocimiento humano o la racionalidad humana. Más aún, pensadores completamente distintos, como Nicholas Rescher - un "idealista pragmático" (pragmatic idealist) — ${ }^{191}$ o Herbert A. Simon — un empirista— ${ }^{192}$, asumen elementos "evolucionistas" en sus visiones de la racionalidad humana.

Junto a otros planteamientos sobre la evolución de contenidos cognitivos está la concepción personal defendida por Richard Dawkins. Ha sugerido una analogía entre "genes" — la evolución biológica - y "memes" — la evolución cultural—, que incluye un crecimiento social del conocimiento como resultado de difundir memes ${ }^{193}$. Y entre aquellos que han propuesto una "Epistemología evolutiva" está Donald T. Campbell, porque considera que el conocimiento humano es una suerte de procedimiento darwiniano. Ha argumentado que "la evolución —incluso en sus aspectos biológicos - es un proceso de conocimiento (knowledge process) y que el paradigma de selección natural para esos incrementos del conocimiento se puede generalizar a otras actividades, tales como aprendizaje, pensamiento y Ciencia" ${ }^{194}$.

Ética es un tercer campo filosófico donde se ha dado una clara influencia darwiniana, especialmente entre aquellos pensadores en favor de naturalizar los valores éticos. Para Philip Kitcher, "hay muchos proyectos diferentes que relacionan a la Biología evolutiva y la Ética, algunos de ellos son perfectamente razonables, otros equivocados (flawed)" ${ }^{195}$. Un problema clave al elegir raíces evolucionistas para la Ética está en distinguir valores éticos descriptivos (el reconocimiento de cambios en la sociedad acerca de algunos principios éticos) y los valores éticos normativos (ciertas prescripciones ideales que han de ser puestas en práctica). En consecuencia, cabe la posibilidad de la "falacia naturalista" en el tránsito del 'es' al 'deber ser' ${ }^{196}$.

Cuatro grupos principales se pueden enumerar para sintetizar las opciones éticas enraizadas en esta perspectiva evolutiva. a) Darwinismo metaético fuerte, cuando la Historia de la vida como

\footnotetext{
189 Cfr. Kitcher, Ph., "Giving Darwin his Due", en Hodge, J. y Radick, G. (eds), The Cambridge Companion to Darwin, pp. 407 y 420.

190 Entendida en términos darwinianos, "evolución” es originalmente un desarrollo biológico con mutaciones, como un árbol con muchas ramas; mientras que "historicidad" es un concepto con un amplio espectro de conexiones, tanto hacia atrás como hacia adelante. Senso stricto, la historicidad pertenece a los humanos: incluye decisiones abiertas a revisiones y, de este modo, tiene un nexo directo con la libertad y la praxis, cfr. Gonzalez, W. J., "Caracterización del objeto de la Ciencia de la Historia y bases de su configuración metodológica”, en Gonzalez, W. J. (ed), Acción e Historia. El objeto de la Historia y la Teoría de la Acción, Publicaciones Universidad de A Coruña, A Coruña, 1996, pp. 25-111.

191 Cfr. Rescher, N., A Useful Inheritance: Evolutionary Epistemology in Philosophical Perspective, Rowman and Littlefield, Savage, MD, 1989; y Rescher, N., Razón y valores en la Era científico-tecnológica, Paidós, Barcelona, 1999.

192 Cfr. Simon, H. A., Reason in Human Affairs, Stanford University Press, Stanford, CA, 1983.

193 Cfr. Dawkins, R., The Selfish Gene, Oxford University Press, Oxford, 1976.

194 Campbell, D. T., "Evolutionary Epistemology", en Schilpp, P. A. (ed), The Philosophy of Karl Popper, Open Court, La Salle, IL, 1974, vol. 1, p. 413. Una perspectiva reciente sobre este tema se encuentra en WuKETITS, F. M., "Evolutionary Epistemology and the Concept of Life", en Gonzalez, W. J. y Alcolea, J. (eds), Contemporary Perspectives in Philosophy and Methodology of Science, Netbiblo, A Coruña, 2006, pp. 137-148.

195 Kitcher, PH., "Giving Darwin his Due", p. 411.

196 "You cannot go from the course or fact of evolution to moral prescriptions", Ruse, M., Darwinism and Its Discontents, p. 255
} 
tal es una fuente de moralidad y nos ofrece nuevos principios éticos básicos (esto es, principios morales centrales descansan fuera del mundo humano). b) Darwinismo ético fuerte: el carácter evolutivo de los principios morales lleva a un tipo de relativismo donde los juicios morales no pueden tener objetividad y, por tanto, el conocimiento moral carece de valores de verdad. c) Darwinismo ético débil, cuando los seres humanos están relacionados con otros animales en la "cadena de la vida" y esta continuidad nos puede llevar a tratar a los seres de modos particulares (esto es, una ampliación de nuestros valores éticos de acuerdo con un reconocimiento de un parentesco vital). d) Darwinismo metaético débil, cuando nuestra especie es vista desde un punto de partida evolucionista que contribuye a comprender los cambios en la Historia humana (incluyendo las variaciones en los valores éticos y en el reconocimiento de principios morales).

\subsubsection{Repercusiones del evolucionismo sobre la Filosofía de la Ciencia}

Han sido numerosas las repercusiones del evolucionismo, en general, y del enfoque darwiniano, en particular, pues ha desempeñado un papel clave para la Filosofía de la Ciencia. Así, muchas concepciones filosóficas, tanto del ámbito que abarca el estudio global de la Ciencia como del terreno especial dedicado a disciplinas concretas, han recibido el influjo evolucionista. La influencia es más visible en las perspectivas naturalistas acerca de la Ciencia, entendida como un todo, y en varias Filosofías de la Ciencia en la esfera especial: aquellas relacionadas con la Biología, la Economía, la Sociología, etc. Las repercusiones pueden encontrarse en el análisis filosófico-metodológico de cada uno de los elementos constitutivos de la Ciencia (lenguaje, estructura, conocimiento, método, actividad, valores, ...) ${ }^{197}$. Habitualmente, estas aproximaciones filosóficas acerca de la Ciencia conllevan una versión de naturalismo. Alguno de estos aspectos ya se han señalado: aquellas posiciones con una inspiración darwiniana (en Metafísica, Teoría del Conocimiento o Ética).

Preferentemente, la Filosofía de la Ciencia aborda el evolucionismo en dos direcciones principales: i) puede analizar las tesis evolucionistas (entre ellas, las posiciones darwinianas) tal como aparecen en la Ciencia en cuanto tal - en los elementos constitutivos de la Ciencia - o en alguna de las Ciencias (Biología, Economía, etc.); y ii) puede asumir el enfoque evolucionista (p. ej., en su rama darwiniana) para caracterizar la Filosofía de la Ciencia como tal, bien sea en el cuadro general o bien en el contexto especial (Filosofía de la Biología, Filosofía de la Economía, etc.). Al primer grupo pertenecen aquellos análisis filosóficos donde el evolucionismo es un tema inter alia, mientras que en el segundo grupo el evolucionismo es un rasgo de la Filosofía de la Ciencia realizada (p. ej., en Philip Kitcher, Eliott Sober, etc.). La aceptación de algunas concepciones naturalistas es muy frecuente en ambos casos.

"Naturalismo" es un término amplio que incluye un conjunto de planteamientos que, de un modo u otro, asumen que "la teoría científica contemporánea es la fuente para la solución de problemas filosóficos. Los naturalistas miran hacia la teoría de la selección natural como un recurso primario para llegar a solventar problemas filosóficos suscitados por los asuntos humanos en particular" 198 . Pero, de un lado, hay cuestiones recientes de la tendencia naturalista que no recibieron la atención de Darwin, puesto que "su Historia Natural [de base] filosófica (philosophical

\footnotetext{
197 Sobre los elementos constitutivos de la "Ciencia", cfr. GonZalez, W. J., "The Philosophical Approach to Science, Technology and Society”, pp. 10-11.

198 Rosenberg, A., "Darwinism in Moral Philosophy and Social Theory”, en Hodge, J. y Radick, G. (eds), The Cambridge Companion to Darwin, p. 310.
} 
natural history) era distinta del nuevo naturalismo filosófico" 199 . Y, de otro lado, hay también filósofos de la Ciencia que recibieron una clara influencia del evolucionismo, como Karl Popper (en su Epistemología evolutiva), que no eran naturalistas en ningún sentido relevante.

No obstante, estos aspectos - las diferencias entre el naturalismo de Darwin y algunas posiciones naturalistas contemporáneas, al igual que la existencia de filósofos con influencia evolucionista que no son naturalistas - son compatibles con la propensión a ver a Darwin como un icono del naturalismo en la Ciencia y, en consecuencia, como una figura clave de la Filosofía de la Ciencia de estilo naturalista. Además, esta tendencia intelectual está en sintonía con la idea de "progresividad" como rasgo central del naturalismo en la reflexión filosófica sobre la Ciencia ${ }^{200}$. Más aún, podemos encontrar varias modalidades de naturalismo en la Ciencia y, por tanto, en el enfoque filosófico que se basa en él.

Perspectivas contemporáneas acerca del naturalismo en la Ciencia son, básicamente, las siguientes: 1) naturalismo semántico, donde se da una aceptación del significado como uso lingüístico, debido a que el significado se basa en una práctica que puede ser descrita en lugar de prescrita; 2) naturalismo epistemológico, donde se acepta que el conocimiento humano está bien orientado y asume una continuidad entre Ciencia y Filosofía (y, en consecuencia, que no hace falta una fundamentación metafísica); 3) naturalismo metodológico, donde el progreso de la Ciencia (incluido el caso de las Ciencias Sociales) puede llevarse a cabo mediante procesos contrastados empíricamente, de acuerdo con criterios usados en Ciencias de la Naturaleza; 4) naturalismo ontológico, que sólo acepta entidades que, de un modo u otro, puedan ser indagadas mediante métodos científico-naturales (esto es, niega la legitimidad la "mente" o la "conciencia", si se entienden como de índole suprasensible, y descarta entidades que trascienden la Naturaleza); y 5) naturalismo axiológico, donde los valores científicos son aquellos que proceden de la práctica científica.

Otro elemento que modula las variedades de naturalismo es temático. Así, según sea el tipo de apoyo para estas versiones de naturalismo (histórico, psicológico, biológico, sociológico, económico, etc.), aparecen variedades adicionales de enfoques naturalistas. Esto resulta especialmente claro en los casos del naturalismo epistemológico y del naturalismo metodológico, puesto que en ellos puede haber una Ciencia (la Historia, la Psicología, la Biología, la Sociología, etc.) que sostiene el edificio naturalista del conocimiento científico o del método científico. Así, en las dos últimas décadas, hemos visto naturalismos basados en un componente histórico (como el "naturalismo normativo"), en un apoyo psicológico (tales como diversas modalidades de "enfoques cognitivos"), en posiciones biológicas (tales como caracterizaciones de tipo darwiniano como la "racionalidad adaptativa"), etc. Algunas de estas versiones de naturalismo se superponen con el "giro social" (social turn) ${ }^{201}$, mientras que otras están abiertas a diversas dimensiones del realismo científico ${ }^{202}$.

199 Hodge, J. y Radick, G., "Introduction”, en Hodge, J. y Radick, G. (eds), The Cambridge Companion to Darwin, p. 12. "The new philosophical naturalists have other aims that do not map at all staightforwardly on to Darwin's aims", HodGe, J. y RADICK, G., "Introduction", p. 11.

200 Cfr. Rosenberg, A., "A Field Guide to Recent Species of Naturalism", The British Journal for the Philosophy of Science, v. 47, (1996), p. 4.

201 Se denomina aquí "giro social" al énfasis en los factores externos a la Ciencia (valores sociales, culturales, económicos, políticos, etc.) a la hora de caracterizar la actividad científica. Cfr. Gonzalez, W. J., "Novelty and Continuity in Philosophy and Methodology of Science", en Gonzalez, W. J. y Alcolea, J. (eds), Contemporary Perspectives in Philosophy and Methodology of Science, pp. 9-11.

202 Cfr. Gonzalez, W. J., "Novelty and Continuity in Philosophy and Methodology of Science”, pp. 1-28; en especial, pp. 5-6. 
Prima facie aparecen dos direcciones principales cuando el evolucionismo — en su rama darwiniana - tiene repercusiones sobre las Ciencias Empíricas (de la Naturaleza, sociales o artificiales) y, en consecuencia, sobre la Filosofía que se lleva a cabo sobre ellas: a) la perspectiva de Darwin es una concepción incorporada en la postura científica en cuanto tal, como se aprecia en casos claros (Sociobiología, Psicología Evolutiva, Biología evolutiva del desarrollo [evolutionary development biology] ${ }^{203}$, Economía evolucionista, etc.); y b) las ideas de Darwin pueden ser utilizadas para caracterizar o hacer inteligible algunas posiciones científicas (p. ej., la "mano invisible" de Adam Smith, algunas tendencias sociológicas, ciertos "fallos del mercado" en Economía, etc. ${ }^{204}$.

Consecuentemente, hay repercusiones en dos modos representativos. Por un lado, existe un buen número de autores que, en mayor o menor medida, reconocen la influencia de concepciones evolucionistas sobre sus planteamientos (en el caso de la Economía: F. von Hayek, J. Schumpeter, H. A. Simon, R. Selten, etc.), donde la incidencia es habitualmente en favor de alguna versión de naturalismo (semántico, epistemológico, metodológico, ...). Y, por otro lado, el evolucionismo es la vía para captar algunas tesis - implícitas o explícitas - de ciertos científicos, una perspectiva que amplía la reflexión filosófica en casos particulares.

Ahora bien, la influencia del evolucionismo llega asimismo a los no naturalistas. Así, junto a los planteamienos naturalistas en Filosofía de la Ciencia, hay enfoques no naturalistas (racionalistas, empiristas, kantianos, etc.) que reciben el influjo evolucionista. Un claro ejemplo es Karl Popper, cuyo racionalismo crítico suscribe una "Epistemología evolutiva", una posición que es preeminente en el segundo periodo de su Pensamiento (durante la década de 1960) ${ }^{205}$. Su libro Conjectures and Refutations ofrece una postura epistemológica de índole evolutiva (un procedimiento adaptativo del conocimiento humano) conectada con la Metodología del falsacionismo ${ }^{206}$. Más tarde, en el volumen Objective Knowledge muestra una clara perspectiva ontológica acerca de la Ciencia $^{207}$, que también incluye propuestas evolucionistas.

Conjeturas y refutaciones combina una Epistemología evolutiva y una Metodología falsacionista. Así, si el progreso de la Ciencia ha de continuar, necesitamos éxitos positivos además de refutaciones con éxito: "debemos ... elaborar teorías que impliquen nuevas predicciones, especialmente predicciones de nuevos efectos, nuevas consecuencias contrastables, sugeridas

203 Cfr. Laubichler, M. y Maienschein, J. (eds), From Embryology to Evo-Devo: A History of Embryology in the 20th Century, The MIT Press, Cambridge, MA, 2007.

204 Acerca de estos ejemplos, cfr. Rosenberg, A., "Darwinism in Moral Philosophy and Social Theory", pp. 328-330.

205 Cfr. Gonzalez, W. J., "La evolución del Pensamiento de Popper”, en Gonzalez, W. J. (ed), Karl Popper: Revisión de su legado, Unión Editorial, Madrid, 2004, pp. 23-194; en especial, pp. 52-56; y Gonzalez, W. J., “The Many Faces of Popper's Methodological Approach to Prediction", en Catton, Ph. y Macdonald, G. (eds), Karl Popper: Critical Appraisals, Routledge, Londres, 2004, pp. 78-98; en especial, pp. 80-85.

206 "Criticism of our conjectures is of decisive importance: by bringing out our mistakes it makes us understand the difficulties of the problem which we are trying to solve. This is how we become better acquainted with our problem, and able to propose more mature solutions: the very refutation of a theory - that is, of any serious tentative solution to our problem - is always a step forward that takes us nearer to the truth. And this is how we can learn from our mistakes.

As we learn from our mistakes our knowledge grows, even though we may never know - that is, know for certain. Since our knowledge grows, there can be no reason here for despair of reason", Popper, K. R., Conjectures and Refutations. The Growth of Scientific Knowledge, Routledge and Kegan Paul, Londres, 1963; 5ªdic. revis., 1989, p. vii.

207 Su concepción de los tres Mundos incluye relaciones causales entre ellos, y el Mundo 3, que es el ámbito de la Ciencia, tiene objetos o entidades objetivas, cfr. Popper, K. R., Objective Knowledge. An Evolutionary Approach, Clarendon Press, Oxford, 1972 ( $5^{\text {a }}$ edic. revis., 1979; reimp. en 1989), pp. 153-190; en especial, pp. 155-158. 
por la teoría y nunca antes pensadas. Una de las predicciones de esa índole fue que los planetas podrían, en ciertas circunstancias, desviarse de las leyes de Kepler; a la luz de eso, a pesar de su masa cero, probaría que han de estar sujetos a la atracción gravitatoria (esto es, el efecto eclipse [eclipse-effect] de Einstein). Otro ejemplo es la predicción de Dirac, según la cual habrá una antipartícula por cada partícula elemental. Nuevas predicciones de este tipo no sólo se han de propugnar, sino que - yo mantengo - deben ser a menudo corroboradas de manera razonable mediante las pruebas experimentales, si es que ha de continuar el progreso científico" ${ }^{208}$.

Conocimiento objetivo también se ocupa de un enfoque evolutivo y resalta el status indeterminista de la Naturaleza y de la realidad social, una postura que afecta directamente al problema de la predicción científica: "los procesos evolutivos o los cambios evolutivos importantes son tan impredecibles (unpredictable) como los procesos históricos o los cambios históricos importantes. Mantengo esta postura porque me inclino fuertemente en favor de una visión indeterminista del mundo, en cierto modo más radical que Heisenberg: mi indeterminismo incluye la tesis según la cual también la Física clásica es indeterminista y, de este modo, es más parecida a [la posición de] Charles Sanders Peirce o Alfred Landé. Y pienso que la evolución procede, en gran medida, de manera probabilística, bajo condiciones constantemente cambiantes o situaciones problema, y que cada tentativa de solución — sea con mayor o menor éxito o, incluso, carente de éxito - crea una nueva situación problema" ${ }^{209}$.

Mirando este planteamiento de Filosofía general de la Ciencia (una Epistemología evolutiva - dentro del racionalismo crítico - que se combina con una Metodología falsacionista), Michael Ruse mantiene que Popper consideró el darwinismo como Filosofía en la medida en que era un "programa de investigación metafísico" (esto es, una posible estructura para teorías científicas contrastables) y trató de tomar en serio al darwinismo como Ciencia. "De alguna manera, el darwinismo no da la talla para nosotros en cuanto a [ser] auténtica Ciencia - una que sea falsable de manera genuina (el criterio popperiano de demarcación) —; al menos, no mediante los estándares de la Física y la Química, los estándares por los que todo lo demás debe ser juzgado. El resultado ni fue grato para la Ciencia ni tampoco para la Filosofía" ${ }^{210}$.

\subsubsection{El impacto evolucionista en la Filosofía especial de la Ciencia}

Hasta ahora, se ha resaltado que la Filosofía especial de la Ciencia —el análisis filosófico de las diversas Ciencias - ha recibido un fuerte influjo evolucionista. Además de la Biología, el impacto ha sido más notorio en algunos ámbitos sociales: Economía, Psicología, Sociología, etc. Por un lado, los criterios del evolucionismo han sido asumidos por destacados científicos de esos campos; y, por otra parte, los filósofos que han trabajado sobre esas disciplinas (Filosofía de la Biología, Filosofía de la Economía, etc.) consideran la repercusión evolucionista en esos científicos y, al mismo tiempo, sus análisis filosóficos están embebidos de alguna modalidad de evolucionismo (darwiniano, lamarckiano, ...). Aquí se llama la atención sobre algunos aspectos de este extenso y complejo panorama intelectual.

Buena parte de los científicos que trabajan en el dominio social (economistas, psicólogos, sociólogos, etc.) aceptan algún tipo de evolucionismo de inspiración darwiniana para

\footnotetext{
208 Popper, K. R., "Truth, Rationality, and the Growth of Knowledge", en Popper, K. R., Conjectures and Refutations, p. 243.

209 Popper, K. R., Objective Knowledge, p. 296 (el énfasis está añadido).

210 Ruse, M., Darwinism and Its Discontents, p. 237.
} 
explicar fenómenos bióticos, pero hay un número representativo de ellos que piensan acerca de la evolución social (económica, cultural, política, etc.) en términos lamarckianos, bien en un sentido literal o en uno metafórico. Así, "destacados economistas como Jack Hirshleifer (1977), Herbert Simon (1981), Richard Nelson y Sidney Winter (1982), Friedrich Hayek (1988), Christopher Freeman (1992) y J. Stanley Metcalfe (1993) han propuesto eso [que la evolución ecónomica es 'lamarckiana'] (Hayek y Simon son ambos Premios Nobel). Otros prominentes teóricos sociales, tales como Karl Popper (1972), William McKelvey (1982), John Gray (1984), y Robert Boyd y Peter Richerson (1985) han aceptado igualmente que la evolución social toma una forma 'lamarckiana'" ${ }_{211}$.

Lamarckismo, dentro de este contexto, supone asumir la "proposición según la cual pueden heredarse los caracteres adquiridos. De acuerdo con esto, las variaciones de tipo (type) se dan, en gran medida, a través de las adaptaciones al ambiente en lugar de mediante mutaciones aleatorias" "212. Así, según Geoffrey M. Hodgson, la distinción entre los enfoques darwiniano y lamarckiano acerca de la evolución social o cultural pueden ofrecernos una lista de partidarios prominentes: darwinianos (David Hull y Daniel Dennett), lamarckianos (Richard Boyd, Friedrich Hayek, Jack Hirshleifer, Richard Nelson, Karl Popper, Sidney Winter, ...), y ni darwiniano ni lamarckiano (Stephen Jay Gould, Alexander Rosenberg, Joseph Schumpeter, ...) ${ }^{213}$.

Algunos de estos autores han desarrollado una Filosofía especial de la Ciencia, pues han estado trabajando en Ciencias concretas, tales como Biología (D. Hull y A. Rosenberg), Ciencia Cognitiva (D. Dennett), etc. Hay otros pensadores que, de facto, tienen una Filosofía especial de la Ciencia, aun cuando su interés primario fuese la Filosofía general de la Ciencia (K. Popper) o estuviesen orientados hacia el desarrollo de una Ciencia específica, como la Economía (F. von Hayek). Habitualmente, sus planteamientos evolucionistas son lo suficientemente complejos como para hacer que sea difícil la reducción de sus posiciones a un simple dualismo, como darwinismo-lamarckismo. Con todo, en algunos casos hay también una defensa explícita de concepciones reduccionistas ${ }^{214}$.

Comúnmente, el darwinismo de estos filósofos de la Ciencia en la esfera especial (Biología, Economía, etc.) comparte alguna modalidad de naturalismo (semántico, epistemológico, metodológico, ontológico, axiológico) del contexto general. Al mismo tiempo, en sus respectivos campos - en los temas de su objeto de estudio - desarrollan los contenidos de Metafísica, Teoría del Conocimiento y Ética antes señalados. Este fenómeno es más notorio en aquellos filósofos con tesis inequívocamente darwinianas (tales como D. Dennett, D. Hull, etc.). Los límites de sus planteamientos dependen de la validez de la concepción de Darwin, que fue pensada como teoría científica en lugar de como una empresa filosófica tout-court.

En suma, hay una serie de enfoques evolucionistas antes del libro de Darwin El origen de las especies, algunos de ellos ya estaban disponibles antes de comenzar su famoso viaje a bordo del HMS Beagle. Tras sus posturas (el árbol de la vida, la selección natural y la selección sexual), hay un conjunto numeroso de planteamientos evolucionistas en la Ciencia (principalmente, en

\footnotetext{
211 Hodgson, G. M., “Is Social Evolution Lamarckian or Darwinian?”, en Laurent, J. y Nightingale, J. (eds), Darwinian and Evolutionary Economics, E. Elgar, Cheltenham, 2001, p. 87.

212 Hodgson, G. M., "Is Social Evolution Lamarckian or Darwinian?", p. 87.

213 Cfr. "Is Social Evolution Lamarckian or Darwinian?", p. 88.

214 Cfr. Rosenberg, A., Darwinian Reductionism. Or How to Stop Worrying and Love Molecular Biology, The University of Chicago Press, Chicago, IL, 2006.
} 
Biología). Aunque recibió influencias filosóficas para su Metodología de la Ciencia (primordialmente de John Herschel y William Whewell), parece claro que - a partir de la publicación de sus obras - ha tenido un influjo importante sobre la concepción filosófica. El evolucionismo, en cuanto Filosofía con una textura darwiniana, ha estado a disposición del público desde la segunda mitad del siglo XIX hasta el momento presente.

De vez en cuando hay debates muy acalorados sobre el evolucionismo en su rama darwiniana, tanto en la Ciencia como en la Filosofía. Pero sobre todo las discusiones son en el medio cultural, debido a una variedad de razones (filosóficas, teológicas, políticas, etc.). Ordinariamente, la controversia no es acerca del evolucionismo como Metodología naturalista, en la medida en que está ampliamente asumido que la Ciencia se elabora, por lo general, a partir de algún tipo de naturalismo en la Metodología de la Ciencia (singularmente en Ciencias de la Naturaleza). Las principales disputas surgen cuando se da un salto desde el naturalismo metodológico hasta el naturalismo ontológico (que no parece haber sido apoyado por el propio Darwin, al menos en cuanto concepción de conjunto) ${ }^{215}$. Pero entonces el asunto es una opción ontológica (una perspectiva filosófica) en lugar de una posición biológica (un enfoque científico).

Cómo evaluar el cambio intelectual que introdujo mediante su enfoque evolucionista es un asunto que requiere matices, como se ha resaltado. Ruse da una visión general: piensa que Darwin "quería un ámbito de la Ciencia Biológica con una base profesional, usando la selección natural como su principal instrumento de investigación. Lo que consiguió al final fue una especie [kind] de sustituto de la Religión, con el progreso en su núcleo, y con escaso interés por los mecanismos. Pero más tarde, en el siglo XX, sus ideas fueron recogidas y utilizadas para lo que tenían valor, en cuanto medios para escudriñar en los misterios de la Naturaleza. Y en esto — sometido a posterior debate - es donde estamos hoy" ${ }^{216}$.

\section{GÉNESIS Y ESTRUCTURA DEL LIBRO}

Puesto que la meta principal de este libro es ofrecer un análisis actualizado del evolucionismo desde una perspectiva filosófica, la estructura del volumen sigue cinco pasos, que están enfocados hacia diferentes dominios temáticos. En primer lugar está el contexto del evolucionismo visto desde una perspectiva contemporánea, que tiene en cuenta la diversidad de evolucionismos existentes y la relevancia del darwinismo. Esto lleva a la consideración de los diversos aspectos en liza, tanto históricos como filosóficos. En segundo término se encuentra el análisis de Darwin dentro del entorno del evolucionismo. En tercera instancia, el foco gira hacia el evolucionismo en la Ciencia actual, buscando nuevos enfoques de la Biología evolutiva. En el cuarto momento, la atención se orienta hacia el evolucionismo en el campo de la Economía, que recibe la influencia evolucionista de diversos modos. Y en el quinto puesto se halla el nexo entre la Filosofía general de la Ciencia - la Epistemología - y el evolucionismo. Esto se estudia considerando las posiciones mantenidas por Karl Popper y Herbert A. Simon.

Cada uno de estos dominios tiene una sección en el libro. 1) Contexto histórico y análisis filosófico: "El evolucionismo desde una perspectiva contemporánea: El enfoque filosóficometodológico", Wenceslao J. González (Universidad de A Coruña). 2) Darwin y la Teoría de

215 Cfr. Ruse, M., Darwinism and Its Discontents, p. 13. Sobre su trayectoria intelectual hay observaciones interesantes en Brooke, J. H., "Darwin and Victorian Christianity", pp. 199-202.

216 Ruse, M., Darwinism and Its Discontents, p. 24. 
la Evolución: "La evolución de los experimentos mentales darwinianos", James G. Lennox (Universidad de Pittsburgh), y ““Está surgiendo una nueva Teoría general de la Evolución? Una valoración filosófica de la evaluación de Stephen Jay Gould acerca de la Teoría de la Evolución contemporánea", Jean Gayon (Universidad de la Sorbona, París). 3) Evolucionismo y la Biología actual: "Los experimentos mentales en la Biología evolucionista actual", James G. Lennox (Universidad de Pittsburgh), y “El concepto de 'especie' en la Biología evolucionista: Polémicas actuales", Alfredo Marcos (Universidad de Valladolid). 4) Evolucionismo y Economía: "Tres ideas evolutivas en Economía: Población, curiosidad ociosa y cambio tecnológico", Santiago López García (Universidad de Salamanca), y "La idea de evolución en Hayek: Instituciones, orden social y proceso económico", José Luis Ramos Gorostiza (Universidad Complutense Madrid). 5) Epistemología y evolucionismo: "Evolucionismo bio-cosmológico y Epistemología evolucionista en Popper", Juan Arana (Universidad de Sevilla) y "La racionalidad como adaptación evolutiva en Herbert A. Simon: Una comparación con Karl Popper y Reinhard Selten", Francisco J. Castro (Universidad de A Coruña).

Originalmente, estos trabajos se presentaron en las Jornadas sobre Evolucionismo: Enfoques actuales, organizadas por la Universidad de A Coruña con el apoyo de la Sociedad de Lógica, Metodología y Filosofía de la Ciencia en España. El Congreso se celebró en el Campus de Ferrol los días 10 y 11 de marzo de 2005. Los temas de análisis estaban orientados hacia una meta principal: la posición filosófico-metodológica contemporánea acerca del evolucionismo, en general, y el darwinismo, en particular. Como en el caso de las precedentes Jornadas sobre Filosofía y Metodología actual de la Ciencia, la décima edición de estos simposios tiene su eje central de atención en las reflexiones desarrolladas en el momento presente.

Hacia esa dirección se encamina, en última instancia, cada uno de los capítulos del libro. El Congreso tuvo un invitado principal: James G. Lennox. Es Catedrático de Historia y Filosofía de la Ciencia en la Universidad de Pittsburgh. Ha sido Director del Center for Philosophy of Science desde 1997 hasta 2005 y responsable de las Annual Lecture Series. Previamente fue el Director del Department of History and Philosophy of Science (1993-1996). En Pittsburgh organizó congresos como "Functional Explanation in Biology and Anthropology" (1983), "Three Lectures on the History, Philosophy and Current Status of Neo-Darwinism" (1991), y "Pittsburgh/Konstanz Conference on the Philosophy of Biology" (1993).

James Lennox obtuvo su Grado en York University (Toronto) en 1971. Dos años después, completó el Máster en Filosofía por la Universidad de Toronto, que fue seguido por la Tesis Doctoral en Filosofía por la misma Universidad (1978). Más tarde, ha sido Profesor Visitante en las Universidades de Cambridge (1987) y Oxford (1994). Como miembro del Consejo Editorial, ha trabajado para History of Philosophy Quarterly, Philosophy of Science and International Studies in the Philosophy of Science. Asimismo ha preparado informes para Oxford University Press, Cambridge University Press, Princeton University Press, Edinburgh University Press y University of Pittsburgh Press.

Lennox, entre sus libros como editor, tiene Philosophical Issues in Aristotle's Biology (1987), Self-Motion from Aristotle to Newton (1994), Concepts, Theories, and Rationality in the Biological Sciences (1995) y Aristotle: On the Parts of Animals I-IV, translation and commentary (2001). Además, es el autor de Aristotle's Philosophy of Biology: Studies in the Origins of Life Science (2001). Sus artículos sobre evolucionismo incluyen "Darwinian 
Thought Experiments: A Function for Just So Stories" (1991), "Darwin was a Teleologist" (1993), "Natural Selection and the Struggle for Existence" (1994), "Darwinism: Its Descent and Modifications" (1995), y "Darwinism" (2004).

Jean Gayon fue otro ponente destacado del Congreso. Es Catedrático de Historia y Filosofía de la Ciencia en la Universidad de la Sorbona, en París (Université Paris 1-Panthéon Sorbonne), donde es el Director de la Escuela de Doctorado en Filosofía. Es miembro del Comité nacional de Francia dedicado a Historia y Filosofía de las Ciencias así como miembro del Consejo científico del Instituto Max Planck de Historia de la Ciencia de Berlín. Es, sin duda, uno de los grandes especialistas internacionales en Historia del evolucionismo.

Gayon es autor de la monografía Darwin et l'après-Darwin (1992), traducida al inglés: Darwinism's Struggle for Survival: Heredity and the Hypothesis of Natural Selection (1998). Es el editor de libros como Philosophie de la biologie: De la biologie à l'éthique (1999). Entre sus trabajos se encuentran "La théorie de l'évolution: que signifie 'darwinisme' aujourd'hui?" (2000), “The Genetics of Experimental Populations: L'Héritier and Teissier's Populations Cages" (2001), "From Darwin to Today in Evolutionary Biology" (2003), "Épistémologie de la médecine" (2004), y "Évolution et philosophie" (2004).

Antes de sus contribuciones a la décima edición de las Jornadas sobre Filosofía y Metodología actual de la Ciencia, una serie de importantes filósofos contribuyeron a estos Congresos. Larry Laudan analizó en 1996 la relación entre Historia de la Ciencia y Filosofía de la Ciencia; Ilkka Niiniluoto desarrolló en 1997 sus ideas sobre progreso científico e innovación tecnológica; Evandro Agazzi resaltó en 1998 la relación entre Ciencia y valores éticos; Daniel Hausman contribuyó en 1999 a la reflexión filosófica y metodológica sobre la Economía; John Worrall ofreció en 2000 nuevas e importantes apreciaciones sobre la Filosofía de Lakatos, 25 años después; Wesley Salmon intervino en 2001 con nuevos pensamientos sobre la explicación científica; en 2002 Peter Machamer arrojó luz sobre las revoluciones científicas de Kuhn; Donald Gillies en 2003 presentó nuevos aspectos de las posturas de Karl Popper; y Kristin Shrader-Frechette en 2004 desarrolló las relaciones entre Ciencia, Tecnología y Sociedad. Todos estos temas - incluido el evolucionismo - tienen un volumen en la colección Gallaecia ${ }^{217}$. Junto a las contribuciones de estos autores, hay también las aportaciones de otros filósofos relevantes (Merrilee Salmon, James E. McGuire, Jarrett Leplin...), quienes tienen capítulos en estos volúmenes.

Cuando una nueva edición de estas Jornadas sale impresa — esta vez en castellano, tras haberlo hecho en inglés - , es momento para agradecer a quienes han patrocinado la actividad. Mi gratitud hacia el Center for Philosophy of Science, que ha contibuido a este Congreso como expresión del Convenio de cooperación entre la Universidad de A Coruña y la Universidad

\footnotetext{
217 La colección Gallaecia. Estudios de Filosofía y Metodología actual de la Ciencia incluye los siguientes volúmenes: Gonzalez, W. J. (ed), Progreso cientifico e innovación tecnológica, número monográfico de Arbor, v. 157, n. 620, (1997); Gonzalez, W. J. (ed), El Pensamiento de L. Laudan. Relaciones entre Historia de la Ciencia y Filosofía de la Ciencia, Publicaciones Universidad de A Coruña, A Coruña, 1998; Gonzalez, W. J. (ed), Ciencia y valores éticos, número monográfico de Arbor, v. 162, n. 638, (1999); GonZALez, W. J. (ed), Problemas filosóficos y metodológicos de la Economía en la Sociedad tecnológica actual, número monográfico de Argumentos de Razón técnica, v. 3, (2000); Gonzalez, W. J. (ed), La Filosofía de Imre Lakatos: Evaluación de sus propuestas, UNED, Madrid, 2001; GonZALEZ, W. J. (ed), Diversidad de la explicación científica, Ariel, Barcelona, 2002; Gonzalez, W. J. (ed), Análisis de Thomas Kuhn: Las revoluciones cientificas, Trotta, Madrid, 2004; Gonzalez, W. J. (ed), Karl Popper: Revisión de su legado, Unión Editorial, Madrid, 2004; Gonzalez, W. J. (ed), Science, Technology and Society: A Philosophical Perspective, Netbiblo, A Coruña, 2005; y Gonzalez, W. J. (ed), Evolutionism: Present Approaches, Netbiblo, A Coruña, 2008.
} 
de Pittsburgh para cuestiones de Lógica y Filosofía de la Ciencia. Reconocimiento hacia el Ayuntamiento de Ferrol: al Alcalde, al Concejal responsable del Campus y al Concejal de Cultura, quienes han apreciado este nexo entre Universidad y Sociedad.

Gratitud hacia el Santander, entidad que contribuye a las actividades promovidas por el Vicerrector de Extensión Cultural de la Universidad de A Coruña. Y, dentro del círculo más cercano, mi reconocimiento hacia la Facultad de Humanidades en la persona del Decano. Asimismo, respecto de estas X Jornadas, deseo dar las gracias a todos aquellos —en su mayoría estudiantes - que han ayudado al Congreso tanto en el terreno material y organizativo como también en la gestión administrativa. Me gustaría resaltar además el papel de los medios de comunicación de la zona (prensa, radio y televisión), que han destacado el interés de estas Jornadas para la ciudad.

Finalmente, deseo expresar mi gratitud a James G. Lennox, tanto por aceptar esta invitación al Congreso como por su apoyo a la actividad. Asimismo agradezco la presencia de Jean Gayon en este proyecto, ámbito en el que es un consumado especialista. Expreso mis gracias a mis colegas Juan Arana (Universidad de Sevilla), Santiago López García (Universidad de Salamanca) y Alfredo Marcos (Universidad de Valladolid), por sus contribuciones a las Jornadas y a este libro (especialmente a este último por las sugerencias relacionadas con este capítulo). También a José Luis Ramos Gorostiza (Universidad Complutense de Madrid) y Francisco J. Castro (Universidad de A Coruña), los autores de las Comunicaciones, deseo hacer llegar este sentimiento. De modo muy especial, estoy agradecido a José Fco. Martínez Solano por su ayuda en las tareas de edición de este volumen.

\section{Bibliografía}

Debido a que ha habido un intenso interés en el evolucionismo - al menos desde la época de Darwin-, el número de publicaciones sobre el tema es enorme. Se trata, además, de un interés dual: científico y filosófico, lo que amplía el radio de los trabajos publicados. Asimismo, la existencia de controversias sobre las principales cuestiones tratadas y la variedad de contenidos abordados, tanto en los libros como en los artículos, ha hecho que esto haya sido considerado como una "industria" ${ }^{218}$. Así, ya que el número de publicaciones rebasa el espacio aquí disponible, se ofrece en estas páginas una selección de libros y artículos sobre evolucionismo. Asimismo, esta sección incluye otras referencias con publicaciones utilizadas para preparar este capítulo, que contempla la vertiente histórica y está enfocado hacia la perspectiva filosófico-metodológica.

Afortunadamente, está a mano The Complete Work of Charles Darwin Online (http://darwinonline.org.uk, acceso 28.1.2008). Además, hay una serie de libros que tienen un extenso registro de publicaciones representativas sobre evolución, en general, y acerca de darwinismo, en particular. Entre las monografías, me gustaría mencionar los libros escritos por Peter Bowler —singularmente Evolution: The History of an Idea (1983, 1989, y 2003)—y Michael Ruse (principalmente, Darwinism and Its Discontents, 2006), que pueden ser complementados

218 Cfr. Ruse, M., “The Darwin Industry: A Guide,” Victorian Studies, v. 39, n. 2, (1996), pp. 217-235. Este fenómeno también se puede ver en el documento de 223 páginas titulado "The Bibliography of Evolution: The Alphabetical List", preparado en noviembre de 2006 por el equipo editorial de la Darwin Digital Library of Evolution (http://darwinlibrary.amnh.org/bibliographyfiles/printbibs/EvolutionBibAuthor.pdf, acceso 12.5.2008). 
con M. Grene y D. Depew (The Philosophy of Biology. An Episodic History, 2004). Los libros editados con un número considerable de referencias bibliográficas son relativamente comunes. Aquí mencionaré dos de ellos, que reflejan bien este fenómeno: los preparados por Francisco J. Ayala y Theodosious Dobzhansky (Studies in the Philosophy of Biology, Reduction and Related Problems, 1974) y J. Hodge y G. Radick (The Cambridge Companion to Darwin, 2003).

Anhart, L., Darwinian Conservatism, Imprint Academic, Exeter, 2005.

Arana, J. (ed), Los filósofos y la Biología, Publicaciones Universidad de Sevilla, Sevilla, 1998.

Ayala, F. J., "Teleological Explanations in Evolutionary Biology”, Philosophy of Science, v. 37, (1970), pp. 1-15.

Ayala, F. J., "The Concept of Biological Progress", en Ayala, F. J. y Dobzhansky, Th. (eds), Studies in the Philosophy of Biology, Reduction y Related Problems, Macmillan, Londres, 1974, pp. 339-355.

Ayala, F. J. y Dobzhansky, Th. (eds), Studies in the Philosophy of Biology, Reduction and Related Problems, Macmillan, Londres, 1974.

Ayala, F. J., Molecular Evolution, Sinauer, Sunderland, MA, 1976.

Ayala, F. J., "Beyond Darwinism? The Challenge of Macroevolution to the Synthetic Theory of Evolution", en Asquith, P. D. y Nickles, Th. (eds), Proceedings of the Philosophy of Science Association 1982, vol. 2, Philosophy of Science Association, East Lansing, MI, 1983, pp. 275-291.

Ayala, F. J., Darwin and Intelligent Design, Fortress Press, Minneápolis, MN, 2006. Vers. cast.: Darwin y el diseño inteligente: Creacionismo, cristianismo y evolución, Alianza Editorial, Madrid, 2007.

Barker, P., Chen, X. y Andersen, H., “Kuhn on Concepts and Categorization”, en Nickles, Th. (ed), Thomas Kuhn, Cambridge University Press, Cambridge, 2003, pp. 212-245.

Barrett, P. H. y Freeman, R. B. (eds), The Works of Charles Darwin, Pickering, Londres, 1986-1989, 29 vols.

Batten, D. F., Discovering Artificial Economics: How Agents Learn and Economics Evolve, Westview Press, Boulder, CO, 2000.

BeAtty, J., "What is Wrong with the Received View of Evolutionary Theory?", en Asquith, P. y Giere, R. (eds), Proceedings of Philosophy of Science Association 1980, vol. 2, Philosophy of Science Association, East Lansing, MI, 1981, pp. 397-426.

Beatty, J., "Chance Variation: Darwin on Orchids", en Solomon, M. (ed), Proceedings of the Philosophy of Science Association 2004, Part II: Symposia Papers, Philosophy of Science, v. 73, n. 5, (2006), pp. 629-641.

Bene, M., Darwin's Black Box: The Biochemichal Challenge to Evolution, Free Press, N. York, 1996.

Bensaude-Vincent, B., Lavoisier. Mémoires d'une révolution, Flammarion, París, 1993.

Bergson, H., L’Evolution créatrice, Alcan, París, 1907 (reimpr. PUP, París, 1959); vers. inglesa de Arthur Mitchell: Creative Evolution, Henry Holt and Company, N. York, 1911 (rep. Dover, New York, 1998). 
Bertalanffy, L. von, "On the Logical Status of the Theory of Evolution", Laval Théologique et Philosophique, v. 8, (1952), pp. 161-168.

Boesiger, E., "Evolutionary Theories after Lamarck and Darwin", en Ayala, F. J. y Dobzhansky, Tн. (eds), Studies in the Philosophy of Biology, Reduction and Related Problems, Macmillan, Londres, 1974, pp. 21-44.

Bowler, P. J., "Malthus, Darwin, and the Concept of Struggle", Journal of the History of Ideas, v. 37, (1976), pp. 631-650.

Bowler, P. J., Fossils and Progress, Science History Publications, N. York, 1976.

Bowler, P. J., The Eclipse of Darwinism: Anti-Darwinian Evolution Theories in the Decades around 1900, Johns Hopkins University Press, Baltimore, MD, 1983.

Bowler, P. J., Evolution: The History of an Idea, University of California Press, Berkeley, 1983; edición revisada, University of California Press, Berkeley, 1989. (Tercera edición, 2003).

Bowler, P. J., Theories of Human Evolution: A Century of Debate, 1844-1944, Johns Hopkins University Press, Baltimore, MD, 1986.

Bowler, P. J., The Non-Darwinian Revolution. Reinterpreting a Historical Myth, Johns Hopkins University Press, Baltimore, MD, 1988.

Bowler, P. J., Charles Darwin: The Man and his Influence, Basil Blackwell, Oxford, 1990. (Nueva edición con prefacio de David Knight: Cambridge University Press, Cambridge, 1996).

Bowler, P. J., Life's Splendid Drama: Evolutionary Biology and the Reconstruction of Life's Ancestry, 1860-1940, The University of Chicago Press, Chicago, 1996.

BOWler, P. J., Reconciling Science and Religion: The Debate in Early Twentieth-Century Britain, The University of Chicago Press, Chicago, 2001.

Bowler, P. J., Monkey Trials and Gorilla Sermons: Evolution and Christianity from Darwin to Intelligent Design, Harvard University Press, Cambridge, MA, 2007.

Brandom, R. N., "Adaptation and Evolutionary Theory", Studies in History and Philosophy of Science, v. 9, (1978), pp. 181-206.

Brandon, R. N., Concepts and Methods in Evolutionary Biology, Cambridge University Press, Cambridge, 1996.

Brooke, J. H., "Darwin and Victorian Christianity", en Hodge, J. y Radick, G. (eds), The Cambridge Companion to Darwin, Cambridge University Press, Cambridge, 2003, pp. 192-213.

Brooks, D. y WiLey, E. Evolution as Entropy, The University of Chicago Press, Chicago, 1986.

Buffon, [George Louis Leclerc,] Conde de, Histoire Naturelle, générale et particulière, 36 vols., Imprimerie Royale puis Plassan, París, 1749-1788.

Campbell, D. T., "Evolutionary Epistemology", en Schilpp, P. A. (ed), The Philosophy of Karl Popper, Open Court, La Salle, IL, 1974, vol. 1, pp. 413-463.

Carpenter, W. B., On the Physiological Inferences to Be Deduced From the Structure of the Nervous System in the Invertebrated Classes of Animals, John Churchill, Edimburgo, 1839.

Carpenter, W. B., Principles of General and Comparative Physiology, J. Churchill, Londres, 1839 (2 $2^{\mathrm{a}}$ ed., 1841).

Castrodeza, C., Teoría histórica de la selección natural, Alhambra, Madrid, 1988. 
Chambers, R., Vestiges of the Natural History of Creation, Churchill, Londres, 1844. Reimpreso en facsímil, con una introducción por James A. Secord: The University of Chicago Press, Chicago, 1994.

Cohen, L. J., "Is the Progress of Science Evolutionary?", The British Journal for the Philosophy of Science, v. 24, (1973), pp. 41-61.

Collins, F., The Language of God, Free Press, N. York, 2006.

Cunninghan, S., Philosophy and the Darwinian Legacy, University of Rochester Press, Rochester, NY, 1996.

CUVIER, G., Le Règne animal distribué d'après son organization, pour servir de base à l'histoire naturelle des animaux et d'introduction à l'anatomie comparée, Déterville, París, 1817.

Darwin, Ch., Journal of Researches into the Geology an Natural History of the Various Countries Visited by H. M. S. Beagle, Colburn, Londres, 1839. Reimpreso en Barrett, P. H. y Freeman, R. B. (eds), The Works of Charles Darwin, Pickering, Londres, 1986.

DARwin, CH., The Origin of Species by Means of Natural Selection: or the Preservation of Favoured Races in the Struggle for Life, John Murray, Londres, 1859; reimpreso por The University of Chicago Press, Chicago, 1952, y más tarde en facsímil, con una introducción por Ernst Mayr, Harvard University Press, Cambridge, MA, 1964.

Darwin, $\mathrm{CH}_{\text {., }}$ The Variation of Animals and Plants under Domestication, John Murray, Londres, 1868, 2 vols.

Darwin, Ch., The Descent of Man and Selection in Relation to Sex, John Murray, Londres, 1871,2 vols.

Darwin, Ch., Autobiography, editado por F. Darwin, J. Murray, Londres, 1887. Editado por Nora Barlow, con las omisiones originales restauradas, Collins, Londres, 1958.

Darwin, Ch. y Wallace, A. R., The Evolution by Natural Selection, con un Prólogo de Sir Gavin de Beer, Cambridge University Press, Cambridge, 1958.

Darwin, Ch., Preservation of Favoured Races in the Struggle for Life, Harvard University Press, Cambridge, MA, 1964.

Darwin, E., Zoonomia; or, The Laws of Organic Life, J. Johnson, Londres, 1794-1796.

Dawkins, R., The Selfish Gene, Oxford University Press, Oxford, 1976.

Deely, J. N. y Nogar, R. J. (eds), The Problem of Evolution: A Study of the Philosophical Repercussions of Evolutionary Science, Appleton-Century-Crofts, N. York, 1973.

Depew, D. J. y Weber, B. H., Darwinism Evolving: Systems Dynamics and the Genealogy of Natural Selection, The MIT Press, Bradford, 1995.

Dobzhansky, Th., Genetics and the Origin of Species, Columbia University Press, N. York, 1937.

Dobzhansky, Th., "Chance and Creativity in Evolution", en Ayala, F. J. y Dobzhansky, Th. (eds), Studies in the Philosophy of Biology, Reduction and Related Problems, Macmillan, Londres, 1974, pp. 307-338.

Dopfer, K. (ed), The Evolutionary Foundations of Economics, Cambridge University Press, Cambridge, 2006.

Dopfer, K. y PotTs, J., The General Theory of Economic Evolution, Routledge, Londres, 2007. 
Drouin, J.-M., "De Linné à Darwin: Les voyageurs naturalists", en SERres, M. (ed), Eléments d'histoire des sciences, Bordas, París, 1989, pp. 321-335.

Eccles, J., "Cultural Evolution versus Biological Evolution”, Zygon, v. 8, (1973), pp. 282-293.

Eldredge, N. y Cracraft, J. (eds), Phylogenetic Pattern and the Evolutionary Process, Columbia University Press, N. York, 1980.

Eldredge, N. y Gould, S. J., "Punctuated Equilibria: An Alternative to Phyletic Gradualism", en Schopf, T. J. M. (ed), Models in Paleobiology, Freeman, San Francisco, CA, 1972, pp. 82-115.

Eldredge, N., Macro-Evolutionary Dynamics. Species, Niches and Adaptive Peaks, McGraw-Hill, N. York, 1989.

Endersby, J., "Darwin on Generation, Pangenesis and Sexual Selection”, en Hodge, J. y Radick, G. (eds), The Cambridge Companion to Darwin, Cambridge University Press, Cambridge, 2003, pp. 69-91.

EReshefsky, M., "The Historical Nature of Evolutionary Theory”, en Nitecki, M. H. y Nitecki, D. V. (eds), History and Evolution, State University of New York Press, N. York, 1992, pp. 81-99.

EReshefsky, M. (ed), The Units of Evolution: Essays on the Nature of Species, The MIT Press, Cambridge, MA, 1992.

Fisher, R. A., The Genetical Theory of Natural Selection, Clarendon Press, Oxford, 1930.

Gayon, J., Darwin et l'après-Darwin, Kimé, París, 1992. Traducido al inglés por Matthew Cobb: Darwinism's Struggle for Survival: Heredity and the Hypothesis of Natural Selection, Cambridge University Press, Cambridge, 1998 (reimpreso en 2007).

Gayon, J., "From Darwin to Today in Evolutionary Biology", en Hodge, J. y Radick, G. (eds), The Cambridge Companion to Darwin, Cambridge University Press, Cambridge, 2003, pp. 240-264.

Ghiselin, M. T., The Triumph of the Darwinian Method, University of California Press, Berkeley, 1969.

Gillespie, N. C., Charles Darwin and the Problem of Creation, The University of Chicago Press, Chicago, 1979.

Gilson, E., D’Aristote à Darwin et retour, Vrin, París, 1971.

Gonzalez, W. J., "Progreso científico, Autonomía de la Ciencia y Realismo", Arbor, v. 135, n. 532, (1990), pp. 91-109.

Gonzalez, W. J., “P. Thagard: Conceptual Revolutions”, Mind, v. 104, n. 416, (1995), pp. 916-919.

Gonzalez, W. J., “Towards a New Framework for Revolutions in Science”, Studies in History and Philosophy of Science, v. 27, n. 4, (1996), pp. 607-625.

Gonzalez, W. J., "Caracterización del objeto de la Ciencia de la Historia y bases de su configuración metodológica”, en Gonzalez, W. J. (ed), Acción e Historia. El objeto de la Historia y la Teoría de la Acción, Publicaciones Universidad de A Coruña, A Coruña, 1996, pp. 25-111.

Gonzalez, W. J., "El empirismo moderado en Filosofía Analítica: Una réplica a P. F. Strawson”, en Falguera, J. L., Zilhão, A. J. T., Martínez, C. y Sagülllo, J. M. (eds), Palabras y pensamientos: Una mirada analítica, Publicaciones Universidad de Santiago, Santiago de Compostela, 2003, pp. 207-237. 
Gonzalez, W. J., "Las revoluciones científicas y la evolución de Thomas S. Kuhn", en Gonzalez, W. J. (ed), Análisis de Thomas Kuhn: Las revoluciones cientificas, Trotta, Madrid, 2004, pp. 15-103.

Gonzalez, W. J., "The Philosophical Approach to Science, Technology and Society", en Gonzalez, W. J. (ed), Science, Technology and Society: A Philosophical Perspective, Netbiblo, A Coruña, 2005, pp. 3-49.

Gonzalez, W. J., "Novelty and Continuity in Philosophy and Methodology of Science", en Gonzalez, W. J. y Alcolea, J. (eds), Contemporary Perspectives in Philosophy and Methodology of Science, Netbiblo, A Coruña, 2006, pp. 1-28.

Gould, S. J., Ever Since Darwin: Reflections in Natural History, W. W. Norton, N. York, 1977.

Gould, S. J. y Lewontin, R. C., "The Spandrels of San Marco and the Panglossian Paradigm: A Critique of the Adaptationist Programme", Proceedings of the Royal Society of London, B 205, (1979), pp. 581-598. Reimpreso en Sober, E. (ed), Conceptual Issues in Evolutionary Biology, $3^{\mathrm{a}}$ ed., The MIT Press, Cambridge, 2006, pp. 79-97.

Gould, S. J., Rocks of Ages: Science and Religion in the Fullnes of Life, Ballantine, N. York, 1999.

Gould, S. J., The Structure of Evolutionary Theory, Belknap Press, Cambridge, MA, 2002.

Grant, B. R. y Grant, P. R., Evolutionary Dynamics of a Natural Population, The University of Chicago Press, Chicago, 1989.

Greene, J. C., Science, Ideology, and World View: Essays in the History of Evolutionary Ideas, University of California Press, Berkeley, 1981.

Grene, M., "Changing Concepts of Darwinian Evolution”, Monist, v. 64, (1981), pp. 195-213.

Grene, M. y Depew, D., The Philosophy of Biology. An Episodic History, Cambridge University Press, Cambridge, 2004.

Grinnell, G., "The Rise and Fall of Darwin's First Theory of Transmutation”, Journal of the History of Biology, v. 7, (1974), pp. 259-273.

Grinnell, G., "The Rise and Fall of Darwin's Second Theory of Transmutation", Journal of the History of Biology, v. 18, (1985), pp. 51-70.

Gruber, H. E., Darwin on Man: A Psychological Study of Scientific Creativity, Wildwood House, Londres, 1974.

Haeckel, E., Generelle Morphologie der Organismen, G. Reimer, Berlín, 1866.

Haldane, J. B. S., Possible World, and Other Papers, Chatto and Windus, Londres, 1927.

Haug, M. C., "Of Mice and Metaphysics: Natural Selection and Realized Population-Level Properties", Philosophy of Science, v. 74, n. 4, (2007), pp. 431-451.

Herbert, S. (ed), The Red Notebook of Charles Darwin, British Museum (Natural History), Londres, 1980.

Himmelfarb, G., Darwin and the Darwinian Revolution, Morton, N. York, 1968.

Hodge, J., "London Notebook Programmes and Projects of Darwin's London Years", en Hodge, J. y Radick, G. (eds), The Cambridge Companion to Darwin, Cambridge University Press, Cambridge, 2003, pp. 40-68.

Hodge, J. y Radick, G. (eds), The Cambridge Companion to Darwin, Cambridge University Press, Cambridge, 2003. 
Hodge, J. y Radick, G., "Introduction", en Hodge, J. y Radick, G. (eds), The Cambridge Companion to Darwin, Cambridge University Press, Cambridge, 2003, pp. 1-14.

Hodgson, G. M., Economics and Evolution: Bringing Life Back to Economics, Polity Press, Cambridge, 1993.

Hodgson, G. M. (ed), The Foundations of Evolutionary Economics: 1890-1973, E. Elgar, Cheltenham, 1998.

Hodgson, G. M., Evolution and Institutions: On Evolutionary Economics and the Evolution of Economics, E. Elgar, Cheltenham, 1999.

Hodgson, G. M., “Is Social Evolution Lamarckian or Darwinian?”, en Laurent, J. y Nightingale, J. (eds), Darwinian and Evolutionary Economics, E. Elgar, Cheltenham, 2001, pp. 87-120.

Hodgson, G. M., Evolution of Institutional Economics: Agency, Structure, and Darwinism in American Institutionalism, Routledge, Londres, 2004.

Hösle, V. y Illies, Ch. (eds), Darwinism and Philosophy, Notre Dame University Press, Notre Dame, IN, 2005.

Hull, D. L., Darwin and His Critics: The Reception of Darwin's Theory of Evolution by the Scientific Community, Harvard University Press, Cambridge, 1973.

Hull, D. L., Philosophy of Biological Science, Prentice-Hall, Englewood Cliffs, NJ, 1974.

Hull, D. L., Science as a Process: An Evolutionary Account of the Social and Conceptual Development of Science, The University Chicago Press, Chicago, 1988.

Hull, D. L., The Metaphysics of Evolution, SUNY Press, Albany, NY, 1990.

Hull, D. y Ruse, M. (eds), The Philosophy of Biology, Oxford University Press, Oxford, 1998.

Hull, D., Science and Selection: Essays on Biological Evolution and the Philosophy of Science, Cambridge University Press, Cambridge, 2001.

Hull, D. L., "Darwin's Science and Victorian Philosophy of Science", en Hodge, J. y Radick, G. (eds), The Cambridge Companion to Darwin, Cambridge University Press, Cambridge, 2003, pp. 168-191.

Hutton, F. W., Darwinism and Lamarckism: Old and New, G. Putnam and Sons, N. York, 1899.

HuxLey, J., Evolution: The Modern Synthesis, Allen and Unwin, Londres, 1942. Reimpreso con una nueva Introducción: J. Wiley, N. York, 1964.

Huxley, J., Hardy, A. C. y Ford, E. B. (eds), Evolution as a Process, Allen and Unwin, Londres, 1954 (2 $2^{\text {a }}$ ed. 1958). Reimpreso por Collier, N. York, 1963.

Jablonka, E. y Lamb, M. J., Evolution in Four Dimensions: Genetic, Epigenetic, Behavioral, and Symbolic Variation in the History of Life, The MIT Press, Cambridge, 2005.

Jenkin, F., "The Origin of Species”, The North British Review, v. 44, (1867), pp. 277-318. Reimpreso en Hull, D. L. (ed), Darwin and His Critics: The Reception of Darwin's Theory of Evolution by the Scientific Community, Harvard University Press, Cambridge, MA, 1867, pp. 302-350.

Kauffman, S. A., The Origins of Order: Self-Organization and Selection, Oxford University Press, Oxford, 1993.

Kauffman, S. A., At Home in the Universe: The Search of Laws of Self-Organization and Complexity, Oxford University Press, N. York, 1995. 
Keller, E. F. y Lloyd, E. (eds), Keywords in Evolution, Harvard University Press, Cambridge, MA, 1992.

Kettlewell, H. B. D., "Selection Experiments on Industrial Melanism in the Lepidoptera", Heredity, v. 9, (1955), pp. 323-342.

Kimura, M., "Evolutionary Rate at the Molecular Level”, Nature, v. 217, (1968), pp. 624-626.

KING, J. L. y Jukes, T. H., "Non-Darwinian Evolution: Random Fixation of Selectively Neutral Mutations”, Science, v. 164, (1969), pp. 788-798.

Kitcher, Pн., Vaulting Ambition: Sociobiology and the Quest for Human Nature, The MIT Press, Cambridge, MA, 1985.

Kitcher, Ph., “Gene”, en Keller, E. F. y Lloyd, E. (eds), Keywords in Evolution, Harvard University Press, Cambridge, MA, 1992, pp. 128-131.

Kitcher, Рн., The Advancement of Science: Science witouth Legend, Objectivity without Illusions, Oxford University Press, N. York, 1993.

Kitcher, Pн., “The Evolution of Human Altruism”, The Journal of Philosophy, v. 90, (1993), pp. 497-516.

Kitcher, Ph., "Psychological Altruism, Evolutionary Origins, and Moral Rules", Philosophical Studies, v. 89, (1998), pp. 283-316.

Kitcher, Рн., In Mendel's Mirror: Philosophical Reflections on Biology, Oxford University Press, N. York, 2003.

Kitcher, Ph., "Giving Darwin his Due”, en Hodge, J. y Radick, G. (eds), The Cambridge Companion to Darwin, Cambridge University Press, Cambridge, 2003, pp. 399-420.

Kitcher, Ph., "Evolutionary Theory and the Social Uses of Biology", Biology and Philosophy, v. 19, n. 1, (2004), pp. 1-15.

Kitcher, Ph., "Between Fragile Altruism and Morality: Evolution and the Emergence of Normative Guidance", en Boniolo, G. y De Anna, G. (eds), Evolutionary Ethics and Contemporary Biology, Cambridge University Press, 2006, pp. 159-177.

Kitcher, Ph., "Ethics and Evolution: How to get Here from There", en De WaAl, F. et al., Primates and Philosophers: How Morality Evolved (Tanner Lectures), Princeton University Press, Princeton, NJ, 2006, pp. 120-139.

Kohn, D. (ed), The Darwinian Heritage, Princeton University Press, Princeton, 1985.

Kunn, TH. S., The Structure of Scientific Revolutions, The University of Chicago Press, Chicago, 1962 (2 ed., 1970).

Kunn, Tн. S., "Second Thoughts on Paradigms", en Suppe, F. (ed), The Structure of Scientific Theories, University of Illinois Press, Urbana, 1974 (2 ed., 1977), pp. 459-482.

Kunn, Tн. S., The Road Since Structure. Philosophical Essays, 1970-1993, with an Autobiographical Interview, editado por James Conant and John Haugeland, The University of Chicago Press, Chicago, 2000.

Lamarck, J. B. [DE Monet, CABAllero] DE, Recherches sur l'organisation des corps vivans, Maillard, París, 1802. 
Lamarck, J. B. [De Monet, Caballero] de, Philosophie zoologique, ou, Exposition des considérations relative à l'Histoire naturalle des animaux, Chez Dentu [et] L'Auteur, París, 1809. Traducido por Hugh Elliot, con un ensayo introductorio de D. L. Hull y R. W. Burkhardt: Zoological Philosophy: An Exposition with Regard to the Natural History of Animals, The University of Chicago Press, Chicago, 1984.

Lamarck, J. B. [De Monet, Caballero] de, Histoire naturelle des animaux sans vertèbres, 7 vols. París, 1815-1822. Reimpreso por Culture et Civilisation, Bruselas, 1969.

Laubichler, M. y Maienschein, J. (eds), From Embryology to Evo-Devo: A History of Embryology in the 20th Century, The MIT Press, Cambridge, MA, 2007.

Laurent, J. y Nightingale, J. (eds), Darwinian and Evolutionary Economics, E. Elgar, Cheltenham, 2001.

Lennox, J., "Darwin's Methodological Evolution”, Journal of the History of Biology, v. 38, (2005), pp. 85-99.

Lenski, G., Ecological-Evolutionary Theory: Principles and Applications, Paradigm Publishers, Boulder, CO, 2005.

Lewens, T., Darwin, Routledge, Londres, 2007.

Lewontin, R. C., "The Units of Selection", Annual Review of Ecology and Systematics, v. 1, (1970), pp. 1-18.

Lewontin, R. C., The Genetic Basis of Evolutionary Change, Columbia Universtity Press, N. York, 1974.

Lorenz, K., Evolution and Modification of Behavior, Harvard University Press, Cambridge, 1961 (publicado por Methuen, Londres, 1965).

Lyell, Ch., Principles of Geology, John Murray, Londres, 1830-1833, 3 vols. Reimpreso en facsímil con una introducción de M. J. S. Rudwick: The University of Chicago Press, Chicago, 1990.

Machamer, P. K., "Las revoluciones de Kuhn y la Historia 'real' de la Ciencia: El caso de la revolución galileana", en Gonzalez, W. J. (ed), Análisis de Thomas Kuhn: Las revoluciones cientificas, Trotta, Madrid, 2004, pp. 253-273.

Malthus, Th. R., An Essay on the Principle of Population as it affects the Future Improvement of Society, with Remarks on the Speculations of Mr. Godwin, M. Condorcet, and Other Writers, J. Johnson, Londres, 1798. Reimpreso por la University of Michigan Press, Ann Arbor, 1959.

Malthus, Th. R., An Essay on the Principle of Population; Or, A View of its Past and Present Effects on Human Happiness, with an Inquiry into Our Prospects Respecting the Future Removal or Mitigation of the Evils which it Occassions, 2a edición, Johnson, Londres, 1803; $6^{\text {a }}$ edición, 2 vols., John Murray, Londres, 1826.

Marcos, A., "Información y Entropía”, Arbor, v. 140, n. 549, (1991), pp. 111-135.

Marcos, A., “Información y evolución”, Contextos, v. 9, n. 17-18, (1991), pp. 197-221.

Marcos, A., "Neodarwinismo, Termodinámica y Teoría de la Información: Estado de la cuestión", Estudios Filosóficos, v. 41, n. 117, (1992), pp. 215-252.

Margulis, L., Cell Evolution, W. H. Freeman, San Francisco, CA, 1981.

Maynard Smith, J., The Theory of Evolution, Cambridge University Press, Cambridge, 1993.

MaYr, E., Animal Species and Evolution, Harvard University Press, Cambridge, MA, 1963. 
Mayr, E. y Provine, W. B. (eds), The Evolutionary Synthesis: Perspectives on the Unification of Biology, Harvard University Press, Cambridge, MA, 1980.

MaYr, E., "Prologue: Some Thoughts on the History of the Evolutionary Synthesis", en MaYr, E. y Provine, W. B. (eds), The Evolutionary Synthesis: Perspectives on the Unification of Biology, Harvard University Press, Cambridge, MA,1980, pp. 1-48.

Mayr, E., "What is Darwinism Today?", en Asquith, P. D. y Kitcher, Ph. (eds), Proceedings of the Philosophy of Science Association 1984, vol. 2, Philosophy of Science Association, East Lansing, MI, 1985, pp. 145-156.

MaYr, E., Toward a New Philosophy of Biology, Harvard University Press, Cambridge, MA, 1988.

Mendel, G., "Versuche über Plflanzenhybriden", Verhandlungen des naturforschenden Vereines in Brünn, Bd. IV für das Jahr 1865, Abbandlungen, pp. 3-47.

Millstein, R. L., "Discussion of 'Four Case Studies on Chance Evolution': Philosophical Themes and Questions", en Solomon, M. (ed), Proceedings of the Philosophy of Science Association 2004, Part II: Symposia Papers, Philosophy of Science, v. 73, n. 5, (2006), pp. 678-687.

Millstein, R. L., "Natural Selection as a Population-Level Causal Process", The British Journal for the Philosophy of Science, v. 57, n. 4, (2006), pp. 627-653.

Mivart, St.-G. J., On the Genesis of Species, Macmillan, Londres, 1871.

Monod, J., “L'evolution microscopique”, Theoria to Theory, v. 10, (1977), pp. 303-311.

Moore, J., "Deconstructing Darwinism: The Politics of Evolution in the 1860s", Journal of the History of Biology, v. 24, (1991), pp. 353-408.

Moorehead, A., Darwin and the Beagle, Crescent Books, N. York, 1969.

Morrell, J., Science at Oxford, 1914-1939: Transforming an Arts University, Clarendon Press, Oxford, 1997.

Morrison, M., "Population Genetics and Population Thinking: Mathematics and the Role of the Individual", en Mitchell, S. D. (ed), Proceedings of the Philosophy of Science Association 2002, Part II: Symposia Papers, Philosophy of Science, v. 71, n. 5, (2004), pp. 1189-1200.

Morrison, M., "Unification, Explanation and Explaining Unity: TheFisher-Wright Controversy", The British Journal for the Philosophy of Science, v. 57, n. 1, (2006), pp. 233-245.

Nersessian, N. J., "Kuhn, Conceptual Change, and Cognitive Science”, en Nickles, Th. (ed), Thomas Kuhn, Cambridge University Press, Cambridge, 2003, pp. 178-211.

Ninnlluoto, I., Is Science Progressive?, Reidel, Dordrecht, 1984.

Numbers, R. L., The Creationists: The Evolution of Scientific Creationism, University of California Press, Berkeley, 1992.

Orzack, S. H. y Sober, E. (eds), Adaptation and Optimality, Cambridge University Press, Cambridge, 2001.

Ospovat, D., The Development of Darwin's Theory (Natural History, Natural Theology and Natural Selection, 1838-1859), Cambridge University Press, Cambridge, 1981.

Paul, D. B., "Darwin, Social Darwinism, and Eugenics", en Hodge, J. y Radick, G. (eds), The Cambridge Companion to Darwin, Cambridge University Press, Cambridge, 2003, pp. 214-239.

Pecknam, M., The Origin of Species by Charles Darwin. A Variorum Text, University of Pennsylvania Press, Philadelphia, PA, 1959. 
Pigliucci, M. y Kaplan, J., Making Sense of Evolution. The Conceptual Foundations of Evolutionary Biology, The University of Chicago Press, Chicago, IL, 2006.

Plutynski, A., "Explanation in Classical Population Genetics", en Mitchell, S. D. (ed), Proceedings of the Philosophy of Science Association 2002, Part II: Symposia Papers, Philosophy of Science, v. 71, n. 5, (2004), pp. 1201-1214.

Plutynski, A., "Explanatory Unification and the Early Synthesis", The British Journal for the Philosophy of Science, v. 56, n. 3, (2005), pp. 595-609.

Popper, K. R., Conjectures and Refutations. The Growth of Scientific Knowledge, Routledge and Kegan Paul, Londres, 1963; $5^{\mathrm{a}}$ ed., revisada, 1989.

Popper, K. R., Objective Knowledge. An Evolutionary Approach, Clarendon Press, Oxford, 1972 (5 ed. rev., 1979; reimp. en 1989).

Provine, W. B., The Origins of Theoretical Population Genetics, The University of Chicago Press, Chicago, IL, 1971.

Radick, G., "Is the Theory of Natural Selection Independent of its History?", en Hodge, J. y Radick, G. (eds), The Cambridge Companion to Darwin, Cambridge University Press, Cambridge, 2003, pp. 143-167.

Raup, D., Extinction. Bad Genes or Bad Luck?, Norton, N. York, 1991.

Rescher, N., A Useful Inheritance: Evolutionary Epistemology in Philosophical Perspective, Rowman and Littlefield, Savage, MD, 1989.

Rescher, N. (ed), Evolution, Cognition, and Realism: Studies in Evolutionary Epistemology, University Press of America, Lanham, 1990.

Rescher, N., Razón y valores en la Era científico-tecnológica, Paidós, Barcelona, 1999.

Richards, R. J., The Meaning of Evolution: The Morphological Construction and Ideological Reconstruction of Darwin's Theory, The University of Chicago Press, Chicago, 1992.

Richards, R. J., "Darwin on Mind, Morals and Emotions", en Hodge, J. y Radick, G. (eds), The Cambridge Companion to Darwin, Cambridge University Press, Cambridge, 2003, pp. 92-115.

Ridley, M., Evolution, 2a edición, Blackwell Scientific Publishing, Cambridge, MA, 1996; $3^{\text {a }}$ edición, Blackwell Scientific Publishing, Malden, MA, 2004.

Ridley, M. (ed), Evolution, Oxford University Press, Oxford, 1997; 2ª edición, 2004.

Robert, J., Embryology, Epigenesis and Evolution: Taking Development Seriously, Cambridge University Press, Cambridge, 2004.

Rosenberg, A., The Structure of Biological Science, Cambridge University Press, Cambridge, 1985.

Rosenberg, A., "A Field Guide to Recent Species of Naturalism", The British Journal for the Philosophy of Science, v. 47, (1996), pp. 1-29.

Rosenberg, A., "Darwinism in Moral Philosophy and Social Theory", en Hodge, J. y Radick, G. (eds), The Cambridge Companion to Darwin, Cambridge University Press, Cambridge, 2003, pp. 310-332.

Rosenberg, A., Darwinian Reductionism. Or How to Stop Worrying and Love Molecular Biology, The University of Chicago Press, Chicago, 2006.

Rostand, J., L'évolution des spèces: Histoire des idées transformistes, Hachette, París, 1932. 
Ruse, M., “The Darwin Industry: An Evaluation”, History of Science, v. 12, (1974), pp. 43-58.

Ruse, M., "Darwin's Debt to Philosophy: An Examination of the Influence of the Philosophical Ideas of John F. W. Herschel and William Whewell on the Development of Charles Darwin's Theory of Evolution", Studies in History and Philosophy of Science, v. 6, (1975), pp. 159-181.

Ruse, M., The Darwinian Revolution, The University of Chicago Press, Chicago, 1979.

Ruse, M., Darwinism Defended: A Guide to the Evolution Controversies, Addison-Wesley, Reading, 1982.

Ruse, M., Taking Darwin Seriously, B. Blackwell, Oxford, 1986.

Ruse, M., "Darwinism", en Keller, E. F. y Lloyd, E. A. (eds), Keywords in Evolutionary Biology, Harvard University Press, Cambridge, MA, 1992, pp. 74-80.

Ruse, M., “The Darwin Industry: A Guide”, Victorian Studies, v. 39, n. 2, (1996), pp. 217-235.

Ruse, M., Monad to Man: The Concept of Progress in Evolutionary Biology, Harvard University Press, Cambridge, MA, 1996.

Ruse, M., Darwin and Design: Does Evolution have a Purpose?, Harvard University Press, Cambridge, MA, 2003.

Ruse, M., "Belief in God in a Darwinian Age", en Hodge, J. y Radick, G. (eds), The Cambridge Companion to Darwin, Cambridge University Press, Cambridge, 2003, pp. 333-354.

Ruse, M., The Evolution-Creation Struggle, Harvard University Press, Cambridge, MA, 2005.

Ruse, M., Darwinism and Its Discontents, Cambridge University Press, N. York, 2006.

Ruse, M. (ed), The Cambridge Companion to the Philosophy of Biology, Cambridge University Press, Cambridge, 2007.

Salet, G., Hasard et Certitude. Le transformisme devant la biologie actuelle, Tequi, París, 1972. Vers. cast.: Azar y certeza. El transformismo frente a la Biología actual, Alhambra, Madrid, 1975.

Salthe, S. N., Development and Evolution: Complexity and Change in Biology, The MIT Press, Cambridge, MA, 1993.

SAPP, J., Evolution by Association: A History of Symbiosis, Oxford University Press, Oxford, 1994.

SARKAR, S., The Founders of Evolutionary Genetics, Kluwer, Dordrecht, 1992.

Sarkar, S., "Evolutionary Theory in the 1920s: The Nature of the "Synthesis", en Mitchell, S. D. (ed), Proceedings of the Philosophy of Science Association 2002, Part II: Symposia Papers, Philosophy of Science, v. 71, n. 5, (2004), pp. 1215-1226.

Schwartz, J. H., Sudden Origins: Fossils, Genes, and the Emergence of Species, John Wiley and Sons, N. York, 1999.

Schwartz, J. H., "Decisions, Decisions: Why Thomas Hunt Morgan Was not the 'Father' of Evo-Devo", en Solomon, M. (ed), Proceedings of the Philosophy of Science Association 2004, Part II: Symposia Papers, Philosophy of Science, v. 73, n. 5, (2006), pp. 918-929.

Shapere, D., "On the Relations between Compositional and Evolutionary Theories", en Ayala, F. J. y Dobzhansky, Th. (eds), Studies in the Philosophy of Biology, Reduction and Related Problems, Macmillan, Londres, 1974, pp. 187-204.

Simon, H. A., Reason in Human Affairs, Stanford University Press, Stanford, CA, 1983. 
Simpson, G. G., Tempo and Mode in Evolution, Columbia University Press, N. York, 1944.

Simpson, G. G., The Meaning of Evolution: A Study of the History of Its Significance for Man, Yale University Press, New Haven, CT, 1949.

Singh, R., Krimbas, C., Paul, D. y Beatty, J. (eds), Thinking About Evolution: Historical, Philosophical and Political Perspectives, Cambridge University Press, Cambridge, 2001.

Sloan, Ph. R., “The Making of a Philosophical Naturalist”, en Hodge, J. y Radick, G. (eds), The Cambridge Companion to Darwin, Cambridge University Press, Cambridge, 2003, pp. 17-39.

Sмiтh, C. U. M., “'Clever Beasts who Invented Knowing,' Nietzsche's Evolutionary Biology of Knowledge", Biology and Philosophy, v. 2, (1987), pp. 1-27.

Smocovitis, V. B., "The 1959 Darwin Centennial Celebration in America”, Osiris, v. 14, (1999), pp. 274-323.

Sober, E., Philosophy of Biology, Westview Press, Boulder, CO, 1993.

SoBer, E., The Nature of Selection, The University of Chicago Press, Chicago, 1993.

Sober, E. y Wilson, D. S., "A Critical Review of Philosophical Work on the Units of Selection Problem", Philosophy of Science, v. 61, (1994), pp. 534-555. Reimpreso en Hull, D. y Ruse, M. (eds), The Philosophy of Biology, Oxford University Press, Oxford, 1998, pp. 198-220.

Sober, E., From a Biological Point of View: Essays in Evolutionary Philosophy, Cambridge University Press, Cambridge, 1994.

Sober, E., "Metaphysical and Epistemological Issues in Modern Darwinian Theory", en Hodge, J. y Radick, G. (eds), The Cambridge Companion to Darwin, Cambridge University Press, Cambridge, 2003, pp. 267-287.

Sober, E. y Orzack, H., "Common Ancestry and Natural Selection", The British Journal for the Philosophy of Science, v. 54, n. 3, (2003), pp. 423-437.

Sober, E. (ed), Conceptual Issues in Evolutionary Biology, $3^{\text {a }}$ edición, The MIT Press, Cambridge, 2006.

Spencer, H., "Progress: Its Law and Cause", Westminster Review, v. 67, (1857), pp. 244-267.

Spencer, H., The Principles of Biology, William and Norgate, Londres, 1864-1867, 2 vols.

Stanford, P. K., "Darwin's Pangenesis and the Problem of Unconceived Alternatives", The British Journal for the Philosophy of Science, v. 57, n. 1, (2006), pp. 121-144.

Stebins, G. L., The Basis of Progressive Evolution, University of North Carolina Press, Chapel Hill, 1969.

Stebins, G. L., "Adaptive Shifts and Evolutionary Novelty: A Compositionist Approach", en Ayala, F. J. y Dobzhansky, Th. (eds), Studies in the Philosophy of Biology, Reduction and Related Problems, Macmillan, Londres, 1974, pp. 285-306.

Stebins, G. L., "Botany and the Synthetic Theory of Evolution", en Mayr, E. y Provine, W. B. (eds), The Evolutionary Synthesis: Perspectives on the Unification of Biology, Harvard University Press, Cambridge, 1980, pp. 139-152.

Sulloway, F. J., "Darwin's Conversion: The Beagle Voyage and its Aftermath", Journal of the History of Biology, v. 15, (1982), pp. 325-396.

Szathmary, E. y Maynard Smith, J., "The Major Evolutionary Transitions”, Nature, v. 374, (1995), pp. 227-232. 
TAx, S. (ed), Evolution After Darwin, The University of Chicago Press, Chicago, 1960, 3 vols.

Templado, J., Historia de las teorías evolucionistas, Alhambra, Madrid, 1982.

Thagard, P., Conceptual Revolutions, Princeton University Press, Princeton, 1992.

Thagard, P., "Mind, Society and the Growth of Knowledge", Philosophy of Science, v. 61, (1994), pp. 629-645.

Thagard, P., "Explaining Scientific Change: Integrating the Cognitive and the Social", Hull, D., Forbes, M. y Burian, R. M. (eds), Proceedings of the 1994 Biennial Meeting of the Philosophy of Science Association, Philosophy of Science Association, East Lansing, MI, vol. 2, 1995, pp. 298-303.

Tinbergen, N., The Study of Instinct, Oxford University Press, N. York, 1951 (reimpreso en 1961).

Toulmin, S. E., Human Understanding, vol. 1. The Collective Use and Evolution of Concepts, Oxford University Press, Oxford, 1972.

Urbach, P., "The Scientific Standing of Evolutionary Theories of Society", London School of Economics Quarterly, v. 1, n. 1, (1987), pp. 23-42.

Waddington, C. H., The Strategy of the Genes, Allen and Unwin, Londres, 1957.

Wallace, A. R., "On the Law Which Has Regulated the Introduction of New Species", Annals and Magazine of Natural History, v. 16, 2ª ser., (1855), pp. 184-196.

Wallace, A. R., Contributions to the Theory of Natural Selection, Macmillan, Londres, 1870 (reimpreso por AMS Press, N. York, 1973).

Wallace, A. R., Studies: Scientific and Social, Macmillan, Londres, 1900.

Walsh, D. M., "The Pomp of Superfluous Causes: The Interpretation of Evolutionary Theory", Philosophy of Science, v. 74, n. 3, (2007), pp. 281-303.

Waters, C. K., "The Arguments in the Origin of Species", en Hodge, J. y Radick, G. (eds), The Cambridge Companion to Darwin, Cambridge University Press, Cambridge, 2003, pp. 116-139.

Whewell, W., The Philosophy of the Inductive Sciences, Parker, Londres, 1840.

Williams, G. C., Adaptation and Natural Selection: A Critique of Some Current Evolutionary Thought, Princeton University Press, Princeton, 1966.

Williams, M. B., "Falsifiable Predictions of Evolutionary Theory", Philosophy of Science, v. 40, (1973), pp. 518-537.

Wicken, J., Evolution, Thermodynamics and Information, Oxford University Press, N. York, 1987.

Wiley, E. O., "Entropy and Evolution”, en Weber, B. H., Depew, D. J. y Smith, J. D. (eds), Entropy, Information and Evolution, The MIT Press, Cambridge, MA, 1988, pp. 173-188.

Wilson, E. O., Sociobiology: The New Synthesis, Harvard University Press, Cambridge, MA, 1975.

Witt, U., The Evolving Economy: Essays on the Evolutionary Approach to Economics, E. Elgar, Cheltenham, 2003.

Wittgenstein, L., Tractatus Logico-Philosophicus, edición bilingüe alemán-inglés, con traducción inglesa de C. K. Ogden y F. P. Ramsey, Routledge and Kegan Paul, Londres, 1922 (reimpreso en 1971). Nueva traducción inglesa de D. F. Pears y B. F. McGuinness, en Routledge and Kegan Paul, Londres, 1961 (reimpreso en 1981). 
Woese, C. R., Kandler, O. y Wheelis, M. L., “Towards a Natural System of Organisms: Proposal for the Domains Archaea, Bacteria, and Eucarya", Proceedings of the National Academy of Science, v. 87, (1990), pp. 4576-4579.

Woese, C. R., "Default Taxonomy: Ernst Mayr's View of the Microbial World", Proceedings of the National Academy of Science, v. 95, (1998), pp. 11043-11046.

Wright, S. G., Evolution: Selected Papers, editado por W. Provine, The University of Chicago Press, Chicago, IL, 1986.

Wuketits, F. M. y Antweiler, CH. (eds), Handbook of Evolution, vol. 1: The Evolution of Human Societies and Cultures, Wiley-VCH, Weinheim, 2003.

Wuketits, F. M. y Ayala, F. J. (eds), Handbook of Evolution, vol. 2: The Evolution of Living Systems, J. Wiley-VCH, Weinheim, 2005.

Wuketits, F. M., "Evolutionary Epistemology and the Concept of Life", en Gonzalez, W. J. y Alcolea, J. (eds), Contemporary Perspectives in Philosophy and Methodology of Science, Netbiblo, A Coruña, 2006, pp. 137-148.

Wynne-Edwards, V. C., Animal Dispersion in Relation to Social Behaviour, Oliver and Boyd, Edimburgo, 1962.

Zuckerland, E., "On the Molecular Evolutionary Lock", Journal of Molecular Evolution, v. 26, (1987), pp. 34-46. 



\section{I}

\section{Darwin y la Teoría de la Evolución}

2. La evolución de los experimentos mentales darwinianos

3. ‘¿Está sugiriendo una nueva Teoría general de la Evolución?’ Una valoración filosófica de la evaluación de Stephen Jay Gould acerca de la Teoría de la Evolución contemporánea 



\title{
LA EVOLUCIÓN DE LOS EXPERIMENTOS MENTALES DARWINIANOS*
}

\author{
James G. Lennox
}

\section{INTRODUCCIÓN}

En un artículo anterior sostuve que Charles Darwin usa una particular estrategia argumentativa en On the Origin of Species ${ }^{1}$, que denominé "Experimento Mental Darwiniano" (EMD). Ofrecí pruebas de que usaba los EMDs a la vez como forma de comprobar la capacidad explicativa de la teoría y como método para desarmar un tipo de críticas particularmente problemáticas. Intento aquí complementar ese análisis previo en dos aspectos. En primer lugar, situaré la idea de experimento mental darwiniano en un contexto filosófico más amplio, que ayudará a explicar una característica un tanto desconcertante de la estructura de Origin y una habitual objeción metodológica en contra suya. En segundo término, rastrearé los orígenes de este método de razonamiento en los Cuadernos de las especies B-E (Species Notebook B-E), y compararé el desarrollo consciente de esta pauta de razonamiento de Darwin con un razonamiento similar, aunque no sea reflexivo, en el segundo volumen de los Principles of Geology de Lyell, una obra que había sido compañía constante de Darwin durante el viaje del HMS Beagle.

\section{INDUCCIÓN E Historia}

A los estudiosos y biógrafos de Darwin les gusta recordarnos que en su autobiografía - escrita a una edad avanzada para entretenimiento privado de su familia - Charles Darwin señaló el Personal Narrative of Travels to the Equinoctial Regions of the New Continent during the Years 1799-1804 de Alexander von Humbolt y el Preliminary Discourse on the Study of Natural Philosophy de Sir John Herschel como las influencias más significativas en su decisión de seguir la vida de naturalista. Pero el comentario de Darwin acerca de la influencia de estos libros carece de detalles. Sencillamente, no dice, por ejemplo, qué aspectos particulares de la interesante Introducción de J. Herschel al método científico dejaron huella en él. Comienzo, pues, intentando perfilar algunas influencias concretas de Herschel sobre los métodos de investigación y búsqueda de Darwin — sobre los aspectos "inductivos" del Pensamiento de Darwin, tal y como esto se entendía a principios del siglo XIX-.

El capítulo VI del Preliminary Discourse de Sir John Herschel, titulado "Del primer estadio de la inducción", sostiene que el avance de la Ciencia nos proporciona "una cantidad creciente de fenómenos previos o causas [...] adecuadas bajo diferentes modificaciones para la producción de una gran multitud de efectos, además de aquellos que originalmente conducen a

La traducción ha sido realizada por Rafaela García Elskamp. N. del E.

1 Cfr. Lennox, J. G., "Darwinian Thought Experiments: A Function for Just-so Stories”, en Horowitz, T. y Massey, G. (eds), Thought Experiments in Science and Philosophy, Rowman and Littlefield, Savage, MD, 1991, pp. $223-246$. 
su conocimiento" ${ }^{2}$. La capacidad de algunos procesos de generar una variedad de efectos más allá de aquellos que inicialmente se investigaron es — según la construcción de Herschel— lo que Newton tenía en mente con el concepto de vera causa: "causas reconocidas que poseen existencia real en la Naturaleza y que no son simples hipótesis o quimeras de la mente" 3 . Curiosamente, Herschel ilustra ese paso del avance de la Ciencia con ejemplos geológicos, esto es, ejemplos extraídos de una Ciencia histórica. Estos ejemplos también demuestran que, para Herschel, el tener una existencia real en la Naturaleza sólo es una débil condición necesaria para que algún agente o proceso sea una vera causa. Porque parte del contenido de estos ejemplos es ilustrar que un número de procesos que se presupone que explican amplios tipos de hechos que menciona son, aunque demostrablemente reales, inadecuados para la tarea explicativa.

Supongamos, por ejemplo, que queremos explicar el hecho según el cual por todo el mundo, en muy diferentes situaciones, se encuentran conchas de seres marinos o sus restos fosilizados a grandes alturas, lejos del mar. Se podría suponer — señala Herschel— que peregrinos (pilgrims) transportaron comida desde el mar hasta grandes alturas y desecharon las conchas; o se podría suponer que la fermentación del suelo produjo estos fósiles. Los dos procesos — dice Herschelocurren de hecho en la Naturaleza: peregrinos llevan moluscos hacia las montañas lejos del mar y desechan sus conchas; y hay un conocido proceso de fermentación, que puede producir restos en el suelo. Pero la hipótesis del "transporte de los peregrinos" no da cuenta de la enorme extensión del fenómeno o de los fósiles; y no hay en absoluto pruebas empíricas (evidence) de que la fermentación, aunque sea la causa real de algunas cosas, pueda producir objetos que se parezcan a conchas de moluscos o sus fósiles. Así, aunque ambos agentes sean causas reales, ninguno es adecuado para la explicación concreta que llevamos entre manos ${ }^{4}$.

Estos ejemplos ilustran que, para Herschel, una vera causa debe (a) poder dar cuenta de la escala completa de fenómenos a explicar y (b) confirmarse como productora de todos esos fenómenos. Establecer estas causas es el primer y fundamental paso de la inducción científica; y es crucial para el proceso establecer que la causa es adecuada para toda la gama de los fenómenos en cuestión.

En 1961, Water Cannon publicó un artículo en el que reprodujo y analizó una carta enviada por Herschel desde Ciudad del Cabo en Sudáfrica a Charles Lyell en Febrero de 1836. Esta carta establece con claridad que se consideraba generalmente que los Principles of Geology de Lyell estaban a favor de explicar los orígenes de nuevas especies a través de mecanismos naturales. Sin embargo, rara vez se analiza la carta de Herschel confrontándola con los trabajos previos sobre Teoría de la Ciencia que Herschel había defendido sólo cinco años antes en su Preliminary Discourse. Cuando se reconoce ese trabajo previo, la carta adquiere un significado añadido. Cuando, por ejemplo, él afirma que “...toda la analogía nos conduce a suponer que Él [el Creador] actúa a través de una serie de causas intermedias" y que "el origen de especies nuevas" debe ser un proceso natural en vez de milagroso $-\mathrm{y}$ en este punto añade que "no percibimos indicaciones de ningún proceso realmente en desarrollo que sea probable que nos

\footnotetext{
2 Herschel, J. F. W., A Preliminary Discourse on the Study of Natural Philosophy, Longman, Londres, 1830; reimpreso por The University of Chicago Press, Chicago, 1987, p. 144.

3 Herschel, J. F. W., A Preliminary Discourse on the Study of Natural Philosophy, p. 144.

4 A Preliminary Discourse on the Study of Natural Philosophy, p. 144. Más adelante, mantiene que “... we cannot only show [these causes] to exist and to act, but the laws of whose action we can derive independently, by direct induction, from experiments purposely instituted...", Herschel, J. F. W., A Preliminary Discourse on the Study of Natural Philosophy, p. 197.
} 
lleve a conseguir ese resultado": está diciendo que, hasta ese momento, no se ha encontrado ni siquiera la débil condición necesaria para una vera causa en este caso ${ }^{5}$.

Esta carta fue escrita sólo cuatro meses antes de que Darwin se encontrara con Herschel por vez primera en Ciudad del Cabo, cuando el Beagle recaló allí en su viaje de vuelta a Gran Bretaña. Leída como yo he sugerido que se lea, a la luz de las anotaciones de la investigación científica de Herschel en su Preliminary Discourse, va más allá de un mero enunciado de búsqueda de un mecanismo natural para el origen de las especies. Especifica un problema más concreto, que es (así lo defenderé) el problema clave del Species Notebooks de Darwin: establecer una vera causa como probable para el origen de una nueva especie. Esto es, no sólo debe mostrarse que se trata de un proceso que opera realmente en la Naturaleza; debe mostrarse además que es adecuado para toda la escala de los efectos, lo cual en este caso resulta desalentador: ¡todos los datos conocidos sobre todos los organismos, pasados y presentes!

En su Diario del Beagle, Darwin se refiere a una cena en la casa de Herschel en Ciudad del Cabo como "el evento más memorable que había tenido la buena fortuna de disfrutar en mucho tiempo" ". Esto no es sorprendente. No sólo sabemos de la ilimitada admiración de Darwin por el Preliminary Discourse de Herschel, también sabemos que ambos habían estudiado detenidamente los Principles of Geology de Lyell durante los tres años anteriores. Herschel afirma en su carta a Lyell que acaba de leerlos por tercera vez, y su carta consta principalmente de páginas con detalladas notas críticas. Darwin, como sabemos por su correspondencia - especialmente la mantenida con John Henslow (su mentor en Cambridge) y a partir de sus anotaciones en el Beagle - , se refería constantemente a ellos [a los Principles of Geology] y se veía como un discípulo de Lyell. ¿Hablaron entonces, durante la cena, de su extensa presentación y crítica de las concepciones de J. B. Lamarck sobre la modificación indefinida de las especies - de los cuatro primeros capítulos del volumen II- o sobre sus especulaciones sobre "la aparición de nuevas especies", del capítulo 11 ?

No existe la "prueba del delito"; sin embargo, la prueba indirecta de esa conversación es intrigante. Nada más partir de Sudáfrica, en sus Ornithological Notes, Darwin escribió que las pruebas empíricas de sus estudios de campo podrían suponer un desafío a la tesis clave del volumen II de los Principios de Lyell: la permanencia de las especies ${ }^{7}$. Esta es nuestra primera prueba de que Darwin ha pensado sobre esta cuestión. Además, hay algunas anotaciones anteriores en el Red Notebook que se refieren a ideas que aparecen en la carta de Herschel a Lyell - y Darwin comenzó este cuaderno nada más zarpar el Beagle de Ciudad del Cabo ${ }^{8}$ — Como

\footnotetext{
5 Cfr. CAnnon, W., "The Impact of Uniformitarianism: Two Letters from John Herschel to Charles Lyell, 1836-1837”, Proceedings of the American Philosophical Society, v. 105, (1961), pp. 301-314; especially, p. 305.

Charles Babbage publicó varios pasajes de esta carta como 'Nota I' de BABBAGE, CH., The Ninth Bridgewater Treatise: A Fragment, John Murray, Londres, 1837. Darwin comenta con aprobación al final de su cuadernos de las especies: "Babbage 2nd Edit, p. 226.-Herschel calls the appearance of new species. the mystery of mysteries. $\&$ has grand passage upon problem.! Hurrah.- 'intermediate causes"', Barrett, P. et AL. (eds), Charles Darwin's Notebooks, 1836-1844, Cornell University Press, Ithaca, NY, 1987, Notebook E, p. 59.

6 Darwin, Ch., Charles Darwin's Diary of the Voyage of H.M.S. Beagle, edición de Nora Barlow a partir del texto original, Cambridge University Press, Cambridge, 1933; reimpreso por Kraus Reprint Co., N. York, 1969, p. 409.

7 Cfr. Darwin, Ch., "Darwin's Ornithological Notes", editado por Nora Barlow, Bulletin of the British Museum (Natural History), Historical Series, v. 2, n. 7, (1963), p. 262.

8 Véase Hodge, J., "Darwin Studies at Work: A Re-examination of Three Decisive Years (1835-37)", en LEVERE, T. H. y SheA, W. R. (eds), Nature, Experiment, and the Sciences, Kluwer, Dordrecht, 1990, pp. 249-274; y Herbert, S. (ed), The Red Notebook of Charles Darwin, British Museum (Natural History), Londres, 1980. Las ideas de la carta de Herschel se analizan en p. 30; cfr. nota 40 de Herbert en p. 86.
} 
mínimo, estos datos establecen que Darwin y Herschel discutieron algunos problemas de los Principles de Lyell que se exponen en la carta de Herschel; y que, por tanto, bien pueden haber discutido el origen de las especies ${ }^{9}$. Eso haría que sea natural la datación del famoso pasaje de las Ornithological Notes después de dejar Ciudad del Cabo y a Herschel. Ese pasaje se refleja en algunos ejemplos de especies estrechamente relacionadas en un mismo archipiélago. Concluye que:

"Si existe el mínimo fundamento para estas observaciones, bien merecerá la pena examinar la Zoología de los Archipiélagos, ya que esos hechos debilitarían la estabilidad de las especies" ${ }^{10}$.

Uno bien podría preguntarse: ¿por qué iba a ser así? En esos casos, los límites entre variedad y especie parecen borrosos, y se torna muy fácil el imaginar que, lo que ahora son especies próximas, muy parecidas, pudieron haber sido con anterioridad variedades de la misma especie. Y, en el momento en que uno contempla ese pensamiento, se aproxima peligrosamente a la idea según la cual las especies "pueden ser capaces de modificarse indefinidamente", la descripción que hace Lyell acerca de la concepción de J. B. Lamarck. Pero acoger esta posición es, como expone Charles Lyell en la primera página del volumen II de los Principles, admitir la perspectiva según la cual las especies no son "reales y permanentes" ". Es, como dice Darwin en la cita anterior, debilitar su estabilidad.

La cuestión suscitada en la primera página de la carta de J. Herschel es un asunto de importancia fundamental para alguien que, como Darwin en 1836, está preocupado por la "estabilidad de las especies" y comprometido con la Metodología actualista de Lyell, que invoca como causas de eventos pasados sólo aquellos procesos que están en funcionamiento en la actualidad y [son] así observables. Un discípulo de Lyell está limitado a explicar los eventos del pasado geológico — que incluyen la introducción de nuevas especies — mediante la referencia a causas de un tipo e intensidad que sea observable en el presente, y abiertos así a la investigación inductiva. Por poner el problema de Lyell en términos de Herschel: la única manera inductivamente responsable de desarrollar hipótesis causales sobre el pasado prehistórico es mediante la referencia a causas reales, observadas repetidamente, que son "capaces de producir una gran multitud de efectos bajo diferentes modificaciones"; efectos al menos análogos a los sustentados en los datos de la Paleontología y en la Historia Natural.

La frase inicial de los Principles de Lyell dice: "La Geología es la Ciencia que estudia los sucesivos cambios que han tenido lugar en los reinos orgánicos e inorgánicos de la Naturaleza" y “... las causas de estos cambios..." 12 . El segundo volumen tiene como objetivo "llamar nuestra atención sobre esos (cambios) actualmente en desarrollo en la creación animada"; el más importante entre éstos [consiste en] "las vicisitudes a las que están sujetas las especies" y, en particular, "si hay pruebas de la extinción sucesiva de especies en el curso normal de la Naturaleza, y si hay alguna razón para conjeturar que se crean nuevas plantas y animales de vez

\footnotetext{
9 De una entrada similar sobre The Red Notebook of Charles Darwin, p. 115, Herbert dice: "Presumiblemente Lyell mostró a Darwin la carta de Herschel, o trató de sus contenidos con él en algún momento de finales de 1836 o comienzos de 1837", (nota 133, p. 104). Pienso que es igualmente posible que la información de Darwin proceda de la misma fuente que la anterior entrada.

10 Darwin, Ch., "Darwin's Ornithological Notes", editadas por Nora Barlow, p. 262.

11 Cfr. Lyell, CH., Principles of Geology, John Murray, Londres, 1830-1833, 3 vols. Reimpreso en edición facsímil, The University of Chicago Press, Chicago, 1990, pp. 1-2.

12 Lyell, CH., Principles of Geology, Volume I, p. 1.
} 
en cuando, para ocupar su lugar" ${ }^{13}$. En el capítulo 11, Lyell aborda esta cuestión, que rechaza la afirmación de A. Humboldt según la cual "estos están entre los misterios que la Ciencia de la Naturaleza no puede alcanzar" ${ }^{14}$. Lyell insiste en que la investigación del estado actual de la creación animada puede arrojar luz sobre su pasado ${ }^{15}$. Nos pide que consideremos qué clase de pruebas empíricas necesitaríamos para estar seguros de que "la creación sucesiva de especies" es "una parte normal de la economía de la Naturaleza". Este es el enfoque elogiado por su valor y coraje en la página inicial de la carta de Herschel.

Sin embargo, Lyell concluye el debate sin plantear si quiera la cuestión de "qué causas actualmente en funcionamiento" pueden conducir a "la creación sucesiva de especies", y menos aún que proponga una respuesta. Para afrontar este asunto con el soporte de la Metodología inductiva herscheliana, se deben buscar agentes observables, capaces de producir la gama completa de efectos necesarios para dar una explicación (en este caso, la aparición histórica y la distribución actual de las especies).

Lyell, pues, plantea el problema de establecer un mecanismo natural para explicar el origen de las especies y Herschel proporciona el soporte metodológico dentro del cual se tiene que buscar una solución al asunto. Este es el problema al que Darwin mismo se dedica en los años 1837-1839, y como argumentaré en un momento, tiene el objetivo de hacerlo dentro de los parámetros planteados por Herschel. Darwin tiene éxito al establecer un proceso causal que, en principio, es observable. Dicho de otra manera, las condiciones que afirma que conducirán a la selección natural - la aparición de variación no dirigida dentro de las especies, la herencia normal de la variación, la lucha por la existencia entre miembros de una misma especie, la tendencia a que las poblaciones naturales crezcan en proporción geométrica- pueden todas ser confirmadas de modo inductivo. Sin embargo, eso no es lo mismo que mostrar que estas características diferentes de las poblaciones naturales se combinan exactamente de la manera adecuada para producir primeras nuevas variedades, después nuevas especies incipientes y, finalmente, nuevas especies. Desde luego, en una Ciencia experimental éste es precisamente el punto en el que se introduce el experimento. Pero la Biología evolucionista se convierte en una Ciencia experimental en el siglo XX. No lo fue para Darwin. El problema central de Darwin es que no sólo necesita establecer que cada uno de los componentes del proceso de selección tiene una "existencia real en la Naturaleza", necesita convencer a la gente de que es capaz de producir la aparición regular de nuevas especies, bien adaptadas a su medio natural.

¿Cómo puede entonces afirmarse, si no hay pruebas empíricas de que en los casos observados una causa ha producido el efecto deseado, que ésta podría producirlo en los casos no observados? En mi análisis previo de los Experimentos Mentales Darwinianos, argumenté que Darwin hizo uso de los experimentos mentales precisamente con esta finalidad ${ }^{16}$. También señalé que la reseña de Fleeming Jenkin sobre Origin reveló las limitaciones de esta técnica y sugirió algunas restricciones de su uso eficaz. Jenkin señaló que la única prueba real en Origin de que la selección provoca sus efectos — la producción doméstica de variedades - era inadecuada para la tarea de la producción de especies en la Naturaleza (o mediante domesticación, para este

13 Principles of Geology, Volume II, pp. 1-2.

14 Lyell, CH., Principles of Geology, Volume II, p. 179.

15 Principles of Geology, Volume II, p. 179.

16 Cfr. Lennox, J. G., "Darwinian Thought Experiments: A Function for Just-so Stories", en Horowitz, T. y Massey, G. (eds), Thought Experiments in Science and Philosophy, pp. 223-246. 
caso). Aceptó el modelo causal de Darwin e introdujo valores cuantitativos plausibles en las narraciones causales imaginarias de Darwin, valores que, por mucho que se multipliquen, no llevarían a la producción de especies nuevas ${ }^{17}$.

En la siguiente sección, analizo brevemente los resultados de esa posición y argumento que este aspecto de la Metodología de Darwin explica una característica de la estructura de Origin que rara vez se aborda.

\section{LOS EXPERIMENTOS MENTALES EN EL ORIGEN DE LAS ESPECIES}

Durante muchos años Jonathan Hodge ha defendido que el objetivo de Darwin en el Origin era cumplir con el ideal herscheliano de establecimiento de una vera causa. Para hacerlo - sostiene Hodge - se necesita establecer la existencia de la causalidad a la que antes se apelaba, su adecuación a la tarea explicativa que llevamos entre manos y su responsabilidad respecto de los efectos necesitados de explicación ${ }^{18}$. Hodge ve que las dos primeras cuestiones se logran conjuntamente en los primeros ocho capítulos. En mi artículo publicado en 1991 ("Darwinian Thought Experiments: A Function for Just-so Stories"), dirigí mi atención sobre el uso de los experimentos mentales como el método que Darwin usó eficazmente para hallar la condición de adecuación (o, en términos más propios de Herschel, la "capacidad" - competency-). Pero los experimentos mentales darwinianos son narraciones imaginarias que sirven como comprobación de la capacidad explicativa de la selección. En ese caso, se plantea una cuestión importante sobre qué papel pueden jugar en la estrategia argumentativa de Darwin.

En los primeros cuatro capítulos de Origin se describe a un nivel muy general una gran variedad de procesos: la herencia mediante reproducción sexual, la generación de la variación de caracteres, la propensión malthusiana a la expansión de la población y las contrastaciones malthusianas sobre dicha expansión, las interacciones entre el organismo y el medio ambiente, los cambios lentos y graduales de las condiciones del medio ambiente. La teoría de Darwin postula que, si hay tiempo suficiente, el funcionamiento interactivo entre estos procesos es capaz de transformar especies ancestrales en una o más especies descendientes.

No obstante, la noción de capacidad (competence) es ambigua. Para defender que algo es capaz de producir un cierto resultado, se podría suponer que es suficiente mostrar que puede hacerlo, aun cuando jamás se haya observado que haya sido así. Si no, se podría insistir que una causa se muestra que es capaz para toda la gama de sus efectos sólo cuando una observación adecuadamente controlada y el experimento han mostrado que produce realmente esos efectos. Darwin pretende lograr el primer resultado; las reacciones de J. Herschel, W. Whewell y Ch. Lyell indican que sólo estarían satisfechos con el segundo.

El uso de Darwin del experimento mental en los capítulos 4 al 9 de Origin proporciona al lector una variedad de ejemplos concretos, pero imaginarios, del modelo causal de Darwin en funcionamiento, y pide que el lector imagine cambios graduales con el paso del tiempo en

\footnotetext{
17 En su copia de 1831 de los Preliminary Discourse de Herschel, Darwin señala varios pasajes que afirman que las inducciones cualitativas y vagas fácilmente se invalidan con comprobaciones (tests) cuantitativamente precisas. Darwin releía a Herschel en 1838.

18 Un análisis sucinto de este caso, que hace referencia a su defensa original de la concepción y lo compara con otras lecturas, puede verse en Hodge, M. J. S., "Discussion: Darwin's Argument in the Origin", Philosophy of Science, v. 59, n. 3, (1992), pp. 461-464.
} 
estas poblaciones imaginarias. Se nos pide si parece posible que, si esos cambios continúan durante un periodo suficientemente largo, podrían resultar una o más especies. Los experimentos mentales darwinianos comparten con todos los experimentos mentales la función de contrastar la capacidad explicativa de las teorías (esto es lo que los diferencia funcionalmente de los experimentos reales).

Los experimentos mentales darwinianos cumplen dos funciones diferentes en Origin: (a) en cuanto narraciones concretas e imaginarias, pretenden mostrar que la selección natural puede producir nuevas variedades y especies; y (b) en cuanto narraciones de "lo posible", se usan para transformar supuestos contraejemplos en consecuencias posibles de las intervenciones de las causas postuladas por la teoría. La tarea (a) destaca en la sección del capítulo 4 titulada "Ilustración de la acción de la selección natural", donde Darwin pide permiso "para dar una o dos ilustraciones imaginarias" ${ }^{19}$. El cometido (b) es el quehacer primario de los capítulos sexto al noveno, en los cuales Darwin se ocupa de las “dificultades en torno a la teoría". En los capítulos 6 y 7, por ejemplo, Darwin anota de modo habitual que, si sus oponentes argumentan que una adaptación compleja o un comportamiento instintivo no pudo haberse producido de ninguna manera mediante la selección lenta y acumulativa de cambios mínimos, entonces su tarea es establecer cómo pudo hacerlo la selección natural, un cometido que ha de ser realizado mediante los experimentos mentales darwinianos.

Pero, ¿sirven estos vuelos de la imaginación como pruebas acerca del modo en el que realmente se produjeron las adaptaciones complejas? Inmediatamente después de un experimento mental, bastante extenso, que imagina cómo el ojo de los vertebrados ha podido evolucionar según la selección natural, se sitúa uno de los pasajes metodológicamente más representativos del Origin:

"Quien vaya tan lejos, si al finalizar este tratado encuentra que numerosos hechos, de otro modo inexplicables, se pueden explicar mediante la teoría de la descendencia, no debería de dudar de ir más allá y admitir que, incluso una estructura tan perfecta como el ojo de un águila, podría formarse por selección natural, aunque en este caso uno no conozca los grados transitorios. Su razón debe conquistar a su imaginación...” ${ }^{20}$.

En otras palabras, es en la combinación entre el experimento mental darwiniano $y$ las pruebas empíricas aportadas en los capítulos 10 al 13 donde apoyará su propuesta. Estas líneas de prueba no son independientes entre sí, sino que se refuerzan mutuamente.

Darwin no es consistente acerca de la necesidad de ambos tipos de soporte. A menudo habla como si una teoría sobre "la capacidad de agrupar y explicar los fenómenos" - la fuerza argumentativa de los capítulos 10-13 - fuese suficiente, como se ve en la siguiente nota a Hooker, que compara su teoría con la teoría ondulatoria de la luz:

“... la descendencia de especies, con sus modificaciones a través de la selección natural, agrupa y explica bastante bien muchos fenómenos (como la clasificación, la Morfología, los órganos rudimentarios, la Embriología, en parte la distrib[ución] geográf[ica] y en parte la Sucesión Geológ[ica]) y, por consiguiente, creo en su verdad" ${ }^{21}$.

19 Darwin, Ch., On the Origin of Species: A Facsimile of the First Edition, Harvard University Press, Cambridge, MA, 1964, p. 90; énfasis añadido.

20 Darwin, CH., On the Origin of Species: A Facsimile of the First Edition, p. 188.

21 Burkhardt, F. et Al. (eds), The Correspondence of Charles Darwin, vol. 9, Cambridge University Press, Cambridge, 1994, p. 50; compárese p. 135, a Herschel. 
Sin embargo, en una carta a Asa Gray de ese mismo año, Darwin subraya otra vez la necesidad de ambas. Explica que podía creer que una estructura fuese diseñada “... hasta que vi un modo de ser formada sin diseño y, al mismo tiempo, vi pruebas en toda su estructura (tales como las homologías, la Embriología, los órganos rudimentarios, la distribución, etc.) de haber sido producida de una manera completamente distinta" ${ }^{22}$. Los experimentos mentales darwinianos son su primera herramienta para convencer a los lectores de que las adaptaciones pudieron formarse mediante la selección natural. Todo lo demás son pruebas empíricas indirectas de que lo han sido.

Darwin subraya este mismo aspecto en un pasaje muy conocido de la Introducción de Origin. Incluso si todas nuestras pruebas empíricas a partir de la Geología y la Historia Natural apoyaran el origen de las especies por descendencia, esa conclusión — según insiste — sería insatisfactoria, si el mecanismo que dirige la descendencia no pudiera explicar la belleza de las adaptaciones resultantes ${ }^{23}$.

Sin embargo, lo que mejor manejó Darwin en este área fue el mostrar cómo era posible que los procesos causales, que describe en los capítulos 2 al 4, interactuaran de tal manera que se produjera tal grado de perfección. Y ahí reside el problema que tuvieron con Origin tantos miembros de su audiencia ideal. Estos experimentos mentales, tan vívidos como parecen ser, son de hecho producto de la fértil imaginación de Darwin. Pueden establecer la posibilidad de especies que surgen como resultado de lentas modificaciones controladas por la selección, pero no hacen más que eso.

El segundo cometido de los experimentos mentales darwinianos —el dar respuesta a argumentos de imposibilidad - subraya una característica innovadora de la estructura de Origin, que normalmente pasa desapercibida. Esta característica se refleja en el capítulo final, que comienza señalando que Origin es "un extenso argumento". Este capítulo, que está pensado en principio como un resumen de ese argumento, comienza con siete páginas de dificultades de su teoría (esto es, con un resumen de los capítulos 6 al 9). Al considerar por qué Darwin expondría las dificultades de su teoría antes de proporcionar las pruebas en su favor, se torna más clara la importancia del experimento mental darwiniano para el argumento de Origin ${ }^{24}$. Este punto está expresado brillantemente en un pasaje del Borrador de Origin escrito por Darwin en 1844:

“... podríamos considerar aquí si los instintos de los animales brindan prima facie una defensa de la imposibilidad de la adquisición gradual, como para justificar el rechazo de cualquier teoría de este tipo, aunque pueda estar fuertemente apoyada en otros hechos. Estoy interesado en repetir que querría considerar aquí no la probabilidad sino la posibilidad de que los instintos complejos se hayan adquirido a través de una selección lenta y prolongada de muy ligeras ... modificaciones de instintos previos más sencillos ..." ${ }_{25}$.

22 Burkhardt, F. ET AL. (eds), The Correspondence of Charles Darwin, vol. 9, p. 302.

23 Darwin, Ch., On the Origin of Species: A Facsimile of the First Edition, p. 3.

24 Por ejemplo, en un artículo reciente Ken Waters indica cuidadosamente la diferencia entre los capítulos 6-9 y 10-13, pero no comenta lo extraño de emplazar el análisis de los problemas antes de las persuasivas pruebas positivas. Cfr. Waters, C. K., "The Arguments in the Origin of Species", en Hodge, J. y Radick, G. (eds), The Cambridge Companion to Darwin, Cambridge University Press, Cambridge, 2003, pp. 116-139.

25 Barrett, P. H. y Freeman, R. B. (eds), The Works of Charles Darwin, vol. 10: The Foundations of the Origin of Species: Two Essays Written in 1842 and 1844, New York University Press, N. York, 1987, p. 92; cfr. pp. 96-97; énfasis en el original. 
Darwin reconoce aquí que, si la prueba empírica tomada de los instintos muestra que la teoría es imposible, ninguna suma de "agrupamientos y explicaciones" la salvará. Pero también insiste en que todo aquello que se necesita para contrarrestar esa afirmación constituye una demostración de que es posible que la teoría trate tales casos. Estos pasajes facilitan la comprensión de la decisión de Darwin, cuando escribe Origin, de presentar tales pruebas en capítulos separados, antes que el apoyo inductivo a la teoría (algo que no hizo en el borrador de 1844).

Es innovador el uso que hace Darwin de esta forma de razonamiento para demostrar lo que podemos llamar la "capacidad débil" (weak competency). Sus orígenes, sin embargo, no son difíciles de encontrar una vez que se sabe qué se busca. En la siguiente sección de este trabajo veremos la aparición de esta estrategia cognitiva y la aparición gradual en la conciencia de Darwin de su valor: en sus Species Notebooks.

\section{LA EVOLUCión de UNA ESTRATEgIA COGNITIVA}

Los cuadernos de Darwin posteriores al Beagle sobre la cuestión de las especies, escritos durante los años 1837-1838 - y bellamente editados y comentados por David Kohn ${ }^{26}$-, constituyen una narración privada del descubrimiento, del desarrollo gradual de algo que, hacia el final del Cuaderno C, denomina como "mi teoría".

En estos cuadernos, Darwin también desarrolla esas estrategias cognitivas abordadas en la sección anterior de este artículo. De hecho, Darwin usaba una forma de razonamiento de "pensamiento experimental" casi desde el principio de estos cuadernos, no como un método de defensa de su teoría, sino como un medio de explorar la capacidad de las ideas que desarrolla para explicar hechos que, normalmente, plantean problemas a las concepciones transformistas (transformist views) acerca del origen de las especies.

Desde que se fue de Ciudad del Cabo Darwin apoyó el transformismo, la concepción según la cual las especies posteriores son descendientes "transformados" de especies previas. Estaba convencido de que una amplia gama de hechos relacionados con la distribución geográfica de organismos y su sucesión geológica encajaba claramente con su visión de la Historia de la vida. Él era bien consciente también de los problemas habituales de todas esas teorías. Ocasionalmente, al reflexionar sobre lecturas relacionadas con "la cuestión de las especies" a la luz del rico tapiz de las experiencias adquiridas en sus años del Beagle, se para a comprobar las ideas teóricas que se esfuerza por articular para enfrentarse a tales problemas. Para hacerlo, plantea escenarios imaginarios, que asumen el funcionamiento de esos procesos causales que considera en ese momento. Es como decir que realiza experimentos mentales.

Por ejemplo, las excavaciones europeas de tumbas en el bajo Egipto realizadas en el siglo XIX revelaron restos de algunos animales momificados y también retratos realistas de los mismos. Estos mostraron que no se había producido virtualmente ningún cambio en estas criaturas a lo largo de muchos miles de años, lo cual sugería la estabilidad o "fijación” de las especies. Darwin conocía esta objeción de Lamarck y Lyell ${ }^{27}$, y la usó para probar sus puntos de vista en desarrollo acerca del aislamiento y la lucha.

26 Cfr. Barrett, P. ET Al. (eds), Charles Darwin's Notebooks, 1836-1844, pp. 167-456.

27 Lamarck, J-B., Zoological Philosophy, University of Chicago Press, Chicago, 1984, pp. 41-42; Lyell, Ch., Principles of Geology, Volume II, p. 28. 
"Los gatos y perros ibis egipcios son como los anteriores, pero al separar una pareja y colocarla en una isla nueva es muy dudoso que permaneciesen invariables; no se dice que el emparejamiento deteriore la raza, sino que se altera de algún modo que es bueno para el Hombre.

Déjese que una pareja se introduzca y que aumenten lentamente tanto el número de los enemigos como los emparejamientos, ¿quién se atreverá a predecir el resultado?”28.

Darwin imagina las consecuencias de trasladar una pareja reproductora de una de estas especies a una isla con depredadores que causen un crecimiento lento de la población ${ }^{29}$. Una consecuencia sería que parientes cercanos se aparearían regularmente, lo que comúnmente conduciría a un "deterioro"; pero lo que todo esto significa es que la descendencia no sería según los deseos del criador. En esta nueva isla, algunas de estas nuevas variaciones emergentes podrían ser de utilidad.

La "objeción de la momia” se podría afrontar, como lo hizo Lamarck, simplemente asumiendo un ambiente constante - en la concepción de Lamarck, si el entorno no cambia, ¿por qué lo haría el organismo? Darwin formula una pregunta indagadora: ¿bajo qué circunstancias se habrían transformado (transformed)? ¿Qué pasaría si una pareja de gatos egipcios fuesen sometidos al tipo de procesos que poblaron las islas Galápagos?, ¿quién se atreverá a predecir el resultado? Se pregunta Darwin.

Unas pocas páginas más adelante Darwin se preocupa por dar cuenta de los casos donde las especies de una isla es genéricamente una especie que se encuentra tanto en el continente como en la isla, aunque específicamente diferente. Darwin se imagina cómo podría haber ocurrido esto en consecuencia con que la forma continental sea el ancestro de alguna de las formas de la isla.

"Luego (al recordar los argumentos acerca del traslado de Lyell) ... las islas cercanas a continentes podrían tener algunas especies iguales a las existentes en la tierra firme más cercana, que hubiera llegadas tardías de otras antiguas (de las que ninguna del mismo tipo había llegado en ese intervalo) y que [las primeras] pudieran haberse desarrollado con alteraciones. De ahí que el tipo procediera del continente, aunque las especies sean del todo diferentes" 30 .

La mayor parte del Vol. II de los Principios de Lyell se dedica a contrastar la hipótesis de que una "única creación” por especie es suficiente para explicar su distribución geográfica actual y pasada ${ }^{31}$. Sin embargo, convencido de que las especies no pueden tener una modificación indefinida, Lyell nunca considera la cuestión que preocupaba a Darwin: ¿por qué hay una correlación entre la proximidad geográfica y la similaridad taxonómica de especies relacionadas pero diferentes? En el pasaje anterior, Darwin imagina un escenario donde una especie isleña puede ser descendiente de una especie encontrada tanto en la misma isla como en otra del continente próximo. Supóngase que miembros de una especie de tierra firme emigran a una isla cercana y se transforman en nuevas especies. Después hay una segunda migración de la especie original; incapaz ya de reproducirse con sus descendientes, permanece distinta.

28 Barrett, P. et AL. (eds), Charles Darwin's Notebooks, 1836-1844, Notebook B, pp. 6-7. Como en la edición de Barrett et al., he mantenido la puntuación y ortografía de Darwin.

29 Una lectura alternativa es que "de muchos enemigos" quiere decir "aislado de muchos enemigos". Leo "de" como "debido a", y así tomo esta frase para explicar la lentitud en el crecimiento.

30 Barrett, P. et AL. (eds), Charles Darwin's Notebooks, 1836-1844, Notebook B, pp. 10-11.

31 Cfr. Lyell, CH., Principles of Geology, Volume II, pp. 124-184. 
El desarrollar estos dos experimentos mentales es una empresa que muestra que el entrecruzamiento de una población es un problema para el cambio evolutivo; la producción de una nueva especie requiere entonces aislamiento de su población ancestral. La producción de una nueva especie está así íntimamente ligada al sube y baja del cambio geológico de Lyell, especialmente la formación de barreras por elevación y hundimientos. La posibilidad de que este mecanismo promueva especiación es aún el foco de otro experimento mental:

"Especies formadas por hundimiento, Java y Sumatra. Rinocerontes. Elevación y unión de profundas diferencias. Dos especies hicieron elevación y hundimiento, formando especies continuamente" ${ }^{32}$.

La pauta de la ilustración imaginativa del capítulo 4 de Origin se ve aquí en forma embrionaria; sin embargo, no como una ilustración de la acción de la selección natural, sino como un medio de funcionar a través de problemas para el desarrollo de su teoría transmutacional. El truco para leer estas notas es determinar dónde están las transiciones y dónde señalar los saltos y transiciones no indicadas por los signos de puntuación. Una interpretación plausible de esta nota, por ejemplo, la extendería como sigue: "[Las] especies [son] formadas por hundimiento, [por ejemplo] Java y Sumatra [sus especies distintas de] rinocerontes. Elevación [de la tierra] y unión [de estas islas] [mientras que el canal entre ellas es] profundo [son] distintas. Dos especies [se] hicieron. Elevación y hundimiento [están] formando especies continuamente".

El uso de experimentos mentales para contrarrestar objeciones de imposibilidad también aparece en los cuadernos. En un pasaje del Cuaderno $C$, por ejemplo, Darwin reconoce el problema planteado por sus puntos de vista sobre las adaptaciones complejas:

"Nunca podremos rastrear los pasos por los que la organización del ojo pasó desde un estado inicial simple a otro más perfecto, manteniendo sus relaciones - la maravillosa capacidad de adaptación que se da en la organización-. Esta es tal vez la mayor dificultad de toda la teoría" ${ }^{33}$.

Escuchamos claramente ecos de esta nota en la introducción de Origin cuando Darwin señala la importancia de contar con las adaptaciones complejas, y en su uso de la experimentación mental para tratar esta misma objeción (y otras similares) en el capítulo 6 de Origin. Cuando escribe estas notas en su cuaderno, no es consciente de que este modo de razonar pueda ser una estrategia efectiva para enfrentarse a la objeción de los "órganos de perfección extrema". Sin embargo, esto ha cambiado al final del Cuaderno D: "En mi teoría”, se dice a sí mismo, "debo referirme a la separación de sexos como una gran dificultad, y después especular para mostrar que no es insuperable" ${ }^{34}$. Darwin reconoce aquí que los experimentos mentales pueden usarse para defenderse de toda una clase de objeciones: un gran avance metodológico.

Está claro, sin embargo, que esta nota necesita ser complementada. No precisamente cualquier especulación lo hará. Debe ser suficientemente concreta para atraer la imaginación del lector, y debe mencionar procesos, objetos e interacciones corrientes y que pueda fácilmente imaginarse que poseen la gama completa de consecuencias deseadas - como en Origin.

Darwin inicia los Species Notebooks con la firme convicción de que, para un grupo de hechos paradigmáticos, la explicación obvia es que las nuevas especies son descendientes

32 Barrett, P. Et AL. (eds), Charles Darwin's Notebooks, 1836-1844, Notebook B, p. 82; cfr. Notebook C, p. 191.

33 Charles Darwin's Notebooks, 1836-1844, Notebook C, p. 175.

34 Barrett, P. ET Al. (eds), Charles Darwin's Notebooks, 1836-1844, Notebook D, p. 159e. 
transformados de especies ancestrales. Pero también considera hechos de la Geografía y de la Historia Natural que presentan verdaderos problemas para esa teoría. Al tratarlos, se imagina instintivamente procesos históricos concretos que podrían producir estos resultados problemáticos por medios transformacionales. Gradualmente se da cuenta de que una respuesta suficiente para ciertas objeciones de "imposibilidad" es mostrar que la teoría es "capaz" de explicarlas. Una forma de "narrativa circunscrita (constrained) a los hechos" está lista para ser usada: la ha usado en todo momento para ayudarse a imaginar cómo explica su teoría. Empezamos a encontrar notas en estos cuadernos privados que utilizan esta pauta en su defensa pública de "sus ideas malthusianas".

Concluyo esta sección con un pasaje de "The Torn Apart Notebook" que revela la estrategia planeada por Darwin para atraer la imaginación y desarmar los casos difíciles (para reconocer que la capacidad de "agrupar y explicar muchos hechos" no es suficiente). Tras mencionar algunos casos difíciles, escribe que "la mente en conjunto está constituida de modo que una dificultad genera una gran impresión, [de manera] que al agrupar 'muchos' hechos en leyes y su explicación probablemente rechará esta teoría”; y entonces se anima a sí mismo a afrontar esta dificultad, "encontrando casos curiosos de estructura intermedia, y suponiendo amplia extinción, para ofrecer un caso paralelo" ${ }^{35}$. Darwin podía dar ya una justificación convincente para colocar sus capítulos sobre "dificultades" donde lo hizo en Origin. Necesita contestar primero esas objeciones de imposibilidad, antes de continuar y mostrar lo bien que su teoría puede agrupar y explicar los hechos.

\section{Conclusión: Una postdata lyelliana}

En uno de los muchos momentos reflexivos e intensos de los Species Notebooks, Darwin comenta "la dificultad de multiplicar los efectos y el poder considerar el resultado con esa claridad de convicción", y, sin embargo, insiste en que ahí yace "la ... piedra fundacional del razonamiento inductivo posterior" - y atribuye a la Geología "la capacidad de proporcionar ideas propias sobre estas materias" 36 -

Por "Geología" seguramente Darwin quiere decir Charles Lyell. Aquí Darwin reconoce su deuda, no por el actualismo y el gradualismo que absorbió de los Principles de Lyell, sino por el uso de la ilustración imaginativa de Lyell. Los ecos de este pasaje resuenan en la conclusión de esa sección del Origin con la que comencé.

"Me doy perfecta cuenta de que esta doctrina de la selección natural, ejemplificada en los ejemplos imaginarios anteriores, está abierta a las mismas objeciones presentadas contra los nobles puntos de vista de Sir Charles Lyell sobre los cambios recientes de la Tierra, en cuanto ilustrativos de la Geología" ${ }^{37}$.

En ambos pasajes, Darwin alaba a Lyell por abrir el camino de su uso de "ejemplos imaginarios" para ilustrar el funcionamiento de las causas postuladas en la teoría. La alabanza (o difamación, dependiendo de la evaluación que cada uno haga de esta estrategia) está asegurada. En el volumen II de los Principles encontramos que Lyell usa vivamente, una y otra vez, experimentos mentales para ilustrar cómo los medios de dispersión disponibles podían tenerse

35 Barrett, P. ET AL. (eds), Charles Darwin's Notebooks, 1836-1844, Torn Apart Notebook, p. 463.

36 Charles Darwin's Notebooks, 1836-1844, Notebook E, p. 6e.

37 Darwin, CH., On the Origin of Species: A Facsimile of the First Edition, p. 95. 
en cuenta en el alcance geográfico de diferentes especies de plantas y animales. Daremos uno de entre las docenas de ejemplos expuestos en estos capítulos:

"Un ciervo abandona la manada buscando ricos pastos, cuando de repente se alarma por la cercanía de su enemigo. Rápidamente atraviesa unos arbustos y cruza ríos y lagos. Las semillas de hierbas y plantas se adhieren a su cuerpo y luego se las llevan las corrientes. Otros restos continúan pegados a su piel hasta que caen al ser ésta cepillada por otros matorrales. Incluso en el lugar donde la víctima es devorada, muchas de las semillas que había ingerido inmediatamente antes de la persecución pueden caer intactas al suelo" 38 .

Este pasaje contiene todas los requisitos del experimento mental darwiniano: una narración concreta e imaginaria, que ejemplifica el proceso causal que conducirá a la dispersión de semillas, que a largo plazo formarán parte del ámbito geográfico de las plantas en cuestión.

Darwin reconoce honestamente el origen Lyelliano del uso de los experimentos mentales para estos fines. Lyell era tan maestro en la técnica como lo fue Darwin. Pero fue Darwin quien reflexionó filosóficamente sobre su valor y sus limitaciones, y quien la desarrolló conscientemente. Como en otras muchas innovaciones darvinianas, las raíces de éstas podemos encontrarlas en Charles Lyell, pero es Darwin quien desarrolló su justificación filosófica. Como con muchas otras innovaciones darwinianas, se encontró con una recepción escéptica.

\section{Bibliografía}

Babbage, Ch., The Ninth Bridgewater Treatise: A Fragment, John Murray, Londres, 1837.

Barrett, P. H. et AL. (eds), Charles Darwin's Notebooks, 1836-1844, Cornell University Press, Ithaca, NY, 1987.

Barrett, P. H. y Freeman, R. B. (eds), The Works of Charles Darwin, vol. 10: The Foundations of the Origin of Species: Two Essays Written in 1842 and 1844, New York University Press, N. York, 1987.

Beatty, J., "Speaking of Species: Darwin's Strategy", en Kohn, D. (ed), The Darwinian Heritage, Princeton University Press, Princeton, 1985, pp. 265-282.

Bowler, P. J., The Eclipse of Darwinism. Johns Hopkins University Press, Baltimore, 1983.

Bowler, P. J., The Non-Darwinian Revolution: Reinterpreting a Historical Myth, The Johns Hopkins University Press, Baltimore, 1988.

Burkhardt, F. et AL. (eds), The Correspondence of Charles Darwin, Volume 9 (1861), Cambridge University Press, Cambridge, 1994.

CAnnon, W., "The Impact of Uniformitarianism: Two Letters from John Herschel to Charles Lyell, 1836-1837”, Proceedings of the American Philosophical Society, v. 105, (1961), pp. 301-314.

Chambers, R., Vestiges of the Natural History of Creation and Other Evolutionary Writings, editado con una nueva Introducción por James A. Secord, The University of Chicago Press, Chicago, 1994.

Darwin, CH., On the Origin of Species: A Facsimile of the First Edition, Harvard University Press, Cambridge, MA, 1964.

38 Lyell, Ch., Principles of Geology, Volume II, p. 79. 
Darwin, Ch., Charles Darwin's Diary of the Voyage of H. M. S. Beagle, edición de Nora Barlow a partir del texto original, Cambridge University Press, Cambridge, 1933; reimpreso por Kraus Reprint Co., N. York, 1969.

DARwin, CH., "Darwin's Ornithological Notes", edición de Nora Barlow, Bulletin of the British Museum (Natural History), Historical Series, v. 2, n. 7, (1963), pp. 201-278.

Di Gregorio, M. y Gill, N. W., Charles Darwin's Marginalia, Vol. I, Garland Publishing, N. York, 1990.

Ghiselin, M. T., The Triumph of the Darwinian Method, University of California Press, Berkeley, 1969.

Herbert, S. (ed), The Red Notebook of Charles Darwin, British Museum (Natural History), Londres, 1980. [Cornell University Press, Ithaca, 1979].

Herschel, J. F. W., A Preliminary Discourse on the Study of Natural Philosophy, Longman, Londres, 1830; reimpreso por The University of Chicago Press, Chicago, 1987.

Hodge, J., "Darwin and the Laws of the Animate Part of the Terrestrial System (1835-1837): On the Lyellian Origins of His Zoonomical Explanatory Program", Studies in History of Biology, v. 6, (1983), pp. 1-106.

Hodge, J., "Darwin Studies at Work: A Re-examination of Three Decisive Years (1835-37)", en Levere, T. H. y SheA, W. R. (eds), Nature, Experiment, and the Sciences, Kluwer, Dordrecht, 1990, pp. 249-274.

Hodge, J., "Discussion: Darwin's Argument in the Origin", Philosophy of Science, v. 59, n. 3, (1992), pp. 461-464.

Hodge, J. y Radick, G. (eds), The Cambridge Companion to Darwin, Cambridge University Press, Cambridge, 2003.

Hodge, J. y Kohn, D., “The Immediate Origins of Natural Selection,” en Kohn, D. (ed), The Darwinian Heritage, Princeton University Press, Princeton, 1985, pp. 185-206.

Horowitz, T. y Massey, G. (eds), Thought Experiments in Science and Philosophy, Rowman and Littlefield, Savage, MD, 1991.

Hull, D. L., "Darwin's Science and Victorian Philosophy of Science”, en Hodge, J. y Radick, G. (eds), The Cambridge Companion to Darwin, Cambridge University Press, Cambridge, 2003, pp. 168-191.

Hutton, F. W., Darwinism and Lamarckism: Old and New, G. Putnam and Sons, N. York, 1899.

Konn, D. (ed), The Darwinian Heritage, Princeton University Press, Princeton, 1985.

Lamarck, J. B., Zoological Philosophy: An Exposition with Regard to the Natural History of Animals, The University of Chicago Press, Chicago, 1984.

Levere, T. H. y SheA, W. R. (eds), Nature, Experiment, and the Sciences. Kluwer, Dordrecht, 1990.

Lennox, J. G., "Darwinian Thought Experiments: A Function for Just-so Stories", en Horowitz, T. y Massey, G. (eds), Thought Experiments in Science and Philosophy, Rowman and Littlefield, Savage, MD, 1991, pp. 223-246.

Lyell, Ch., Principles of Geology, John Murray, Londres, 1830-1833, 3 vols. Reimpreso en edición facsímil por The University of Chicago Press, Chicago, 1990. 
Ruse, M., "Darwin's Debt to Philosophy: An Examination of the Influence of the Philosophical Ideas of John F. W. Herschel and William Whewell on the Development of Charles Darwin's Theory of Evolution", Studies in History and Philosophy of Science, v. 6, (1975), pp. 159-181.

SloAn, PH. R., "The Making of a Philosophical Naturalist", en Hodge, J. y Radick, G. (eds), The Cambridge Companion to Darwin, Cambridge University Press, Cambridge, 2003, pp. 17-39.

Waters, C. K., "The Arguments in the Origin of Species", en Hodge, J. y Radick, G. (eds), The Cambridge Companion to Darwin, Cambridge University Press, Cambridge, 2003, pp. 116-139. 



\title{
‘Está surgiendo una nueva Teoría general de la Evolución?' Una Valoración Filosófica de la eVAluación de STEPhen JaY Gould aCERCA de la TeORÍA de la EvoluCión CONTEMPORÁNEA*
}

\author{
Jean Gayon
}

\section{INTRODUCCIÓN}

En 1980 Stephen Jay Gould (1941-2002) publicó un provocativo artículo titulado “¿Está surgiendo una nueva Teoría general de la Evolución?" . Este artículo declaraba que la teoría sintética, en cuanto propuesta general, estaba muerta: "Recuerdo bien cómo la teoría sintética me sedujo con su fuerza unificadora cuando yo era estudiante de Doctorado a mediados de los años 60. Desde entonces he estado viendo su lenta explicitación como una descripción universal de la evolución. Primero vino el asalto molecular, seguido rápidamente por la atención renovada a las teorías no ortodoxas de la especiación y por los desafíos (challenges) en el propio nivel de la macroevolución. He sido reacio a admitirlo, puesto que la seducción es para siempre, pero si la caracterización de [Ernst] Mayr es acertada ${ }^{2}$, entonces esa teoría, en cuanto propuesta general, está efectivamente muerta, a pesar de su persistencia como ortodoxia de libro de texto"3.

El monumental testamento científico de Gould, La estructura de la Teoría de la Evolución ${ }^{4}$, proporciona una imagen sensiblemente diferente de su relación con la tradición darwiniana. Este libro de 1433 páginas, que apareció poco antes de la muerte de Gould en 2002, es un libro muy personal, donde prácticamente cada tema se relaciona con algún aspecto de la prolífica producción de Gould. La tesis más general es que se mantiene el núcleo central de la Teoría de la Evolución darwiniana, aunque la estructura de la Biología evolutiva contemporánea ha sido ampliada y modificada de un modo que la convierte en una entidad genuinamente nueva ${ }^{5}$.

Esto comporta un significativo cambio de actitud. En 1980 Gould sostenía que la teoría sintética había sido destruida y reemplazada; en 2002 señala que la visión darwiniana de la evolución ni ha permanecido sin cambios ni ha sido reemplazada, sino que más bien ha "cambiado sustancialmente" ${ }^{6}$. En términos de Gould, existe una fuerte continuidad conceptual

\footnotetext{
* La traducción ha sido realizada por Pablo Vara y Wenceslao J. González. N. del E.

1 Gould, S. J., “Is a New and General Theory of Evolution Emerging?”, Paleobiology, v. 6, n. 1, (1980), pp. 119-130.

2 Gould alude a la siguiente afirmación de Mayr: "Los que proponen la teoría sintética mantienen que toda evolución se debe a la acumulación de pequeños cambios genéticos, guiados por la selección natural, y que la evolución transespecífica no es sino una extrapolación de los sucesos (events) que tienen lugar dentro de las poblaciones y especies", Mayr, E., Animal Species and Evolution, The Belknap Press of Harvard University Press, Cambridge, MA, 1963, p. 586. [Vers. cast.: Especies animales y evolución, Ariel, Barcelona, 1968]. Texto citado en Gould, S. J., "Is a New and General Theory of Evolution Emerging?", p. 120.

3 "Is a New and General Theory of Evolution Emerging?", p. 120.

4 Gould, S. J., The Structure of Evolutionary Theory, The Belknap Press, Cambridge, MA, 2002. [Vers. cast. de

A. García Leal: La estructura de la Teoría de la Evolución, Tusquets, Barcelona, 2004].

5 Gould, S. J., The Structure of Evolutionary Theory, p. 6.

6 Cfr. The Structure of Evolutionary Theory, pp. 3-6.
} 
entre la teoría darwiniana clásica y la nueva teoría, una continuidad que no es meramente genealógica y conlleva una genuina similitud conceptual. El marco conceptual antiguo no se ha "sustituido" por uno nuevo, [sino que] se ha "desarrollado" en uno nuevo?.

Podría objetarse que la rebelión de Gould de 1980 se dirigía contra la síntesis moderna, no contra el darwinismo en general. Es verdad. Sin embargo, el escrito de 1980 contiene numerosas alusiones a la "ortodoxia darwiniana" y al propio Darwin ${ }^{8}$. Aunque Gould era un poco más caritativo con Darwin que con el "darwinismo" estricto (esto es, la versión del darwinismo de Wallace), su crítica de la síntesis moderna era también una crítica del darwinismo en su totalidad, considerado como una Teoría de la Evolución en la que la selección natural de las especies es el factor evolutivo más importante ${ }^{9}$.

Gould era plenamente consciente de la dimensión filosófica de sus propuestas acerca de la sutil continuidad entre el darwinismo y su concepción final acerca de la evolución. En la introducción a su libro de 2002, rechaza la propuesta de David Hull de definir los linajes conceptuales (tales como "darwinismo") "exclusivamente por medio de la genealogía y no por el contenido" ${ }^{10}$. Para Gould, el historiador de la Ciencia no debería sentirse obligado a escoger entre la Historia abstracta de las ideas y la Historia conceptual de las comunidades intelectuales: los linajes conceptuales deben ser descritos tanto en términos de continuidad como de similitud morfológica ${ }^{11}$.

Este trabajo examina la cuestión de la "continuidad" del darwinismo a través del tiempo a gran escala histórica. En primer lugar, trato la cuestión en sí misma, sin énfasis particular en Gould (aunque, a veces, es parte de la Historia como actor científico). En segundo lugar, analizo la propia posición de Gould sobre el mismo asunto.

\section{2. ¿Es "DARWINIANA" LA Biología CONTEMPORÁNeA, Y EN QUÉ SENTIDo?}

Durante casi siglo y medio, los biólogos evolucionistas han estado encarrilados hacia la cuestión de si sus concepciones son o no son "darwinianas". Este persistente posicionamiento de los nuevos desarrollos científicos con referencia a una figura singular, pionera, es algo bastante excepcional en la Historia de la Ciencia moderna. Los físicos que trabajan en el dominio de la relatividad o de la Teoría Cuántica pueden referirse a Einstein o a Bohr (o a otros individuos). Pero sus debates no están estructurados de forma mayoritaria a través de la referencia a estos nombres de individuos del modo en que se ha hecho y se continúa haciéndolo hoy en la teoría evolucionista ${ }^{12}$. No conozco nada semejante a "einsteiniano" o "bohriano" en Física, mientras que "darwinismo" se ha convertido en una palabra clave entre los biólogos evolucionistas desde el primer momento de su acuñación.

¿Cómo se puede dar razón de tal hecho? Una explicación podría ser que darwinismo, igual que marxismo, no es sólo el nombre de un tradición científica ordinaria, sino también un fenómeno

\footnotetext{
Cfr. Gould, S. J., The Structure of Evolutionary Theory, p. 9.

Cfr. "Is a New and General Theory of Evolution Emerging?", pp. 119-130.

Cfr. Gould, S. J., The Structure of Evolutionary Theory, pp. 120 y 122.

The Structure of Evolutionary Theory, p. 9.

Cfr. The Structure of Evolutionary Theory, p. 8.

12 Cfr. Gayon, J., "Critics and Criticisms of the Modern Synthesis: the Viewpoint of a Philosopher", Evolutionary Biology, v. 24, (1990), pp. 1-49. Véanse también otras referencias en la nota 13. Concepciones similares se han desarrollado recientemente de un modo muy original en Lewens, T., Darwin, Routledge, Londres, 2007.
} 
histórico considerable, que es transversal a muchas áreas de la cultura y la política modernas. En esos casos es habitual identificar una Tradición de Pensamiento con un nombre de persona. Pero aunque esto es del todo correcto, esa explicación no nos puede satisfacer o, de un modo más preciso, únicamente esa explicación [aislada]. El hecho es que los biólogos que trabajan en evolución no han cesado nunca de volver a Darwin y de leer su obras maestras. Hoy sigue siendo así. Y, de nuevo, no observamos nada semejante en otras áreas de las Ciencias de la Naturaleza. Tengo la convicción de que el interés ininterrumpido de los biólogos evolucionistas en Darwin desde 1859 indica un tipo de conexión fuerte, como la que se da entre un modelo (Darwin) y sus sucesivos ejemplares (las sucesivas versiones del "darwinismo" [como tradición científica]).

Sostengo que existe algún tipo de isomorfismo entre el darwinismo de Darwin y el darwinismo histórico. No quiero decir con ello que todo lo presente en las concepciones evolucionistas de Darwin se haya conservado en la tradición "darwiniana". Quiero decir, simplemente, que algo crucial en la propia concepción de Darwin ha constreñido permanentemente el desarrollo de la teoría evolucionista. Este algo es no tanto una lista de hipótesis o doctrinas concretas (como una interpretación concreta de la selección natural, o de la herencia, o de la variación $\mathrm{o}$, incluso, de la descendencia $[$ descent $])^{* *}$, sino más bien una concepción general relacionada con la estructura de la Teoría de la Evolución ${ }^{13}$. O, para ser más preciso, una perspectiva de conjunto acerca del marco general dentro del cual la investigación evolucionista cobra sentido. Lo que importa es la estructura global, no la verdad de las hipótesis particulares de Darwin sobre este o aquel elemento de su estructura (al menos hasta cierto punto: si Darwin se hubiese equivocado sobre cada elemento, la estructura general no habría durado mucho tiempo).

Deseo recordar, en primer lugar, cómo llamaba Darwin a su teoría en The Origin of Species: "descendencia con modificación a través de la selección natural" ${ }^{14}$. Esta fórmula sugiere que la teoría de Darwin estaba compuesta de dos elementos o, incluso, de [dos] sub-teorías: el primer componente es la "descendencia con modificación", que es una teoría sobre lo que denominaríamos hoy la "pauta" (pattern) de la evolución; la segunda parte — "a través de la selección natural" - se refiere a la conjetura según la cual la selección natural es la principal explicación para la modificación de las especies.

\footnotetext{
** Aquí se ha tenido presente que descent se ha traducido como "origen" en una obra central de Darwin. Pero es un término que tiene dos vertientes: por un lado, alude a los antepasados (esto es, a la descendencia de los que me preceden); y, por otro lado, remite a los sucesores y a los rasgos que se poseen en cuanto descendiente de otros (es decir, al individuo en cuanto depositario de la línea de la herencia). N. de T.

13 Durante algún tiempo he tratado de desarrollar esta concepción estructural de la Historia del darwinismo. El presente escrito está en relación con diversos (más o menos exitosos) esfuerzos en esa dirección: GAYON, J., "Critics and Criticisms of the Modern Synthesis: the Viewpoint of a Philosopher", pp. 1-49; GAYON, J., "Neo-Darwinism" en Wolters, G. Lennox J. G. y Mclaughlin, P. (eds), Concepts, Theories, and Rationality in the Biological Sciences, The Second Pittsburgh-Konstanz Colloquim in the Philosophy of Science, Universitätsverlag Konstanz y University of Pittsbourgh Press, Konstanz-Pittsbourgh, 1995, pp. 1-25; GAYon, J., "The Paramount Power of Selection: From Darwin to Kauffman", en Dalla Chiara, M. L., Doets, K. D., Mundici, D. y Van Benthem, J. (eds), Structures and Norms in Science, Volume Two of the Tenth International Congress of Logic, Methodology and Philosophy of Science, Kluwer, Dordrecht, 1997, pp. 265-282; GAYON, J., "Sélection”, en LECOURT, D. (ed), Dictionnaire d'histoire et de philosophie des sciences, Presses Universitaires de France, París, 1999, pp. 854-861; Gayon, J., "From Darwin to Today in Evolutionary Biology", en Hodge, J. y RADick, G. (eds), The Cambridge Companion to Darwin, Cambridge University Press, Cambridge, 2003, pp. 240-264; y GAYON, J. y RiCQLĖs, A. DE, "Evolutionisme", en Dictionaire des idées, Encyclopaedia Universalis, París, 2005, pp. 271-275. Véase también nota 30.

14 Darwin, CH., On the Origin of Species by Means of Natural Selection, or the Preservation of Favoured Races in the Struggle for Life, John Murray, Londres, 1859, p. 459. [Existen múltiples traducciones castellanas, todas ellas con el título El origen de las especies]. Esta fórmula permaneció así hasta la sexta y última edición, donde Darwin añadió una palabra: “... descendencia con modificación a través de la variación y la selección natural”.
} 
Darwin no organizó su libro a tenor de esta distinción. En efecto, organizó la totalidad del libro de tal modo que las dos partes están siempre estrechamente conectadas entre sí. No obstante, hay dos buenas razones para tomar en serio esta distinción. En primer lugar, Darwin era perfectamente consciente de su importancia. En una carta al botánico americano Asa Gray, que reaccionó bastante favorablemente a El origen, escribió esta reveladora frase en 1863: "Personalmente, por supuesto, me interesa mucho la selección natural, pero que parece ser notoriamente poco importante comparada con la [idea de] Creación o Modificación" "

La segunda razón es que la comunidad científica no reaccionó a las dos partes de la teoría de Darwin del mismo modo. "Descendencia con modificación" fue redenominada rápidamente como "evolución" por los lectores de Darwin y por el propio Darwin, que aceptó este término y lo introdujo en la última edición de The Origin (1872), donde aparece siete veces como abreviatura de "descendencia con modificación" de las ediciones anteriores. Esta parte de la teoría tuvo tanto éxito y fue adoptada de modo tan rápido en el último tercio del siglo XIX que se hizo común denominarla "el hecho general de la evolución”, mientras la explicación de este "hecho general" mediante la selección natural ha sido objeto de interminables controversias desde 1859. Por estas razones, el asunto de la continuidad versus la discontinuidad del darwinismo a lo largo del tiempo requiere ser examinado desde estas dos perspectivas diferentes y no sólo desde el punto de vista de la selección natural.

\subsection{Descendencia con modificación o "el hecho general de la evolución"}

Darwin no proporcionó una definición explícita de lo que entendía por "descendencia con modificación" en El origen de las especies. Pensaba probablemente que esta expresión, formada con dos términos comunes entre los naturalistas, era autoevidente: las especies "descienden" de otras y se "modifican". No obstante, Darwin hizo una interpretación bastante restrictiva de esta idea común — podría decirse más que bien [hizo] un modelo de ella. Este modelo se expresa claramente no en una definición, sino en la única ilustración que aparece en El origen, el famoso diagrama ramificado que figura en el capítulo 4. Este diagrama (ver figura 1) era tan importante para Darwin que sintió la necesidad de comentarlo por extenso dos veces en su libro, empleando no menos de once páginas completas en el capítulo 4 (dedicado a la selección natural) y tres páginas completas en el capítulo 13 (dedicado a al clasificación y Embriología) ${ }^{16}$.

Este diagrama expresa una serie de conjeturas, ninguna de ellas trivial:

[1] Las especies están sujetas a modificación.

[2] Esta modificación es lenta y gradual.

[3] Muchas especies se extinguen.

[4] Las especies que no se extinguen se dividen normalmente en otras especies.

[5] Una vez que dos o más especies se han dividido, divergen indefinidamente.

[6] El diagrama se aplica a todos los niveles taxonómicos, desde las variedades locales más elementales a los grupos más abarcantes (p. ej., "A" puede ser una variedad que lleva a una especie con ocho variedades, o una especie que conduce a un género con ocho especies o a un género que conduce a una familia que contiene ocho géneros, etc.).

15 Darwin, Ch., Letter to A. Gray, 11 de mayo de 1863; reimpresa en BuRkhardt, F. ET AL., The Correspondence of Charles Darwin, Cambridge University Press, Cambridge, 1985-2007, v. XI, p. 403. (Las cursivas y la negrita son del texto).

16 Cfr. Darwin, CH., On the Origin of Species, pp. 116-126 y 420-422 (páginas dedicadas por completo a comentar el diagrama). 
[7] El postulado [6] quiere expresar que la clasificación está por completo determinada por la genealogía. Por eso, hay tantos "niveles" (ranks) de diversificación con ramificaciones, y todas las categorías taxonómicas utilizadas en la sistemática (especies, géneros, familias, etc.) son arbitrarias.

[8] El postulado [6] también implica para Darwin que el entero proceso de diversificación reduce la diversificación al nivel más bajo (variedades y especies); los taxones (taxa) supra-específicos no tienen un papel particular en la evolución: no son más que un resultado.

Para ser justo, añadiría que existe una asimetría entre los dos pasajes dedicados a la explicación del diagrama. En el capítulo IV, Darwin se refiere con frecuencia al proceso de selección natural; en el capítulo XIII no lo hace, y sólo comenta la "distribución" clasificatoria (classificatory "arrangement") (o pauta [pattern] en términos modernos).

El diagrama arbóreo de Darwin tuvo un efecto casi inmediato en el conjunto de la comunidad biológica. En un breve periodo de tiempo, llegó a ser la representación paradigmática de la evolución orgánica como hecho establecido: el "hecho general de la evolución". El efecto súbito y llamativo de este diagrama constituye uno de los ejemplos más espectaculares de un cambio de paradigma en Historia de la Ciencia, por emplear la famosa terminología de Thomas Kuhn. No se podría decir lo mismo de la teoría de la selección natural de Darwin, que abrió una larga serie de controversias.

Sin embargo, desde un punto de vista metodológico, la caracterización del árbol de la vida de Darwin como un "hecho general" de la Naturaleza es engañosa. Este diagrama, con los postulados no triviales que ilustra, es una construcción teórica. El tipo de teoría que comporta no es una teoría causal, aunque se podría utilizar para fines explicativos en determinados contextos. Es una teoría que postula la existencia general en la Naturaleza de varias clases de fenómenos. Esa teoría parece una generalización descriptiva, pero no lo es. Es un recurso heurístico, una apuesta plausible acerca de la forma y la senda de los fenómenos que constituyen la evolución y que requieren explicación. Desde luego, cuantos más científicos acumulan datos en este marco, más tienden a considerarlo una descripción literal. Pero éste no es el caso: la teoría de Darwin de "descendencia con modificación", tal como aparece esquematizada en su diagrama, es una teoría de bajo nivel pero es, no obstante, una teoría. Como escribieron recientemente Doolittle y Bapteste en un artículo fascinante, "la descendencia con modificación es sólo uno de los mecanismos [evolutivos], y la pauta sencilla que asemeja a un árbol (tree-like pattern) no es el resultado necesario (o esperado) de su operar colectivo" ${ }^{17}$.

Ahora la pregunta es: ¿el consenso científico acerca del denominado "hecho de la evolución”, tal como aparece representado por el diagrama de Darwin, ha sido puesto en cuestión seriamente desde la época de Darwin? Al menos en tres ocasiones ha sido seriamente cuestionado el árbol de la vida de Darwin. Todos estos cuestionamientos o tipos de crítica se refieren a la forma del árbol. Los dos primeros han sido recurrentes desde la época de Darwin. El tercero es reciente.

El primer tipo de crítica se puede encontrar entre los biólogos o paleontólogos que han defendido una representación no gradual o saltacionista del origen de las especies. Desde

17 Doolittle, W. F. y Bapteste, E., "Pattern Pluralism and the Tree of Life Hypothesis", Proceedings of the National Academy of Sciences of the United States of America, v. 104, n. 7, (2007), p. 2043, abstract. 
Thomas Henry Huxley, Francis Galton y los primeros mendelianos, las teorías saltacionistas de la emergencia de las especies han sido numerosas y variadas ${ }^{18}$. Las han defendido científicos pertenecientes a disciplinas biológicas muy diferentes: morfólogos, paleontólogos, biometristas, genetistas y biólogos del desarrollo. Hoy el ejemplo más famoso y convincente lo representa la teoría del "equilibrio puntuado" de Eldredge y Gould. Esta teoría, formulada por vez primera en $1972^{19}$, postula que el cambio evolutivo se produce primeramente durante los fenómenos (events) de especiación o cladogénesis (i. e., la división de una especie dada en dos o más especies). Aunque pude llevar muchas generaciones, a escala geológica este cambio es rápido.

Cualquiera que sea la forma concreta que tomen, las teorías saltacionistas de la evolución comportan una alteración significativa del árbol de Darwin. En vez de ramas que divergen progresivamente, el árbol tomará la forma de candelabros sucesivos. El ejemplo más famoso es el "árbol" de Gould y Eldredge en su artículo de 1972 [figura 2]. Este tipo de crítica, que se centra en el nivel de las especies (o al menos en los niveles taxonómicos más bajos) cuestiona los postulados segundo y sexto de Darwin de la lista precedente: la gradualidad del cambio y la divergencia indefinida después de la división.

Una segunda clase de crítica resalta la postura según la cual la evolución es algo que no se da sólo en el nivel de las variedades y especies, sino que también tiene lugar en los niveles taxonómicos más altos. Este tipo de crítica ha sido también extremadamente popular desde Darwin, en especial entre morfólogos y paleontólogos. En su expresión más común, afirma que los taxones (taxa) tienden más bien a aparecer y diversificarse de manera bastante rápida, dando origen a tipos morfológicos que permanecen estables a partir de ese momento. En esta postura, la modificación y multiplicación de las especies son fenómenos superficiales, no el núcleo del proceso evolutivo. Los biólogos y paleontólogos que adoptan esta concepción no aceptan el "árbol" de Darwin, hacen referencia a la imagen de matorral con pequeñas ramas (twigs) paralelas que parten de un nivel dado. En 1929, el morfólogo francés Louis Vialleton ofreció un vívido resumen del giro desde el tradicional árbol darwiniano a los "arbustos" en la sistemática de finales del siglo XIX y principios del XX:

"Los árboles genealógicos, que materializan de un modo simple relaciones infinitamente complejas en la realidad, han sido muy útiles al transformismo, proporcionándole los ejemplos concretos de transformación que Lyell reclamaba a Darwin ... Estos primeros esquemas dieron al principio plena satisfacción. Representaban de una forma sorprendente, fácil de retener, el despliegue evolutivo de los seres y parecían dar la solución tanto tiempo buscada de sus relaciones naturales. Pero el desencanto se produjo pronto. Rápidamente se vio que los árboles eran muy diferentes según los autores, en razón del criterio escogido para construirlos. En efecto, la mayor parte de ellos no estaban basados en el conjunto de características ni en una justa apreciación de la constitución o de la verdadera naturaleza de los seres ... Teniendo en cuenta la época de la aparición de las diversas formas, no se tardó mucho en ver que los árboles genealógicos tomaban un aspecto absolutamente diferente

\footnotetext{
18 Para una visión general acerca de las primeras fases de las teorías saltacionistas, véase Bowler, P. J., The Eclipse of Darwinism. Anti-Darwinian Evolution Theories in the Decades around 1900, John Hopkins University Press, Baltimore, 1983, en especial, capítulo 8. [Vers. cast. de J. Faci Lacasta: El eclipse del darwinismo. Teorías evolucionistas antidarwinistas en las décadas en torno a 1900, Labor, Barcelona, 1985].

19 Eldredge, N. y Gould, S. J. "Punctuated equilibria. An Alternative to Phyletic Gradualism”, en Schopf, T. J. M. (ed), Models in Paleobiology, Freeman, Cooper and Co., San Francisco, CA, pp. 82-115.
} 
del adoptado hasta entonces. En lugar de pesentar un tronco más o menos alargado, que respondía al tiempo durante el que existió la única forma inicial supuesta, tenían la forma de matorrales cuyas ramas, que partían más o menos de un mismo nivel sobre el suelo, se separan paralelamente las unas de las otras, ramificándose más o menos" ${ }^{20}$.

Para ilustrar estas dudas sobre los "árboles” darwinianos, Vialleton ofreció dos representaciones diferentes del árbol genealógico de los mamíferos: una estaba tomada del paleontólogo americano Henry Fairfield Osborn (figura 3), la otra era la representación de Vialleton de exactamente los mismos datos e interpretación (figura 4). La representación de Vialleton resalta la idea según la cual algo decisivo sucede en los niveles (ranks) taxonómicos altos. Resulta más ajustado decir que Vialleton fue tan antidarwiniano como podamos imaginar: pensaba que el "transformismo" (su nombre para la evolución darwiniana — esto es, la modificación gradual y diversificación de las especies-) era sólo un fenómeno superficial, mientras que la "evolución" genuina era la generación de novedades morfológicas importantes en grupos que aparecían súbitamente y permanecían más o menos estables en adelante.

Más recientemente, el equilibrio puntuado de Eldredge y Gould ha ofrecido una versión totalmente nueva de la vieja idea según la cual la evolución no está circunscrita al nivel de las especies. El famoso diagrama que se ha reproducido en la figura 2 ilustra la hipótesis de que una tendencia evolutiva dada en un grupo taxonómico (ya esté en estancamiento o en evolución direccional) podría muy bien resultar de cambios por encima del nivel de las especies. Por ejemplo, en el linaje "B", la dirección evolutiva resulta a partir del diferencial de éxito de las especies (estáticas) que exhiben un cambio morfológico en una dirección particular. Aunque este modo de pensar está lejos del enfoque tipológico de Vialleton (y, en ese sentido, más cercano a Darwin), ejemplifica otra manera de apelar a la evolución por encima del nivel de las especies y, en consecuencia, de poner en cuestión los postulados darwinianos [6] y [8] de la lista anterior (y, también, el [5]: las entidades que "divergen" no son necesariamente especies). La mayor parte de la literatura paleobiológica desde mediados de los años 70 del siglo XX ilustra una búsqueda similar de pautas específicamente macroevolutivas ${ }^{21}$.

La tercera clase de crítica al diagrama de Darwin es más reciente y, en cierto sentido, más radical. La sospecha es que este diagrama representa sólo una fracción de la pauta real de la Historia de la vida. El árbol de Darwin comporta la convicción de que árbol de divergencia irreversible de las especies representa de manera adecuada y suficiente la Historia de la diversidad biológica. Aunque Darwin no señaló esto de modo explícito, se entendió que el diagrama

20 Vialleton, L., L'Origine des êtres vivants. L'illusion transformiste, Librairie Plon, París, 1929, pp. 179-180. Original francés: "Les arbres généalogiques, matérialisant d'une manière simple des rapports infiniment complexes dans la réalité, ont beaucoup servi le transformisme, en lui fournissant les exemples concrets de transformation que Lyell réclamait à Darwin... Ces premiers schémas donnèrent d'abord pleine satisfaction. Ils représentaient d'une manière saisissante, facile à retenir, le déploiement évolutif des êtres et ils paraissaient donner la solution si longtemps recherchée de leurs rapports naturels. Mais on déchanta bientôt. On s'aperçut bien vite que les arbres étaient très différents suivant les auteurs, en raison même du critérium choisi pour les construire. La plupart d'entre eux en effet n'étaient point fondés sur l'ensemble des caractères et sur une juste appréciation de la constitution ou de la vraie nature des êtres... En tenant compte de l'époque de l'apparition des diverses formes, on ne tarda pas à voir que les arbres généalogiques prenaient un aspect tout différent de celui adopté jusqu'alors. Au lieu de présenter un tronc plus ou moins allongé répondant à la durée pendant laquelle existait seule la forme initiale supposée, ils avaient la forme de buissons dont les tiges, partant à peu près du même niveau au-dessus du sol, s'écartaient parallèlement les unes des autres en se ramifiant plus ou moins".

21 Para una visión de conjunto, véase Stanley, S. M., Macroevolution. Pattern and Process, The Johns Hopkins Press, Baltimore, 1998. 
quería decir que existe, de hecho, un único "árbol de la vida”, cuyas ramas (denominadas especies) llegarán a estar tarde o temprano totalmente aisladas de cualesquiera otras en términos de reproducción y transmisión hereditaria. Un número creciente de fenómenos cuestiona esta concepción de las especies como mónadas (materiales) "sin puertas ni ventanas", parafraseando libremente la famosa fórmula de Leibniz ${ }^{22}$. Estos dos fenómenos son la transferencia lateral de genes y la simbiosis.

Desde fines de los años 90 del pasado siglo, se sabe que la transferencia lateral de genes es un fenómeno fundamental entre las procariotas (eubacterias y arqueas). Las procariotas son organismos unicelulares que carecen de núcleo limitado por una membrana. Desde el trabajo pionero de Carl Woese de las décadas de 1970 y 1980 se dividen en dos "dominios": bacterias y arqueas. Las eucariotas constituyen el tercer "dominio": incluyen todos los organismos unicelulares y pluricelulares con núcleo limitado por membrana. En un principio, la aplicación de técnicas moleculares a las procariotas generó la esperanza de reconstruir el único y universal árbol de la vida ${ }^{23}$.

Pero un creciente número de anomalías llevó al descubrimiento de que la transmisión de genes entre las procariotas no es sólo vertical, sino también horizontal. Se ha debatido intensamente la magnitud de este fenómeno durante casi veinte años. Ahora está claro que es lo suficientemente importante para arrojar serias dudas sobre la existencia misma de un árbol único que represente las relaciones naturales entre todos los organismos celulares o, al menos, sobre la posibilidad de reconstruir este árbol, si es que existe ${ }^{24}$. Esto se debe a que casi todos (si no todos) los genes procarióticos han sido objeto de la transferencia lateral de genes y que la alteración (turnover) de genes en las diferentes especies es increíblemente alta en todas las escalas de la evolución. No hay en la actualidad certeza acerca de si la "hipótesis del árbol de la vida" será capaz de combatir con éxito la "hipótesis de la red de la vida". En realidad, es probable que ambos, el "árbol" y la "red", tengan que coexistir en una concepción pluralista de pautas evolutivas, donde se narran diversas Historias mediante [el uso de] diversas Metodologías ${ }^{25}$.

Lo cierto es que la moderna teoría evolucionista debe admitir que el diagrama de Darwin, que se centra exclusivamente en el nivel de las especies, capta sólo una fracción de la Historia de la vida. Al menos en el caso de las procariotas, la transferencia lateral de genes ha sido lo suficientemente importante para anular (obliterate) y, quizás, superar la "transmisión vertical" en la gran escala histórica. Hoy algunos especialistas en la evolución de las procariotas sostienen que la transferencia lateral de genes entre organismos pertenecientes a especies diferentes es análoga a la panmixia en especies sexuadas: "En efecto, si se descubriese que las proporciones de THG [transferencia horizontal de genes] observadas en E. coli son válidas para todas las procariotas, su Historia evolutiva sería esencialmente horizontal. Esto es, las procariotas compartirían de hecho un común acervo genético $\mathrm{y}$, desde un punto de vista evolutivo, podrían comportarse de un modo que no es diferente al [comportamiento] de las poblaciones de una única especie" ${ }^{26}$.

22 Desde luego, las mónadas de Leibniz no eran materiales, sino entidades espirituales.

23 Cfr. Woese, C. R., "Bacterial Evolution”, Microbiology Reviews, v. 51, (1987), pp. 221-271.

24 Para una revisión reciente y excelente, véase McInerney, J. O., Cotton, J. A. y Pisani, D., "The Prokaryotic Tree of Life. Past, Present... and Future?", Trends in Ecology and Evolution, v. 3, n. 5, (2008), pp. 276-281.

25 Cfr. Doolittle, W. F. y Bapteste, E., "Pattern Pluralism and the Tree of Life Hypothesis", pp. 2043-2049.

26 McInerney, J. O., Cotton, J. A. y Pisani, D., “The Prokaryotic Tree of Life: Past, Present... and Future?”, p. 277. 
Otro proceso que pone en peligro la representación genealógica de Darwin es la simbiosis. La simbiosis ha sido probablemente el principal proceso evolutivo, especialmente en el nivel de la evolución celular ${ }^{27}$. La simbiosis es mucho más rara que la transferencia lateral de genes, pero cuando se produce puede tener efectos drásticos, porque comporta la coexistencia de dos genomas completos. La simbiosis parece haber sido un proceso clave en el surgimiento de un cierto número de grupos importantes de organismos eucarióticos unicelulares, y de las propias eucariotas. La simbiosis no cuestiona la noción de divergencia irreversible de las especies, porque los organismos independientes que se fusionan inician nuevas especies que divergen de otras. Pero los fenómenos (events) de fusión entre los organismos introducen complicaciones que no pueden ser asimiladas por una pauta exclusivamente arborescente (tree-like) de filogenia. La figura 5, tomada de un estudio reciente, ofrece una representación ciertamente equilibrada de las complicaciones que la transferencia horizontal de genes y la simbiosis añaden al "árbol de la vida" tradicional.

Concluyo ahora lo que se refiere al primer aspecto de la teoría de Darwin (la descendencia con modificación de especies). El diagrama de Darwin ha probado ser inmensamente fértil. La intuición básica, que late en la mayor parte de la investigación hecha sobre filogénesis, se mantiene. Pero no es verdad que el diagrama se haya mantenido inalterado. Varios de los postulados incorporados a la representación de Darwin parecen ser si no falsos, sí al menos una visión simplificada. Al menos cuatro de los siete postulados de mi lista han sido seriamente cuestionados: [2] (gradualidad de la modificación), [5] (divergencia irreversible de las especies), [6] (validación uniforme del diagrama arbóreo en todos los niveles), y [8] (evolución por encima del nivel de las especies). Los modernos biólogos evolutivos no están de acuerdo con respecto a la afirmación de que la modificación de las especies es siempre lenta y gradual (contra [2]). La divergencia indefinida después de la división no es estrictamente falsa, sino sólo una parte de la Historia de la vida: hay que tener en cuenta las importantes relaciones horizontales (contra [5] y [6]). Finalmente, muchos biólogos contemporáneos (en especial, paleobiólogos) no aceptan que la evolución sea nada más que la modificación de las especies (contra [8]).

Aunque no he elaborado este análisis retrospectivo del destino del diagrama de Darwin en relación con el caso específico de Stephen Jay Gould, queda suficientemente claro que se ha visto concernido por todos estos retos, tanto en sus escritos teóricos como en los divulgativos.

\subsection{La selección natural como principio explicativo}

Vuelvo ahora a la segunda mitad de la “teoría de Darwin”, la teoría de la modificación a través de la selección natural. Mientras que la "descendencia con modificación" era una teoría de primer nivel acerca de la senda general de la evolución, la selección natural fue, para Darwin, una hipótesis explicativa que estaba orientada hacia la unificación de los fenómenos evolutivos bajo un conjunto compartido de enunciados legaliformes (law-like statements). Al igual que en el caso de la "descendencia con modificación", recordaré primero la perspectiva de Darwin acerca del estatus teórico de la selección natural. Después compararé la Historia de la Biología evolucionista post-darwiniana con la concepción de Darwin acerca de su teoría explicativa.

27 Para una síntesis, ver el estimulante y provocativo libro de Lynn Margulis y Dorion Sagan: MARGuLIS, L. y SAGAn, D., Adquiring Genomes. A Theory of the Origin of Species, Basic Books, Nueva York, 2002. [Vers. cast. de D. Sempau: Capturando genomas. Una teoría sobre el origen de las especies, Kairós, Barcelona, 2003]. 
Para ser sincero, debería añadir que no creo que haya, ni en la obra de Darwin ni en la posterior, una frontera perfectamente bien definida entre los dos aspectos de la teoría de Darwin: el nivel descriptivo y el explicativo o, en términos más modernos, [entre] "pautas" y “procesos". Sin embargo, esta distinción ayuda a aclarar la cuestión de si la teoría evolutiva contemporánea es o no darwiniana. Pero, por el momento, pasaré por alto esta complicación y volveré sobre ella más adelante en este trabajo.

En El origen de las especies, Darwin utilizó una doble estrategia para justificar el principio de la selección natural. La primera estrategia consistía en proporcionar argumentos inductivos en favor de la existencia de la selección natural como proceso. La segunda estrategia era hipotético-deductiva: consistía en mostrar que la selección natural explica y unifica varias clases de hechos independientes.

Sorprendentemente, Darwin no hizo explícita esta doble estrategia en el texto de El origen, aunque la estructura global del libro corresponde más o menos a ella: en líneas generales, desde el capítulo 1 al 6 de la primera edición establece la plausibilidad de la existencia de la selección natural sobre la base de una mezcla de generalizaciones empíricas y deducciones; los capítulos que van del 7 al 13 se dedican a establecer su poder explicativo. Resulta que eso es un poco más complicado, porque la primera parte del libro ya incluye un aspecto de explicación; pero es una aproximación útil. De hecho, sólo la introducción a The Variation of Animal and Plants Under Domestication, publicada nueve años después de la primera edición de El origen de las especies, es donde Darwin hace del todo explícita su estrategia argumentativa. En esta introducción, en la que dedica una gran parte a una explicación retrospectiva del proyecto de El origen, Darwin escribió una página maravillosa, probablemente la respuesta a quienes le reprochaban no emplear un método científico bien definido. Este es el texto:

"En las investigaciones científicas está permitido inventar alguna hipótesis, y si eso explica diversas clases de hechos, numerosas e independientes, [entonces] alcanza el rango de teoría bien fundada. Las ondulaciones del éter e, incluso, su existencia son hipotéticas, aunque ahora todos admitan la teoría ondulatoria de la luz. El principio de selección natural pudo ser visto como una mera hipótesis, pero se convirtió en probable hasta cierto punto por lo que conocemos de la variabilidad de los seres orgánicos en un estado de la Naturaleza; - por lo que conocemos positivamente de la lucha por la existencia, y la conservación consiguiente, casi inevitable, de las variaciones favorables, - y a partir de la formación [de manera] análoga de las razas domésticas. Ahora esta hipótesis se puede contrastar - y ésta me parece la única manera equilibrada (fair) y legítima de considerar toda la cuestión, - al tratar de probar si explica diversas clases de hechos, importantes e independientes; como puede ser la sucesión geológica de seres orgánicos, su distribución en épocas pasadas y presentes, y sus mutuas afinidades y semejanzas (homologies). Si el principio de selección natural explica éste y otros conjuntos amplios de hechos, ha de ser atendido" 28 .

Este texto merece una lectura cuidadosa. En una formulación extremadamente densa, Darwin distingue dos niveles de justificación de la selección natural como principio teórico.

En el primer nivel, la selección natural es una "mera hipótesis" que se convierte en probable a través de argumentos empíricos. Se invocan [en este caso] dos tipos diferentes de

28 Darwin, Ch., The Variation of Animal and Plants Under Domestication, John Murray, Londres, 1868, pp. 8-9. [Vers. cast. de A. García González: La variación de los animales y las plantas bajo domesticación, C.S.I.C./Los Libros de la Catarata, Madrid, 2008, 2 vols.]. 
argumentos. Uno es [de carácer] analógico: la selección artificial, que comparte algunas precondiciones con el proceso hipotético de la selección natural (variación, herencia, tendencias en favor de la supervivencia o tasas de reproducción) que modifica las especies. Este argumento (desarrollado en los capítulos 1 y 2 de El origen) fue crucial para Darwin, puesto que no tenía ninguna prueba empírica (evidence) directa de la existencia de la selección natural en la Naturaleza.

El segundo tipo de argumento que se invoca a este nivel se basa en generalizaciones empíricas acerca de las dos precondiciones específicas de la selección natural: la "lucha por la existencia" o el "principio malthusiano", que resulta de la tasa de reproducción de los organismos y la limitación de los recursos (desarrollado en el capítulo 3 de El origen) y la noción de variaciones más o menos "favorables" (capítulo 4 de El origen). Considerados en conjunto, estos argumentos establecen la plausibilidad de la selección natural como un proceso muy general que se da en la Naturaleza - en todas las especies — para muchos caracteres y en todas las épocas.

En el segundo nivel Darwin dice: "esta hipótesis se puede contrastar" por medio de su capacidad para "explicar" una larga serie de "clases independientes de hechos". Esto hace referencia a los capítulos del 7 al 13 de El origen, y Darwin menciona algunos de los hechos explicados en el pasaje citado. Se podrá estar en desacuerdo sobre lo que debería contener exactamente la lista; pero, en general, Darwin sostiene que la selección natural explica al menos [lo siguiente]: las adaptaciones (morfológicas e instintivas), la distribución geográfica de las especies, la distribución estratigráfica de los fósiles, la extinción, la divergencia, las semejanzas (homologies), la relación entre desarrollo y evolución y las pautas taxonómicas. Este segundo nivel de justificación de la selección natural era crucial para Darwin, puesto que es en este nivel donde la "mera hipótesis" se torna "una teoría bien fundada".

Diversos comentaristas han subrayado el estilo newtoniano del argumento en su conjunto ${ }^{29}$. El aspecto que quiero resaltar aquí es que la estructura argumentativa proporciona una herramienta poderosa para la comprensión de la investigación evolucionista desde Darwin. El primer nivel conduce al desarrollo de la Biología de poblaciones, con una exploración cuidadosa de las bases y modos de la selección natural en cuanto un principio ampliamente extendido en la Naturaleza. El segundo nivel proporciona un principio teórico para reformular el campo completo de la Historia Natural. En el segundo nivel, la selección natural no sólo es un proceso común y fascinante de la Naturaleza, sino también un principio que unifica muchas clases de hechos y, en última instancia, a la Biología como un todo. La figura 6 ofrece una representación esquemática de esta estructura argumentativa.

Hay que notar que la explicación de la adaptación no se ajusta perfectamente a esta representación, puesto que el surgimiento de rasgos adaptativos es el resultado directo del proceso de selección natural. Por tanto, pertenece a ambos niveles de la argumentación. Quizás un mejor modo de representar la estructura argumentativa completa sería tomar la adaptación como un

29 Cfr. Kavaloski, V. C., The vera causa Principle. A Historico-Philosophical Study of a Metatheoretical Concept fron Newton throug Darwin, Tesis Doctoral, University of Chicago, 1974; Ruse, M., "Darwin's Debt to Philosophy: An Examination of the Influence of the Philosophical Ideas of John F. W. Herxchel and William Whewell on the Development of Charles Darwin's Theory of Evolution", Studies in History and Philosphy of Science, v. 6, (1975), pp. 159-181; y Hodge, M. J. S., "Natural Selection as a Causa, Empirical, and Probabilistic Theory", en KRÜGER, L., Gigerenzer, G. y Morgan, M. S. (eds), The Probabilistic Revolution The MIT Press, Cambridge, MA, 1987, vol. 2, pp. 233-270. 
cuello de botella justo por debajo de la "hipótesis", [de modo que] todos los otros explananda (los recuadros al pie de la figura) estén subordinados a este explanandum primario.

Vamos ahora a evaluar el destino de este gran esquema. Los primeros cien años de teoría evolucionista desde Darwin podrían resumirse de un modo bastante simple. Durante un periodo de aproximadamente 70 años a partir de la publicación de El origen (1859), la mayor parte de los debates y las críticas tuvieron como objetivo la existencia real de la selección natural como proceso y su capacidad para dar cuenta de la adaptación. La razón para ello era la ausencia de una teoría convincente de la variación y la herencia. Desde luego, si este nivel era problemático, el segundo lo era incluso más. En las décadas de los años 1920 y 1930 quedó claro que la Genética mendeliana podía reformular la hipótesis de Darwin (o un modelo concreto de ella, diría yo) de un modo que la hacía contrastable y predictiva. No voy a continuar comentando esta historia complicada, a la que he dedicado un libro entero ${ }^{30}$.

Entonces llegó la “Síntesis moderna”, construida en el periodo 1930-1950. Como señaló Julian Huxley al acuñar esta expresión ${ }^{31}$, este periodo consistió en un "renacimiento del darwinismo". Desde que la Genética de poblaciones pudo probar (prove) la existencia y eficacia de la selección natural, los tiempos estaban maduros para desarrollar el segundo aspecto de la teoría de Darwin. La Síntesis moderna consistió en un intento de mostrar, en su modernizada versión genética, que la selección natural era, en efecto, un principio destacado para la explicación de fenómenos tales como la variación geográfica, la modificación de las especies a largo plazo (anagénesis), la especiación (cladogénesis), la extinción, el tempo de evolución y las tendencias filogenéticas. Esta empresa fue auténticamente colectiva. Diversas disciplinas y científicos de todo el mundo contribuyeron a la "Síntesis": genetistas de Teoría de Poblaciones (Fisher, Haldane, Wright), genetistas de poblaciones, de campo y experimental (p. ej., Dobzhansky), citogenetistas (Darlington, White), especialistas en sistemática animal y vegetal (Mayr, Stebbings), paleontólogos (Simpson, Newell), embriólogos (Schmalhausen, Waddington), expertos en Ecología (Lack) y especialistas en evolución humana (Rensch), por mencionar sólo unos pocos ${ }^{32}$.

En 1959, el año del centenario de El origen de las especies de Darwin, el triunfo de la selección natural como principio explicativo parecía no tener límite ${ }^{33}$. Esos años se corresponden con la época en que la Biología evolucionista se institucionalizó como disciplina. Sin embargo, en los años posteriores los biólogos evolucionistas se volvieron más circunspectos. Se desarrollaron dos tipos de crítica: en los niveles microevolutivo y macroevolutivo. Antes de examinar la propia participación de Stephen Jay Gould en esta rebelión contra la ortodoxia, voy a ofrecer aquí una clasificación esquemática de estos retos al darwinismo ${ }^{34}$.

30 Cfr. Gayon, J., Darwin et l'après-Darwin, Kimé, París, 1992. Traducido al inglés como Gayon, J., Darwinism's Struggle for Survival: Heredity and the Hypothesis or Natural Selection, Cambridge University Press, Cambridge, 1998.

31 Huxley, J., Evolution: The Modern Synthesis, Allen and Unwin, Londres, $3^{\text {a }}$ ed., 1978, p. 26. El texto de la tercera edición permanece sin cambios respecto a la primera, publicado en 1942.

32 Véase los libros de referencia de Mayr, E. y Provine, W. B., The Evolutionary Synthesis, Harvard University Press, Cambridge, MA, 1980, y Smocovitis, B. V., Unifying Biology. The Evolutionary Synthesis and Evolutionary Biology, Princeton University Press, Princeton, NJ, 1996.

33 Véase, por ejemplo, Mayr, E., “Where are we?”, Cold Spring Symposia on Quantitative Biology, v. 24, (1959), pp. 409-440.

34 Para una exposición más detallada, ver GAYON, J., "Critics and Criticisms of the Modern Synthesis: the Viewpoint of a Philosopher", pp. 1-49; GAYON, J., "The Paramount Power of Selection: From Darwin to Kauffman”, pp. 265-282; y GAYON, "From Darwin to Today in Evolutionary Biology", pp. 240-264. 
- Críticas a la selección natural en el nivel de la microevolución. En el nivel de la microevolución, lo que la selección natural explica, primero y ante todo, son las adaptaciones. Se debería observar que, desde la síntesis moderna, esta aspiración nunca se ha cuestionado seriamente. Para casi todos los biólogos contemporáneos, la selección natural es la única explicación para las adaptaciones. Esto era verdad hace sesenta años y es incluso más verdad hoy. Muchos libros de texto modernos sobre Biología evolucionista pueden atestiguar esto ${ }^{35}$. Sin embargo, se han dirigido a la selección natural en el nivel microevolutivo tres críticas principales en los últimos cincuenta años.

Primera: en el nivel molecular, el descubrimiento de una cantidad inesperada de polimorfismo en proteínas y ADN ha llevado a que se reconozca que la mayor parte de este polimorfismo es aproximadamente neutral con respecto a la selección natural. Esta ha sido la tesis central de la "hipótesis de la mutación neutral-deriva aleatoria (random drift) de la evolución molecular" "36. Esta teoría ha generado una de las controversias más intensas en Genética de poblaciones en la segunda mitad del siglo XX, precisamente porque cuestiona la idea según la cual la selección natural controla la evolución de los fenómenos biológicos en todos los niveles ${ }^{37}$. La teoría está ahora ampliamente admitida. Sostiene que la selección natural no lo controla todo en el nivel molecular, especialmente el ADN; controla sólo la fracción de mutaciones limitada que afecta al fenotipo en un momento dado de la evolución.

Segunda: ha habido un enorme debate acerca de la selección de grupo. Darwin y la mayor parte de los genetistas de poblaciones a mediados del siglo XX negaron la existencia de la selección de grupo o, al menos, su capacidad de generar adaptaciones. Aquí también las cosas han cambiado. La selección de grupo, que al principio fue percibida como una amenaza para el darwinismo (porque iba contra el modelo concreto de selección natural favorecido por Darwin y por los biólogos de poblaciones en el periodo 1930-1980), se trata ahora como un modelo legítimo de selección natural, que parece importante para la explicación del origen de un fenómeno biológico tan importante como el sexo y una serie de fenómenos de cooperación ${ }^{38}$.

Tercera: los biólogos teóricos en nombre de la complejidad han formulado fuertes ataques contra el darwinismo en el nivel microevolutivo. Aquí la propuesta es que la complejidad impone fuertes límites al poder modificador de la selección natural. Debido a que existe una gran cantidad de conectividad entre los sistemas genéticos, la selección natural puede fallar para incrementar la aptitud media (the mean fitness) de la población, cualquiera que sea la intensidad de la selección ${ }^{39}$.

\footnotetext{
35 Véase, por ejemplo, el que quizás haya tenido más éxito de ellos: RidLEy, M., Evolution, $2^{\mathrm{a}}$ ed., Blackwell Scientific Publishing, Cambridge, MA, 1996, capítulo 13, pp. 338-368. Para dar una idea, los títulos sde las tres primeras secciones de este capítulo son: "13.1. La selección natural es la única explicación conocida para las adaptaciones"; "13.2. El pluralismo es apropiado para el estudio de la evolución, no de la adaptación"; y "13.3. La selección natural puede, en principio, explicar toda adaptación conocida".

36 Esta hipótesis se publicó por vez primera en Kimura, M., "Evolutionary Rate at the Molecular Lever", Nature, v. 217, (1968), pp. 624-626. La expresión "hipótesis de la mutación neutral-deriva aleatoria en la evolución molecular" fue empleada por vez primera en Kimura, M., "Mutation and Evolution at the Molecular Level", Genetics, (supplement), v. 73, (1973), pp. 19-35.

37 La mejor imagen de esta controversia se puede encontrar en LEwontin, R. C., The Genetic Basis of Evolutionary Change, Columbia University Press, Nueva York, 1974. [Vers. cast.: La base biológica de la evolución, Omega, Barcelona, 1979].

38 Para un enfoque general, véase SoBer, E. y Wilson, D. S., Unto Others. The Evolution of Unselfish Behavior, Harvard University Press, Cambridge, MA, 1998.

39 Cfr. Kauffman, S. A., The Origins of Order: Self-Organisation and Selection, Oxford University Press, Oxford, 1993.
} 
Estos retos al darwinismo en el nivel de la microevolución son importantes. Todos ellos han conducido al desarrollo de dominios de investigación en Biología evolucionista nuevos y fértiles. El primero y el tercero (la teoría neutral de la evolución molecular y la teoría de la complejidad) comparten un carácter similar: ambas relativizan la idea de la selección natural como un principio por completo suficiente (all-sufficient) de la evolución. El segundo reto (la selección de grupo) es diferente: al admitir modelos multinivel de selección natural, aumenta el contenido teórico y el poder explicativo de la selección natural en lugar de restringirse. También hace la selección natural mucho más complicada, mucho menos intuitiva y probablemente [más] difícil de poner a prueba. Gould diría que esto es una "expansión” del darwinismo (véase más adelante). Pero, en último término, ninguna de estas críticas ha cuestionado la selección natural como la única explicación aceptable para las adaptaciones. Por tanto, en conjunto, todos los intentos de cuestionar el poder explicativo de la selección natural en el nivel microevolutivo han supuesto un enriquecimiento más que un declive del darwinismo.

- Críticas macroevolutivas de la selección natural. En los últimos cuarenta años, ha sido principalmente en el nivel de la macroevolución donde se han producido las mayores brechas en el edificio darwiniano. Hay que recordar aquí que, para Darwin, la prueba crucial para la "aceptabilidad" de la selección natural era la capacidad de esta hipótesis de explicar "clases independientes de hechos", no sólo las adaptaciones, sino también la extinción, la divergencia y otros fenómenos macroevolutivos (los recuadros en la zona de abajo de la figura 6). Lo que se ha tornado problemático en los últimos cuarenta años es, precisamente, la propuesta según la cual la selección natural basta para explicar todos los fenómenos macroevolutivos. Aquí voy a poner dos ejemplos.

El primer ejemplo es la extinción. En la perspectiva darwiniana tradicional (esto es, la [postura] del propio Darwin y las teorías clásicas de la extinción de mediados del siglo XX), la extinción es un efecto a gran escala de la selección natural dentro de las especies: en cuanto que la selección natural transforma las especies biológicas, alguna resulta ser más apta en la competición con otras especies. Las especies menos favorecidas (aquellas que evolucionan más lentamente) disminuyen su número y se extinguen. Pero los paleobiólogos han mostrado que esa explicación no funciona en el caso de extinción masiva. En los episodios de extinción masiva (un fenómeno que ha sucedido muchas veces en la Historia de la vida, a diferentes escalas), las especies se extinguen no debido a su relativo éxito en la competencia con otras especies por espacios en el teatro ecológico, sino porque están mal equipadas para afrontar una brutal perturbación de su entorno físico.

Por ejemplo, si los diátomos sobrevivieron mejor que otras formas planctónicas durante la gran extinción cretácica, es porque estaban dotados de la capacidad de poder quedar enquistados. Esta propiedad había evolucionado por razones que no tenían nada que ver con las condiciones ambientales que generaron la extinción masiva del cretácico. El letargo del diátomo es una adaptación a la vida en el agua fría adquirida mucho tiempo antes. Como dijo David Raup en su libro magistral sobre la extinción, cuando las especies se extinguen en fenómenos (events) de extinción masiva, no es debido a "malos genes" sino a "mala suerte" ${ }^{40}$.

Otro ejemplo es la divergencia. Siguiendo el trabajo inicial de Eldredge y Gould sobre el equilibrio puntuado, una serie de paleobiólogos han rechazado que la divergencia morfológica sea necesariamente el resultado de la selección continuada dentro de las especies. Han apoyado

40 Cfr. Raup, D., Extinction. Bad Genes or Bad Luck, Norton and Company, N. York, 1991. 
explicaciones alternativas, según las cuales la divergencia también puede ser la consecuencia de sucesos repetidos de especiación y extinción de especies, bien sea debido a la selección de especies o bien a tenor de la "deriva (drift) de especies" (que resulta de consideraciones estocásticas o de algún tipo de restricción en cuanto al desarrollo). Este tipo de teoría está siendo debatida en la actualidad entre los paleobiólogos ${ }^{41}$.

Cabe usar otros ejemplos para mostrar que el predominio de la selección natural en la explicación de los fenómenos macroevolutivos está hoy seriamente contestada. Esto no supone decir que los biólogos evolucionistas rechazan que la selección natural sea una fuerza destacada, que siempre debería ser tenida en cuenta cuando se estudia la Historia de la vida. Pero la mayoría de ellos piensan que las cosas son más complicadas: se necesitan otros principios y quizá no haya esperanza en [poder] deducir todo en la Historia de la vida a partir de una lista de principios teóricos: la Historia y la cuestión de la contingencia.

\section{3. ¿Muerte o persistencia del darwinismo? Del Gould de 1980 al Gould de 2002}

No es este el lugar de entrar en detalle en la biografía intelectual de Stephen Jay Gould. Sin embargo, me gustaría recordar tres aspectos relevantes de sus contribuciones científicas. Uno es su producción temprana sobre Alometría (esto es, crecimiento relativo). En su trabajo inicial, Gould era un biometrista notable que trataba de introducir este importante fenómeno dentro del ámbito de la Síntesis moderna ${ }^{42}$. Este trabajo temprano le hizo sensible a las restricciones que el cambio de tamaño impone a la evolución morfológica. La segunda contribución destacada fue mostrar que la heterocronía es una ilustración significativa de las restricciones impuestas a la evolución ${ }^{43}$. La última - y más importante contribución teórica- fue la teoría del equilibrio puntuado ${ }^{44}$. Como ya se señaló, esta teoría fue el punto de partida de importantes propuestas entre los paleobiólogos que consideran la evolución por encima del nivel de las especies.

La cuestión que me gustaría aclarar aquí es aquella de la relación entre Gould y el darwinismo. Este fue siempre uno de los intereses explícitos de Gould. Se pueden distinguir tres periodos.

El primer periodo corresponde a los artículos tempranos sobre Alometría (aproximadamente de 1966 a 1972). En aquel tiempo, Gould aún era un estudiante de Doctorado que trabajaba bajo la dirección de Norman Newell, un paleontólogo próximo a Georg Gaylord Simpson, que trabajó duro para mostrar que la Alometría y, más en general, la Morfología, podían ser completamente moldeadas de nuevo de un modo darwiniano. Al igual que Newell, el joven Gould estaba motivado por la prospectiva de la total integración de la Morfología en el marco teórico de la síntesis moderna. En este extraordinario trabajo, quizás el más riguroso de toda su carrera, se puede ver en acción el estilo inimitable de Gould: ambición teórica fuera de lo común, interés excepcional y minucioso por la Historia de la Ciencia y conocimiento de gran

\footnotetext{
41 Véase Stanley, S. M., Macroevolution. Pattern and Process, passim.

42 Los dos importantes artículos eran: Gould, S. J., "Allometry and Size in Ontogeny and Philogeny", Biological Review of the Cambridge Philosophical Society, v. 41, (1966), pp. 587-640; y Gould, S. J., "An Evolutionary Microcosm: Pleistocene and Recent History of the Land Snail P. (Poecilozomites) in Bermuda", Bulletin of the Museum of Comparative Zoology, v. 138, (1969), pp. 407-532.

Para un enfoque histórico general, véase GAYON, J., "History of the Concept of Allometry", American Zoologist, v. 40, (2000), pp. 748-758; y GAYON, J., “Gould biométricien”, Comptes Rendues Palevol, v. 2, (2003), pp. 353-360.

43 Gould, S. J., Ontogeny and Philogeny, Harvard University Press, Cambridge, MA, 1977.

44 Cfr. Eldredge, N. y Gould, S. J., "Punctuated Equilibria. An Alternative to Phyletic Gradualism", pp. 82-115.
} 
cantidad de literatura relevante escrita en lenguas distintas del inglés. Aunque en esta obra ya mostraba un considerable interés en temas de restricciones al desarrollo y de heterocronía, no se podían ver en ella signos claros de revuelta contra el neodarwinismo. La idea era más bien abrir el marco darwiniano clásico.

El segundo periodo comienza en 1972 con el artículo conjunto con Eldredge sobre el equilibrio puntuado ${ }^{45}$, y culmina con el artículo de 1980, tiltulado provocativamente "¿Está surgiendo una nueva Teoría general de la Evolución?" ${ }^{46}$. Este artículo fue, probablemente, el ataque más radical que Gould publicó contra el darwinismo o, de modo más preciso, contra la "síntesis moderna". Este trabajo merece un análisis cuidadoso, porque proporciona un hito excepcional para cualquiera que quiera entender lo que estaba en juego cuando, en torno a 1980, una serie de biólogos evolucionistas comenzaron a decir que la perspectiva "darwiniana" clásica acerca de la evolución estaba en una crisis profunda.

Señalemos primero el objetivo preciso del ataque de Gould. Aunque escribe con frecuencia acerca del "darwinismo", sólo tiene en mente una versión particular del darwinismo: la síntesis moderna. En la seccción inicial del artículo, titulada "La síntesis moderna" ${ }^{47}$, Gould cita el siguiente pasaje de Mayr: "Los que proponen la teoría sintética mantienen que toda la evolución se debe a la acumulación de pequeños cambios genéticos, guiados por la selección natural, y que esa evolución transespecífica no es sino una extrapolación y magnificación de los sucesos (events) que tienen lugar dentro de las poblaciones y las especies" ${ }^{48}$.

He aquí la reacción de Gould a esta declaración, ya citada en la introducción al presente escrito: “ ... si la caracterización de [Ernst] Mayr es acertada, entonces esa teoría, en cuanto propuesta general, está efectivamente muerta, a pesar de su persistencia como ortodoxia de libro de texto" 49 .

¿Cuáles eran los argumentos de Gould para apoyar la "muerte" de la teoría sintética? El artículo de 1980 aboga por un "enfoque jerárquico" de la evolución, con tres niveles principales: variación dentro de las poblaciones, especiación y pautas de macroevolución ${ }^{50}$. Gould defiende que, en cada uno de estos tres niveles, la propuesta de la concepción de la evolución como acumulación de pequeños cambios genéticos, guiados por la selección natural, ha sido refutada.

Dentro del nivel de la Genética de poblaciones ${ }^{51}$, Gould recuerda la neutralidad de muchos cambios genéticos: "En resumen, el espectro de la estocasticidad se ha entrometido en la explicación del cambio evolutivo. Esto supone un reto fundamental para el darwinismo, que sostiene, como su base genuina, que los factores aleatorios sólo entran en la producción de materia prima (raw materials) y que el proceso determinista de la selección produce el cambio y la dirección" ${ }^{52}$.

45 Cfr. "Punctuated Equilibria. An Alternativa to Phyletic Gradualism", pp. 82-115.

46 Cfr. Gould, S. J., "Is a New and General Theory of Evolution Emerging?", pp. 119-130.

47 Cfr. "Is a New and General Theory of Evolution Emerging?", pp. 119-121.

48 Mayr, E., Animal Species and Evolution, p. 586. [Vers. cast. de F. Cordón: Especies animales y evolución, Universidad de Chile/Ariel, Barcelona, 1968]. La cita de Gould está en la página 120 de su artículo.

49 "Is a New and General Theory of Evolution Emerging?", p. 120.

50 Cfr. "Is a New and General Theory of Evolution Emerging?", sección II: "Reduction and Hierarchy", p. 121.

51 Cfr. "Is a New and General Theory of Evolution Emerging?", sección III: "A Note on Local Populations and Neutrality", pp. 121-122.

52 Gould, S. J., "Is a New and General Theory of Evolution Emerging?", p. 122. 
En el nivel de la especiación ${ }^{53}$, se refiere a varios modelos de especiación (especialmente al modelo parapátrico de White) que muestran que el aislamiento reproductivo no es un subproducto de la adaptación sino, más bien, un suceso rápido y estocástico: "Podemos, en efecto, dar la vuelta a la concepción convencional y argumentar que la especiación, al formar nuevas entidades estocásticamente, proporciona materia prima (raw material) para la seleccción ... Existe una discontinuidad en la explicación entre las sustituciones alélicas (secuenciales, lentas y adaptativas) y el origen de nuevas especies (con frecuencia, discontinuo y no adaptativo). Durante el apogeo de la Síntesis moderna, Richard Goldschmidt fue censurado por su defensa de la especiación puntuacional ... Ahora no aceptamos todos sus argumentos sobre la naturaleza de la variación, pero su explícita declaración anti-extrapolacionista es el epítome y fundamento de las posturas emergentes de la especiación abordadas en esta sección. Hay una discontinuidad causal y explicativa entre la adaptación en las poblaciones locales y la especiación..." ${ }^{54}$.

Finalmente, en el nivel de la macroevolución ${ }^{55}$, Gould trata, en primer lugar, del equilibrio puntuado, y propone que las tendencias evolutivas no son una mera extrapolación de la evolución intraespecífica, sino el resultado de los índices diferenciales (differential rates) de la especiación y la extinción entre especies: “... si las especies se originan en instantes geológicos y, después, no se alteran de modo significativo, entonces las tendencias evolutivas no pueden representar una simple extrapolación de sustitución alélica dentro de una población. Las tendencias deben ser el producto del éxito diferencial entre especies ${ }^{56}$. En otras palabras, las especies mismas pueden ser inputs, y las tendencias el resultado de su origen y supervivencia diferenciales. La especiación se interpone como un nivel irreductible entre el cambio en poblaciones locales y las tendencias en tiempo geológico. Como sostiene Stanley ${ }^{57}$, la macroevolución está disociada (decoupled) de la microevolución" ${ }^{58}$.

Así pues, el artículo de 1980 de Gould deja al lector con la convicción de que la tradicional Teoría de la Evolución "darwiniana" o sintética se ha venido abajo y ha sido —o será pronto - reemplazada por otra teoría, donde la selección natural de la variación heredada en el nivel de pequeños individuos es sólo un proceso entre otros y, en definitiva, no [es] su principio unificador para el proceso evolutivo en su totalidad.

Si miramos ahora el testamento de Gould, el exuberante libro publicado en 2002 -el mismo año de su muerte- bajo el título The Structure of Evolutionary Theory [La estructura de la teoría evolucionista], observamos una actitud bastante diferente en lo que atañe al darwinismo. El primer capítulo está enteramente dedicado a resumir la totalidad del argumento del libro. Gould, una vez más, explica la estructura del nuevo marco teórico mediante una comparación con el marco clásico primitivo o puramente darwiniano. Pero en esta ocasión se refiere al propio Darwin más que a la teoría sintética. Sostiene que el nuevo marco teórico de la Biología

53 Cfr. "Is a New and General Theory of Evolution Emerging?, sección titulada "The Level of Speciation end the Goldschmidt Break", pp. 122-125.

54 Gould, S. J., "Is a New and Genral Theory of Evolution Emerging?", p. 124.

55 Cfr. "Is a New and General Theory of Evolution Emerging?", sección V: "Macroevolution and the Wright Break", pp. 125-128.

56 Cfr. Eldredge, N. y Gould, S. J., "Punctual Equilibria. An Alternative to Phyletica Gradualism", pp. 82-115; y Stanley, S. M., "A Theory of Evolution above the Species Level", Proceedings of the National Academy of Sciences of the United States of America, v. 72, n. 2, (1975), pp. 646-650.

57 Cfr. Stanley, S. M., "A Theory of Evolution above the Species Level”, p. 648.

58 Gould, S. J., "Is a New and General Theory of Evolution Emerging?", pp. 125-126. 
evolucionista no es una "extensión" de la vieja teoría darwiniana, ni una "destrucción" o "sustitución" (replacement) de ella.

Este vocabulario, que el autor emplea muy cuidadosamente, es a la vez desconcertante (puzzly) y estimulante. En términos de Gould, "extensión" significa que se han aplicado los mismos principios a un espectro de fenómenos más amplio. "Sustitución" quiere decir que otros principios están ahora en el centro de la teoría evolucionista. En lugar de estos dos términos, Gould prefiere "expansión". Con "expansión" expresa que los mismos principios se mantienen centrales en la teoría, pero han sido reformulados de un modo tal que da un aspecto auténticamente diferente al edificio entero (del mismo modo que un arquitecto hace un edificio nuevo a partir de otro más viejo, añadiendo partes nuevas a las ya existentes, que quedan sin cambiar y que, por sí mismas, condicionan el edificio completo):

"Creo que el marco darwiniano, y no sólo su fundamento, persiste en la estructura que surge de una teoría más adecuada. Pero también sostengo ... que los cambios sustanciales, introducidos durante la última mitad del siglo $\mathrm{XX}$, han construido una estructura expandida lejos del núcleo darwiniano, y [está] tan ampliada por nuevos principios de explicación macroevolutiva que la exposición completa, aunque permanezca dentro del dominio de la lógica darwiniana, debe ser elaborada como [algo] básicamente diferente de la teoría canónica de la selección natural, en lugar de [ser] simplemente extendida" ${ }^{59}$.

Esta noción de expansión es más bien poco ortodoxa en términos de la actual Filosofía de la Ciencia. "Extensión" hacía pensar a los filósofos en un alcance (scope) explicativo más amplio. "Sustitución" (replacement) evoca irremisiblemente el "cambio de paradigma" de Thomas Kuhn. Pero, obviamente, Gould quiere evitar estos dos modos clásicos de interpretar el cambio científico. ¿Qué entiende, pues, concretamente por "expansión”? Define el "marco darwiniano" (al que también llama "la lógica darwiniana") como un conjunto de tres principios: 1. La "actuación" (agency): la selección natural funciona casi enteramente en el nivel de los organismos. 2. La "eficacia": la selección natural es el mecanismo responsable del surgimiento de la novedad evolutiva, el único factor que configura el cambio evolutivo. 3. El "alcance": la extrapolación de cambios mínimos, [de índole] aumentativa, puede explicar la entera Historia de la vida ${ }^{60}$.

Conociendo como conocemos las tesis que Gould mantuvo durante su carrera, es obvio que no podía aceptar estos tres principios generales. Para Gould, la selección natural no opera sólo en el nivel de los organismos: - la selección de especies o, incluso, de clados (clade) es para él esencial (de hecho, esta es sin duda la tarea principal de su libro de 2002). Tampoco es la selección el único mecanismo de novedad evolutiva: las restricciones morfológicas, las restricciones del desarrollo y las restricciones históricas desempeñan un papel importante en la evolución. Para Gould, estas restricciones no son límites externos, sino factores positivos que canalizan las sendas (pathways) evolutivas. Finalmente, Gould no admite que la totalidad de la vida se explique mediante la extrapolación a la macroevolución de los pequeños cambios intraespecíficos.

¿Por qué, entonces, dice Gould que los principios de Darwin se han "expandido" y no "sustituido"? "Expansión" parece ser una palabra conveniente para expresar dos ideas:

1. La generalización de los principios darwinianos (o, más precisamente, sintéticos): selección de especies, deriva de las especies (species drift), selección de clados y deriva de

59 Gould, S. J., The Structure of Evolutionary Theory, pp. 14-15.

60 Cfr. Gould, S. J., The Structure of Evolution Theory, pp. 14-15. 
clados son ejemplos obvios de esta estrategia. El juicio último de Gould es que él y otros paleobiólogos han aplicado esquemas darwinianos a entidades que no fueron tenidas en cuenta por Darwin ${ }^{61}$.

2. La adición de nuevos principios, tales como restricciones morfológicas, de desarrollo e históricas.

Para hacer más intuitivas estas ideas, Gould emplea una imagen (figura 7). Compara la relación entre el darwinismo y el nuevo marco teórico con un coral. En su base, este coral tiene un tronco con tres ramas sucesivas. El tronco central representa la teoría de la selección natural y no puede ser cortado. Las ramas representan los tres "principios darwinianos" (actuación [agency], eficacia, alcance). Estos principios permanecen en la base del nuevo marco teórico, pero cada uno de ellos ha sido "truncado" a un nivel bastante bajo, de modo que todos ellos se expanden y "dan lugar" a un "organismo" sustancialmente diferente del original.

Hay, por supuesto, una gran cantidad de metáfora en la retórica de Gould. Me gustaría concluir este escrito con tres observaciones sobre esta retórica.

Mi primer comentario es psicológico. Es interesante ver que uno de los más brillantes críticos de los esquemas darwinianos en la segunda mitad del siglo XX concluyó su carrera diciendo, aproximadamente, lo siguiente: "No he reemplazado la teoría de Darwin por otra, he contribuido a la expansión de sus intuiciones básicas".

Mi segundo comentario es sobre las metáforas del desarrollo empleadas por Gould para presentar la relación entre el estado actual de la teoría evolutiva y el marco darwiniano clásico (o neodarwiniano). En términos de Gould, una teoría nueva no ha sustituido a la Teoría clásica de la Evolución, más bien se ha desarrollado en una nueva. No es necesario insistir en el considerable interés de Gould por el desarrollo en cuanto práctica científica.

Lo que merece la pena subrayar aquí es el empleo masivo por parte de Gould de la Historia de la Ciencia en toda su obra, y más que nunca en este libro. Igual que en su trabajo inicial sobre Alometría, o su Ontogeny and Phylogeny, The Structure of Evolutionary Theory pretende ser un genuino tratado científico, pero tiene más de 400 páginas dedicadas a la Historia de la Ciencia (de [un total de] 1343). En la introducción al libro, Gould dice que la Historia ha desempeñado un papel principal en los procesos, tanto de descubrimiento como justificación, de sus propias concepciones. Esto es algo bastante inusual en la Ciencia contemporánea, incluida la Biología evolucionista. No hay duda alguna que la relación de Gould con el darwinismo se ha visto afectada profundamente por su elección intelectual de utilizar la Historia en sus escritos científicos.

Mi tercer y último comentario es sobre esta relación con la Historia. Gould sostiene que esto no es un asunto sólo de genealogía. La nueva teoría que ha surgido no está conectada sólo con la antigua teoría darwiniana a través de una cadena de influencias contextuales (que podrían incluir el hecho de ser Gould discípulo de Newell, a quien inspiró Simpson, quien a su vez admiraba a Darwin). La propuesta es que hay una similitud conceptual genuina o "isomorfismo" (no identidad) entre las dos teorías. En otras palabras, la relación entre Darwin, el darwinismo y la teoría evolutiva moderna no es sólo histórica: es también una relación formal.

Esto me devuelve a la parte anterior de este escrito, donde expuse mi propia concepción de la relación entre el darwinismo original (la propia perspectiva de la evolución de Darwin) y

${ }^{61}$ Cfr. Gould, S. J., The Structure of Evolutionary Theory, p. 6. 
el darwinismo en cuanto tradición histórica. Al igual que Gould, estoy convencido de que las repetidas referencias a Darwin hechas por tantos biólogos evolucionistas desde 1859 no son sólo un asunto de "genealogía". En un sentido muy fuerte, Darwin estableció un marco que restringió la estructura misma de la teoría evolucionista por mucho tiempo, aunque, ciertamente, no la totalidad de su contenido empírico.

\section{Conclusión}

Para concluir, me gustaría añadir una palabra sobre la distinción que he hecho en la sección 2 de este trabajo entre los dos aspectos de la teoría de Darwin: la descendencia con modificación y la selección natural. Hoy esta distinción es comúnmente redenominada pautas versus procesos. Esta distinción no es, ciertamente, una distinción absoluta, en especial si se entiende que significa "hechos generales" frente a "hipótesis teóricas". En realidad, las teorías afectan profundamente al tipo de pautas que buscan los biólogos evolucionistas. Por ejemplo, el árbol de Darwin, con sus rasgos particulares, refleja de muchos modos su concepción del proceso evolutivo como dirigido por la selección natural, que actúa sobre pequeñas diferencias individuales dentro de las especies.

De manera similar, el "árbol" de Eldredge y Gould (figura 2) no se puede separar con facilidad de la convicción de estos autores, según la cual existen importantes procesos que canalizan el cambio evolutivo por encima del nivel de las especies. Aparece, en efecto, de modo explícito en el texto de esta figura, que menciona índices diferenciales (differential rates) de especiación y extinción. Además, en ambos casos (Darwin y Eldredge-Gould), es muy difícil disociar los aspectos de las pautas y los procesos: es como si estos autores hiciesen todo lo posible por eliminar la distinción. Esto puede ser debido a la concepción de la Ciencia que privilegia a las teorías sobre los hechos.

Sin embargo, pienso que la distinción pautas/procesos, que ha adquirido considerable importancia en la teoría evolucionista contemporánea, es una directriz segura para una valoración correcta de lo que ha cambiado y aquello que no ha cambiado en la teoría evolucionista desde Darwin. Se han producido cambios importantes en ambos sentidos, pero la continuidad de la teoría evolucionista desde Darwin no puede ser subestimada. Darwin parece haber impuesto un marco general, tanto para las pautas como para las hipótesis explicativas, que ha canalizado la mayoría de los debates evolutivos y que todavía los canaliza. Para entender correctamente esta afirmación, se ha de tener claro el "marco" (framework).

La mayoría de los cambios teóricos que se han producido desde Darwin, tanto en los casos de pautas como en los procesos, han consistido en proponer modelos alternativos dentro del mismo marco teórico general. En el caso de las pautas, el "árbol” de Darwin era un modelo concreto de las relaciones genealógicas entre linajes; se han propuesto otros, pero siempre como modelos de relaciones genealógicas. El árbol de Eldredge y Gould es otro modelo de estas relaciones genealógicas. Este incluye el enfoque "reticular" (network approach) de los biólogos contemporáneos, que resaltan la transferencia lateral de genes, permanece dentro del paradigma genealógico, aunque en niveles diferentes (p. ej., genes, membranas, etc.). Lo mismo cabe decir para las teorías sobre procesos. Los biólogos evolucionistas contemporáneos admiten muchos más modelos de selección natural y de competición de los que admitía Darwin; pero, en general, se mantienen dentro de un paradigma general que, en todos los niveles, favorece un enfoque poblacional respecto del fenómeno evolutivo. 


\section{Agradecimientos}

Agradezco a Tim Lewens sus correcciones lingüísticas y sus útiles sugerencias. Estoy agradecido especialmente a Eric Bapteste por cientos de intercambios fascinantes sobre el asunto de la transferencia lateral de genes, que conoce tan bien. Su lectura cuidadosa de este escrito me ha ayudado a evitar una serie simplificaciones excesivas (oversimplifications).

\section{REFERENCIAS}

Bowler, P. J., The Eclipse of Darwinism. Anti-Darwinian Evolution Theories in the Decades around 1900, Johns Hopkins University Press, Baltimore, 1983. [Vers. cast. de J. Faci Lacasta: El eclipse del darwinismo. Teorías evolucionistas antidarwinistas en las décadas en torno a 1900, Labor, Barcelona, 1985].

Burkahrdt, F. et Al., The Correspondence of Charles Darwin, Cambridge University Press, Cambridge, 1985-2007, 15 vols.

Darwin, CH., On the Origin of Species by Means of Natural Selection, or the Preservation of Favoured Races in the Struggle for Life, John Murray, Londres, 1859. [Hay múltiples traducciones al castellano, todas ellas con el título El origen de las especies].

DARwin, CH., The Variation of Animals and Plants Under Domestication, John Murray, Londres, 1868, 2 vols. [Vers. cast. de A. García González: La variación de los animales y las plantas bajo domesticación, C.S.I.C./Los Libros de la Catarata, Madrid, 2008, 2 vols.].

Doolittle, W. F. y Bapteste, E., "Pattern Pluralism and the Tree of Life Hypothesis", Proceedings of the National Academy of Sciences of the United Sates of America, v. 104, n. 7, (2007), pp. 2043-2049.

Eldredge, N. y Gould, S. J., "Punctuated Equilibria. An Alternative to Phyletic Gradualism", en Schopf, T. J. M. (ed), Models in Paleobiology, Freeman, Cooper and Co., San Francisco, 1972, CA, pp. 82-115.

Gayon, J., "Critics and Criticisms of the Modern Synthesis: the Viewpoint of a Philosopher", Evolutionary Biology, v. 24, (1990), pp. 1-49.

Gayon, J., “Neo-Darwinism”, en Wolters, G., Lennox J. G., y Mclaughlin, P. (eds), Concepts, Theories, and Rationality in the Biological Sciences, The Second Pittsburgh-Konstanz Colloquium in the Philosophy of Science, Universitätsverlag Konstanz y University of Pittsburgh Press, Konstanz-Pittsburgh, 1995, pp. 1-25.

Gayon, J., "The Paramount Power of Selection: From Darwin to Kauffman”, en Dalla Chiara, M. L., Doets, K. D., Mundici, D. y van Benthem, J. (eds), Structures and Norms in Science, Volume Two of the Tenth International Congress of Logic, Methodology and Philosophy of Science, Kluwer, Dordrecht, 1997, pp. 265-282.

Gayon, J., Darwin et l'après-Darwin, Kimé, París, 1992. Traducido al inglés como Gayon, J., Darwinism's Struggle for Survival: Heredity and the Hypothesis of Natural Selection, Cambridge University Press, Cambridge, 1998.

Gayon, J., “Sélection”, en Lecourt, D. (ed), Dictionnaire d'histoire et de philosophie des sciences, Presses Universitaires de France, París, 1999, pp. 854-861.

Gayon, J. y Ricqlès, A. De, "Le darwinisme en question", in: La science au présent, Encyclopaedia Universalis, París, 1999, pp. 193-199. 
Gayon, J., "History of the Concept of Allometry", American Zoologist, v. 40, (2000), pp. 748-758.

Gayon, J., "Gould biométricien”, Comptes Rendus Palevol, v. 2, (2003), pp. 353-360.

Gayon, J., "From Darwin to Today in Evolutionary Biology", en Hodge, J. y Radick, G. (eds), The Cambridge Companion to Darwin, Cambridge University Press, Cambridge, 2003, pp. 240-264.

Gayon, J. y Ricqlès, A. De, "Évolutionnisme”, en: Dictionnaire des idées, Encyclopaedia Universalis, París, 2005, pp. 271-275.

Gould S. J., "Allometry and Size in Ontogeny and Phylogeny", Biological Reviews of the Cambridge Philosophical Society, v. 41, (1966), pp. 587-640.

Gould S. J., "An Evolutionary Microcosm: Pleistocene and Recent History of the Land Snail P. (Poecilozonites) in Bermuda", Bulletin of the Museum of Comparative Zoology, v. 138, (1969), pp. 407-532.

Gould, S. J., Ontogeny and Phylogeny, Harvard University Press, Cambridge, MA, 1977.

Gould, S. J., “Is a New and General Theory of Evolution Emerging?”, Paleobiology, v. 6, n. 1, (1980), pp. 119-130.

Gould, S. J., The Structure of Evolutionary Theory, The Belknap Press, Cambridge, MA, 2002. [Vers. cast. de A. García Leal: La estructura de la Teoría de la Evolución, Tusquets, Barcelona, 2004].

Hodge, M. J. S., "Natural Selection as a Causal, Empirical, and Probabilistic Theory", en Krüger, L., Gigerenzer, G. y Morgan, M. S. (eds), The Probabilistic Revolution, The MIT Press, Cambridge, MA, 1987, vol. 2, pp. 233-270.

HuxLey, J., Evolution: The Modern Synthesis, Allen and Unwin, Londres, $3^{\text {a }}$ ed., 1978. [Vers. cast.: La evolución: Síntesis moderna, Losada, Buenos Aires, 1946, y reediciones posteriores].

Kauffman, S. A., The Origins of Order: Self-Organisation and Selection, Oxford University Press, Oxford, 1993.

Kavaloski, V.C., The vera causa Principle: A Historico-philosophical Study of a Metatheoretical Concept from Newton through Darwin, Tesis Doctoral, University of Chicago, 1974.

Kimura, M., "Evolutionary Rate at the Molecular Level”, Nature, v. 217, (1968), pp. 624-626.

Kimura, M., "Mutation and Evolution at the Molecular Level", Genetics (Supplement), v. 73, (1973), pp. 19-35.

Lewens, T., Darwin, Routledge, Londres, 2007.

Lewontin, R. C., The Genetic Basis of Evolutionary Change, Columbia University Press, Nueva York, 1974. [Vers. cast.: La base biológica de la evolución, Omega, Barcelona, 1979].

Margulis, L. y Sagan, D., Acquiring Genomes. A Theory of the Origins of Species, Basic Books, Nueva York, 2002.

MaYr, E., "Where are We?", Cold Spring Harbor Symposia on Quantitative Biology, v. 24, (1959), pp. 409-440.

MaYr, E., Animal Species and Evolution, The Belknap Press of Harvard University Press, Cambridge, MA, 1963. [Vers. cast. de F. Cordón: Especies animales y evolución, Ediciones Universidad de Chile/Ariel, Barcelona, 1968]. 
Mayr, E. y Provine, W. B., The Evolutionary Synthesis, Harvard University Press, Cambridge, MA, 1980.

McInerney, J. O., Cotton, J. A. y Pisani, D., "The Prokaryotic Tree of Life: Past, Present... and Future?”, Trends in Ecology and Evolution, v. 3, n. 5, (2008), pp. 276-281.

Raup, D., Extinction. Bad Genes or Bad Luck, Norton and Company, N. York, 1991.

Ridley, M., Evolution, 2a ed., Blackwell Scientific Publishing, Cambridge, MA, 1996; $3^{\text {a }}$ ed., Blackwell Scientific Publishing, Malden, MA, 2004.

Ruse, M., "Darwin's Debt to Philosophy: An Examination of the Influence of the Philosophical Ideas of John F. W. Herschel and William Whewell on the Development of Charles Darwin's Theory of Evolution", Studies in History and Philosophy of Science, v. 6, (1975), pp. 159-181.

Smocovitis, B. V., Unifying Biology. The Evolutionary Synthesis and Evolutionary Biology, Princeton University Press, Princeton, NJ, 1996.

Sober, E. y WiLson, D. S., Unto Others: The Evolution and Psychology of Unselfish Behavior, Harvard University Press, Cambridge, MA, 1998.

Stanley, S. M., "A Theory of Evolution above the Species Level", Proceedings of the National Academy of Sciences of the United Sates of America, v. 72, n. 2, (1975), pp. 646-650.

Stanley, S. M., Macroevolution. Pattern and Process, The Johns Hopkins Press, Baltimore, 1998.

Vialleton, L., L'Origine des êtres vivants. L'illusion transformiste, Librairie Plon, París, 1929.

Woese, C. R., “Bacterial Evolution”, Microbiology Reviews, v. 51, (1987), pp. 221-271. 


\section{Figuras}

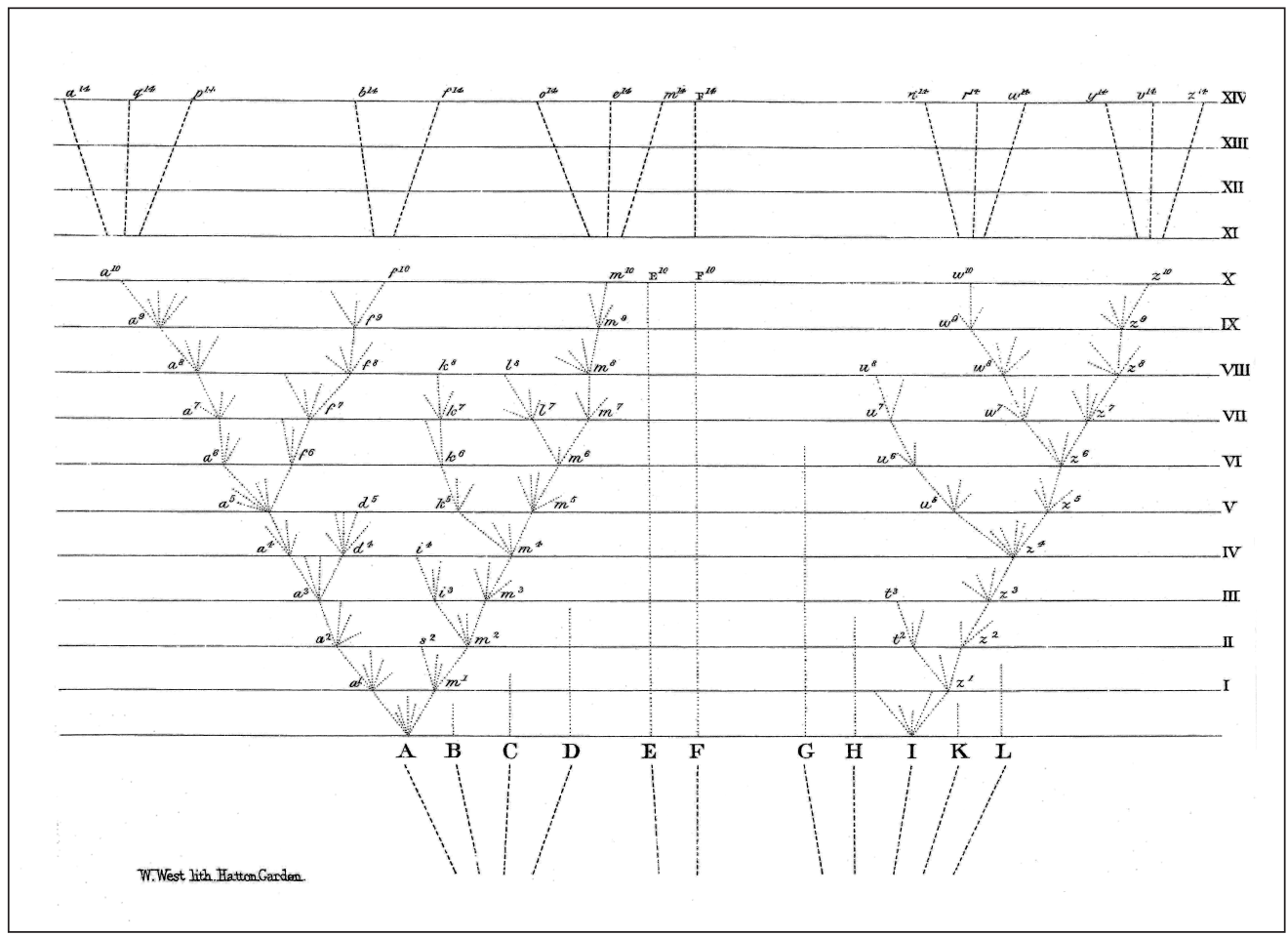

Figura 1. Charles Darwin, On the Origin of Species (1859), doble página contra p. 117. Esta es la única figura del libro. No hay texto explicativo. El "diagrama", como lo llama Darwin, se comenta en dos lugares del libro: en el capítulo IV. "Natural selection" ["Selección natural"], pp. 116-125, y en el capítulo XIII, sección sobre "clasificación”, pp. 420-422. En el capítulo IV, A, B, C... L representan "las especies de un género amplio dentro de su propio terreno (country)". Dan lugar a variedades locales que se modifican y divergen durante muchas generaciones. Darwin señala que el intervalo entre las líneas horizontales puede representar mil o diez mil que han sobrevivido [y que] se han diversificado en varias especies (por ejemplo, A ha llevado a [originar] 8 especies). En el capítulo XIII, A, B, C... L representan "géneros conexos" (allied genera), que llevarán al nivel XIV a un gran número de genera (por ejemplo, A se ha diferenciado en 8 genera que forman una familia). El mismo razonamiento se puede aplicar a cualquier nivel de las categorías taxonómicas que se desee. Lo que es natural es la "ordenación” (arrangement) taxonómica. La "clasificación” [ranking] (variedad, especie, género, sub-familia, etc.) es arbitraria. 


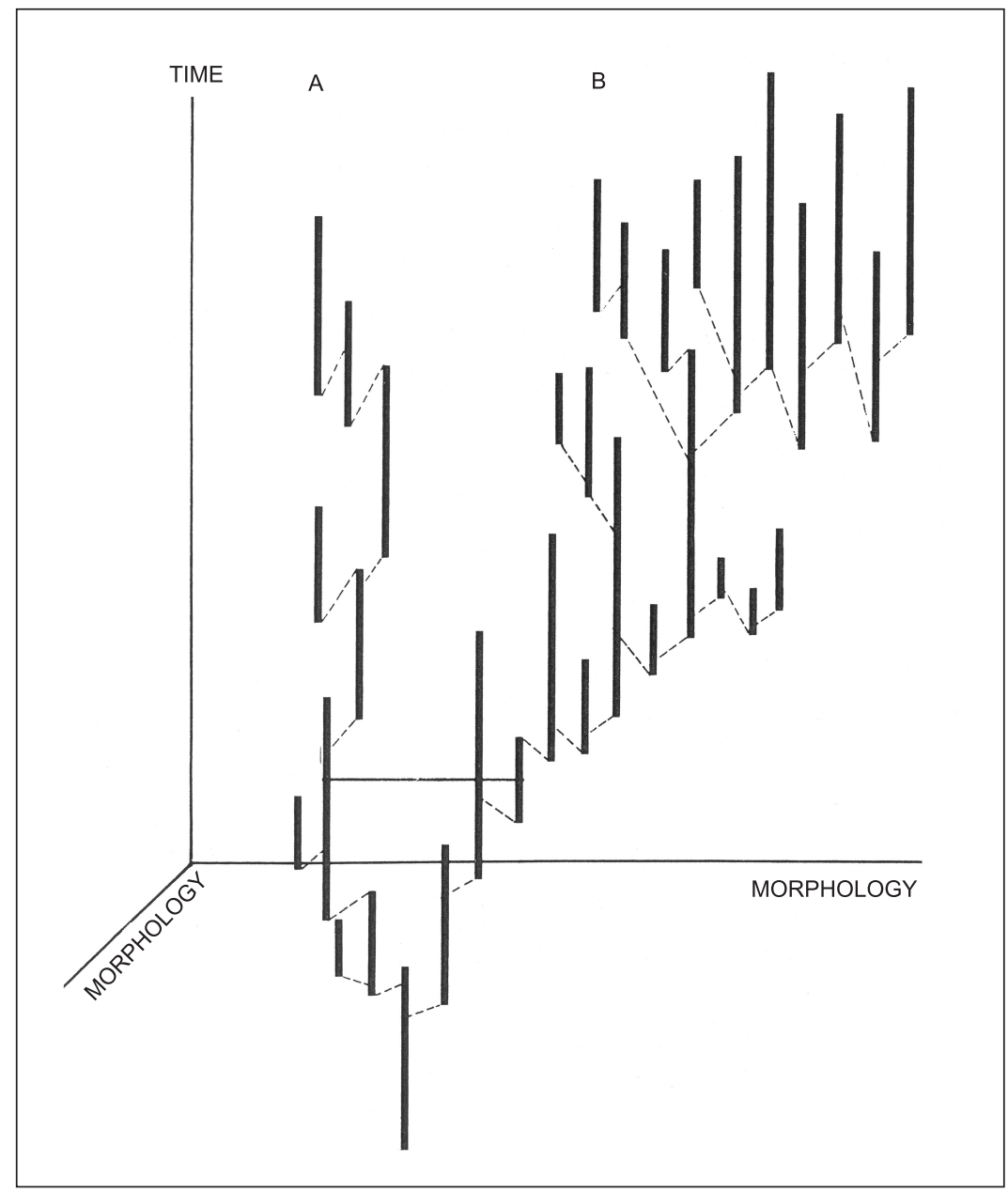

Figura 2. Niles Eldredge y Stephen Jay Gould, "Punctuated Equilibria. An Alternative to Phyletica Gradualism", (1972), p. 113. Texto original: "Esquema (sketch) tridimensional que contrasta una pauta de relativa estabilidad (A) con una tendencia (B), donde la especiación (líneas de guiones) se está dando en los dos linajes principales. El cambio morfológico se representa aquí a lo largo de los ejes horizontales, mientras que el eje vertical es el tiempo. Aunque una pauta retrospectiva de la selección direccional se podría encajar como una línea recta en (B), la pauta real (actual) es estática dentro de las especies, y el éxito diferencial de las especies exhibe un cambio morfológico en una dirección concreta". Nótese la mezcla de "pauta" $\mathrm{y}$ "proceso" en este texto (véase la conclusión del presente trabajo). 


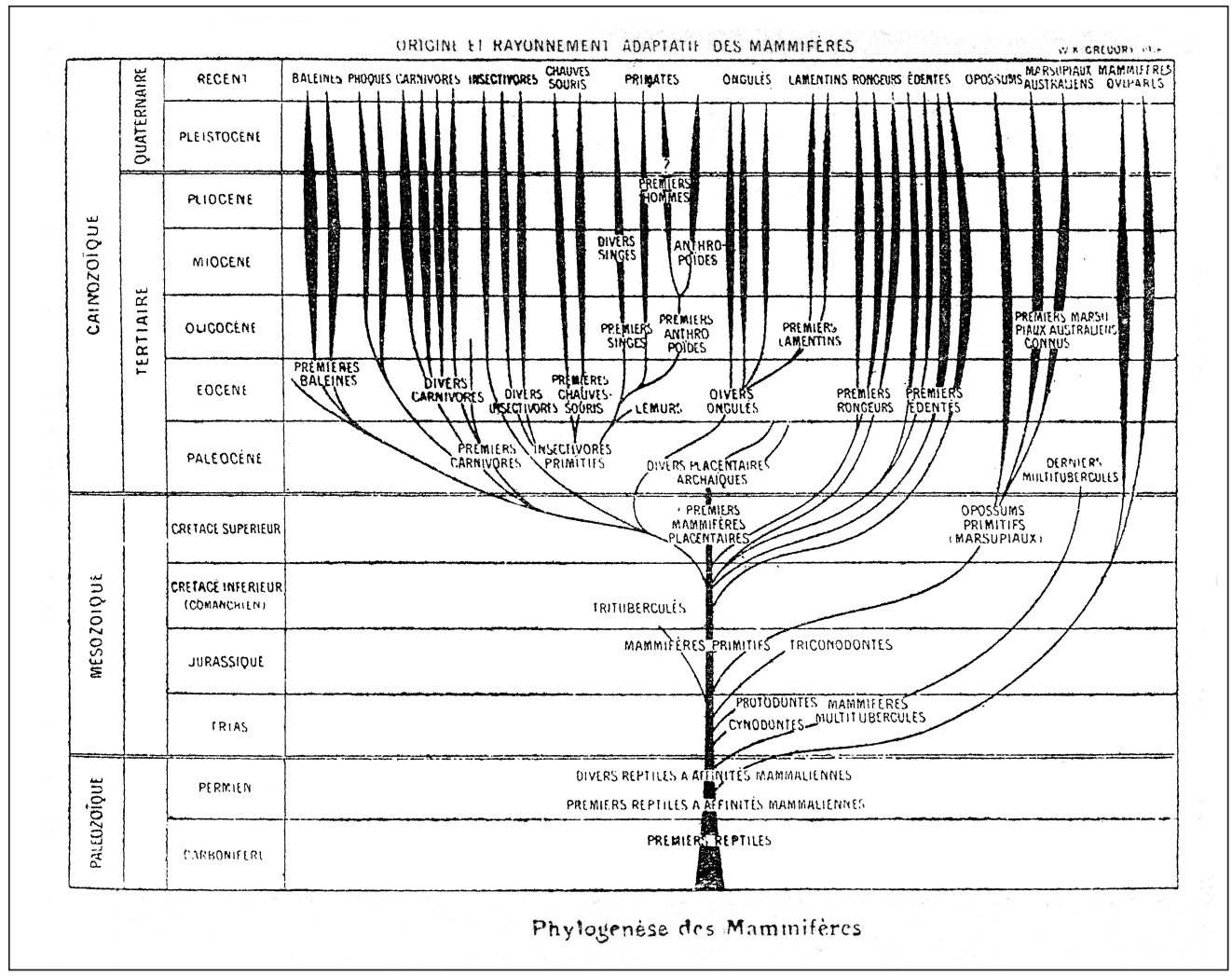

Figura 3. Louis Vialleton, L'origine des êtres vivants. L'illusion transformiste (1929), p. 183. El texto original es: "Arbre généalogique des mammifères (d’après Osborn)" [Árbol genealógico de los mamíferos (según Osborn)]. Vialleton se refiere a Osborn, H. F., L'origine et l'evolution de la vie, Masson, París, 1921. 


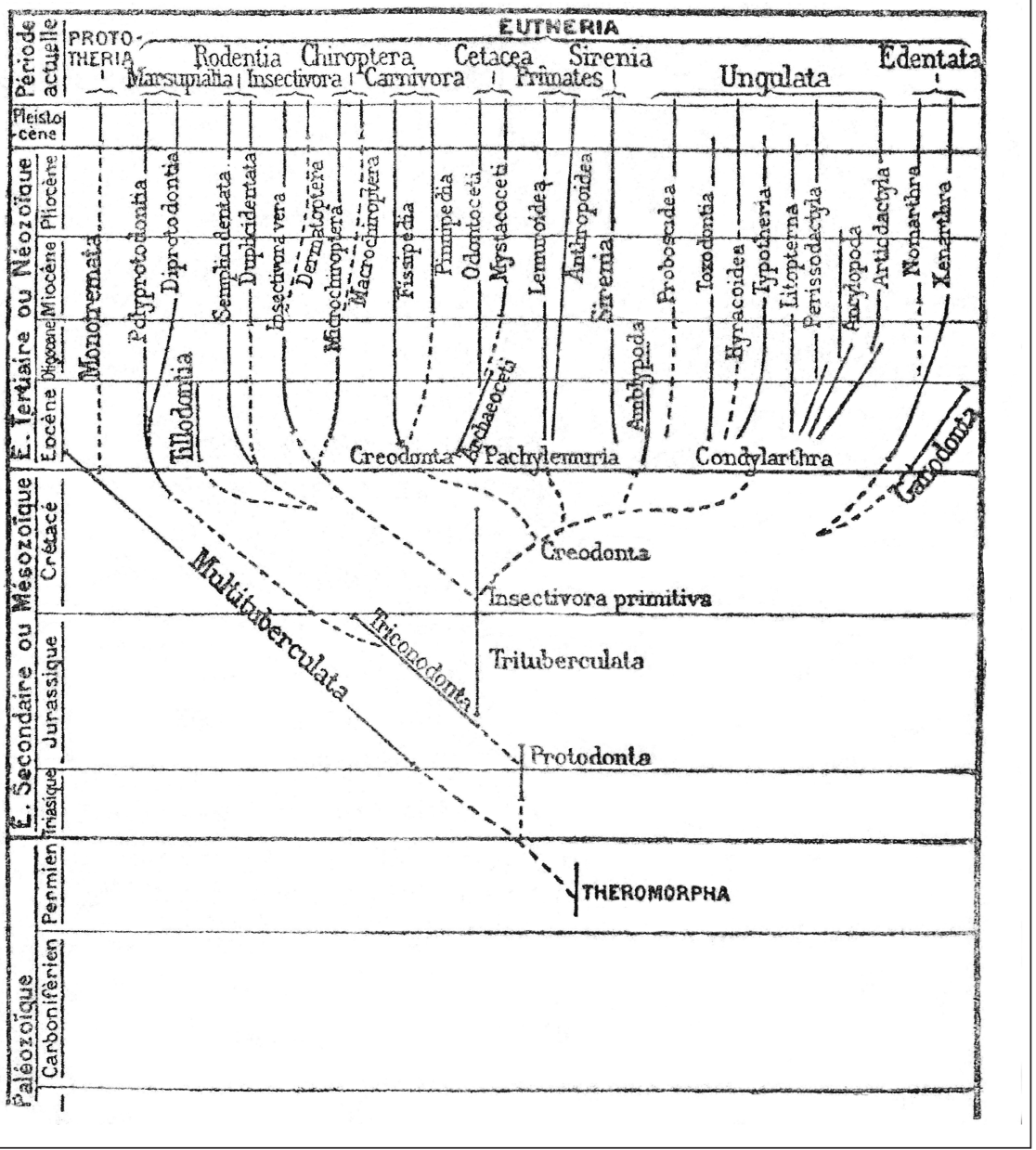

Figura 4. Louis Vialleton, L'origine des êtres vivants. L'illusion transformiste (1929), p. 181. El texto original es: "Arbre généalogique des mammifères (d'après Vialleton)" [Árbol genealógico de los mamíferos (según Vialleton)]. 


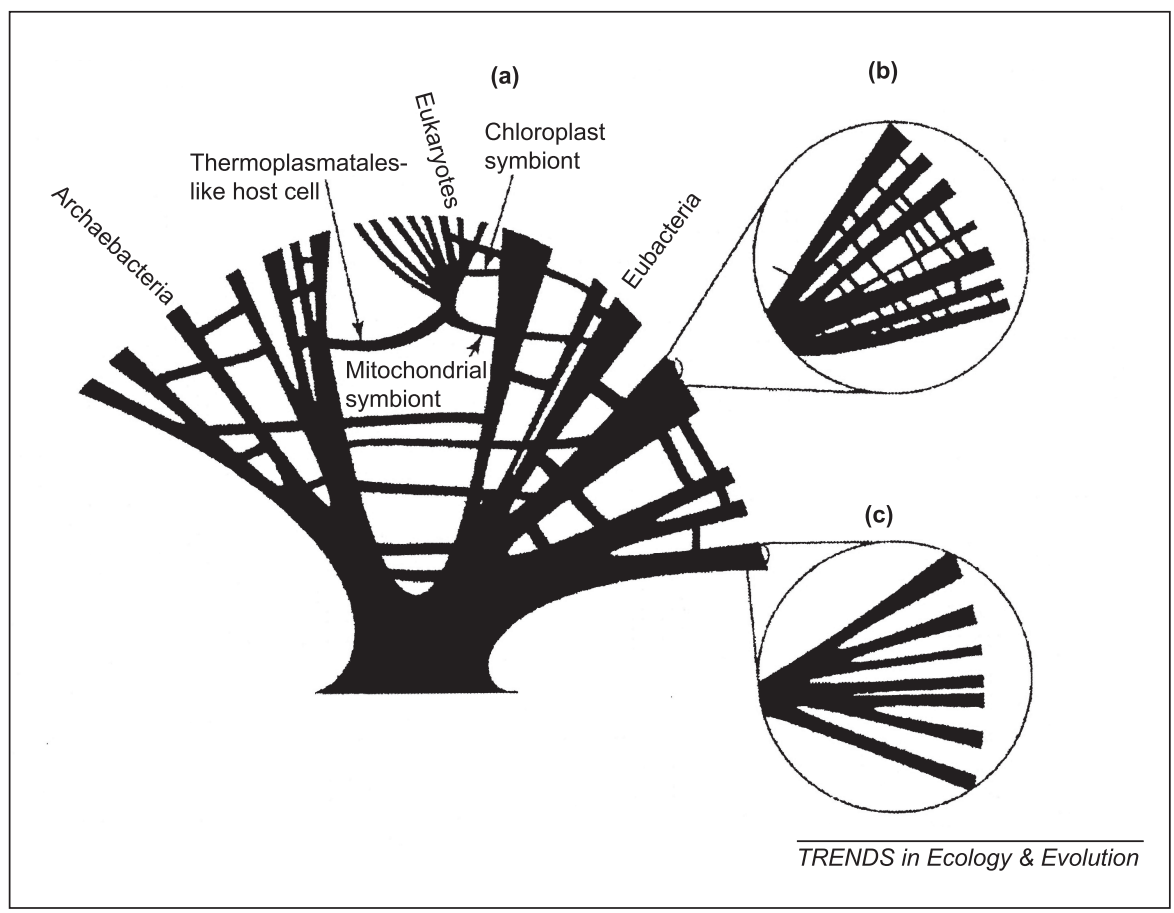

Figura 5. James O. McInerney, James A. Cotton y Davide Pisani, "The Prokaryotic Tree of Life: Past, Present... and Future?”, (2008), p. 278. Texto original: "Una red de vida. (a) Se sabe que las eucariotas son quiméricas, con cloroplasto y genes mitocondriales que tienen un origen diferente de los genes del núcleo, y que provienen de grupos diferentes de eubacterias. Existe un gran debate sobre si la transferencia lateral de genes entre las eubacterias, arqueobacterias y eucariotas, y entre los grupos principales de procariotas es común o rara. (b) Se sabe que la transferencia lateral de genes es normal entre miembros de algunos grupos de bacterias que son efectivamente panmícticos, mientras que (c) puede estar completamente ausente de otros grupos". Así, la pauta real de la entera genealogía de la vida es una mezcla de árbol y red. 


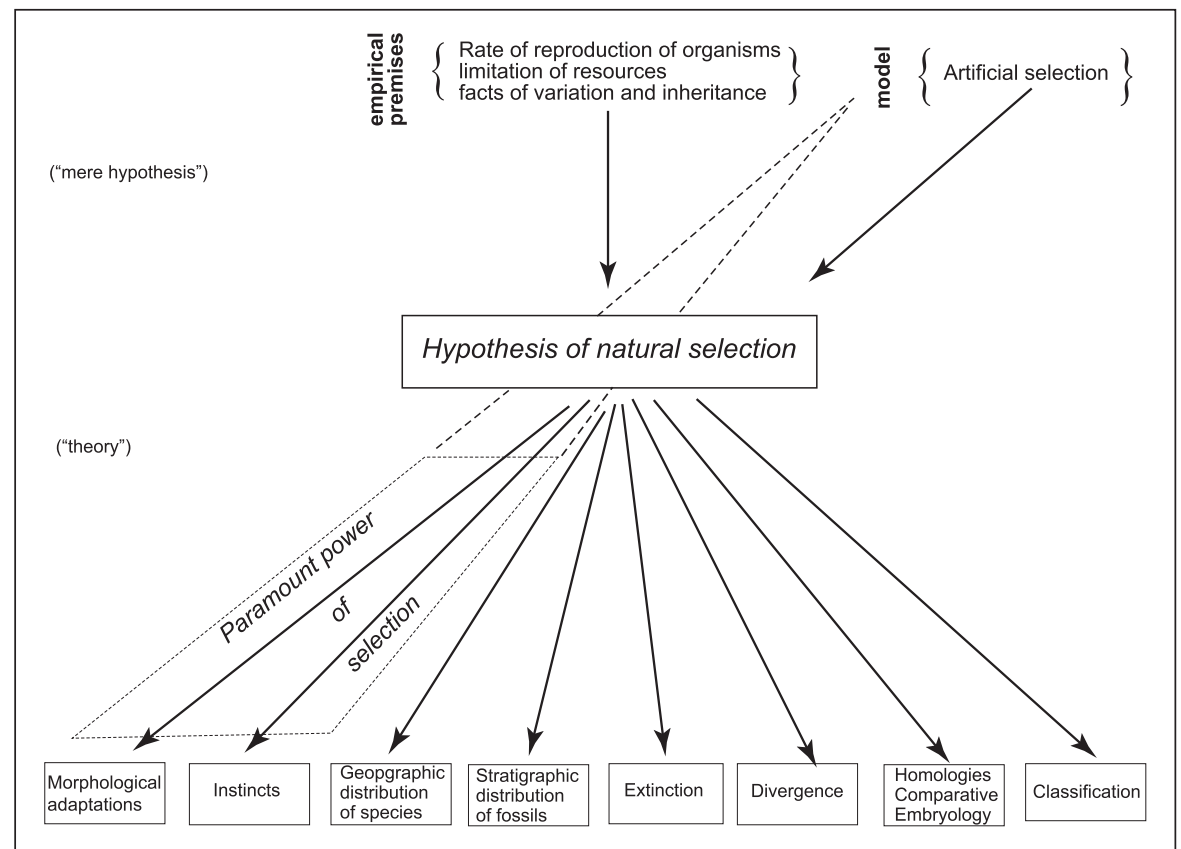

Figura 6. De Jean Gayon, "The 'Paramount Power of Selection': From Darwin to Kauffman”, (1997), p. 270. Este diagrama es una representación visual del comentario de Darwin sobre la estructura del argumento que apoya la hipótesis de la selección natural en El origen de las especies. Los dos niveles del diagrama (arriba y abajo de la "hipótesis de la selección natural") representan los dos niveles de justificación de la hipótesis según Darwin (véase el texto). Nótese que las adaptaciones (morfológica e instintiva) son el resultado directo de la selección natural; Darwin habla de "la fuerza primordial (the paramount power) de la selección" sólo para las adaptaciones. Los otros recuadros en la parte de abajo del diagrama representan las consecuencia más remotas del proceso de selección natural. 


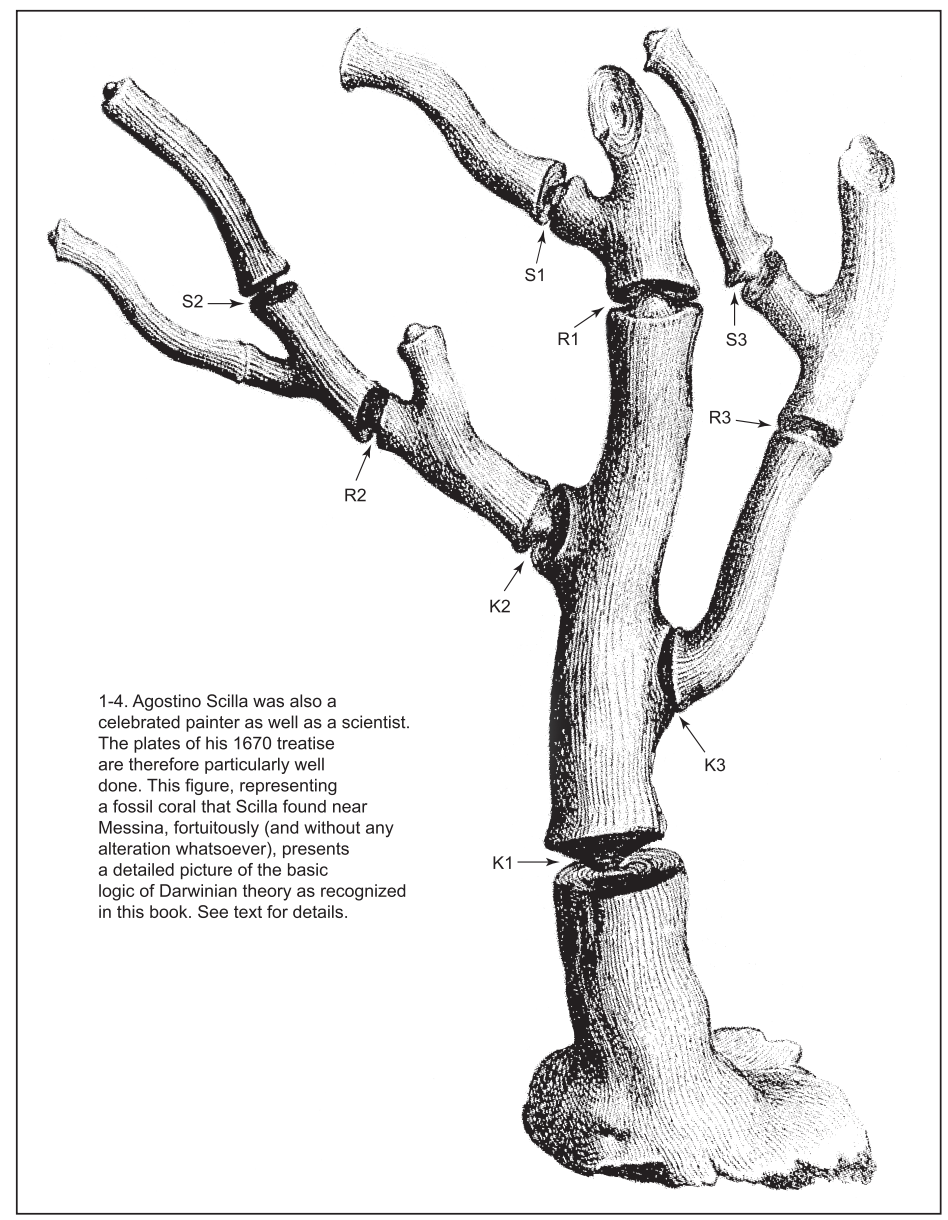

Figura 7. Stephen Jay Gould, The Structure of Evolutionary Theory (2002), p. 18. La lámina está tomada de la lámina $17^{\mathrm{a}}$, que representa un coral. Gould la utiliza para ilustrar el destino (fate) de la "lógica darwiniana". Las letras "K", "R" y "S" las ha añadido Gould. "K" es para "cortes mortales" (killing cuts). Los cortes-K "seccionan (sever) al menos uno de los tres principios centrales de la lógica darwiniana $\mathrm{y}$, en consecuencia, destruyen la teoría tout court". "R" es para "cortes de revisión". Un corte de revisión "modifica lo suficiente la forma original de una de las ramas para asegurar que la nueva (y más fuerte o más arborescente), al rebrotar a partir del corte, construirá una teoría con un fundamento darwiniano intacto, pero con una forma general lo suficientemente expandida, revisada o reconstruida que presenta una estructura de la explicación general interesantemente diferente". Los cortes secundarios modifican más aspectos especiales de la teoría original. Esta imagen domina la organización globlal del libro de Gould. 


\section{II}

\section{Evolucionismo y Biología actual}

4. Los experimentos mentales en la Biología evolucionista actual

5. El concepto de "especie" en la Biología evolucionista: Polémicas actuales 



\title{
LOS EXPERIMENTOS MENTALES EN LA Biología eVOlUCiOnista ACTUAL *
}

\author{
James G. Lennox
}

\section{InTRODUCCIÓN}

En mi artículo precedente en este libro, en el que analizaba el uso de Darwin de los experimentos mentales, utilizaba la expresión "Experimento Mental Darwiniano" (EMD) 1 , como lo hacía en mi trabajo de 1991 sobre el tema para referirme a una narración imaginaria que sirve como comprobación de la capacidad explicativa de la selección natural ${ }^{2}$. [Un EMD] establece las condiciones de comprobación hipotéticas e imaginarias que especifican las concreciones particulares de los procesos causales identificados por la teoría; y muestra un estado de cosas concreto que necesita explicación, en cuanto resultado final de repetidas iteraciones de estos procesos.

En una breve sección final de mi artículo original de 1991 sobre este asunto, señalé dos aspectos, fundamentalmente por medio de ejemplos ${ }^{3}$. El primer aspecto era que el problema de mostrar cómo algo que, a primera vista, parece imposible es de hecho posible dentro de los parámetros del darwinismo, se ha dado de manera constante a lo largo de la Historia del darwinismo en el siglo veinte. Apunté, por ejemplo, que en los años veinte Ronald Fisher y J. B. S. Haldane, ambos brillantes matemáticos y naturalistas, se propusieron integrar una generalización matemática de la Genética de Mendel para las poblaciones naturales y la Teoría de la Evolución por selección natural. Prima facie, había un escollo (roadblock) en el camino de esta tarea: a tenor de lo que se sabía acerca de la Genética subyacente, no parecía posible que una ligera ventaja selectiva, que le confería a una rara mutación mendeliana un lugar genético singular, pudiera difundirse a lo largo de una amplia población — que se reproducían entre sí de una manera aleatoria - de modo que tuviera una proporción adecuada para dar razón del cambio evolutivo. Como matemáticos, ambos hombres vieron como una de sus tareas más relevantes el probar que era posible que una leve variación, con una ligera ventaja selectiva, se volviera fija en una población durante un periodo sorprendentemente corto. Mostrar que esto ocurre de hecho era tarea de otros. Sugerí brevemente que era la tarea primordial de los primeros defensores de la "selección por parentesco" (kin selection) y de la "eficacia biológica inclusiva" (inclusive fitness) el establecer por medio de experimentos mentales la plausibilidad de estos constructos teóricos como explicaciones de la denominada conducta "altruista", y más cuando Darwin las buscó para la explicación de la selección de la conducta social de

\footnotetext{
La traducción ha sido realizada por José Fco. Martínez Solano. N. del E.

1 Cfr. Lennox, J. G., "La evolución de los experimentos mentales darwinianos", en Gonzalez, W. J. (ed), Evolucionismo: Darwin y enfoques actuales, Netbiblo, A Coruña, 2009, pp. 63-77.

2 Cfr. Lennox, J. G., "Darwinian Thought Experiments: A Function for Just-so Stories", en Horowitz, T. y MasSEY, G. (eds), Thought Experiments in Science and Philosophy, Rowman and Littlefield, Savage, MD, 1991, pp. $223-246$.

3 Cfr. Lennox, J. G., "Darwinian Thought Experiments: A Function for Just-so Stories”, pp. 238-241.
} 
las hormigas y de la construcción de colmenas de abejas. Como con Darwin, el objetivo fue mostrar que los fenómenos que parecen imposibles de explicar con referencia a la selección natural, podrían explicarse de este modo.

\section{Los Experimentos Mentales Darwinianos y la síntesis}

Estos ejemplos muestran de modo gráfico la importancia histórica de los experimentos mentales darwinianos. Porque lo que hicieron estas pruebas iniciales de plausibilidad - como hacen habitualmente los experimentos mentales - fue abrir un ámbito para la investigación experimental e histórico-natural. En efecto, cuando se hacen bien, sugieren modos de explicación y comprobación que no se les habían ocurrido a los investigadores en el área.

Igualmente podría añadir que la alternativa "neutralista" al neo-darwinismo pretendía hacer lo mismo; esto es, [buscaba] demostrar que era plausible suponer que una característica que fuera estrictamente neutral, desde un punto de vista selectivo, podría convertirse en fija en una población bajo condiciones que no fueran inusuales en la Naturaleza. De nuevo, los principales argumentos fueron experimentos mentales - es todavía una cuestión a debate que los experimentos efectivos para mostrar que lo que era posible demostrar acontezca de hecho, de modo que se aproxime en un número interesante de casos-. Quizá en este caso sea en cierto modo pickwickiano el llamarlos experimentos mentales darwinianos; en igual medida en que lo fue para mí el referirme al uso que hace Jenkin de experimentos mentales darwinianos contra la teoría presentada en la primera edición del Origen de Darwin. Pero la pauta y la meta del razonamiento es en ambos casos el mismo.

Tanto Fisher como Haldane eran conscientes del papel del experimento mental en su trabajo. Véanse los comentarios siguientes del prefacio a la primera edición de The Genetical Theory of Natural Selection (y téngase en cuenta que la formación inicial de Fisher era en Física matemática).

"La imaginación es algo profundamente susceptible de entrenamiento, y los matemáticos y los biólogos parecen disentir enormemente en el modo como usan su imaginación. A la mayoría de los biólogos les parecerá que esta ventaja está completamente de su lado [...] Quizá puedo dejar más claro que la imaginación de los matemáticos también ha sido entrenada con alguna ventaja, citando una observación que Eddington deja caer de manera informal en un libro reciente: 'No es preciso añadir que la reflexión en la Ciencia de la Naturaleza acerca de un terreno más amplio que el ámbito de lo real conduce a una comprensión mucho mejor de lo que hay' ${ }^{4}$. Para un matemático la afirmación es casi una obviedad. Desde [el punto de vista de] un biólogo [...] esto sugeriría una actitud extraordinariamente amplia. Ningún biólogo práctico interesado en la reproducción sexual se prestaría a calcular las consecuencias detalladas que podrían experimentar organismos que tuvieran tres o más sexos: ¿qué más debería hacer él si desea comprender por qué los sexos son, de hecho, siempre dos? El procedimiento matemático común para tratar un problema real consiste - tras abstraer lo que se cree que son los elementos esenciales del problema - en considerarlo como uno más de un sistema de posibilidades infinitamente más amplio que el real" 5 .

4 Eddington, A., The Nature of the Physical World, Cambridge University Press, Cambridge, 1928, p. 267.

5 Fisher, R. A., The Genetical Theory of Natural Selection: A Complete Variorum Edition, Oxford University Press, Oxford, 1999, pp. viii-ix. 
La recomendación que hace Fisher aquí de lo que un biólogo tendría que hacer para comprender por qué el aparente número límite superior de sexos es dos —el calcular las consecuencias detalladas de tener tres o más - es un experimento mental, no necesito recordárselo a nadie en este momento. Consiste en suponer imaginariamente una población de 3 , 4 o 5 sexos, y después estudiar detenidamente en su imaginación las consecuencias que se darían a largo plazo para una población ficticia así, especialmente si estuviera compitiendo con una población con dos sexos.

El segundo aspecto que toqué en aquella conclusión tenía que ver con los usos y abusos de lo que Steven Jay Gould, que seguía a Rudyard Kipling y es seguido por muchos otros, se refería con "narraciones imaginarias" (just-so stories). Señalé que dependía bastante de los fines del que cuenta la historia el que fueran vilipendiadas o alabadas. Consideren el ejemplo de Richard Dawkins que cité:

"Cavar un hoyo en el suelo es una pauta compleja de conducta. Cuesta tiempo y energía, y satisface los criterios más precisos para su reconocimiento como adaptación [al medio] ${ }^{6}$. Debe, pues, haber evolucionado por selección natural. ¿Cómo podría haber ocurrido esto? Los detalles no interesan para la moraleja que quiero extraer. Probablemente, existió un ancestro de las hormigas león que no cavaba agujeros sino que, simplemente, se escondía debajo de la superficie de la arena a la espera de la presa para echarse sobre ella. De hecho, algunas especies todavía lo hacen. Una conducta posterior que llevara a la creación de una depresión poco profunda en la arena estuvo favorecida, probablemente, por la selección, porque la depresión impedía ligeramente que la presa escapara. Por medio de variaciones paulatinas en muchas generaciones, la conducta cambió hasta el punto de que lo que era una depresión poco profunda se convirtió en más profunda y más ancha" 7 .

Este es un clásico Experimento Mental Darwiniano. [Dawkins] pregunta cómo podría haberse desarrollado la evolución de la conducta de excavación de la hormiga león. Afirma, de un modo arriesgado, que los detalles no importan para la moraleja que quiere extraer. Esto es bueno, porque, francamente, ¡nadie sabe o sabrá los detalles! La Paleontología de la conducta de los invertebrados está un poco corta de datos. Entonces, [Dawkins] cuenta un relato sobre lo que probablemente ocurrió — posiblemente habría sido una mejor elección del término. Nótese que Dawkins inserta una observación sobre la conducta real de una especie existente para ayudar a convencer de que su narración imaginaria es una historia plausible, precisamente como Darwin tendía a hacer.

¿Cuál es la moraleja que quiere extraer? ¿que los detalles no importan (no quiere decir [Dawkins] que los detalles puedan omitirse; quiere decir que no importa qué detalles elijas)?, ¿que un experimento mental es suficiente? La moraleja es que, en cuanto compleja y perfectamente diseñada que parece ser la conducta que sirve a los fines de la hormiga león, nada le impide ser el producto de una lenta y gradual selección natural. Es exactamente como las respuestas de Darwin con experimentos mentales a sus críticos del diseño inteligente en el capítulo 6 de Origen. Compárese el fragmento anterior de The Extended Phenotype de Dawkins

6 Dawkins cita aquí Williams, G. C., Adaptation and Natural Selection: A Critique of Some Current Evolutionary Thought, Princeton University Press, Princeton, 1966; y Curio, E., "Towards a Methodology of Teleonomy", Experientia, v. 29, (1973), pp. 1045-1058.

7 Dawkins, R., The Extended Phenotype, Oxford University Press, Oxford, 1982, p. 20. 
con el siguiente pasaje de la primera edición de On the Origin of Species, que imagina cómo la selección produjo los primitivos mamíferos voladores.

"Considérese ahora el Galeopithecus o lémur volador, que se clasificó erróneamente entre los murciélagos. Tiene una membrana lateral extremadamente amplia, que se despliega desde los extremos de su mandíbula hasta la cola, y que incluye las extremidades y los dedos alargados; la membrana lateral también está provista de un músculo extensor. Aunque sin conexiones graduales de estructura, adaptada para planear por el aire, conéctese ahora el Galeopithecus con los otros Lémures, no puedo ver, con todo, ninguna dificultad en suponer que tales conexiones existieron con anterioridad, y que cada uno había sido formado por los mismos eslabones, como en el caso de las ardillas que vuelan de un modo menos perfecto; y que cada escalón de la estructura había sido útil para su poseedor. Tampoco puedo ver ninguna dificultad insuperable en creer posible además que los dedos conectados de la membrana y el antebrazo de los Galeopithecus podría alargarse más por selección natural; y, en lo que se refiere a los órganos de vuelo, éste se convertiría en un murciélago" ${ }^{8}$.

¿Tiene Darwin alguna prueba real de que es así cómo evolucionaron el lémur volador o los murciélagos? Desde luego que no. Pero no es eso lo que él está tratando de probar. Ni Darwin ni Dawkins está tratando de convencer a sus colegas evolucionistas de que hay buenas pruebas en favor de esta narración concreta. Lo que intentan probar es que la teoría de la selección natural tiene los recursos explicativos para explicar tales casos.

Usar a Dawkins como mi ejemplo actual de un Experimentador Mental Darwiniano no es una selección aleatoria por mi parte. En la primera parte de The Extended Phenotype, de la que se ha tomado la cita de arriba sobre las hormigas león, Dawkins proclama que él no está "tratando de convencer a nadie de la verdad de una proposición fáctica". Su cometido es "mostrar al lector una manera de ver los hechos biológicos"9. Defiende, pues, el uso de los experimentos mentales para alcanzar esa meta (una defensa que se inicia, por cierto, con una discusión de la defensa previa de Fisher de "imaginar lo posible").

"Jugar con un mundo imaginario para incrementar nuestra comprensión del mundo real es la técnica del 'experimento mental'. Es muy usado por los filósofos [...] En este libro haré uso frecuente de la técnica del experimento mental. Advierto al lector de esto por adelantado, puesto que algunas veces los científicos se irritan con la falta de realismo de esas formas de razonar. No se supone que los experimentos mentales sean realistas. Se supone que están para clarificar nuestro pensamiento sobre la realidad" ${ }^{10}$.

Hay un número de cuestiones que es necesario responder sobre el uso de Dawkins de los experimentos mentales y volveré sobre esas cuestiones en un momento. Pero antes de hacerlo permítanme explorar lo que Dawkins dice sobre sus propósitos en The Extended Phenotype.

8 Darwin, CH., On the Origin of Species: A Facsimile Edition, Harvard University Press, Cambridge, MA, 1964, p. 181; énfasis añadido.

9 Dawkins, R., The Extended Phenotype, p. 1.

10 The Extended Phenotype, pp. 4-5. Aunque los temas que estoy tratando no están principalmente en su foco, el lector encontrará de bastante interés, en cuanto a los problemas y las posibilidades, [el número sobre] The Extended Phenotype en Biology and Philosophy, v. 19, n. 3, (2004). Hay tres artículos que revisan sus argumentos después de veinte años: Eva Jablonka ("From Replicators to Heritably Varying Phenotype Traits: The Extended Phenotype Revisited", pp. 353-375), Kevin Laland ("Extending the Extended Phenotype", pp. 313-323) y J. Scott Turner ("Extended Phenotypes and Extended Organisms", pp. 327-352) y una respuesta de veinte páginas de Dawkins (“Extended Phenotype - But not too Extended. A Reply to Laland, Turner, and Jablonka”, pp. 377-396). 
Se pretendía que este libro fuera una especie de segunda parte de The Selfish Gene ${ }^{11}$. En estos libros, Dawkins no ofrece ninguna información biológica nueva. Ninguno de los libros presenta los resultados de una larga investigación, como hicieron, por ejemplo, Peter y Rosemary Grant en Evolutionary Dynamics of a Natural Population ${ }^{12}$. Más bien, Dawkins nos está pidiendo que veamos de una manera particular los procesos implicados en la evolución $-\mathrm{y}$, especialmente, en la producción de adaptación- Ni siquiera es un camino nuevo: como reconoce con franqueza, defiende un punto de vista vigorosamente expresado antes que él por un número de genetistas de poblaciones, tales como George G. Williams en Adaptation and Natural Selection ${ }^{13}$. En el primer capítulo, [Dawkins] responde a aquellos que leyeron The Selfish Gene como una defensa del determinismo genético (no lo es), y en el segundo capítulo trata las diversas limitaciones de la selección como mecanismo para la producción de adaptaciones.

Pero el objetivo general del libro está claro: quiere que pensemos en las adaptaciones como buenas para elementos a los que denomina "replicadores" (replicators) [los genes], en lugar de serlo para "los que interactúan" (interactors) [los organismos individuales]. La diferencia principal, aunque no la única, que tiene en mente es que las adaptaciones se tienen que considerar en cuanto al bien de los genes de un organismo, no a tenor del bien del organismo. En la medida que puede, Dawkins está interesado en llegar al límite de esta manera de pensar sobre la adaptación. El título del libro proviene del tema del capítulo 11, en el que trata de mostrar que incluso la selección adaptativa de las variaciones en los "artefactos" de los animales - como las presas de castor, los nidos de los pájaros o las telas de araña- son adaptaciones por el bien de los alelos de los genes que conllevan variaciones de conducta que, a su vez, conducen a variaciones en los artefactos.

\section{Los Experimentos Mentales Darwinianos y The Extended Phenotype}

Para comprender el sentido concreto del papel de los Experimentos Mentales Darwinianos en su argumento, comenzaré con una serie de ejemplos del capítulo 11 de The Extended Phenotype. Después haré la pregunta crucial: ¿por qué usar un experimento mental para este fin? Para tomar prestada una frase de David Hull, quizá sea este el momento de iniciar una "defensa de los ejemplos reales" en la Biología evolucionista ${ }^{14}$.

Se puede comenzar con la afirmación teórica clave que Dawkins quiere hacer: "Es habitual hablar como si las diferencias quisieran siempre decir diferencias entre los cuerpos individuales o entre otros 'vehículos' diferenciados. La finalidad de los tres capítulos siguientes es mostrar que podemos liberar el concepto de la diferencia fenotípica de aquel del vehículo diferenciado en general, y éste es el significado del título "fenotipo extendido"” ${ }^{15}$.

Como pueden observar, este es el movimiento clave en el "cambio de Gestalt" que quiere conseguir en sus lectores. Dawkins quiere que pensemos en los organismos como vehículos

11 Cfr. Dawkins, R., The Selfish Gene, Oxford University Press, Oxford, 1976.

12 Cfr. Grant, B. R. y Grant, P. R., Evolutionary Dynamics of a Natural Population, University of Chicago Press, Chicago, 1989.

13 Véase la nota 6 de este capítulo.

14 Cfr. Hull, D. L., Science and Selection: Essays on Biological Evolution and the Philosophy of Science, Cambridge University Press, Cambridge, 2001, pp. 151-165 y 196-221.

15 Dawkins, R., The Extended Phenotype, p. 196. 
“poseídos y conducidos" por sus genes (como ustedes piensan en su coche como un vehículo "que es suyo y que conducen" ustedes). En el capítulo 11, [Dawkins] investiga la "emancipación conceptual" de la diferencia fenotípica del vehículo diferenciado, poniendo el enfoque sobre los artefactos construidos por los organismos como diferencias fenotípicas sin relación con la diferenciación corporal. Realmente, el capítulo es una sucesión de Experimentos Mentales Darwinianos; un hecho que reconoce con franqueza cuando se acerca al final:

"Es poco afortunado que este capítulo haya tenido que ser bastante hipotético. Sólo ha habido unos pocos estudios sobre Genética de la conducta de construcción de cualquier animal, pero no hay ninguna razón para pensar que la 'Genética de los artefactos' será algo diferente, en principio, de la Genética de la conducta en general" ${ }^{16}$.

Volveré sobre este pasaje, como ejemplo de un investigador que usa el experimento mental con la esperanza de generar un área nueva de investigación científica.

La serie de experimentos mentales en el capítulo [11] tiene dos objetivos: en primer lugar, patentar un uso de la expresión "gen para X", donde el gen no tiene ningún vínculo bioquímico directo con $\mathrm{X}$; $\mathrm{y}$, en segundo término, legitimar la idea según la cual puede haber genes para [construir] presas de castor, telas de araña y termiteras, esto es, artefactos que no son aspectos de los cuerpos o de las conductas de los organismos que portan los genes. De hecho, en el caso de los termiteros, algunos de los genes decisivos no son ni siquiera genes de las termitas sino los genes de los animales simbióticos de las termitas que viven en sus tractos digestivos y que les ayudan en el proceso de la digestión que produce el material para esas termiteras.

Dawkins empieza con "una especie hipotética de friganea (caddis-fly) cuyas larvas construyen alojamientos fuera de las rocas que seleccionan entre aquellas disponibles sobre el fondo del arroyo" "17. Imagina que hay dos alojamientos de color diferente, y que hacemos experimentos y descubrimos que las friganeas crían larvas que seleccionan guijarros oscuros frente a guijarros claros en su actividad de construcción. Después de apuntar que el ejemplo es enteramente un producto de su imaginación, concluye:

"Pero mi posición es que, si se pudieran superar las dificultades prácticas, nadie se sorprendería si el color del alojamiento resultara ser un simple carácter mendeliano en concordancia con mi experimento mental" ${ }^{18}$.

Bien se podría preguntar, en ese caso, ¿cuál es la característica del experimento mental? Dawkins responde:

"Todo lo que este capítulo añade [con lo que cualquier etólogo estaría de acuerdo] es una cuestión lógica: una vez que hemos aceptado que hay genes para la conducta constructiva, las reglas de la terminología existente implican que el artefacto mismo debería tratarse como parte de la expresión fenotípica de los genes en el animal" ${ }^{19}$.

Antes de continuar con la ampliación que hace Dawkins de este ejemplo, permítanme dirigir su atención hacia un número de características de su argumento para este punto que muestran que es un ejemplo de un Experimento Mental Darwiniano. De un modo más general, el asunto

16 The Extended Phenotype, p. 207.

17 Dawnins, R., The Extended Phenotype, pp. 197-198.

18 The Extended Phenotype, p. 198.

19 Dawnins, R., The Extended Phenotype, p. 198. 
en juego — para Dawkins - es ampliar el enfoque de la evolución por selección natural que él apoya (donde el objetivo de la selección es el gen y el organismo es un simple "vehículo"), para romper el vínculo conceptual entre el fenotipo y el vehículo. Las propiedades fenotípicas no necesariamente son propiedades del vehículo, pero pueden estar no obstante bajo el control de causas genéticas. De manera que el asunto en juego es cómo entender la selección, incluso aunque el enfoque tienda a caer sobre el vínculo entre la expresión fenotípica y la variación genética. En segundo término, está haciendo uso de la técnica de la narración imaginaria, pero teniendo cuidado de contar una historia que sea lo suficientemente parecida a casos reales y que dependa suficientemente de los hechos reales, de modo que la narración y su resultado sean plausibles. Eso es lo que le autoriza a decir que "nadie estaría muy sorprendido" si las cosas resultaran ser de la manera como sugiere su narración imaginaria.

Esta es también la finalidad de usar [como ejemplo] un organismo real y hablar de una conducta real de sus larvas. [Dawkins] aspira a hacer plausible que piensen ustedes en la variación en el color de los guijarros como un rasgo fenotípico bajo control genético. Al parecer, cree que es preciso hacer eso, porque piensa que, en principio, nos resistiremos a esta idea. Finalmente, confía en que la narración les permitirá ver que hablar en este sentido está, de hecho, de acuerdo con — quizá incluso exigido por - las normas habituales para usar la distinción genotipo/fenotipo. Eso es, el marco retórico necesario está en su sitio — una audiencia escéptica que pregunta “¿cómo puede esto ser posible?”- para los Experimentos Mentales Darwinianos. En este caso, Dawkins nos imagina tan comprometidos con la idea según la cual los genes están conectados a sus expresiones fenotípicas por caminos bioquímicos y que esos caminos acaban al final del cuerpo del "vehículo", que necesita hacer algo para hacer parecer plausible el concepto de fenotipo extendido - y ese algo es el experimento mental-.

Tal vez el lector esté ideando en este momento experimentos mentales sobre cómo Richard Dawkins podría desarrollar su narración imaginaria para incluir las arañas y los castores — se puede hacer sin demasiada dificultad-. El enfoque es idéntico:

"Piénsese ahora en una araña que se sitúa en el centro de su tela. [...] En un sentido muy real su tela es una extensión funcional provisional de su cuerpo, una enorme extensión de la zona eficaz de captación de sus órganos predatorios. [...] Una vez más, no conozco ningún análisis genético de la morfología de la araña, pero no hay, en principio, ninguna dificultad en imaginar ese análisis. Se sabe que las arañas individuales tienen formas de comportamiento sistemático que se repiten tela tras tela. Por ejemplo, se vió a una Aygiella-x-notata hembra construir más de un centenar de telas, careciendo todas de un anillo concéntrico concreto $^{20}$. Nadie [...] se sorpendería si las formas de comportamiento observado de las arañas individuales resultaran tener una base genética" ${ }^{21}$.

Obsérvese, otra vez, el uso de un caso real de una variación aparentemente integrada para dar plausibilidad a su narración, y el leit-motiv de "no hay ninguna dificultad en imaginar eso", "ni nadie debería sorprenderse si" estos "fenotipos extendidos" resultaran estar basados genéticamente. Uno escucha de nuevo ecos claros del lenguaje de Darwin en contextos similares.

Con la presa del castor, Dawkins hace más explícita la relevancia de todo esto para la selección natural.

20 Cfr. Witt, P. N., Reed, C. F. y Peakall, D. B., A Spider Web, Springer, Berlín, 1968.

21 The Extended Phenotype, pp. 198-199. 
"En cuanto a la ventaja de la represa desde la perspectiva del castor, la mejor conjetura parece ser que incrementa la distancia que el castor puede desplazarse por el agua, lo cual es más seguro que desplazarse por tierra, y más fácil para transportar madera. [...] Al construir una presa que cruza el arroyo, el castor crea una amplia ribera que le facilita unos suministros fáciles y seguros, sin que el castor tenga que hacer largos y difíciles desplazamientos por tierra. Si esta interpretación es correcta, se puede considerar el lago como un enorme fenotipo extendido. [...] Como en el caso de la tela de araña, nadie ha realizado un estudio genético de las presas de castor, pero no lo necesitamos para convencernos de lo correcto de considerar la presa, y el lago [que ésta produce], como parte de la expresión fenotípica de los genes del castor. Es suficiente que aceptemos que los diques de castor han evolucionado por selección natural darwiniana: esto sólo puede haber sucedido si las presas han variado bajo el control de los genes (Capítulo 2)" 22 .

Vemos aquí la historia completa, sólo implícita en los dos experimentos mentales previos. La razón por la que la idea del fenotipo extendido es tan importante para Dawkins es porque esto nos libera de pensar que el organismo individual es central para la teoría de la selección natural. Hay una fuerte inclinación en todos nosotros - eso cree Dawkins - a pensar que las características fenotípicas deben pertenecer a los cuerpos de los vehículos y deben estar ligados a su base genética a través de un camino bioquímico. Pero puede mostrarse que una presa de castor es una característica fenotípica sólo con pensar detenidamente las implicaciones de su experimento mental $-\mathrm{y}$, además, esto es producto de la actividad de muchos castores relacionados a menudo durante muchas generaciones - ; y los genes que dirigen la conducta que conduce a su producción no están en absoluto relacionados con el lago por ningún camino bioquímico. Dawkins argumenta, sin embargo, que si existen esas obvias ventajas para los castores de crear lagos por medio de la construcción de diques, estamos autorizados a decir que evolucionaron por selección natural; y esa evolución sólo puede tener lugar si existió una variación genéticamente fundamentada en los diques que se construían. Pero esto es pintar un cuadro en el que el organismo individual es contingente respecto del vínculo entre el genotipo y el fenotipo; y esta es la imagen que Dawkins quiere que, finalmente, encontremos atractiva.

\section{Los CRíticos de los eXPerimentos mentales de DaWkins}

Ahora bien, quiero dejar claro que yo no encuentro atractiva esta imagen, ni mucho menos me resultan muy persuasivos los argumentos de Dawkins. Pero mi insatisfacción no se debe a que use el experimento mental, que me parece completamente apropiado para los fines teóricos que él busca aquí. Creo que hay objeciones lógicas a su afirmación según la cual el replicador es el objetivo de la selección, y que la evolución es un proceso cuyo centro es el replicador. Pero, en vez de poner el foco sobre estos desacuerdos, lo cual nos podría alejar del tema de los Experimentos Mentales Darwinianos, deseo considerar dos críticas a Dawkins que se centran en su uso del experimento mental. Las dos críticas proceden de The Structure of Evolutionary Theory, de Stephen Jay Gould ${ }^{23}$, y de Science and Selection de David Hull ${ }^{24}$.

22 Dawkins, R., The Extended Phenotype, p. 200.

23 Cfr. Gould, S. J., The Structure of Evolutionary Theory, Harvard University Press, Cambridge, MA, 2002.

24 Cfr. Hull, D. L., Science and Selection: Essays on Biological Evolution and the Philosophy of Science, Cambridge University Press, Cambridge, 2001. 


\subsection{Gould sobre Dawkins}

En el capítulo 8 de The Structure of Evolutionary Theory, Steven Jay Gould defiende una "teoría jerárquica de la selección" contra una variedad de puntos de vista alternativos, siendo uno de ellos el tipo concreto de Dawkins de la selección génica. [Steven Jay Gould] comienza esbozando la historia de la distinción entre el replicador [el gen] y el que interactúa [el organismo] desde G. C. Williams, pasando por David Hull hasta Richard Dawkins. Se siguen una serie de críticas conceptuales y lógicas; y, con algunas reservas, yo diría que Gould gana la partida. Sin embargo, también se encarga de la Metodología de Dawkins en The Extended Phenotype. Cita la introducción de Dawkins en la que dice que no está tratando de convencernos de la verdad de una nueva hipótesis o teoría sobre los hechos, sino que trata en cambio de convencernos para mirar los hechos de un modo diferente. De facto, hay pasajes donde Dawkins parece decir que ningún experimento u observación podría ayudar a decidir entre su perspectiva sobre la selección centrada en el gen y la concepción "ortodoxa”. En la concepción de Gould esto es simple convencionalismo, y un rechazo absoluto de la concepción que Dawkins defendía en The Selfish Gene ${ }^{25}$. Sin embargo, [Gould] no condena el convencionalismo de forma total, sino que en vez de eso argumenta que es inadecuado aquí:

"Pero el convencionalismo no se puede aplicar a este caso porque existe una solución empírica, y la aparente dualidad de cubo de Necker entre gen u organismo no indica, como argumenta erróneamente Dawkins, [que haya] dos perspectivas igualmente válidas sobre el mismo tema, sino que expresa más bien una visión 'correcta frente a una falsa' de la naturaleza de la causalidad en la teoría darwiniana" ${ }^{26}$.

"El convencionalismo de The Extended Phenotype invalida y desmiente la defensa explícita del seleccionismo del gen como realidad empírica, como la presentó en The Selfish Gene" ${ }^{27}$.

Con el debido respeto hacia Gould, creo que esto es injusto. Observemos con cuidado lo que Dawkins dice sobre su objetivo en The Extended Phenotype y sobre por qué el experimento mental será importante para alcanzar ese objetivo. Dawkins usa la analogía del cubo de Necker — de hecho, elige la imagen para la cubierta del libro-, pero lo que no nos dice Gould sobre el tema es el siguiente pasaje.

"La analogía del cubo de Necker expresa mi esperanza mínima para este libro. Tengo bastante confianza en que mirar la vida en términos de replicadores genéticos, que se preservan a sí mismos por medio de sus fenotipos extendidos, es como mínimo tan satisfactorio como mirarlos en términos de organismos egoístas que maximizan su adaptación global. [...] Pero dije que era una esperanza mínima. Trataré fenómenos, por ejemplo la 'deriva meiótica' (meiotic drive), cuya explicación se inscribe lúcidamente en la segunda cara del cubo, pero que no tiene sentido en absoluto si mantenemos nuestra mirada mental fijada con firmeza en la otra cara, la [faz] del organismo egoísta. Pasar desde mi esperanza mínima a mi fantasía más delirante está en que áreas completas de la Biología —el estudio de la comunicación animal, los artefactos animales, el parasitismo y la simbiosis, la ecología de las comunidades, de hecho todas las interacciones entre los organismos y dentro de ellos - sean finalmente iluminadas de una manera nueva por la doctrina del fenotipo extendido" 28 .

25 Gould, S. J., The Structure of Evolutionary Theory, p. 640.

26 The Structure of Evolutionary Theory, p. 640.

27 Gould, S. J., The Structure of Evolutionary Theory, p. 641.

28 Dawnins, R., The Extended Phenotype, p. 7. 
Y ahora es el momento de recordarles un pasaje del capítulo 11 de The Extended Phenotype que cité antes, donde Dawkins habla de la posibilidad de un campo denominado "Genética de los artefactos", de modo que él no necesitara recurrir a los experimentos mentales para defender su posición. Aquí va mucho más allá, al soñar con una especie de revolución en una variedad de terrenos iniciada por la "visión" del fenotipo extendido. De hecho, aunque Dawkins pone reparos a su mayor parte, los ensayos críticos de Jablonka, Laland y Turner en Biology and Philosophy mencionados antes tratan ampliaciones más recientes sobre la evolución, el desarrollo y la ecología como posibles aplicaciones de la concepción de Dawkins.

Ahora bien, es fácil leer todo este lenguaje de "iluminación” y "cubo de Necker" en el mejor de los casos como "metedura de pata" (fluff), y en el peor como convencionalismo y relativismo. Pero la cita de arriba muestra que, en este caso, esto no es verdad. Tómese el todavía hipotético terreno de la "Genética de los artefactos" como un ejemplo verdaderamente simple de cómo esto impactaría en las Ciencias Biológicas. En la concepción de Dawkins, la investigación científica de esta clase no existe porque la gente tiene problemas para imaginarse los artefactos animales como herramientas construidas por los replicadores para favorecer su perpetuación. Y hasta que se pueda pensar de esa manera, ninguna investigación así tendrá lugar.

En eso es precisamente en lo que yo quiero centrar su atención. Un papel extremadamente importante del experimento mental en la Ciencia es que permite a los investigadores ver las cosas de una manera no ortodoxa y desconocida, y, por tanto, concebir la investigación y los experimentos que, de otro modo, no se considerarían. Al lector del capítulo 11 de The Extended Phenotype se le presenta tanto un argumento de la plausibilidad de ver cosas tales como las presas de castor y las telas de araña como características genéticas; como también se le proporciona abundancia de ideas sobre la investigación científica que podría realizarse al transformar esta conjetura plausible en una teoría confirmada. Nada de las observaciones de Gould les prepararía a ustedes para eso.

\subsection{Hull sobre los experimentos mentales en Biología}

Otra objeción posible al uso del experimento mental en Biología puede encontrarse en una serie de artículos de David Hull, dos de los cuales están convenientemente incluidos en la recopilación publicada como Science and Selection: Essays on Biological Evolution and the Philosophy of Science ${ }^{29}$. El argumento tiene dos partes. La primera es el impacto negativo del método del experimento mental en Filosofía. No es difícil presentar montones de ejemplos de eso (XYZ en la Tierra gemela, cerebros en cubetas, verdules y azerdes, etcétera). Resulta interesante que Hull tiende a pensar en los experimentos mentales exclusivamente en términos de contraejemplos imaginarios, del tipo de los que usa Fleeming Jenkin contra Darwin ${ }^{30}$, donde mostraba que, bajo determinadas condiciones plausibles, se podría admitir la selección natural de Darwin y que nunca se produciría una nueva especie. Curiosamente, al contrario de lo que Hull les llevaría a pensar, estos experimentos mentales fueron extremadamente

29 Cfr. Hull, D. L., Science and Selection: Essays on Biological Evolution and the Philosophy of Science, Cambridge University Press, Cambridge, 2001.

30 Cfr. Lennox, J. G., "Darwinian Thought Experiments: A Function for Just-so Stories”, pp. 230-236. 
valiosos: Darwin reconoció la influencia del estudio de Jenkin en numerosas ocasiones ${ }^{31}$, y reescribió sistemáticamente Origin en respuesta a estos experimentos mentales. Pero lo que yo he llamado Experimentos Mentales Darwinianos no son contraejemplos imaginarios. Su papel es positivo: se pretende que ayuden al lector a ver que es plausible que un determinado fenómeno, que quizá se piensa que está por encima del ámbito de la selección natural, es el producto de un proceso de selección.

Hull encuentra esto bastante innecesario en Biología. En cuanto a los debates sobre cómo definir las especies, considera dos casos hipotéticos que cuestionan una u otra definición.

"Al final, ninguno de esos experimentos mentales es necesario, porque la Naturaleza proporciona numerosos ejemplos de ambas situaciones y de muchas más además. En ausencia de esos ejemplos, los biólogos podrían verse forzados a inventarlos, y estoy dispuesto a apostar que incluso la más fértil de las imaginaciones no habría podido plantear las singulares situaciones que ocurren realmente en la Naturaleza" ${ }_{32}$.

Veo dos problemas aquí. En primer lugar, se sobreentiende un papel altamente delimitado para los experimentos mentales, esto es, plantear contraejemplos extremos y extraños. Hull no parece imaginar que un ejemplo modesto - pero altamente plausible, lleno de información sobre el mundo real, tales como aquellos que encontramos tanto en Darwin como en el capítulo 11 de The Extended Phenotype - podría, sin embargo, ser un experimento mental. En segundo término, Hull piensa, aparentemente, que si los ejemplos de la vida real son posibles o concebibles, entonces no deberíamos tener ninguna necesidad de experimentos mentales. Pero como he resaltado - y como se ve en el trabajo de Dawkins- , una función de un Experimento Mental Darwiniano es animar a los investigadores a pensar en nuevas direcciones, lo cual puede, de hecho, generar nueva información.

Y el resultado no está preordenado. Dawkins da por supuesto que, si nos ponemos con la Genética de artefactos, vamos a descubrir los genes de las presas de castor. Después de todo, ¿no son esas presas ventajosas para los castores?, ¿no son adaptaciones?, ¿no son productos de la selección? Bien, supongamos que la respuesta a todas estas cuestiones es "sí". En contra del supuesto más básico de Dawkins, esto no prueba que haya un gen, o un juego de genes, para las presas de castor. Pero eso no es criticar su uso de experimentos mentales; eso es criticar su presupuesto básico según el cual la evolución por selección natural opera siempre sobre los replicadores.

\section{Conclusión}

Quiero terminar señalando que hay muchos otros lugares donde encontrar Experimentos Mentales Darwinianos dentro de la Biología evolucionista contemporánea. Hay una creciente área de investigación sobre lo que se denomina "vida artificial", que se realiza casi por entero por medio de simulaciones de ordenador que se basan en supuestos plausibles programados. Yo los llamaría "experimentos mentales", y los llamaría darwinianos si los supuestos que se contrastan incluyeran la capacidad de la selección natural para generar cierta clase de resultado.

31 Cfr. Jenkin, F., "The Origin of Species", North British Review, v. 46, (1867), pp. 277-318; reimpreso en Hull, D. L., Darwin and His Critics: The Reception of Darwin's Theory of Evolution by the Scientific Community, Harvard University Press, Cambridge, MA, 1973, pp. 302-350.

32 Hull, D., Science and Selection, p. 155. 
En ese caso, existe el ámbito de la "optimalidad" (optimality). Miren la siguiente sugerencia de Peter Abrams sobre cómo entender este concepto en la Biología evolucionista:

"Los modelos de optimalidad, o una variante dinámica de esos modelos, representan la única manera razonable de determinar qué características serían adaptativas bajo circunstancias hipotéticas, cuando no es suficiente el razonamiento verbal" ${ }^{33}$.

Eso - a mi juicio - es proclamar que los modelos de optimalidad funcionan como Experimentos Mentales Darwinianos. ¡Y que no son menos útiles por ello!

\section{Bibliografía}

Abrams, P., "Adaptationism, Optimality Models, and Tests of Adaptive Scenarios", en Orzack, S. H. y Sober, E. (eds), Adaptation and Optimality, Cambridge University Press, Cambridge, 2001, pp. 273-302.

Curio, E., “Towards a Methodology of Teleonomy”, Experientia, v. 29, (1973), pp. 1045-1058.

Darwin, Ch., On the Origin of Species: A Facsimile Edition, Harvard University Press, Cambridge, MA, 1962.

Dawkins, R., The Selfish Gene, Oxford University Press, Oxford, 1976.

Dawkins, R., The Extended Phenotype, Oxford University Press, Oxford, 1982.

Dawkins, R., "Extended Phenotype - But not too Extended. A Reply to Laland, Turner and Jablonka", Biology and Philosophy, v. 19, n. 3, (2004), pp. 377-396.

Eddington, A., The Nature of the Physical World, Cambridge University Press, Cambridge, 1928.

Fisher, R. A., The Genetical Theory of Natural Selection: A Complete Variorum Edition, Oxford University Press, Oxford, 1999.

Gould, S. J., The Structure of Evolutionary Theory, Harvard University Press, Cambridge, MA, 2002.

Grant, B. R. y Grant, P. R., Evolutionary Dynamics of a Natural Population, University of Chicago Press, Chicago, 1989.

Horowitz, T. y Massey, G. (eds), Thought Experiments in Science and Philosophy, Rowman and Littlefield, Savage, MD, 1991.

Hull, D. L., Darwin and His Critics: The Reception of Darwin's Theory of Evolution by the Scientific Community, Harvard University Press, Cambridge, MA, 1973.

Hull, D. L., Science and Selection: Essays on Biological Evolution and the Philosophy of Science, Cambridge University Press, Cambridge, 2001.

JABLONKA, E., "From Replicators to Heritably Varying Phenotypic Traits: The Extended Phenotype Revisited", Biology and Philosophy, v. 19, n. 3, (2004), pp. 353-375.

Jenkin, F., “The Origin of Species”, North British Review, v. 46, (1867), pp. 277-318; reimpreso en Hull, D. L., Darwin and His Critics: The Reception of Darwin's Theory of Evolution by the Scientific Community, Harvard University Press, Cambridge, MA, 1973, pp. 302-350.

Laland, K., "Extending the Extended Phenotype", Biology and Philosophy, v. 19, n. 3, (2004), pp. 313-325.

33 Abrams, P. "Adaptationism, Optimality Models, and Tests of Adaptive Scenarios", en Orzack, S. H. y Sober, E. (eds), Adaptation and Optimality, Cambridge University Press, Cambridge, 2001, p. 293. 
Lennox, J. G., "Darwinian Thought Experiments: A Function for Just-so Stories", en Horowitz, T. y Massey, G. (eds), Thought Experiments in Science and Philosophy, Rowman and Littlefield, Savage, MD, 1991, pp. 223-246.

Lennox, J. G., "La evolución de los experimentos mentales darwinianos", en GonZaLez, W. J. (ed), Evolucionismo: Darwin y enfoques actuales, Netbiblo, A Coruña, 2009, pp. 63-77.

Orzack, S. H. y Sober, E. (eds), Adaptation and Optimality, Cambridge University Press, Cambridge, 2001.

Turner, J. S., "Extended Phenotypes and Extended Organisms", Biology and Philosophy, v. 19, n. 3, (2004), pp. 327-352.

Williams, G. C., Adaptation and Natural Selection: A Critique of some Current Evolutionary Thought, Princeton University Press, Princeton, 1966.

Witt, P. N., Reed, C. F. y Peakall, D. B., A Spider Web, Springer, Berlín, 1968. 



\title{
El CONCEPTO DE "ESPECIE" EN LA BiOLOGÍA EVOLUCIONISTA: Polémicas actuales
}

\author{
Alfredo Marcos
}

\section{INTRODUCCIÓN}

La Filosofía de la Ciencia actual reconoce que muchos de los conceptos científicos están cargados teóricamente, es decir, que su significado depende en cierta medida de la teoría en la que se hallan insertos y que puede cambiar cuando se produce un cambio teórico. Esto ha podido suceder con el concepto de "especie" en Biología. El cambio teórico más profundo que se ha dado en Biología fue el paso de una perspectiva fijista a una evolucionista. No es raro que con semejante mutación el concepto de especie también haya sufrido cambios (apartado 2).

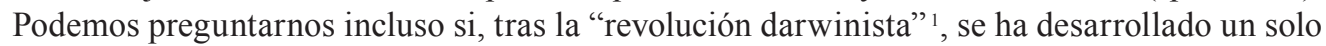
concepto de especie o bien son varios los que se disputan el terreno. La cuestión de la especie tiene repercusiones inmediatas en todas las ramas de la Biología, y cada rama de la Biología parece exigir un cierto concepto de especie (apartado 3).

Fuera del estricto campo de las Ciencias Biológicas, los cambios en la noción de especie inciden también sobre la Filosofía de la Biología. Los debates sobre el realismo científico, sobre la naturaleza de las leyes y teorías, así como sobre la cientificidad de la Biología, pueden resultar afectados por la discusión acerca del estatuto ontológico de las especies (apartado 4) ${ }^{2}$.

Tras este recorrido haremos un breve balance (apartado 5) para poder afrontar a continuación las repercusiones del debate más lejos todavía, en el territorio ya de la Ética, donde algunas cuestiones importantes dependen de la noción de especie que se ha ido fraguando dentro del marco evolucionista. Dedicaremos especial atención, en el apartado 6, a los problemas éticos conectados con la conservación de la biodiversidad y al llamado dilema del anti-especista. Este último afecta tanto a la Ética ambiental como a la cuestión de la dignidad humana.

\section{EL CONCEPTO DE "ESPECIE" Y LA REVOLUCIÓN DARWINISTA}

El relato histórico del concepto de "especie" suele comenzar por Platón. Una "especie" (eidos) sería para él un tipo, una Idea, cuya existencia es inmutable y eterna. En el mundo

\footnotetext{
1 Esta expresión se ha hecho ya común, cfr. Ruse, M., The Darwinian Revolution: Science Red in Tooth and Claw, The University of Chicago Press, Chicago, 1979. Vers. cast. de C. Castrodeza: La revolución darwinista, Alianza, Madrid, 1983, Empleo esta expresión sin el convencimiento de que se haya producido realmente una revolución darwinista.

Como aduce Bowler, el evolucionismo triunfó rápidamente, de un modo que podríamos considerar revolucionario, cfr. Bowler, P., The Non-Darwinian Revolution: Reinterpreting a Historical Myth, Johns Hopkins University Press, Baltimore, 1988). Pero el seleccionismo, que es el componente más netamente darwinista, no se impuso hasta mucho tiempo después de la publicación del Origen de las especies (1859), y siempre ha sido un punto muy controvertido, aún lo es en nuestros días.

2 Cfr. Marcos, A., "Sobre el concepto de especie en Biología”, en ABEl, F. y CAÑón, C. (eds), La mediación de la Filosofía en la construcción de la Bioética, Universidad Pontificia de Comillas, Madrid, 1993, pp. 41-60.
} 
sensible nos encontramos con copias más o menos degradadas de la Idea. Este concepto de especie no está pensado solamente para seres vivos, sino que puede ser aplicado a toda la realidad. Es más, no resulta particularmente adecuado para los vivientes, precisamente por su carácter estático.

Fue Aristóteles quien, con ojo e intereses de biólogo, criticó la noción platónica de especie. En el libro I de su tratado Sobre las partes de los animales critica duramente el sistema clasificatorio mediante división dicotómica seguido por los discípulos de Platón. Este procedimiento le parece excesivamente orientado hacia el logos, hacia la satisfacción de la razón humana, y poco respetuoso con la realidad de las cosas, muchas veces no tan ordenada como nuestro gusto podría desear. Junto al punto de vista del logos, Aristóteles potenció el de la physis. Renunció al estatismo del mundo platónico de las Ideas, y abandonó en gran medida la intención clasificatoria ${ }^{3}$, pero pretendió aun así hallar elementos de orden y racionalidad en el mundo dinámico y cambiante de lo vivo.

Esta tensión está presente a lo largo de toda la obra de Aristóteles. En palabras de Jean Gayon: "El corpus aristotélico deja aparecer una tensión entre dos conceptos de eidos. Uno de estos conceptos es de naturaleza lógica y clasificatoria; utilizado en conexión con el de género (genos), se aplica directamente a todos los dominios de la realidad, y constituye un útil de jerarquización de los universales. Este concepto de eidos como clase lógica vale sin restricción particular para todos los seres vivos. En los tratados biológicos interviene, no obstante, un segundo concepto de eidos, el de eidos-forma: desde este punto de vista, el eidos es el alma del organismo individual, es decir, un principio organizador transmisible por generación [...] En la mayoría de los contextos Aristóteles evita utilizar eidos en el sentido de clase subordinada a un género y se sirve más a menudo de una palabra para connotar la forma (morphé), o la configuración (schema)" ${ }^{4}$.

Lo importante el pensamiento aristotélico en este punto es que deja ya planteado el difícil problema de las relaciones entre la especie como clase lógica y la especie como principio físico que interviene en la generación. Sin embargo, esta riqueza matizada de la biofilosofía aristotélica es muchas veces olvidada, de modo que "Aristóteles — según señala James Lennox - es a menudo caracterizado, tanto por filósofos como por biólogos evolucionistas, como la fuente de una teoría tipológica de las especies que es absolutamente inconsistente con el pensamiento evolucionista" 5 . Sin embargo, continúa Lennox, "Aristóteles trata las variaciones entre una forma [eidos] de una clase [genos] y otra como diferencias de grado. Este movimiento entra en conflicto con la suerte de Pensamiento tipológico tradicionalmente atribuido a Aristóteles por biólogos y filósofos [...] Debería quedar claro que el esencialismo de Aristóteles no es tipológico, y tampoco es en ningún sentido obvio 'anti-evolucionista'. Sea cual fuere el conflicto de Darwin, no lo era con el esencialismo aristotélico".

La última afirmación de Lennox es valiosa en este contexto. El relato estereotípico de la Historia hace emerger el concepto evolucionista de especie por contraste con un supuesto concepto

3 Cfr. Pellegrin, P., La classification des animaux chez Aristote, Les Belles Lettres, París, 1982.

4 Gayon, J., “L’Espèce sans la forme”, en Gayon, J. y Wunenburger, J-J. (eds), Les figures de la forme, L'Harmattan, París, 1992, pp. 51-52.

5 Lennox, J., "Kinds, Forms of Kinds, and the More and Less in Aristotle's Biology", en Gotthelf, A. y Lennox, J. (eds), Philosophical Issues in Aristotle's Biology, Cambridge University Press, Cambridge, 1987. p. 339.

6 Lennox, J., "Kinds, Forms of Kinds, and the More and Less in Aristotle's Biology", en Gotthelf, A. y Lennox, J. (eds), Philosophical Issues in Aristotle's Biology, pp. 340-341. 
tipológico de Aristóteles. Esta simplificación injusta, no sólo desaprovecha las sugerencias que pueda aportar aun hoy el Pensamiento de Aristóteles, sino que dificulta la apreciación del propio concepto evolucionista de especie. Para discutir el concepto evolucionista de especie tenemos que saber previamente con qué otro u otros conceptos de especie entra directamente en conflicto. Parece evidente, según apunta Jean Gayon, que "es en el Pensamiento naturalista del siglo XVIII donde debemos buscar el uso moderno del término especie en las Ciencias de la Vida"7.

Sin embargo, la confusión que venimos detectando respecto a Aristóteles conduce a afirmaciones como la que sigue: "El concepto tipológico (a veces llamado concepto esencialista) de especie - escribe Ernst Mayr — que se remonta a las Filosofías de Platón y Aristóteles, fue el concepto de especie de Linneo y sus seguidores" ${ }^{8}$. No es así, el concepto de especie con el que se enfrentó Darwin es el de Linneo y los naturalistas de los siglos XVIII y primera mitad del XIX, pero no el de Aristóteles. Entre otras cosas, porque el concepto de especie del XVIII está ya pensado contra un transfondo "evolucionista", cosa que no ocurre con el de Aristóteles. Entre Aristóteles y Linneo el concepto de especie ha pasado por diversas vicisitudes. No podemos olvidar la polémica medieval sobre los universales y las posiciones extremas de realistas y nominalistas ${ }^{9}$. Tampoco podemos pasar por alto la caótica prodigalidad con que los renacentistas repartían las transformaciones acá y allá a lo largo y ancho de la Naturaleza.

No es extraño, pues, que los naturalistas anteriores a Darwin pensasen que sólo se podría establecer una Biología científica, racional y realista sobre la base de una constancia del tipo de organismos a través de la reproducción, o lo que es lo mismo, sobre la base de la estabilidad de las especies. Sólo así la Biología podría llegar a construir clasificaciones y leyes auténticamente científicas, como ya existían en las Ciencias Físicas.

La insistencia con que aparece el elemento fijista en las definiciones de especie desde John Ray, si algo muestra es que éstas se han formulado con la intención de impedir tentaciones transformacionista que devolviesen la Biología a un estado precientífico. La posición de Darwin sobre el concepto de especie es comprometida, ya que tiene que negar el fijismo, pero sin abandonar el propio concepto de especie que precisamente en sus tiempos había sido definido en términos fijistas, y sin romper con el estatuto de cientificidad de la Biología que parecía depender de esa definición. Veamos algunas de esas definiciones inmediatamente pre-darwinistas para poder apreciar mejor la cuestión.

John Ray (1627-1705) ofrece una primera definición clara de especie biológica como un grupo constante de organismos genealógicamente relacionados ${ }^{10}$. Ray comienza a construir la especie desde abajo, desde los individuos que guardan entre sí similaridad, y no desde arriba, desde la Idea. Este movimiento es clave para transformar un concepto meramente lógico de especie en uno propiamente biológico. Sin embargo, el elemento fijista está

\footnotetext{
7 Gayon, J., "L'Espèce sans la forme”, en Gayon, J. y Wunenburger, J-J. (eds), Les figures de la forme, p. 51.

8 Mayr, E., "Species Concepts and Their Application", en Ereshesfsky, M. (ed), The Units of Evolution. Essays on the Nature of Species, The MIT Press, Cambridge, MA, 1992, p. 16. El influyente texto de Mayr fue publicado por primera vez en 1963, desde entonces el autor ha modificado sus posiciones, cfr. MAYr, E., Towards a New Philosophy of Biology, Harvard University Press, Cambridge, MA, 1988. Pero el texto se ha seguido publicando sin cambios en este punto.

9 Cfr. Stamos, D., The Species Concept: Biological Species, Ontology, and the Metaphysics of Biology, Lexington, Lanham, MD, 2003, pp. 1-9 y cap. 2.

10 Cfr. Jahn, I., Lother, R., y Senglaub, H. (eds), Geschichte der Biologie, Gustav Fischer Verlag, Jena, 1985. Vers. cast. de J. L. Gil Aristu: Historia de la Biología. Labor, Barcelona, 1989, p. 179.
} 
explícitamente contemplado en su definición. En Buffon (1707-1788) encontramos también una definición fijistas: "Debemos considerar dos animales como pertenecientes a la misma especie sí, mediante cópula, pueden perpetuarse a sí mismos y preservar el parecido de la especie; y debemos considerarlos como pertenecientes a distintas especies si son incapaces de producir progenie por el mismo medio" $"$.

Linneo (1707-1778) aspiró en principio a establecer una clasificación natural, aunque en el curso de sus investigaciones se percató de la dificultad de semejante empresa y de la necesidad de conformarse con una clasificación útil, clara y operativa. Aún así, siempre creyó que las especies y los géneros estaban presentes en la Naturaleza, si bien las categorías superiores surgían únicamente de la mirada humana y de nuestra necesidad de simplificar la compleja realidad natural. Entendió que las especies eran unidades separadas, pero también en este punto el curso de las investigaciones le llevó a matizar sus posturas, hasta aceptar que varias especies de un mismo género podrían tener un origen común, pero, eso sí, semejante origen común no podría darse entre dos géneros. Con todo, al menos en el nivel de los géneros el fijismo estaba garantizado según Linneo ${ }^{12}$.

Charles Bonnet (1720-1793) sentencia: "No hay cambios ni alteraciones, sino una identidad plena. Se mantienen las especies triunfando sobre las fuerzas de la naturaleza" ${ }^{13}$. Para Cuvier (1769-1832), "una especie comprende todos los individuos que descienden unos de otros, o de ancestros comunes, y todos aquellos que se parecen a éstos tanto como éstos entre sí” ${ }^{14}$. Cuvier defiende explícitamente el fijismo, frente a Lamarck, y su concepto de especie es obviamente incompatible con la idea darwinista de un origen común de todos los vivientes. Según Marc Ereshefsky, "Linneo, John Ray, Maupertuis, Bonnet, Lamark y Lyell, todos ellos adoptaron una perspectiva esencialista (o tipológica) respecto de la sistemática" ${ }^{15}$.

Cabe citar, por último, a Charles Lyell, una de las personas que más ascendiente e influencia tuvo sobre el propio Darwin: "El nombre de especie, observa Lamarck, ha sido habitualmente aplicado a 'toda colección de individuos similares producidos por otros individuos como ellos' [...] Pero esto no es todo lo que normalmente implica el término especie; pues la mayoría de los naturalistas coinciden con Linneo en suponer que todos los individuos procedentes de un mismo origen [propagated from one stock] tienen ciertos caracteres distintivos en común, que no variarán nunca, y que han permanecido iguales desde la creación de cada especie" ${ }^{16}$. Como afirma James Lennox, "Lyell asume prácticamente que aceptar la evolución es tanto como negar la realidad de las especies [...] Para aceptar el cambio evolutivo, según él, uno debe acabar acomodándose a alguna variedad de nominalismo respecto a las especies" ${ }^{17}$.

Podríamos preguntarnos por la razón de tanta insistencia en la noción tipológica de especie, en el fijismo y en el esencialismo. La respuesta no puede ser otra: porque ya estaba en el ambiente el

\footnotetext{
11 Texto citado en Beatty, J., "Speaking of Species: Darwin's strategy", en Ereshesfsky, M. (ed), The Units of Evolution. Essays on the Nature of Species, p. 229. Sabemos, no obstante, que la posición de Buffon sobre la estabilidad de las especies fue cambiante a lo largo de su actividad como naturalista.

12 Cfr. Jahn, I., Lother, R., y Senglaub, H. (eds), Historia de la Biología, pp. 239-255.

13 Texto citado en Jahn, I., Lother, R. y Senglaub, H. (eds), Historia de la Biología, p. 219.

14 Cuvier, G., Essay on the Theory of the Earth, Blackwood, Edimburgo, 1813, p. 120.

15 Ereshesfisk, M. (ed), The Units of Evolution. Essays on the Nature of Species, p. 187.

16 Lyell, Ch., Principles of Geology, John Murray, Londres, 1835, 4ª ed., vol. 2, p. 407.

17 Lennox, J., "Darwinism", en Zalta, E. N. (ed), The Stanford Encyclopedia of Philosophy, http://plato.stanford. edu/archives/fall2004/entries/darwinism (edición de primavera 2004).
} 
debate sobre la posible transformación de las especies y esto amenazaba, según muchos naturalistas de la época, a la cientificidad de la Biología, a la posibilidad de establecer leyes y de explicar las desviaciones como perturbaciones (tal como lo hace la Física desde Galileo) ${ }^{18}$.

Ahora podemos apreciar con justicia cuál es el conflicto de Darwin respecto a la noción de especie y cuál es la posición que adopta. Darwin no puede aceptar la definición de especie vigente en sus días, pero necesita contar con las especies para que su teoría no se vea expuesta a objeciones anti-evolucionistas como la formulada por William Hopkins en 1860: "Cada especie natural, por definición, debe haber tenido un origen separado e independiente, de modo que todas aquellas teorías — como las de Lamarck y Mr. Darwin_ que afirman la derivación de todas las clases de animales desde un origen común, de hecho, lo que hacen es negar absolutamente la existencia de especies naturales" ${ }^{19}$. O más sucintamente: "Si las especies no existen en absoluto - se pregunta Louis Agassiz-, como mantienen los partidarios de la teoría de la transmutación, ¿cómo pueden variar?" ${ }^{20}$.

En definitiva, Darwin tenía que comunicar sus nuevas ideas a la comunidad de naturalistas en la que él se sentía ubicado, para ello tenía que utilizar el lenguaje común entre los miembros de esa comunidad, en particular por lo que al término "especie" se refiere. Y, sin embargo, lo que tenía que decirles negaba las características definitorias de la propia categoría de especie ¿Cuál fue la estrategia de Darwin ante este problema? La estrategia consistió en aceptar la referencia común del término "especie" sin asumir la definición del mismo. Lo que Darwin tenía que decir a sus colegas naturalistas era que lo que ellos llamaban especies, y que creían grupos estables e independientes, en realidad han evolucionado desde un origen común. "Tenemos que discutir en esta obra - propone Darwin - si las formas llamadas por todos los naturalistas especies distintas no son descendientes lineales de otras formas" ${ }^{21}$.

No pone en duda la identificación de los taxones pertenecientes a la categoría de especie según la establecían los naturalistas coetáneos, lo que niega es la naturaleza inmutable e independiente que les atribuían. En El Origen podemos leer: "Al determinar si una forma debe ser clasificada como especie o como variedad, la opinión de los naturalistas de buen juicio y larga experiencia parece la única guía que seguir" ${ }^{22}$. Actuando de este modo se asegura que está hablando de los mismos segmentos genealógicos que sus colegas identifican como especies. Se asegura, además de que puede comunicar su nueva tesis, a saber, que dichos segmentos genealógicos evolucionan a lo largo del tiempo y tienen un origen común.

No obstante, si Darwin discrepa de la definición entonces vigente de la categoría de especie, nosotros podemos preguntarnos qué definición ofrece a cambio. La respuesta será esta: "Tampoco discutiré aquí las varias definiciones que se han dado del término 'especie'.

\footnotetext{
18 Poco tiene esto que ver, por cierto, con las motivaciones de Aristóteles, para quien la especie ni siquiera fue una categoría taxonómica fija, anclada en un sistema jerarquizado, sino un mero correlato del género.

19 Texto citado en Beatty, J., "Speaking of Species: Darwin's Strategy”, p. 232.

20 Texto en Beatty, J., “Speaking of Species: Darwin's Strategy”, p. 232.

21 Darwin, Сн. R., Charles Darwin's Natural Selection: Being the Second Part of this Big Species Book Written From 1856 To 1858, edición de Robert C. Stauffer, Cambridge University Press, Cambridge, 1975, p. 97.

22 Darwin, CH. R., On the Origin of Species by Means of Natural Selection, John Murray, Londres, 1859. Vers. cast. de J. Fuster: El origen de las especies, Petronio, Barcelona, 1974, vol. I, p. 83. En consecuencia, “en las siguientes páginas - advierte Darwin — entenderé por especie aquellas agrupaciones de individuos que han sido comúnmente designadas como tales por los naturalistas", Darwin, CH. R., Charles Darwin's Natural Selection; Being the Second Part of this Big Species Book Written From 1856 to 1858, p. 98.
} 
Ninguna definición ha satisfecho a todos los naturalistas; sin embargo, todo naturalista sabe vagamente lo que quiere decir cuando habla de una especie" ${ }^{23}$. Respecto de la empresa de encontrar una definición adecuada de la categoría de especie, se pronuncia en estos términos: "Los naturalistas han encontrado en ello una dificultad sin esperanzas, si juzgamos por el hecho de que apenas dos de ellos han dado la misma" ${ }^{24}$. Esta dificultad procede, según creía Darwin de "tratar de definir lo indefinible" ${ }^{25}$, de perseguir "la esencia indescubierta e indescubrible del término especie" 26 .

Reparemos aquí en la necesaria distinción entre los taxones que llamamos especies, como por ejemplo Homo sapiens o Panthera Leo, y la propia categoría taxonómica de especie, que limita con la de variedad por un lado y con la de género por otro. Pues bien, Darwin acepta los taxones tal y como los establezcan los naturalistas, y renuncia a definir la categoría de especie. El problema reside, para él, en trazar una distinción clara entre lo que debe ser considerado variedad, especie o género. Entendemos por qué el límite entre las tres categorías se hace tan borroso para Darwin en el momento en que adoptamos como él una perspectiva evolutiva. Entre especies y variedades, así como entre especies y géneros, hay un continuo, no hay ya límites abruptos, las variedades son especies haciéndose y los géneros son especies ya escindidas reproductivamente.

Respecto de las aves observadas en las islas Galápagos, Darwin recuerda que quedó muy sorprendido "de lo completamente arbitraria y vaga que es la distinción entre especies y variedades [...] Pero discutir si deben llamarse especies o variedades, antes de que haya sido generalmente aceptada cualquier definición de estos términos, es dar inútilmente palos de ciego" 27 . Y, del otro lado, "tendremos que tratar a las especies del mismo modo que los naturalistas tratan a los géneros, quienes admiten que los géneros son meras combinaciones artificiales establecidas por pura conveniencia" 28 .

¿Pero puede funcionar la Biología sin definir nada menos que el concepto de "especie"? ¿Es imposible elaborar una noción realista de especie desde una perspectiva evolucionista? Como afirma Popper, el conocimiento científico se desarrolla de pregunta en pregunta. Esta claro que Darwin legó estas nuevas cuestiones como tarea a sus sucesores. Del mismo modo que él se encontró con definiciones de especie dependientes de teorías fijistas, definiciones destruidas por el cambio teórico propuesto por el propio Darwin, los darwinistas posteriores tendrán la tarea de elaborar nuevas definiciones de especie adaptadas a la perspectiva evolucionista. Eso es lo que ha sucedido. Pero el resultado no ha sido una definición de especie, sino muchas. Veámoslo.

\section{Los diversos CRITERIOS DE ESPECIE EN LA BIOLOGía EVOLUCIONISTA}

La noción de "especie" está en el mismo corazón de la llamada revolución darwinista, junto con las nociones de "evolución" y de "selección". Darwin hizo gran parte del trabajo al argumentar largamente sobre la evolución y la selección. Sin embargo, sus sucesores no abordaron

23 Darwin, CH. R., El origen de las especies, vol. I, pp. 76-77.

24 Darwin, CH. R., Charles Darwin's Natural Selection; Being the Second Part of this Big Species Book Written From 1856 to 1858 , p. 95.

25 Texto citado en Beatty, J., "Speaking of Species: Darwin's Strategy", p. 237.

26 Darwin, Ch. R., El origen de las especies, vol. II, p. 772.

27 El origen de las especies, vol. I, p. 85-87.

28 DaRwin, Ch. R., El origen de las especies, vol. II, p. 772. 
la parte del trabajo correspondiente al concepto de especie hasta casi un siglo después de la publicación del Origen de las especies. Y cuando la labor fue abordada, resultaron diversos conceptos y un proceloso debate. David Stamos adelanta la explicación de los dos hechos ${ }^{29}$. En primer lugar, la reflexión sobre el concepto de especie se retrasó porque tuvo que esperar al establecimiento de la Teoría sintética de la Evolución, cosa que no ocurre hasta mediado el siglo veinte. En segundo término, la maduración de la Biología como Ciencia ha producido la inevitable especialización, de modo que en realidad cada disciplina ha construido su propio concepto de especie según su perspectiva y necesidades.

En conjunto, sin embargo, podremos ver cómo se mantiene la tensión entre el componente morfológico, que se fija en el parecido, y el genealógico, que se fija en el parentesco. El criterio que más se ha generalizado, hasta convertirse en el más clásico, es el concepto biológico de especie. Por relación a este concepto, ya sea como contraposición o desarrollo, iremos viendo el resto.

La formulación canónica del concepto biológico de especie se encuentra en los textos de Ernst Mayr ${ }^{30}$. Recoge la idea de que las especies son poblaciones mendelianas máximas, es decir, comunidades reproductoras aisladas reproductivamente del resto. Mayr estima que este criterio es básico y que posibilita una serie de predicciones adecuadas acerca de los procesos de especiación, barreras reproductivas e integración del genotipo. Sostiene Mayr que, tanto la Genética de Poblaciones, como la Ecología, son tributarias de este concepto de especie ${ }^{31}$.

De hecho, el criterio estrictamente reproductivo ha sido complementado por el propio Mayr añadiendo elementos ecológicos ${ }^{32}$, de modo que una especie sería la población mendeliana máxima que ocupa un nicho ecológico propio. La razón está vinculada con la teoría de la especiación también desarrollada por Mayr, según la cual todo proceso de especiación comienza por una fase de aislamiento geográfico que, con el tiempo, acaba por convertirse en un aislamiento reproductivo. Sin aislamiento reproductivo dos grupos acabarán por fundirse en uno, pero sin un nicho ecológico propio ningún grupo puede sobrevivir a la extinción. De modo que una entidad específica suficientemente estable para ser tenida en cuenta debe presentar estos dos elementos definitorios: aislamiento reproductivo y nicho ecológico propio.

Las bioespecies de Mayr, aunque tienen en cuenta el elemento ecológico, no deben ser confundidas con las ecoespecies, tal y como las define Van Valen ${ }^{33}$. Según este último, la interfertilidad no es condición ni necesaria ni suficiente para definir la categoría de especie. Las especies, en su opinión, se mantienen principalmente por causas ecológicas. Y elabora un concepto ecológico de especie, según el cual cada especie viene a ser un linaje que ocupa una zona adaptativa, o nicho ecológico, mínimamente diferente de la de cualquier otro linaje, y que evoluciona separadamente. El conjunto de presiones selectivas de cada nicho ecológico es el que mantiene las especies como unidades taxonómicas distintas. El papel del nicho ecológico es muy distinto en Mayr y en Van Valen, ya que para el primero es el aislamiento reproductivo

\footnotetext{
29 Cfr. Stamos, D., The Species Concept: Biological Species, Ontology, and the Metaphysics of Biology, Lexington, Lanham, MD, 2003, pp. 352-353.

30 Cfr. Mayr, E., Animal Species and Evolution, Harvard University Press, Cambridge, MA, 1963. En un sentido muy parecido se expresa también Theodosius Dobzhansky, uno de los creadores de la Teoría sintética de la Evolución, cfr. Dobzhansky, Th., Genetics and the Evolutionary Process, Columbia University Press, N. York, 1970 , p. 357.

31 Cfr. Mayr, E., Towards a New Philosophy of Biology, p. 318.

32 Cfr. Mayr, E., The Growth of Biological Thought, Harvard University Press, Cambridge, MA, 1982, pp. 273.

33 Van Valen, L., "Ecological Species, Multispecies and Oaks", Taxon, v. 25, (1976), pp. 233-239.
} 
el que asegura que una especie permanece adaptada a su nicho ecológico, mientras que para el segundo son las presiones selectivas propias del nicho ecológico las que mantienen las características de la especie, y, entre ellas, las características de su reproducción.

Por otro lado, el criterio biológico de especie no deja de tener sus limitaciones y problemas. En primer lugar, es obvio que la categoría de especie así definida no es aplicable a organismos que carezcan de reproducción sexual. Por otra parte el cruzamiento entre miembros de una determinada población o entre dos poblaciones debe ser entendido como potencial, pues es obvio que muchos individuos considerados coespecíficos nunca llegarán a cruzarse ${ }^{34}$. Siendo así, ¿qué tipo de barreras deben ser consideradas suficientes para hablar de especies distintas?, ¿bastarían las barreras geográficas, las comportamentales? Si fuese así tendríamos que considerar como poblaciones de distinta especie grupos que pueden ser idénticos desde el punto de vista morfológico y genético. Y, en sentido contrario, hay grupos con notables diferencias que sin embargo son interfértiles en determinadas condiciones.

Por estas y otras razones han ido apareciendo otros conceptos de especie que hacen énfasis en los aspectos morfológicos ${ }^{35}$, como el concepto fenético de especie, que está en la base de la taxonomía fenética, también llamada numérica. Sus defensores proponen clasificar los organismos de acuerdo con sus parecidos morfológicos medidos o codificados numéricamente. Mediante comparación, podrá ser calculado el índice de similitud entre taxones. De esta forma pueden delimitarse las categorías taxonómicas en función de la proximidad de los índices ${ }^{36}$. En el caso de especies politípicas ${ }^{37}$ se impone la elaboración de listas de rasgos, de modo que algunas combinaciones pueden ser tomadas como condición suficiente de pertenencia, pero ningún rasgo concreto como condición necesaria.

El problema de la taxonomía fenética es que puede colocar especies íntimamente emparentadas que han divergido morfológicamente durante la evolución en taxones muy distantes, mientras que especies que se parecen pero que están menos relacionadas es posible que acaben en taxones más próximos ${ }^{38}$. De hecho, se hace inevitable la introducción de criterios teóricos para la valoración de la importancia relativa de los diversos caracteres; de lo contrario, como señala Mayr ${ }^{39}$, las diferencias dentro de las especies polimórficas, así como las debidas a la edad, sexo o variantes individuales, darían lugar a clasificaciones muy extrañas. En contrapartida, los conceptos más tipológicos de especie, como el de la taxonomía fenética, tienen la ventaja indiscutible de su operatividad. En muchos casos es mucho más factible la comparación

34 De hecho, Mayr introduce explícitamente la referencia al cruzamiento potencial en su definición de 1942, cfr. MAYr, E., Systematics and the Origin of Species, Harvard University Press, Cambridge, MA, 1942, p. 120. Posteriormente elimina esta cláusula por considerarla redundante.

35 Cfr Sokal, R. y Crovello, Th., “The Biological Species Concept: A Critical Evaluation”, en EREShesfSKy, M. (ed), The Units of Evolution. Essays on the Nature of Species, pp. 27-56.

36 La exposición clásica de estas técnicas puede verse en Sneath, P. H. y Sokal, R., Numerical Taxonomy, Freeman, San Francisco, 1973. Sobre ellas, con enfoque filosófico, pueden verse Ruse, M., The Philosophy of Biology, Hutchinson, Londres, 1973, vers. cast. de I. Cabrera: La Filosofía de la Biología, Alianza Editorial, Madrid, 1979; Rosenberg, R., The Structure of Biological Science, Cambridge University Press, N. York, 1985; y MAYR, E., Towards a New Philosophy of Biology, Harvard University Press, Cambridge, MA, 1988.

37 El polimorfismo es la variabilidad dentro de cada población de una especie dada, mientras que el politipismo es la variabilidad entre poblaciones de una misma especie. Cfr. Dobzhansky, Th., Ayala, F., Stebbins, L. y Valentine, J., Evolution, W. H. Freeman and Company, San Francisco, 1977. Vers. cast. de M. Aguadé: Evolución, Omega, Barcelona, 1983, p. 129.

38 Cfr. Dobzhansky, Th., Ayala, F., Stebiins, L. y Valentine, J., Evolución, p. 239.

39 Cfr. Mayr, E., Towards a New Philosophy of Biology, p. 316. 
de características morfológicas que la comprobación de la interfertilidad. Incluso para los partidarios de las bioespecies, la comparación de características constituye un valioso síntoma para inferir el status específico de un grupo dado.

Las dificultades en la determinación de bioespecies son particularmente arduas cuando tratamos con poblaciones separadas por largos períodos de tiempo. Resulta extremadamente difícil conjeturar a partir de restos fósiles si dos poblaciones eran interfértiles. Y lo que es peor, podemos suponer razonablemente que cualquier individuo se puede cruzar con uno de la generación anterior ${ }^{40}$, lo que amenaza con hacer colapsar el entero árbol de la vida en una sola especie. Esto es lo que ha llevado a los paleontólogos y a los investigadores de la fílogénesis a estipular el concepto evolutivo de especie, útil para la determinación de especies sobre la base de restos fósiles.

Una especie evolutiva, según George G. Simpson ${ }^{41}$, es un linaje que evoluciona separadamente de otros, con funciones y tendencias propias en el curso de la evolución. Edward O. Wiley lo expresa en otros términos ${ }^{42}$, insistiendo en que una especie conserva a lo largo de la evolución su identidad, sus tendencias evolutivas y su destino histórico. Según Mayr, este criterio sólo sirve para especies monotípicas, y además las tendencias evolutivas sólo pueden detectarse en series muy largas. En consecuencia, en opinión de $\mathrm{Mayr}^{43}$, la determinación de cronoespecies, es decir, de especies que se suceden en el tiempo a lo largo de una misma línea filogenética, no deja de ser arbitraria.

En un sentido muy parecido al de Simpson, Joel Cracraft adopta también una perspectiva diacrónica ${ }^{44}$. Propone un concepto filogenético de especie. Para él una especie es un linaje cuyos miembros comparten un único conjunto característico de nuevas características evolutivas. Paul Ehrlich y Peter Raven tampoco reconocen la interfertilidad como condición necesaria ni suficiente para hablar de especies ${ }^{45}$. Aducen lo que según ellos son razones empíricas. No es condición necesaria, ya que existen grupos cuyas poblaciones están aisladas geográficamente $\mathrm{y}$, aun así, querríamos decir que forman una única especie.

Algo análogo sucede con los organismos asexuales. Tampoco es condición suficiente, ya que existen especies diferenciadas que permanecen distintas a pesar de que sus miembros con cierta frecuencia intercambian material genético. Lo que no está tan claro, a mi modo de ver, es que estas razones sean puramente empíricas. Aquí lo empírico y lo teórico van de la mano, ya que para seguir tomando como especies separadas poblaciones que intercambian genes con frecuencia, necesitamos un concepto de especie distinto del biológico. En efecto, los referidos autores proporcionan un concepto seleccionista de especie. Según ellos, es la selección natural la que logra que poblaciones geográficamente aisladas puedan seguir indefinidamente perteneciendo a la misma especie.

40 Esto sucede con la única excepción de los fenómenos de especiación abrupta, es decir, en una sola generación. Por ejemplo, entre las plantas se producen a veces fenómenos de poliploidismo: un organismo cuenta con $x$ cromosomas y sus descendientes inmediatos con el mismo número duplicado o multiplicado por $n$. En estos casos los descendientes son ya de una especie distinta y no podría darse retrocruzamiento.

${ }^{41}$ Cfr. Simpson, G. G., Principles of Animal Taxonomy, Columbia University Press, N. York, 1963.

42 Wiley, E. O., Phylogenetics: The Theory and Practice of Phylogenetic Systematics. John Wiley, N. York, 1981.

43 Mayr, E., Towards a New Philosophy of Biology, pp. 323-324.

44 Cracraft, J., "Species Concept and Speciation Analysis", en Ereshefsky, M. (ed), The Units of Evolution. Essays on the Nature of Species. pp. 93-120.

45 Cfr. Ehrlich, P. y Raven, P., "Differentiation of Populations", Ereshefsky, M. (ed), The Units of Evolution. Essays on the Nature of Species. pp. 57-68. 
También por relación a la definición clásica de Mayr podemos entender la de Hugh Paterson ${ }^{46}$. Esta vez no por contraposición sino más bien por desarrollo. Paterson desarrolla el llamado concepto de especie según pautas de reconocimiento (the recognition species concept). Según Paterson éste se produce cuando los individuos de un grupo no reconocen como parejas potenciales a los de otro. Y a la inversa, los organismos que pueden reconocerse mutuamente como pareja reproductiva pertenecen a la misma especie. En consecuencia, la definición de Mayr debería, en opinión de Paterson, ser modificada, de manera que consideremos especie la más inclusiva población de organismos biparentales individuales que comparten un sistema común de fertilización.

Alan Templeton observa que el concepto de "especie" propuesto por Paterson cuenta con las mismas dificultades que ya hemos registrado en relación al concepto clásico de bioespecie ${ }^{47}$. Sostiene que el concepto de especie puede ser reformulado en términos genéticos de manera que abarque también poblaciones que de hecho no se cruzan, como las de organismos asexuados o las que están geográficamente aisladas. Pertenecerían a una misma especie aquellas poblaciones con suficiente parecido genético. La cohesión entre estas poblaciones se mantiene mediante varios mecanismos. Uno es el cruzamiento, pero no es el único. También la exposición a las mismas presiones medioambientales favorece la cohesión entre varias poblaciones. Así, una novedad genética, como una mutación, puede llegar a fijarse en dos poblaciones sin que haya cruzamiento, sencillamente porque se produce en ambas y ambas están sometidas a las mismas presiones medioambientales. En suma, las especies serían canales genéticos a lo largo de los que fluyen genes.

\section{El debate sobre el estatuto ontológico de las especies}

El otro eje de la discusión actual sobre el concepto de especie tiene un cariz más filosófico, aunque no excluye, claro está, la perspectiva biológica. Se trata de establecer cuál es el estatuto ontológico de las especies, o dicho de otra manera, qué tipo de entidades son. "La especie darwiniana — señala Jean Gayon — no es una forma: es un grupo de individuos variable, cuya coherencia es casi exclusivamente reproductiva, y que constituye la cosa física que realmente se modifica. Esta cosa no tiene el status de una clase lógica (un universal), dado que es precisamente una cosa: sólo una cosa se transforma; una abstracción, que es por definición intemporal, no se transforma. A fortiori, la especie darwinista no es ni una esencia ni un tipo" ${ }^{48}$.

La evolución no admite esencias inmutables, es cierto, pero la opción del nominalismo extremo tampoco parece la mejor solución, de modo que varios autores han optado por considerar la especie de la Biología evolucionista como una cosa física, como una entidad concreta. Algunos incluso han optado por la solución radical de considerar las especies como entidades individuales. Este movimiento tiene indudables ventajas: dota de realismo a la noción de especie y permite encauzar la cuestión de la cientificidad de la Biología. Sin embargo, la tesis de las especies como individuos ("species as individuals thesis", en adelante $s-a-i$ ) no carece

46 Cfr. Paterson, H., "The Recognition Concept of Species", en Ereshefsky, M. (ed), The Units of Evolution. Essays on the Nature of Species, pp. 139-158.

47 Cfr. Templeton, A., "The Meaning of Species and Speciation: A Genetic Perspective”, en EreshefSKy, M. (ed), The Units of Evolution. Essays on the Nature of Species, pp. 159-183.

48 Gayon, J., "L'Espèce sans la forme”, en GAyon, J. y WunEnburger, J-J. (eds), Les figures de la forme, p. 58. 
de problemas. En vista de lo cual han aparecido vía intermedias entre la concepción de las especies como clases y la concepción de las especies como individuos. Veremos más abajo las propuestas en este sentido de Mayr, Ruse y Kitcher. David Stamos ha propuesto recientemente una concepción de las especies como relaciones que intenta romper con lo que él considera una falsa alternativa entre clases e individuos. Trataré de presentar aquí lo esencial de este debate sobre el estatuto ontológico de las especies.

La tesis $s-a-i$ parte del zoólogo californiano Michael Ghiselin ${ }^{49}$. Ha recibido apoyo también del filósofo David Hull ${ }^{50}$. La tesis resuelve en principio la cuestión del realismo de las especies. Si cada una de ellas es un individuo, entonces tiene una existencia tan real como cualquier organismo. Además, al igual que los organismos, y a diferencia de las clases lógicas, pueden hacer cosas, es decir, pueden evolucionar, producir otras especies mediante un proceso de especiación, extinguirse... Por otra parte, teníamos el problema de la cientificidad de la Biología. La homologación de la misma como Ciencia es una de las preocupaciones de Hull, quien cree que la tesis $s-a-i$ constituye un avance en este sentido. También Ghiselin insiste en que su tesis no afecta meramente a cuestiones técnicas relacionadas con la taxonomía, sino que es un intento de unificar el conocimiento científico y de apuntalar una metafísica monista. Si cada especie fuese una clase, nos extrañaría que la Biología no pudiese formular leyes para cada una de ellas, como la Física o la Química hacen para las clases con las que trabajan. Por ejemplo, existen leyes generales de carácter químico para el carbono que cumplen todas las muestras de carbono.

Sin embargo, no hay leyes biológicas universales para cada especie. Tampoco somos capaces de establecer una serie de condiciones suficientes y necesarias de pertenencia, ni podemos definir las especies. Pero si cada especie es un individuo, nada hay de raro en todo esto. Los individuos no se definen, sólo se describen. Los individuos no constan de elementos, como si fuesen un conjunto, ni de miembros, como los de una clase, sino de partes que consideramos propias del individuo por su origen y relación física con el resto de las partes. Si las especies son individuos los organismos serían sus partes. Y las leyes biológicas habría que buscarlas un escalón más arriba, serían regularidades que cumplirían todas las especies. Así, en cualquier sistema dotado de variación, herencia y selección, se darán unas ciertas regularidades. Tenemos, pues, leyes para la clase de las especies como unidades de evolución, no para esta especie en particular, que es un individuo, del mismo modo que la física o la química presentan leyes para el átomo o para el carbono, no para este átomo o para esta muestra de carbono.

Por supuesto, se podría objetar que el concepto de ley científica que maneja Hull está demasiado próximo a lo que en Filosofía de la Ciencia se denomina la "Concepción heredada". Frederick Suppe afirma, en este sentido, que el hecho de que haya o no leyes válidas para cada especie depende de cómo es el mundo, no de que nosotros decidamos considerar las especies como individuos o como clases. Además, a partir de un individuo dado, siempre se puede formar la clase de sus partes. El que esta clase sea natural o no, el que sus miembros cumplan leyes

49 Cfr. Ghiselin, M., “A Radical Solution to the Species Problem”, Systematic Zoology, v. 23, (1974), pp. 536-544; Ghiselin, M., "Species Concepts, Individuality and Objectivity”, Biology and Philosophy, v. 2, (1987), pp. 127-145; y Ghiselin, M., Metaphysics and the Origin of Species, State University of New York Press, Albany, 1997.

50 Cfr. Hull, D., “Are Species Really Individuals?”, Systematic Zoology, v. 25 (1976), pp. 174-191; Hull, D., “A Matter of Individuality", Philosophy of Science, v. 45, (1978), pp. 335-360; y Hull, D., "The Role of Theories in Biological Systematics", Studies in History and Philosophy of Biological and Biomedical Sciences, v. 32, (2001), pp. 221-238. 
o no, viene a ser una cuestión empírica. De modo que, según Suppe, la tesis $s-a-i$ es irrelevante en relación a la posibilidad de establecer leyes en el ámbito de la Biología evolutiva ${ }^{51}$.

Desde el punto de vista taxonómico, la tesis $s-a-i$ se complementa bien con los criterios de clasificación propuestos por la escuela taxonómica cladista, ya que estos permiten establecer cortes bastante precisos entre las distintas especies. Los cladistas consideran que una especie coincide con el grupo de organismos situado entre dos eventos de especiación, o entre un evento de especiación y otro de extinción, lo cual tiende a solventar el problema de la delimitación de las especies como individuos. Mark Ridley ${ }^{52}$ llega a afirmar que la explicación correcta de por qué las especies en la teoría evolutiva son individuos y no clases la encontramos en el concepto cladista de especie.

Desde el punto de vista de la tesis $s-a-i$, y también del cladismo, la unidad de evolución, es decir, la especie, pasa a ser también la unidad de clasificación. No se clasifican organismos, sino especies. Por debajo de la especie, los organismos son entidades individuales, pero carecen de continuidad suficiente como para evolucionar. Por encima sucede lo contrario: los taxones superiores evolucionan, pero no como unidades. Dado que no hay clasificación exenta de teoría, bien está que la clasificación biológica se ajuste a la teoría evolutiva, es decir, que las unidades de evolución sean al mismo tiempo las de clasificación.

Incluso el procedimiento para nombrar especies parece cobrar sentido desde el punto de vista de la tesis $s-a-i$. Tal procedimiento puede ser visto como un acto bautismal consistente en tomar un espécimen-muestra, que ni siquiera tiene por qué ser particularmente típico y, sobre él, otorgar un nombre a la especie. El nombre así aplicado sobre una parte circunstancialmente representativa es un nombre propio carente de intensión.

Pero, como habíamos adelantado, la tesis $s-a-i$ no deja de presentar problemas. El más obvio es que no parte de ninguna definición previa de individuo. Aquí la estrategia de Hull es clara: nos pide que nos apañemos con nuestras intuiciones previas acerca de lo que es un individuo y con el caso paradigmático de los organismos. Pero las especies en algunos aspectos no parecen ajustarse a los rasgos del caso que se ofrece como paradigma. Por ejemplo, las especies no tienen la misma unidad y continuidad espaciotemporal que presentan los organismos. Es cierto que el flujo genético da a las especies una cierta continuidad, pero, como señala Michael Ruse, "se pensó una vez que el flujo genético entre poblaciones era el factor clave en la conservación del parecido entre los organismos de una especie. Ahora parece mucho más probable que sea la selección normalizadota el factor causal clave" ${ }^{53}$.

$\mathrm{Si}$ es cierto lo que afirma Ruse, entonces la tesis $s$ - $a$ - $i$ tiene un serio problema. También existe un problema relacionado con la especies gemelas, que están aisladas reproductivamente pero no difieren apenas en nada ${ }^{54}$. La pura decisión de ver las especies como individuos nos obligaría a considerarlas especies distintas. Otro tanto sucede con la posibilidad de recuperar especies ya extintas mediante Ingeniería Genética. La discontinuidad temporal nos obligaría

51 Cfr. Suppe, F., The Semantic Conception of Theories and Scientific Realism, University of Illinois Press, Chicago, 1989, pp. 223-225.

52 Cfr. Ridley, M., "The Cladistic Solution To The Species Problem”, Biology and Philosophy, v. 4, (1989), pp. 1-17. Para el concepto cladista de especie, véase también Mishler, B. y Donoghue, M., "Species Concept: a Case for Pluralism", en EReshesfsky, M. (ed), The Units of Evolution. Essays on the Nature of Species, pp. 121-138.

53 Ruse, M., The Darwinian Paradigm, Routledge, Londres, 1989, pp. 108-109.

54 Es el caso, por ejemplo, de Drosophila pseudoobscura y Drosophila persimilis. 
a decir que no estamos ante la misma especie, aunque la "nueva" sea en todo idéntica a la extinta. Y el mismo problema generan los casos de poliploidismo reiterado.

Dado el estado del debate podríamos preguntarnos si no existe una tercera vía, algo que reúna las ventajas de la condición de clase y de la condición de individuo, pero sin los inconvenientes que éstas presentan cuando tratamos de pensar las especies. "Clases individualizadas" o "particulares complejos", han sido categorías híbridas propuestas por Van Valen y Suppe respectivamente ${ }^{55}$. Philip Kitcher y Bradley Wilson han defendido que las especies son conjuntos $^{56}$, Mayr que son poblaciones ${ }^{57}$, Ruse que son grupos $^{58} \mathrm{y}$, recientemente, Stamos ha hablado de las especies como relaciones ${ }^{59}$. Permítaseme examinar brevemente las ventajas y problemas que presentan estas posiciones. Me centraré en las cuatro últimas, como propuestas más elaboradas.

Kitcher propone leer el enunciado "las especies evolucionan" en términos conjuntistas como "puede haber organismos, descendientes de una especie dada, que no pertenezcan a esa especie, sino a un conjunto disjunto". Sin embargo, hay que reconocer que los moldes conjuntistas se adaptan muy mal a realidades con decurso temporal. Tendríamos que preguntarnos cuáles son los elementos de una especie-conjunto dada, como por ejemplo Canis lupus. Podríamos incluir todos los lobos actuales más todos los que alguna vez han existido, esto ya parece problemático, pero peor aún es lo que se refiere al futuro. Si no hemos incluido los lobos futuros, cada vez que nazca uno tendremos un nuevo conjunto, en virtud del axioma de extensionalidad, y, en consecuencia, una nueva especie. Por otra parte, incluir a todos los lobos futuros es algo bastante extraño, dado que no tienen existencia en ningún sentido razonable de la palabra. La especie estaría constituida por una mezcla de entidades existentes e inexistentes.

A la postre hay que recurrir a la conceptualización de cada especie no como un conjunto, sino como una larga ristra de conjuntos correspondientes, cada uno de ellos, a los organismos que forman parte de una especie en un momento dado. Añadamos a esto que si adoptamos el criterio biológico de especie como criterio de pertenencia, entonces la copertenencia a un mismo conjunto deja de ser una relación transitiva. Me explico: aunque el organismo A pueda cruzarse con el B y el B con C, eso no garantiza que el A pueda cruzarse con el C. Fenómenos biológicos como las clinas (por ejemplo la clina que forman las salamandra de Norte a Sur del continente americano) o los anillos (por ejemplo el de las gaviotas en torno al Polo Norte) así lo atestiguan. Poblaciones contiguas pueden cruzarse, pero los extremos de la clina no. En el caso de los anillos el fenómeno es más llamativo, dado que las poblaciones extremas compartes territorio. De nuevo nos topamos con la dificultad para captar fenómenos biológicos en conceptos lógicos como el de conjunto.

\footnotetext{
55 Este tipo de conceptos híbridos entre lo lógico y lo físico recuerdan las Ideas de Platón, que son entidades concretas al tiempo que hacen funciones de conceptos universales abstractos. También Hegel habla del universal concreto como la síntesis dialéctica lo general abstracto y de lo particular.

56 Cfr. Kitcher, Ph., "Species”, Philosophy of Science, v. 51, (1984), pp. 308-333; y Wilson, B., "Are Species Sets?", Biology and Philosophy, v. 6, (1991), pp. 413-432.

57 Cfr. MAYr, E., "The Ontological Status of Species: Scientific Progress and Philosophical Terminology", Biology and Philosophy, v. 2, (1987), pp. 145-166.

58 Cfr. Ruse, M., The Darwinian Paradigm, pp. 108-109.

59 Cfr. Stamos, D., The Species Concept: Biological Species, Ontology, and the Metaphysics of Biology, Lexington, Lanham, MD, 2003.
} 
Por su parte, Mayr simpatiza en lo esencial con la tesis $s-a-i$, pero discrepa en cuanto a la terminología. Llamar a las especies "individuos" resulta demasiado chocante. Lo que sí es cierto es que tratamos, según él, con entidades concretas, no con abstracciones lógicas. Pero los biólogos entenderían mejor que llamásemos a estas entidades "poblaciones”, o, mejor aún, "biopoblaciones", para indicar así que no son poblaciones cualesquiera, sino poblaciones cuyos miembros pueden cruzarse. Sin embargo, el filósofo Mario Bunge señala atinadamente que si pudiéramos igualar "bioespecies" y "biopoblaciones" ${ }^{60}$, alguno de los dos términos sería redundante. Pero resulta que necesitamos los dos por la evidente razón de que hay poblaciones uniespecíficas y otras pluriespecíficas.

Según Michael Ruse, las especies son precisamente grupos. Los grupos son vistos como cosas más concretas, más físicas que las clases. Pero si extremamos la consideración de los mismos como cosas, nos encontramos con que los hemos vaciado de todo contenido formal, tal y como advierte Jean Gayon en las líneas citadas más arriba. Al vaciar el grupo de contenido formal nos quedamos también sin otro criterio de pertenencia que el reproductivo, pero hemos visto que este criterio dista de ser claro y completo, como sabía el propio Darwin.

Nos queda por considerar la propuesta de Stamos. Para él, las especies deben ser pensadas como relaciones de semejanza. Filosóficamente se apoya en la noción de relación de Bertrand Russell y en el tratamiento de la relación de semejanza, como un objeto real, que ha hecho recientemente Arda Denkel ${ }^{61}$. Cuando uno piensa en relaciones, contempla también los relata, es decir, los polos de la relación, pero ve algo más, a saber, la relación propiamente dicha. Cada especie sería, pues, tanto un complejo de relaciones de semejanza, como los correspondientes relata, es decir, los organismos que están en dicha relación. Se puede objetar que todo organismo se parece a cualquier otro en algún sentido. Stamos responde que efectivamente es así, pero que la propia naturaleza, mediante relaciones causales nos ofrece guías para distinguir aquellos complejos de relaciones de semejanza que con base real podemos llamar especies. Las relaciones causales que delimitan las especies son de varios tipos: principalmente de interfertilidad, de tranferencia de genes, ecológicas, ontogenéticas y sociales.

En palabras de Stamos: "La misma naturaleza está compuesta en parte por varias relaciones causales que más o menos dividen en especies las relaciones de semejanza" ${ }^{2}$. En opinión del autor, la concepción de las especies como relaciones de "biosemejanza" tiene importantes ventajas. Permite rechazar el puro nominalismo. De hecho, Stamos defiende una concepción realista de las especies. También ve como una ventaja el hecho de que las especies no tengan necesariamente que ser monofiléticas. Así se evita el tener que clasificar en distintos taxones las especies con origen múltiple, como es el caso de las que se originan por poliploidismo reiterado o por Ingeniería Genética. También evita el tener que considerar como definitiva, por definición, cualquier extinción. Por añadidura, es un concepto suficientemente amplio como para incluir a los organismos de reproducción no sexual. Por otro lado, la concepción de las especies como complejos de relaciones de biosimilaridad presenta también problemas.

En el plano biológico esos problemas se presentan sobre todo cuando uno repara en la dimensión llamada vertical de las especies, es decir, en el desarrollo de las mismas a lo largo

60 Cfr. Bunge, M., "Biopopulations, not Biospecies, Are Individuals and Evolve", The Behavioural and Brain Sciences, v. 4, (1981), pp. 284-285.

61 Cfr. Denkel, A., Object and Property, Cambridge University Press, Cambridge, 1996.

62 Stamos, D., The Species Concept: Biological Species, Ontology, and the Metaphysics of Biology, p. 297. 
del tiempo. La biosimilaridad está pensada como una relación principalmente horizontal, de parecido entre organismos relacionados causalmente. Dicho de otro modo, esta forma de ver las especies puede encajar mal, por ejemplo, en paleontología, $\mathrm{y}$, desde luego, encaja mal con alguna de las escuelas taxonómicas, sobre todo con las que ponen más énfasis en el origen común y único de los taxones. En el plano filosófico puede presentar problemas en cuanto a la realidad física de las relaciones, y particularmente de las relaciones de semejanza ${ }^{63}$.

\section{Balance: El CONCEPTO de "ESPECIE" en la Biología EVOluCiONiSTA}

Tras el recorrido que hemos hecho podemos establecer que la Biología actual requiere un concepto de especie plural, pues tiene que ser útil en diversas disciplinas, cada una con sus intereses y puntos de vista. La noción de "especie" que puede ser útil en Paleontología no lo es tanto en Zoología o en Botánica, ni éstas tienen por qué coincidir con la que interesa al biólogo que trata con organismos asexuales. Y cada una de ellas dará lugar a una ordenación peculiar del mundo vivo. Algo similar sucede con el concepto de gen, que no identifica exactamente un fragmento de ADN, sino varios posibles según la función en la que nos fijemos. Es decir, el gen visto como unidad de mutación, de recombinación o de codificación de proteínas da lugar a cortes diferentes en la secuencia de ADN. A la especie también se le piden muchas funciones diferentes. Será un grupo de organismos semejantes, pero también interfértiles, con origen próximo común, con una trayectoria filogenético propia y un nicho ecológico diferenciado, es la unidad de evolución y también para algunos la de biodiversidad. No es raro que, según nos fijemos en una u otra de las funciones de la noción de especie, nos salgan cortes de la realidad no plenamente coincidentes. Y, en cualquier caso, la tensión entre el aspecto morfológico y el genealógico siempre está presente.

En mi opinión, se debe mantener la distinción conceptual entre especies y poblaciones por las razones aducidas por Bunge y porque una especie puede estar constituida por varias poblaciones. La idea es que el concepto de población cargue con los aspectos físicos y el de especie con los lógicos. Una población siempre es una entidad concreta, situada espaciotemporalmente. Incluso podemos discutir si es o no un individuo. Desde mi punto de vista, se trata de una cuestión empírica y que admite grados. Una población puede presentar un mayor o menos grado de individualidad. Será más individual en la medida en que presente mayor grado de cohesión o integración funcional y en la medida en que posea una mayor memoria de pasadas interacciones. La integración funcional nos permite hablar de un individuo y la memoria de un mismo individuo a lo largo del tiempo. Tanto la memoria como la integración funcional admiten variaciones graduales.

Las especies deberían ser consideradas como clases, quizá clases difusas, a las que pueden pertenecer diversas poblaciones. $\mathrm{O}$ bien, si se quiere, como clases construidas a partir de relaciones de semejanza. Siendo clases retienen su componente intensional o formal. La expresión "las especies evolucionan" habría que entenderla ahora como "las poblaciones evolucionan, pasando, a lo largo del tiempo, de una especie a otra". De la misma forma, no decimos "la infancia crece", sino "el niño crece y pasa de la infancia a la adolescencia". El aspecto difuso las especies puede no provenir de un defecto epistémico por nuestra parte, sino de la realidad misma. Tal vez la mejor forma de entender las especies sea sobre la estructura de la teoría

63 Cfr. Goodman, N., "Seven Strictures on Similarity”, en M. Douglas y D. Hull (eds), How Classification Works, Edinburgh University Press, Edimburgo, 1992, pp. 13-23. 
de conjuntos difusos. Así se evitaría la paradoja de la no transitividad en de la relación de copertenencia. Por otra parte, esta opción permite la existencia de leyes generalizadas sobre el dominio de cada clase. Si aceptamos que los bordes de las mismas son difusos, las leyes vendrían formuladas en términos probabilísticos. Obviamente, lo que sugiero aquí son tan sólo indicaciones que quizá puedan ser de alguna utilidad para pensar un concepto tan antiguo y complejo como el de especie, cargado de connotaciones teóricas cambiantes y afectado por nuevos descubrimiento empíricos.

\section{Repercusiones en Ética de la Cuestión de las ESPECIES}

Consideremos ahora en qué medida el concepto de especie, tras la mutación teórica producida con la Biología evolucionista, afecta a debates de carácter ético. Tendremos que preguntarnos incluso si tal concepto sigue teniendo alguna utilidad en contextos morales o si se trata más bien de una fuente de problemas y confusión. En este último caso surgiría inevitablemente la pregunta por los posibles sustitutos del concepto de especie en las discusiones de carácter ético y político. Me centraré en dos cuestiones en las que creo que la presencia de la noción de especie es particularmente notoria e importante. En primer lugar me referiré al debate sobre la conservación de las especies, que obviamente depende en gran medida de la propia noción de especie. En segundo lugar trataré sobre el llamado dilema del anti-especista. Es un problema moral en el que también de un modo obvio hallamos implicada la noción de especie.

\subsection{Especies y biodiversidad}

El debate sobre la biodiversidad bascula entre intuiciones muy arraigadas y compartidas, favorables a la conservación, y una incapacidad notable para establecer con claridad tanto las razones de estas intuiciones como el propio concepto de diversidad biológica. El concepto de "biodiversidad" es muy general y atañe a todos los niveles de la vida, desde el celular al ecológico e incluso paisajístico. Pero en particular nos interesa el número de especies que hay en nuestro planeta ${ }^{64} \mathrm{y}$ la diversidad interna de las mismas.

Según autores como Stamos ${ }^{65}$ y Cracraft ${ }^{66}$, es precisamente el riesgo de extinción que hoy corren muchas especies lo que más presión pone en la reflexión sobre el propio concepto de especie. Ambos estiman que el debate sobre tal concepto requiere una resolución, y no sólo por razones intelectuales, sino también por motivos prácticos que tiene que ver con nuestra supuesta responsabilidad sobre la extinción de especies. Con ello apuntan hacia la necesidad de una solución realista del debate, pues el nominalismo no parece ser un buen motor para las políticas de conservación de las especies. Incluso si pensamos las especies como abstracciones las motivaciones para la conservación parecen salir debilitadas. Veamos este asunto.

Los argumentos para conservar la diversidad se suelen dividir en antropocéntricos y no antropocéntricos. Los primeros son los que proponen conservar las especies por su utilidad para el hombre, los segundos, por su valor intrínseco. Ni el concepto de "utilidad para el hombre"

64 Cfr. Gleich, M., Maxeiner, D., Miersch, M. y Nicolay, F. (eds), Life Counts. Eine globale Bilanz des Lebens, Berlin Verlag, Berlín, 2000. Vers. cast. de B. Galán: Las cuentas de la vida. Un balance global de la Naturaleza, Galaxia Gutenberg, Barcelona, 2000.

65 Cfr. Stamos, D., The Species Concept: Biological Species, Ontology, and the Metaphysics of Biology, p. 356.

66 Cfr. Cracraft, J., "Species Concept in Systematics and Conservation Biology - An Ornithological Viewpoint", en Claridge, M. F., Dawah, H. A. y Wilson, M. R. (eds), Species: The Units of Biodiversity, Chapman and Hall, Londres, 1997, pp. 325-339. 
ni el de valor intrínseco están nada claros. Por ejemplo, a veces se habla de la conveniencia de conservar una especie por el placer estético o intelectual que puede producir su contemplación, y se ofrece éste como argumento no antropocéntrico. El argumento, a mi modo de ver, es tan antropocéntrico como el que propone la conservación en razón del sustento del hombre. Habría que pensar en una ampliación de los argumentos antropocéntricos hasta contener los que hacen alusión a los valores estéticos, emocionales o cognoscitivos. Así entendida, la justificación antropocéntrica puede ser perfectamente digna y legítima.

Por otra parte, tal como hemos visto, la especie es una entidad cuyo estatuto ontológico está lejos de ser claro en la Biología actual, de modo que el concepto de valor intrínseco de tales especies no puede ser tampoco claro. Por ejemplo, para un nominalista estricto no puede darse tal valor intrínseco. No estoy muy seguro de que el discurso conservacionista se acompañe siempre de conciencia de los supuestos ontológicos que exige.

Según la propuesta hecha en el apartado 5, deberíamos establecer una distinción entre las razones para respetar la vida de poblaciones y organismos, y las razones para preservar las especies. En algunos supuestos ambas finalidades pueden incluso entrar en conflicto. Sólo las razones para respetar la vida poblaciones y organismos pueden ser no-antropocéntricas. Pero siempre que se hable de razones para preservar especies habremos de admitir que tienen carácter antropocéntrico. Las especies, aunque tengan base objetiva en las características de los organismos, no son cosas concretas.

Cuando uno piensa en la conservación de una especie, no piensa en poblaciones e individuos concretos, sino en las funciones que éstos ejecutan de modo aproximadamente equivalente. Funciones de dos tipos: por un lado, ecológicas y, por otro, cognoscitivas, estéticas o emotivas. Cada tipo de ser vivo tiene una función ecológica que contribuye al mantenimiento del ecosistema al que pertenece. La idea de mantener una especie por su valor ecológico transfiere a la especie el valor que otorgamos al ecosistema.

Los ecosistemas siempre han estado en proceso de cambio, unos equilibrios ceden y aparecen otros. Se puede eliminar o dañar la vida de un organismo o de una población sin aportar nada a la de otro, pero, salvo destrucción total de la vida en nuestro planeta, no se puede desequilibrar una situación ecológica sin generar otra. La misma identidad de los ecosistemas es difícil de establecer. Si unos nos parecen más valiosos que otros es porque nos resultan más útiles o bellos a nosotros, con lo cual, la fuente última del valor ecológico de una especie está en su relación con el hombre.

Las especies tienen también un papel cognoscitivo, como objetos de conocimiento. El conocimiento de universales exige diferentes tipos de individuos como su "alimento". No podemos eliminar especies, es decir, laminar la riqueza del universo como objeto de contemplación, sin jugarnos nuestras posibilidades de ser felices. Esta idea, de un modo u otro, se expresa frecuentemente en el discurso conservacionista. Las especies como tales no pueden ser sujetos de derechos. Son los humanos los que pueden reconocerse mutuamente el derecho de pedir protección para la vida de otros seres o para sus propios intereses vinculados a la biodiversidad.

\subsection{El dilema del anti-especista}

El especismo sería, según algunos autores, una forma de discriminación análoga al racismo o al sexismo, y por tanto injusta. El anti-especista pide que no se discrimine a ningún viviente en función de la especie a la que pertenece. Pero, si desechamos el criterio de la 
especie tenemos que buscarnos algún otro para valorar los seres y ajustar nuestra conducta a su valor, pues necesariamente tenemos que discriminar. Ahora bien, dicho criterio se fijará en alguna característica concreta de los vivientes, no en su mera pertenencia a una especie. Por ejemplo, podemos establecer el valor en función de las capacidades de cada ser vivo, capacidad de sufrir o gozar, presencia de mente, capacidades lingüísticas o sociales, autonomía, ... Mas, de obrar así podría estar en riesgo la igualdad básica entre los seres humanos en cuanto a su dignidad. Es decir, el anti-especista, que impugna toda discriminación en función de la especie, o no discrimina en absoluto entre los vivientes, lo cual es inviable, o bien pone en riesgo la igualdad entre los humanos, lo cual es indeseable.

Si no queremos emplear la especie como criterio de discriminación nos haría falta una teoría del valor de los seres vivos que cumpliese tres desiderata: i) que reconozca valor objetivo a los seres vivos, y este punto es importante, pues si sólo reconocemos el valor instrumental y no discriminamos por la especie, resultaría necesariamente que unos seres humanos podrían ser simplemente medios al servicio de otros; ii) que introduzca una cierta graduación del valor de los vivientes no basada en la especie; y iii) que no rompa la igual dignidad de todos los humanos.

Hay que aceptar que tal teoría aún no ha surgido y constituye un reto para la Ética de nuestros días. Las ideas de Peter Singer, por ejemplo, incumplen la tercera desiderata. Según su Ética, quedan desprotegidos precisamente los seres humanos más débiles. No se puede ver sino con recelo que la misma mano escriba a favor de la liberación animal y del infanticidio: "La vida de un recién nacido — advierte Singer — tiene menos valor que la de un cerdo, un perro o un chimpancé" ${ }^{67}$.

Tras esta afirmación, se puede esperar que Singer emprenda una defensa de todos ellos, pero no es eso lo que sigue, sino un intento de justificación del infanticidio: "No considero que el conflicto entre la posición que he adoptado y tan ampliamente aceptadas opiniones sobre la santidad de la vida infantil sea motivo para abandonar mi posición. Creo que es necesario cuestionar esas opiniones de tan amplia aceptación [...] Nada de todo eso demuestra que la matanza de un niño sea tan mala como la de un adulto (inocente) [...] Las razones para no matar personas no son válidas para los recién nacidos" ${ }^{68}$.

Esto, indudablemente, rompe la igualdad mínima entre humanos. Puede causar inquietud adicional la poca claridad de Singer en cuanto a la edad de los infantes que según él no merecen mayor protección. Menciona como edad "una semana", "un mes", "un año", e incluso "tres años" " ${ }^{9}$. Singer no pretende dejar desprotegidos a los niños de tres años, aunque sugiere que no sería ninguna catástrofe: "Claro que cuando lo que está en juego son los derechos, es preferible errar por el lado de la seguridad. Si se hubiera de legislar sobre este problema, probablemente sólo se negaría a los bebés el pleno derecho jurídico a la vida durante un periodo muy breve, tal vez un mes a partir del nacimiento" 70 . Singer señalar incluso cuáles serían las circunstancias en las que "la matanza de un niño" sería permisible. Indudablemente, "se deberían imponer condiciones muy estrictas al infanticidio". Pero, de hecho, la única condición que Singer pone al infanticidio es "que quienes están más próximos al niño no quieran que viva" 71.

67 Singer, P., Practical Ethics, Cambridge University Press, Cambridge, 1979. Vers. cast. de M. I. Guastavino: Ética práctica, Ariel, Barcelona, 1984, p. 155.

68 Singer, P., Ética práctica, pp. 155-157.

69 Ética práctica, pp. 155-158.

70 Singer, P., Ética práctica, pp. 158-159.

71 Ética práctica, p. 160. 
La cuestión es si se puede apoyar el respeto a los animales, el buen trato a los mismos, evitar el que sean considerados torpemente como máquinas u objetos, evitar la perspectiva conductista que les niega mente y emociones, sin caer en las consecuencias antihumanistas de Singer. Yo creo que sí se puede buscar un fundamento distinto, que no nos conduzca al desprecio de la vida de los humanos más débiles.

Quizá uno de los problemas del anti-especismo resida en que el propio concepto de especie no es el más adecuado en contextos morales o políticos. Ya tiene sus propios problemas en contextos biológicos, como hemos visto. En contextos éticos cuentan principalmente los individuos y las poblaciones, que son entidades concretas. Cuando queramos referirnos a los seres humanos en su conjunto es preferible utilizar una expresión con claras connotaciones morales y referencia a entidades concretas, como "familia humana", como hace la Declaración Universal de los Derechos Humanos en su preámbulo.

La coespecificidad no es una relación que conlleve necesariamente vínculos emotivos, sociales, afectivos y morales, mientras que la pertenencia a una misma familia sí. Este tipo de vínculos son los que habría que extender gradualmente al resto de los animales y de los seres vivos. Para ello, evidentemente, es imprescindible que sean respetados en el seno de la propia familia humana. Si conseguimos reconocer en los otros humanos - en todos - las señas de la familiaridad, si conseguimos extender, desde los más próximos hasta los más alejados, los vínculos de respeto y afecto que nos unen — o deberían unirnos - a nuestra familia, y que nacen del más elemental amor propio, entonces estaremos en condiciones de proceder a una nueva extensión, entonces podremos hacer que nuestra compasión alcance también a otros vivientes. No se trata, por lo tanto, de razonar en abstracto sobre criterios de discriminación entre clases o conjuntos, sino de hacer extensivos a otros vivientes los vínculos que nos unen —o deberían unirnos — al resto de los miembros de nuestra familia humana.

\section{Bibliografía}

Beatty, J., "Speaking of Species: Darwin's Strategy", en Ereshefsky, M. (ed), The Units of Evolution. Essays on the Nature of Species, The MIT Press, Cambridge, MA, 1992, pp. 227-246.

Bowler, P., The non-Darwinian Revolution: Reinterpreting a Historical Myth, Johns Hopkins University Press, Baltimore, 1988.

Bunge, M., "Biopopulations, not Biospecies, Are Individuals and Evolve", The Behavioural and Brain Sciences, v. 4, (1981), pp. 284-285.

Cracraft, J., "Species Concept and Speciation Analysis", en Ereshefsky, M. (ed), The Units of Evolution. Essays on the Nature of Species, The MIT Press, Cambridge, MA, 1992, pp. 93-120.

Cracraft, J., "Species Concept in Systematics and Conservation Biology. An Ornithological Viewpoint", en Claridge, M. F., Dawah, H. A. y Wilson, M. R. (eds), Species: The Units of Biodiversity, Chapman and Hall, Londres, 1997, pp. 325-339.

Cuvier, G., Essay On The Theory Of The Earth, Blackwood, Edimburgo, 1813.

Darwin, CH. R., On the Origin of Species by Means of Natural Selection, John Murray, Londres, 1859 (reimp. Penguin Classics, Londres, 1985). Vers. cast. de J. Fuster: El origen de las especies, Petronio, Barcelona, 1974, 2 vols. 
Darwin, CH. R., Charles Darwin's Natural Selection: Being the Second Part of this Big Species Book Written From 1856 To 1858, edición de Robert C. Stauffer, Cambridge University Press, Cambridge, 1975.

Denkel, A., Object and Property, Cambridge University Press, Cambridge, 1996.

Dobzhansky, Th., Ayala, F., Stebbins, L. y Valentine, J., Evolution, W. H. Freeman and Company, San Francisco, CA, 1977. Vers. cast. de Montserrat Aguadé: Evolución, Omega, Barcelona, 1983.

Dobzhansky, Th., Genetics and the Evolutionary Process, Columbia University Press, N. York, 1970.

Ehrlich, P. y Raven, P., "Differentiation of Populations", en Ereshefsky, M. (ed), The Units of Evolution. Essays on the Nature of Species, The MIT Press, Cambridge, MA, 1992, pp. 57-68.

EReshefsky, M. (ed), The Units of Evolution. Essays on the Nature of Species, The MIT Press, Cambridge, MA, 1992.

Ereshefsky, M., "Introduction to the Part II: Philosophical Issues", en Ereshefsky, M. (ed), The Units of Evolution. Essays on the Nature of Species, The MIT Press, Cambridge, MA, 1992, pp. 187-198.

Gayon, J., "L'Espèce sans la forme”, en Gayon, J. y Wunenburger, J-J. (eds), Les figures de la forme, L'Harmattan, París, 1992, pp. 49-61.

Ghiselin, M., “A Radical Solution to the Species Problem”, Systematic Zoology, v. 23, (1974), pp. 536-544.

Ghiselin, M., “Species Concepts, Individuality and Objectivity”, Biology and Philosophy, v. 2, (1987), pp. 127-145.

Ghiselin, M., Metaphysics and the Origin of Species, State University of New York Press, Albany, NY, 1997.

Gleich, M., Maxeiner, D., Miersch, M. y Nicolay, F. (eds), Life Counts. Eine globale Bilanz des Lebens, Berlin Verlag, Berlín, 2000. Vers. cast. de B. Galán: Las cuentas de la vida. Un balance global de la Naturaleza, Galaxia Gutenberg, Barcelona, 2000.

Goodman, N., "Seven Strictures on Similarity", en Douglas, M. y Hull, D. (eds), How Classification Works, Edinburgh University Press, Edimburgo, 1992, pp. 13-23.

Hull, D., “Are Species Really Individuals?”, Systematic Zoology, v. 25, (1976), pp. 174-191.

Hull, D., “A Matter of Individuality", Philosophy of Science, v. 45, (1978), pp. 335-360.

Hull, D., "The Role of Theories in Biological Systematics", Studies in History and Philosophy of Biological and Biomedical Sciences, v. 32, (2001), pp. 221-238.

Jahn, I., Lother, R. y Senglaub, H. (eds), Geschichte der Biologie, Gustav Fischer Verlag, Jena, 1985. Vers. cast. de J. L. Gil Aristu: Historia de la Biología. Labor, Barcelona, 1989.

JAHN, I. (ed), Geschichte der Biologie, Spektrum Akademischer Verlag, Berlín, 2000.

JAHN, I., "Naturphilosophie und Empire in der Frühaufklärung (17. Jh.)", en JAHN, I. (ed), Geschichte der Biologie, Spektrum Akademischer Verlag, Berlín, 2000, pp. 198-230.

JAHN, I., "Biologische Fragestellungen in der Epoche der Aufklärung (18. Jh.)", en JAHN, I. (ed), Geschichte der Biologie, Spektrum Akademischer Verlag, Berlín, 2000, pp. 231-273.

Kitcher, PH., “Species”, Philosophy of Science, v. 51, (1984), pp. 308-333. 
Lennox, J., "Kinds, Forms of Kinds, and the More and Less in Aristotle's Biology", en Gotthelf, A. y Lennox, J. (eds), Philosophical Issues in Aristotle's Biology, Cambridge University Press, Cambridge, 1987, pp. 339-359.

Lennox, J., "Darwinism," en Zalta, E. N. (ed), The Stanford Encyclopedia of Philosophy, http://plato.stanford.edu/archives/fall2004/entries/darwinism (edición de primavera 2004).

Lyell, C., Principles of Geology, John Murray, Londres, 1835, 4a ed., 2 vols.

Marcos, A., "Sobre el concepto de especie en Biología", en ABel, F. y CAÑón, C. (eds), La mediación de la Filosofía en la construcción de la Bioética, Publicaciones Universidad Pontificia de Comillas, Madrid, 1993, pp. 41-60.

Mayr, E., Systematics and the Origin of Species, Harvard University Press, Cambridge, MA, 1942.

MaYr, E., Animal Species and Evolution, Harvard University Press, Cambridge, MA, 1963.

MAYr, E., The Growth of Biological Thought, Harvard University Press, Cambridge, MA, 1982.

MaYr, E., "The Ontological Status of Species: Scientific Progress and Philosophical Terminology", Biology and Philosophy, v. 2, (1987), pp. 145-166.

MaYr, E., Towards a New Philosophy of Biology, Harvard University Press, Cambridge, MA, 1988.

Mayr, E., "Species Concepts and Their Application”, en Ereshesfrky, M. (ed), The Units of Evolution. Essays on the Nature of Species, The MIT Press, Cambridge, MA, 1992, pp. 15-26.

Mishler, B. y Donoghue, M., "Species Concept: a Case for Pluralism”, en Ereshesfsky, M. (ed), The Units of Evolution. Essays on the Nature of Species, The MIT Press, Cambridge, MA, 1992, pp. 121-138.

Paterson, H., “The Recognition Concept of Species", en Ereshesfrky, M. (ed), The Units of Evolution. Essays on the Nature of Species, The MIT Press, Cambridge, MA, 1992, pp. 139-158.

Pellegrin, P., La classification des animaux chez Aristote, Les Belles Lettres, París, 1982.

Ridley, M., “The Cladistic Solution To The Species Problem”, Biology and Philosophy, v. 4, (1989), pp. 1-17.

Rosenberg, R., The Structure of Biological Science, Cambridge University Press, N. York, 1985.

Ruse, M., The Philosophy of Biology, Hutchinson, Londres, 1973. Vers. cast. de I. Cabrera Calvo-Sotelo: La Filosofía de la Biología, Alianza Editorial, Madrid, 1979.

Ruse, M., The Darwinian Revolution: Science Red in Tooth and Claw, The University of Chicago Press, Chicago, 1979. Vers. cast. de C. Castrodeza: La revolución darwinista: La Ciencia al rojo vivo, Alianza Editorial, Madrid, 1983.

Ruse, M., The Darwinian Paradigm, Routledge, Londres, 1989.

Simpson, G. G., Principles of Animal Taxonomy, Columbia University Press, N. York, 1963.

Singer, P., Practical Ethics, Cambridge University Press, Cambridge, 1979. Vers. cast. de M. I. Guastavino: Ética práctica, Ariel, Barcelona, 1984.

Sneath, P. H. y Sokal, R., Numerical Taxonomy, Freeman, San Francisco, CA, 1973.

Sokal, R. y Crovello, Th., "The Biological Species Concept: A Critical Evaluation", en Ereshesfsky, M. (ed), The Units of Evolution. Essays on the Nature of Species, The MIT Press, Cambridge, MA, 1992, pp. 27-56. 
Stamos, D., The Species Concept: Biological Species, Ontology, and the Metaphysics of Biology, Lexington, Lanham, MD, 2003.

Suppe, F., The Semantic Conception of Theories and Scientific Realism, University of Illinois Press, Chicago, 1989.

Templeton, A., "The Meaning of Species and Speciation: A Genetic perspective", en EReshesfsky, M. (ed), The Units of Evolution. Essays on the Nature of Species, The MIT Press, Cambridge, MA, 1992, pp. 159-183.

Van Valen, L., "Ecological Species, Multispecies and Oaks", Taxon, v. 25, (1976), pp. 233-39.

Wiley, E. O., Phylogenetics: The Theory and Practice of Phylogenetic Systematics. John Wiley, N. York, 1981.

Wilson, B., “Are Species Sets?”, Biology and Philosophy, v. 6, (1991), pp. 413-432. 


\section{III}

\section{Evolucionismo y Economía}

6. Tres ideas evolutivas en Economía: Las poblaciones, la pura curiosidad y el cambio tecnológico

7. La idea de evolución en Hayek: Instituciones, orden social y proceso económico 



\section{Tres ideas evolutivas en ECONOMÍA: LAS POBLACIONES, LA PURA CURIOSIDAD Y EL CAMBIO TECNOLÓGICO Santiago López García}

\section{INTRODUCCIÓN}

En The Expression of the Emotions in Man and Animals and The Descent of Man and Selection in Relation to Sex, Darwin mostró su interés por el comportamiento humano. Desde su perspectiva el estudio del comportamiento debía empezar por el transfondo biológico del mismo ${ }^{1}$. Desde entonces los biólogos han hecho proposiciones similares. Uno de los mayores abogados de este planteamiento ha sido O. Wilson ${ }^{2}$. Él mantiene que los economistas y los científicos sociales deberían buscar en la Biología las premisas que necesitan para sus modelos predictivos, de la misma manera en que la Biología las busca en la Química y la Física. Sin embargo, la mayoría de los economistas no aceptan este punto de vista. Pero sin este cambio de mentalidad la Economía continuará siendo lo que es ahora: una Ciencia Social llena de posturas ideológicas, buenas descripciones del pasado y conjeturas relativamente bien adaptadas a la formulación matemática.

Con todo, dentro de la Economía hay algunas Escuelas que basan sus principios en las ideas evolutivas. Los economistas evolutivos tienen orígenes intelectuales diversos. Unos utilizan el concepto darwinista de ser humano e intentan llevar a la práctica el aserto de A. Marshall "la Meca del economista se encuentra en la Biología económica (economic biology) en lugar de la dinámica económica (economic dynamics)" ${ }^{3}$. Otros se consideran seguidores de J. A. Schumpeter, quien vendría a ser el creador de la Economía evolutiva desde dentro de la Economía, es decir, sin tener que partir de los principios darwinistas. Algunos aplican la Filosofía de Th. Veblen, que fue el primero que defendió una Economía evolutiva basada en los cambios tecnológico y, principalmente, institucionales. Él consideraba a las instituciones como las unidades de la selección evolutiva en la Economía ${ }^{4}$.

Sin entrar en la extensa e integradora taxonomía realizada por G. M. Hodgson ${ }^{5}$, podemos diferenciar tres puntos de vista en la Economía evolutiva. a) La Neoschumpeteriana, con G. Dosi, R. R. Nelson y S. G. Winter al frente, a los que les une el estudio del cambio tecnológico desde la perspectiva que introdujeran autores como N. Rosenberg y C. Freeman. b) Los institucionalistas y neo institucionalistas, siendo unos más cercanos a Th. Veblen y otros a R. Coase. c) Los economistas que aplican la Teoría de Juegos de manera similar a como lo hacen los biólogos evolutivos, los cuales estarían encabezados por J. Maynard Smith ${ }^{6}$.

\footnotetext{
Cfr. Maynard Smith, J., Evolution and the Theory of Games, Cambridge University Press, Cambridge, MA, 1982.

2 Cfr. Wilson, O., Consilence, Knopf, N. York, 1998.

3 Cfr. Marshall, A., Principles of Economics, Macmillan, Londres, 1890; $8^{\text {a }}$ edición, Macmillan, Londres, 1948, p. XIV.

4 Cfr. Veblen, Th., The Theory of the Leisure Class: An Economic Study of Institutions, Macmillan, N. York, 1899, p. 188.

5 Cfr. Hodgson, G. M., Economics and Evolution. Bringing Life Back into Economics, Blackwell, Oxford, 1993.

6 Cfr. Tirole, J., The Theory of Industrial Organization, The MIT Press, Cambridge, MA, 1988, pp. 261 y 311-314.
} 
Esta agrupación no es exhaustiva. Sin entrar en detalle a estos tres conjuntos de científicos, podríamos añadir una larga serie de autores que, partiendo del estudio del comportamiento humano, han intentado mantenerlo unido a las bases biológicas que lo determinan. Se trataría de expertos que están más cercanos a la Biología que a la Economía, por tanto su base de análisis no está en la Economía: sería el caso de H. A. Simon, de G. Becker (el más economista por su formación), de I. Eibl-Eibesfeldt y de O. Wilson (padre de la Sociobiología) ${ }^{7}$. Por otro lado, hay una literatura evolutiva que identifica a la empresa como si se tratase de una clase de identidad sometida a las reglas de la evolución. Desde esta última perspectiva el trabajo de Alchian permanece como un clásico ${ }^{8}$.

Con este amplio panorama de puntos de vista e intereses resulta adecuado delimitar de alguna manera el análisis del evolucionismo en Economía. Me gustaría concentrarme en tres ideas o debates que han sido planteados por los autores evolutivos desde finales del siglo XVIII hasta nuestros días.

Empezaré por la relación entre Malthus y Darwin y la cuestión de las poblaciones, que es un concepto fundamental de la Economía evolutiva, en oposición a la perspectiva individualista, que es la predominante en el resto de la Economía. En el segundo apartado trataré la naturaleza innovadora del individuo, que está basada en mi caso en la idea de "la pura curiosidad" (idle curiosity) de Veblen, una idea contraria a la de optimización individualista, basada en el utilitarismo de Bentham y su concepto maximización del placer, en la que los economistas solemos basarnos. Finalmente, tras haber visto los conceptos de poblaciones e individuo y de haber profundizado en lo que podríamos definir como la quintaesencia de los fenómenos de innovación, insertada en todas las culturas humanas, me ocuparé del concepto de paradigma tecnológico, que ha resultado ser uno de los ejes fundamentales de la teoría económica evolutiva, tal y como se ha ido conformando en los últimos treinta años.

Por tanto, intentaré analizar tres conceptos (las poblaciones, la pura curiosidad y el paradigma tecnológico) en referencia a las polémicas, controversias y nociones complementarias que se han dado entre diferentes autores desde los tiempos de Mathus, desde finales del siglo XVIII, hasta los años ochenta del siglo pasado, cuando la escuela evolutiva en Economía quedó establecida por Dosi, Nelson y Winter. ${ }^{9}$

\section{Malthus y el Concepto de población en Economía}

Malthus influyó a Darwin — tal como el mismo Darwin puntualizó—, tanto es así que podríamos considerarlo como un precursor del evolucionismo ${ }^{10}$. Es más, podemos derivar de Malthus tres cuestiones que nos permiten entender el evolucionismo de Darwin:

7 Cfr. Gandolfi, A. E., Gandolfi, A. S y Barash, D. P., Economics as an Evolutionary Science: From Utility to Fitness, Transaction Publishers, N. Brunswick, 2002; Simon, H. A., Models of Bounded Rationality, vols. 1 y 2, The MIT Press, Cambridge, MA, 1982; Eibl-Eibesfeldt, I., Ethology: The Biology of Behavior, Holt-Rinehart, N. York, 1975; y Alcock, J., The Triumph of Sociobiology, Oxford University Press, Oxford, 1999.

8 Cfr. Alchian, A. A., "Uncertainty, Evolution and Economic Theory", Journal of Political Economy, v. 58, (1950), pp. 211-221.

9 Cfr. Dosi, G., "Technological Paradigms and Technological Trajectories: A Suggested Interpretation of the Determinants and Directions of Technical Change", Research Policy, v. 11, n. 3, (1982) pp. 147-162; y Nelson, R. R. y Winter, S. G., An Evolutionary Theory of Economic Change, Harvard University Press, Cambridge, MA, 1982.

10 Cfr. Young, R. M., "Malthus and the Evolutionists: The Common Context of Biological and Social Theory", Past and Present, v. 43, (1969), pp. 109-145; y Hodgson, G. M., Economics and Evolution. Bringing Life Back into Economics, pp. 62-67. 
1. Malthus percibió la infinita variedad de la vida en la Naturaleza y la existencia de "aparentes imperfecciones", ambas nociones chocaban con la idea de la Naturaleza que había en la Ilustración. En ese sentido, Malthus descubrió una de las claves de la teoría evolutiva: el binomio variedad-mutación. Desde este punto de vista, consideró la diversidad junto con la mutación como los factores que al unísono eran cruciales para la existencia de una población como un conjunto. Mantuvo que en la diversidad estaba el principio del cambio, y que esos cambios eran renovados a través de un cierto proceso de selección. Al igual que Darwin, Malthus comprendió que la variedad existe, causa cambios y que la influencia del entorno (la selección natural) venía después a completar esa acción. Darwin compartió esta visión maltusiana.

2. También afirmó que el desarrollo natural no tiene solo lugar en la lucha por la vida (supervivencia del más apto), sino también en la muerte (éxito al reproducirse y fallo al morir sin dejar descendencia).

3. Otra noción crucial para entender la transcendencia de Malthus en el pensamiento evolutivo es que para él no hay teleología, es decir, que no se va hacia una harmonía ulterior. En oposición a la noción general de "equilibrio" propia de la Escuela escocesa, que consideraba el mundo como lo hacían el resto de ilustrados, Malthus enfrentaba la noción de "crisis" y las situaciones que terminaban en catástrofe como intrínsecas. Más adelante veremos como Veblen compartía este relevante punto de vista.

El trabajo de Malthus sobre el comportamiento humano es de naturaleza filosófica; en él se considera a los humanos como un grupo y no solamente como unos individuos. Este enfoque le condujo a concentrarse en el "comportamiento" de las poblaciones. De ahí, que cuando estudió las poblaciones humanas fuera capaz de discernir el proceso evolutivo que subyace. Sin embargo, nunca formuló una Teoría explícita de la Evolución, como sí lo hiciera Darwin, debido a que el solo quería mostrar la lucha por los recursos escasos en una situación de crecimiento de la población, $\mathrm{y}$, tampoco consideró la posibilidad de un incremento de los recursos a través de la innovación que pudiera asegurar el éxito en la capacidad para reproducirnos.

Con respecto a An Essay on the Principle of Population de Malthus ${ }^{11}$, Darwin reconoció que el problema para entender la evolución estaba en comprender la evolución de las poblaciones por encima y antes de la evolución de los individuos. Nosotros podríamos imaginarnos a Darwin preguntándose, no tanto por cómo los individuos evolucionan, sino más bien por cómo una determinada población evoluciona hasta dar con el concepto de especie: el par formado por la mutación en el individuo y la replicación de ella en la población. El mecanismo podría haber sido el mismo; el conjunto de la población podría sufrir el mismo proceso, en el sentido de que la misma ley podría conducir a todas las poblaciones de todas las especies. De acuerdo a esta ley, como dedujo del trabajo de Malthus, la evolución tendría que ver con la escasez de recursos a disposición de las poblaciones. Sin embargo, donde Darwin vio evolución Malthus vio solamente la crisis de una población, porque para el las poblaciones permanecerían sin mutaciones, sin innovaciones, que les permitieran incrementar exponencialmente la obtención de recursos.

Darwin mantenía que una situación de escasez de recursos llevaba a una lucha por ellos y entre las especies y dentro de cada una. De este modo, dentro de una población A de una especie, un individuo obtendría más recursos si él hubiera desarrollado una mutación, y por

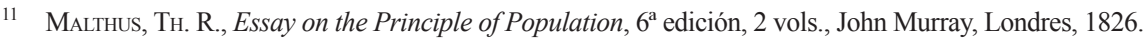


reproducción podría llegar a establecer una nueva especie, algo diferente de A: una nueva población $\mathrm{B}$ (en la que la mutación habría proliferado). La ratio reproductiva de $\mathrm{B}$ dentro del conjunto $\mathrm{A}+\mathrm{B}$ estaría determinando la velocidad a la que B sustituiría o se separaría de A. Así, se añade al modelo general el éxito del mecanismo de mutación-proliferación en una situación de lucha por los recursos y/o la consecución de una alta tasa reproductiva.

Desde este punto de vista, la impronta de Malthus en la Biología evolutiva es fundamental, pero en Economía él no desarrolló una idea alternativa a la lucha por y en el mercado. Él nunca superó la visión clásica de Adam Smith, basada en la especialización del trabajo y de los mercados. Para los economistas el problema fue y continúa siendo el de la utilización de los recursos escasos entre los individuos. Mathus como Smith se interesó en el día a día de cómo los humanos podrían llegar a hacer una mejor distribución de sus recursos escasos. La antigua noción aristotélica de "equilibrio" lo invadía todo en aquellos tiempos. La solución era obvia: el mercado ofrece a cada individuo, de acuerdo a sus preferencias, la oportunidad de pagar (en el sentido de luchar por comprar un bien) la cantidad que ellos estén dispuestos a poner.

Para Darwin, este era un problema de importancia secundaria. Así por ejemplo, cuando Darwin veía un pico de flamenco, veía lo bien diseñado que estaba ese filtro para comer que tenían los flamencos. Él no estaba tan pendiente de la constante competición entre un particular flamenco y su idéntico vecino, sino más bien entre todas las aves similares (especies separadas de una especie ancestral) que abarrotaban el lago. Los colegas economistas contemporáneos de Darwin sólo se interesaban en ver y establecer la comparación; ver que les sucede a los humanos cuando compiten por algo a lo que ellos conceden valor. Por tanto, sólo veían la competencia dentro de la especie, lo que conducía a ver sólo la lucha por la supervivencia y no la capacidad de mutar-innovar. En cierto sentido seguían siendo maltusianos. Esta persistencia en la falta de perspectiva era la que conducía una y otra vez al darwinismo social, y no a una teoría evolutiva del comportamiento económico del ser humano. Por su parte, Darwin deseaba conocer más acerca de cómo el pico del primitivo pájaro había llegado a ser un filtro de comida y, con el tiempo y una serie de coincidencias, llegado a dar origen a una nueva especie: la de los flamencos.

Si en vez de flamencos hablamos de humanos, entonces podríamos preguntarnos por las siguientes cuestiones: ¿qué es lo que le podría permitir a un ser humano obtener más y mejores nutrientes? Es decir, ¿cuál fue nuestro particular pico de flamenco? La respuesta es la capacidad para cocinar los alimentos, tal como R. Wrangham ha demostrado ${ }^{12}$. El fuego habría sido la clave, una buena herramienta en definitiva. Una chispa en las manos de un individuo que tenía en su cabeza información acerca de cómo funciona el mundo (Ciencia, aunque primitiva), así como una noción de cómo se emplean las herramientas para conseguir las cosas que ofrece ese mundo (Tecnología, aunque primitiva). El hecho de poder cocinar disparó las posibilidades de acceder a nuevos alimentos y digerirlos rápidamente. La especie se modificó físicamente con un mayor cerebro y un estómago menor ${ }^{13}$. Las nuevas especies se multiplicaron. Salieron una y otra vez de sus aislamientos. Poblaciones con estómagos rápidos y cerebros tremendamente exigentes en consumo de energía a la busca de alimentos escasos. Ahora el problema era optar por las continuas escaramuzas en los bordes de los territorios de cada gran familia o una nueva herramienta: ¿cómo se realiza la distribución de recursos escasos entre los miembros de la especie homo sapiens?

12 Cfr. Wrangham, R., C Catching Fire. How Cooking Made Us Human, Basic Books, N. York, 2009.

13 Igual que el pico primitivo fue haciendo que el cuerpo del flamenco ancestral se modificase. 
La respuesta es: con el mercado. Podríamos decir que también con la violencia o el afecto, apelando a los instintos, pero desde la perspectiva de la mutación-innovación, ¿qué es el mercado sino otra herramienta más en la mano? La siguiente cuestión relevante, refiriéndonos al caso particular del mercado, es: ¿quiénes fueron los humanos a los que se les ocurrió utilizar el intercambio como método (como una herramienta) para obtener más y mejores nutrientes? Obviamente, podemos generalizar este razonamiento e ir aún más allá en lo realmente relevante: ¿desde cuándo la Humanidad ha tenido la habilidad de utilizar herramientas (incluyendo instituciones en el sentido de herramientas e incluyendo entre ellas las instituciones que permiten el intercambio comercial) para lograr más y mejores nutrientes?

Si tomamos por bueno que la Economía es la Ciencia que estudia la forma más eficiente de repartir los recursos escasos entre los humanos, entonces, deduciremos que para ella el mercado es la manera. Se sobrentiende que los humanos hacemos Ciencia y Tecnología, y que por ello hemos desarrollado y continuamos desarrollando el mercado y las subsiguientes formas cada vez más eficientes de mercado. Pero a los economista nos cuesta comprender que antes de explicar las operaciones del mercado deberíamos mostrar los mecanismos por los que los que el ser humano construye Ciencia y Tecnología. Si no incluimos este propósito en el centro de nuestra disciplina, seremos conducidos una y otra vez, independientemente de nuestras ideologías y Escuelas de Pensamiento, a explicaciones y predicciones erróneas y a esas continuas pequeñas paradojas que aparecen en nuestros modelos cuando tratamos de comprobarlos.

Jevons predijo en 1866 el final del sistema económico para 1914, porque las reservas de carbón habrían desaparecido ${ }^{14}$. Siempre habrá economistas u organismos que harán predicciones de manera semejante, como el Rome Report y sus derivaciones, o la posición defendida por Baran y Sweezy, que predijeron catástrofes del sistema, sin necesidad de mencionar la crisis final del capitalista preconizada por el marxismo o no haber previsto la crisis actual ${ }^{15}$. Sin lugar a dudas habrá una crisis final, pero los pronósticos fallan una y otra vez. De igual modo que son débiles los pronósticos sobre países que tendrían que llegar a converger en un estado estacionario con los avanzados y nunca lo logran.

Focalizar el estudio de la Economía en el mercado y sus crisis o en su estado estacionario es ver tan sólo una parte de la condición humana, la del homo optimizer (luchando por la escasez de los recursos), mientras que no permite ver la del homo innovator (generador de ideas). Fue Veblen quien percibió que el hombre estaba empujado por su innata pura curiosidad: "the most substantial achievement of the race — its systematized knowledge and quasi-knowledge of things" ${ }^{16}$.

\section{VEBLEN Y EL CONCEPTO DE "PURA CURIOSIDAD"}

Veblen había superado las deficiencias del darwinismo social y las conjeturas absurdas de Herbert Spencer sobre las implicaciones sociales de aplicar el darwinismo. En lo que se refiere a evitar cualquier teleología rechazaba a Spencer, pero también a los economistas clásicos y neoclásicos. Junto con Malthus, forma parte de los economistas que podríamos considerar

\footnotetext{
14 Cfr. Jevons, W. S., The Coal Question: An Inquiry Concerning the Progress of the Nation, and the Probable Exhaustion of Our Coal-Mines, Macmillan, Londres, 1866.

15 Cfr. Meadows, D. H., Meadows, D. L., Randers, J. y Behrens III, W. W., The Limits to Growth: A Report for the Club of Rome's Project on the Predicament of Mankind, Universe Books, N. York, 1972; y BARAN, P. A. y Sweezy, P. M., Monopoly Capital: An Essay on the American Economic and Social Order, Monthly Review Press, N. York, 1966.

16 VeBlen, T., The Instinct of Workmanship and the State of the Industrial Arts, The Macmillan, N. York, 1914, p. 87.
} 
evolutivos por sí mismos, porque ninguno de los dos aceptaron un estado de equilibrio o de reposo; en última instancia de culminación ${ }^{17}$.

En el Pensamiento de Veblen la gente no son calculadores racionales de dolores y placeres, sino seres curiosos que, juntos y debido a su propia naturaleza, daban con nuevas maneras para hacer las cosas ${ }^{18}$. Por tanto, no hay una ley natural que guíe a los individuos en la senda de un mayor bienestar para un cada vez mayor número de gente en la sociedad. Esto último podría acontecer o no. El concepto de "óptimo de Pareto", que es el que sintetizó esta idea, es sólo aplicable a una situación de equilibrio momentáneo, fruto de unas determinadas circunstancias. El equilibrio paretiano es inestable debido a que las personas son criaturas complejas y, sobre todo, creativas, cuyo comportamiento es difícil de comprender sin recurrir a lo que el mismo Veblen llamaba "instintos" y "hábitos", y que hoy en día denominamos como componentes antropológicos o Etología humana.

Cuando Veblen hizo del ser humano un innovador, denominándolo useless curious, con una tendencia a la realización de actos deliberados y creador por naturaleza, infringió la norma de todo el edificio de la Economía clásica, porque introdujo el desequilibrio como el quid del comportamiento, y no la utilidad. Como opuesto al utilitarismo, Veblen antepuso el concepto de la pura curiosidad (useless curiosity) innata en los humanos para describir el proceso económico ${ }^{19}$. La curiosidad es casual y necesita tiempo - el lapso de tiempo que un ser humano necesita entre una innovación y otra ${ }^{20}$ - Son esos lapsos durante los que se dan los equilibrios, pero son pasajeros.

Para dar significado a este nuevo concepto de los humanos, Veblen recurrió a la cultura material de los hombres, es decir, a su Tecnología. Para esto, primero evitó caer en cualquier tipo de peligro historicista, porque sabía que los fundamentos, los puntos de vista sobre el mundo y sobre sus propias sociedades que tienen los humanos descansaban sobre sus dotaciones materiales concretas, bajo las cuales los humanos se habían ido constituyendo a sí mismos. Es decir, tenía un modelo analítico, no sólo descriptivo. En este sentido, él creó una visión antropológica fundamentada en la más invariable característica de la naturaleza humana, que es la necesidad de crear e innovar, y que actúa conectando tecnologías (invenciones, innovaciones y procesos productivos) e instituciones (formas de hacer las cosas, formas de pensar las cosas, incluyendo la Filosofía y la Religión, formas de distribución de las recompensas por hacer las cosas y reglas de gobierno sobre las propiedad, gestión y distribución de las cosas).

Para Veblen, el cambio económico era la interacción entre tecnologías e instituciones, la cuales eran puestas en funcionamiento o se activaban por la gente que está dispuesta a cambiar

17 Cfr. Hodgson, G. M., Economics and Evolution. Bringing Life Back into Economics, pp. 43-46.

18 Cfr. Veblen, Th., "Why is Economics not an Evolutionary Science?", The Quarterly Journal of Economics, v. 12, n. 4, (1898), pp. 373-397; Veblen, TH., The Theory of the Leisure Class: An Economic Study of Institutions, passim; Veblen, Th., The Place of Science in Modern Civilisation and Other Essays, Augustus Kelly, N. York, 1919; Veblen, Th., The Engineers and the Price System, The Viking Press, N. York, 1921; y Veblen, Th., Essays on Our Changing Order, edición de L. Ardzrooni, The Viking Press, N. York, 1934. Sorprende la modernidad de Veblen cuando, cien años más tarde, las más modernas teorías acerca de lo que diferencia a los humanos del resto de los grandes simios sea nuestra adaptación biológica para participar y colaborar en actividades que implican compartir objetivos y planes de acción socialmente coordinados. Cfr. Tomasello, M., Carpenter, M., Call, J., Behne, T. y Moll, H., "Understanding and Sharing Intentions: The Origins of Cultural Cognition", Behavioral and Brain Sciences, v. 28, (2005), pp. 675-691, en especial, p. 676

19 Hoy sabemos que la curiosidad está presente en los grandes simios.

20 Cfr. Bergson, H., L'évolution créatrice, Les Presses universitaires de France, París, 1907. Vers. inglesa: Creative Evolution, Dover, N. York, 1998. 
cualquier aspecto tecnológico o institucional dentro de una población. Cuando esto sucedía y las tecnologías e instituciones funcionaban al unísono, entonces se daba el incremento de producción y productividad.

Veblen anticipó algunos pensamientos incitantes y básicos para las ideas de los economistas de hoy en día. Él reflejó los problemas de su época: la separación de la propiedad y la gestión, a la vez que su unión de cara a los tecnólogos y explicó la tecnología como el acervo de conocimientos de una comunidad ${ }^{21}$. Fue el primer economista que desarrolló la noción de "empresa" como si fuera un conjunto de decisiones basadas en rutinas que se habrían formado a lo largo del tiempo. Este concepto sería también desarrollado por H. A. Simon y, posteriormente, por Nelson y Winter.

Por otro lado, Veblen subrayó que las recesiones en el capitalismo hundían sus raíces en desplazamientos de unas Tecnologías por otras causados por nuevas y más eficientes innovaciones, las cuales retiraban a las industrias obsoletas que se veían forzadas a parar de invertir y causaban a su vez extinciones generalizadas que eran las que daban la sensación de recesión. Así, Veblen aparece como predecesor de Schumpeter. Esta perspectiva la completó cuando intentó formalizar una teoría de los derechos de propiedad. Llegó a identificar como sabotaje por parte de los empresarios la acción de captura de los aparatos de regulación del Estado, especialmente a través de las restricciones al comercio exterior y las barreras arancelarias. Y esto, que hoy llamamos en Economía captura de rentas, lo relacionó con las crisis.

Aunque es cierto que Veblen anunció diferentes caminos por los que los economistas luego han transitado, sin embargo, no tuvo una corriente o escuela que siguiera su Pensamiento ${ }^{22}$. El llamado posteriormente "Nuevo institucionalismo" desechó a Veblen y prefirió partir de los llamados costes de transacción de R. Coase. ${ }^{23}$ El mejor ejemplo al respecto es D. North. ${ }^{24}$ Es cierto, los costes de transacción son la material de la que están hechas las instituciones pero, a su menor o mayor presencia como explicación de cómo funcionan las instituciones, es necesario añadir la inquebrantable voluntad del ser humando por crear nuevas instituciones. Eso no está en Coase y sí en Veblen.

Gracias a Mathus y Veblen los economistas tenemos nuestras propias bases teóricas de evolucionismo sin necesidad de utilizar la teoría darwinista. De hecho, el análisis evolutivo más extenso que se ha hecho en la Economía nacería sin necesidad de apelar a Darwin y versaría sobre el cambio tecnológico de la mando de Schumpeter.

\section{Cambio tecnológico: Wolf y Schumpeter}

Julius Wolf fue un economista alemán de principios del siglo XX cuyo trabajo es poco conocido y cuya importancia es mucho menor que la de Schumpeter. Sin embargo, su contribución para comprender como afecta el cambio tecnológico al desarrollo económico es esencial. Presentar las ideas de Wolf supone hacerse las siguientes preguntas: ¿Qué sucede

21 Veblen, TH., The Engineers and the Price System, p. 19.

22 Cfr. Veblen, Th., "Why is Economics not an Evolutionary Science?”, pp. 373-397.

23 Cfr. Coase, R. H., "The Nature of the Firm", Economica, v. 4, n. 4, (1937) pp. 386-405.

24 Cfr. North, D. C., Institutions, Institutional Change and Economic Performance, Cambridge Univesity Press, Cambridge, 1990; y NoRTH, D. C. y Wallis, J. J., "Integrating Institutional Cange and Technical Change in Economic History. A Transaction Cost Approach", Journal of Institutional and Theoretical Economics, v. 150, n. 4, (1994), pp. 609-624. 
con el crecimiento económico basado en el cambio tecnológico cuando aplicamos el principio de los rendimientos decrecientes a la tecnología? ¿Qué es lo que nos permite comprender el proceso de diseminación, convergencia y declive tecnológicos?

Wolf publicó su principal obra Die Volkswirtschaft der Gegenwart und Zukunft en $1912^{25}$. Se trataba de una colección de lecturas sobre el fenómeno del atraso o postergación de algunas economías y de sectores industrial, dentro del fenómeno general de progreso económico. Wolf definió su Ley de los límites del desarrollo tecno-económico o Ley de los obstáculos al progreso tecnológico (das Gesetz der technisch-ökonomischen Entwicklungsgrenze). Su Ley señalaba que el progreso tecnológico en las primeras fases del desarrollo de una industria es más rápido que cuando ésta se acerca a su madurez. Además, estableció que este fenómeno ocurre bajo dos condiciones: 1) que el conocimiento necesario para el incremento gradual de una determinada tecnología es limitado; y 2) que el coste de los consecutivos incrementos aumenta según la tecnología se acerca a su nivel de operación a largo plazo o madurez.

La originalidad de Wolf fue usar y aplicar el concepto de los rendimientos decrecientes a la Tecnología. Él sabía que el progreso tecnológico podía incrementar la productividad de los recursos de una manera decisiva, tal y como los estudios empíricos mostraban una y otra vez. Pero también que la productividad que se ganaba con el uso de las innovaciones (de producto, proceso y organizativas) en algunas economías e industrias mostraría una tasa decreciente con el paso del tiempo. Existen multitud de ejemplos al respecto, tanto para países como para sectores industriales y especialmente para empresas. Ellos son la verificación de la explicación teórica que diera Wolf. Ahora bien, si quitamos el tiempo del modelo explicativo de Wolf, entonces tendremos un mundo casi en perfecto equilibrio; el verdadero estado estacionario causado por el uso de tecnologías sin apenas innovación; los lapsos de tiempo entre innovaciones a los que antes nos referíamos. Lo interesante de la Ley de Wolf es, por tanto, el tiempo y como las compañías, organizaciones, industrias y economías trabajan durante periodos de progreso o estancamiento tecnológicos ${ }^{26}$.

Después de Wolf otros autores estudiaron con detenimiento la relación entre crecimiento económico y progreso tecnológico ${ }^{27}$. El primero y más sistemático fue Kuznets, quien en 1930 retornaría a la interpretación de Wolf sobre la relación del progreso tecnológico y económico. La conclusión de Kuznets fue que, a través del estudio de las patentes, se podía observar que el crecimiento de la innovación en cada rama industrial tendía en su totalidad a decrecer con el tiempo, como si la invención inicial fuera llegando a su perfección ${ }^{28}$.

Unos años más tarde, en 1939, la teoría de la innovación de Schumpeter emergió y, desde ese momento en adelante, sería la guía de las investigaciones sobre la relación entre cambio tecnológico y crecimiento económico. Esto significó un cambio en la relevancia de los puntos

\footnotetext{
25 Wolf, J., Die Volkswirtschaft der Gegenwart und Zukunft, A. Deichertsche Verlagsbuchhandlung, Leipzig, 1912.

26 Cfr. PAcey, A., Technology in World Civilization, Basil Backwell, Oxford, 1990, pp. 94-97; y MoKyr, J., The Lever of Riches: Technological Creativity and Economic Progress, Oxford University Press, Oxford, 1990.

27 Cfr. Usher, A. P., A History of Mechanical Inventions, Harvard University Press, Harvard, edición revisada, 1954 (1ª edición, 1929).

28 Cfr. Kuznets, S. S., Secular Movements in Production and Prices Their Nature and Their Bearing upon Cyclical Fluctuations, Houghton Mifflin-The Riverside Press, Cambridge, 1930, pp. 10-11; y Burns, A. F., Production Trends in the Unites States since 1870, National Bureau of Economic Research, N. York, 1934, p. 141.
} 
de vista cercanos a la Ley de Wolf. ${ }^{29}$ Para Schumpeter, la Ley de Wolf no era importante. Su noción de "innovación radical" había hecho que la postura de los rendimientos decrecientes quedase como un hecho menor.

Sin embargo, las visiones de Wolf y Schumpeter, aunque parezcan antagónicas, son complementarias. La primera actúa en el corto plazo y explica el ciclo de vida de los productos y procesos e incluso de tecnologías concretas. Se trata de la macroevolución que es adaptativa, parcialmente reversible, gradual y relativamente finalizada. La segunda funciona más en el largo plazo y nos ilumina acerca de cómo la innovación cambia productos y procesos en toda una serie de tecnologías y métodos de forma cualitativa y en un sentido radical. Es macroevolución y resulta irresistible, aleatoria y episódica ${ }^{30}$.

La síntesis entre ambas teoría comenzó a finales de los años cuarenta con los trabajos de B. S. Keirstead, quien vino a concluir que las innovaciones mayores de Schumpeter no eran la clave del crecimiento económico, sino que éste se debía a la innovaciones que se adaptaban a un amplio espectro de actividades. Keirstead se refería a innovaciones que causaban un flujo de mejoras menores a través de muchas actividades económicas. En este sentido, se adaptaban a un amplio espectro de sectores y conectaban esas mejoras con otros sectores a los que se transmitían. Para él, las características de la utilidad y la capacidad interconectar sectores de algunas innovaciones eran lo que causaba el crecimiento económico, gracias a que inducían la inversión, el empleo y, a largo plazo, el incremento general del bienestar ${ }^{31}$. La contribución de Keirstead vino a suponer un maridaje entre las visiones de Wolf y de Schumpeter y, a través de su concepto de innovaciones de amplia adaptabilidad, la introducción de una idea que está muy cerca de la de senda tecnológica, que aparecería en los años setenta.

La nueva manera de entender a las innovaciones vino de N. Rosenberg, quien puso sobre el tapete de nuevo este dilema evolutivo entre lo micro y lo macro asumiendo que, aunque el cambio tecnológico cubre formas diferentes, no obstante todas ellas están fundadas en denominadores comunes de determinados tipos de conocimientos que hacen posible obtener un mayor volumen de producción, o una superior calidad partiendo de una calidad determinada de los recursos ${ }^{32}$.

En los años ochenta se formaría una síntesis con los diferentes puntos de vista en torno al concepto de "paradigma tecnológico" y la idea de que las innovaciones mayores no son el único factor de crecimiento económico. Las pequeñas contribuciones y los procesos de mejora que se logran durante la producción y el posterior uso también afectan al crecimiento,

\footnotetext{
29 Se dejó de lado esta perspectiva hasta que fue retomada por J. S. Metcalfe, C. Freeman, C. Perez y L. Soete en los años ochenta del pasado siglo. Cfr. Metcalfe, J. S., "Impulse and Diffusion in the Study of Technical Change", Futures. The Journal of Forecasting and Planning, v. 13, n. 5, (1981), p. 351; Freeman, C., Clark, J. y Soete, L., Unemployment and Technical Innovation: A Study of Long Waves in Economic Development, Pinter, Londres, 1982; y Perez, C. y Soete, L., "Catching up in Technology: Entry Barriers and Windows of Opportunity", en Dosi, G., Freeman, C., Nelson, R., Silverberg, G. y Soete, L. (eds), Technical Change and Economic Theory, Printer Publisher, Londres, 1988, pp. 458-479.

30 Cfr. Metcalfe, J. S., "Impulse and Diffusion in the Study of Technical Change”, pp. 351-354.

31 Cfr. Keirstead, B. S., The Theory of Economic Change, Macmillan, Toronto, 1984, pp. 135-136.

32 Cfr. Rosenberg, N., Inside the Black Box: Technology and Economics, Cambridge University Press, Cambridge, 1990; Schumpeter, J. A., The Theory of Economic Development, Harvard University Press, Cambridge, MA, 1934; Schumpeter, J. A., Business Cycles. A Theoretical, Historical and Statistical Analysis of the Capitalist Process, McGraw-Hill, N. York, 1939; Schumpeter, J. A., Capitalism, Socialism, and Democracy, Harper, N. York, 1942; y Schumpeter, J. A., "The Creative Response in Economic History", Journal of Economic History, v. 7, (1947), pp. 149-159.
} 
y esas contribuciones no pueden darse sin una base de conocimientos previos y de experimentación. Partiendo de este punto, el reto fue dilucidar como de integradas estaban las innovaciones mayores en las menores y adaptativas. Autores como G. Dosi ${ }^{33}$, D. Sahal ${ }^{34}, \mathrm{C}$. Freeman, C. Perez y L. Soete dieron las claves para entender esa relación gracias a conceptos como paradigma tecnológico ${ }^{35}$. Ellos dedujeron los componentes tecnológicos en el proceso económico cuando el objetivo es la consecución de innovaciones, y los subordinaron a lo que denominaron como paradigma.

Un paradigma tecnológico puede ser definido como un patrón de soluciones para un particular conjunto de problemas tecnoeconómicos que están relacionados con un determinado conjunto de principios derivados de las Ciencias de la Naturaleza. A ello se uniría unas reglas específicas encaminadas a la adquisición de nuevos conocimientos y a la salvaguardia de los mismos, si fuera posible, para evitar una rápida difusión de los mismos entre la competencia ${ }^{36}$.

Contiene un paradigma las soluciones a un problema tecnológico-económico y nos ofrece el panorama de los logros (productos y procesos). Es tanto un conjunto de principios teóricos (modelos y leyes científicas), como políticos (patentes y contratos de transferencia de Tecnología) y económicos (obtención de economías de escala y alcance), que actúan como referencia para modelos subsecuentes. En síntesis, un paradigma es un conjunto de innovaciones y su modelo conceptual de referencia que permiten avanzar a un sistema económico generado nuevos proyectos y aportar innovaciones ${ }^{37}$.

Al introducir el concepto de "paradigma" estamos convirtiendo la noción de "innovación radical" de Schumpeter en un concepto más amplio que cubre de manera más satisfactoria los propios requerimientos del modelo de Schumpeter. Es en este punto donde encontramos la interpretación que presentó Dosi. En su visión, la innovación radical pasa a ser un concepto más simbólico que un artefacto concreto. Así, por ejemplo, desde la perspectiva schumpeterriana el motor de combustión interna sería contemplado como un objeto único, que se realizó en un concreto momento y que ha sido después reproducido una y otra vez. La realidad no es así. Todos los motores de combustión interna son parte del paradigma del motor de combustión interna. Este paradigma contiene los principios físicos, químicos y de Ingeniería presentes en el conjunto de experiencias que suponen todos los motores realizados.

El paradigma del motor existe y se exterioriza en las patentes originales y la enorme variedad de artefactos que incorporan mejoras a la vez que van descartando las aportaciones

33 Cfr. Dosi, G., "Technological Paradigms and Technological Trajectories: A Suggested Interpretation of the Determinants and Directions of Technical Change", pp. 147-162; Dosi, G., Technical Change and Industrial Transformation the Theory and an Application to the Semiconductor Industry, Macmillan, Londres, 1984; Dosi, G., "Sources, Procedures, and Microeconomic Effects of Innovation", Journal of Economic Literature, v. 26, (1988), pp. 1120-1171; Dosi, G., Freeman, C., Nelson, R., Silverberg, G. y Soete, L. (eds), Technical Change and Economic Theory, Printer Publisher, Londres, 1988; Dosi, G., Pavitt, K. y Soete, L., The Economics of Technical Change and International Trade, Harvester Wheatsheaf, Londres, 1990; y Dosi, G., Giannetti, J. y Toninelli, P. A. (eds), Technology and Enterprise in a Historical Perspective, Oxford University Press, Oxford, 1992.

34 Cfr. Sahal, D., “Technology Guide-Post and Innovation Avenues”, Research Policy, v. 14, n. 2, (1985), pp. 61-82.

35 Cfr. Freeman, C. y Perez, C., "Structural Crises of Adjustment, Business Cycles and Investment Behavior", en Dosi, G., Freeman, C., Nelson, R., Silverberg, G. y Soete, L. (eds), Technical Change and Economic Theory, pp. 38-66.

36 Cfr. Dosi, G., Technical Change and Industrial Transformation the Theory and an Application to the Semiconductor Industry, cap. 2.

37 Cfr. Dosi, G., "Sources, Procedures, and Microeconomic Effects of Innovation", p. 1127. 
pasadas que se van quedando anticuadas. Así, el diseño básico se mantiene mientras continúa desarrollándose de acuerdo a los mismos principios físicos, químicos y de ingeniería que le dieron carta de naturaleza, basándose a su vez en un conjunto de patentes conectadas de una $\mathrm{u}$ otra forma al original motor de explosión interna.

Un paradigma consiste, en sentido amplio, en diferentes innovaciones radicales (mutaciones) unidas a conjuntos de innovaciones menores basadas en múltiples acumulaciones de conocimientos a lo largo del tiempo. Esto es lo que da la característica de continuidad al cambio tecnológico. Esas innovaciones menores han sido el fruto de la exploración de variaciones siguiendo diferentes vías y que han sido testadas, desde el punto de vista de su utilidad y funcionamiento, antes de salir al mercado ${ }^{38}$.

Mantener esta idea en la mente es esencial, ya que es como funciona el mecanismo de selección en la evolución de la Tecnología. Este mecanismo ofrece tanto al innovador como al imitador que no todas las posible variaciones de una innovación tengan que ser exploradas (lo que supondría estar constreñidos por la continua, gradual y aleatoria evolución gobernada por la Ley de Wolf). En otras palabras, el aprendiz elije los conocimientos que le resultan útiles y que están más próximos al paradigma en el que está inmerso, excluye los conocimientos obsoletos de ese paradigma y salva, si es posible, las nociones obsoletas o avanzadas por si éstas le resultaran útiles en el futuro.

\section{Conclusión}

En 1995 R. Nelson se preguntaba cuales serían las características de la teoría evolutiva relacionada con la Economía, y señalaba que para aplicar el término evolutivo a una teoría económica ésta debía seguir los siguientes criterios ${ }^{39}$ :

1. Cambio. Su objetivo tendría que tener en cuenta el movimiento de algo a lo largo del tiempo, o la explicación de la relación de algo que existe en un momento con respecto a lo que termina siendo. El análisis debería ser expresamente dinámico. La atención debería centrarse en el cambio de una variable o un sistema de variables y, desde un punto de vista teórico, en la razón de ese cambio.

2. Selección-adaptación. Debería presentar variables aleatorias. Variables susceptibles de modificación a través de variaciones y que darían origen a nuevas variables. Esas variaciones aparecerían a través de mecanismos que a la vez actuarían para mantener la variable estable, es decir, mecanismos de selección de variaciones que afectan a la variable pero que también actúan para fijarla en el sentido de una especialización particular.

3. Aprendizaje. Los procesos analizados deberían presentar la premisa de que existe inercia y que ésta refuerza la continuidad de aquellos que han sobrevivido en el proceso de selección. Estos procesos tendrían que estudiarse como si siguieran pautas, y como si aprendiesen de su propia experiencia, pero a la vez dependiendo de una selección aleatoria.

Bajo este conjunto de premisas (cambio, adaptación-selección y aprendizaje) en este trabajo hemos revisado tres ideas recurrentes en la Economía evolutiva: (i) la importancia

38 Cfr. Durand, T., "Dual Technological Trees: Assessing the Intensity and Strategic Significance of Technological Change", Research Policy, v. 21, (1992), p. 361.

39 Cfr. Nelson, R. R., "Recent Evolutionary Theorizing About Economic Change", Journal of Economic Literature, v. 33, (1995), pp. 48-90. 
de adoptar una perspectiva de análisis de las poblaciones; (ii) la curiosidad intrínseca del ser humano; y (iii) el cambio tecnológico, que se ha sintetizado en el concepto de paradigma tecnológico. Pero en cierto grado lo que he hecho es presentar la "prehistoria" de la Economía evolutiva.

En el presente la Neuroeconomía busca desde el lado neurológico las razones de los fenómenos de adaptación, selección y aprendizaje en los agentes económicos ${ }^{40}$. Su atención se fija en conocer el proceso y localización de la toma de decisiones económicas en el cerebro del ser humano. Estudia los partes del cerebro, los conjuntos neuronales y los estados mentales que se activan al tomar decisiones económicas. Al estudiar estas localizaciones se abren nuevos temas sobre la naturaleza evolutiva del ser humano, dese el hecho de plantearse el proceso de decisión hasta el hecho de que todas las decisiones (instrucciones) que intervienen en un determinado comportamiento. ¿Cómo se mantienen, replican y se modifican en el cerebro instrucciones y comportamientos? ¿Pueden evolucionar esas instrucciones y comportamientos? ¿Pueden infestar o reproducirse en otros cerebros?

En mi opinión, lo mejor que nos ofrece la Neuroeconomía son las posibilidades y criterios para formalizar mejor la Teoría de Juegos evolutiva y la formalización microeconómica ortodoxa (la conducta basada en el concepto de utilidad), que tantas posibilidades de análisis han dado hasta la fecha ${ }^{41}$. Pero es obvio que habría que abrirse a otros puntos de vista que proceden de las otras Ciencias que también estudian el comportamiento humano (la Etología humana, la Psicología, la Inteligencia Artificial y la Sociobiología).

Partiendo de estas disciplinas se podría resaltar que la Teoría de Juegos evolutiva nos permite llevar a cabo un examen sistemático y combinado de los ingredientes del proceso evolutivo (selección, adaptación y aprendizaje) sin destruir el concepto de utilidad tan característico de la Ciencia económica. Por ingredientes en los juegos evolutivos debemos entender los agentes (jugadores, compañías y organizaciones creadas por los humanos), las acciones (comportamientos posibles procedentes de la imitación o de la invención de cada agente en el proceso de juego), los pagos (recompensas por las acciones realizadas a la que hay que restar los costes presentes en el juego, tanto si se está activo como si no), el nacimiento y la muerte (en este sentido la muerte o existencia de los jugadores depende de su capacidad para obtener un mínimo de pagos positivos al ejecutar las acciones, y nacimiento los pagos por reproducirse) y los intervalos entre las fases de información (entre acción y acción hay tiempos de transmisión y de asimilación).

Este tipo de formalización permite detectar aparentes paradojas en el comportamiento utilitarista esperado. Aparece así la cuestión clave: ¿por qué los individuos toman decisiones aparentemente equivocadas o decisiones contrarias a su propio interés? El hecho es que no tenemos una respuesta concreta. Tenemos la idea de la utilidad vista ésta a lo larga del ciclo vital (utilidad diferida), propia de los análisis de Becker; y tenemos diferentes nociones de

40 Cfr. Glimcher, P. W. y Rustichini, A., "Neuroeconomics: the Consilence of Brain and Decision", Science, v. 306, (2004), pp. 447-452; y Aunger, R., The Electric Meme, The Free Press, N. York, 2002.

41 Cfr. Maynard Smith, J., Evolution and the Theory of Games, passim; Fundenberg, D. y Tirole, J., Game Theory, The MIT Press, Cambridge, MA, 1991; Vega Redondo, F., "Technological Change and Institutional Inertia: A Gametheoretic Approach", Journal of Evolutionay Economics, v. 3, (1993), pp. 199-224; VegA Redondo, F., "Evolución y estrategia: Teoría de Juegos con agentes limitados y un contexto cambiante", Hacienda Pública Española, v. 125, n. 2, (1993), pp. 127-142; Vega Redondo, F., Evolution, Games, and Economic Behavior, Oxford University Press, Oxford, 1996; y Vega Redondo, F., Economics and the Theory of Games, Cambridge University Press, Cambridge, 2003. 
altruismo que nos llevan a entender algunas de sus formas como un egoísmo en el largo plazo. Pero estas respuestas a veces son más bien intuiciones.

Sabemos por intuición que somos seres utilitaristas, pero sabemos que no siempre somos utilitaristas. La solución a esas paradojas desde el punto de vista económico venía siendo decepcionante. Una opinión era que se debían aislar esos casos a la espera de mayores avances en la formalización de nuestros modelos. La otra alternativa era rechazar el problema: clasificarlo como irracionalidad y descartarlo como comportamiento económico irrelevante. Más reciente se mira hacia las Ciencias que se ocupan de entender el cerebro, lo que ha dado origen a la Neuroeconomía que nos va mostrando lentamente como operan las decisiones económicas en el cerebro.

Cuando llegamos a una paradoja en el comportamiento humano (comportamientos no utilitaristas), ésta se puede formalizar por medio de la Teoría de Juegos evolutiva, ya que captan su relación con el proceso evolutivo de la especie. Llegados a ese punto, podemos tan solo argumentar que las paradojas se dan porque, como sostiene el evolucionismo, las acciones humanas están controladas, tanto por la lucha por el espacio (obtener comida para mantenerse uno mismo), que nos llevaría al comportamiento utilitarista, como por la lucha por reproducirse (dedicar recursos a mantener la prole), que nos llevaría al comportamiento altruista. Un comportamiento que en la Economía ortodoxa no tiene un concepto de referencia tan claro como el utilitarismo. Así, si no consideramos ambos lados estaremos encontrando paradojas donde realmente sólo hay un espejo con dos reflejos: el reflejo del comportamiento reproductivo maximizador (más intuitivo que consciente) y el reflejo del comportamiento utilitarista individual (más consciente que intuitivo).

Así pues, si sustituimos visiones basadas en el utilitarismo (aunque sea a largo plazo y utilizando utilidades diferidas) por visiones basadas en el doble fenómeno de la adaptación y la reproducción ¿qué es lo que pasa? La cuestión clave que emerge es que, mientras intentamos entender los procesos estudiados por la Neuroeconomía, ¿podemos decir qué en realidad los dos comportamientos actúan en el cerebro al unísono? La respuesta, aún débil, es que sí, tal y como intuyera hace tres siglos Espinoza y la Ilustración no admitiera. En cualquier caso, es necesario multiplicar los experimentos y diseñar los dilemas y proponer las situaciones para las tomas de decisiones. Luego se precisa observar todo ello en el cerebro mejorando nuestros sistemas actuales de captación de las funciones en el cerebro, detectando los circuidos y relaciones que se activan en los estados mentales que contienen la acción que decidimos realizar.

Hoy, por ejemplo, ya podemos observar, dependiendo de las circunstancias, los circuitos neuronales del cerebro que están relacionados con la utilidad, y en el mismo instante, de acuerdo a las circunstancias, como se activan o no otra áreas que avisan de situaciones de riesgo. Normalmente son áreas asociadas con las decisiones para asegurarnos la supervivencia como especie, que bloquean o controlan a las anteriores (áreas dedicadas a decisiones basadas en la utilidad). Evidentemente, si hay reacciones en cadena en el cerebro (mapas neuronales) que identifican estados mentales de la mente que son activados por esos dilemas, entonces, la pregunta desde la perspectiva evolutiva que se debe planteare es: ¿esos estados mentales se reproducen, se modifican, evolucionan? ¿Se transmiten esos estados mentales a través de la actividad cultural? ¿En la Historia de la evolución, cuándo aparecieron (evolucionaron) estos mapas neuronales? ¿Son ellos los "memes"? 


\section{Bibliografía}

Alchian, A. A., "Uncertainty, Evolution and Economic Theory”, Journal of Political Economy, v. 58, n. 3, (1950), pp. 211-221.

Alcock, J., The Triumph of Sociobiology, Oxford University Press, Oxford, 1999.

Aunger, R., The Electric Meme, The Free Press, N. York, 2002.

Baran, P. A. y Sweezy, P. M., Monopoly Capital: An Essay on the American Economic and Social Order, Monthly Review Press, N. York, 1966.

Bergson, H., L'évolution créatrice, Les Presses universitaires de France, París, 1907. Edición inglesa: Creative Evolution, Dover, N. York, 1998.

Burns, A. F., Production Trends in the Unites States since 1870, National Bureau of Economic Research, N. York, 1934.

Coase, R. H., “The Nature of the Firm”, Economica, v. 4, n. 4, (1937) pp. 386-405.

Dosi, G., “Technological Paradigms and Technological Trajectories: A Suggested Interpretation of the Determinants and Directions of Technical Change", Research Policy, v. 11, n. 3, (1982) pp. 147-162.

Dosi, G., Technical Change and Industrial Transformation the Theory and an Application to the Semiconductor Industry, Macmillan, Londres, 1984.

Dosi, G., "Sources, Procedures, and Microeconomic Effects of Innovation", Journal of Economic Literature, v. 26, (1988), pp. 1120-1171.

Dosi, G., Freeman, C., Nelson, R., Silverberg, G. y Soete, L. (eds), Technical Change and Economic Theory, Printer Publisher, Londres, 1988.

Dosi, G., Pavitt, K. y Soete, L., The Economics of Technical Change and International Trade, Harvester Wheatsheaf, Londres, 1990.

Dosi, G., Giannetti, J. y Toninelli, P. A. (eds), Technology and Enterprise in a Historical Perspective, Oxford University Press, Oxford, 1992.

Durand, T., "Dual Technological Trees: Assessing the Intensity and Strategic Significance of Technological Change", Research Policy, v. 21, (1992), pp. 361-380.

Eibl-Eibesfeldt, I., Ethology: The Biology of Behavior, Holt-Rinehart, N. York, 1975.

Freeman, C., Clark, J. y Soete, L., Unemployment and Technical Innovation: A Study of Long Waves in Economic Development, Pinter, Londres, 1982.

Freeman, C. y Perez, C., "Structural Crises of Adjustment, Business Cycles and Invesment Behaviour”, en Dosi, G., Freeman, C., Nelson, R., Silverberg, G. y Soete, L. (eds), Technical Change and Economic Theory, Printer Publisher, Londres, 1988, pp. 38-66.

Fundenberg, D. y Tirole, J., Game Theory, The MiT Press, Cambridge, MA, 1991.

Gandolfi, A. E., Gandolfi, A. S. y Barash, D. P., Economics as an Evolutionary Science: From Utility to Fitness, Transaction Publishers, N. Brunswick, 2002.

Glimcher, P. W. y Rustichini, A., "Neuroeconomics: the Consilence of Brain and Decision", Science, v. 306, (2004), pp. 447-452.

Hodgson, G., Economics and Evolution. Bringing Life Back into Economics, Polity Press, Cambridge, 1993. 
Jevons, W. S., The Coal Question: An Inquiry Concerning the Progress of the Nation, and the Probable Exhaustion of Our Coal-Mines, Macmillan, Londres, 1866.

KeIrstead, B. S., The Theory of Economic Change, Macmillan, Toronto, 1984.

KuZnets, S. S., Secular Movements in Production and Prices Their Nature and Their Bearning Upon Cyclical Fluctuations, Houghton Mifflin-The Riverside Press, Cambridge, 1930.

Malthus, Th. R., Essay on the Principle of Population, $6^{\text {a }}$ edición, 2 vols., John Murray, Londres, 1826.

Marshall, A., Principles of Economics, Macmillan, Londres, 1890; 8a edición, Macmillan, Londres, 1948.

Maynard Smith, J., Evolution and the Theory of Games, Cambridge University Press, Cambridge, MA, 1982.

Meadows, D. H., Meadows, D. L., Randers, J. y Behrens III, W. W., The Limits to Growth: A Report for the Club of Rome's Project on the Predicament of Mankind, Universe Books, N. York, 1972.

Metcalfe, J. S., "Impulse and Diffusion in the Study of Technical Change", Futures. The Journal of Forecasting and Planning, v. 13, n. 5, (1981), pp. 347-359.

Mokyr, J., The Lever of Riches: Technological Creativity and Economic Progress, Oxford University Press, Oxford, 1990.

Nelson, R. R. y Winter, S. G., An Evolutionary Theory of Economic Change, Harvard University Press, Cambridge, MA, 1982.

Nelson, R. R., "Recent Evolutionary Theorizing About Economic Change", Journal of Economic Literature, v. 33, (1995), pp. 48-90.

North, D. C., Institutions, Institutional Change and Economic Performance, Cambridge University Press, Cambridge, 1990.

North, D. C. y Wallis, J. J., "Integrating Institucional Cange and Technical Change in Economic History. A Transaction Cost Approach", Journal of Institucional and Theoretical Economics, v. 150, n. 4, (1994), pp. 609-624.

PACEy, A., Technology in World Civilization, Basil Backwell, Oxford, 1990.

Perez, C. y Soete, L., "Catching up in Technology: Entry Barriers and Windows of Opportunity", en Dosi, G., Freeman, C., Nelson, R., Silverberg, G. y Soete, L. (eds), Technical Change and Economic Theory, Printer Publisher, Londres, 1988, pp. 458-479.

Rosenberg, N., Inside the Black Box: Technology and Economics, Cambridge University Press, Cambridge, 1990.

Rosenberg, N., The Emergence of Economic Ideas. Essays in the History of Economics, Edward Elgar, Cambridge, 1994.

SAHAL, D., "Technology Guide-Post and Innovation Avenues", Research Policy, v. 14, n. 2, (1985), pp. 61-82.

Schumpeter, J., Theory of Economic Development, Harvard University Press, Cambridge, 1911, 2a edición 1934 (reimpreso en 1961).

Schumpeter, J. A., Business Cycles. A Theoretical, Historical and Statistical Analysis of the Capitalist Process, McGraw-Hill, N. York, 1939.

Schumpeter, J. A., Capitalism, Socialism, and Democracy, Harper, N. York, 1942.

Schumpeter, J. A., "The Creative Response in Economic History", Journal of Economic History, v. 7, (1947), pp. 149-159. 
Simon, H. A., Models of Bounded Rationality, vols. 1 y 2, The MIT Press, Cambridge, MA, 1982.

Simon, H. A., Reason in Human Affairs, Stanford, Stanford University Press, 1983.

Tirole, J., The Theory of Industrial Organization, The MIT Press, Cambridge, MA, 1988.

Tomasello, M., Carpenter, M., Call, J., Behne, T. y Moll, H., "Understanding and Sharing Intentions: The Origins of Cultural Cognition", Behavioral and Brain Sciences, v. 28, (2005), pp. 675-691.

Usher, A. P., A History of Mechanical Inventions, Harvard University Press, Harvard, edición revisada, 1954 ( $1^{\text {a }}$ edic., 1929).

Veblen, Тн., "Why is Economics not an Evolutionary Science?", The Quarterly Journal of Economics, v. 12, n. 4, (1898), pp. 373-397.

Veblen, Th., The Theory of the Leisure Class: An Economic Study of Institutions, Macmillan, N. York, 1899 (reimpreso por George Allen y Unwin, Londres, 1949).

Veblen, T., The Instinct of Workmanship and the State of the Industrial Arts, The Macmillan, N. York, 1914.

Veblen, Th., The Place of Science in Modern Civilisation and Other Essays, Augustus Kelly, N. York, 1919.

Veblen, Th., The Engineers and the Price System, The Viking Press, N. York, 1921.

Veblen, Th., Essays on Our Changing Order, edición de L. Ardzrooni, The Viking Press, N. York, 1934.

Vega Redondo, F., “Technological Change and Institutional Inertia: A Game-theoretic Approach”, Journal of Evolutionay Economics, v. 3, (1993), pp. 199-224.

Vega Redondo, F., "Evolución y estrategia: Teoría de Juegos con agentes limitados y un contexto cambiante", Hacienda Pública Española, v. 125, n. 2, (1993), pp. 127-142.

Vega Redondo, F., Evolution, Games, and Economic Behavior, Oxford University Press, Oxford, 1996.

Vega Redondo, F., Economics and the Theory of Games, Cambridge University Press, Cambridge, 2003.

Wilson, O., Consilence, Knopf, N. York, 1998.

Wolf, J., Die Volkswirtschaft der Gegenwart und Zukunft, A. Deichertsche Verlagsbuchhandlung, Leipzig, 1912.

Wrangham, R., C Catching Fire. How Cooking Made Us Human, Basic Books, N. York, 2009.

Young, R. M., "Malthus and the Evolutionists: The Common Context of Biological and Social Theory", Past and Present, v. 43, (1969), pp. 109-145. 


\title{
LA IDEA de EVOLUCión EN HAYEK: INSTITUCIONES, ORDEN SOCIAL Y PROCESO ECONÓMICO
}

\author{
Jose Luis Ramos Gorostiza
}

\section{INTRODUCCIÓN}

Aunque desde la década de 1980 parece haberse ido consolidando una corriente de Economía evolucionista, con revistas especializadas, congresos internacionales y asociaciones diversas, la presencia de la metáfora evolucionista en Economía ha sido muy poco importante, al menos hasta su aplicación relativamente reciente a la teoría de la empresa, de la mano de autores como Nelson y Winter ${ }^{1}$. Es más, la idea de evolución no sólo ha tenido poca presencia en la Historia del Pensamiento económico, sino que cuando se ha aludido abiertamente a ella se ha hecho a menudo en un sentido muy vago y general, refiriéndose a la simple noción de cambio, o bien en un tono de mera declaración de intenciones, al modo de Alfred Marshall.

En cualquier caso, lo importante es destacar que las concepciones económicas donde el evolucionismo ha tenido mayor peso, aunque con frecuencia en un sentido inadecuado, son las de aquellos economistas con una visión menos restrictiva del hecho económico, que han otorgado un papel destacado a las instituciones en el funcionamiento de la Economía, y que han intentado adoptar una perspectiva dinámica sobre dicho funcionamiento. Nombres como los de Marx, Menger, Veblen, Schumpeter o Hayek — que Geoffrey Hodgson cita en su libro Economía y evolución ${ }^{2}$, al hacer una revisión de la Historia de las ideas económicas-, u otros como los de Boulding o Hirshleifer, son representativos en este sentido. No en vano, se trata de economistas que de un modo u otro se alejan de la concepción económica que ha venido siendo dominante desde finales del siglo XIX: a-institucional, basada en la estática y el equilibrio, centrada en el corto plazo, y crecientemente formalizada en términos matemáticos. Es decir, estos economistas intentaron apartarse, en mayor o menor medida, de la analogía mecanicista que ha impregnado la teorización económica desde que los autores marginalistas tomaron como modelo a la Física clásica para poner las bases de lo que sería la Microeconomía actual.

De entre todos los economistas citados, Hayek es quizá el que ha hecho un mayor esfuerzo explícito por dar amplia cabida en su obra a la idea de evolución de un modo coherente, en conexión con la importancia otorgada al estudio de las instituciones humanas. No es casualidad que precisamente estemos hablando de un autor atípico por su amplitud de miras, que se interesó por la Ciencia Política, el Derecho, la Economía e incluso la Psicología teórica, intentando integrar todos estos campos a la hora de analizar el proceso de mercado. De hecho, recibió el Nobel en 1974 por su análisis de la interdependencia entre aspectos sociales,

\footnotetext{
1 Cfr. Nelson, R. R. y Winter, S. G., An Evolutionary Theory of Economic Change, Harvard University Press, Cambridge, MA, 1982.

2 Hodgson, G., Economics and Evolution, Polity Press, Cambridge, 1993.
} 
económicos e institucionales. Con su peculiar concepción económica, inscrita en la tradición austriaca que inauguró Menger, intentó ir, por tanto, mucho más allá de las estrechas fronteras de la Economía convencional que hoy recogen los manuales.

Hayek es una figura central en la Economía del siglo XX y un destacado representante de la tradición austriaca. Las más importantes aportaciones hayekianas, como la idea del sistema de precios como red de información, han sido incorporadas a la corriente principal de la literatura económica. Hoy en día, como ha señalado Peter Boettke ${ }^{3}$, la influencia de Hayek puede apreciarse en las investigaciones sobre aspectos cognitivos desarrolladas por Timur Kuran y Douglass North ${ }^{4}$. También, por ejemplo, en los trabajos de Mancur Olson y Andrew Shleifer sobre calidad institucional ${ }^{5}$, o en los trabajos sobre la relevancia del entorno institucional, fomentando la cooperación y minimizando el conflicto ${ }^{6}$. Finalmente, hay asimismo una línea de investigación sobre la importancia de la empresarialidad para entender el crecimiento económico y el proceso competitivo de mercado ${ }^{7}$. Pero la influencia de Hayek ha ido más allá de la Economía, debido a sus ya aludidas contribuciones en el ámbito de la Filosofía y de la Ciencia Política, así como en los campos de la Psicología y del Derecho.

Este trabajo analiza el evolucionismo en Hayek ligado a la idea de cambio institucional. Hayek otorgaba un papel decisivo en el orden social y en el proceso de mercado a las instituciones, a las que mayoritariamente suponía un origen espontáneo y un carácter evolutivo. El grueso del capítulo se centrará precisamente en exponer y discutir la consistencia de este planteamiento (apartado 4). Pero antes se hará una breve referencia al lugar que la idea de evolución ha tenido en Economía (apartado 2), con objeto de situar y desatacar la singularidad o rareza del evolucionismo hayekiano en la Historia de esta disciplina. Asimismo, se hará alusión a la influencia que el propio Hayek consideraba que habían ejercido los primeros economistas, como Smith o Malthus, en el surgimiento de la idea de evolución biológica (apartado 3). Por último, el trabajo se cerrará con una sección dedicada a conclusiones (apartado 5).

\section{El evolucionismo en la Historia del Pensamiento económico: La singularidad} DE HAYEK

En el lenguaje del Pensamiento social, el término "evolución" para indicar cambio continuado por medio de pequeños pasos, frente al uso del término "revolución" para aludir a una transformación súbita y grande del orden social, es anterior a la publicación de El origen de las especies (1859) en al menos dos siglos ${ }^{8}$. Pero tras la aparición de la obra de Darwin, la caracterización del desarrollo socio-cultural como un proceso de acumulación continua de pequeños

\footnotetext{
3 Cfr. Boettke, P., "Hayek and Market Socialism: Science, Ideology and Public Policy", London School of Economics, conferencia, 19 de octubre de 2004, pp. 10-11.

4 Cfr. Kuran, T., Private Truths, Public Lies, Harvard University Press, Cambridge, MA, 1995; y North, D. C., Understanding the Process of Economic Change, Princeton University Press, Princeton, 2004.

5 Cfr. Olson, M., Power and Prosperity, Basic Books, N. York, 2000; y Shleifer, A. ET Al., “The New Comparative Economics”, Policy Research Working Paper Series 3054, Banco Mundial, N. York, 2003.

6 Véase, por ejemplo, Ostrom, E. Gibson, C., Shivakumar, S. y Andersson, K., Aid, Incentives and Sustainability, Swedish International Development Cooperation Agency (SIDCA), Estocolmo, 2002.

7 Véase, por ejemplo, Baumol, W., The Free-Market Innovation Machine, Princeton University Press, Princeton, 2002.

8 Cfr. Gordon, S., The History and Philosophy of Social Science, Routledge, Londres, 1991, p. 538.
} 
cambios, en vez de saltos bruscos e inconexos, se empezó a enfatizar abiertamente entre los científicos sociales, como hizo por ejemplo el economista y politólogo Walter Bagehot ${ }^{9}$.

Sin embargo, más allá de esta idea de cambio gradual referida a los fenómenos sociales en general, en el terreno concreto de la Economía, y más específicamente en la corriente principal de esta disciplina, la idea de evolución no consiguió ningún arraigo efectivo, y ello a pesar de la gran admiración que el sociólogo Herbert Spencer suscitó en un economista de la importancia de Alfred Marshall, fundador de la tradición neoclásica. Spencer, que siempre se mostró muy interesado por la Biología, fue un evolucionista lamarckiano ya antes de la publicación del libro de Darwin ${ }^{10}$, y pretendió describir la evolución cultural del organismo social como un proceso adaptativo, donde ciertos caracteres sociales nacidos en un determinado momento podían ser transmitidos entre generaciones y retenidos por la cultura durante periodos muy prolongados, convirtiéndose así en elementos establecidos de la estructura social ${ }^{11}$. Asimismo, Spencer subrayó que el proceso evolutivo tendía a generar una heterogeneidad en constante aumento, manifestada en la sociedad en una creciente diferenciación funcional de instituciones e individuos.

Pues bien, Marshall sentía una profunda admiración por la obra de Spencer y mostraba un gran interés por la Biología, que se dejan notar especialmente en sus Principios de Economía $^{12}$. Sin embargo, aunque Marshall señaló que la Biología debía de ser la Meca del economista como fuente de inspiración y de metáforas adecuadas ${ }^{13}$, todo quedó en una mera declaración de intenciones de cara al futuro, cuando la Economía como Ciencia estuviera mucho más desarrollada. En la práctica, a la hora de elaborar su propia teoría económica, optó sin dudar por la analogía mecánica: "los conceptos biológicos son mucho más complejos que los de la mecánica; por ello, un libro de Fundamentos tiene que dedicar un espacio relativamente importante a las analogías mecánicas; se hace un frecuente uso del término equilibrio, que sugiere algo parecido a una analogía estática" ${ }^{14}$. En realidad, Marshall no hizo más que

\footnotetext{
$9 \quad$ Frente a la visión tradicional de los historiadores, que tendían a centrarse en la Historia política y en una periodificación marcada por grandes acontecimientos (guerras, cambios dinásticos, etc.) que llevaban acarreadas transformaciones revolucionarias profundas y rápidas, Bagehot subrayó la idea de cambio gradual en su obra Física y política. Pensamientos sobre la aplicación de los principios de la "selección natural" y la "herencia" a la sociedad política (1872). Sin embargo, no utilizó para nada las ideas de competencia y supervivencia del más apto; su "aplicación" real de la Teoría de la Evolución fue muy pobre, restringiéndose prácticamente a la idea del gradualismo. En otras obras suyas, como La Constitución inglesa (1867) o Lombard Street (1873), también subrayó que la formación de las instituciones políticas y financieras de Gran Bretaña tuvo lugar de forma evolutiva, sólo en el sentido de la acumulación de pequeños cambios.

10 La idea de evolución lamarckiana, que Spencer intentó trasladar a la sociedad, consiste en la transmisión a la progenie de caracteres adquiridos en la adaptación al medio, mientras que la idea de evolución darwinista destaca que la progenie no es idéntica, heredando los distintos individuos caracteres diferentes a pesar de un origen común: debido a la presión poblacional, acaban sobreviviendo los individuos con variaciones genéticas que les permiten cierta ventaja sobre los demás en la adaptación al medio. En suma, Lamarck habla de transmisión hereditaria entre generaciones discontinuas de organismos (lo que no se adapta del todo bien a la Historia continuada de la sociedad), mientras Darwin subraya la acumulación continua de pequeños cambios o mutaciones a lo largo del tiempo en un proceso de selección natural de la especie en su conjunto.

11 Spencer fue incluso más lejos, afirmando que la evolución, presente en todos los reinos de la existencia, era un fenómeno universal e inevitable que derivaba de la naturaleza metafísica del cosmos. Por otra parte, llegó a vincular la Teoría de la Evolución y la idea de progreso, ligando así Ciencia y Ética. Por lo que se refiere al terreno de la política social, la obra de este autor inglés fue adoptada por muchos como bandera del "social-darwinismo", según el cual la competencia en un marco de laissez-faire actuaría como mecanismo de selección para la supervivencia de los más aptos.

12 Cfr. Marshall, A., Principles of Economics, Macmillan, Londres, 1890, $8^{\text {a }}$ edición, 1920 (reimp. en 1994), capítulo 8, libro IV.

13 Marshall, A., Principles of Economics, $8^{\mathrm{a}}$ edición, p. xii.

14 Principles of Economics, $8^{\mathrm{a}}$ edición, p. xii.
} 
ahondar en la línea que ya habían marcado autores del primer marginalismo como Walras o Jevons a comienzos de la década de 1870 , y que de hecho se acabaría convirtiendo en la de la corriente principal de la Economía.

El problema que se propusieron estudiar los marginalistas fue el de la asignación, lo que supuso el destierro de la dinámica económica de la agenda de trabajo de los economistas. Ya no se trataba de "investigar la naturaleza y causas de la riqueza de las naciones" en el largo plazo, sino de buscar la mejor utilización posible de unos medios dados entre diversos usos alternativos. Por tanto, las antiguas preocupaciones sobre el marco institucional, sobre los determinantes del incremento poblacional o sobre el papel de los recursos naturales en el crecimiento económico perdieron razón de ser, y con el abandono de la perspectiva dinámica se esfumó también la oportunidad de otorgar un papel destacado a la idea de evolución. La guía para desarrollar la cuestión de la asignación se buscó en la Física clásica ${ }^{15}$. De este modo, ante el triunfo de la analogía mecánica en la corriente principal de la Economía a finales del siglo XIX, la posibilidad de desarrollar un planteamiento evolucionista o de hacer uso de analogías biológicas quedó restringida a las posiciones críticas, como las representadas por Marx o Veblen, o a planteamientos que partiendo del modelo de equilibrio competitivo intentaban ir más allá, como en los casos de Menger o Schumpeter.

Marx conocía la obra de Darwin, del que fue contemporáneo, y parece que el libro de éste último causó en él una gran impresión ${ }^{16}$. Llegó incluso a elogiar el evolucionismo darwinista como "una base científico-natural para la lucha de clases en la Historia" ${ }^{17}$. Sin embargo, la concepción marxiana del cambio socioeconómico, por más que Marx y sobre todo Engels citaran a Darwin en diferentes contextos, no es en absoluto evolucionista en sentido darwinista, sino que es revolucionaria, marcada por la brusquedad y la discontinuidad. Además, tanto Marx como Engels rechazaban abiertamente el mecanismo de selección natural por basarse en la idea de inspiración maltusiana de la "lucha por la existencia" ${ }^{18}$.

Veblen, fundador del institucionalismo americano, rechazó abiertamente la analogía mecánica que fundamentaba la Economía neoclásica y buscó inspiración en la Biología, tal como expresó en un artículo de 1898 titulado “¿Por qué la Economía no es una Ciencia evolucionista?” ${ }^{19}$ De hecho, en su principal obra, la Teoría de la clase ociosa ${ }^{20}$, aparecían sugerentes intuiciones

\footnotetext{
15 "Todo sistema que implique un principio de conservación (medios dados) y una regla de maximización (satisfacción óptima) es una analogía mecánica", Georgescu-Roegen, N., The Entropy Law and the Economic Process, Harvard University Press, Cambridge, MA, 1971, reimpreso en 1976, pp. 318-319.

Por un lado, en virtud de las ideas de optimización y sustitución en el margen que caracterizan a los problemas asignativos, éstos eran especialmente susceptibles de ser tratados en lenguaje matemático. Por otro, la idea del equilibrio de fuerzas físicas parecía ser un buen modelo a seguir. Economistas como Jevons, Walras, Edgeworth, Pareto o Fisher reconocieron abiertamente su pretensión de elaborar una "mecánica del propio interés y la utilidad", Jevons, W. S., The Theory of Political Economy, Macmillan, Londres, 1871; reimpreso en Reprints of Economic Classics, Agustus Kelley, Nueva York, 1965, pp. xvii-xviii.

16 Cfr. Ureña, E. M., "Marx and Darwin”, History of Political Economy, v. 9, n. 4, (1977), pp. 548-559.

17 Citado en Hodgson, G., Economics and Evolution, p. 73.

18 Engels, que era quien se ocupaba de los temas de Ciencia, discutió explícitamente la teoría darwinista en la Dialéctica de la Naturaleza. Cfr. Engels, F., The Dialectics of Nature [escrita en 1866-1873, publicada en 1925], Progress Publishers, Moscú, 1954. Aceptaba la idea de evolución de Darwin, pero rechazaba la noción de "lucha por la existencia", que asociaba a Malthus. Para Engels, la "lucha por la existencia" era un débil apoyo ideológico dirigido a justificar la competencia capitalista.

19 Cfr. Sowell, T., "The Evolutionary Economics of Thorstein Veblen", Oxford Economic Papers, v. 19, n. 2, (1967), pp. 177-198.

20 Veblen, Th., The Theory of the Leisure Class: An Economic Study of Institutions, Macmillan, Nueva York, 1899; reimpreso por George Allen and Unwin, Londres, 1949.
} 
evolucionistas. Por ejemplo, la idea de que las instituciones, que para él eran hábitos de pensamiento estables o rutinarios que compartían gran número de personas en una sociedad, proporcionaban estabilidad y garantizaban un principio de continuidad y herencia a lo largo del tiempo, y eran a la vez objeto de procesos de mutación y selección, de forma que las instituciones bien adaptadas se multiplicaban y eran imitadas mientras que las peor adaptadas se extinguían ${ }^{21}$. Asimismo, Veblen señaló al cambio técnico como uno de los principales motores del avance económico cuyo estudio necesariamente habría de llevarse a cabo desde una perspectiva evolutiva. Sin embargo, su imprecisión y el modo asistemático de expresión de sus ideas, junto al limitado grado de desarrollo de la Biología de su tiempo, que impedía comprender plenamente los mecanismos de la evolución, hicieron que Veblen no llegara a construir una teoría evolucionista coherente y acabada.

Por lo que se refiere a Schumpeter (1979 [1912]), hoy es considerado como el principal referente de la Economía evolucionista por su teoría de la innovación basada en una peculiar visión de la función empresarial, que remite a la idea de cambio económico endógeno. Pero además de esta concepción de su Teoría del desarrollo económico ${ }^{22}$, se ha querido ver también en la idea "destrucción creadora", que Schumpeter asociaba al capitalismo, una clara analogía con la idea de "selección natural". Sin embargo, el punto de partida de la dinámica que plantea Schumpeter es en todo momento el admirado modelo de equilibrio general walrasiano, con el que intentó compatibilizar, no sin grandes dificultades, su teoría del desarrollo económico; de hecho, nunca consideró la Biología como fuente de inspiración teórica. Por otra parte, la idea de un capitalismo sujeto a constantes innovaciones perturbadoras remite a una transformación económica más "revolucionaria" que "evolutiva" (en el sentido de continuidad y acumulación de pequeños cambios). Por tanto, podemos convenir con Hodgson en que, a pesar de seguir siendo una fuente de inspiración valiosa para los teóricos de los sistemas económicos dinámicos, "Schumpeter no proporciona ni una teoría sistemática ni un compendio ideal para una Economía evolucionista nueva" ${ }^{23}$.

Menger, fundador de la Escuela Austriaca de Economía, intentó aplicar la metáfora evolucionista al análisis del surgimiento de las instituciones sociales. Menger abrió el camino para el posterior análisis de Hayek, y por tanto su contribución se considerará conjuntamente con la de éste en el apartado 4. Baste señalar aquí que, si bien Menger es hoy considerado, junto a Walras y Jevons, uno de los fundadores del marginalismo al haber formulado la teoría subjetiva del valor al mismo tiempo que éstos, su enfoque es, de hecho, bien distinto, inaugurando una nueva forma de aproximarse a la realidad económica alejada del equilibrio estático y del agente maximizador perfectamente racional (véase la sección 4).

De este breve repaso de lo que ha sido la idea de evolución en la Historia del Pensamiento, cabe concluir que su presencia ha sido muy poco significativa y ha estado vinculada a autores con una amplia visión del proceso económico, alejada de un modo u otro de la concepción que ha dominado la corriente principal — a-institucional, basada en la estática y el equilibrio, y centrada en el corto plazo-. Asimismo, dado el pobre panorama evolucionista en Economía, la obra de Hayek se antoja particularmente importante, pues — como se tendrá ocasión de

\footnotetext{
21 El "principio de la mera curiosidad" era para Veblen, a su vez, la fuente de variación o mutación en el proceso evolutivo.

22 Schumpeter, J., Theory of Economic Development, Harvard University Press, Cambridge, 1911, 2a edición 1926, traducida del alemán al inglés en 1934 (reimpr. en 1961).

23 Hodgson, G., Economics and Evolution, p. 151.
} 
comprobar - él ha sido quizá el economista que, explícitamente, ha intentado elaborar un planteamiento evolucionista más amplio, desarrollado y coherente.

Por último, cabe señalar que hoy la Economía evolucionista vive un momento de apogeo que se inició en la década de 1980. Antes de esta fecha Kenneth Boulding fue el principal promotor de un maridaje entre Economía y Biología a través de varios libros imbuidos de preocupaciones medioambientales, aunque también hubo otros economistas, como J. Hirshleifer, que intentaron establecer interesantes paralelismos en algunos textos concretos ${ }^{24}$.

Pero el verdadero punto de inflexión se sitúa cuando Nelson y Winter ${ }^{25}$ plantearon una convincente teoría evolutiva de la empresa, donde las rutinas organizativas se equiparaban a los genes, ciertos caracteres adquiridos por adaptación al medio se consideraban heredables (al modo lamarckiano), la fuerza de la competencia en el mercado se tomaba como mecanismo de selección, y la analogía de la mutación se aplicaba a los sistemas económicos ${ }^{26}$. A partir de entonces la idea de Economía evolutiva se ha desarrollado en distintos ámbitos, aunque el mundo de la empresa sigue siendo quizá el campo de desarrollo más destacado ${ }^{27}$.

\section{LAS CONCEPCIONES SOCIOECONÓMICAS Y EL SURGIMIENTO DE LA IDEA DE EVOLUCIÓN DARWINISTA: LA VISIÓN DE HAYEK}

Para entender bien el interés de Hayek por la analogía evolucionista es preciso tener en cuenta su combativa postura frente al ingenierismo social y la imitación acrítica por parte de la Economía de analogías procedentes de la física. De hecho, Hayek acuñó el término "cientifismo" (scientism) para aludir a la indebida aplicación del método propio de las Ciencias

24 Por ejemplo, Boulding, K., A Primer on Social Dynamics: History as Dialectics and Development, The Free Press, Nueva York, 1970; Boulding, K., Ecodynamics: A New Theory of Societal Evolution, Sage, Beverly Hills, 1978; Boulding, K., Evolutionary Economics, Sage, Beverly Hills, 1981; Hirshleifer, J., "Economics from a Biological Viewpoint", Journal of Law and Economics, v. 20, n. 1, (1977), pp. 1-52; HirshleIfER, J., "Competition, Cooperation and Conflict in Economics and Biology", American Economic Review, v. 68, n. 2, (1978), pp. 238-243; y HIRSHLEIFER, J., "Natural Economy versus Political Economy", Journal of Social and Biological Structures, v. 1, (1978), pp. $319-337$.

25 Nelson, R. R. y Winter, S. G., An Evolutionary Theory of Economic Change, Harvard University Press, Cambridge, MA, 1982.

26 Ya antes había habido interesantes planteamientos evolucionistas en relación a la empresa, pero sin llegar a conformar una teoría acabada como la de Nelson y Winter. Por ejemplo, Penrose, E. T., "Biological Analogies in the Theory of the Firm", American Economic Review, v. 42, n. 5, (1952), pp. 804-819.

27 Por ejemplo, véase Aldrich, H., Organizations Evolving, Sage, Londres, 1999; Langlois, R. N. y Robertson, P. L., Firms, Markets and Economic Change: A Dynamic Theory of Business Institutions, Routledge, Londres, 1995; o Sutton, J., Technology and Market Structure: Theory and History, The MIT Press, Cambridge, MA, 1998.

También pueden encontrarse planteamientos evolutivos, entre otras disciplinas, en Microeconomía y Teoría de Juegos. Por ejemplo, Bowles, S., Microeconomics: Behaviour, Institutions and Evolution, Princeton University Press, Princeton, NJ, 2003; Gintis, H., Game Theory Evolving: A Problem-Centered Introduction to Modeling Strategic Interaction, Princeton University Press, Princeton, 2000; o SAmuelson, L., Evolutionary Games and Equilibrium Selection, The MIT Press, Cambridge, MA, 1997. Y en Economía internacional, como DE LA Mothe, J. y Paquet, G. (eds), Evolutionary Economics and the New International Political Economy, Pinter, Londres, 1996.

En el ámbito concreto del análisis institucional cabría destacar obras como las de Young, H. P., Individual Strategy and Social Structure: An Evolutionary Theory of Institutions, Princeton University Press, Princeton, NJ, 1998; o Vromen, J. J., Economic Evolution: An Inquiry into the Foundations of the New Institutional Economics, Routledge, Londres, 1995.

Para una revisión global de la literatura económica evolucionista véase Nelson, R. R., "Recent Evolutionary Theorizing About Economic Change", Journal of Economic Literature, v. 33, (1995), pp. 48-90; y Valdaliso, J. M. y LoPEZ, S., "Economía y evolución. Un enfoque multidisciplinar", Revista Anthropos, n. 182, (1999), pp. 21-26.

Sobre el paradigma evolucionista en general, véase, por ejemplo, HanAPPI, H., Evolutionary Economics: The Evolutionary Revolution in the Social Sciences, Avebury Publishers, Aldershot, 1994; o Andersen, E. S., Evolutionary Economics: Post-Schumpetrian Contributions, Pinter, Londres, 1996. 
de la Naturaleza al campo de las Ciencias Sociales, cuando ni es posible la experimentación controlada, ni hay registros sistemáticos de datos exactos, ni existen invariantes cuantitativas o relaciones funcionales que permitan el empleo del lenguaje matemático ${ }^{28}$.

Como se ha apuntado anteriormente, el triunfo de la analogía mecánica en la corriente principal de la Economía se asocia a la revolución marginal y a la estrecha imitación de los métodos y el lenguaje de la Física que ésta trajo consigo, y que Hayek criticó con dureza. De hecho, la cronología y el contenido intelectual del primer marginalismo pueden ser explicados por desarrollos paralelos en la Física de mediados del siglo diecinueve. Como señala Mirowski ${ }^{29}$, el auge de la energética en la Física fue fundamental para el nacimiento de la teoría neoclásica en la medida en que proporcionó unidad: una metáfora de enorme importancia (el principio de conservación), unas técnicas matemáticas como nuevo modo de expresión, y unas nuevas actitudes hacia la construcción de la teoría. En algunos casos, la formulación de los problemas llegó incluso al mimetismo absoluto, hasta el extremo de llegar a sustituir simplemente el término energía por el de utilidad en las mismas ecuaciones ${ }^{30}$. En realidad, con la excepción de Marshall, los marginalistas no plantearon adecuadamente la analogía mecánica ni entendieron plenamente las restricciones que ésta suponía para el desarrollo de la teoría económica.

Hayek, consciente de las limitaciones que había conllevado el uso y abuso de la analogía mecánica en Economía, y con una peculiar concepción dinámica del proceso económico propia de la Escuela Austriaca — a la que se ha alude en la sección siguiente_, volvió la vista hacia la idea de evolución, siguiendo la estela que había marcado Menger. Y, como se tendrá ocasión de comprobar más tarde, no sólo intentó aplicarla a su explicación del cambio socioeconómico e institucional, sino que también se interesó por la relevancia que ciertas ideas económicas del siglo XVIII pudieron tener en el surgimiento de la idea darwiniana de evolución biológica.

Consideraba Hayek la obra de Darwin como la culminación de un desarrollo que había comenzado en Mandeville y la Ilustración escocesa (Hume, Ferguson, Smith, etc.) ${ }^{31}$. Es decir, la idea de evolución — tomada en un sentido muy general - era mucho más antigua en las Ciencias Sociales que en las Ciencias de la Naturaleza, y se relacionaba con el surgimiento de la ley, la moral, el derecho, el dinero, el mercado o el lenguaje. En el siguiente texto Hayek se expresa en este sentido con amplitud:

"La tradición iniciada por Mandeville alcanza también a Edmund Burke y, en gran medida a través de Burke, a todas las 'Escuelas históricas' que, sobre todo en el continente y a través de hombres como Herder y Savigny, hicieron de la idea de evolución un lugar común en el siglo XIX, mucho tiempo antes de Darwin. Y fue en esta atmósfera del Pensamiento evolutivo en el estudio de la sociedad donde los 'darwinianos anteriores a Darwin' habían pensado largo tiempo en términos de predominio de hábitos y prácticas más eficaces en la que Charles Darwin aplicó finalmente la idea, de manera sistemática, a los organismos

28 Cfr. Hayex, F. A., The Counter-Revolution of Science: Studies on the Abuse of Reason, Collier-Macmillan, Londres, 1964.

29 Cfr. Mirowski, Pн., Against Mechanism: Protecting Economics from Science, Rowman and Littlefield, Lanham, MD, 1988, pp. 13 y 17.

30 Cfr. Mirowski, Ph., More Heat than Light. Economics as Social Physics: Physics as Nature's Economics, Cambridge University Press, Cambridge, 1989, pp. 222-231.

31 Cfr. Hayer, F. A., New Studies in Philosophy, Politics, Economics and the History of Ideas, Routledge and Kegan Paul, Londres, 1978, p. 265. 
biológicos. Por supuesto, no deseo sugerir que Mandeville ejerciera ninguna influencia directa sobre Darwin (aunque es probable que David Hume sí lo haya hecho). Pero me parece que, en muchos sentidos, Darwin es la culminación de un proceso iniciado por Mandeville en mayor medida que cualquiera otro hombre" ${ }^{32}$.

En otras obras, Hayek remarca la misma concepción, incluso de un modo más explícito que en el fragmento anteriormente transcrito, llegando a apuntar abiertamente que Darwin pudo inspirarse de forma indirecta en la idea de evolución cultural de Mandeville y Hume: "La idea de evolución cultural es indudablemente más antigua que el concepto biológico de evolución. Incluso es probable que su aplicación por parte de Charles Darwin a la Biología fuese, a través de su abuelo Erasmus, obtenida a partir del concepto de evolución cultural de Bernard Mandeville y David Hume, si es que no fue obtenida más directamente de las contemporáneas escuelas históricas de Derecho y de Filología" "33. Además, "las obras de Smith marcan el nacimiento de un enfoque evolucionista, que, poco a poco, fue desplazando la estática visión aristotélica" ${ }^{34}$

Curiosamente, sin embargo, Hayek no analiza la teoría evolucionista de Herbert Spencer, al que sólo cita de pasada y raramente, a pesar de haber sido uno de los grandes defensores del evolucionismo cultural. Llama la atención también que Hayek no se refiera abiertamente a Malthus al tratar el tema de la evolución, pues éste influyó en Darwin de forma clara. De hecho, las alusiones de Darwin a Malthus en su Autobiografía, en El origen de las especies y en otras publicaciones llevan a la conclusión de que la formulación de la Teoría de la Evolución en Biología debe mucho al desarrollo previo de la teoría de la población en Economía. La idea de presión demográfica sobre los 'medios de subsistencia' parece que fue básica para Darwin.

En concreto, lo que le abrió los ojos fue la afirmación de Malthus de que "la población, cuando no está controlada, crece en proporción geométrica": el naturalista se dio cuenta entonces de que hay una fuerza que actúa sobre los organismos en el estado natural análoga a la que ejercen los ganaderos y agricultores artificialmente cuando se proponen modificar las características de las plantas y animales domésticos: "El ganadero, por ejemplo, selecciona los pocos miembros del rebaño que tienen las características deseadas y sólo los aparea a ellos. [...] La idea básica de Darwin es que se produce un grado similar de selección en el estado de naturaleza si los animales procrean 'geométricamente': se producen constantemente muchas más crías de las que pueden alimentarse", y una elevada proporción de ellas no sobrevive hasta la edad reproductiva; sólo sobreviven los que están mejor adaptados a las condiciones ambientales, de forma que la población se mantiene estable ${ }^{35}$. La 'lucha por la existencia' a lo largo de numerosas generaciones producirá variedades modificadas, e incluso, la aparición de especies completamente nuevas.

El porqué de la sorprendente omisión de Spencer y Malthus en la obra de Hayek al tratar la cuestión de la evolución no está claro. En el caso de Spencer, probablemente se deba a que ha sido un autor cuya teoría social suscitó poco entusiasmo a lo largo del siglo XX e, incluso, se vio desprestigiada. El nombre de Spencer se vio vinculado al darwinismo social,

\footnotetext{
32 Hayek, F. A., The Trend of Economic Thinking: Essays on Political Economists and Economic History, Routledge, Londres, 1991, pp. 96-97.

33 Hayer, F. A., Law, Legislation and Liberty. Volume 3: The Political Order of a Free People, Routledge and Kegan Paul, Londres, 1979, p. 154.

34 Hayer, F. A., The Fatal Conceit, Routledge, Londres, 1990, p. 146.

35 Cfr. Gordon, S., The History and Philosophy of Social Science, pp. 541-542.
} 
al que Hayek alude de forma crítica en distintas ocasiones en su trilogía Derecho, legislación $y$ libertad. Por otra parte, aunque es cierto que Spencer comparte con Hayek una posición crítica frente al intervencionismo estatal y el positivismo jurídico, así como una idea de la sociedad como fruto espontáneo e inintencionado de innumerables acciones humanas, Hayek no habla e un organismo social que - al modo de un organismo individual — pasa por etapas de evolución, hacia formas más elevadas en complejidad y diferenciación social, de manera que la evolución conduce siempre al progreso. En el caso de Malthus, quizá sea el interés de Hayek por subrayar la aparición de un orden espontáneo, el mercado, en cuyo eficiente funcionamiento muestra gran confianza, lo que le hace destacar a Smith o Hume (en vez de a Malthus, que había señalado posibles problemas tanto en el funcionamiento del mercado — demanda insuficiente — como en la oscura situación social derivada del crecimiento poblacional). Además, para Hayek la civilización va asociada de algún modo al aumento de la población, pues ese aumento permite una mayor especialización, $y$, por consiguiente, una mayor productividad.

\section{La idea de Evolución EN HAYeK}

Como miembro de la Escuela Austriaca, Hayek tiene un claro punto de partida para sus ideas evolucionistas: la concepción austriaca de las instituciones sociales y del proceso económico, que fue desarrollada principalmente por Menger. Según Hayek, el conocimiento está contenido en las instituciones sociales, que son adaptaciones al entorno derivadas de la ignorancia humana. Aunque su visión de la evolución socioeconómica y cultural como proceso de adaptación de grupo es ciertamente atractiva y original, ha sido criticada desde diferentes perspectivas, en particular desde un punto de vista económico.

\subsection{La visión austriaca de las instituciones sociales: Orden espontáneo y carácter evolutivo}

Las ideas básicas de la escuela austriaca sobre la naturaleza y el papel de las instituciones derivan de Menger ${ }^{36}$, aunque tienen su base en la tradición del orden espontáneo, representada, entre otros, por Mandeville, Hume, Ferguson y Smith. Dichas ideas se inscriben y cobran pleno significado dentro de una particular concepción del proceso económico, caracterizada por el subjetivismo radical y la adhesión a un estricto individualismo metodológico, así como por la prevención frente a los agregados macroeconómicos y el uso de las matemáticas como lenguaje de expresión de la Economía.

Frente al modelo neoclásico del optante racional que, con una información perfecta y en un marco estático, maximiza su utilidad eligiendo siempre la mejor alternativa (u asignación de medios dados a fines dados), en el enfoque austriaco cada individuo busca sus propios fines, elabora expectativas y planes de acción, e intenta descubrir nuevas oportunidades de acuerdo a valoraciones subjetivas y a su propio conocimiento imperfecto de un mundo dinámico, en constante cambio o desequilibrio, donde el tiempo, la ignorancia, el error, los hábitos o las consecuencias no intencionadas de las acciones humanas tienen una importancia esencial.

Precisamente, el subjetivismo radical de la escuela austriaca y su énfasis en la idea de cambio, incertidumbre y desequilibrio, hacen que estos economistas estén muy interesados en

36 Mises y sobre todo Hayek, especialmente en referencia a la capacidad del mercado para difundir información a través del mecanismo de precios, serían quienes las desarrollarían más tarde. 
cómo adquieren información los individuos y cómo ésta se transmite por la sociedad. Y dado que para la escuela austriaca las instituciones desempeñan un papel crucial en la producción, transmisión y uso de la información, es especialmente importante desde esta perspectiva contar con una teoría adecuada sobre las mismas. Y es que el conocimiento - de tipo práctico e inarticulable - en parte se crea y se descubre constantemente a través de la interacción social, pero también se encarna en hábitos, tradiciones e instituciones sociales, transmitiéndose de generación en generación. Precisamente, el estudio de las instituciones, que facilitan la vida en común y la interacción social beneficiosa de multitud de agentes que persiguen fines particulares, era para Menger la tarea clave de las Ciencias Sociales, y a ella se aproximó —al igual que Hayek - desde una perspectiva evolutiva.

Carl Menger establecía una analogía entre los organismos naturales y aquellos fenómenos sociales que son el resultado no intencionado de un desarrollo histórico: “Cómo es posible que las instituciones, que sirven al bienestar común y son extremadamente significativas para que éste tenga lugar, existan sin que haya una voluntad común dirigida a su establecimiento? [...] La solución a los problemas más importantes de las Ciencias Sociales en general y de la Economía en particular está, por tanto, íntimamente ligada al entendimiento teórico del origen y el cambio de estas estructuras sociales 'orgánicamente' creadas" ${ }^{37}$.

Es decir, para Menger entender el funcionamiento de las instituciones era la clave que permitiría dar explicación a otros fenómenos económicos que compartían la misma naturaleza espontánea, derivada de la interacción de multitud de agentes que operan buscando su propio interés: "La ley, el lenguaje, el estado, el dinero, y otras estructuras sociales [...] son en buena medida el resultado de un desarrollo social no intencionado. Los precios de los bienes, las tasas de interés, las rentas, los salarios, y una multitud de otros fenómenos de la vida social en general y de la Economía en particular exhiben esa misma peculiaridad. Por ello, su comprensión [...] debe ser análoga a la comprensión de las instituciones sociales no creadas deliberadamente [...], [que son] resultado de innumerables esfuerzos de los sujetos económicos persiguiendo sus intereses individuales" ${ }^{38}$.

A pesar de que Menger reconocía la existencia de instituciones de origen pragmático (o deliberado) junto a las de carácter orgánico, creía que buena parte de las más importantes instituciones sociales (el mercado, el dinero, el lenguaje, las normas informales de comportamiento, etc.) obedecían a un orden espontáneo y eran las que realmente había que explicar, dada su relevancia. Popper sintetiza esta idea central para la escuela austriaca: "Sólo una minoría de las instituciones sociales son proyectadas conscientemente, mientras que la gran mayoría sólo han nacido como resultado impremeditado de las acciones humanas" ${ }^{39}$. Es decir, "las instituciones sociales no proyectadas nacen como consecuencias involuntarias de acciones racionales" ${ }^{40}$, de modo que, a partir de las actuaciones individuales, va surgiendo una estructura social de gran complejidad.

\footnotetext{
37 Menger, C., Untersuchungen über die Methode der Socialwissenschaften und der Politischen Oekonomie insbesondere, editado por Louis Schneider y traducido por F. J. Nock: Problems of Economics and Sociology, University of Illinois Press, Urbana, 1963, libro III, pp. 146-147.

38 Menger, C., Problems of Economics and Sociology, p. 147.

39 Popper, K., The Poverty of Historicism, Routledge and Kegan Paul, Londres, 1957, reimpreso en 1969, p. 65 (cursivas en el original).

40 Popper, K., The Poverty of Historicism, p. 65, nota (cursivas en el original).
} 
En sus Principios de Economía Política Menger realizó explícitamente una descripción del origen y la evolución del dinero a partir de su concepción orgánica ${ }^{41}$, pero no hizo lo mismo con otras instituciones a las que él atribuía en gran medida ese mismo carácter, como por ejemplo el Estado ${ }^{42}$, y que sin embargo no encajan bien en una explicación del tipo "mano invisible" 43 .

\subsection{El evolucionismo hayekiano: Las instituciones como condensado de conocimiento}

No es exagerado afirmar que sin instituciones no hay sociedad ni economía posible. Sería inimaginable que pudiéramos interactuar del modo en que lo hacemos cotidianamente: la incertidumbre y los costes de transacción serían inconmensurables, y tendríamos que procesar cantidades ingentes de información antes de tomar cualquier decisión, por simple que ésta fuera. Esta es la idea básica que subyace a la visión hayekiana de las instituciones.

Hayek sostiene que las instituciones sociales, los hábitos y las costumbres, las tradiciones y otros tipos de conducta regular encierran sabiduría, conocimiento de acción, "saber hacer", experiencia acumulada por generaciones y generaciones. En muchos casos desconocemos cuál es la razón de su forma actual ni cómo operan exactamente, pero lo que sí sabemos es que posibilitan la vida social ${ }^{44}$. El símil sería el de muchas de las herramientas que a menudo utilizamos: ignoramos “por qué estos instrumentos están hechos de una forma determinada, y no de otra, pues son producto de la experiencia de generaciones sucesivas que nos las han entregado. Cada vez que descubrimos un perfeccionamiento lo añadimos y lo entregamos a la generación siguiente; así esas herramientas encerrarán nuestra experiencia y el "saber" de las generaciones que nos han precedido" ${ }^{45}$.

41 Cfr. Menger, C., Grundsätze der Volkswirtschaftlehre, W. Braumüller, Viena, 1871. Vers. inglesa de J. Dingwall y B. Hoselitz: Principles of Economics, The Free Press, Glencoe, IL, 1950, pp. 257-271.

Como señala Hodgson, existe cierta semejanza entre la visión de Menger sobre la aparición y evolución del dinero, y el relato que sobre esta misma cuestión hace un institucionalista americano como Mitchell. Pero, sin embargo, cabe destacar dos diferencias importantes. En primer lugar, para Mitchell la cuestión de la aparición del dinero no puede limitarse sencillamente a la reducción de costes que supone o al hecho de facilitar las actividades comerciales de intercambio: "la penetración del intercambio monetario en la vida social alteró las mismísimas configuraciones de racionalidad, incluyendo las concepciones concretas de abstracción, medida, cuantificación y cálculo. Constituyó la transformación de los individuos, y no simplemente la aparición de unas instituciones y unas reglas", HodGSON, G., Economics and Evolution, pp. 118-119. En segundo lugar, para los "viejos" institucionalistas como Veblen o su discípulo Mitchell, la evolución es un proceso sin fin de causación acumulativa, donde las instituciones son a la vez causa y efecto; por el contrario, Menger parece suponer que el proceso evolutivo que describe terminará por alcanzar un estado final en que la unidad monetaria quede definitivamente establecida.

42 Cfr. Menger, C., Problems of Economics and Sociology, p. 156.

43 Según Hodgson, Menger no distingue adecuadamente entre aquellas normas y convenciones que se autorregulan y aquellas otras que precisan ser respaldadas por una red de otras instituciones —incluyendo el Estado- para garantizar su cumplimiento. Entre las primeras Hodgson señala la adopción del ancho de vía, usar el idioma siguiendo determinadas reglas lingüísticas, conducir por el lado derecho de la carretera, utilizar un determinado software muy generalizado, etc.; seguir estas reglas tiene externalidades de red, de forma que nos vemos "forzados" a utilizar o hacer algo simplemente porque otros lo utilizan o lo hacen, y no tenemos incentivo alguno para hacer otra cosa diferente. Sin embargo, la mayoría de las leyes y regulaciones (las leyes tributarias, los límites de velocidad, etc.) pertenecen al segundo grupo: precisan de algún tipo de intervención coactiva del Estado para evitar incumplimientos. Para Hodgson, el dinero está en este segundo grupo, de forma que el establecimiento de dinero legal por parte del Estado puede ser en ocasiones necesario para lograr un resultado más satisfactorio o para mantener un resultado (valor de la moneda) frente a cualquier perturbación o amenaza (Hodgson defiende esta afirmación a pesar de reconocer ciertas enseñanzas de la Historia monetaria: posibilidad de free banking, manipulación gubernamental de la moneda acompañada de grandes inflaciones, etc.). Hodgson, G., Economics and Evolution, pp. 117-118.

44 Cfr. Hayer, F. A., The Constitution of Liberty, Routledge and Kegan Paul, Londres, 1960, capítulo II, n. 3.

45 Cfr. Butler, E., Hayek. His Contribution to the Political and Economic Thought of our Time, Tempel-Smith, Londres, 1983, p. 42. 
Por tanto, las instituciones — según Hayek — son un recurso clave para que los individuos puedan desenvolverse satisfactoriamente en un mundo que conocen de manera muy imperfecta. Como sintetiza muy bien Paloma de la Nuez, "el conocimiento se incorpora en normas, hábitos, convenciones, tradiciones, y todo tipo de instituciones que no son sino adaptaciones al medio fruto de la ignorancia humana. La mayor ventaja de la civilización consiste precisamente en proporcionar a todos ese conocimiento de modo que pueda utilizarse individualmente para lograr fines personales [...]. La civilización [...] supone sobre todo crecimiento acumulativo de conocimiento; suma de experiencias humanas, de costosos ensayos y errores, que se transmite de generación en generación, bien como conocimiento explícito, bien como conocimiento tácito e inarticulable" ${ }^{46}$.

Hayek concibe la evolución socioeconómica y cultural como un proceso de adaptación grupal - no individual - en el que no hay plan o dirección preestablecida, y que nunca es lineal, continuo, uniforme, ya que a veces aparecen errores y retrocesos ${ }^{47}$. Los individuos se adaptan al entorno, a hechos y circunstancias concretas, mediante el sometimiento a unas normas que conforman su actuación y que no han sido diseñadas por reconocer en ellas de antemano los beneficios que podían reportar en el futuro. Las reglas de comportamiento están inmersas en un proceso de selección, de prueba y error, de forma que aquellas que han contribuido a la supervivencia, crecimiento y expansión de una sociedad permanecerán y probablemente serán incorporadas - imitadas - por otras sociedades. A la vista de la experiencia se modifican comportamientos o se ensayan otros nuevos ${ }^{48}$.

El desarrollo cultural descansa sobre la herencia, es decir, sobre la transmisión de conocimientos a través de generaciones de individuos ${ }^{49}$. En este sentido, se ha llegado a afirmar que las instituciones, los hábitos y rutinas sociales, y las estructuras organizacionales juegan un papel similar al de los genes en lo que se refiere a la transmisión de esa herencia de conocimiento práctico no articulable. La clave de la evolución cultural es el aprendizaje y la imitación.

Para Hayek, las normas explícitas formales — deliberadamente escogidas - no son más importantes que aquellas otras implícitas que seguimos pero que no podemos expresar con palabras, o las de origen consuetudinario aprendidas por el mero proceso de observarlas en acción. Todo este conjunto de reglas facilitan la interacción con los otros sin tener que preocuparnos

46 De La Nuez, P., La politica de la libertad. Estudio del Pensamiento politico de F. A. Hayek, Unión Editorial, Madrid, 1994, p. 200.

47 Cfr. Hayek, F. A., Law, Legislation and Liberty. Volume 1: Rules and Order, Routledge and Kegan Paul, Londres, 1977, pp. 17-19. Aunque el concepto de selección de grupo ha recibido fuertes críticas desde una perspectiva biológica, es sin embargo bastante apropiado desde una perspectiva socioeconómica. Por otra parte, Hayek no afirma con la rotundidad de Spencer que la evolución implique un progreso y una eficiencia crecientes, aunque en el fondo comparte esta idea. Es decir, Hayek — ante el ejemplo de los horrores totalitaristas del siglo XX — rechaza que la evolución conduzca de forma automática al progreso.

48 Cfr. Hayek, F. A., Law, Legislation and Liberty. Volume 1: Rules and Order, p. 19. Es decir, el proceso de cambio institucional es un proceso evolutivo, de forma que a largo plazo las instituciones sobreviven y se van adaptando mientras son útiles a la sociedad, en el sentido de contribuir a la supervivencia de una población creciente. Existe cierta analogía con la visión popperiana del método hipotético-deductivo en el proceso ciéntifico: las ideas son creadas y constantemente puestas a prueba, y la refutación de las ideas antiguas aporta un estímulo al desarrollo de nuevas ideas, que a su vez se someterán a prueba. Sin embargo, hay que tener en cuenta que el método popperiano es "absolutista": la nueva hipótesis es mejor que la refutada; en cambio, el análisis de las instituciones suele considerarlas no óptimas, es decir, mejor una institución que la ausencia de ella.

49 Schutz, A., Studies in Social Theory, Martinus Nijhoff, La Haya, 1964, desarrolla ampliamente esta idea desde una perspectiva sociológica. 
a cada instante de nuestro comportamiento ${ }^{50}$. Es decir, nos indican cuál es el modo correcto y cuál el incorrecto de actuar en determinadas circunstancias, si bien en la mayoría de los casos los individuos actúan sin ser realmente conscientes de esas reglas ni capaces de articularlas con palabras (conocimiento práctico no articulable) ${ }^{51}$. De esta forma, las normas y valores morales transmitidos de generación en generación facilitan el mutuo ajuste y coordinación de las acciones individuales, es decir, contribuyen a crear un orden general dentro del cual los individuos pueden actuar libremente: el que nuestra conducta sea normada permite saber a cada individuo que los demás se van a conducir ateniéndose a ciertas maneras regulares y previsibles. Como señala el mismo Hayek, "las instituciones nos facilitan la vida en común" al favorecer el mutuo ajuste y coordinación de las acciones individuales ${ }^{52}$.

De lo dicho hasta aquí, resulta claro que las ideas de Hayek sobre evolución socioeconómica y cultural — que desarrolló esencialmente en su trilogía Derecho, legislación y libertad y en La fatal arrogancia - guardan similitudes importantes con la evolución biológica, pues en ambos casos hablamos de conceptos como los de selección, herencia, competencia o adaptación al medio. Asimismo, tanto la evolución cultural hayekiana como la biológica no responden a un plan o dirección consciente - por lo que no es posible hacer ningún tipo de predicción sobre el desarrollo evolutivo-, y no son procesos lineales, continuos o uniformes, sino procesos de experimentación y ensayo constantes.

Pero también hay diferencias que es importante destacar. La evolución cultural, que es mucho más rápida que la biológica, responde a un proceso de selección grupal —no individual - : se ven favorecidos aquellos grupos humanos cuyas normas de comportamiento, usos, costumbres, tradiciones, etc. les permiten una mejor adaptación al entorno. Esto es, se acaban "eligiendo" o seleccionando las instituciones que benefician más al conjunto. Por otro lado, la herencia — sobre la que descansa el desarrollo cultural — no está genéticamente determinada, sino que actúa por aprendizaje e imitación. Además, es posible transmitir "características" desarrolladas para adaptarse al medio, es decir, la evolución cultural sería en este sentido lamarckiana: a través de la experiencia, la prueba y el error, el grupo modifica o ensaya nuevos comportamientos para mejor adaptarse al medio que luego puede legar a las generaciones posteriores.

\subsection{Problemas del evolucionismo hayekiano}

El planteamiento de Hayek ha sido objeto de críticas de diverso calado. Se ha subrayado, por ejemplo, el irracionalismo del evolucionismo hayekiano, dado que el autor austriaco defiende el sometimiento a fuerzas y normas impersonales, que no han sido conscientemente elaboradas por el hombre y que éste ni siquiera comprende en su totalidad. Del mismo modo,

50 Cfr. Butler, E., Hayek. His Contribution to the Political and Economic Thought of Our Time, p. 50.

51 Hayek cita al comienzo del capítulo II de The Constitution of Liberty una frase del filósofo y matemático A. N. Whitehead que es muy ilustrativa a este respecto: "La civilización progresa al aumentar el número de cosas importantes que podemos ejecutar sin pensar en ellas”, p. 22.

52 Cfr. HayeK, F. A., Law, Legislation and Liberty. Volume 1: Rules and Order, p. 19; De La Nuez, P., La política de la libertad. Estudio del Pensamiento político de F. A. Hayek, pp. 192-194. Como indica North, en muchos casos las instituciones alteran los ratios coste/beneficio de los individuos en favor de la cooperación en el "intercambio" impersonal, en situaciones en las que, de otro modo, esa cooperación no tendría lugar, dado el gran número de jugadores, la falta de información que cada jugador tiene sobre el resto, y el carácter único — no repetido- de muchas interacciones. Cfr. North, D. C., "Economic Performance Through Time", American Economic Review, v. 84, n. 3, (1994), p. 365. 
se ha destacado el conservadurismo de la teoría hayekiana, dada "la asunción acrítica y pasiva de las tradiciones heredadas [...] por el simple hecho de haber sobrevivido a los avatares de la historia y del tiempo", así como el ingenuo optimismo que implica suponer que lo mejor adaptado "desplazará aquello que es perjudicial para la humanidad". También se ha apuntado la "imposibilidad de demostrar que la Teoría de la Evolución cultural está ligada indisolublemente a la formación de órdenes espontáneos" ${ }_{53}$, o el carácter funcionalista del argumento que afirma que la contribución de una norma a la conservación del sistema es suficiente para explicar la existencia de dicha norma ${ }^{54}$. Incluso se ha llegado a criticar a Hayek desde una perspectiva ética ${ }^{55}$. Todas estas críticas, sin embargo, son quizá menos significativas desde un punto de vista económico que las tres cuestiones que se desarrollan a continuación.

\section{a) La intervención en el proceso evolutivo: La cuestión de la reforma institucional}

Hayek es escéptico ante la reforma institucional; aunque admite que a veces puedan ser necesarias ciertas modificaciones, desconfía ante la posibilidad de que este tipo de reformas vayan más allá de lo estrictamente necesario, cayendo con facilidad en el "constructivismo racionalista". De la postura evolucionista de Hayek se deduce que la intervención sobre el marco institucional debe ser muy sopesada, restringida y puntual, sobre todo en lo que se refiere a la ley (la ley de la libertad o nomos) — conjunto de normas de conducta generales de origen espontáneo vinculadas al proceso judicial y ejemplificadas en el common law británico-, que se diferencia claramente de la legislación (thesis) — conjunto de normas de organización deliberadamente establecidas por el poder legislativo- ${ }^{56}$.

A pesar de todo, como señala De la Nuez, en la obra de Hayek "no queda bien resuelto el problema de la intervención o no intervención en el proceso evolutivo. [...] Nunca defendió la inactividad total y con ella una actitud [totalmente] conservadora, pero si se defiende una intervención - aun modesta y gradual-, se supone un conocimiento del fin o del proceso o, al menos, una voluntad de dirigirlo hacia una meta determinada que no se corresponde bien con algunas de sus ideas más características" ${ }^{57}$.

Frente a la teoría "orgánico-evolucionista” de Menger-Hayek sobre el origen y la evolución de gran parte de las instituciones sociales, aparecen otras explicaciones que ponen el acento bien en el carácter deliberado de la mayoría de las instituciones, o bien en la posibilidad de una intervención amplia y premeditada sobre las mismas con el fin de mejorarlas. Ejemplos

53 Cfr. De La Nuez, P., La politica de la libertad. Estudio del Pensamiento político de F. A. Hayek, p. 198.

54 Cfr. Vanberg, V. J., Rules and Choice in Economics, Routledge, Londres, 1994, pp. 77-94.

55 Walker señala que el único fin de la ética hayekiana es la perpetuación de aquella forma de organización social que favorece la supervivencia de la especie, que se convierte así en el único elemento que justifica la ley y la moral. Cfr. Walker, G., The Ethics of F. A. Hayek, University Press of America, Boston, 1986, p. 94.

Miller considera que Hayek defiende la libertad sólo como un medio para la multiplicación de la especie, llegando a equiparar de algún modo valor ético y valor evolutivo. Y es que justificar la adhesión a principios de validez universal, como la libertad y la dignidad humanas, en un marco evolutivo resulta problemático. Cfr. MiLler, D., "The Fatalistic Conceit", Critical Review, v. 2, n. 3, (1989), pp. 312-318).

Se puede explicar desde una perspectiva evolutiva cómo surgieron instituciones y normas de comportamiento, pero no justificarlas directamente. La defensa de la libertad, sin embargo, puede basarse en razones de eficacia y utilidad: el evolucionismo puede servir para mostrar que la libertad es eficaz para promover el progreso del conocimiento y con ello la civilización (que en los últimos escritos de Hayek se identifica prácticamente con el mero crecimiento de la población, lo que resulta cuestionable).

56 Cfr. Hayeк, F. A., Law, Legislation and Liberty. Volume 1: Rules and Order, pp. 124-126.

57 Cfr. De La Nuez, P., La política de la libertad. Estudio del Pensamiento político de F. A. Hayek, p. 199. 
de este tipo de enfoques son, respectivamente, el de Commons ${ }^{58}$ — basado en la idea de acción colectiva - o el contractualista de Buchanan (al que se hará referencia más tarde). Hayek clasificaría a este tipo de posturas dentro de lo que él denomina la tradición del "racionalismo constructivista", la cual arranca históricamente del racionalismo cartesiano y de la idea del contrato social rousseauniano. Para Hayek, dicha posición sólo se justifica desde un desconocimiento de los límites de la razón y de la compleja naturaleza del conocimiento en la sociedad: pensar que la mente humana es capaz de diseñar y modificar a voluntad todas o gran parte de las complejas estructuras institucionales en que descansa el orden social ha conducido, entre otros, a errores como el del socialismo real.

La diferenciación excesivamente rígida entre evolucionismo y "constructivismo racionalista”, hace que el propio Hayek encuentre difícil buscar un lugar adecuado para el diseño y la reforma constitucional deliberada dentro de su esquema teórico. Así, Hayek alaba la constitución americana como un ejemplo de constitución de libertad; si bien es claro que fue el resultado de una acción deliberada, como recuerda Buchanan ${ }^{59}$, Hayek señala que fue elaborada a partir de principios tradicionales y la experiencia del pueblo inglés ${ }^{60}$. Sin embargo este es un argumento diferente al de la drástica diferenciación entre evolucionismo y "racionalismo constructivista".

Por otra parte, Hayek incurre en cierta contradicción con sus concepciones evolucionistas al realizar — en la tercera parte de Derecho, legislación y libertad — una propuesta de reforma constitucional relativa a la división de poderes, propuesta que podría calificarse como un intento de 'ingeniería constitucional' que tanto le disgustaba. Como señala De la Nuez, su proposición de reforma institucional "parece algo más que una revisión de simples hábitos y tradiciones. Se parece más a los modelos de reforma a los que tan aficionados son los racionalconstructivistas que él tanto criticaba" ${ }^{61}$.

También frente a la situación reforma de los países del Este después de 1989, donde no existían ni mercados ni derechos de propiedad privada sobre los medios de producción, Hayek se vio en una encrucijada: la defensa de la introducción de los mercados, por un lado, y la oposición a grandes cambios estructurales premeditados o "constructivistas", por otro.

\footnotetext{
58 Commons define una institución como una acción colectiva (deliberada) para el control de la acción individual, o más concretamente, como una "acción colectiva para limitar, liberar o expandir la acción individual", Commons, J. R., Institutional Economics. Its Place in Political Economy, Macmillan, Nueva York, 1934; publicado por The University of Wisconsin Press, Madison, 1959, p. 73.

En esta definición identificamos los dos niveles a los que se refiere Commons. Al nivel de la sociedad en su conjunto, la existencia de una serie de reglas — que nacen de la acción colectiva - impone restricciones a la acción individual, pero al mismo tiempo, al limitar también las posibilidades de actuación de los otros, "libera" al individuo, en el sentido de que le otorga un campo de acción donde los demás no pueden inmiscuirse. En este sentido, Commons está interesado en lo que hace posible la cooperación pacífica a pesar de los conflictos de intereses que surgen constantemente de la escasez: es preciso analizar el proceso por el cual los hombres establecen y mantienen entre ellos un sistema de reglas para regular esos conflictos. Cfr. VANBERG, V. J., Rules and Choice in Economics, p. 153.

Por otro lado, al nivel de organizaciones concretas, el someterse a ciertas reglas de funcionamiento dentro de las mismas acaba permitiendo al individuo la realización de logros que no podría alcanzar por sí mismo, es decir, le permite "expandir" su acción individual más allá de lo que resultaría de su esfuerzo aislado. A este nivel —el que más interesa a Commons - se contempla a las organizaciones como actores corporativos, como sujetos de acción colectiva que son cada vez más importantes en la vida económica de nuestros días. Cfr. VanBerg, V. J., Rules and Choice in Economics, pp. 153 y $156-157$.

59 Cfr. Buchanan, J. M., Freedom in a Constitutional Contract, Texas A\&M University Press, College Station, 1977 , p. 38.

60 Cfr. HaYeK, F. A., The Constitution of Liberty, capítulo XII, § 2.

61 Cfr. De La Nuez, P., La politica de la libertad. Estudio del Pensamiento político de F. A. Hayek, p. 252.
} 


\section{b) Individualismo metodológico y alcance de lo institucional: Un difícil encaje}

Como se intentará mostrar a continuación, hay una cierta incompatibilidad entre la ambiciosa concepción de Hayek sobre el papel de las instituciones y su estricta adhesión al individualismo metodológico. La Escuela Austriaca diferencia entre información (o datos sensitivos disponibles) y conocimiento (en este caso, en el sentido de información efectivamente aprehendida). La disponibilidad de información no significa, como parece deducirse de los modelos económicos al uso, que ésta sea igual o uniformemente percibida por los agentes económicos.

Para Hayek, los hechos están cargados de las preconcepciones y modelos de realidad de los individuos, de modo que hasta cierto punto los propios individuos "crean" la realidad en la que actúan. Dado que éstos se forman en un determinado entorno cultural e institucional, parece lógico pensar que - para Hayek — las instituciones no sólo se dejan sentir como restricciones a nuestras posibilidades de actuación o como medios de transmisión de conocimiento, sino que de algún modo también contribuyen a moldear la formación de nuestras preferencias y nos ayudan a filtrar (seleccionar) la adquisición de nueva información sobre la que luego realizaremos nuestras elecciones. Es decir, no se puede hablar del carácter intrínsecamente autónomo de nuestras preferencias, ya que éstas están marcadamente condicionadas por un entorno institucional y cultural; además, los aspectos culturales e institucionales están actuando como un "filtro" a la hora de seleccionar y aprehender una pequeña parte de la ingente cantidad de estímulos e información de todo tipo que recibimos, puesto que para ordenar la masa aparentemente caótica de datos nos servimos de conceptos, reglas y símbolos adquiridos ${ }^{62}$.

Sin embargo, estas ideas tan ambiciosas sobre el alcance de lo institucional — que en principio parecen derivarse 'naturalmente' de la concepción hayekiana- parecen casar mal con la estricta adscripción de Hayek al individualismo metodológico. El individualismo metodológico implica partir del individuo para investigar los fenómenos sociales y considerarlo como "dado"; es decir, suponer - con fines heurísticos- que sus intereses, creencias, preferencias, objetivos, etc. son datos, lo que significa que, aun admitiendo que el marco cultural-institucional influye en ellos, en la práctica dicha influencia no se toma en consideración o no se intenta explicar ${ }^{63}$. Sin duda, esta postura puede ser legítima en la investigación de procesos a corto plazo, pero no encaja bien en la perspectiva evolucionista y dinámica que adopta el propio Hayek, y en la que se otorga gran importancia al papel de la cultura y las instituciones.

62 La adquisición de ese "bagaje" de normas y símbolos en un determinado entorno cultural e institucional es lo que en sociología se conoce como proceso de socialización. En concreto, la socialización sería el proceso por cuyo medio la persona humana aprende e interioriza, en el transcurso de su vida, los elementos socioculturales de su medio ambiente, los integra a la estructura de su personalidad, bajo la influencia de agentes sociales significativos, y se adapta así al entorno en cuyo seno debe vivir. Véase Rocher, G., Introduction à la sociologie générale, Hurtubise HMH, Montréal, 1992, capítulo V.

Esto conecta con la "racionalidad limitada" de los seres humanos, que — según Herbert Simon— da lugar a que la toma de decisiones individuales se apoye en hábitos, en formas previamente aprendidas de "visualizar" los problemas concretos. Cfr. Simon, H. A., Reason in Human Affairs, Stanford University Press, Stanford, 1983.

63 Para Hayek, si la acción consciente tiene que ser explicada, es tarea de la Psicología, no de la Economía. Esta actitud ha sido tachada de "psicologismo" (Popper), y de ser poco integradora y excesivamene restrictiva dentro del ámbito de las Ciencias Sociales. Por su parte, otros "austriacos" como Lachmann o Shackle afirman que la imaginación y las expectativas tienen esencialmente una naturaleza no causal, y por tanto no pueden explicarse en absoluto; los individuos al escoger realizan elecciones básicas y espontáneas. Sin embargo, parece difícil admitir que ni siquiera algunas de las intenciones humanas tengan causas que merecen ser investigadas basándose en las instituciones, la cultura, etc. Cfr. Hodgson, G., Economics and Evolution, pp. 153-156. 
Como lo expresa Hodgson: "Aunque las normas sean [en el modelo de Hayek] claros objetos de reproducción de la evolución socioeconómica, los humanos no están 'instruidos' sólo por esas normas; también realizan elecciones. Si la elección se hace suprema en el ámbito humano, la analogía entre la norma escogida y el gen se vuelve imperfecta [...] la adscripción explícita de Hayek a la elección, al comportamiento intencionado y al individualismo metodológico parece inconsistente con su énfasis supremo en que las normas son el objeto de selección" ${ }^{64}$.

Por otra parte, la idea de selección grupal — que resulta bastante apropiada desde una perspectiva socioeconómica, aunque no en términos biológicos - parece alejarse del individualismo metodológico de Hayek, pues en la evolución sería el grupo como tal, o el orden general, el criterio de eficacia y selección. Recordemos que en el planteamiento hayekiano se "eligen" o seleccionan las normas de comportamiento que benefician al conjunto, es decir, se ven favorecidos los grupos humanos cuyas normas les capacitaron para adaptarse mejor al entorno cambiante.

\section{c) Evolución, progreso y eficiencia}

Hayek no afirma con la rotundidad de Spencer que la evolución implique directamente un mayor progreso, aunque en ciertas ocasiones parezca compartir implícitamente esta idea por la forma de expresarse. Es decir, Hayek — ante el ejemplo de los horrores totalitaristas del siglo XX - rechaza que la evolución conduzca de forma automática al progreso. El proceso de evolución cultural no es lineal, continuo o uniforme. Hay retrocesos y errores.

Sin embargo, aunque - debido a factores políticos como la actuación de grupos de interés - puedan sobrevivir durante largos periodos algunas instituciones parásitas o incluso dañinas, si el conjunto de instituciones de un grupo humano está mejor adaptado que otro, la cultura de ese grupo prosperará. Por ello, en un sentido genérico, no maximalista y a largo plazo, sí podría afirmarse que — de acuerdo con Hayek — hay una conexión entre evolución y progreso ${ }^{65}$ : se van seleccionando aquellos conjuntos de instituciones o marcos institucionales que contribuyen a favorecer la supervivencia y alimentación de una población creciente y

64 Hodgson, G., Economics and Evolution, p. 166.

65 Se tiende a pensar popularmente que los procesos evolutivos conducen al óptimo de eficiencia, a lo mejor posible. Esto es lo que hoy se llama en Biología la falacia adaptacionista: una cosa es que la selección natural pueda acarrear una mejora, pues supone la adaptación al entorno, y otra que conduzca al mejor de los resultados posibles. En apoyo de esta idea pueden señalarse dos argumentos. Por un lado, para que la selección opere tiene que existir una variedad de formas (es decir, un incesante y sistemático error). Por otro lado, está el argumento de la dependencia de trayectoria: el desarrollo evolutivo futuro viene afectado por la trayectoria que se ha seguido en el pasado. Así, hay una cierta inflexibilidad en los procesos evolutivos.

El ejemplo de la Tecnología es una buena ilustración: cuando se adopta un "paradigma” tecnológico — debido a las externalidades de la introducción de estándares - se condiciona a veces una determinada dirección de desarrollo tecnológico futuro que no es la más eficiente. Cfr. Hodgson, G., Economics and Evolution, p. 206. Por ejemplo el teclado "QWERTY", el ancho de vías ferroviarias, el sistema de vídeo VHS, etc. Es decir, no estaríamos hablando de un máximo global al que llegamos en cualquier caso, sino de una multiplicidad de máximos adaptativos y cambiantes, donde la trayectoria previa es determinante. En definitiva, en Biología la selección natural no conduce a una actitud superlativa sino sólo tolerable. "La selección natural siempre es un instrumento imperfecto, y puede, a veces, llevar a resultados claramente inferiores al óptimo", Hodgson, G., Economics and Evolution, p. 197.

En Economía, sin embargo, la analogía biológica del adaptacionismo se ha utilizado para justificar una idea importante: autores como Alchian o el propio Hayek, han señalado que la idea de la selección natural en un marco competitivo permite apoyar la hipótesis del comportamiento maximizador o racional de los agentes económicos (individuos y empresas). Cfr. Alchian, A. A., "Uncertainty, Evolution and Economic Theory", Journal of Political Economy, v. 58, n. 3, (1950), pp. 211-221. 
enfrentada a problemas cada vez más complejos ${ }^{66}$. Esta idea seguramente sería matizada o cuestionada por autores actuales como North o Williamson, sobre todo si se vinculan - específicamente - evolución institucional y crecimiento económico ${ }^{67}$. Sin embargo, es menos controvertida que la que se expone a continuación.

Hayek considera que aquellas normas que son fruto de un proceso evolutivo - como el conjunto de normas de conducta generales de origen espontáneo vinculadas al proceso judicial y ejemplificadas en el common law británico - son superiores o más eficientes que las que son el resultado de un diseño deliberado por el poder legislativo. Dado el proceso de selección al que están sometidas las instituciones que derivan de un orden espontáneo, perviven a largo plazo las normas que son útiles a la sociedad, de forma que las "soluciones" institucionales que resultan de una evolución gradual serán superiores a las que son fruto de un diseño premeditado (que en las sociedades modernas constituyen una parte significativa del entramado global de normas) ${ }^{68}$. Esta postura es también la que mantiene uno de los principales exponentes del análisis económico del derecho, Richard Posner ${ }^{69}$.

El premio Nobel James Buchanan comparte con Hayek el apego al individualismo metodológico y a la tradición liberal, pero disiente de su evolucionismo optimista, aun aceptando el hecho de que una buena parte de las instituciones tenga un origen espontáneo: "las fuerzas de la evolución únicamente [...] no garantizan que se irán dando resultados socialmente eficientes a lo largo del tiempo"70. Toda institución es susceptible de reforma premeditada, y no se puede presumir - como hace Hayek — que las instituciones fruto del principio de la mano invisible serán eficientes, mientras que las diseñadas deliberadamente tenderán a ser ineficientes. Antes de poder realizar afirmaciones de este tipo es preciso explicitar un criterio de evaluación para las normas e instituciones existentes y para aquellas otras que se propongan en el futuro, lo cual no hace Hayek ${ }^{71}$.

\footnotetext{
66 Esta postura debe distinguirse claramente de otra distinta pero igualmente criticable, que consiste en afirmar que sobreviven las instituciones mejor adaptadas al entorno existente en determinado tiempo y circunstancia. Según esta idea, las instituciones se seleccionarían por las características favorables a su propia supervivencia, no por su contribución al progreso económico y social. En este caso, la supervivencia y expansión de muchas instituciones podría venir dada precisamente por su ineficiencia.

Del mismo modo que la mala educación conlleva prolongar el periodo educativo, o que un sistema penitenciario donde los criminales se vuelven peores crea las precondiciones para su expansión, las regulaciones mal concebidas precisan de regulaciones adicionales y las malas leyes generan una necesidad de nuevas leyes. Así, partiendo de una determinada situación inicial, podría actuar una especie de ley de Gresham de las instituciones. Esto parece poco plausible, aunque sólo sea porque en la práctica - como ocurre con los organismos vivos- la capacidad de una sociedad para sostener instituciones "parásitas" tiene un límite. Cfr. DE JASAY, A., Social Contract, Free Ride, Oxford University Press, Nueva York, 1990, p. 77.

67 Véanse, por ejemplo, las reflexiones que hace North, D. C., Institutions, Institutional Change and Economic Performance, Cambridge University Press, Cambridge, 1990, pp. 17-26. Dado que los agentes manejan información incompleta (e incluso errónea) y su capacidad de procesarla es limitada, y dado además que existen fricciones importantes en el sistema (costes de transacción), no puede esperarse la eficiencia institucional global que resultaría de un mundo competitivo. North concluye que las instituciones no son creadas por fuerza ni tampoco para ser eficientes socialmente; más bien, las instituciones, o cuando menos las reglas formales, son hechas para servir los intereses de quienes tienen el poder de negociación para idear nuevas normas.

68 En concreto, la legislación - o lo que Hayek llama normas organizativas - es necesariamente fruto de un proceso de elección colectiva y difícilmente se le puede aplicar la idea evolucionista. Por tanto, en el caso de las reglas constitucionales el apelativo de "constructivismo racionalista" no resulta apropiado. Según Hayek, las reglas constitucionales son las reglas de organización del gobierno que determinan su estructura y funciones, es decir, las reglas que regulan los poderes de los agentes del gobierno sobre los recursos materiales y personales a ellos confiados. Cfr. HAYEK, F. A., Law, Legislation and Liberty. Volume 1: Rules and Order, capítulo VI.

69 Véase Posner, R. A., The Economic Analysis of Law, $3^{\text {a }}$ ed., Little Brown, Boston, 1992.

70 Buchanan, J. M., Freedom in a Constitutional Contract, p. 31.

71 Cfr. Buchanan, J. M., Freedom in a Constitutional Contract, p. 32.
} 
Para Buchanan, la perspectiva individualista que comparten tanto él como Hayek requiere, por razones de coherencia, que dicho criterio sea contractual: "podemos evaluar cualquier elemento de la estructura legal existente en términos de su posible consistencia con lo que resultaría de un auténtico 'contrato social' entre todas las personas que están involucradas en la interacción" 72. Es decir, así como el intercambio voluntario indica acuerdo entre las partes implicadas - de modo que es precisamente el acuerdo voluntario el criterio último para juzgar si una transacción de mercado es eficiente-, análogamente, con respecto a las elecciones colectivas, el acuerdo voluntario entre todos los participantes en una elección es en última instancia el criterio para evaluar la eficiencia de la misma. Una postura basada en el individualismo implica que la eficiencia no puede juzgarse "externamente" a los valores de los individuos; el criterio expuesto es el único verdaderamente consistente con la postura individualista.

Según Buchanan, lo eficiente - en sentido contractual - es aquello que surge del pacto, y por tanto, no es único, dado que las posibilidades de acuerdo no están limitadas a un solo resultado. En definitiva, no hay un único conjunto de instituciones óptimo con existencia independiente al margen del acuerdo. La reforma social es posible, y para llevarla a cabo no se precisa un conocimiento perfecto, pues no se pretende alcanzar el orden social óptimo, como han buscado muchos reformadores sociales.

La estructura básica dentro de la que tiene lugar nuestra interacción puede modificarse por consenso. Dicho consenso, cuando hablamos de las reglas constitucionales o fundamentales, y no de normas de política ordinaria, puede adoptar fácilmente una forma cercana a la unanimidad. Es decir, cuando se elige entre reglas constitucionales alternativas las posibilidades de consenso son mucho mayores que en el terreno de la política ordinaria: la incertidumbre acerca del funcionamiento de reglas cada vez más generales y más permanentes en el tiempo hace que los intereses futuros de las personas y grupos bajo tales normas no se puedan identificar con claridad, y que los agentes atiendan sobre todo a aquellos aspectos que puedan evitar un resultado desastroso, como podría ser la falta misma de acuerdo ${ }^{73}$.

Como afirma Buchanan, este criterio contractual no es un instrumento arbitrario para justificar cualquier tipo de reforma legal que se pretenda llevar a cabo: el suponer un contrato hipotético permite hacer conjeturas sobre posibles fallos y mejoras del sistema de normas, pero la modificación efectiva de las reglas debería estar sujeta a la evidencia de acuerdo explícito entre los concernidos por la misma ${ }^{74}$. El propio Buchanan define esta postura como constructivismo contractualista.

En resumen, la principal diferencia entre Hayek y Buchanan es que éste último no admite que deba presuponerse la eficiencia de las instituciones de origen espontáneo y carácter evolutivo y la ineficiencia de las diseñadas de forma deliberada. Ello no tiene por qué ser así necesariamente: no sólo es posible diseñar deliberadamente nuevas reglas que resulten eficientes, sino también redefinir amplia y premeditadamente las ya existentes con el fin de mejorarlas. En todo caso, es preciso evaluar las normas, y para ello Buchanan propone un criterio contractual.

72 Buchanan, J. M., Freedom in a Constitutional Contract, p. 33.

73 Cfr. Buchanan, J. M. y Brennan, G., The Reason of Rules, Cambridge University Press, Cambridge, 1987, pp. 54-58 y 104-109.

74 Cfr. Buchanan, J. M., Freedom in a Constitutional Contract, p. 33. 


\section{Conclusión}

Este trabajo se ha centrado en exponer el evolucionismo en la obra de Hayek. En primer lugar, se ha mostrado que en la Historia del Pensamiento económico la aproximación evolucionista de Hayek constituye una auténtica rareza, ya que hasta muy recientemente - la década de 1980 - la Economía evolutiva no ha empezado a despertar interés entre una parte de los economistas, que aún permanecen mayoritariamente fieles a la analogía estática y mecanicista. Hasta tal fecha algunos autores - como Veblen, Menger, Marshall o Schumpeter - lanzaron algunas ideas que iban en la dirección de un planteamiento evolutivo, pero o bien no desarrollaron dichas propuestas, o lo hicieron de forma poco consistente.

Sin embargo, Hayek - recogiendo el testigo de Menger- sí elaboró una teoría bastante completa y coherente sobre la evolución institucional como elemento fundamental para el funcionamiento del sistema socioeconómico. En cualquier caso, el denominador común a todos los intentos de acercarse a una visión evolutiva de la Economía ha sido la búsqueda de una concepción más amplia de la disciplina, alejada de un modo u otro de la estática y el equilibrio a corto plazo y del enfoque a-institucional que ha dominado la corriente principal de la Economía desde mediados del siglo XIX.

En segundo lugar, se ha visto que Hayek consideraba que la idea de evolución en las Ciencias Sociales - entendida en un sentido muy general - era muy anterior a la idea de evolución biológica. Incluso señalaba que el propio Darwin pudo inspirarse de forma indirecta en la idea de evolución cultural de Mandeville y Hume para elaborar su teoría evolutiva. Sin embargo, curiosamente, Hayek no presta atención a Malthus y Spencer, dos autores cuya relevancia parece indiscutible tanto por su influencia en Darwin —en el caso de la obra de Malthus - , como por representar un notable exponente del evolucionismo cultural —en el caso de Spencer-. Explicar tales omisiones resulta difícil y controvertido, pero en este trabajo se han apuntado algunas posibles razones.

Y, en tercer lugar, se ha presentado el evolucionismo hayekiano, que se inscribe - y sólo puede entenderse adecuadamente - en el seno de una visión muy particular del proceso económico, la visión austriaca, marcada por la dinámica, el desequilibrio y la incertidumbre. Es en este escenario en el que la adquisición de información por parte de los individuos resulta crucial, y precisamente las instituciones desempeñan un papel fundamental en la producción y transmisión de dicha información. Las principales instituciones sociales — cuyo origen es espontáneo - son un condensado de conocimiento y experiencia acumulada que se transmite de generación en generación vía aprendizaje e imitación.

La evolución cultural implica un proceso de selección grupal, de forma que se ven favorecidos aquellos grupos humanos cuyas normas, usos, costumbres, tradiciones, etc., permiten una mejor adaptación al entorno; de este modo, las reglas que han contribuido a la supervivencia, el crecimiento y la expansión de una determinada sociedad permanecen y serán imitadas por otras sociedades. Aunque hay claros paralelismos entre la idea de evolución darwinista y la evolución cultural hayekiana — pues en ambos casos se hace referencia a conceptos como los de selección, herencia, competencia o adaptación — también hay diferencias importantes: la evolución cultural es mucho más rápida, se basa en la selección grupal, no está genéticamente determinada, y opera en sentido lamarckiano.

El evolucionismo hayekiano ha sido objeto de diferentes críticas. En este trabajo se ha centrado la atención en tres de ellas por considerarlas de especial significación. Primero, está 
la espinosa cuestión de la reforma institucional o de la intervención en el proceso evolutivo, dada la drástica distinción que hace Hayek entre evolucionismo y "constructivismo racionalista”. En segundo lugar, hay que destacar el difícil encaje entre la estricta adhesión de Hayek al individualismo metodológico y la perspectiva dinámica y evolucionista que adopta el propio autor, otorgando un papel muy relevante a las instituciones. Por último, resulta muy controvertida la idea hayekiana de que las normas que son fruto de un proceso evolutivo - como el common law británico — son superiores o más eficientes que las que son el resultado de un diseño premeditado.

\section{Bibliografía}

Alchian, A. A., "Uncertainty, Evolution and Economic Theory", Journal of Political Economy, v. 58, n. 3, (1950), pp. 211-221.

Aldrich, H., Organizations Evolving, Sage, Londres, 1999.

Andersen, E. S., Evolutionary Economics: Post-Schumpetrian Contributions, Pinter, Londres, 1996.

Baumol, W., The Free-Market Innovation Machine, Princeton University Press, Princeton, 2002.

Birner, J. y Van Zisp, R. (eds), Hayek, Co-ordination and Evolution: His Legacy in Philosophy, Politics, Economics, and the History of Ideas, Routledge, Londres, 1994.

Boettke, P., "Hayek and Market Socialism: Science, Ideology and Public Policy", London School of Economics, conferencia, 19 de octubre, 2004.

Boulding, K., A Primer on Social Dynamics: History as Dialectics and Development, The Free Press, N. York, 1970.

Boulding, K., Ecodynamics: A New Theory of Societal Evolution, Sage, Beverly Hills, 1978.

Boulding, K., Evolutionary Economics, Sage, Beverly Hills, 1981.

Bowles, S., Microeconomics: Behaviour, Institutions and Evolution, Princeton University Press, Princeton, NJ, 2003.

Brunner, K. y Meckling, W. H., "The Perception of Man and the Conception of Government", Jourmal of Money, Credit and Banking, v. 9, n. 1, (1977), pp. 70-85.

Brunner, K., "The Perception of Man and the Conception of Society: Two Approaches to Understanding Society", Economic Inquiry, v. 25, (1987), pp. 367-388.

Buchanan, J. M. y Tullock, G., The Calculus of Consent, University of Michigan Press, Michigan, 1965.

Buchanan, J. M., "A Contractarian Paradigm for Applying Economic Theory", American Economic Review, v. 65, n. 1, (1975), pp. 225-230.

Buchanan, J. M., Freedom in a Constitutional Contract, Texas A\&M University Press, College Station, 1977.

Buchanan, J. M., “What Should Economists Do?”, en Buchanan, J. M., What Should Economists Do?, Liberty Press, Indianápolis, 1979, pp. 1-63.

Buchanan, J. M. y Brennan, G., The Reason of Rules, Cambridge University Press, Cambridge, 1987.

Butler, E., Hayek. His Contribution to the Political and Economic Thought of Our Time, Tempel-Smith, Londres, 1983. 
Clark, C. M. A., "Spontaneous Order Versus Instituted Process: The Market as Cause and Effect”, Journal of Economic Issues, v. 27, n. 2, (1994), pp. 373-385.

Commons, J. R., Institutional Economics. Its Place in Political Economy, Macmillan, N. York, 1934; publicado por The University of Wisconsin Press, Madison, 1959, 2 vols.

DE JaSAY, A., The State, Basil Blackwell, Oxford, 1985.

DE JASAY, A., Social Contract, Free Ride, Oxford University Press, Nueva York, 1990.

De La Mothe, J. y Paquet, G. (eds), Evolutionary Economics and the New International Political Economy, Pinter, Londres, 1996.

De La Nuez, P., La política de la libertad. Estudio del Pensamiento político de F. A. Hayek, Unión Editorial, Madrid, 1994.

Delorme, R. y Dopfer, K. (eds), The Political Economy of Diversity: Evolutionary Perspectives on Economic Order and Disorder, Edward Edgar, Cheltenham, 1994.

Demsetz, H., Economic, Legal and Political Dimensions of Competition, North Holland, Ámsterdam, 1982.

EgGertsson, T., Economic Behavior and Institutions, Cambridge University Press, Cambridge, 1990.

Engels, F., The Dialectics of Nature [escrito en 1866-1873, publicado en 1925], Progress Publishers, Moscú, 1954.

Georgescu-Roegen, N., The Entropy Law and the Economic Process, Harvard University Press, Cambridge, MA, 1971, reimpreso en 1976.

Gintis, H., Game Theory Evolving: A Problem-Centered Introduction to Modeling Strategic Interaction, Princeton University Press, Princeton, 2000.

Gonzalez, W. J., "Historismo y anti-historismo en la polémica metodológica entre G. Schmoller y C. Menger", en Valera, M. y López Fernández, C. (eds), Actas del V Congreso de la Sociedad Española de Historia de las Ciencias y las Técnicas, S. E. H. C. y T., Murcia, 1991, pp. 2027-2041.

Gonzalez, W. J., "Marco teórico, trayectoria y situación actual de la Filosofía y Metodología de la Economía", Argumentos de Razón Técnica, v. 3, (2000), pp. 13-59.

Gordon, S., The History and Philosophy of Social Science, Routledge, Londres, 1991.

Hamilton, D. B., Evolutionary Economics: A Study of Change in Economic Thought, Transaction Publishers, Piscataway, NJ, 1991.

HanappI, H., Evolutionary Economics: The Evolutionary Revolution in the Social Sciences, Avebury Publishers, Aldershot, 1994.

Hayek, F. A., The Constitution of Liberty, Routledge and Kegan Paul, Londres, 1960.

Hayer, F. A., The Counter-Revolution of Science: Studies on the Abuse of Reason, CollierMacmillan, Londres, 1964.

Hayer, F. A., Individualism and Economic Order, Routledge and Kegan Paul, Londres, 1976.

HaYeK, F. A., Law, Legislation and Liberty. Volume 1: Rules and Order, Routledge and Kegan Paul, Londres, 1977.

Hayer, F. A., New Studies in Philosophy, Politics, Economics and the History of Ideas, Routledge and Kegan Paul, Londres, 1978.

HayeK, F. A., Law, Legislation and Liberty. Volume 2: The Mirage of Social Justice, Routledge and Kegan Paul, Londres, 1979. 
Hayer, F. A., Law, Legislation and Liberty. Volume 3: The Political Order of a Free People, Routledge and Kegan Paul, Londres, 1979.

Hayex, F. A., The Fatal Conceit, Routledge, Londres, 1990.

Hayek, F. A., The Trend of Economic Thinking: Essays on Political Economists and Economic History, Routledge, Londres, 1991.

Hirshleifer, J., "Economics from a Biological Viewpoint", Journal of Law and Economics, v. 20, n. 1, (1977), pp. 1-52.

Hirshleifer, J., “Competition, Cooperation and Conflict in Economics and Biology”, American Economic Review, v. 68, n. 2, (1978), pp. 238-243.

Hirshleifer, J., "Natural Economy versus Political Economy", Journal of Social and Biological Structures, v. 1, (1978), pp. 319-337.

Hodgson, G., Economics and Evolution. Bringing Life Back into Economics, Polity Press, Cambridge, 1993.

Hodgson, G., Evolution of Institutional Economics: Agency, Structure, and Darwinism in American Institutionalism, Routledge, Londres, 2004.

Jevons, W. S., The Theory of Political Economy, Macmillan, Londres, 1871; reimp. en Reprints of Economic Classics, Agustus Kelley, Nueva York, 1965.

Kirzner, I. M., The Economic Point of View, Sheed and Ward, Kansas City, 1976.

Koford, K. J. y Miller, J. B. (eds), Social Norms \& Economic Institutions, The University of Michigan Press, Michigan, 1994.

Kuran, T., Private Truths, Public Lies, Harvard University Press, Cambridge, MA, 1995.

Langlois, R. N. y Robertson, P. L., Firms, Markets and Economic Change: A Dynamic Theory of Business Institutions, Routledge, Londres, 1995.

Leibenstein, H., “The Prisoners' Dilemma in the Invisible Hand: An Analysis of Intrafirm Productivity", American Economic Review (Papers and Proceedings), v. 72, (1982), pp. 92-97.

Marshall, A., Principles of Economics, Macmillan, Londres, 1890, $8^{\text {a }}$ edición, 1920 (reimp. en 1994).

MéNARD, C., "Markets as Institutions versus Organizations as Markets? Disentangling some Fundamental Concepts", Journal of Economic Behavior and Organization, v. 28, (1995), pp. 161-182.

Menger, C., Untersuchungen über die Methode der Socialwissenschaften und der Politischen Oekonomie insbesondere, editado por Louis Schneider y traducido por F. J. Nock: Problems of Economics and Sociology, University of Illinois Press, Urbana, 1963.

Menger, C., Grundsätze der Volkswirtschaftlehre, W. Braumüller, Viena, 1871. Vers. inglesa de J. Dingwall y B. Hoselitz: Principles of Economics, The Free Press, Glencoe, IL, 1950.

Miller, D., "The Fatalistic Conceit”, Critical Review, v. 2, n. 3, (1989), pp. 310-342.

Mirowski, Ph., Against Mechanism: Protecting Economics from Science, Rowman and Littlefield, Lanham, MD, 1988.

Mirowski, Ph., More Heat than Light. Economics as Social Physics: Physics as Nature's Economics, Cambridge University Press, Cambridge, 1989.

Nelson, R. R., "Recent Evolutionary Theorizing About Economic Change", Journal of Economic Literature, v. 33, (1995), pp. 48-90. 
Nelson, R. R. y Winter, S. G., An Evolutionary Theory of Economic Change, Harvard University Press, Cambridge, MA, 1982.

North, D. C., Structure and Change in Economic History, Norton, Londres, 1981.

North, D. C., Institutions, Institutional Change and Economic Performance, Cambridge University Press, Cambridge, 1990.

North, D. C., “Institutions”, Journal of Economic Perspectives, v. 5, (1991), pp. 97-112.

North, D. C., "Economic Performance Through Time", American Economic Review, v. 84, n. 3, (1994), pp. 359-368.

North, D. C., Understanding the Process of Economic Change, Princeton University Press, Princeton, 2004.

Olson, M., Power and Prosperity, Basic Books, Nueva York, 2000.

Ostrom, E. Gibson, C., Shivakumar, S. y Andersson, K., Aid, Incentives and Sustainability, Swedish International Development Cooperation Agency (SIDA), Estocolmo, 2002.

Penrose, E. T., "Biological Analogies in the Theory of the Firm", American Economic Review, v. 42, n. 5, (1952), pp. 804-819.

Popper, K., The Poverty of Historicism, Routledge and Kegan Paul, Londres, 1957, reimpreso en 1969.

Posner, R. A., The Economic Analysis of Law, 3a ed., Little Brown, Boston, 1992.

Rocher, G., Introduction à la sociologie générale, Hurtubise HMH, Montreal, 1992.

Rutherford, M., “The Old and the New Institutionalism: Can Bridges Be Built?”, Journal of Economic Issues, v. 29, n. 2, (1995), pp. 443-451.

Rutherford, M., Institutions in Economics. The Old and the New Institutionalism, Cambridge University Press, Cambridge, 1996.

Samuelson, L., Evolutionary Games and Equilibrium Selection, The MIT Press, Cambridge, MA, 1997.

Schumpeter, J., Theory of Economic Development, Harvard University Press, Cambridge, 1911, 2a edición 1926, traducido del alemán al inglés en 1934 (reimp. en 1961).

Schutz, A., Studies in Social Theory, Martinus Nijhoff, La Haya, 1964.

Shleifer, A. ET Al., "The New Comparative Economics", Policy Research Working Paper Series 3054, The World Bank, Nueva York, 2003.

Simon, H. A., Reason in Human Affairs, Stanford, Stanford University Press, 1983.

Sowell, T., "The Evolutionary Economics of Thorstein Veblen”, Oxford Economic Papers, v. 9, n. 2, (1967), pp. 177-198.

Sugden, R., The Economics of Rights, Co-operation and Welfare, Basil Blackwell, Oxford, 1986.

Sugden, R., "Spontaneous Order”, Journal of Economic Perspectives, v. 3, n. 4, (1989), pp. 85-97.

Sutton, J., Technology and Market Structure: Theory and History, The MIT Press, Cambridge, MA, 1998.

Ureña, E. M., “Marx and Darwin”, History of Political Economy, v. 9, n. 4, (1977), pp. 548-559. 
Valdaliso, J. M. y Lopez, S., "Economía y evolución. Un enfoque multidisciplinar", Revista Anthropos, n. 182, (1999), pp. 21-26.

Valdaliso, J. M. y Lopez, S., "Nota bibliográfica sobre Economía y evolución”, Revista Anthropos, n. 182, (1999), pp. 26-29.

VAldaliso, J. M. y Lopez, S., "Economía, Biología y evolución. Algunas reflexiones sobre la 'Economía evolutiva' y la importancia de la Historia”, Revista Anthropos, n. 182, (1999), pp. 30-41.

Vanberg, V. J., Rules and Choice in Economics, Routledge, Londres, 1994.

Veblen, Th., The Theory of the Leisure Class: An Economic Study of Institutions, Macmillan, Nueva York, 1899; reimpreso por George Allen \& Unwin, Londres, 1949.

Vromen, J. J., Economic Evolution: An Inquiry into the Foundations of the New Institutional Economics, Routledge, Londres, 1995.

Walker, G., The Ethics of F. A. Hayek, University Press of America, Boston, 1986.

Young, H. P., Individual Strategy and Social Structure: An Evolutionary Theory of Institutions, Princeton University Press, Princeton, NJ, 1998.

Zаnotтi, G. J., Introducción filosófica al Pensamiento de F. A. Hayek, Unión Editorial, Madrid, 2003. 



\section{IV}

\section{Epistemología y evolucionismo}

8. Evolucionismo bio-cosmológico y Epistemología evolucionista en Popper

9. Racionalidad como adaptación evolutiva en Herbert A. Simon:

Una comparación con Karl Popper y Reinhard Selten 



\section{EvoluCIONISMO BIO-COSMOLÓGICO y Epistemología evolucionista en Popper}

\section{Juan Arana}

\section{El problema de la Reducción en Biología}

En Septiembre de 1972 Theodosius Dobzhansky y Francisco Javier Ayala organizaron en Bellagio, Italia, una congreso internacional sobre "Problemas de reducción en Biología". Asistió a ella un selecto grupo de científicos y filósofos. Las actas de aquel encuentro fueron publicadas en un volumen titulado Estudios de Filosofía de la Biología. Karl Popper figuraba entre los invitados y su ponencia ${ }^{1}$, incluida luego como addenda en El universo abierto ${ }^{2}$, sonó como una nota discordante en el seno de aquella docta reunión. Los anfitriones formaban parte de la más rancia observancia neodarwinista y, aunque el programa cubría un amplio espectro de posiciones, en lo tocante al problema del fondo casi todos estaban de acuerdo. Popper ni siquiera se alineó con las pocas voces discrepantes. Sin entrar en casuísticas que ahora serían engorrosas, intentaré resumir las posiciones de unos y otro.

Cabe distinguir dos aspectos fundamentales en la problemática de la reducción en Biología: el ontológico y el epistemológico. Por una parte hay que decidir si los organismos vivos contienen ingredientes, dinamismos o entidades diferentes de los que hay en los cuerpos inorgánicos o, por decirlo de un modo más simple, si las bacterias, animales y plantas están hechos de otra pasta que las piedras. Por otro lado interesa averiguar si para dar una explicación cabal de los fenómenos que estudia el biólogo es preciso apelar a conceptos, principios o leyes que no se puedan definir o deducir a partir de los que emplea el químico y el físico. Que uno sea o no reduccionista desde el punto de vista ontológico no prejuzga que también o tampoco lo sea en sentido epistémico. La combinatoria da lugar a cuatro alternativas posibles, y la escogida por Popper es la más inusual. Pero veamos antes las otras.

En primer lugar, cabe ser antirreduccionista tanto en lo lógico como en lo ontológico. Muchos antiguos y medievales lo fueron, en línea con el precursor de los estudios biológicos. Aristóteles, en efecto, piensa que la presencia o ausencia del alma determina la frontera entre los dos grandes reinos de la Naturaleza, y atribuye a ese concepto una consistencia ontológica inequívoca: "Luego el alma es necesariamente entidad en cuanto fuerza específica de un cuerpo natural que en potencia tiene vida" ${ }^{3}$. Pero además constituye un instrumento epistémico capital: "Por otra parte, el alma es causa y principio del cuerpo viviente" ${ }^{4}$.

\footnotetext{
1 Véase Popper, K. R., "Scientific Reduction and the Essential Incompleteness of All Science", en Ayala, F. J. y Dobzhansky, Th. (eds), Studies in the Philosophy of Biology, University of California Press, Berkeley, 1974, pp. 258-284. Vers. cast.: "La reducción científica y la incompletitud esencial de toda Ciencia", en Ayala, F. J. y DoBZHAnSKY, Th, (eds), Estudios de Filosofía de la Biología, Ariel, Barcelona, 1983, pp. 333-364.

2 Cfr. Popper, K. R., The Open Universe, Hutchison, Londres, 1982, pp. 131-162. Vers. cast.: El universo abierto. Un argumento en favor del determinismo, Tecnos, Madrid, 1986, pp. 153-183.

3 Aristóteles, Acerca del Alma, edición de Tomás Calvo Martínez, Gredos, Madrid, 1978, p. 168.

4 Aristóteles, Acerca del Alma, p. 180.
} 
En las antípodas de la postura aristotélica aparece el doble reduccionismo, defendido por bastantes modernos. Descartes, por ejemplo, dedica su Tratado del hombre a emular todas las funciones orgánicas mediante dispositivos mecánicos. Concluye el libro con la siguiente tesis: "no debemos concebir en esta máquina alma vegetativa o sensitiva alguna, ni otro principio de movimiento y de vida" 5 . Concibe, en efecto, los animales como artefactos impulsados por el calor de la víscera cardiaca, trasformado en movimientos a través de un sistema de inyección de fluidos. Todos los medios explicativos empleados provienen de la mecánica, ya que incluso la noción clave de "espíritus animales" designa un simple destilado de la sangre.

A pesar de que durante los siglos XVII y XVIII el iatromecanicismo conoció un auge creciente, la mayoría de los naturalistas siguió utilizando procedimientos explicativos muy diferentes de la Física, puesto que las causas finales, prácticamente proscritas en aquella Ciencia, tenían amplia circulación dentro de la Biología. Esta situación fáctica no cambió hasta Darwin, quien, lejos de excluir las estrategias epistémicas teleológicas, se limitó a desligarlas de compromisos ontológicos antirreduccionistas. Así lo testimonia su portavoz autorizado, Thomas Huxley:

"Quizá el servicio más notable que el Sr. Darwin ha prestado a la Filosofía de la Biología haya sido la reconciliación de la teleología y la morfología, y la explicación de los hechos de ambas que ofrece en sus teorías. La teleología que supone que el ojo, tal como lo vemos en el hombre o en los vertebrados superiores, fue creado con la misma estructura que hoy presenta con el fin de capacitar al animal que lo posee para la visión, ha recibido, indudablemente, un golpe de muerte. Sin embargo, tenemos que recordar que existe una teleología más amplia a la que la doctrina de la evolución no afecta, sino que, más bien, se basa de hecho en la proposición fundamental del evolucionismo" ${ }^{6}$.

El mismo Popper ha tomado buena nota de este extremo en varios lugares de su obra. En la conferencia Spencer, pronunciada en 1961 e incorporada luego a Conocimiento objetivo, apunta: "No obstante, la influencia revolucionaria de Darwin sobre nuestra imagen del mundo en torno fue, por lo menos, tan grande - si bien no tan profunda - como la de Newton, ya que la teoría darwinista de la selección natural mostró que en principio era posible reducir la teleología a la causación, mediante la explicación, en términos puramente físicos, de la existencia en el mundo de planes y propósitos"7.

En la reunión de Bellagio volvió asimismo a subrayar que "el gran logro de Darwin fue, naturalmente, demostrar que es posible explicar teleología en términos no teleológicos o términos causales corrientes. El darwinismo es la mejor explicación que tenemos. En este momento no existen hipótesis que le hagan una competencia seria" ${ }^{8}$. Más adelante comprobaremos el uso teórico que Popper pretende extraer de este extremo. Por ahora, basta tomar buena nota de que el creador de la Teoría de la Evolución abrió la puerta a una solución mixta para el problema del reduccionismo. Desde entonces, cualquier biólogo puede ser reduccionista en lo

\footnotetext{
5 Descartes, R., L'Homme, in: Oeuvres de Descartes, edición de Ch. Adam y P. Tannery, Vol. XI, Vrin, París, 1974, p. 202. Vers. cast.: Tratado del hombre, Editora Nacional, Madrid, 1980, p. 117.

6 Huxley, Th., Genealogy of Animals, The Academy, Londres, 1869; citado en Darwin, CH., The Autobiography of Charles Darwin, 1809-1882, selección de F. Darwin, edición de Nora Barlow, Collins, Londres, 1958. Vers. cast.: Autobiografia, Alianza Editorial, Madrid, 1977, pp. 426-427.

7 Popper, K. R., Objective Knowledge. An Evolutionary Approach, Clarendon Press, Oxford, 1972, p. 267. Vers. cast.: Conocimiento objetivo, Tecnos, Madrid, 1974, p. 245.

8 Popper, K. R., The Open Universe, p. 150/El universo abierto, p. 171.
} 
ontológico y autonomista en lo epistemológico. Un ejemplo de esta actitud lo ofrece el propio Dobzhansky, que en el simposio anteriormente citado sostuvo lo siguiente:

"La mayor parte de los biólogos, creo que todos los que están reunidos alrededor de esta mesa, son reduccionistas en tanto que ven la vida como un ejemplo de procesos físicos y químicos altamente complejo, especial e improbable. Para mí, éste es el reduccionismo 'razonable'. ¿Pero tenemos que ir más lejos, e insistir en que la Biología ha de reducirse tanto a la Química como para que las regularidades y leyes biológicas puedan deducirse a partir de lo que aprenderemos acerca de la Química de los procesos vitales? Esto, creo yo, constituye el reduccionismo 'irrazonable'. En nuestros tiempos, los avances más espectaculares en Biología han sido incuestionablemente los realizados en Biología Molecular. Ello no implica, no obstante, que la Biología de organismos resulte de ahora en adelante improductiva, o que todos nosotros debamos trabajar exclusivamente con la Biología Molecular. ¿Por qué no han de seguir desarrollándose a la par la Biología de organismos y la molecular, ya que la una sin la otra sólo puede dar una visión distorsionada de la vida? ¿Debe la Filosofía biológica tratar de los aspectos organísmicos, de los moleculares, o de ambos?" 9.

La confianza con que el conferenciante apela al consenso de todos los presentes certifica que se trata de una postura "políticamente correcta". En el último siglo el doble antirreduccionismo ha sido defendido por los vitalistas, postura que se encuentra en franca decadencia, como manifestaba Francis Crick en su libro ¿Ha muerto el vitalismo? ${ }^{10}$. El doble reduccionismo sigue siendo promovido por los más entusiastas partidarios de la capacidad explicativa de la Biología Molecular, pero en general se propone la mixtura de reduccionismo ontológico - antirreduccionismo metodológico como la fórmula más civilizada para enfrentarse al asunto. Así hace, por ejemplo, John Maynard Smith en Los problemas de la Biología ${ }^{11}$.

\section{La actitud de Popper}

Popper, no obstante, sigue una línea diametralmente opuesta: agota la combinatoria y opta por combinar reduccionismo metodológico y antirreduccionismo ontológico. Si su decisión careciera de otros méritos, al menos no es legítimo negarle originalidad, porque son muy pocos los que han seguido esta vía. Y, a pesar de la soledad en que se encuentra, es tajante: "El reduccionismo filosófico es, creo yo, un error. Es debido al deseo de reducirlo todo a una explicación final en términos de esencias y sustancias, esto es, a una explicación que ni es capaz de ninguna explicación ulterior, ni la necesita" ${ }^{12}$.

Apenas es necesario agregar que lo que llama "reduccionismo filosófico" consiste en negar la existencia de los mundos 2 y 3 , y coincide con lo que he descrito como "reduccionismo ontológico", término que he tomado de Ayala ${ }^{13}$. Popper ve en él un ejemplo de Metafísica en

\footnotetext{
9 Dobzhansky, Th., "Introductory Remarks", en Ayala, F. J. y Dobzhansky, Th. (eds), Studies in the Philosophy of Biology, p. 1. Vers. cast. en: Estudios de Filosofía de la Biología, p. 23.

10 Crick, F., On Molecules and Men, University of Washington Press, Washington, 1966. Vers. cast.: ¿Ha muerto el vitalismo?, Antoni Bosch, Barcelona, 1979.

11 Maynard Smith, J., The Problems of Biology, Oxford University Press, Oxford, 1986. Vers. cast.: Los problemas de la Biología, Cátedra, Madrid, 1987, pp. 10-12.

12 Popper, K. R., "Scientific Reduction and the Essential Incompleteness of All Science", p. 279/ "La reducción científica y la incompletitud esencial de toda Ciencia", p. 359.

13 Ayala, F. J., "Introduction", en Ayala, F. J. y Dobzhansky, Th. (eds), Studies in the Philosophy of Biology, pp. vii-xvi. Vers. cast.: "Introducción”, en Ayala, F. J. y Dobzhansky, Th. (eds), Estudios de Filosofia de la Biología, pp. 10-16.
} 
el peor sentido del término: pretende captar la esencia de la realidad mediante un ejercicio apriorístico de la razón que supera todo lo que la experiencia enseña y se pone a cubierto de cualquier desmentido empírico concebible. Sean cuales sean los hechos que en el futuro lleguen a ser constatados, siempre cabrá postular dinamismos escondidos que supuestamente “explicarían” la aparente irreductibilidad de los fenómenos biológicos. Afirmar tal cosa es signo de una arraigada creencia que resultará quizá histórica, social o psicológicamente comprensible, pero en ningún caso constituye un ejercicio de racionalidad crítica.

Ahora bien, lo que en el plano ontológico revela un dogmatismo gratuito, en el plano metodológico resulta no solo justificable sino exigible por la índole misma de la empresa científica: “... sugeriré que, por motivos metodológicos, deberíamos, no obstante, continuar intentando las reducciones. La razón de ello es que podemos aprender muchísimo, incluso de intentos no logrados o incompletos de reducción, y que los problemas que se dejan abiertos mediante este sistema pertenecen a las posesiones intelectuales más valiosas de la Ciencia: sugiero que un énfasis mayor sobre lo que a menudo se consideran nuestros fracasos científicos (o, en otras palabras, sobre los problemas abiertos importantes de la Ciencia) puede sernos de gran provecho" 14 .

La apreciación popperiana es interesante por más de un motivo. El problema del reduccionismo ontológico va más allá de averiguar si los animales y las plantas son asimilables a las piedras. En la práctica lo que se intenta con él es reducir los vivientes a los modelos teóricos y conceptuales que la tradición occidental de pensamiento ha forjado para explicar los novivientes. Habría que decir — siguiendo a Popper - que ni siquiera las piedras se reducen a los conceptos físico-químicos, porque la realidad a que aludimos con dicho sustantivo ("piedra") escapa al significado preciso que hemos pretendido otorgarle desde tales y cuales teorías. En cambio, discutir si la Biología es o no reducible no a la Física y la Química es un asunto más viable, aunque de menor importancia teórica. La especificidad de los conceptos, leyes, lenguaje y Metodología de las disciplinas que estudian tanto la vida como otros tipos de objetos es histórica, relativa y coyuntural. Se trata por tanto de algo respetable, pero provisional. Hay que evitar convertir en definitivos los límites entre disciplinas; de lo contrario sacralizaríamos formas históricas y las convertiríamos en absolutas e intocables, cuando lo cierto es que las Ciencias mismas evolucionan y su contenido también.

¿Cómo se explica, por ejemplo, que la Química esté confinada dentro de la Física? ¿Por qué la limitan por un lado la Mecánica, la Teoría electromagnética o la Termodinámica, y por otro la Física atómica, nuclear y de partículas? Si a mediados del XIX la frontera entre ambas materias se encontraba en el nivel molecular, ¿en virtud de qué criterio fue atribuido a los físicos el mundo subatómico? La respuesta es que ello fue consecuencia de un accidente histórico: el electrón fue descubierto por especialistas en electricidad que, como J. J. Thomson, estudiaban el comportamiento de los rayos catódicos. El nacimiento de la Biología Molecular también ofrece una buena muestra de cómo es colonizado un terreno fronterizo por oportunistas con antecedentes diversos: físicos como Delbrück y Crick, o químicos como Pauling.

En definitiva, la cuestión relevante no es averiguar si las leyes de la Biología son o no reducibles a las de la Química o las de la Física, porque siempre cabe redefinir desde una lógica más abarcativa un concepto de ley capaz de comprender cualquier regla, sin importar el ámbito fenoménico involucrado o el formalismo utilizado. Lo importante es saber si la realidad se puede reducir o no a un conjunto dado de leyes, o si más bien eso que llamamos

14 Popper, K. R., "Scientific Reduction and the Essential Incompleteness of All Science", p. 260/ "La reducción científica y la incompletitud esencial de toda Ciencia", p. 334. 
"realidad" tiene tal complejidad que siempre desbordará cualquier racionalización finita con que pretendamos atraparla. Lo demás son simples peleas gremiales, pleitos de jurisdicción y asuntos a debatir por los sindicatos.

Al filósofo debería preocuparle menos decidir si el pensamiento se reduce al funcionamiento integrado de un conjunto de neuronas, o si la vida es algo más que la acumulación de un montón de moléculas, que saber si nuestros conceptos de neurona o de molécula abarcan de verdad la realidad que pretenden objetivar. Sospecho que no. La Mecánica Cuántica ya ha cuestionado el valor de verdad objetivo de los conceptos que se refieren a los niveles más elementales del mundo material. Sería incongruente que el realismo ingenuo recibiera una validación allí donde se da un grado mayor de complejidad.

\section{El estatuto epistemológico del darWinismo}

Cuando alienta el reduccionismo metodológico y condena el filosófico, Popper es coherente con los principios de su Epistemología. Más aún: consigue poner en orden su propia postura frente a la Teoría de la Evolución, que no carecía de ambivalencias. Sabidas son las dificultades que muchas Filosofías de la Ciencia han tenido que afrontar a la hora de encasillar la teoría darwinista, que en muchos respectos resulta inclasificable. Es indudable que no supera el test de la falsabilidad e incumple por tanto el requisito clave para darle carta de ciudadanía científica.

Haciendo balance de largas reflexiones, sobre las que debió volver muchas veces a lo largo de los años, Popper refiere en su autobiografía intelectual que "la cuestión del status científico de la teoría darwinista se torna en una cuestión interesante" ". Añade a continuación: "he llegado a la conclusión de que el darwinismo no es una teoría científica contrastable", lo cual podría ser lamentable desde varios puntos de vista, pero se apresura a matizar: "sino un programa metafísico de investigación —un posible marco conceptual para teorías científicas contrastables" ${ }^{16}$.

Las dudas sobre el rigor epistémico del darwinismo son de alguna manera escandalosas, puesto que forma el pilar fundamental de las concepciones del mundo contemporáneas sedicentemente científicas. Popper se atreve a poner el dedo en una llaga que muchos espíritus considerarían intolerablemente dolorosa, pero como el buen tardoilustrado que profesa ser, salva in extremis la amenazada ciudadela y le confiere el honorable rango de "programa metafísico de investigación", esto es, algo que no siendo refutable, puede al menos soportar una discusión racional. En un pasaje ulterior, la compara con las concepciones teológicas, juzgándola preferible a ellas por los siguientes motivos:

"Su teoría de la adaptación [la de Darwin] fue la primera teoría no teísta convincente; y el teísmo era algo peor que un abierto reconocimiento de fracaso, pues creaba la impresión de que se había logrado una explicación última. Ahora bien, en la medida en que el darwinismo crea la misma impresión, no es mucho mejor que la concepción teísta de la adaptación; resulta, por tanto, importante mostrar que el darwinismo no es una teoría científica, sino metafísica. Pero su valor para la Ciencia como programa de investigación metafísico es muy grande, especialmente si se admite que puede ser criticada y mejorada" ${ }^{17}$.

15 Popper, K. R., Unended Quest. An Intellectual Autobiography, Fontana/Collins, Londres, 1976; Routledge, Londres, 1992, p. 168. Vers. cast.: Búsqueda sin término, Tecnos, Madrid, 1977, p. 227.

16 Popper, K. R., Unended Quest. An Intellectual Autobiography, p. 168. Vers. cast.: Búsqueda sin término, p. 227.

17 Unended Quest. An Intellectual Autobiography, p. 172/ Búsqueda sin término, p. 232. 
Popper es enemigo de espacios clausurados: promueve una sociedad abierta, cree que el mundo es abierto y exige que las teorías y disciplinas tengan igualmente un carácter abierto. Se opone a la explicación teológica porque a su juicio es incompatible con cualquier intento de reevaluación crítica y pretende poner punto final a la dinámica indagatoria. Sería interesante discutir si todas las concepciones teológicas y religiosas están abocadas por necesidad a encerrarse en una autoafirmación acrítica. Es indudable que algunas sí lo hacen; son las que podríamos llamar fundamentalismos teológicos. Popper se pregunta si algunos representantes del darwinismo no hay caído en el mismo vicio. Cree que lo malo de una teoría no es tanto la falta de contrastabilidad empírica — es decir, el hecho de ser de índole metafísica — como la falta de contrastabilidad racional, esto es, que no admita críticas ni sea susceptible de mejora.

\section{Selección natural y falsacionismo}

El interés que pudiera tener esta contraposición es superado, al menos en lo que concierne personalmente a Popper, por otra: la que establece entre la Teoría darwinista de la Evolución y su propia Epistemología, pues ambas presentan rasgos de sorprendente coincidencia. En la Lógica de la investigación científica ya había llamado la atención sobre este punto: "Elegimos la teoría que se mantiene mejor en la competición con las demás teorías, la que por selección natural muestra ser más apta para sobrevivir; y ésta será la que no solamente haya resistido las contrastaciones más exigentes, sino que sea, asimismo, contrastable del modo más riguroso" 18 .

Luego, en Búsqueda sin término, acaba por certificar el parentesco: "Si la concepción de la teoría darwinista como lógica situacional fuese aceptable, entonces podríamos explicar la extraña similitud entre mi teoría del aumento del conocimiento y el darwinismo: los dos serían casos de lógica situacional" "19. Tanta semejanza implica que la propuesta teórica de Darwin y la de Popper tienen que superar los mismos obstáculos y responder a críticas parecidas por lo que respecta a su justificación y solvencia. Ninguna de las dos es susceptible de falsación empírica, lo que les da cierto carácter metafísico, o quizá más bien metateórico: Popper quiere situarlas en la matriz teórica del conocimiento específicamente científico.

Son fuentes de inspiración de posibles teorías, de futuros experimentos, y así se presentan respectivamente como Teoría de la Evolución de las especies y como Teoría evolutiva del Conocimiento. También sirven como protocolos para articular comprensivamente el pasado de los procesos que contemplan, como Historia de la evolución de la vida en un caso y como Historia de la evolución del conocimiento en el otro. Popper pronunció en 1989 una conferencia en la London School of Economics donde en la que ahondaba en estas consideraciones. Le dio el significativo título de Hacia una Teoría evolutiva del Conocimiento ${ }^{20}$.

Los paralelismos entre el falsacionismo popperiano y el evolucionismo darwiniano son evidentes: nacen de la simbiosis de un elemento azaroso y otro necesario. Las desconocidas fuentes de variaciones hereditarias se corresponden con las no menos misteriosas fuerzas inspiradoras de nuevas hipótesis. Indagar la etiología de mutaciones concretas es una tarea

18 Popper, K. R., The Logic of Scientific Discovery, Hutchison, Londres, 1959; edición revisada en 1968 (reimp. 1980), p. 108. Vers. cast.: La lógica de la investigación científica, Tecnos, Madrid, 1971, p. 103.

19 Unended Quest. An Intellectual Autobiography, p. 169/ Búsqueda sin término, p. 228.

20 Cfr. Popper, K. R., A World of Propensities, Thoemmes, Bristol, 1990, pp. 27-51. Vers. cast.: R., Un mundo de propensiones, Tecnos, Madrid, 1992, pp. 55-91. 
poco prometedora; lo mismo pasa cuando se estudia el contexto del descubrimiento. Tal vez quepa dar una explicación causal de estos eventos: ahí están el estudio de la mutagénesis y la Psicología de la invención para intentarlo. Pero a efectos prácticos el evolucionismo biológico, al igual que el epistemológico, puede considerarlos casuales. Lo importante es que tanto las especies biológicas como los sujetos del conocimiento son capaces de aprender de sus errores e iniciar una dinámica de rectificaciones para completar una trayectoria de superación creciente. La lucha por la vida y la contrastación empírica se encargan de cumplir con este expediente, gracias a un elemento de racionalidad negativa dotado de indudable eficacia. Los vivientes desfavorecidos sucumben, las teorías ineficaces también.

Cualquier análisis comparativo corre el riesgo de conformarse con analogías cada vez más vagas y acabar asido a semejanzas tangenciales. En el otro extremo, puede pretender artificialmente que existe identidad formal. En el presente caso, es más fácil caer en lo primero que en lo segundo, puesto que al menos hay una diferencia crucial: mientras que la mayor parte de los darwinistas antiguos y modernos son reduccionistas ontológicos y antirreduccionistas epistemológicos, Popper defiende la opción inversa: "Mi posición puede, pues, ser descrita como una posición que sostiene una teoría de la irreducibilidad y la emergencia" ${ }^{21}$. En estas condiciones sería deseable conseguir dos cosas: en primer lugar, no conformarse con constatar rasgos comunes, sino investigar de dónde surgen. En segundo lugar, explicar por qué partiendo de premisas tan próximas llega a conclusiones tan dispares.

Para otorgar mayor entidad a las coincidencias entre evolución por selección natural y falsacionismo, lo que hace Popper es generalizar algunas nociones gnoseológicas, como las de "conocimiento" y "a priori". Casi consigue así convertir su Teoría del Conocimiento en una Ontología, por no decir en una concepción del mundo. Como primer paso, atribuye conocimiento no sólo al hombre, sino a los animales: "la proposición los animales pueden conocer revoluciona por completo la teoría del conocimiento tal y como todavía se imparte" ${ }^{22}$. Se trata de una ampliación semántica en toda regla, porque, dando un paso más, se lo atribuye también a las plantas y a cualquier organismo: “ ¿Sólo los animales pueden conocer? ¿Por qué no las plantas? Obviamente, en el sentido evolutivo de conocimiento del que hablo, no sólo animales y hombres pueden tener expectativas y, por tanto, conocimiento (inconsciente), sino también las plantas y, en realidad, todos los organismos" ${ }^{23}$.

¿Estamos ante un caso de antropomorfismo o más bien de desantropomorfismo? ¿Proyecta Popper las prerrogativas humanas hacia afuera, o por el contrario las deduce de atributos incontrastablemente biológicos? Parece que su intención es ésta última, porque sostiene: "Toda adaptación a regularidades ambientales e internas, a situaciones a largo y a corto plazo, es un tipo de conocimiento, cuya gran importancia podemos aprender con la Biología evolutiva" ${ }^{24}$. Sabemos que es partidario de la teoría sobre la verdad de Tarski, lo que le permite recuperar a Aristóteles y su doctrina de la verdad como adecuación. Sin embargo, la adecuación no tiene que quedar restringida a una adaptación premeditada de formas mentales a cosas exteriores a la mente; cualquier propuesta puede quedar satisfecha o frustrada: aunque sea inconsciente, aunque sea innata.

21 Popper, K. R., Unended Quest. An Intellectual Autobiography, p. 178/ Búsqueda sin término, p. 240.

22 Popper, K. R., A World of Propensities, p. 30/ Popper, K. R., Un mundo de propensiones, p. 58.

23 A World of Propensities, Thoemmes, Bristol, 1990, p. 35/ Un mundo de propensiones, p. 65.

24 Popper, K. R., A World of Propensities, p. 38/ Un mundo de propensiones, p. 71. 


\section{ConcePción eVOlutiva del CONOCIMIENTo}

Según Popper, el conocimiento humano no es más que un caso particular de ajuste de expectativas. Por eso llega a afirmar que: "el origen y la evolución del conocimiento coinciden con los de la vida, y que están íntimamente ligados a los de nuestro planeta Tierra" ${ }^{25}$. Me pregunto la razón de que, puesto a generalizar, se detenga aquí, y no diga, por ejemplo, que el electrón está predispuesto a girar en torno al núcleo atómico, y en este sentido "posee cierto conocimiento" de los orbitales cuánticos, etc. Las fronteras del conocer podrían ampliarse entonces mucho más y alcanzar incluso hasta el mismo origen del universo. Sin ir tan lejos, el hecho de desligar el conocimiento de la conciencia permite preservar para el hombre una prerrogativa exclusiva y convertir el conocimiento en clave de un evolucionismo omnicomprensivo.

Todo viviente interacciona con el entorno, ensaya unas fórmulas de las que parte como dotación innata y que reciben a lo largo de la existencia una sanción positiva o negativa, de la que en muchos casos depende la supervivencia del proponente, así como la consagración o rechazo de las innovaciones que encarna y la consiguiente evolución del sistema vital o cognoscente involucrado. Aquí tiende Popper un puente hacia Kant, cuya noción de $a$ priori revaloriza: "En mi opinión, Kant anticipó los resultados más importantes de la teoría evolutiva del conocimiento. Pero yo voy mucho más allá que Kant. Creo que el 99 por 100 del conocimiento de todos los organismos es innato y se encuentra incorporado en nuestra constitución bioquímica" ${ }^{26}$.

Es evidente que el kantismo de Popper es muy heterodoxo, porque en el creador del idealismo crítico el recurso al a priori es una forma de salvar la necesidad (apodicticidad) de ciertos conocimientos, mientras que su seguidor austriaco iguala lo apriórico con lo meramente conjetural, se traduce en meros prejuicios arriesgados, que a pesar de todo sirven para edificar una epistemología rigurosa con materiales inciertos.

Ilustrémoslo con un par de casos concretos: Un tigre nacido en un mundo carente de presas comestibles recibiría sus garras y dientes como una tara hereditaria que muy pronto sería barrida de la escena. Tampoco prosperará quien haya sido imbuido en la infancia de prejuicios absurdos sobre cuestiones decisivas. Lo que pasa es que los miembros de la especie humana tienen una posibilidad de sobrevivir a los errores mucho mayor que los animales y las plantas. Hay que tener en cuenta que los "sujetos" del "conocimiento" biológico no son los individuos, sino las especies o, mejor aún, las líneas filogénicas; mientras que en el caso del conocimiento "humano", los sujetos son los individuos y por derivación las escuelas, tradiciones de pensamiento y en último término las culturas. Gracias a esta diferencia nuestras teorías mueren por nosotros, como dice tan gráficamente Popper, salvo — cabría añadir - que nos aferremos a ellas como un capitán de antaño a su barco. Pero nadie nace sabiendo. Las conjeturas aventuradas — en realidad gratuitas — son el punto de partida obligado, a no ser que contemos con el escarmiento de los fracasos ancestrales de la estirpe.

La selección natural es el procedimiento para incorporar a los genes ese escarmiento, en el sentido de que ninguno de los antecesores de cualquier viviente fue eliminado en la lucha por salir adelante. Como señala Dawkins, "los genes que penetran en el futuro no son una muestra aleatoria, sino una elite. Han sobrevivido a glaciaciones y sequías, a pestes y depredadores, a

25 A World of Propensities, p. 39/Un mundo de propensiones, p. 72.

26 Popper, K. R., A World of Propensities, p. 46/ Un mundo de propensiones, p. 84. 
explosiones y menguas demográficas" ${ }^{27}$. Por lo que afecta al hombre, la racionalidad crítica es en opinión de Popper el mejor expediente para evitar jugarse la vida al despejar cualquier incógnita. Pero nadie tiene hilo directo con la verdad, todo se reduce a técnicas biológicas o gnoseológicas para optar por los prejuicios menos desaconsejables.

Para Popper, "la invención del ojo constituye, pues, la invención de un nuevo conocimiento teórico a priori. Fue la primera adaptación a una estructura ambiental a largo plazo: a la existencia de luz solar potencialmente nutritiva; incorpora así un conocimiento de esta estructura ambiental. Es conocimiento teórico con un elevado grado de generalidad, casi como el conocimiento kantiano del espacio y del tiempo" ${ }^{28}$.

\section{LO REAL Y LO RACIONAL}

Consideradas desde cierto ángulo, tanto la teoría darwinista de la evolución biológica como la popperiana de la evolución gnoseológica son tan plausibles que llegan a ser triviales. Si hay variaciones hereditarias y eliminación preferente de los menos aptos, las variaciones positivas no tienen más remedio que acumularse. Si continuamente surgen nuevas hipótesis y todas ellas se ponen de algún modo a prueba, los errores tendrán que ir siendo desechados. Son tesis tan palmarias como teoremas geométricos. La única duda en ambos casos es si este planeta es un escenario con el grado de transparencia y racionalidad que Darwin y Popper presuponen.

Debe recordarse, sin embargo, que Darwin tuvo menos confianza que sus continuadores en la bondad de la selección natural. Tampoco Popper cree que la humanidad se rija habitualmente por los criterios del falsacionismo, aunque en su opinión esta circunstancia no anula su validez, sólo retarda su operatividad. El problema es que si la eficacia a la hora de descartar las malas opciones baja, el trabajo a cumplimentar amenaza con volverse demasiado arduo. El número de variaciones biológicas perjudiciales y el de errores epistémicos es infinito, inconmensurablemente mayor que el de soluciones viables y afirmaciones correctas. Desde el punto de vista combinatorio la tarea se vuelve abrumadora y el peso del azar difícilmente puede ser domeñado por el contrapeso de la necesidad. A no ser, claro, que haya servomecanismos para incrementar exponencialmente las virtudes discriminatorias de la selección natural y la falsación.

Los neodarwinistas piensan que el carácter acumulativo de la selección natural basta para restablecer el equilibrio. La selección no se enfrenta de una sola vez a todo el espectro de variaciones posibles, sino que actúa generación tras generación según el principio del todo o nada. Esto permite eliminar de raíz las secuelas de las variaciones perjudiciales, de modo que con el tiempo disminuye en proporción geométrica el número de opciones a escrutar. No obstante, la cuestión sigue siendo objeto de controversia, sobre todo porque la fuerza del argumento depende de la estricta continuidad en el proceso de aparición y filtrado de variaciones, algo que no está nada claro a partir de los datos disponibles (debido a la deriva genética, fenómenos de extinción en masa, períodos de eclosión vertiginosa de nuevas especiaciones, etc.).

Sorprendentemente, sobre la Teoría evolutiva del Conocimiento gravitan amenazas paralelas. Sería más fácil creer en las virtudes explicativas del falsacionismo si el progreso del saber hubiera seguido un ritmo de crecimiento menos desigual, si interferencias de todo orden no

27 Dawkins, R., Climbing Mount Improbable, Penguin Books, Londres, 1997. Vers. cast.: Escalando el monte improbable, Tusquets, Barcelona, 1998, p. 101.

28 Popper, K. R., A World of Propensities, p. 49/ Un mundo de propensiones, pp. 87-88. 
empañasen una y otra vez los métodos de confrontación de la hipótesis con la experiencia, si los procesos heurísticos fuesen menos complejos y se plegasen mejor a la lógica del azar.

El hecho de que Popper apele cada vez con mayor insistencia a marcos teóricos especulativos, como los "programas metafísicos de investigación”, obscurece la pura dialéctica de azar-necesidad de su teoría evolucionista del conocimiento y la contamina de lo que sólo se me ocurre denominar "tendencias ortogenéticas" a la hora de explorar nuevos caminos en la senda del conocimiento. Es como si no bastase el ciego mecanismo de la falsación empírica y el investigador tuviera que apelar a algún tipo de intuición metaempírica para adivinar hacia dónde deben apuntar futuras conjeturas. Por seguir con las analogías biológicas evolucionistas, es como si el relojero ciego de Dawkins estuviera haciendo trampas y mirase de soslayo por debajo del antifaz que le cubre el rostro.

\section{Ortogénesis}

Lo más curioso de todo es que Popper intenta reintroducir el punto de vista ortogenético en Biología evolucionista. En la conferencia Spencer de 1961 hizo una propuesta en este sentido. Demostró poseer una gran osadía, habida cuenta de que estaba lejos de ser una autoridad en la materia. De hecho, confiesa en un apéndice redactado una década después que cierto especialista le desaconsejó la publicación del escrito ${ }^{29}$. Pero al actuar así seguía los pasos de otro gran entrometido amateur, el físico Erwin Schrödinger, cuyo libro ¿Qué es la vida? desempeñó un papel muy controvertido en el origen de la Biología Molecular ${ }^{30}$.

Popper ha confesado el influjo que sobre su Pensamiento ha tenido este autor, con quien también mantiene grandes desavenencias ${ }^{31}$. Lo cierto es que en el terreno de las analogías, el físico austriaco ya había explorado las que existen entre el darwinismo y la Mecánica estadística ${ }^{32}$. En lo tocante al debate ortogenético, "Schrödinger sostenía que desde un punto de vista filosófico la solución de Darwin resulta pesimista y desalentadora (por la pasividad que implica en el viviente respecto a la evolución), mientras que la de Lamarck es, por el contrario, bella, alentadora y vigorizante (porque otorga protagonismo a los organismos en la mejora de la descendencia)" "33.

Para recuperar esta riqueza perdida en el desarrollo de la Teoría de la Evolución, proponía una solución de compromiso: ciertamente los esfuerzos adaptativos del viviente no alteran su material genético, pero ciertas decisiones, como la de trasladarse a un hábitat diferente, pueden modificar las condiciones en que se ejerce la selección natural, al cambiar sustancialmente las presiones selectivas (por ejemplo, las referentes al clima, alimento, predadores, etc. ${ }^{34}$. Los primeros pinzones que emigraron del continente americano a las islas Galápagos, por poner

29 Popper, K.R., Objective Knowledge. An Evolutionary Approach, p. 281/ Conocimiento objetivo, p. 256.

30 Schrödinger, E., What is Life? The Physical Aspect of the Living Cell, Cambridge University Press, Cambridge, MA, 1944.

31 Cfr. Popper, K. R., Unended Quest. An Intellectual Autobiography, pp. 135-138/ Búsqueda sin término, pp. 181-185.

32 Arana, J., "Erwin Schrödinger, filósofo de la Biología", en Arana, J. (ed), Los filósofos y la Biología, número monográfico de Thémata, Sevilla, 1998, pp. 171-172.

33 Arana, J., "Erwin Schrödinger, filósofo de la Biología", p. 172.

34 Schrödinger, E., "The Future of Understanding”, en Schrödinger, E., Gesammelte Abhandlungen, vol. 4, V. O. A. W., Viena, 1984, pp. 468-473. 
un ejemplo, no cambiaron sus genes, pero hicieron que la selección natural actuara sobre ellos de un modo muy distinto a como lo había hecho en su lugar de origen.

La propuesta popperiana guarda cierto parentesco con la de su ilustre compatriota, aunque lleva la marca de la ambición teórica característica del filósofo: no se conforma con "rescatar" a Lamarck, si trata de rehabilitar también opciones tan desprestigiadas como el vitalismo y el animismo: "Para decirlo con brevedad, mi hipótesis dualista nos permite, en principio, aceptar no sólo el lamarckismo simulado, sino también un vitalismo y animismo simulados, con lo que 'explica' estas teorías como primeras aproximaciones. Por eso nos permite explicar en principio la evolución de los órganos complejos, como el ojo, mediante muchos pasos que van hacia una dirección definida" ${ }^{35}$.

La idea matriz de esta recuperación es sustancialmente la misma que la de Schrödinger: el comportamiento del viviente no incide sobre la conformación de sus fluidos seminales, pero altera las circunstancias externas que rodean su existencia. Por consiguiente, los mecanismos de selección que gravitan sobre las ulteriores mutaciones favorecerán a las que estén en línea con las nuevas condiciones. No hay "herencia de los caracteres adquiridos", pero se puede elegir y legar el dinamismo que consagrará los caracteres que conviene adquirir.

Para reforzar la tesis, Popper se apoya en la idea de "monstruo prometedor" propuesta por Richard Goldschmidt ${ }^{36}$, transformándola en el modelo del "monstruo comportamental". Simplificando mucho, equivale a decir que no fueron meras mutaciones azarosas las que convirtieron ardillas normales en ardillas voladoras, sino que algunas de aquéllas empezaron a vivir en ambientes donde la habilidad para planear constituía un factor determinante de supervivencia. Sus mutaciones seguían siendo tan fortuitas e imprevisibles como siempre, pero el mecanismo que las convertía en patrimonio habitual del grupo había quedado reorientado en el sentido más conveniente. Así pues, los vivientes no pueden predeterminar las variaciones de su estirpe, pero sí el tipo de variaciones que se generalizará entre sus descendientes en cuanto la oportunidad se presente:

"Propongo, por tanto, una versión del darwinismo según la cual los monstruos comportamentales desempeñan una función decisiva. Si una novedad comportamental tiene éxito, lleva a la selección de aquellos nichos ecológicos que, a su vez, operarán selectivamente; es decir, operarán sobre esas novedades comportamentales, ejerciendo una presión selectiva en una dirección parcialmente predeterminada: en la dirección determinada por un fin indeterminado genéticamente posible; por ejemplo, el gusto por un nuevo tipo de alimento o el placer de utilizar regiones de la piel sensibles a la luz. De este modo, podemos llegar a la ortogénesis que era, después de todo, el problema principal de Goldschmidt. [...] En términos generales, la estructura anatómica sólo puede cambiar despacio, razón por la cual sus cambios serán insignificantes si no están guiados por cambios en la estructura propositiva y de destreza. Por tanto, en principio, se podrá explicar en términos darwinistas la evolución de un aparato genético que establezca la primacía de ambas estructuras. [...] Como se puede ver, esta teoría darwinista de los prometedores monstruos comportamentales no sólo ‘simula' el lamarckismo, sino también el vitalismo bergsoniano" ${ }^{37}$.

35 Popper, K.R., Objective Knowledge. An Evolutionary Approach, p. 279/ Conocimiento objetivo, p. 255.

36 Cfr. Goldschmidt, R. B., The Material Basis of Evolution, Yale University Press, New Haven, CT, 1940.

37 Objective Knowledge. An Evolutionary Approach, pp. 283-284/ Conocimiento objetivo, p. 259. 
La capacidad de generalizar es uno de los rasgos más característicos de Popper como filósofo. Propone un lamarckismo sin Lamarck, un vitalismo sin principios vitales ni entelequias, y un animismo sin alma. En el fondo, es lo mismo que hizo Darwin con la teleología gracias a la selección natural: patrocinar un finalismo sin fines. La especulación es atrevida pero en modo alguno rechazable. El problema de Popper es que a veces no sabe contenerse y se implica demasiado en el debate científico de primera línea. Le ocurrió algo parecido con las discusiones que siguieron al desarrollo de la Mecánica cuántica: en lugar de moverse con cautela en el terreno de la reflexión metateórica, tuvo que proponer un "experimento mental" para mediar en la controversia Einstein-Bohr, cometiendo un error de principiante que — según manifestó luego — le sumió en una profunda depresión y lo disuadió durante años de volver a tocar el tema ${ }^{38}$.

En el campo de los estudios biológicos también llevo a cabo algunas incursiones que no me consta hayan gozado del favor de los profesionales del ramo. Tal es la conjetura del "dualismo genético", que consiste en distinguir dentro de los organismos la parte que controla la conducta y la parte ejecutiva, para afirmar a renglón seguido que las mutaciones heredables se trasmiten por separado en cada uno de los dos subsistemas ${ }^{39}$. Con ello pretende dar carta de ciudadanía orgánica a su neo-pseudo-lamarckismo y también introducir un protodualismo biológico que preludia la vieja distinción cuerpo-alma. Otras propuestas son aún más intrépidas, y probablemente revelen la impaciencia por pisar el terreno de lo fáctico de un filósofo como él, que bien podría ser calificado de "empirista ilustrado" (esto es, todo para la experiencia, pero sin la experiencia).

Así entiendo su impetuosa discusión de las explicaciones del origen de la vida sobre la tierra, donde toma partido a favor de algunas opciones y en contra otras con excesiva vehemencia ${ }^{40}$. Por otro lado, tal vez haya sido víctima en todos estos pasajes de un exceso de probidad intelectual: dado que defiende una epistemología del riesgo en la que las teorías no rehuyen, sino que buscan ocasiones de ser refutadas por los hechos, tal vez se aplicó a sí mismo el precepto con demasiado arrojo, sin acabar de asumir que — al fin y a cabo — también él se movía en el marco de "programas metafísicos de investigación".

\section{El ÁRbol de la VIDA Y El ÁRbol del CONOCIMIENTo}

Me queda un solo punto por tratar antes de poner punto final a esta exposición. Dije antes que Popper detecta un profundo paralelismo entre su Teoría del Conocimiento y la Teoría darwinista de la Evolución. No obstante, su postura ante el problema de la reducción es opuesta a la de la mayor partes de los representantes del darwinismo. ¿Cabe dar razón de esta discrepancia? En El yo y su cerebro ha resumido las razones que le respaldan:

"Con todo, pienso que es importante darse cuenta de que hay dos modos distintos de buscar simplicidad, que pueden denominarse brevemente reducción filosófica y reducción científica. La primera se caracteriza por un intento de simplificar nuestra visión del mundo, y la segunda, por un intento de suministrar teorías audaces y contrastables de elevado poder explicativo. Creo que el último constituye un método extremadamente valioso, mientras que el primero sólo tiene valor si poseemos buenas razones para suponer que corresponde a los hechos relativos al universo" ${ }^{41}$.

38 Cfr. Popper, K. R., Unended Quest. An Intellectual Autobiography, pp. 92-94/ Búsqueda sin término, pp. 124-125.

39 Cfr. Objective Knowledge. An Evolutionary Approach, pp. 272-273/ Conocimiento objetivo, pp. $250-251$.

40 Popper, K. R., A World of Propensities, pp. 40-44/ Un mundo de propensiones, pp. 74-79.

41 Popper, K. R. y Eccles, J. C., The Self and Its Brain, Springer, Berlín, 1977, p. 60. Vers. cast.: El yo y su cerebro, Labor, Barcelona, 1985, p. 68. 
Einstein descreía de que Dios juegue a los dados. Pensaba que es sutil pero no malvado. Hay que suponer que en su opinión jugar a los dados es un rasgo de maldad si es Dios el que los lanza. Popper, que no está de acuerdo con el determinismo einsteiniano, probablemente lo considere un detalle de sofisticación.

Por otro lado, después de ahondar en las semejanzas del la evolución darwiniana y la del conocimiento, encuentra entre ambas una clara diferencia: "El árbol de la evolución crece desarrollando cada vez más ramas a partir de un tronco común. Es como un árbol ordinario: el tronco común está formado por todos nuestros antecesores unicelulares comunes, los antecesores de todos los organismos. Las ramas representan desarrollos tardíos" ${ }^{42}$. El crecimiento del conocimiento aplicado sigue una pauta semejante, pero el conocimiento puro evoluciona más bien hacia la simplicidad, hacia teorías cada vez más integradas:

"Suponiendo la misma dirección del tiempo, habremos de representar el árbol del conocimiento como surgiendo de incontables raíces que crecen en el aire, más bien que bajo tierra, y que, finalmente, tienden a unirse en un tronco común. En otras palabras, la estructura evolucionista del desarrollo del conocimiento puro es casi la opuesta a la del árbol de la evolución de los organismos vivos, los instrumentos humanos o el conocimiento aplicado." ${ }_{43}$

Cuesta un poco representarse la imagen, pero en definitiva lo que tenemos es un árbol puesto del revés, con la parte ramificada hacia abajo y el tronco común sobresaliendo de la estructura como la punta de una flecha que apunta hacia la imposible culminación de la verdad, que siempre se encuentra más allá de nuestras averiguaciones. Por otra parte, lo cierto que los árboles comunes también se ramifican bajo tierra, en las raíces. Por eso es un espejismo creer que sus ramas nacen de un único principio, de acuerdo con los módulos de la simplicidad monista. En el árbol del conocimiento todo está a la vista. Por eso las raíces son aéreas y la copa no existe: sólo es una aspiración y una promesa.

Tanto en la evolución biológica como en la evolución gnoseológica se da una síntesis de unidad y diversidad, de tronco y ramificaciones, de necesidad y contingencia. Igualmente en ambas hay algo que no vemos, en un caso las raíces - el principio último de donde procede la vida - y en el otro las ramas - la verdad absoluta hacia la que intentamos enderezar nuestros pasos-. No los vemos porque, como diría Kant, son principios regulativos y porque lo más probable es que tanto el mundo que vivimos como el mundo del saber sean estructuras de imposible culminación, realidades que siempre permanecerán abiertas.

\section{Bibliografía}

Arana, J., "Erwin Schrödinger, filósofo de la Biología", en Arana, J. (ed), Los filósofos y la Biología, número monográfico de Thémata, Sevilla, 1998, pp. 159-174.

Aristóteles, Acerca del Alma, edición de Tomás Calvo Martínez, Gredos, Madrid, 1978.

Ayala, F. J. y Dobzhansky, Th. (eds), Studies in the Philosophy of Biology, University of California Press, Berkeley, 1974. Vers. cast.: Estudios de Filosofia de la Biología, Ariel, Barcelona, 1983.

Ayala, F. J., "Introduction", en Ayala, F. J. y Dobzhansky, Th. (eds), Studies in the Philosophy of Biology, University of California Press, Berkeley, 1974, pp. vii-xvi. Vers. cast.: "Introducción”, en Ayala, F. J. y Dobzhansky, Th. (eds), Estudios de Filosofía de la Biología, Ariel, Barcelona, 1983, pp. 10-16.

42 Objective Knowledge. An Evolutionary Approach, p. 262/ Conocimiento objetivo, p. 241.

43 Popper, K.R., Objective Knowledge. An Evolutionary Approach, pp. 262-263/ Conocimiento objetivo, p. 242. 
Crick, F., On Molecules and Men, University of Washington Press, Washington, 1966. Vers. cast.: ¿Ha muerto el vitalismo?, Antoni Bosch, Barcelona, 1979.

Darwin, CH., The Autobiography of Charles Darwin, 1809-1882, selección de F. Darwin, edición de Nora Barlow, Collins, Londres, 1958. Vers. cast.: Autobiografía, selección de F. Darwin, Alianza Editorial, Madrid, 1977.

Dawkins, R., Climbing Mount Improbable, Penguin Books, Londres, 1997. Vers. cast.: Escalando el monte improbable, Tusquets, Barcelona, 1998.

Descartes, R., L'Homme, in: Oeuvres de Descartes, edición de Ch. Adam y P. Tannery, Vol. XI, Vrin, París, 1974, pp. 119-202. Vers. cast.: Tratado del hombre, Editora Nacional, Madrid, 1980.

Goldschmidt, R. B., The Material Basis of Evolution, Yale University Press, New Haven, CT, 1940.

Huxley, Th., Genealogy of Animals, The Academy, Londres, 1869.

Maynard Smith, J., The Problems of Biology, Oxford University Press, Oxford, 1986.

Popper, K. R., The Logic of Scientific Discovery, Hutchison, Londres, 1959; edición revisada en 1968 (reimp. 1980). Vers. cast.: La lógica de la investigación científica, Tecnos, Madrid, 1971.

Popper, K. R., Conjectures and Refutation. The Growth of Scientific Knowledge, Routledge and Kegan, Londres, 1962. Vers. cast.: El desarrollo del conocimiento científico, Paidós, Buenos Aires, 1967.

Popper, K. R., "Scientific Reduction and the Essential Incompleteness of All Science", en Ayala, F. J. y Dobzhansky, Th. (eds), Studies in the Philosophy of Biology, University of California Press, Berkeley, 1974, pp. 258-284. Vers. cast.: "La reducción científica y la incompletitud esencial de toda Ciencia”, en Ayala, F. J. y Dobzhansky, Th, (eds), Estudios de Filosofía de la Biología, Ariel, Barcelona, 1983, pp. 333-364.

Popper, K. R., Objective Knowledge. An Evolutionary Approach, Clarendon Press, Oxford, 1972. Vers. cast.: Conocimiento objetivo, Tecnos, Madrid, 1974.

Popper, K. R., Unended Quest. An Intellectual Autobiography, Fontana/Collins, Londres, 1976; Routledge, Londres, 1992. Vers. cast.: Búsqueda sin término, Tecnos, Madrid, 1977.

Popper, K. R. y Eccles, J. C., The Self and Its Brain, Springer, Berlín, 1977. Vers. cast.: El yo y su cerebro, Labor Barcelona, 1985.

Popper, K. R., The Open Universe, Hutchison, Londres, 1982. Vers. cast.: El universo abierto. Un argumento en favor del determinismo, Tecnos, Madrid, 1986.

Popper, K. R., A World of Propensities, Thoemmes, Bristol, 1990. Vers. cast.: Un mundo de propensiones, Tecnos, Madrid, 1992.

Schrödinger, E., What is Life? The Physical Aspect of the Living Cell, Cambridge University Press, Cambridge, MA, 1944.

SCHRÖDIngER, E., "The Future of Understanding”, en SchrödingER, E., Gesammelte Abhandlungen, vol. 4, V. O. A. W., Viena, 1984, pp. 468-473. 


\title{
Racionalidad como adaptación evolutiva en Herbert A. Simon: Una comparación con Karl Popper y Reinhard Selten
}

\author{
Francisco J. Castro
}

El evolucionismo ha impregnado múltiples aspectos de la Filosofía y Metodología de la Ciencia. Entre sus ámbitos de influencia figura la Epistemología, en un caso tan representativo como la racionalidad, y la Metodología de las Ciencias Sociales, especialmente en Psicología y en Economía. Uno de los autores donde este fenómeno se aprecia con claridad es Herbert Simon, Premio Nobel de Economía en 1978, que desarrolla una "racionalidad adaptativa”. Este autor, a su vez, ha influido en Reinhard Selten, que fue galardonado con el Nobel en Economía en 1994 e insiste en la racionalidad como un conjunto de instrumentos adaptativos (adaptive toolbox). Aquí el análisis se centra en cómo la racionalidad humana es vista en términos evolutivos — como adaptación-y en algunas consecuencias que se derivan de ese enfoque.

\section{UN MODELO ALTERNATIVO DE RACIONALIDAD: LA RACIONALIDAD ADAPTATIVA}

En Reason in Human Affairs, un libro publicado en 1983, dedicado a las concepciones acerca de la racionalidad, Herbert Simon ofrece tres alternativas posibles a la hora de hablar de "racionalidad". Presenta así tres modos distintos de entender cómo toman decisiones los seres humanos. Se trata de un intento de abarcar los tipos de procesos más representativos para la toma de decisiones racionales, de modo que no está directamente orientado hacia los resultados.

La primera forma la denomina "modelo olímpico" (olympian model). Es la racionalidad que propugna la tendencia dominante (mainstream) en Economía — la posición neoclásica-, donde se asume que el ser humano siempre busca una maximización de la utilidad subjetiva esperada 2. El segundo tipo lo llama "modelo conductual" (behavioral model). Este enfoque entiende que, en la toma de decisiones, el ser humano utiliza una racionalidad limitada (bounded rationality), debido a la limitación de sus capacidades computacionales y cognitivas ${ }^{3}$. A su

1 Cfr. Simon, H. A., Reason in Human Affairs, Stanford University Press, Stanford, CA, 1983, pp. 34-35.

2 Simon también llama a este tipo de racionalidad "the Robinson Crusoe's Rationality". Cfr. SimON, H. A., "Some Strategic Considerations in the Construction of Social Science Models", en LAZARSFELD, P. (ed), Mathematical Thinking in the Social Sciences, The Free Press, Glencoe, IL, 1954. Reimpreso en Simon, H. A., Models of Bounded Rationality. Vol. 2: Behavioral Economics and Business Organization, The MIT Press, Cambridge, MA, 1983 (2 reimp.), pp. 215-217.

3 Cfr. Simon, H. A., "Bounded Rationality", en Eatwell, J., Milgate, M. y Newman, P. (eds), The New Palgrave: A Dictionary of Economics, vol. 1, Macmillan, Londres, 1987. Reimpreso en Simon, H. A., Models of Bounded Rationality. Vol. 3: Empirically Grounded Economic Reason, The MIT Press, Cambridge, MA, 1997, p. 291. 
juicio, hay pruebas empíricas (empirical evidence) que muestran que esta teoría proporciona una explicación válida de cómo los seres humanos toman decisions ${ }^{4}$. La tercera posibilidad es el "modelo intuitivo" (intuitive model). Este planteamiento resalta los procesos de intuición que intervienen en la toma de decisiones, si bien Simon considera que el modelo intuitivo es un componente más de la Teoría conductual de la Racionalidad.

Junto a estas tres visiones de la racionalidad, Simon añade una cuarta posición: la racionalidad como adaptación evolutiva (evolutionary model of adaptation), donde se aprecia el influjo epistemológico y evolucionista. En este planteamiento el proceso evolutivo es, en sí mismo, un modelo de racionalidad, puesto que los organismos que se adaptan al entorno con el objetivo de sobrevivir actúan como si ellos fuesen racionales. En efecto, seleccionan los medios más adecuados para adaptarse al entorno.

\subsection{Racionalidad limitada y racionalidad como adaptación}

Simon trata de examinar si este tipo de racionalidad es aplicable a la racionalidad humana y hasta qué punto. Busca así conectar esta cuarta posibilidad con su teoría de la racionalidad limitada (bounded rationality), según la cual el ser humano sigue una racionalidad circunscrita — por la capacidad limitada de procesamiento de la información — a la hora de tomar decisiones racionales ${ }^{5}$.

Mediante su concepción epistemológica, Simon insiste en que hay un límite en la capacidad racional del ser humano. Éste sólo está capacitado para efectuar un cálculo teniendo en cuenta un número limitado de variables pertinentes a una situación; sus limitaciones cognoscitivas le impiden conocer todas las variables que entran en juego ${ }^{6}$. Son limitaciones que afectan, de una parte, al agente mismo que toma decisiones y, de otra, al agente que trata de predecir la decisión que tomará el otro. El primero se ve afectado porque tiene limitaciones de cálculo, que le impiden tomar la decisión más ventajosa para él; y el segundo agente también está limitado: no puede conocer todas las características del ambiente en el que será tomada la decisión y la percepción que el agente tiene de él.

Resalta Simon una distinción fundamental que la teoría neoclásica no hace: la diferencia entre el entorno objetivo que rodea al individuo y la percepción que de dicho ambiente tiene

\footnotetext{
4 Señala Simon: "there is a great deal of empirical evidence supporting this kind of theory as a valid description of how human beings make decisions", Reason in Human Affairs, p. 34. Desde el punto de vista de Simon, las limitaciones en la racionalidad humana se expresan en dos aspectos: 1) el agente sólo tiene una información incompleta acerca de las alternativas posibles; y 2) las limitaciones que introduce el entorno impiden al elector calcular cuál sería el mejor curso de acción teniendo en cuenta tales limitaciones. Cfr. Simon, H. A., "Theories of Bounded Rationality”, en Mcguire, C. B. y Radner, R. (eds), Decision and Organization, North-Holland, Ámsterdam, 1972. Reimpreso en Simon, H. A., Models of Bounded Rationality. Vol. 2: Behavioral Economics and Business Organization, pp. 410-411.

5 Para Simon, la idea de que la racionalidad humana está limitada no es reciente, sino que tiene ya precedentes en los tiempos clásicos, pues ya entonces se había prestado atención a las limitaciones racionales humanas. Cfr. Simon, H. A., "Bounded Rationality in Social Science: Today and Tomorrow", Mind and Society, v. 1, (2000), pp. 26-27. Vers. cast. de Wenceslao J. González y María G. Bonome: "Racionalidad limitada en Ciencias Sociales: Hoy y mañana", en Gonzalez, W. J. (ed), Racionalidad, historicidad y predicción en Herbert A. Simon, Netbiblo, A Coruña, 2003, pp. 98-99.

6 Estas limitaciones también impiden al ser humano, a juicio de Simon, realizar todos los cálculos que serían necesarios para predecir con ciertas garantías una determinada situación social. Cfr. SimON, H. A., "Rationality", en Gould, J. y Kolb, W. L. (eds), A Dictionary of the Social Sciences, The Free Press, Glencoe, IL, 1964, pp. 573-574. Reimpreso en Simon, H. A., Models of Bounded Rationality, vol. 2: Behavioral Economics and Business Organization, pp. 405-407.
} 
ese individuo ${ }^{7} ;$ y esto es más relevante en situaciones complejas ${ }^{8}$. A mi juicio, esto repercute de un modo decisivo en la posibilidad de realizar predicciones acerca de la conducta del agente, porque las características objetivas del entorno no son las mismas que las percibidas por el individuo.

Herbert Simon es un crítico frontal del modelo de racionalidad que sustenta la tendencia neoclásica en Economía, esto es, la racionalidad como maximizadora de la utilidad subjetiva esperada, en la cual el ser humano siempre busca lo máximo o lo óptimo cuando toma decisiones. La critica porque entiende que este tipo de racionalidad asume que el agente racional no sólo conoce todas las alternativas posibles que caben en un momento dado, sino que además es capaz de captar aquellas alternativas que, con mayor o menor probabilidad, se puedan presentar en estados futuros del mundo 9

Para Simon, la teoría maximizadora no describe la conducta humana real. La cuestiona porque el ser humano no tiene el poder de razonamiento necesario para tomar en consideración todas las posibles variables y alternativas; ni siquiera en situaciones de elección relativamente simples cabe semejante capacidad omniabarcante ${ }^{10}$. Frente a este modelo, que llama olímpico, Simon sostiene que el modelo conductual se acerca más a la forma real en la que los seres humanos toman decisiones. Es un modelo basado en una racionalidad limitada, en cuanto que la capacidad de computación y de decisión están limitados no sólo por las propiedades del mundo externo sino también por el conocimiento que el agente tiene de él ${ }^{11}$.

Cuando ofrece esta "versión conductual" de la racionalidad limitada, Simon se apoya en dos afirmaciones: a) Existe base empírica suficiente para sostener que así es como, en efecto, la gente toma decisiones y resuelve problemas. Considera que es una teoría que describe de manera fehaciente la conducta humana ${ }^{12}$; y b) esta teoría explicaría, además, cómo los organismos logran sobrevivir de hecho en un mundo tan complejo y en constante evolución, a pesar de ser limitadas sus capacidades de cálculo ${ }^{13}$. Con estas ideas señala por qué prefiere

7 Cfr. Simon, H. A., "Economics and Psychology", en Koch, S. (ed), Psychology: A Study of a Science, vol. 6, McGraw-Hill, N. York, 1963. Reimpreso en Simon, H. A., Models of Bounded Rationality. Vol. 2: Behavioral Economics and Business Organization, p. 342. A juicio de Simon, en la teoría neoclásica no se hace tal distinción, puesto que si se asume que el individuo tiene una racionalidad ilimitada, éste percibirá tal y como el mundo es: tendrá una percepción objetiva del mundo y no meramente subjetiva. Cfr. Simon, H. A., "Rationality in Psychology and Economics", Journal of Business, v. 59, (1986). Reimpreso en Simon, H. A., Models of Bounded Rationality, Vol. 3: Empirically Grounded Economic Reason, pp. 368-370.

Desde el punto de vista de Simon, la conducta racional está determinada por el "ambiente interno" de las mentes de las personas tanto como por el ambiente externo del mundo sobre el que actúan. Cfr. SimON, H. A., "Racionalidad limitada en Ciencias Sociales: Hoy y mañana", p. 97.

8 Cfr. Simon, H. A., "Rationality as Process and as Product of Thought", American Economic Review, v. 68, n. 2, (1978). Reimpreso en Simon, H. A., Models of Bounded Rationality. Vol. 2: Behavioral Economics and Business Organization, pp. 451-452.

9 Cfr. Reason in Human Affairs, p. 13.

10 A su juicio, el mundo real es tan complejo que la teoría de la maximización de la utilidad tiene, en consecuencia, poca relevancia en elecciones reales. Cfr. Simon, H. A., "Theories of Decision-Making in Economics and Behavioral Science", American Economic Review, v. 49, n. 1, (1959). Reimpreso en Simon, H. A., Models of Bounded Rationality, Vol. 2: Behavioral Economics and Business Organization, pp. 292-293.

11 "Las elecciones (choices) realizadas por la gente están determinadas no sólo por un objetivo general (overall goal) que sea consistente y por las propiedades del mundo externo, sino también por el conocimiento del mundo que tienen o dejan de tener quienes toman decisiones...", Simon, H. A., "Racionalidad limitada en Ciencias Sociales: Hoy y mañana”, en Gonzalez, W. J. (ed), Racionalidad, historicidad y predicción en Herbert A. Simon, p. 97.

12 Simon es consciente de las dificultades que entraña descubrir las bases que rigen la conducta de elección humana. Cfr. Simon, H. A., "Decision-Making and Problem Solving”, Interfaces, v. 17, n. 5, (1987), p. 20.

13 Cfr. Simon, H. A., Reason in Human Affairs, pp. 22-23. 
el modelo que busca satisfacer nuestras necesidades — la racionalidad limitada —, en vez del modelo basado en la maximización de la utilidad subjetiva esperada ${ }^{14}$.

Este modelo conductual que usa en Economía conecta con la Psicología y tiene en consideración la racionalidad limitada de los agentes, especialmente en elecciones donde hay incertidumbre ${ }^{15}$. La sustitución del supuesto de la "maximización" en favor de la idea de "satisfacción" es el eje sobre el que gira el planteamiento metodológico en Economía de Herbert Simon. Propone esta alternativa basándose en la observación empírica que, a su juicio, ha mostrado que los individuos en situaciones de toma de decisiones racionales buscan meramente satisfacer y no maximizar las utilidades subjetivas esperadas ${ }^{16}$.

Aprecia que hay una estrecha analogía entre la racionalidad conductual humana y el modelo de evolución darwiniana. Así, en la teoría conductual, para llevar a cabo una elección racional, se requiere de una búsqueda selectiva: se ha de seleccionar una respuesta adaptativa al entorno que satisfaga nuestras necesidades, de acuerdo con el nivel de aspiración (aspiration level) del agente. Para Simon, este mecanismo de relación con el entorno por parte de los agentes humanos es análogo al mecanismo de variación-selección de la teoría darwiniana ${ }^{17}$.

Considera que la racionalidad es adaptativa, tanto en la teoría evolucionista darwiniana como en la teoría conductual de la toma de decisiones humanas. Para Simon, los organismos se adaptan para satisfacer ciertas necesidades y aspiraciones, no para optimizar utilidades subjetivas ${ }^{18}$. En las decisiones humanas racionales aparece — a su juicio- una racionalidad que no busca la optimización, sino la búsqueda de alternativas que permita satisfacer las aspiraciones y resolver los problemas de adaptación de los organismos ${ }^{19}$. En este sentido, mantiene que la racionalidad que sostiene los procesos evolutivos es una racionalidad más bien "miope" (myopic) 20: no es un proceso maximizador sino sólo un proceso de mejora, que busca la satisfacción de necesidades. De este modo, Simon argumenta que el resultado de los procesos evolutivos puede ser tomado como una forma de racionalidad ${ }^{21}$.

14 Herbert Simon cita seis variables a tener en cuenta en el estudio de la Economía basándose en la teoría de la racionalidad limitada: i) continuos cambios en el conocimiento e información sobre la Economía y el mundo; ii) cambios en la habilidad humana para estimar consecuencias de acciones; iii) cambios en el entorno institucional donde la conducta económica tiene lugar; iv) variaciones en el foco de atención y en creencias y expectativas; v) cambios en el altruismo humano; y vi) modificaciones en la identificación de grupo. Cfr. Simon, H. A., "Economics as a Historical Science", Theoria, v. 13, n. 32, (1998), pp. 241-260, en especial, pp. 251-258.

15 Cfr. Simon, H. A., "Economics and Psychology”, pp. 330-337.

16 Cfr. Simon, H. A., "From Substantive to Procedural Rationality", en Latsis, S. J. (ed), Method and Appraisal in Economics, Cambridge University Press, Cambridge, 1976. Reimpreso en Simon, H. A., Models of Bounded Rationality, Vol. 2: Behavioral Economics and Business Organization, pp. 430-432. Es famoso su ejemplo de los jugadores de ajedrez que una vez que han encontrado una alternativa que satisface sus expectativas, su "aspiration level", no siguen buscando ya otras alternativas. Véase Simon, H. A., "A Behavioral Model of Rational Choice", Quarterly Journal of Economics, v. 69, (1955). Reimpreso en Simon, H. A., Models of Bounded Rationality, Vol. 2: Behavioral Economics and Business Organization, pp. 250-251.

17 Para Simon, "is the direct analogue, in the behavioral theory of rationality, of the variation-selection mechanism of the Darwinian theory”, Simon, H. A., Reason in Human Affairs, p. 40.

18 Cfr. Simon, H. A., "Rational Choice and the Structure of the Environment", Psychological Review, v. 63, n. 2, (1956). Reimpreso en Simon, H. A., Models of Bounded Rationality, Vol. 2: Behavioral Economics and Business Organization, pp. 259-260.

19 Cfr. Simon, H. A., Reason in Human Affairs, pp. 41 y 73-74.

20 Cfr. Reason in Human Affairs, p. 66.

21 Cfr. Simon, H. A., Reason in Human Affairs, p. 38. 
Simon considera que la optimización o maximización se apoya en la deliberación consciente y en la previsión e intuición; mientras que la adaptación requiere siempre supervivencia y movimiento hacia el equilibrio ${ }^{22}$. Para él, la conducta optimizadora denota búsqueda consciente de la elección mejor (best), mientras que la conducta adaptativa lo que manifiesta es movimiento hacia algo mejor (better), sin que intervenga, de forma consciente, ningún mecanismo optimizador ${ }^{23}$.

\subsection{Racionalidad instrumental y racionalidad evaluativa}

Sostiene Simon que, en el proceso evolucionista, se da un tipo especial de teleología, puesto que no hay una meta concreta. El único fin evolutivo corresponde al organismo en su búsqueda de los mejores medios que le permitan adaptarse al entorno. Estamos ante una racionalidad que va de medios a fines ${ }^{24}$.

Para Simon, la racionalidad comporta el tipo de conducta apropiada que lleva a la consecución de unos fines que ya están dados ${ }^{25}$. En la concepción que él defiende, la racionalidad es una racionalidad de medios, esto es, puede ayudarnos a descubrir los medios que necesitamos para conseguir nuestros fines, pero tiene poco que decir de los fines en sí mismos ${ }^{26}$. Es una razón instrumental: nos indica el medio acerca de cómo llegar a un fin, pero no el propio fin, sea bueno o malo. A su juicio, la razón no puede seleccionar nuestros fines, únicamente nos puede ayudar a llegar a ellos de un modo más eficiente ${ }^{27}$.

Conviene señalar a este respecto que esta posición, como ha apuntado Wenceslao J. González ${ }^{28}$, comporta una restricción innecesaria del campo de la racionalidad y que la postura de N. Rescher supone, sin duda, un avance al incorporar una visión más amplia de la racionalidad. Cabe así hablar de tres tipos de racionalidad: i) una racionalidad cognitiva, presente en los planteamientos de Simon, la cual versa sobre lo que cabe aceptar o creer tanto en el saber teórico como en el conocimiento empírico; ii) una racionalidad práctica, que decide acerca de las acciones a realizar, cuya existencia también acepta, y iii) una racionalidad evaluativa o de fines $^{29}$, que no aparece en sus escritos, y es aquella racionalidad que dictamina sobre qué fines o metas se han de preferir o valorar, teniendo en cuenta los medios de los que disponemos. La ausencia de una racionalidad de fines en sus planteamientos supone una limitación en su

22 Cfr. "Some Strategic Considerations in the Construction of Social Science Models", pp. 217-221.

23 Cfr. Simon, H. A., "Some Strategic Considerations in the Construction of Social Science Models", pp. 219-220.

24 Simon entiende así que "evolution is sometimes regarded as a preferred explanation for rationality precisely because it doesn't require a detailed explanation of process; the important thing is adaptation... Evolution permits one to postulate the end without specifying the means". Simon, H. A., Reason in Human Affairs, p. 70.

25 Cfr. Simon, H. A., "Theories of Bounded Rationality", pp. 408-411.

26 Cfr. Reason in Human Affairs, p. 7.

27 Dice Simon: “... can't select our final goals... All reason can do is help us reach agreed-on goals more efficiently”, Simon, H. A., Reason in Human Affairs, p. 106.

28 Cfr. Gonzalez, W. J., "Racionalidad y Economía: De la racionalidad de la Economía como Ciencia a la racionalidad de los agentes económicos", en Gonzalez, W. J. (ed), Racionalidad, historicidad y predicción en Herbert A. Simon, p. 71.

En la racionalidad científica, en general, y en la racionalidad económica, en particular, se da una racionalidad de medios. Esta lleva a elegir los mejores medios para alcanzar unos fines previstos, pero hay también una racionalidad de fines o evaluativa, que contribuye a escoger los fines apropiados para la actividad que se desarrolla, cfr. GoNZALEZ, W. J., "Racionalidad científica y actividad humana. Ciencia y valores en la Filosofía de Nicholas Rescher", en Rescher, N., Razón y valores en la Era científico-tecnológica, Paidós, Barcelona, 1999, pp. 11-44.

29 Cfr. Rescher, N., Rationality: A Philosophical Inquiry into the Nature and the Rationale of Reason, Clarendon Press, Oxford, 1988, p. 3. 
punto de vista sobre la Economía entendida como Ciencia de lo Artificial. El Diseño necesita que se dé una complementariedad entre una racionalidad de medios o instrumental y una racionalidad de fines o evaluativa ${ }^{30}$.

Resulta significativo que la idea de "racionalidad evaluativa" sea aceptada de facto por R. Selten. Por un lado, asume la existencia de racionalidad limitada, basada en los planteamientos de H. Simon; y, por otro lado, admite claramente la presencia de una racionalidad de fines o evaluativa en una Ciencia como la Economía ${ }^{31}$. En concreto, la acepta en el campo que trabaja, que es la Economía Experimental ${ }^{32}$. Así, Selten se aleja de la corriente dominante en Economía - la tendencia neoclásica - al tiempo que desarrolla una noción de racionalidad más amplia que la propuesta por Simon ${ }^{33}$.

Ciertamente, tiene una serie de implicaciones aceptar un punto de vista evolutivo con respecto a los procesos racionales. Las más relevantes, dentro del presente contexto, son las siguientes: 1) aceptar una racionalidad evolutiva supone asumir la idea de movilidad: lo que hay es adaptación a un entorno — no perfeccionamiento - que está en continuo movimiento ${ }^{34}$; y 2) seguir un modelo evolucionista de racionalidad — una racionalidad adaptativa — nos proporciona un mecanismo particular para el proceso que tiene lugar en la toma de decisiones racionales ${ }^{35}$. El modelo únicamente señala las distintas direcciones y alternativas que puede tomar ese proceso y no cuál es la mejor ${ }^{36}$. Se trata de un proceso de elección de medios permanentemente abierto.

La conducta humana es siempre en Simon una conducta adaptativa: el ser humano es visto como un organismo adaptativo que tiene que ir resolviendo problemas para sobrevivir ${ }^{37}$, en vez de ser un conseguidor de logros óptimos. Más aún, la conducta humana adaptativa conecta directamente con la incapacidad que, a menudo, el ser humano tiene para predecir con exactitud lo que le es relevante del futuro ${ }^{38}$. La elección que el ser humano puede hacer está marcada por una racionalidad procesual (procedural) en vez de sustantiva (substantive).

$\mathrm{Su}$ origen es paradójico: la racionalidad procesual busca descubrir la conducta adaptativa más apropiada, lo cual convierte en una tarea extremadamente difícil la predicción conductual

30 Cfr. Gonzalez, W. J., "Rationality and Prediction in the Sciences of the Artificial: Economics as a Design Science”, en Galavotti, M. C., Scazzieri, R. y Suppes, P. (eds), Reasoning, Rationality and Probability, CSLI Publications, Stanford, 2008, pp. 165-186.

31 Cfr. Gonzalez, W. J., "Rationality in Experimental Economics: An Analysis of Reinhard Selten's Approach", en Galavotti, M. C. (ed), Observation and Experiment in the Natural and Social Sciences, Kluwer, Dordrecht, 2003, p. 75.

32 Cfr. Gonzalez, W. J., "Racionalidad y Economía: De la racionalidad de la Economía como Ciencia a la racionalidad de los agentes económicos”, p. 79. La Economía Experimental ha contribuido a apreciar de manera más clara la distinción y complementariedad entre la racionalidad evaluativa y la racionalidad instrumental. Véase GonZALEZ, W. J., "Rationality and Prediction in the Sciences of the Artificial: Economics as a Design Science", pp. 176-179.

33 Cfr. "Racionalidad y Economía: De la racionalidad de la Economía como Ciencia a la racionalidad de los agentes económicos", p. 81.

34 Cfr. Simon, H. A., Reason in Human Affairs, p. 72.

35 Cfr. Reason in Human Affairs, p. 72.

36 Cfr. Simon, H. A., Ibidem.

37 Cfr. "Some Strategic considerations in the construction of Social Science Models", pp. 217-221.

38 Cfr. "From Substantive to Procedural Rationality", pp. 437-439. Simon no niega a las Ciencias Sociales la posibilidad de efectuar predicciones, sino que, al contrario, considera que hay tanto procesos individuales como sociales que son predecibles de la misma forma que en las Ciencias de la Naturaleza. Cfr. Simon, H. A., "Accurate predictions and fixed point theorems: Comments", Social Science Information, v. 25, n. 4/5, (1982), pp. 605-612. 
de un agente en un entorno que está evolucionando y cambiando de una manera constante ${ }^{39}$. En otras palabras, a Simon le interesa más el proceso que lleva a cabo el ser humano en la toma de decisiones que las decisiones tomadas ${ }^{40}$.

En el planteamiento de Herbert Simon, el énfasis está claramente puesto en el sujeto: en su capacidad cognitiva y en su relación con el entorno. Considera, en efecto, que es el sujeto el que, utilizando una racionalidad limitada, elige la opción que considera que se adapta mejor al medio. Una concepción muy distinta de racionalidad es la que ofrece Karl Popper. En éste no es el sujeto el que elige unas teorías en lugar de otras, sino que lo que se da es una "selección natural" en la que las mejores hipótesis son las que sobreviven frente a las que se muestran menos aptas.

\section{Racionalidad y Epistemología evolutiva en Karl R. Popper}

Un autor que también se ha interesado por los aspectos evolucionistas es Karl R. Popper, sobre todo en una determinada etapa de su Filosofía — entre los años 1960 a 1969—, que es cuando desarrolla su Epistemología evolutiva (evolutionary epistemology). El conocimiento científico y cómo éste progresa, su carácter evolutivo, son los ejes fundamentales que centran el interés de su Pensamiento en este periodo ${ }^{41}$. Sin embargo, Popper aborda el evolucionismo desde un ángulo muy distinto del utilizado por Herbert A. Simon: difieren abiertamente acerca del papel del sujeto cognoscente en la Epistemología.

\subsection{El giro hacia la Epistemología evolutiva}

En la etapa que va de 1960 a 1969, la concepción filosófica general de Karl Popper experimenta, en efecto, un cambio de enfoque en cuanto a la perspectiva de su planteamiento. En ese período da un "giro epistemológico" en su Filosofía y Metodología de la Ciencia. Presenta entonces su concepción de una Epistemología evolutiva, que rebasa el plano epistemológico y afecta a toda su Filosofía y Metodología de la Ciencia ${ }^{42}$. Lo hace después de décadas de énfasis lógico-metodológico en su enfoque de la Ciencia.

Cuando Popper ofrece su Epistemología evolutiva resalta que el proceso del conocimiento se da en el tiempo ${ }^{43}$ : es una dinámica de resolución de problemas. Estos problemas se solucionan mediante la elaboración de teorías o hipótesis, con una posterior discusión

39 Cfr. Gonzalez, W. J., "Racionalidad y Economía: De la racionalidad de la Economía como Ciencia a la racionalidad de los agentes económicos", pp. 76-77.

40 Cfr. Simon, H. A., "Bounded Rationality", p. 293. A su juicio, "human reason is less a tool for modeling and predicting the general equilibrium of the whole world system... it is a tool for exploring specific partial needs and problems", Simon, H. A., Reason in Human Affairs, p. 105.

41 A Popper, en los años 60, sólo le interesa cómo aumenta el conocimiento objetivo. Sostiene, además, que únicamente podemos estudiar el conocimiento subjetivo mediante el conocimiento objetivo. Cfr. Popper, K. R., Knowledge and the Body-Mind Problem. In Defence of Interaction, editado por Mark Notturno, Routledge, Londres, 1994, p. 4.

42 Este giro en el Pensamiento de Popper también ha recibido el nombre de "giro biológico", cfr. Queraltó, R., Karl Popper: De la Epistemología a la Metafísica, Publicaciones de la Universidad de Sevilla, Sevilla, 1996, p. 232. Para W. W. Bartley III, Popper unifica su Pensamiento merced a sus estudios sobre la Biología. Cfr. BARTLEY III, W. W., "Philosophy of Biology versus Philosophy of Physics", en Radnitzky, G. y Bartley III, W. W. (eds), Evolutionary Epistemology, Rationality, and the Sociology of Knowledge, Open Court, La Salle, IL, 1987, (1993, $3^{\text {a }}$ reimp.), pp. $18-20$.

43 El tipo de "Epistemología evolutiva" que ofrece Popper debería, a juicio de D. Campbell, ser llamada "a natural selection epistemology", cfr. Campbell, D., "Evolutionary Epistemology", en Schilpp, P. A. (ed), The Philosophy of Karl Popper, Open Court, La Salle, IL, 1974, vol. 1, p. 437. Para un mayor estudio acerca de la Epistemología evolutiva de Popper, cfr. Currie, G., "Popper's Evolutionary Epistemology: A Critique", Synthese, v. 37, (1978), pp. 413-431. 
crítica y evaluación de esas hipótesis, y una fase de contrastación crítica de las mismas ${ }^{44}$, buscando su falsación.

Aceptar este planteamiento evolutivo supone asumir la emergencia ontológica de novedades biológicas, que comporta la impredecibilidad de los cambios evolutivos ${ }^{45}$. La novedad respecto de su concepción anterior estaba en que Popper introduce el carácter "emergente" de las teorías científicas. Establece un paralelismo: al igual que los cambios históricos y evolutivos son emergentes e impredecibles (unpredictable) científicamente, también las teorías propuestas para adaptarse a esos cambios son emergentes y, en principio, asimismo impredecibles ${ }^{46}$.

Hubo un recelo inicial de Popper hacia las teorías evolucionistas, incluida la concepción de Darwin. Esto se aprecia al hilo de sus textos acerca de las doctrinas "historicistas" ${ }^{47}$. El historicismo — en la acepción popperiana - puede suponer que la sociedad humana, a través de la historia, sigue una evolución. Esta evolución se vuelve predecible en la medida en que se descubran las leyes que rigen tal evolución. Por tanto, evolucionismo e historicismo pueden ir asociados, lo cual le hace ser cauteloso sobre el tema del evolucionismo en los años 40 y buena parte de los $50^{48}$.

Cabe añadir que no es hasta 1977 cuando Popper confiere a la teoría de la selección natural el status de teoría científica. Si bien se trata de una teoría que — a su juicio - ha resultado falsada $^{49}$. Hasta aquel entonces había considerado que el evolucionismo era — debido a su carácter de hecho histórico aislado y al carácter irrepetible que conlleva el proceso evolutivo - una

44 Cfr. Popper, K. R., "Epistemology Without a Knowing Subject”, en Van Rootselaar, B. y Staal, J. F. (eds), Proceedings of the Third International Congress for Logic, Methodology and Philosophy of Science: Logic, Methodology and Philosophy of Science III, North-Holland, Amsterdam, 1968. Reimpreso en PopPER, K. R., Objective Knowledge. An Evolutionary Approach, Clarendon Press, Oxford, 1972, (5 ${ }^{\text {th }}$ ed. revisada, 1979$)$, p. 142.

Popper considera que la preferencia por una teoría en lugar de otra no es subjetiva, sino que responde a consideraciones objetivas, cfr. Popper, K. R., "Epistemology Without a Knowing Subject", p. 142. Entiende que es diferente justificar por qué se prefiere, de manera momentánea, una teoría y no otra, que la justificación en sí de una teoría. Esto es, la preferencia por una teoría en lugar de otra teoría rival viene determinada porque, al menos en ese momento, se considera que aquélla teoría está más cerca de la verdad, es más verosímil, que ésta. En cambio, justificar una teoría significa, para él, demostrar que es verdadera. Esta justificación racional de teorías no cabe en el pensamiento popperiano, puesto que todas las teorías son conjeturas. Cfr. Popper, K. R., Knowledge and the Body-Mind Problem. In Defence of Interaction, p. 138.

45 Cfr. Popper, K. R., "Scientific Reduction and the Essential Incompleteness of All Science", en Ayala, F. J. y Dobzhansky, T. (eds), Studies in the Philosophy of Biology, Macmillan, Londres, 1974. Reimpreso en Popper, K. R., The Open Universe. An Argument for Indeterminism. From the Postscript to The Logic of Scientific Discovery, editado por W. W. Bartley III, Hutchinson, Londres, 1982, (Routledge, Londres, 1998, 4ª reimp.), p. 145, nota.

46 Cfr. Popper, K. R., “A Realist View of Logic, Physics and History”, en Yourgrau, W. y Breck, A. D. (eds), Physics, Logic and History, Plenum Press, Londres, 1970. Reimpreso en Popper, K. R., Objective Knowledge. An Evolutionary Approach, p. 298. Para un estudio comparativo acerca de la concepción que de la predicción en Ciencias Sociales tienen Karl Popper y Herbert Simon, véase Castro, F. J., "La predicción científico-social en K. Popper y Herbert A. Simon”, en Gonzalez, W. J. (ed), Racionalidad, historicidad y predicción en Herbert A. Simon, pp. 235-278.

47 Cfr. Schwartz, P., "Karl Popper y la Teoría de la Evolución”, Enrahonar, n. 11, (1985), p. 44.

48 En los años 40, Popper sostenía que eran fenómenos históricos únicos tanto las novedades evolutivas biológicas como las novedades sociales. En consecuencia, ambos fenómenos eran absolutamente impredecibles. Conocer las novedades - históricas o biológicas - no permitía inferir acontecimientos humanos futuros o sucesos naturales del futuro. Cfr. Popper, K. R., The Poverty of Historicism, Routledge and K. Paul, Londres, 1957, $3^{\text {a }}$ ed., 1961 (Routledge, Londres, reimpreso en 1999), p. 109.

49 Popper, K. R., "Natural Selection and the Emergence of Mind" (First Darwin Lecture, pronunciada en el Darwin College, Cambridge, el 8 de noviembre de 1977), Dialectica, v. 32, (1978), pp. 339-355. Reimpreso en RADNITZKY, G. y Bartley iII, W. W. (eds), Evolutionary Epistemology, Rationality, and the Sociology of Knowledge, pp. 139-153. 
hipótesis difícilmente contrastable y, en consecuencia, no científica, según el criterio popperiano de demarcación científica ${ }^{50}$.

En la década de 1960, Karl Popper cambia de opinión con respecto a las teorías evolucionistas y la propia Teoría darwiniana de la Evolución ${ }^{51}$. De hecho, en una conferencia pronunciada en 1961, reformula la teoría darwinista y propone su propia teoría evolucionista ${ }^{52}$. En esta etapa, en parte también se retracta de lo que había dicho en décadas anteriores, especialmente en torno a las teorías evolucionistas (y a su intento de predecir los cambios evolutivos mediante el descubrimiento de las leyes que rigen la evolución) ${ }^{53}$. Se aprecia un giro que se manifiesta en un menor interés por el historicismo ${ }^{54}$.

Al adoptar la Epistemología evolutiva, Popper cambia en aspectos importantes. En los años 40 afirmaba que no había leyes en la evolución ${ }^{55}$ : ninguna ley se podía calificar de "ley evolutiva", puesto que tanto la evolución de la vida como la evolución de la sociedad humana eran vistas como procesos únicos, de carácter irrepetible y, por tanto, no sujetos a leyes ${ }^{56}$. Después, al pasar a un enfoque epistemológico evolutivo, en los años 60, Popper sostiene que el ser humano intenta resolver sus problemas y obtiene soluciones tentativas para resolver sus problemas dentro de un proceso de eliminación de errores ${ }^{57}$; las soluciones o hipótesis más satisfactorias son las que sobreviven al proceso de eliminación de error y crítica ${ }^{58}$.

50 Cfr. Martinez Solano, J. F., "El puesto de la Biología en la Epistemología y Metodología de la Ciencia de Karl Popper", Thémata, v. 20, (1998), pp. 189-193. Cabe señalar que Popper se interesó a lo largo de toda su trayectoria filosófica en distinguir de qué manera el conocimiento científico difiere del no científico, mientras que Simon mostró interés por mostrar lo que tenían en común el pensamiento científico con otros procesos de pensamiento creativos que tienen que ver con la invención o el diseño. Cfr. DAsGupta, S., "Multidisciplinary Creativity: the Case of Herbert A. Simon", Cognitive Science, v. 27, (2003), p. 686.

51 Véase Popper, K. R., Of Clouds and Clocks: An Approach to the Problem of Rationality and the Freedom of Man, Washington University Press, S. Louis, MI, 1966. Reimpreso en Popper, K. R., Objective Knowledge. An Evolutionary Approach, p. 241.

52 Cfr. Popper, K. R., "Evolution and the Tree of Knowledge" (versión aumentada de la Herbert Spencer Lecture, pronunciada en Oxford, en 1961), en Popper, K. R., Objective Knowledge. An Evolutionary Approach, pp. $272-280$. Popper añade una nueva conjetura a la teoría evolucionista: la variabilidad. Así, sostiene que se puede predecir que habrá variaciones en una especie a lo largo de su evolución biológica, y el abanico de posibles variaciones que tendría una determinada especie estaría regido por la selección natural.

53 Cfr. Popper, K. R., "Of Clouds and Clocks. An Approach to the Problem of Rationality and the Freedom of Man”, p. 241. A este respecto, se ha apuntado que este cambio de enfoque por parte de Popper tiene lugar dentro de un cambio más amplio en su Pensamiento, y es la introducción de elementos metafísicos en su Filosofía de la Ciencia. Cfr. Martinez Solano, J. F., "El puesto de la Biología en la Epistemología y Metodología de la Ciencia de Karl Popper", p. 177.

54 La noción de "historicismo" en Popper tiene un carácter específico, distinto del que tiene en la bibliografía histórica. Sobre su concepto de "historicismo", cfr. GonZalez, W. J., "La interpretación historicista de las Ciencias Sociales”, Anales de Filosofía, v. 2, (1984), pp. 109-137, en especial, pp. 123-137.

55 Cfr. The Poverty of Historicism, p. 117.

56 La introducción de elementos evolucionistas en la Epistemología y Metodología popperianas es, en cierto modo, paradójica o incluso contradictoria. Según Popper, las teorías neodarwinistas son metafísicas, en cuanto que son infalsables; sin embargo, al mismo tiempo, parece afirmar que las teorías darwinistas suministran predicciones contrastables, predicciones acerca de cambios graduales en la evolución. Esto - a juicio de M. Ruse- significa que, si son predicciones contrastables, no son metafísicas, aunque esas predicciones sean falsas. Cfr. RuSE, M., "Karl Popper's Philosophy of Biology", Philosophy of Science, v. 44, (1977), p. 650.

57 A juicio de R. Springer, Popper pasa por alto el que no sólo las teorías propuestas tienen lugar dentro de un marco teórico básico, sino que también las críticas que se efectúan a esas teorías que se han propuesto tienen lugar dentro de un esquema teórico concreto. Cfr. Springer de Freitas, R., "Back to Darwin and Popper. Criticism, Migration of Piecemeal Conceptual Schemes, and the Growth of Knowledge", Philosophy of the Social Sciences, v. 27, n. 2, (1997), pp. 160-161.

58 Cfr. "Evolution and the Tree of Knowledge", p. 261. 
Aunque es a partir de 1960 cuando Popper desarrolla su "Epistemología evolutiva", Donald T. Campbell considera que ya en los años 30 Popper hace sus primeras aportaciones a lo que más tarde sería su Epistemología evolutiva. Lo hace, a su juicio, cuando contempla el proceso de sucesión de teorías en la Ciencia como un proceso de eliminación selectiva de hipótesis ${ }^{59}$, en el que unas teorías luchan por sobrevivir frente a otras ${ }^{60}$. Más tarde, a este proceso evolutivo del conocimiento científico le añade Popper un elemento nuevo: admite, como hecho, que el progreso del conocimiento no es irracional. Así, la aceptación de teorías se produce de manera racional, mediante el método de ensayo y error, esto es, mediante el método de proponer teorías, intentar demostrar que son erróneas, y aceptarlas de modo tentativo, al menos mientras sean infructuosos nuestros intentos por falsarlas ${ }^{61}$.

Este procedimiento de progreso del conocimiento - a juicio de Popper - se da tanto en los seres humanos como en los animales ${ }^{62}$. Esto hace que sintonice con el naturalismo de fondo del evolucionismo, puesto que, en su intento de resolver los problemas que se le plantean, humanos y animales tendrán pautas compartidas. La diferencia entre el conocimiento humano y el animal está en la actitud crítica: el científico, a diferencia del animal, busca de un modo consciente el error en sus teorías; por eso intenta contrastarlas tan severamente como le sea posible ${ }^{63}$.

La Epistemología evolutiva de Popper asume que el proceso de conocimiento es un proceso de eliminación selectiva de hipótesis ${ }^{64}$. Así, es un darwinismo sobre medios. Hay, a su juicio, una selección de las mejores hipótesis, donde las más aptas sobreviven. Establece Popper así una analogía entre la evolución del conocimiento y el proceso biológico evolutivo de Darwin ${ }^{65}$, en ambos casos el resultado final no es conocido de antemano, es algo abierto.

El aumento del conocimiento mediante un proceso evolutivo tiene importantes consecuencias para el aspecto predictivo de la Ciencia. Desde el punto de vista de Popper, tanto la evolución que seguirá el conocimiento como la propia evolución biológica son procesos únicos y, por tanto, impredecibles ${ }^{66}$. Para él, no hay bases lógicas que permitan predecir el aumento del conocimiento, a causa de la capacidad que poseen los seres humanos para innovar. La evolución del conocimiento comporta siempre novedad, por lo que no es predecible sobre bases

59 Cfr. Campbell, D. T., "Evolutionary Epistemology", p. 415. Véase Popper, K. R., The Logic of Scientific Discovery, Hutchinson and Co., Londres, 1959, (Routledge, Londres, 2001, 6 a reimp.), p. 108. Según Popper: "We choose the theory which best holds its own in competition with other theories; the one which, by natural selection, proves itself the fittest to survive," Popper, K. R., The Logic of Scientific Discovery, p. 108. Las cursivas son mías.

60 Cfr. The Logic of Scientific Discovery, p. 42.

61 Cfr. Popper, K. R., "Philosophy of Science: A Personal Report", en MAce, C. A. (ed), British Philosophy in the Mid-Century: A Cambridge Symposium, George Allen and Unwin, Londres, 1957. Reimpreso en: Popper, K. R., "Science: Conjectures and Refutations", en Popper, K. R., Conjectures and Refutations. The Growth of Scientific Knowledge, Routledge and K. Paul, Londres, 1963; 5ª ed. revisada, 1989 (Routledge, Londres, Reimpreso en 2000), p. 51.

62 Cfr. Popper, K. R., "Science: Conjectures and Refutations”, p. 52.

63 Cfr. "Science: Conjectures and Refutations", p. 52.

64 Cfr. Campbell, D., "Evolutionary Epistemology", p. 415.

65 Cfr. Castrodeza, C., "De la Epistemología popperiana a la Epistemología darwinista”, en Schwartz, P., Rodriguez Braun, C. y Mendez Ibisate, F. (eds), Encuentro con Karl Popper, Alianza Ed., Madrid, 1993, pp. 147-149.

66 Ya en The Poverty of Historicism Popper había señalado que es impredecible la evolución que seguirá el conocimiento, porque - a su juicio - es un proceso único, al igual que lo es la evolución biológica. Cfr. POPPER, K. R., The Poverty of Historicism, pp. 108-109. 
lógicas. Los productos creados por la mente humana, como pueden ser las teorías científicas, son también de un carácter emergente ${ }^{67}$, esencialmente impredecibles ${ }^{68}$.

La unicidad del proceso de conocimiento científico y su carácter innovador son la causa que Popper aduce para negar la predecibilidad de los procesos cognitivos evolutivos. Estos procesos carecen de leyes universales. No puede haber, a su juicio, leyes acerca de procesos únicos. Por tanto, considera que no hay leyes evolutivas: ni acerca de la evolución de la Historia, ni sobre la evolución del conocimiento (y tampoco de la evolución biológica) ${ }^{69}$. Del mismo modo que no se puede conocer cómo progresará nuestro conocimiento científico, tampoco podemos saber de antemano qué parte de nuestro conocimiento actual fracasará en un futuro ${ }^{70}$.

En Popper el enfoque evolucionista del conocimiento tiene dos vertientes: una propiamente epistemológica y otra metodológica. El aspecto epistemológico viene propiciado por el concepto de "adaptación": el conocimiento, tanto humano como animal 71 , tiene como cometido el adaptarse al medio. Y el factor metodológico de la Epistemología evolutiva es la noción de "selección": hay una "selección natural" en las hipótesis, de modo que sólo sobreviven las mejores; mientras que las teorías o hipótesis falsas son desechadas y eliminadas.

El crecimiento epistemológico o evolutivo supone que el aumento del conocimiento científico se produce mediante la crítica y eliminación de error en las teorías, que lleva, a su vez, a la consideración de nuevas soluciones para nuevos problemas ${ }^{72}$. Este es un aspecto que separa a Popper de los planteamientos de Simon, pues en la postura popperiana la preferencia por las teorías mejores es una preferencia crítica y objetiva, no una elección subjetiva, mientras que en la concepción simoniana es el sujeto el que, con unas capacidades racionales limitadas, selecciona la teoría que mejor se adapta al medio.

\subsection{El proceso racional como semejante a la selección natural}

Cuando en la década de 1960 da el giro epistemológico, lo novedoso de Popper es que considera que el aumento del conocimiento sigue un proceso similar a la Teoría de la selección

67 Cfr. Popper, K. R., “A Realist View of Logic, Physics and History”, pp. 297-298.

68 Cfr. Knowledge and the Body-Mind Problem. In Defence of Interaction, p. 71. Para un mayor estudio acerca de la predicción en Karl Popper, así como sus características y etapas. Cfr. Gonzalez, W. J., "The many faces of Popper's Methodological Approach to Prediction", en Catton, Ph. y Macdonald, G. (eds), Karl Popper. Critical Appraisals, Routledge, Londres, 2004, pp. 78-98.

69 El argumento fundamental de Popper para negar la predecibilidad de los procesos evolutivos es su unicidad. Por eso, las críticas dirigidas en contra de esta afirmación popperiana han ido en la dirección de negar que los procesos evolutivos sean únicos, como Popper sostiene. Cfr. Olding, A., "A Defence of Evolutionary Laws", British Journal for the Philosophy of Science, v. 29, n. 2, (1978), pp. 134-135.

70 Cfr. The Poverty of Historicism, pp. 108-109.

71 Cfr. Popper, K. R., "Towards an Evolutionary Theory of Knowledge”, reimpreso en Popper, K. R., A World of Propensities, Thoemmes, Bristol, 1990 (1 $1^{\mathrm{a}}$ reimp. 1995), p. 32.

72 Cfr. Popper, K. R., "Epistemology Without a Knowing Subject”, p. 107. Popper no deja claro por qué lleva a la consideración de "nuevos problemas" la eliminación de error de aquellas teorías que habían sido propuestas para solucionar los problemas planteados, ni tampoco aclara por qué sólo se pueden considerar a un tiempo un número limitado de teorías que intentan solucionar los problemas. Que Popper no explique por qué surgen nuevos problemas puede llevarnos a pensar — según Springer de Freitas — que el crecimiento del conocimiento científico no es un fenómeno cognitivo sino sociológico. Cfr. Springer de Freitas, R., "Back to Darwin and Popper. Criticism, Migration of Piecemeal Conceptual Schemes, and the Growth of Knowledge", pp. $158-159$. 
natural propuesta por Darwin ${ }^{73}$. Admite así una "selección natural de hipótesis" 74 , de modo que las hipótesis mejores o aquellas que se muestran más aptas son seleccionadas, puesto que han resistido mejor las contrastaciones a las que han sido sometidas.

Que Popper se adhiera a un enfoque evolucionista es un aspecto ampliamente controvertido de su Pensamiento. En un principio consideraba que la Teoría de la "selección natural" de Darwin era una teoría cuasi-tautológica. Esto le llevó a catalogar a la teoría darwinista como un "programa de investigación metafísica", un programa que sólo es capaz de predecir que los cambios evolutivos se harán con una cierta gradualidad ${ }^{75}$. Más adelante, cambió de parecer, para señalar que veía a la teoría darwinista no como universalmente verdadera pero sí al menos como una teoría contrastable ${ }^{76}$.

Al introducir la perspectiva evolutiva en su Epistemología, Popper se intenta desmarcar de aquellos autores que - a su juicio - son partidarios de una concepción del conocimiento "tradicional" 77 (o, en rigor, moderna), que es una Epistemología interesada en el Mundo 2, el mundo de las creencias subjetivas. Así, tanto algunos racionalistas como - sobre todo- autores empiristas, ven el conocimiento como un tipo de creencia, y - añado yo- insistan en la idea del concepto como "representación mental" en el sujeto. En sus enfoques, la adopción de las teorías mejores y la eliminación de las teorías falsas se producen de manera subjetiva, no objetiva. Por eso, considera Popper que no pueden explicar cómo se produce realmente el desarrollo del conocimiento científico, que es mediante la actitud crítica de los científicos respecto de sus propias teorías ${ }^{78}$. Aquí reside una diferencia con un autor de Epistemología de corte empirista - Herbert Simon— ${ }^{79}$, un pensador que criticó a Popper por su concepción del proceso de descubrimiento científico ${ }^{80}$.

Frente a Popper, Simon sostiene que la racionalidad no es algo abstracto e impersonal; y, a diferencia de Popper, no concibe su Epistemología al margen del sujeto cognoscente.

73 Cfr. Popper, K. R., "Evolution and the Tree of Knowledge", p. 261. "All this may be expressed by saying that the growth of our knowledge is the result of a process closely resembling what Darwin called 'natural selection'; that is, the natural selection of hypotheses: our knowledge consists, at every moment, of those hypotheses which have shown their (comparative) fitness by surviving so far in their struggle for existence; a competitive struggle which eliminates those hypotheses which are unfit". Popper, K. R., "Evolution and the Tree of Knowledge", p. 261. Las cursivas son del autor.

74 Cfr. "Evolution and the Tree of Knowledge", p. 261. No obstante, esta idea de "selección natural" de teorías está ya en sus primeros textos, en cuanto que - a juicio de Popper- elegimos la teoría que se muestra más apta para sobrevivir. Cfr. The Logic of Scientific Discovery, p. 108.

75 Cfr. Popper, K. R., Unended Quest. An Intellectual Autobiography, Fontana/Collins, 1976 (edic. ampliada, Routledge, Londres, 1992; 1993, $1^{\text {a }}$ reimp.), p. 168. Véase también Corcó, J., "La Selección Natural en Popper y Peirce", Anuario Filosófico, v. 34/ 1, n. 69, (2001), pp. 140-141.

76 Cfr. Popper, K. R., "Natural Selection and the Emergence of Mind”, p. 145.

77 Popper cita como partidarios de esta Epistemología a Locke, Berkeley, Hume y Russell, véase "Epistemology Without a Knowing Subject”, p. 108.

78 Cfr. Popper, K. R., “Epistemology Without a Knowing Subject”, p. 122.

79 Es preciso señalar que H. Simon nace en 1916, catorce años después que Karl Popper. Para un mayor estudio acerca de la trayectoria filosófica y vital de Simon, véase Gonzalez, W. J., "Herbert A. Simon: Filósofo de la Ciencia y economista (1916-2001)", en Gonzalez, W. J. (ed), Racionalidad, historicidad y predicción en Herbert A. Simon, pp. 7-63, en especial, pp. 8-14. Selten también otorga al conocimiento empírico mayor importancia que al conocimiento teórico. Cfr. "Rationality in Experimental Economics: An Analysis of Reinhard Selten's Approach", p. 72.

80 Simon sostiene, en contra de Popper, que el descubrimiento científico es analizable desde un punto de vista lógico. Cfr. Simon, H. A., Models of Discovery, Reidel, Dordrecht, 1977, p. 326. Sobre esto, véase Castro, F. J., "El proceso de descubrimiento científico: De Karl Popper a Herbert Simon", en Gonzalez, W. J. (ed), Karl Popper: Revisión de su legado, Unión Editorial, Madrid, 2004, pp. 267-295. 
Esto se aprecia de manera clara en sus estudios sobre Economía, pues no considera que los procesos económicos sean ajenos al quehacer humano. La Epistemología de Simon difiere de la popperiana en cuanto que aquélla resalta la capacidad cognitiva humana. La racionalidad limitada es una racionalidad subjetiva, mientras que la Epistemología de Popper se desarolla sin tener en cuenta el papel de los agentes, el papel del sujeto que conoce, intenta ser, en efecto, una racionalidad objetiva.

Ahora bien, Popper y Simon coinciden en ver el conocimiento como un producto humano. Pero difieren en que, para el primero, una vez que se ha creado, se convierte en un conocimiento objetivo y autónomo: el conocimiento, las teorías e hipótesis científicas forman parte del Mundo 3; y el Mundo 3 es de suyo autónomo. Así, para Popper, el crecimiento del conocimiento no es un proceso eo ipso acumulativo, sino que es un proceso de crítica y eliminación de error ${ }^{81}$. En otras palabras, en cuanto a descartar lo falso, se trata más bien de un proceso de selección darwiniana, que de una instrucción lamarckiana ${ }^{82}$.

El proceso del conocimiento en Popper se produce proponiendo múltiples hipótesis y abandonando aquellas que resulten falsadas, de forma que se pueda llegar a una teoría que esté lo más cerca de la verdad posible ${ }^{83}$. Con la supervivencia de las teorías que se muestren más aptas, lo que se consigue es, a su juicio, una mejor aproximación a la verdad, una mayor verosimilitud de las hipótesis ${ }^{84}$.

No obstante, cabe señalar que, al introducir Popper la teoría de la verosimilitud, en este proceso de eliminación de error para ganar en verosimilitud hay — a mi juicio- cierta acumulación. La aproximación progresiva a la verdad en el sentido popperiano comporta no dejar muchas ramas abiertas, hay una rama que adquiere mayor protagonismo al poseer mayor verosimilitud y, por tanto, estar más próxima a la verdad. Así pues, el contenido mismo del conocimiento evolutivo no sería meramente darwiniano sino que se trataría más bien de un proceso de instrucción lamarckiano. Popper, a diferencia de Darwin, entiende que el "árbol del conocimiento" está invertido. Esto es, múltiples hipótesis, mediante la crítica y eliminación de error, se unificarán en una sola teoría, aquella que se encuentre más próxima a la verdad ${ }^{85}$.

Siempre insiste Popper en la idea del conocimiento como un proceso activo: el conocimiento es un producto creado por la mente humana con el fin de encontrar soluciones adecuadas

\footnotetext{
81 J. Blachowicz objeta a Popper que éste no tenga en cuenta un tipo de eliminación, la eliminación correctiva. Esto es, en Popper no hay lugar para la corrección de las hipótesis que han sido refutadas. Cfr. BlACHOwicz, J., "Elimination, Correction and Popper's Evolutionary Epistemology", International Studies in the Philosophy of Science, v. 9, n. 1, (1995), pp. 5-17, en especial, p. 9.

En este sentido, se ha considerado que un principio metodológico fundamental en Popper, distinto del principio antidogmático presente en la Metodología popperiana, es el llamado “principio de eliminación”. Este principio prescribe que, en la medida en que se ha llegado a la conclusión de que una hipótesis no ha resistido ciertas contrastaciones, (esto es, se ha constatado que esa teoría tiene enunciados falsadores reales en la experiencia), esa teoría debe ser refutada y abandonada. Cfr. Meana Menendez, L., "Crítica, falsación y eliminación”, Teorema, v. 14/n. 1-2, (1987), p. 93.

82 Cfr. Popper, K. R., "Epistemology Without a Knowing Subject”, p. 144. Véase Popper, K. R., "Replies to my Critics", en Schilpp, P. A. (ed), The Philosophy of Karl Popper, vol. 2, Open Court, La Salle, IL, 1974, p. 1060.

83 Popper, K. R., "Evolution and the Tree of Knowledge", pp. 261-262.

84 Cfr. Martinez Solano, J. F., El problema de la verdad en K. R. Popper: Reconstrucción histórico-sistemática, Netbiblo, A Coruña, 2005, pp. 223-224.

85 Cfr. El problema de la verdad en K. R. Popper: Reconstrucción histórico-sistemática, p. 223.
} 
a sus problemas ${ }^{86}$. Es un elemento del Mundo 3 popperiano ${ }^{87}$, el mundo del conocimiento objetivo; al mismo tiempo es un conocimiento evolutivo, no estático sino dinámico. Ve el proceso del conocimiento humano como un proceso de adaptación, en cuanto que el ser humano formula teorías científicas para adaptarse al medio en el que vive ${ }^{88}$. Es también un proceso de selección, ya que se seleccionan las hipótesis: hay una "lucha por la supervivencia", donde las hipótesis o teorías científicas más aptas permanecen y las no aptas se desechan ${ }^{89}$. Además, Popper sostiene que podemos dejar mueran en nuestro lugar ${ }^{90}$.

El conocimiento objetivo es - para Popper - independiente del sujeto, de modo que conocer no es entonces una creencia subjetiva, sino un hecho objetivo. Popper sostiene que el conocimiento, en sentido objetivo", es conocimiento sin sujeto cognoscente" ${ }^{91}$. Más aún, a su juicio, el conocimiento en sentido subjetivo es irrelevante para el estudio del conocimiento científico $^{92}$. Esto supone que la Epistemología tiene prioridad sobre cualquier aportación de la Teoría del Conocimiento en general.

En definitiva, lo que cuenta — según Popper- es el estudio del Mundo 3, el ámbito del conocimiento objetivo ${ }^{93}$ : los científicos actúan sobre la base de conjeturas, creencias subjetivas; buscan hipótesis que, en principio, puedan proporcionar más conocimiento, o resultados dentro del Mundo 3 (del conocimiento objetivo) ${ }^{94}$. El estudio del Mundo 3 ayuda a saber acerca de los procesos de pensamiento de los científicos; pero no hay viceversa: el estudio del Mundo 2 no proporciona un mayor conocimiento del Mundo 3, puesto que éste es en gran medida autónomo, el conocimiento objetivo es independiente del sujeto cognoscente ${ }^{95}$, justo lo contrario de lo que sostiene Simon.

86 Cfr. "A Realist View of Logic, Physics and History", p. 289.

87 Popper ha recibido críticas frontales en lo que se refiere a su concepción del Mundo 3 y a la vinculación que tiene con una Epistemología evolutiva. Para L. J. Cohen, Popper es incoherente al comparar el desarrollo del conocimiento con la Teoría de la Evolución, puesto que siguen pautas distintas. Este autor considera que, mientras que la lucha por la vida de las especies sigue una dinámica irracional (prevalece la interacción con el medio), el desarrollo del conocimiento es de suyo, para Popper, un proceso racional. Cfr. CoHEN, L. J., "Third World Epistemology", en Currie, G. y Musgrave, A. (eds), Popper and the Human Sciences, M. Nijhoff, Dordrecht, 1985, p. 9.

88 Cfr. Popper, K. R., "The Rationality of Scientific Revolutions", en Harré, R. (ed), Problems of Scientific Revolution. Progress and Obstacles to Progress in the Sciences, Clarendon Press, Oxford, 1975. Reimpreso en Popper, K. R., The Myth of the Framework. In Defence of Science and Rationality, editado por Mark Notturno, Routledge, Londres, 1994, p. 2. Sostiene Popper que: "From a biological or evolutionary point of view, science, or progress in science, may be regarded as a means used by the human species to adapt itself to the environment: to invade new environmental niches, and even to invent new environmental niches", PoPPER, K. R., "The Rationality of Scientific Revolutions", p. 2.

89 Cfr. Martinez Solano, J. F., "El puesto de la Biología en la Epistemología y Metodología de la Ciencia de Karl Popper", p. 179.

90 Véase Knowledge and the Body-Mind Problem, p. 12. En este sentido, Popper establece una analogía entre la elaboración humana de teorías y una mutación. Así, el ser humano, en lugar de tener mutaciones biológicas en su propio cuerpo, crea nuevos productos o instrumentos con los que solucionar sus problemas. Cfr. Knowledge and the Body-Mind Problem, p. 34.

91 Popper, K. R., "Epistemology Without a Knowing Subject”, p. 109. Las cursivas son del autor. Algunos autores se han mostrado críticos con esta posición popperiana. Cfr. HAACK, S., "Epistemology With a Knowing Subject", Review of Metaphysics, v. 33, (1979-1980), pp. 309-335.

92 Cfr. Popper, K. R., "Epistemology Without a Knowing Subject”, p. 111.

93 Dice Popper: "But the characteristic thing about specifically human knowledge — science- is that is formulated in a descriptive and argumentative language, and that the problems, theories, and errors which are embedded in this language stand in their own peculiar relations, constituting what I call 'world 3"', POPPER, K. R., "Replies to my Critics", p. 1060.

94 Cfr. Popper, K. R., “Epistemology Without a Knowing Subject”, p. 111.

95 Cfr. "Epistemology Without a Knowing Subject", p. 112. 


\section{La RACIONALIDAD LIMITADA COMO "CAJA DE HERRAMIENTAS ADAPTATIVA"}

Tras el enfoque de Simon de la racionalidad adaptativa de tipo subjetivo y la visión de Popper sobre selección natural de teorías conviene profundizar sobre la racionalidad limitada en cuanto influida por un enfoque evolucionista. Como se ha visto, Simon plantea una racionalidad adaptativa de carácter restringido, de modo que mantiene una estrecha relación con el entorno del agente individual. Años más tarde, Reinhard Selten ha retomado el concepto de racionalidad limitada ${ }^{96}$. Lo ha llevado a ámbitos hasta ahora no transitados por los otros autores.

\subsection{Avances de Selten respecto de la racionalidad: Comparación con Simon}

Reinhard Selten se muestra de acuerdo con Simon en cuanto a los principales factores que constituyen la racionalidad limitada. Estos factores son tres: a) hay una búsqueda de alternativas, esto es, las diferentes alternativas existentes en una elección de tipo racional no están dadas, sino que éstas deben ser descubiertas mediante un proceso de búsqueda; b) el agente no busca maximizar las utilidades subjetivas esperadas sino que meramente busca satisfacer ${ }^{97}$, y c) hay, por parte del ser humano, una adaptación a sus niveles de aspiración ${ }^{98}$.

Coincide Selten con Simon en que el ser humano no cuenta con una racionalidad completa, en el sentido de que tenga unas capacidades cognitivas ilimitadas ${ }^{99}$. Pero ha ido más lejos que él, pues sí acepta la presencia de una racionalidad evaluativa dedicada a los fines, junto a una racionalidad práctica sobre los medios y una racionalidad epistémica. Como ha señalado Wenceslao J. González, Selten constituye un avance respecto de Simon: su planteamiento de la racionalidad económica admite una racionalidad de fines o evaluativo ${ }^{100}$, que ciertamente no estaba en la racionalidad puramente instrumental de Simon ${ }^{101}$.

Otro aspecto que Selten propone y supone una mejoría respecto de Simon es en el campo del componente motivacional en la decisión racional. Así, los límites de la racionalidad no son sólo unos límites de tipo cognitivo, debido a la restringida capacidad humana para pensar y efectuar cálculos computacionales, sino que hay también —a su juicio — unos límites motivacionales, que se ejemplifican en los fracasos para comportarse de acuerdo con las intuiciones racionales del agente ${ }^{102}$.

\footnotetext{
96 Reinhard Selten admite que abandona la teoría de la maximización de la utilidad subjetiva esperada cuando conoce el libro de Herbert Simon: Models of Man. Desde ese momento se da cuenta de que la conducta económica ha de ser explicada desde los planteamientos de la racionalidad limitada. Cfr. SELTEN, R., "In Search of a Better Understanding of Economic Behaviour", en Heertje, A. (ed), The Makers of Modern Economics, vol. 1, Simon and Schuster, N. York, 1993. Reimpreso en Selten, R. (ed), Game Theory and Economic Behaviour. Selected Essays, vol. 1, E. Elgar, Northampton, MA, 1999, p. 5.

97 R. Selten llama "racionalismo ingenuo" al punto de vista según el cual el agente siempre busca la maximización de la utilidad subjetiva esperada. Cfr. Selten, R., "New Challenges to the Rationality Assumption", Journal of Institutional and Theoretical Economics, v. 150, n. 1, (1994), p. 42.

98 Cfr. "What is Bounded Rationality?", p. 14.

99 Cfr. Selten, R., "Evolution, Learning, and Economic Behaviour", Games and Economic Behaviour, v. 3, (1991). Reimpreso en Selten, R. (ed), Game Theory and Economic Behaviour. Selected Essays, vol. 1, p. 162.

100 Cfr. Gonzalez, W. J., "Racionalidad y Economía: De la racionalidad de la Economía como Ciencia a la racionalidad de los agentes económicos”, pp. 81-82.

101 Cfr. Gonzalez, W. J., "Rationality in Experimental Economics: An Analysis of Reinhard Selten's Approach”, pp. 74-76.

102 Cfr. Selten, R., "In Search of a Better Understanding of Economic Behaviour", pp. 20-21. Véase también GonZALEZ, W. J., "Análisis de la racionalidad y planteamiento de la predicción en Economía Experimental”, en GonZALEZ, W. J., Marques, G. y Avila, A. (eds), Enfoques Filosófico-Metodológicos en Economía, FCE, Madrid, 2002, pp. 145-172, en especial, pp. 155-156. Cfr. Selten, R., "In Search of a Better Understanding of Economic Behaviour", p. 21.
} 
Para Selten, cuando se da la falta de control sobre la conducta, se debe más bien a limitaciones de tipo motivacional que a limitaciones cognitivas ${ }^{103}$. Introduce también el aspecto emocional en la racionalidad: no considera que las emociones (emotions) sean algo opuesto a la racionalidad ${ }^{104}$. En este sentido, la racionalidad puede ir acompañada de aspectos afectivos o emotivos que modulen la decisión del agente individual. Simon no otorga a este aspecto de las emociones tanta importancia dentro de su esquema de racionalidad limitada ${ }^{105}$.

Selten y, en menor medida, Gigerenzer han conseguido ir más lejos que Simon, pues ofrece una visión específica de la racionalidad limitada: la noción de "caja de herramientas adaptativa" (toolbox adaptive), que aclara el componente evolutivo como heurística. La razón como instrumento adaptativo tiene una serie de características relevantes: i) se refiere a una serie de reglas heurísticas más que a un algoritmo general para la toma de decisiones; ii) es una heurística de "sobriedad de factores" (parsimonious factors); iii) estas reglas heurísticas están adaptadas a entornos particulares, pasados y presentes, tanto físicos como sociales; y iv) este conjunto de reglas heurísticas está dirigido por algún tipo de mecanismo ${ }^{106}$.

\subsection{Características de la "caja de herramientas adaptativa"}

Sobre la base de la racionalidad limitada de Simon, Selten propone la "teoría de la adaptación a los niveles de aspiración" (aspiration adaptation theory), una teoría que —a su juicio - aún no se ha mostrado como una teoría empíricamente válida para describir la conducta humana en toma de decisiones. Reconoce que es una teoría que aún precisa de ciertas modificaciones ${ }^{107}$.

Esta teoría asume que el agente tiene una valoración de una serie de metas u objetivos finales: posee unos niveles de aspiración. Así, Selten considera que, en la toma de decisiones, el agente tiene un nivel de aspiración previo. Cuando la persona selecciona una determinada alternativa de decisión, se produce un nuevo nivel de aspiración. Considera que la elección (choice) se produce sobre la base de la alternativa que satisface el nuevo nivel de aspiración (the new aspiration level) ${ }^{108}$.

Con la teoría de la caja de herramientas adaptativa hay una serie de criterios simples para detener este proceso de búsqueda de alternativas ${ }^{109}$. Esto sucede al contrario que en la teoría de la racionalidad limitada propuesta originalmente por Simon, donde la búsqueda de alternativas finaliza cuando hay una primera que satisface el nivel de aspiración del agente. En la teoría de Selten hay tres premisas: 1) el objetivo de la teoría es entender cómo toman decisiones los agentes, considerando que tienen una serie de restricciones, tales como un tiempo

\footnotetext{
103 Cfr. Selten, R., "What is Bounded Rationality?", en Gigerenzer, G. y Selten, R. (eds), Bounded Rationality. The Adaptive Toolbox, The MIT Press, Cambridge, MA, 2001, p. 15.

104 Cfr. Gigerenzer, G. y Selten, R., "Rethinking Rationality", en Gigerenzer, G. y Selten, R. (eds), Bounded Rationality. The Adaptive Toolbox, p. 9.

105 Véase, por ejemplo, Simon, H. A., "Motivational and Emotional Controls of Cognition", Psychological Review, v. 74, (1967), pp. 29-39. Reimpreso en Simon, H. A., Models of Thought, Yale University Press, New Haven, CT, 1979, pp. 29-38.

106 Cfr. "Rethinking Rationality", p. 9.

107 Cfr. Selten, R., "What is Bounded Rationality?, p. 18.

108 Cfr. "What is Bounded Rationality?, p. 19.

109 Gigerenzer, G., “The Adaptive Toolbox", en Gigerenzer, G. y Selten, R. (eds), Bounded Rationality. The Adaptive Toolbox, pp. 44-45. Véase también Gigerenzer, G., Adaptive Thinking. Rationality in the Real World, Oxford University Press, N. York, 2000, p. 167.
} 
y un conocimiento limitados, así como unas capacidades computacionales también limitadas; 2) la teoría ofrece una heurística que se refiere a un ámbito específico; y 3) la racionalidad presente en esta heurística es una "racionalidad ecológica" (ecological rationality), esto es, no es una racionalidad omnisciente, como posee la teoría de la maximización de la utilidad subjetiva esperada.

El éxito de esta heurística está en su grado de adaptación a la estructura del ambiente, sea éste físico o social ${ }^{110}$. La "caja de herramientas adaptativa" que esta posición ofrece no son sino un medio de alcanzar unas deteminadas metas, pero éstas incluyen un mecanismo de aprendizaje que permite un ajuste de esas "herramientas" — los medios — cuando cambia el entorno $^{111}$. De este modo, Gigerenzer — en sintonía con Selten — entiende que la función de dicha teoría es proveer una serie de estrategias: cognitivas, emocionales y sociales. Ellas han de permitir manejar (handle) una multitud de objetivos o metas para efectuar una elección racional de manera rápida y precisa ${ }^{112}$.

Esta teoría incluye mejoras sobre la propuesta por Simon, pero sobre la base de su idea de la racionalidad limitada. En esta heurística rápida y austera (fast and frugal heuristics) no sólo se da una búsqueda de alternativas (con el fin de satisfacer las utilidades esperada), como ocurre en Simon, sino que también tiene lugar una evaluación de las distintas alternativas. Esta valoración de los medios incluye la parte afectiva o emocional: para Selten la gente tiene sentimientos evaluativos (evaluative feelings) cuando toma decisiones. Pero ésta no es la única influencia sobre la conducta de elección humana, sino que también intervienes otros factores como son las normas sociales, las limitaciones morales o las simples rutinas ${ }^{113}$. Ninguno de estos aspectos aparece en ningún momento en los escritos de Simon ${ }^{114}$.

Parece, por tanto, que el modelo conductual que ofrece Simon, basándose en su teoría de la racionalidad limitada, supone una mejora con respecto a los planteamientos neoclásicos en Economía, principalmente en cuanto a que la sustitución del supuesto de la racionalidad como maximización por el criterio de la racionalidad como satisfacción. Sin duda, su enfoque describe de manera más verosímil cómo actúan los agentes cuando toman decisiones de manera racional e incorpora un componente adaptativo al entorno, que tiene inspiración evolucionista.

Así pues, la racionalidad adaptativa de Simon, en la que el organismo busca satisfacer sus expectativas y necesidades, para adaptarse a un entorno cambiante, constituye un avance respecto de las posiciones popperianas, que se expresa en una Epistemología evolutiva. En Popper la racionalidad es tomada como algo abstracto, al margen del sujeto que conoce. El énfasis que Simon pone en las limitaciones cognitivas humanas refleja mejor la conducta humana real cuando toma decisiones y esto se puede contrastar empíricamente. Esto, a su vez, hace posible que disciplinas como la Economía, y los procesos que en ella tienen lugar, sean contempladas como quehacer humano y no como algo impersonal o atemporal.

Sin embargo, Simon apenas aprecia — a mi juicio — que en situaciones de elección racional no sólo intervienen limitaciones de tipo cognitivo, sino que puede haber limitaciones reales de tipo motivacional y también emocional. En este sentido, la teoría que propone Selten

110 Cfr. "The Adaptive Toolbox", p. 38.

111 Cfr. Gigerenzer, G., "The Adaptive Toolbox", p. 40.

112 Cfr. "The Adaptive Toolbox", p. 43.

113 Cfr. Selten, R., "New Challenges to the Rationality Assumption”, pp. 42-43.

114 Cfr. Gigerenzer, G., “The Adaptive Toolbox”, pp. 43-44. 
parece caracterizar mejor la manera en la que los seres humanos toman decisiones. Desde mi punto de vista, Selten — al igual que N. Rescher — acierta al ver la necesidad de adoptar también una racionalidad de fines o evaluativa, de manera que el agente pueda efectuar una evaluación de las distintas metas u objetivos en vez de centrarse sólo en la selección de los mejores medios.

\section{Bibliografía}

Bartley III, W. W., "Philosophy of Biology versus Philosophy of Physics", en Radnitzky, G. y Bartley III, W. W. (eds), Evolutionary Epistemology, Rationality, and the Sociology of Knowledge, Open Court, La Salle, IL, 1987, (1993, $3^{\text {a }}$ reimp.), pp. 7-45.

Blachowicz, J., "Elimination, Correction and Popper's Evolutionary Epistemology", International Studies in the Philosophy of Science, v. 9, n. 1, (1995), pp. 5-17.

CampBell, D. T., "Evolutionary Epistemology”, en Schilpp, P. A. (ed), The Philosophy of Karl Popper, vol. 1, Open Court, La Salle, IL, 1974, pp. 413-463.

Castro, F. J., "La predicción científico-social en K. Popper y Herbert A. Simon”, en Gonzalez, W. J. (ed), Racionalidad, historicidad y predicción en Herbert A. Simon, Netbiblo, A Coruña, 2003, pp. 235-278.

Castro, F. J., "El proceso de descubrimiento científico: De Karl Popper a Herbert Simon", en Gonzalez, W. J. (ed), Karl Popper: Revisión de su legado, Unión Editorial, Madrid, 2004, pp. 267-295.

Castrodeza, C., "De la Epistemología popperiana a la Epistemología darwinista”, en Schwartz, P., Rodriguez Braun, C. y Mendez Ibisate, F. (eds), Encuentro con Karl Popper, Alianza Ed., Madrid, 1993, pp. 132-164.

Cohen, L. J., "Third World Epistemology", en Currie, G. y Musgrave, A. (eds), Popper and the Human Sciences, M. Nijhoff, Dordrecht, 1985, pp. 1-12.

Corcó, J., “La Selección Natural en Popper y Peirce”, Anuario Filosófico, v. 34/ 1, n. 69, (2001), pp. 139-155.

Currie, G., "Popper's Evolutionary Epistemology: A Critique”, Synthese, v. 37, (1978), pp. 413-431.

Dasgupta, S., "Multidisciplinary Creativity: the Case of Herbert A. Simon", Cognitive Science, v. 27, (2003), pp. 683-707.

Gigerenzer, G., Adaptive Thinking. Rationality in the Real World, Oxford University Press, N. York, 2000.

Gigerenzer, G. y Selten, R., "Rethinking Rationality”, en Gigerenzer, G. y Selten, R. (eds), Bounded Rationality. The Adaptive Toolbox, The MIT Press, Cambridge, MA, 2001, pp. 1-12.

Gigerenzer, G., "The Adaptive Toolbox", en Gigerenzer, G. y Selten, R. (eds), Bounded Rationality. The Adaptive Toolbox, The MIT Press, Cambridge, MA, 2001, pp. 37-50.

Gonzalez, W. J., "La interpretación historicista de las Ciencias Sociales", Anales de Filosofía, v. 2, (1984), pp. 109-137.

Gonzalez, W. J., "Racionalidad científica y actividad humana. Ciencia y valores en la Filosofía de Nicholas Rescher", en Rescher, N., Razón y valores en la Era científico-tecnológica, Paidós, Barcelona, 1999, pp. 11-44. 
Gonzalez, W. J., "Análisis de la racionalidad y planteamiento de la predicción en Economía Experimental", en Gonzalez, W. J., Marques, G. y Avila, A. (eds), Enfoques FilosóficosMetodológicos en Economía, FCE, Madrid, 2002, pp. 145-172.

Gonzalez, W. J., "Herbert A. Simon: Filósofo de la Ciencia y economista (1916-2001)", en Gonzalez, W. J. (ed), Racionalidad, historicidad y predicción en Herbert A. Simon, Netbiblo, A Coruña, 2003, pp. 7-63.

Gonzalez, W. J., "Racionalidad y Economía: De la racionalidad de la Economía como Ciencia a la racionalidad de los agentes económicos", en Gonzalez, W. J. (ed), Racionalidad, historicidad y predicción en Herbert A. Simon, Netbiblo, A Coruña, 2003, pp. 65-96.

Gonzalez, W. J., "Rationality in Experimental Economics: An Analysis of Reinhard Selten's Approach", en Galavotti, M. C. (ed), Obsevation and Experiment in the Natural and Social Sciences, Kluwer, Dordrecht, 2003, pp. 71-83.

Gonzalez, W. J., "The many faces of Popper's Methodological Approach to Prediction”, en Catton, Ph. y Macdonald, G. (eds), Karl Popper: Critical Appraisals, Routledge, Londres, 2004, pp. 78-98.

Gonzalez, W. J. (ed), Karl Popper: Revisión de su legado, Unión Editorial, Madrid, 2004.

Gonzalez, W. J., "Rationality and Prediction in the Sciences of the Artificial: Economics as a Design Science", en Galavotti, M. C., Scazzieri, R. y Suppes, P. (eds), Reasoning, Rationality and Probability, CSLI Publications, Stanford, 2008, pp. 165-186.

HaAck, S., "Epistemology With a Knowing Subject", Review of Metaphysics, v. 33, (19791980), pp. 309-335.

Martinez Solano, J. F., "El puesto de la Biología en la Epistemología y Metodología de la Ciencia de Karl Popper", Thémata, v. 20, (1998), pp. 175-194.

Martinez Solano, J. F., El problema de la verdad en K. R. Popper: Reconstrucción históricosistemática, Netbiblo, A Coruña, 2005.

Menna Menendez, L., “Crítica, falsación y eliminación”, Teorema, v. 14/ 1-2, (1987), pp. 91-101.

Olding, A., "A Defence of Evolutionary Laws", British Journal for the Philosophy of Science, v. 29, n. 2, (1978), pp. 131-143.

Popper, K. R., The Poverty of Historicism, Routledge and K. Paul, Londres, 1957, $3^{\text {a }}$ ed., 1961 (Routledge, Londres, reimpreso en 1999).

Popper, K. R., "Philosophy of Science: A Personal Report", en Mace, C. A. (ed), British Philosophy in the Mid-Century: A Cambridge Symposium, George Allen and Unwin, Londres, 1957, pp. 155-191. Reimpreso como: "Science: Conjectures and Refutations", en Popper, K. R., Conjectures and Refutations. The Growth of Scientific Knowledge, Routledge and K. Paul, Londres, 1963; $5^{\text {a }}$ ed. revisada, 1989 (Routledge, Londres, reimpreso en 2000), pp. 33-65.

Popper, K. R., The Logic of Scientific Discovery, Hutchinson and Co., Londres, 1959, (Routledge, Londres, 2001, $6^{\mathrm{a}}$ reimp.).

Popper, K. R., "Evolution and the Tree of Knowledge" (versión aumentada de la Herbert Spencer Lecture, pronunciada en Oxford, en 1961). Reimpreso en Popper, K. R., Objective Knowledge. An Evolutionary Approach, Clarendon Press, Oxford, 1972, (5 ed. revisada, 1979), pp. 256-284.

Popper, K. R., Of Clouds and Clocks: An Approach to the Problem of Rationality and the Freedom of Man, Washington University Press, San Louis, MI, 1966 (transcripción de la $2^{\mathrm{a}}$ Arthur Holly Compton Memorial Lecture, presentada en la Universidad de Washington en 1965). Reimpreso en Popper, K. R., Objective Knowledge. An Evolutionary Approach, Clarendon Press, Oxford, 1972, (5 ed. revisada, 1979), pp. 206-255. 
Popper, K. R., "Epistemology Without a Knowing Subject”, en Van Rootselaar, B. y Staal, J. F. (eds), Proceedings of the Third International Congress for Logic, Methodology and Philosophy of Science: Logic, Methodology and Philosophy of Science III, North-Holland, Amsterdam, 1968, pp. 333-373. Reimpreso en Popper, K. R., Objective Knowledge. An Evolutionary Approach, Clarendon Press, Oxford, 1972, (5 ed. revisada, 1979), pp. 106-152.

Popper, K. R., "A Realist View of Logic, Physics and History”, en Yourgrau, W. y Breck, A. D. (eds), Physics, Logic and History, Plenum Press, Londres, 1970, pp. 1-30 y pp. 35-37. Reimpreso en Popper, K. R., Objective Knowledge. An Evolutionary Approach, Clarendon Press, Oxford, 1972, (5ª ed. revisada, 1979), pp. 285-318.

Popper, K. R., "Replies to my Critics", en Schilpr, P. A. (ed), The Philosophy of Karl Popper, vol. 2, Open Court, La Salle, IL, 1974, pp. 961-1197.

Popper, K. R., "Scientific Reduction and the Essential Incompleteness of All Science”, en Ayala, F. J. y Dobzhansky, T. (eds), Studies in the Philosophy of Biology, Macmillan, Londres, 1974, pp. 259-284. Reimpreso en Popper, K. R., The Open Universe. An Argument for Indeterminism. From the Postscript to The Logic of Scientific Discovery, editado por W. W. Bartley III, Hutchinson, Londres, 1982, (Routledge, Londres, 1998, $4^{\text {a }}$ reimp.), pp. 131-162.

Popper, K. R., “The Rationality of Scientific Revolutions”, en Harré, R. (ed), Problems of Scientific Revolution. Progress and Obstacles to Progress in the Sciences, Clarendon Press, Oxford, 1975, pp. 72-101. Reimpreso en PoPPER, K. R., The Myth of the Framework. In Defence of Science and Rationality, editado por Mark Notturno, Routledge, Londres, 1994, pp. 1-32.

Popper, K. R., Unended Quest. An Intellectual Autobiography, Fontana/Collins, 1976 (edic. ampliada, Routledge, Londres, 1992; 1993, $1^{\text {a }}$ reimp.).

Popper, K. R., "Natural Selection and the Emergence of Mind", Dialectica, v. 32, n. 3, (1978), pp. 339-355. Reimpreso en RADNITZKY, G. y BARTLEy III, W. W. (eds), Evolutionary Epistemology, Rationality, and the Sociology of Knowledge, Open Court, La Salle, IL, 1987, (1993, $3^{\text {a }}$ reimp.), pp. 139-153.

Popper, K. R., "Towards an Evolutionary Theory of Knowledge”, (versión de una conferencia pronunciada en la London School of Economics en 1989). Reimpreso en PopPer, K. R., A World of Propensities, Thoemmes, Bristol, 1990 (1ª reimp. 1995), pp. 29-51.

Popper, K. R., Knowledge and the Body-Mind Problem. In defence of Interaction (recopilación de conferencias pronunciadas en la Universidad de Emory en 1969), editado por Mark Notturno, Routledge, Londres, 1994.

Queraltó, R., Karl Popper: De la Epistemología a la Metafísica, Publicaciones de la Universidad de Sevilla, Sevilla, 1996.

RESCHER, N., Rationality: A Philosophical Inquiry into the Nature and the Rationale of Reason, Clarendon Press, Oxford, 1988.

Ruse, M., "Karl Popper's Philosophy of Biology", Philosophy of Science, v. 44, (1977), pp. 638-661.

Schwartz, P., "Karl Popper y la Teoría de la Evolución”, Enrahonar, n. 11, (1985), pp. 43-52.

Selten, R., "Evolution, Learning, and Economic Behaviour", Games and Economic Behaviour, v. 3, (1991), pp. 3-24. Reimpreso en Selten, R. (ed), Game Theory and Economic Behaviour. Selected Essays, vol. 1, pp. 161-182.

Selten, R., "In Search of a Better Understanding of Economic Behaviour", en HeertJe, A. (ed), Makers of Modern Economics, Vol. 1, Simon and Schuster, N. York, 1993, pp. 115-139. Reimpreso en Selten, R. (ed), Game Theory and Economic Behaviour. Selected Essays, vol. 1, E. Elgar, Northampton, MA, 1999, pp. 3-27. 
Selten, R., "New Challenges to the Rationality Assumption", Journal of Institutional and Theoretical Economics, v. 150, n. 1, (1994), pp. 42-44.

Selten, R. (ed), Game Theory and Economic Behaviour. Selected Essays, 2 vols., E. Elgar, Northampton, MA, 1999.

Selten, R., "What is Bounded Rationality?", en Gigerenzer, G. y Selten, R. (eds), Bounded Rationality. The Adaptive Toolbox, The MIT Press, Cambridge, MA, 2001, pp. 13-36.

Simon, H. A., "Some Strategic Considerations in the Construction of Social Science Models", en Lazarsfeld, P. (ed), Mathematical Thinking in the Social Sciences, The Free Press, Glencoe, IL, 1954, pp. 388-416. Reimpreso en Simon, H. A., Models of Bounded Rationality. Vol. 2: Behavioral Economics and Business Organization, The MIT Press, Cambridge, MA, 1983 (2 ${ }^{\text {a }}$ reimp.), pp. 209-238.

Simon, H. A., "A Behavioral Model of Rational Choice", Quarterly Journal of Economics, v. 69, (1955), pp. 99-118. Reimpreso en Simon, H. A., Models of Bounded Rationality. Vol. 2: Behavioral Economics and Business Organization, The MIT Press, Cambridge, MA, 1983 (2a reimp.), pp. 239-258.

Simon, H. A., "Rational Choice and the Structure of the Environment", Psychological Review, v. 63, n. 2, (1956), pp. 129-138. Reimpreso en Simon, H. A., Models of Bounded Rationality. Vol. 2: Behavioral Economics and Business Organization, The MIT Press, Cambridge, MA, 1983 (2 ${ }^{\mathrm{a}}$ reimp.), pp. 259-268.

Simon, H. A., "Theories of Decision-Making in Economics and Behavioral Science", American Economic Review, v. 49, n. 1, (1959), pp. 253-283. Reimpreso en Simon, H. A., Models of Bounded Rationality. Vol. 2: Behavioral Economics and Business Organization, The MIT Press, Cambridge, MA, 1983 (2 ${ }^{\text {nd }}$ reimp.), pp. 287-317.

Simon, H. A., "Economics and Psychology", en Косн, S. (ed), Psychology: A Study of a Science, vol. 6, McGraw-Hill, N. York, 1963, pp. 715-752. Reimpreso en Simon, H. A., Models of Bounded Rationality. Vol. 2: Behavioral Economics and Business Organization, The MIT Press, Cambridge, MA, 1983 (2 ${ }^{\text {a }}$ reimp.), pp. 318-355.

Simon, H. A., "Rationality", en Gould, J. y Kolb, W. L. (eds), A Dictionary of the Social Sciences, The Free Press, Glencoe, IL, 1964, pp. 573-574. Reimpreso en Simon, H. A., Models of Bounded Rationality. Vol. 2: Behavioral Economics and Business Organization, The MIT Press, Cambridge, MA, 1983 (2ª reimp.), pp. 405-407.

Simon, H. A., "Theories of Bounded Rationality", en Mcguire, C. B. y Radner, R. (eds), Decision and Organization, North-Holland, Ámsterdam, 1972, pp. 161-176. Reimpreso en Simon, H. A., Models of Bounded Rationality. Vol. 2: Behavioral Economics and Business Organization, The MIT Press, Cambridge, MA, 1983 (2 reimp.), pp. 408-423.

Simon, H. A., "From Substantive to Procedural Rationality", en Latsis, S. J. (ed), Method and Appraisal in Economics, Cambridge University Press, Cambridge, 1976, pp. 129-148. Reimpreso en Simon, H. A., Models of Bounded Rationality. Vol. 2: Behavioral Economics and Business Organization, The MIT Press, Cambridge, MA, 1983 (2 ${ }^{\mathrm{a}}$ reimp.), pp. 424-443.

Simon, H. A., Models of Discovery, Reidel, Dordrecht, 1977.

Simon, H. A., "Rationality as Process and as Product of Thought", American Economic Review, v. 68, n. 2, (1978), pp. 1-16. Reimpreso en Simon, H. A., Models of Bounded Rationality. Vol. 2: Behavioral Economics and Business Organization, The MIT Press, Cambridge, MA, 1983 (2 reimp.), pp. 444-459.

Simon, H. A., "Accurate Predictions and Fixed Point Theorems: Comments", Social Science Information, v. 25, n. 4/5, (1982), pp. 605-612. 
Simon, H. A., Reason in Human Affairs, Stanford University Press, Stanford, CA, 1983.

Simon, H. A., "Rationality in Psychology and Economics", Journal of Business, v. 59, (1986), pp. 209-224. Reimpreso en Simon, H. A., Models of Bounded Rationality. Vol. 3: Empirically Grounded Economic Reason, The MIT Press, Cambridge, MA, 1997, pp. 367-385.

Simon, H. A., "Bounded Rationality”, en Eatwell, J., Milgate, M. y Newman, P. (eds), The New Palgrave: A Dictionary of Economics, vol. 1, Macmillan, Londres, 1987, pp. 266-268. Reimpreso en Simon, H. A., Models of Bounded Rationality. Vol. 3: Empirically Grounded Economic Reason, The MIT Press, Cambridge, MA, 1997, pp. 291-294.

Simon, H. A., "Decision-Making and Problem Solving”, Interfaces, v. 17, n. 5, (1987), pp. 11-31.

Simon, H. A., "Economics as a Historical Science", Theoria, v. 13, n. 32, (1998), pp. 241-260.

Simon, H. A., "Bounded Rationality in Social Science: Today and Tomorrow", Mind and Society, v. 1, (2000), pp. 25-39. Vers. cast. de Wenceslao J. González y María G. Bonome: "Racionalidad limitada en Ciencias Sociales: Hoy y mañana", en Gonzalez, W. J. (ed), Racionalidad, historicidad y predicción en Herbert A. Simon, Netbiblo, A Coruña, 2003, pp. 97-110.

Springer de Freitas, R., "Back to Darwin and Popper. Criticism, Migration of Piecemeal Conceptual Schemes, and the Growth of Knowledge", Philosophy of the Social Sciences, v. 27, n. 2, (1997), pp. 157-179. 


\section{ÍNDICE DE NOMBRES}

ABEL, F., 125n, 145

Abrams, P., 122

AdAm, Ch., 194n, 206

Agassiz, J. L. R., 17, 129

Agazzi, E., 44

Aguadé, M., 132n, 144

Alchian, A. A., 150, 162, 181n, 185

Alcock, J., 150n, 162

AlcoleA, J., 36n, 38n, 50

Aldrich, H., 170n, 185

Andersen, E. S., 170n, 185

Andersen, H., 21n, 46

Andersson, K., 166n, 188

AnHART, L., 46

Anna, G. De, 52

AranA, J., viii, 43, 45-46, 193, 202n, 205

Ardzrooni, L., 154n, 164

Aristóteles, 126-127, 129n, 193, 199, 205

Asquith, P. D., 46, 54

Aunger, R., 160n, 162

Avila, A., 221n, 225

Ayala, F. J., 5n, 18n, 26n-27n, 46-48, 57, 59, 132n, 144, 193, 195, 205-206, 214n, 226

BabBage, CH., 65n, 75

BACON, F., 31

BAGehot, W., 167

Bapteste, E., 83, 86n, 99

BARAN, P. A., 153, 162

BArash, D. P., 150n, 162

BARKER, P., 21n, 46

BARlow, N., 48, 65n, 76, 194n, 206

Barrett, P. H., 10n, 46, 48, 65n, 70n-75

BARTLEy III, W. W., 213n-214n, 218, 224

BAteson, W., 23

BAtTen, D. F., 46

BAumol, W., 166n, 185

BeAtty, J., 46, 75, 128n-130n, 143

Becker, G., 150, 160

BeER, G. DE, 9n, 48
Behe, M., 18n, 46

Behne, T., 154n, 164

Behrens III, W. W., 153n, 163

Bensaude-Vincent, B., 14n, 46

Bentham, J., 150

Bergson, H., 33, 46, 154n, 162

Berkeley, G., 218n

Bertalanffy, L. von, 47

BIRNER, J., 185

Blachowicz, J., 219n, 224

Blyth, E., 16

Boettke, P., 166, 185

Bohr, N., 78, 204

Boniolo, G., 52

Bonnet, CH., 4, 128

Bonome, M. G., 208n, 228

Boulding, K. 165, 170, 185

BOWler, P. J., 4n-5n, 7, 9n, 11n-12n, 14n, 16n-18n, 22, 24n, 32n, 45, 47, 75, 84n, 99, $125 \mathrm{n}, 143$

Bowles, S., 170n, 185

Boyd, R., 41

BRANDOM, R. N., 47

Breck, A. D., 214n, 226

BrenNAN, G., 183n, 185

Brocchi, G. B., 16-17

Brooke, J. H., 8n, 23n, 42n, 47

Brooks, D., 24n, 47

BRUNNER, K., 185

Buch, CH. L. VON, 16-17

Buchanan, J. M., 179, 182-183, 185

Buffon [George Louis Leclerc], Conde de, 5 , $10,47,128$

Bunge, M., 138-139, 143

Burian, R. M., 58

Burke, E., 171

Burkhardt, F., 69n-70n, 75, 82n, 99

BurkhaRd, R. W., 53

Burns, A. F., 156n

Butler, E., 175n, 177n, 185 
Cabrera Calvo-Sotelo, I., 132n, 145

Calvo Martínez, T., 193, 205

Campbell, D. T., 36, 47, 213n, 216, 224

Candolle, Augustin Pyrame de, 8-9, 16-17

CAnnon, W., 65, 75

CAÑón, C., 125n, 145

Carpenter, W. B., 8, 16, 47

Castle, W., 25

Castro, F. J., viii, 43, 45, 207, 214n, 218n, 224

Castrodeza, C., 11n, 47, 125n, 145, 216n, 224

Catton, Ph., 39n, 217n, 225

Chambers, R., 8, 15, 17, 48, 75

Chardin, Th. De, 22

Chen, X., 21n, 46

Claridge, M. F., 140n, 143

Clark, C. M. A., 186

Clark, J., 157n, 162

CoAse, R. H., 149, 155, 162

CoвB, M., 28n, 49

Cohen, L. J., 48, 220n, 224

Collins, F. S., 19n, 48

Commons, J. R., 179, 185

Conant, J., 14n

Condorcet [Jean Antoine Nicolas Caritat], Marques de, 5

Copérnico, N., 14

Corcó, J., 218n, 225

Cordón, F., 94n, 100

Cotton, J. A., 86n, 101, 106

Cracraft, J., 49, 133, 140, 143

CRICK, F., 195-196, 206

Crovello, Th., 132n, 145

CuÉnOt, L., 23

Cunninghan, S., 13n, 22n, 32n-34n, 48

Curio, E., 113n, 122

Currie, G., 213n, 220n, 224

Cuvier, G., 17-18, 48, 128, 143

Dalla Chiara, M. L., 81n, 99

Darlington, C. D., 90

DARwin, Ch. R., ix, 3-4, 6-26, 28-39, 42, 45, 48, 63, 65-76, 80-92, 95-99, 102, 107, 111-114, 117, 120-122, 126-130, 138, 143-144, 149-152, 155, 166-168, 171-172, 184, 194, 197-198, 201-202, 204, 206, 214, 216, 218-219
DARWIN, E., 6, 15, 172

DARWIn, F., 48, 194n, 206

DAsGupta, S., 215n, 224

DAWAH, H. A., 140n, 143

Dawkins, R., 36, 48, 113-122, 200-202, 206

De JASAY, A., 182n, 186

De la Mothe, J., 170n, 186

De la Nuez, P., 176-179, 186

DE VRIES, H., 23

DeEly, J. N., 48

DelbrÜCK, M., 196

Delorme, R., 186

Demsetz, H., 186

Denkel, A., 138, 144

Dennett, D., 41

Depew, D. J., 24n, 26n-28n, 46, 48, 50, 58

Descartes, R., 194, 206

Dewey, J., 33

Di Gregorio, M., 75

DingWall, J., 175n, 187

DirAC, P., 40

Dobzhansky, Th., 5n, 25-26, 46-48, 56-57, 90, 131n-132n, 144, 193, 195, 205-206, 214n, 226

Doets, K. D., 83n, 99

Donoghue, M., 136n, 145

Doolittle, W. F., 83, 86n, 99

DOPFER, K., 48, 186

Dosi, G., 149-150, 157n-158, 162-163

Douglas, M., 139n, 144

Drouin, J.-M., 11n, 49

DURAND, T., 159n, 162

EAtwell, J., 207n, 228

ECCles, J. C., 49, 204n, 206

Eddington, A. S., 112, 122

Edgeworth, F. Y., 168n

EDWARDS, V. C. W., 28

EgGertsson, T., 186

Ehrlich, P., 133, 144

Eibl-EibeSFELDT, I., 150, 162

Einstein, A., 40, 78, 204-205

Eldredge, N., 23, 29n, 49, 84-85, 92-95n, 98-99, 103 
ELLiot, H., 53

ENDERSBY, J., 49

ENGELS, F., 168, 186

ERESHEFSKY, M., 27n, 49, 131n-133n, 136n-138n, 140n, $147-150$

EsPinOZA, B., 161

FACI LACASTA, J., 84n, 99

FAlguera, J. L., 20n-21n, 49

Ferguson, A., 171, 173

FisHER, I., 168n

FisHeR, R. A., 25, 49, 90, 111-114, 122

Forbes, M., 58

FORD, E. B., 51

Freeman, Ch., 41, 149, 157n-158, 162-163

Freeman, R. B., 10n, 46, 48, 70n, 75

FundenBERG, D., 160n, 162

Fuster, J., 129n, 143

Galan, B., 140n, 144

Galavotti, M. C., 212n, 225

Galileo Galilei, 129

Galton, F., 23, 84

Gandolfi, A. E., 150n, 162

GAndolfi, A. S., 150n, 162

GARCía ElSKAMP, R., 63n

García GonZÁlez, A., 88n, 99

García LeAL, A., 79n, 100

GAYON, J., vii, 3n-4, 11n-12n, 17n, 23n-31n, 34n, 43-45, 49, 79-81n, 90n, 93n, 99-100, 107, 126-127, 134, 138, 144

Georgescu-Roegen, N., 168n, 186

Ghiselin, M. T., 49, 76, 135, 144

GiannetTi, J., 158n, 162

GibSON, C., 166n, 188

Giere, R., 46

Gigerenzer, G., 89n, 100, 222-224, 227

Gil Aristu, J. L., 127n, 144

GiLl, N. W., 76

Gillespie, N. C., 11n, 49

Gillies, D. A., 44

GiLson, E., 11n, 34n, 49

GinTis, H., 170n, 186

Gleich, M., 140n, 144

GLimcher, P. W., 160n, 162

GoldschmidT, R. B., 23, 95, 202, 206
Gonzalez, W. J., vii, ix, 3, 5n, 10n, 14n, 20n-21n, 36n-39n, 42-44n, 49-50, 53, 79n, $111 n, 123,186,208 n-209 n, 211-213 n, 215 n$, 217n-218n, 221, 224-225, 228

Goodman, N., 139n, 144

Gordon, S., 166n, 172n, 186

Gotthelf, A., 126n, 145

Gould, S. J., 6-7n, 27, 29, 41, 49-50, 79-80, 84-85, 87, 90, 92-100, 103, 108, 113, 118-120, $122,208 \mathrm{n}, 227$

Grant, B. R., 50, 115, 122

Grant, P. R., 50, 115, 122

GRANT, R., 9

GraY, A., 70, 82

Gray, J., 41

Green, TH. H., 33

Greene, J. C., 50

Grene, M., 27n-28n, 46, 50

GrinNELl, G., 11n, 50

Gruber, H. E., 11n, 50

Guastavino, M. I., 142n, 145

HAack, S., 220n, 225

HAECKel, E., 50

Haldane, J. B. S., 25, 50, 90, 111-112

Hamilton, D. B., 186

HANAPPI, H., 170n, 186

HaRdy, A. C., 51

HARRÉ, R., 220n, 226

Haug, M. C., 50

Haugeland, J., 14n

Hausman, D., 44

HAYEK, F. A., 39, 41, 165-166, 169-171, 173-187

HeErTJe, A., 221n, 226

Hegel, G. W. F., 137n

Henslow, J., 9, 65

Herbert, S., 50, 65n-66n, 76

Herder, J. G., 171

Herschel, J. F. W., 30-32, 42, 63-69n, 76

Himmelfarb, G., 11n, 50

Hirshleifer, J., 41, 165, 170, 187

Hodge, J. [M. J. S.], 4n-6n, 8n-12n, 16n, 23n, 30n-31n, 34n, 36n-38n, 46-47, 49-52, 54-58, 65n, 68, 70n, 76-77, 81n, 89n, 100 
Hodgson, G. M., 41, 51, 149-150n, 154n, 162， Kolb, W. L., 208n, 228

$165,168 \mathrm{n}-169,175 \mathrm{n}, 180 \mathrm{n}-181,187$

Krimbas, C., 57

Hooker, J., 9n, 11n, 69

KRÜGER, L., 89n, 100

Hopkins, W., 129

Horowitz, T., 63n, 67n, 76, 111n, 122-123

Kunn, Tн. S., 14, 20-21, 36, 44, 52, 83, 96

KurAN, T., 166, 187

Hoselitz, B., 175n, 187

HöSLE, V., 35n, 51

KuZnEts, S. S., 156, 163

HuLl, D. L., 4n, 11n, 27n, 31n-33n, 41, 51, 57-58,

76, 78, 115, 118-122, 135-136, 139n, 144

Humboldt, A. von, 63, 67

Hume, D., 171-173, 184, 218n

Hutton, F. W., 51, 76

HuXley, J., 25-26, 51, 89, 100

Huxley, Th. H., 17, 23, 84, 194, 206

ILLIES, CH., 35n, 51

LACHMANN, L. M., 180n

LACK, D., 26, 90

LAKATOS, I., 36, 44

LaLAND, K., 114n, 120, 122

Lamarck [Jean Baptiste Pierre Antonine de Monet], Caballero de, 6-8, 15, 17, 21, 52-53, 65-66, 71-72, 76, 128-129, 167n, 202-204

LAMB, M. J., 51

LANDÉ, A., 40

JABLONKA, E., 51, 114n, 120, 122

LANGLOIS, R. N., 170n, 187

JAHN, I., 127n-128n, 144

JAMES, W., 33

LATsis, S. J., 210n, 228

LAUBiCHLER, M., 39n, 53

JENKIN, F., 51, 67, 112, 120-122

LAUDAN, L., 44

LAURENT, J., 41n, 51, 53

JeVONS, W. S., 153, 163, 168-169, 187

JohANNSEN, W., 23

Jukes, TH. H., 27, 52

Lavoisier, A. L. DE, 14n-15, 18, 21n

LAZARSFELD, P., 207n, 227

LeCourt, D., 81n, 100

KandLER, O., 24n, 59

Leibenstein, H., 187

Leibniz, G. W., 20, 83

KaPLAN, J., 55

KaufFman, S. A., 28, 51, 91n, 100, 107

Kavaloski, V. C., 89n, 100

Lennox, J. G., vii, 30n, 43, 45, 53, 63, 67n, 76, $81 \mathrm{n}, 99,111,120 \mathrm{n}, 123,126,128 \mathrm{n}, 145$

Keirstead, B. S., 157, 163

LENSKi, G., 53

LEPLin, J., 44

LeVERe, T. H., 65n, 76

LEWENS, T., 53, 80n, 99-100

Kepler, J., 40

Kettlewell, H. B. D., 25, 52

Lewontin, R. C., 23, 29, 50, 53, 90n, 100

Kimura, M., 27, 29n, 52, 91n, 100

KING, J. L., 27, 52

KipLing, R., 29, 113

Linnaeus [Linné/Linneo], CARL von, 10, 127-128

Lloyd, E. A., 52, 56

LOCKE, J., 218n

Lopez Fernandez, C., 186

Lopez Garcia, S., vii, 43, 45, 149, 170n, 189

LoRENZ, K., 26, 53

LOTHER, R., 127n-128n, 144

Koch, S., 209n, 228

Lyell, CH., 8-9n, 11, 16, 53, 63-68, 71-76, 84, 128,145 
MacArthur, R., 26

Macdonald, G., 39n, 217n, 225

Mace, C. A., 216n, 225

Machamer, P. K., 14n, 44, 53

Maienschein, J., 39n, 53

Malthus, Th. R., 9, 12, 15, 53, 150-153, 155, $163,166,168 \mathrm{n}, 172-173,184$

Mandeville, B., 171-173, 184

Marcos, A., vii, 24n, 43, 45, 53, 125, 145

Margulis, L., 53, 87n, 100

Marques, G., 221n, 225

Marshall, A., 149, 163, 165, 167, 171, 184, 187

Martinez, C., 20n-21n, 49

Martinez Solano, J. F., 45, 111n, 215n, 219n-220n, 225

MARX, K., 165, 168

Massey, G., 63n, 67n, 76, 111n, 122-123

Matthew, P., 16n

Maupertuis, P. L., 128

Maxeiner, D., 140n, 144

Maynard Smith, J., 21, 28n, 53, 57, 149, 160n, 163, 195, 206

MAYr, E., 22-23n, 26, 48, 53, 57, 79, 90, 94, 100-101, 127, 131-134, 137-138, 145

McGuinness, B. F., 34n, 58

McGuire, C. B., 208n, 228

McGuire, J. E., 44

MCInerney, J. O., 86n, 101, 106

McKelvey, W., 41

McLaughlin, P., 35n, 81n, 99

Meadows, D. H., 153n, 163

Meadows, D. L., 153n, 163

Meana Menendez, L., 219n, 226

Meckling, W. H., 185

Ménard, C., 187

Mendel, G., 25, 54, 111

Mendez Ibisate, F., 216n, 224

Menger, C., 165-166, 168-169, 171, 173-175, $178,184,187$

Metcalfe, J. S., 41, 157, 163

Miersch, M., 140n, 144

Milgate, M., 207n, 228

Miller, D., 178n, 187

Miller, J. B., 187
Millstein, R. L., 54

Mirowski, Рн., 171, 187

Mises, L. von, 173n

Mishler, B., 136n, 145

Mitchell, A., 33n, 46

Mitchell, S. D., 54, 56

Mitchell, W. C., 175n

Mivart, St. G. J., 17, 54

Mokyr, J., 156n, 163

Moln, H., 154n, 164

Monod, J., 54

Moore, G. E., 33

Moore, J., 54

Moorehead, A., 11n, 54

Morgan, M. S., 89n, 100

Morgan, Th. H., 24-25

Morrell, J., 54

Morrison, M., 54

Mundici, D., 81n, 99

Musgrave, A., 220n, 224

Nelson, R., 41, 149-150, 154, 156n-158, 162-163, $165,170,187-188$

Nersessian, N. J., 21n, 54

Newell, N., 90, 93, 97

Newman, F., 8

Newman, P., 207n, 228

Newton, I., 10, 20, 64, 194

Nickles, Th., 21n, 46, 54

Nicolay, F., 140n, 144

Nietzsche, F., 33n

Nightingale, J., 41n, 51, 53

NiIniluoto, I., 5n, 44, 54

Nitecki, D. V., 49

NiteCKi, M. H., 49

Nock, F. J., 174n, 187

Nogar, R. J., 48

North, D. C., 155, 163, 166, 177n, 182, 188

Notturno, M. A., 213n, 220n, 226-227

Numbers, R. L., 54

Ogden, C. K., 34n, 58

OKEN, L., 16 
Olding, A., 217n, 225

Olson, M., 166, 188

Orzack, S. H., 54, 57, 122-123

Osborn, H. F., 85, 104

Ospovat, D., 11n, 54

Ostrom, E., 166n, 188

Owen, R., 17

PACEy, A., 156n, 163

Paley, W., 10n, 16-19

Paquet, G., 170n, 186

Pareto, W., 154, 168n

Paterson, H., 134, 145

Paul, D. B., 54, 57

Pauling, L. C., 196

Pavitt, K., 158n, 162

Peakall, D. B., 118n, 123

Pears, D. F., 34n, 58

Pearson, K., 25

Peckham, M., 54

Peirce, Ch. S., 33, 40

Pellegrin, P., 126n, 145

Penrose, E. T., 170n, 188

Perez, C., 157-158, 162-163

Pigliucci, M., 55

PisAni, D., 86n, 101, 106

Platón, 125-127, 137n

Plutynski, A., 55

Popper, K. R., 38-42, 44, 55, 130, 174, 180n,

188, 191, 193-207, 213-221, 225-226

Posner, R. A., 182, 188

Potts, J., 48

Powell, B., 8

Provine, W. B., 22n, 25n-26n, 54, 55, 57, 90n, 101

Queraltó Moreno, R., 213n, 226

RADICK, G., 4n-6n, 8n-9n, 11n-12n, 16n, 23n, 30n-31n, 34n, 36n-37n, 46-47, 49, 51-53, 55-58, 70n, 76-77, 79n, 97, 100

RADNER, R., 208n, 228

RADNITZKY, G., 213n-214n, 224, 227
Ramos Gorostiza, J. L., vii, 43, 45, 165

RAMSEY, F. P., 34n, 58

RANDERS, J., 153n, 163

RAuP, D., 29n, 55, 92, 101

RAVEN, P., 133, 144

RAY, J., 127-128

REED, C. F., 117n, 123

ReNsCh, B., 90

Rescher, N., 35n-36, 55, 211, 224, 226

Richards, R. J., 13n, 55

RiCHERSON, P., 41

RICQLÈs, A. DE, 81n, 99-100

Ridley, M., 55, 90n, 101, 136, 145

RoBert, J., 55

RoBertson, P. L., 170n, 187

Rocher, G., 180n, 188

Rodriguez Braun, C., 216n, 224

Rosenberg, A., 37n-39n, 41, 55, 132n, 145

Rosenberg, N., 149, 157, 163

Rostand, J., 55

Rudwick, M. J. S., 9n, 53

Ruse, M., 4n-7n, 11n-13, 19n, 24n, 27n-36n, 40, 42, 45, 51, 56-58, 77, 89n, 101, 125n, $135-138,145,215 \mathrm{n}, 226$

Russell, B. A., 33-34, 138, 218n

Rustichini, A., 160n, 162

RUTHERFORD, M., 188

SAGAN, D., 87n, 100

SAGÜIllo, J. M., 20n-21n, 49

SAHAL, D., 158, 163

Saint-Hilaire, Etienne Geoffroy, 9, 16-17

SALMON, M. H., 44

SAlmon, W. Ch., 44

SAlthe, S. N., 56

SAmuelson, L., 170n, 188

SAPP, J., 56

SARKAR, S., 56

SAvigny, J. C. L. DE, 171

SCAZZIERI, R., 212n, 225

Schilpp, P. A., 36n, 47, 213n, 219n, 224, 226

Schmalhausen, I. I., 90 
SCHNEIDER, L., 174n, 187

Schopf, T. J. M., 23n, 48, 84n, 99

SchrÖDINGER, E., 202-203, 206

Schumpeter, J. A., 39, 41, 149, 155-158, 163, 165 , 168-169, 184, 188

Schutz, A., 176n, 188

Schwartz, J. H., 56

SchWARTZ, P., 214n, 216n, 224, 226

ScIlla, A., 108

SECord, J. A., 8n, 48, 75

Selten, R., 39, 191, 207, 212, 219n, 221-224, 226-227

SEMPaU, D., 87n

Senglaub, H., 127n-128n, 144

Serres, M., 11n, 49

Shackle, G. L. S., 180n

ShaPere, D., 56

SHEA, W. R., 65n, 76

SHIVAKUMAR, S., 166n, 188

Shleifer, A., 166, 188

Shrader-Frechette, K., 44

SilverberG, G., 157n-158, 162-163

SimON, H. A., 35, 38, 41-42, 56, 150, 155, 164, 180n, 188, 191, 207-214n, 217-223, 227-228

Simpson, G. G., 26, 57, 90, 93, 97, 133, 145

Singer, P., 142-143, 145

Singh, R., 57

SlOAN, PH. R., 6n, 9n-10n, 16n, 30n, 57, 77

Sмith, A., 38, 152, 166, 171-173

Smith, C. U. M., 33n, 57

Sмith, J. D., 24n, 58

Smocovitis, B. V., 57, 90n, 101

Sneath, P. H., 132n, 145

Sober, E., 23n, 27n, 35n, 37, 49, 54, 57, 91n, $101,122-123$

SoEte, L., 157-158, 162-163

SOKAL, R., 132n, 145

Solomon, M., 46, 54, 56

Sowell, T., 168n, 188

Spencer, H., 12n, 17, 32-33, 57, 153, 167, 172-173, 176n, 181, 184

Springer de Freitas, R., 215n, 217n, 228

StAAL, J. F., 214n, 226
Stahl, G., 18

Stamos, D., 127n, 131, 135, 137-138, 140, 146

STANFORD, P. K., 57

StANLEy, S. M., 85n, 93n, 95, 101

StAuffer, R. C., 129n, 144

Stebiins, G. L., 26, 57, 90, 132n, 144

Stirling, J. H., 33

Stuart Mill, J., 32-33

Sugden, R., 188

Sulloway, F. J., 11n, 57

SupPe, F., 14n, 135-137, 146

Suppes, P., 212n, 225

Sutton, J., 170n, 188

Sweezy, P. M., 153, 162

SzAThmary, E., 28n, 57

TANNERY, A., 194n, 206

TARSKI, A., 199

TAX, S., 58

Templado, J., 11n, 58, 134

Templeton, A., 134, 146

Thagard, P., 14-21, 58

Thompson, J. J., 196

Tinbergen, N., 26, 58

Tirole, J., 149n, 160n, 162, 164

Tomasello, M., 154n, 164

Toninelli, P. A., 158n, 162

Toulmin, S. E., 58

Tullock, G., 185

Turner, J. S., 114n, 120, 123

URBACH, P., 58

Ureña, E. M., 168n, 188

Usher, A. P., 156n, 164

VAldaliso, J. M., 170n, 189

VAlentine, J., 132n, 144

Valera, M., 186

VAn Benthem, J., 81n, 99

VAN RootselaAr, B., 214n, 226

Van Valen, L., 131, 137, 146

VAN ZIJP, R., 185

VANBERG, V. J., 178n-179n, 189 
VARA, P., 79n

VeBLEN, Th., 149-151, 153-155, 164-165, 168-169, 175n, 184, 189

Vega Redondo, F., 160n, 164

ViALLETON, L., 84-85, 91, 101, 104-105

Voltaire (François-Marie Arouet), 29

VROMEN, J. J., 170n, 189

WAAL, F. DE, 52

Waddington, C. H., 26, 58, 90

WALKER, G., 178n, 189

Wallace, A. R., 8-9, 16-17, 20, 28, 47, 58, 80

WALlis, J. J., 155n, 163

WALRAS, L., 168-169

WALSh, D. M., 26n, 58

WAters, C. K., 8n-9, 12n, 22n, 24n, 32n, $70 \mathrm{n}, 77$

Weber, B. H., 24n, 26n, 48, 58

Weldon, W. F. R., 25

Wells, W. CH., 16n

WheELis, M. L., 24n, 59

WheWeLl, W., 17, 30-32, 42, 58, 68

White, M. J. D., 90, 95

Whitehead, A. N., 177n

WiCKEN, J., 24n, 58

Wiley, E. O., 24n, 47, 58, 133, 146

Williams, G. C., 58, 113n, 115, 119, 123

Williamson, O. E., 182
WiLson, B., 137, 146

WiLSON, D. S., 27n, 58, 91n, 101

WiLson, E. O., 26, 58, 149-150, 164

Wilson, M. R., 140n, 143

Winter, S. G., 41, 149-150, 155, 163, 165, 170, 188

WitT, P. N., 117n, 123

WitT, U., 58

Wittgenstein, L., 34, 58

Woese, C. R., 24, 59, 86, 101

Wolf, J., 155-157, 158, 164

Wolters, G., 81n, 99

Worrall, J., 44

WRANGHAM, R., 152n, 164

Wright, S. G., 25, 59, 90

Wuketits, F. M., 36n, 59

WunENBURGER, J.-J., 126n-127n, 134n, 144

Wynne-Edwards, V. C., 28n, 59

YARRELL, W., 16

Young, H. P., 170n, 189

Young, R. M., 150n, 164

YourgRAu, W., 214n, 226

ZaLta, E. N., 128n, 145

ZANOTTI, G. J., 189

ZiLhão, A. J. T., 20n-21n, 49

ZuCKerland, E., 27, 59 


\section{Í́NDICE TEMÁTICO}

actuación (agency), principio de, 96-97

actualismo, 66, 74

adaptación, 12n, 27, 29, 69, 89, 94, 114, 116, 130, 159-160, 167n, 171, 184, 196, 200, 207, 210-211, 217, 220

- a los niveles de aspiración, teoría de la, 221-222

- de grupo, 24, 173, 176

adaptacionismo, 23

ADN, 26-27, 90, 139

Alometría, 92-93, 97

altruismo, 111, 161, 210n

altura competitiva (competitive highness), 27-28

anagénesis, 89

Anatomía, 10, 31

Anatomía comparada, 9, 25

animismo, 203-204

anti-reduccionismo, 194-195

Antropología, 4, 44

Antropología Filosófica, 34

aptitud (fitness), 27-28

árbol de la vida, 5, 7, 12-13, 21-22, 24, 35, 41, $83,85-86,133,204$

árbol del conocimiento, 205, 219

arquea(s), 86

arqueobacteria, 109

axioma of extensionalidad, 137

biodiversidad, 7, 125, 139-141

bioespecies, 131, 133-134, 138

Biología, 3-6, 13, 17-18, 27, 29-30, 33, 36-38, 40-42, 89, 121, 125, 127, 129-131, 134-135, 139, 141, 149-150, 160, 167-170, 183, 193-196

- evolutiva, 26, 29, 36, 39, 42, 67, 77-78, 87, 90-91, 95, 97, 116, 122, 129, 134, 136, 140, 152, 197, 199, 202

- Molecular, 202

- de plantas, 26

— de población, 89 biológico/a

— diseño, 17

- diversidad, 7

- giro, 213n

- revolución, 15, 18

Botánica, 9, 139

caja de herramientas adaptativa, 207, 221-223

cambio de forma (Gestalt shift), 115

capacidad (competence/ competency), 68, 71

capitalismo, 155, 169

causa(s) verdadera (vera causa), 31-32, 63-65, 68

Ciencia Aplicada, 4

Ciencia Básica, 3

Ciencia Política, 165-166

cientifismo, 170-171

cladista, Escuela taxonómica, 136

cladogénesis, 23, 84, 89

Club de Roma, informe del, 153

competición, $167 \mathrm{n}$

complejidad, 4-7, 13, 15, 23, 27-28, 91, 174, 197

Concepción heredada, 135

conceptual

— innovación, 15, 20

- revolución, 14-15, 17, 19, 21, 29

conmensurabilidad de teorías, 21

constructivismo contractualista, 183

contexto de descubrimiento, 198

convencionalismo, 122-123

convergencia de las inducciones (consilience of inductions), 30-31

conversión psicológica, 15

creación, 17-19, 67, 72, 80, 128

— animada, 66-67

— idea de, 17, 34

creacionismo, 10n, 16-19

Creador, 16n-18, 64

curiosidad, pura (idle curiosity), 149-150, $153-155,160$ 
darwiniano/a

- evolucionismo, 10n, 24, 42, 169, 198

- Experimento Mental (EMD), 63, 67, 69-70, 74, 111-113, 115-118, 120-121

- revolución, 14, 17

- Teoría de la Evolución, 78, 87 darwinismo, 3-5, 18, 22-24, 26, 28-29, 32-34, 36, 40-43, 45, 80-83, 90-98, 153, 194, 197-198, 202-204, 216

- eclipse del, 24

— ético, 37

- metaético, 36-37

- social, 152-153, 167n, 173

demarcación, criterio de, 41, 215

Derecho, 165-166

deriva (drift)

— aleatoria de la evolución molecular, 91

- de especies, 93, 96

- de la población, 26

descendencia con modificación, 11-12n, 31, 81-87, 98

determinismo

- einsteiniano, 205

- genético, 116

dilema del anti-especista, 140-141

diseño, 211

diseño inteligente, 18,114

dualismo genético, 204

ECHO, 21

ecoespecies, 131

Ecología, 25-26, 119, 131

económica/o

- Biología, 149, 168

- dinámica, 149, 168

- Teoría, 168-169

Economía, 4, 37, 39-43, 149-150, 152-155, $159,161,165-170,172,177-181,183,207$, 209-212, 219, 224

- Escuela austriaca de, 169, 174-175, 180

- experimental, 212

— neoclásica, 167-168

- evolutiva, 3, 39, 149-150, 159-160, 165, $169-170,183$

educación, 5

eficacia biológica inclusiva (inclusive fitness), 111 eidos, 126 élan vital, 22, 34

Embriología, 10, 25, 31-32

emergencia, 214

enfoque

- como principio (scope), 96

- evolucionista, 4, 6

— jerárquico, 94

- reticular (network approach), 98

- tipológico, 85

epigénesis, $12 \mathrm{n}$

Epistemología, 35, 42, 197-198, 200, 204, 207, 213

equilibriopuntuado(punctuatedequilibrium), teoría del, 23, 27, 29, 84-85, 92-95, 103

esencialismo, 126, 128

especiación, 29, 95, 98, 103, 136

especies, 4-6, 9-10, 12, 16, 18, 22-24, 26-28, $35 \mathrm{n}, 64-68,70-73,78 \mathrm{n}-79,81-82,85-87$, 92-94, 95-98, 103, 114, 121, 125-143, 151

— como grupo, 137

- como inmutables, $11 \mathrm{n}$

- como individuos, 134-136, 138

- como relaciones, 135, 137-138

- concepto cladista de, 136

- concepto evolutivo de, 133

- concepto fenético de, 132

- concepto filogenético de, 133

- concepto seleccionista de, 133

- monotípica(s), 133

— estatuto ontológico de las, 134-139

— politípica(s), 132

- realismo de, 135

— transmutación de, 9-11, 15, 17, 24, 32, 129

especismo (speciesism), 141-143

espontáneo/a

— generación, 6-8

— orden, 164

Estadística, 33

Ética, 3-4, 30, 33-37, 41, 125, 142, 168n, 172

- ambiental, 125

— de la Ciencia, 35

ético(s)

— principios, 36

— valores, 36

Etología, 26, 154, 160

eubacteria, 86, 106

eucariota, 106 
evolución, 4-5, 7-10, 12-13, 17-18, 21-24, 31-33, 35-36, 40-41, 46, 77-78, 81-87, 90, 93-95, 96, 114, 117, 119-120, 127, 130-135, $138,148-151,165-173,176-179,181-184$, 194, 196, 199-201, 205, 210, 215

- adaptativa, 25

— como despliegue (unfolding), 4n, 12n

- como hecho, 31-32

- creadora, 34

- cultural, 36

- hayekiana, 184

- lamarckiana, 41, 167n

- molecular, 91

- no-darwiniana, 27

- principio, $12 \mathrm{n}$

- progresiva, 16

- sin selección, $23 \mathrm{n}$

- social, 33

— teísta, 22

— teorías saltacionistas de la, 83-85

— teoría sintética de la, 95, 131

evolutivo/a(s)

- altruismo, 27

—Epistemología, 36-40, 213, 215-217, 220n, 224

- Psicología, 38, 40

- revolución, $14 \mathrm{n}$

- teoría, 12n, 32, 80-81, 86-87, 87, 95-98, $135,151,158,168$

— Teoría de la Empresa, 165, 170

- Teoría del Conocimiento, 201-202

- visiones, 3

evolucionismo, 3-6, 8, 10, 12, 16-19, 22, 24-30, $32-35,37-45,125,150,155,165-166,168$, $172,177-179,181-185,191,194,196-200$, 207, 213-214, 216

- de Darwin, 13, 18, 24, 35

- diversidad de, 3

— de Hayek, 167

- hayekiano, 175

— versiones de, 21

expectativas, 199

experimentación, 13

experimento(s) mental(es), 68, 70-74, 112-115, $117-122$

experimento mental de Dawkins, 119 extinción, 13, 16n, 91-92, 94, 98, 129, 134, 136,138

— del cretácico, 92

— extinción masiva, 92

falacia adaptacionista, 181

falacia naturalista, 36

falsabilidad, 197, 200

falsación, 197, 201-202, 214

falsacionismo, 39, 197-199, 201

finalismo, 204

fijismo, $12,17-19,127-128$

filogénesis, 132

Filosofía de la Biología, 3-4, 30, 37, 40, 125, 127, 129, 194

Filosofía de la Economía, 3-4, 30, 37, 40

Filosofía de la Mente, 30, 34

Física, 27, 40, 129, 135, 149, 154, 166, 171, 194, 196

— clásica, 40, 165, 168

- newtoniana, 32

flogisto, teoría del, 18

forma, 7

función, 7

funcionalismo, $7 \mathrm{n}$

gen(es), 36, 117, 134, 139, 170, 200, 203

- transferencia horizontal de, 86

— transferencia lateral de, 86-87, 98-99, 106

género(s) (genus, genera, genres), 24, 80, 124, $126,128,130$

Genética, 25-26

- citológica, 25

- experimental, 25

- Ingeniería, 136, 138

- mendeliana, 89

— de poblaciones, 25, 90, 94, 131

geofroyismo, 22

Geografía, 10, 25

Geología, 10, 16, 30, 66, 69, 74

giro histórico, 35-36

giro social, 38

gradualismo, $74,167 \mathrm{n}$

guerras culturales, $5 \mathrm{n}$

heredabilidad, $12 \mathrm{n}$

herencia, 79, 135, 167, 176

hipótesis creacionista, 17-18, 72 
hipótesis del "transporte de los peregrinos", 64 Historia, 38, 126

— de la Ciencia, 15, 20, 93, 96

— de la vida, 5, 7, 36

historicidad, 36

historicismo, 214-215

holismo, 195

Iglesia Anglicana, 16

Ilustración escocesa, 171

inconmensurabilidad, 14

indeterminismo, 40

índices diferenciales (differential rates), 95

individualismo metodológico, 174, 179, 182, 184-185

inducción, 30-32, 64

inferencia hacia la mejor explicación (inference to the best explanation), 31

innovación(es), 20, 156-159, 216

institución(es), 165-167, 169, 175-176, 179-185

institucionalismo, 169

instrucción, 219-220

Inteligencia Artificial, 160

involución, $12 \mathrm{n}$

jerarquía en el mundo natural, 6-7, 13

laissez-faire, $167 \mathrm{n}$

lamarckismo, 7n, 16n, 22, 41-42, 203-204

Lavoisier, teoría del oxígeno de, 14, 18, 21n

legislación, 5

ley, 172, 174

- de Kepler, 40

- de la sucesión de los tipos, 10n

— de Wolf, 156-157, 159

leyes biológicas, 135

Literatura, 4

lógica situacional, 197

lucha

- competitiva (competitive struggle), 9

- por la existencia (struggle for existence), $12,16,67,88,168$

- por la supervivencia, 220

— por la vida, 13, 16, 199

macroevolución, 5, 26-29, 77, 90-92, 94-96, 157 mano invisible, principio de, 39, 175, 182 marxismo, 79, 153

Mecánica Cuántica, 14, 197, 204

Mecánica newtoniana, 14

melanismo industrial, 25

memes, 36, 161

mercado, 152, 165-166

Metafísica, 3-4, 30, 33-35, 37, 41, 195

Microeconomía, 165

microevolución, 5, 26-29, 90-91, 95, 156, 159

migración, 26

modificación, 13n, 81-82

Morfología trascendental, 4, 9

Mundo 3, 39n, 195, 219-221

mutación(es), 26, 41, 151-153, 167n, 169-170, 203-204, 220n

- neutral, 29n, 91

— teoría de la, 22

mutacionismo saltacionista, 25

narraciones imaginarias (just-so stories), 23, $29,68-69,75,113-114$

Natural

- Filosofía, 10

- Historia, 5, 10, 30-31, 37, 66, 69, 89

naturalismo, 3, 30, 33-34, 37-39, 41-42

— axiológico, 38

— epistemológico, 37-38

- hiper[naturalismo], 34

- metodológico, 38

- normativo, 38

— ontológico, 35, 38, 42

- semántico, 38-39, 41

neodarwinismo, 22, 113, 215n

Neopositivismo lógico, 20

Neuroeconomía, 160-161

nicho ecológico, 130-131, 203

nominalismo, 128, 134, 138, 140

novedad, 19

Ontología, 199

Ontología de la Ciencia, 35

ortogénesis, 22, 202-203

Paleobiología, 27, 85

Paleontología, 3, 10, 24-26, 31, 66, 114, 139

pan-adaptacionismo, 29

panglosianismo, 29 
panmixia, 86

paradigma(s), 20, 136

— cambio de, 14, 83, 96

— evolucionista, 170

— de la selección natural, 36

- genealógico, 98

— tecnológico, 150, 157-158, 160, 181

- y etapas de Kuhn, 14, 20

pautas (patterns) y procesos, 81, 98, 103

periodismo, 4

polimorfismo, 27, 132n

poliploidismo, 133n, 137-138

politipismo, 132n

predicción(es), 39-40, 72, 131, 153, 209, 212, 214-217

preexistencia de gérmenes (germs), teoría de, 4

principio de eficacia, 95

principio malthusiano, 25,88

procariota, 85-86, 106

programa de investigación, 19

programa metafísico de investigación, 40, 197, 202, 204, 218

progresividad, 13

progreso, 4-6, 20, 168n, 181

— biológico, $5 \mathrm{n}$

- científico, 15, 21, 38, 40

psicologismo, 180n

Psicología, 4, 160, 165-166, 180, 199, 207, 209-210

— evolutiva, 38-39

— de la invención, 198

Química, 18, 27, 40-41, 135, 149, 158, 196

racionalidad, 36, 207-211, 213, 219, 221-222

- adaptativa, 38, 207, 212, 223-224

- como adaptación, 208

- cognitiva, 211

- crítica, 201

- de la Ciencia, 21

- de Robinson Crusoe, 207n

- ecológica, 223

— evaluativa (o de fines), 211-212, 221-222, 224

- evolutiva, 212
— instrumental, 211-212n, 222

- maximizadora, 150

— modelo conductual de, 207, 209-210

- modelo intuitivo de, 208

— modelo olímpico de, 207

- objetiva, 219

- optimizadora, 150

- práctica, 211, 221

- procesual, 212

- sustantiva, 212

racionalidad limitada, 180n, 207-210, 212-213, 217, 221-224

Racionalismo constructivista, 178-180, 182n, 184-185

Racionalismo crítico, 39-40

ratio de reproducción, 24

ratio de supervivencia, 24

realismo, 115, 133, 196

realismo científico, 38, 125

reducción, 193, 204

reduccionismo, 193-197

relativismo, 37,122

Religión, 42, 154

revolución(es)

— científica(s), 14, 17-21

— darwinista, 125, 130

- evolucionista, $14 \mathrm{n}$

— intelectual, 5, 10, 14

- marginal, 171

— química, 15, 18

s-a-i tesis (species as individuals thesis), 134-136, 138

saltacionismo, 22

satisfacción, 210, 222-223

selección, 12n, 24, 28-29, 70, 91, 94, 96, 107, 114, 116-117, 120, 122, 130, 135, 149, 151, 159-160, 168n-169, 173, 177, 181-182, 184, 200, 202, 217, 219-220

- artificial, 22, 32

- genética, 119

- de grupo, 24, 27-28, 91, 176n, 181, 184

- sexual, 13, 41

— tribal, 27

— unidades de, 27 
selección natural, 5, 7n, 9-19, 22-29, 32, 34-35, 37, 41, 67, 69, 72, 74, 77n-81, 87, 89-93, 95-97, 111, 113-114, 116-118, 120-122, 132, 151, 167n-168, 173, 181n, 196, 199-204, 213-214, 217-218, 221

— como proceso y con capacidad causal, 29

- hipótesis de la, 107

- darwiniana, 16, 28

— principio de, 88

- y las mejores hipótesis, 213, 216-218

seleccionismo, 16n, 122, 125n

seleccionismo gradual, 25

série rameuse, 7

simbiosis, 85-86

síntesis moderna, 25-26, 80, 91, 93-94, 112

sistemática (systematics), 31, 80, 128

sobriedad de factores (parsimonius factors), 222-223

sociedad abierta, 197

Sociobiología, 38-39, 150, 160

Sociología, 4, 37-38, 40

subjetivismo, 174

supervivencia de los más aptos (fittest), 13, $147,167 \mathrm{n}$

taxones, 129-130, 132, 136, 138-139

taxonomía, 134

- numérica, 132

- fenética, 132

Tecnología(s), 152-154, 156-159

teleología, 151, 194, 204, 211

Teoría Electromagnética, 196

Teoría de Juegos, 149, 160-161, 170n teoría de la embriogénesis, 4

Teoría de la Evolución, 10-11, 15, 21-22, 26-27, $30,32,78,87,96,112,151,167 \mathrm{n}, 194$, 197-198, 202, 220n

— de Darwin, 14, 204, 210

- darwinista, 204

Teoría del Conocimiento, 3-4, 33-35, 37, 41, 199, 201, 204, 220

teoría de los tres Mundos, 39n, 218

Teoría de la Relatividad, 14

teoría del sistema solar de Copérnico, 14

teoría geológica de tectónica de placas, 14

teoría neutral de evolución de proteína, 27, 29n

teoría ondulatoria de la luz, 69, 88

teoría sintética, 77

Teoría de la Empresa, 161

Termodinámica, 196

transformismo, 11, 16-17, 20, 71, 85

utilidad, teoría de maximización de la, 209n utilidad subjetiva esperada, teoría de la, 221

utilitarismo, 150, 154, 161

variabilidad, $6,12 \mathrm{n}-13,34,132 \mathrm{n}$

variación, 22, 24, 79, 89, 91, 94, 135, 169n

verdad, 20, 40n, 199, 201, 205, 210, 219-220

verosimilitud, 219-220

vida artificial, 122

visiones creacionistas, 15

vitalismo, 195, 203-204

vitalismo bergsoniano, 203

Zoología, 25, 66, 139 


\section{Serie de Filosofía Y Metodología de la Ciencia}

\section{Títulos publicados en la Serie:}

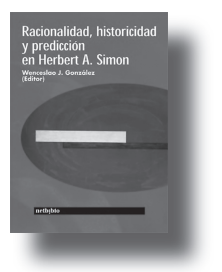

Racionalidad, historicidad y predicción en Herbert A. Simon W. J. Gonzalez (ed) ISBN: 84-9745-021-3

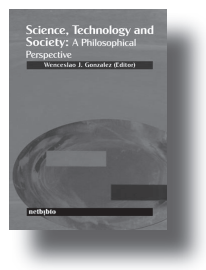

Science, Technology and Society: A Philosophical Perspective W. J. Gonzalez (ed) ISBN: 0-9729892-2-6

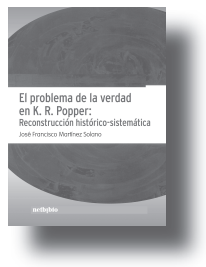

El problema de la verdad en K. R. Popper: Reconstrucción histórico-sistemática J. F. Martínez Solano ISBN: 84-9745-102-3

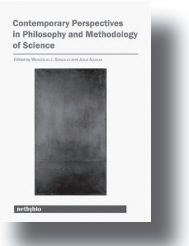

Contemporary Perspectives in Philosophy and Methodology of Science

W. J. Gonzalez y

J. Alcolea (eds)

ISBN 13: 978-0-9729892-3-7

ISBN 10: 0-9729892-3-4

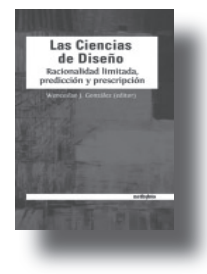

Las Ciencias de Diseño: Racionalidad limitada, predicción y prescripción

W. J. Gonzalez (ed) ISBN: 978-84-9745-212-0

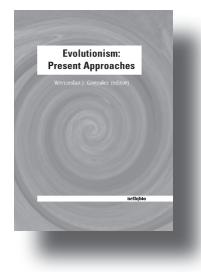

Evolutionism:

Present Approaches

W. J. Gonzalez (ed)

ISBN: 978-0-9729892-8-2

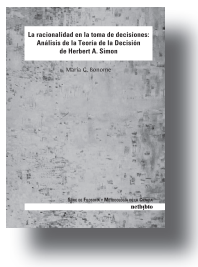

La racionalidad en la toma de decisiones: Análisis de la Teoría de la Decisión de Herbert A. Simon

M. G. BonOME

ISBN: 978-84-9745-459-9

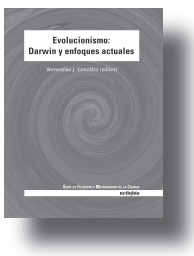

Evolucionismo: Darwin y enfoques actuales

W. J. GonZALEZ (ed)

ISBN: 978-84-9745-409-4

New Methodological Perspectives on Observation and Experimentation in Science

W. J. Gonzalez (ed) próxima publicación

\section{netbiblo}




